UNITED STATES DEPARTMENT OF THE INTERIOR

Harold L. Ickes, Secretary

GEOLOGICAL SURVEY

W. C. Mendenhall, Director

Professional Paper 195

\title{
GEOLOGY OF
}

\section{THE KETTLEMAN HILLS OIL FIELD \\ CALIFORNIA}

STRATIGRAPHY, PALEONTOLOGY, AND STRUCTURE

BY

W. P. WOODRING, RALPH STEWART, AND R. W. RICHARDS

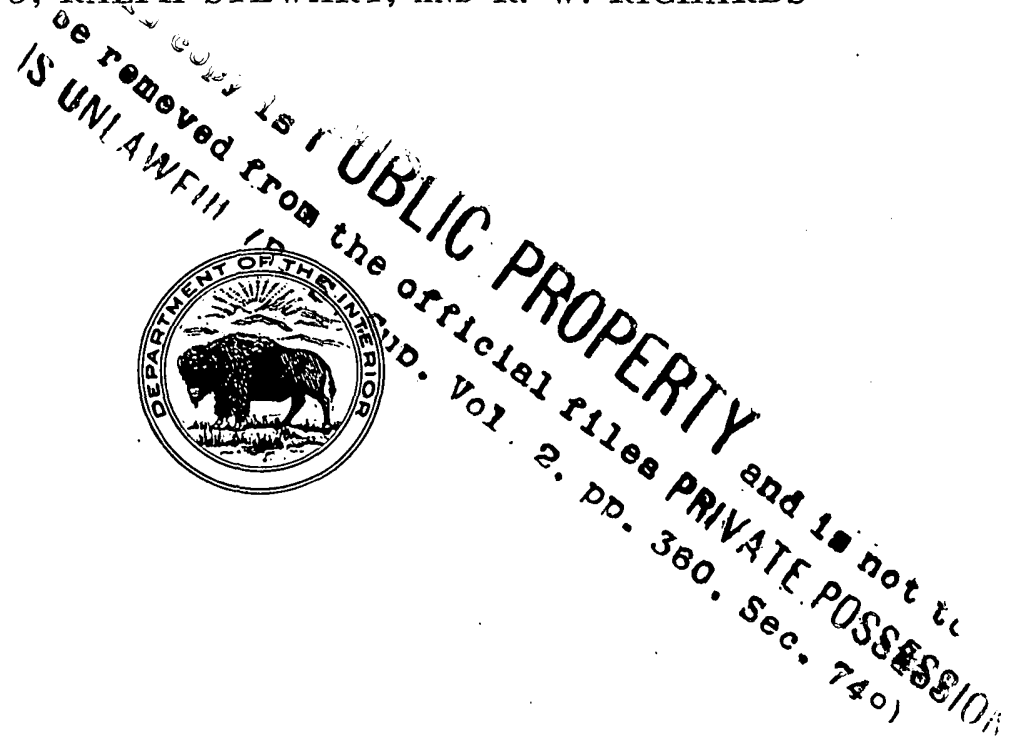

UNITED S'TATES

GOVERNMENT PRINTING OFFICE

WASHINGTON : 1940

For sale by the Superintendent of Documents, Washington, D. C. - . - . - - . - Price $\$ 1.50$ 



\section{CON'TENTS}

Abstract

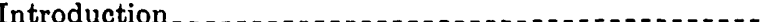

Previous work

Scope of report........

Field work

Advance edition of geologic map..............

Presentation of data. . . . . . .

Acknowledgments...........

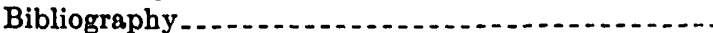

Location and geographic features......................

Outline of stratigraphy

Stratigraphy of exposed formations. . . . . . . . . . . . .

Pleistocene and Recent series......................

Younger alluvium and eolian deposits........

Older alluvium . ..............................

Pleistocene (?) and Pliocene series...............

Tulare formation . . . . . . .

Stratigraphy and lithology ...............

East flank of North Dome..........

East flank of Middle Dome.........

West flank of North Dome

West flank of Middle Dome..........

West flank of South Dome..........

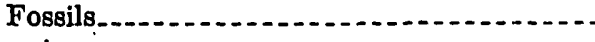

Pliocene series

Classification and nomenclature..............

San Joaquin formation. . . . . . . . . . . . . . .

Upper Mya zone........................ Stratigraphy and lithology Fossils.

Strata between upper Mya zone and Acila zone . . . . . . . .

Stratigraphy and lithology ...........

Fossils

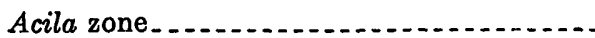

Stratigraphy and lithology .......... Fossils

Strata between Acila zone and Pecten zone.

Pecten zone and Trachycardium zone......

Stratigraphy and lithology .........

Fossils

Occurrence elsewhere in San Joaquin

Valley................................

Strata between Pecten zone and Neverita

zone ................................ Stratigraphy and lithology ........... Fossils.

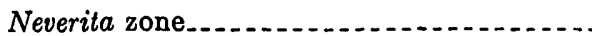

Stratigraphy and lithology

Fossils

Strata between Neverita zone and Cascajo conglomerate member................. Stratigraphy and lithology ........... Fossils

Cascajo conglomerate member........ Stratigraphy and lithology . . . . . . . Occurrence elsewhere in San Joaquin Valley.

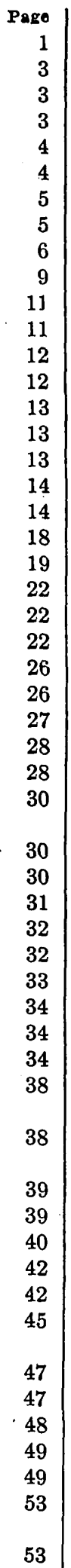

Stratigraphy of exposed formations-Continued. Pliocene series-Continued.

Etchegoin formation . . . . . North Dome............................

Strata overlying Littorina zone........

Littorina zone.......................

Strata between Littorina zone and upper Pseudocardium zone..........

Upper Pseudocardium zone (upper Mulinia zone)

Strata between upper Pseudocardium zone and Siphonalia zone

Siphonalia zone.........................

Macoma zone........................

Patinopecten zone....................

Strata underlying Patinopecten zone...

Middle Dome and South Dome.........

Upper part of formation. ...........

Strata overlying Pseudocardium-

Anadara zone.....................

Pseudocardium-Anadara zone.... Strata underlying PseudocardiumAnadara zone.

Lower part of formation.............

Source of volcanic material in exposed formations........

Paleontology of exposed formations.

Echinoids

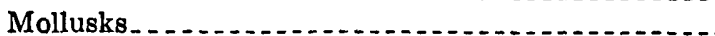

Gastropods . . . . .

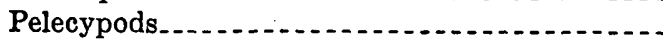

Barnacles....................

Fish

Land mammals....

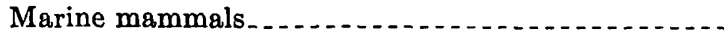

Diatoms_. . . . . . . . . .

Calcareous algae....

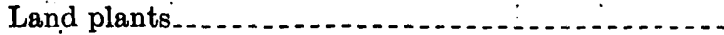

Environment suggested by fossils .................

Etchegoin and San Joaquin formations........

Tulare formation . . . . . . . .

Age and correlation of exposed formations .

Age.

Etchegoin and San Joaquin formations . . ..... 102

Tulare formation . .

Correlation . . . . .

San Joaquin Valley . .

Coast Ranges between Coalinga district and

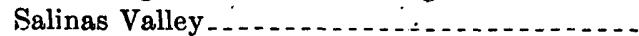

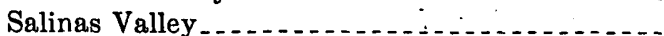

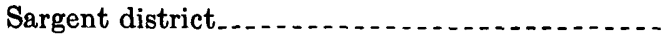

Santa Cruz quadrangle and San Francisco Peninsula . . . . .

Santa Rosa district. . .

Eel River Basin.............

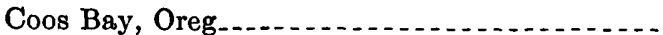

Santa Maria Basin

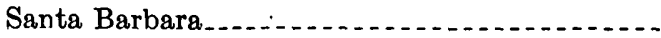

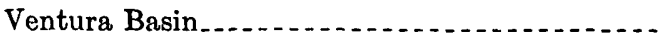

Los Angeles Basin. 
Age and correlation of exposed formations-Continued. Correlation-Continued.

San Diego.

Cedros Island, Lower California

Summary

Stratigraphy and paleontology of formations penetrated by wells and exposed nearby

Pliocene series.

Undifferentiated Etchegoin and Jacalitos formations . . . . . . . Stratigraphy, lithology, and fossils ........ Outcrop sections of Jacalitos formation. Subsurface section

Age and correlation of Jacalitos formation

Miocene series...................................

Classification and nomenclature ............

Reef Ridge shale...............................

Stratigraphy, lithology, and fossils....... Outcrop section along Reef Ridge..... Subsurface section................ Age and correlation

McLure shale member of Monterey shale.....

Stratigraphy, lithology, and fossils...... Outcrop sections...................... Subsurface section . . . . . . . . .

Age and correlation ........................

Temblor sandstone..........

Stratigraphy, lithology, and fossils....... Outcrop sections.................... Subsurface section ............... First zone (Milham zone) ........ Upper variegated zone.......... Second zone (Elsinore zone) ....... 600 -foot shale................... Third zone.......... 800-foot shale.................. Fourth zone...................... Lower variegated zone

Page

112

113

113

114

114

114

115

115

115
Stratigraphy and paleontology of formations, etc.-Con. Miocene series-Continued.

Temblor sandstone-Continued.

Stratigraphy, lithology, and fossils-Con. Subsurface section-Continued.

Fifth zone... Felix siltstone ................. Whepley shale Sixth zone (Beal zone)

Age and correlation

Oligocene (?) and Eocene series................. Kreyenhagen shale.

Stratigraphy, lithology, and fossils....... Outcrop sections.....................

Subsurface section. . .

Age and correlation Eocene series.

McAdams sand ........................ 147

Stratigraphy, lithology, and fossils ....... Outcrop section Subsurface section Age and correlation

Structure ... _... General relations. North Dome. . . . Middle Dome

South Dome.

Origin of structure

General and regional features........... Physiography

(154

General features.............. 154

Old surfaces of low relief ..................... 154

Minor erosional features.

Present land forms........... 155

Fossil localities...

Index

\section{ILLUSTRATIONS}

P LATE 1. Airplane photograph mosaic of Kettleman Hills

2. Relief map of California .

3. Geologic map of the Kettleman Hills and generalized stratigraphic sections of exposed formations.

4. Fossils from Tulare formation

5. Fossils from Tulare formation

6. Fossils from Tulare formation

7. Diatoms from Tulare formation

8. Fossils from upper $M y a$ zone of San Joaquin formation

9. Fossils from upper Mya zone of San Joaquin formation

10. Fossils from strata in San Joaquin formation between upper Mya and Acila zones

11. Fossils from Acila zone of San Joaquin formation

12. Sections of Pecten zone of San Joaquin formation

13. Fossils from Pecten zone of San Joaquin formation.

14. Fossils from Pecten zone of San Joaquin formation

15. Fossils from Pecten and Trachycardium zones of San Joaquin formation, and from strata in San Joaquin formation between Pecten and Neverita zones.

16. Fossils from Pecten zone of San Joaquin formation

17. Sandstone and sand in San Joaquin and Etchegoin formations of North Dome...

18. Neverita and Pecten zones of San Joaquin formation .

19. Limy sandstone from Neverita layer of basal sandstone of Neverita zone showing characteristic faunal association...

20. Fossils from Neverita zone of San Joaquin formation.

21. Fossils from Neverita zone of San Joaquin formation

22. Diatoms from Neverita zone of San Joaquin formation and from strata in San Jnaquin formation between Pecten and Neverita zones. 
23. Diatoms from Neverita zone of San Joaquin formation and from strata in San Joaquin formation between Pecten and Neverita zones.....-

24. Fossils from lower part of San Joaquin formation and upper part of Etchegoin formation

25. Strata in lower part of San Joaquin formation and upper part of Etchegoin formation of North Dome ........

26. Strata in Itchegoin formation of North Dome.

27. Strata in Etchegoin formation of North Dome.

28. Sections of strata in Etchegoin formation of North Dome underlying Littorina zone

29. Fossils from Littorina and upper Pseudocardium zones of Etchegoin formation of North Dome....................

30. Tossils from upper Pseudocardium zone of Etchegoin formation of North Dome

31. Fossils from Siphonalia zone of Etchegoin formation of North Dome

32. Fossils from Siphonalia zone of Etchegoin formation of North Dome

33. Fossils from Siphonalia zone of Etchegoin formation of North Dome

34. Fossils from Macoma and Patinopecten zones of Etchegoin formation of North Dome

35. Fossils from Patinopecten zone of Etchegoin formation of North Dome

36. Fossils from Patinopecten zone of Etchegoin formation of North Dome and underlying strata

37. Fossils from Etchegoin formation of Middle Dome and South Dome....

38. Diatoms from Etchegoin formation of South Dome .

39. Sand dollars and other fossils from San Joaquin and Etchegoin formations of North Dome

40. Sand dollars from Etchegoin formation of North Dome.

41. Sand dollars from Etchegoin and San Joaquin formations of North Dome...

42. Sand dollars from Etchegoin formation of North Dome.

43. Sand dollars from Etchegoin formation of North Dome

44. Sand dollars from Etchegoin formation of North Dome

45. Sand dollars from upper part of San Joaquin formation of North Dome

46. Sand dollars from upper part of San Joaquin formation of North Dome.

47. Miocene formations of North Dome subsurface section and nearby outcrop sections and their chronologic relations as inferred from faunal and mineralogical data

48. Miocene formations on Reef Ridge, 8 miles southwest of Kettleman Hills . . . .

49. Foraminifera from Reef Ridge shale of wells in Kettleman Hills and of outcrop along foot of Reef Ridge.......

50. Foraminifera from basal part of McLure shale member of Monterey shale on Reef Ridge, and from Gould shale member of Monterey shale on Zemorra Creek .

51. Structure contour map of exposed formations in the Kettleman Hills, with structure sections and generalized stratigraphic section

52. Fault map of North Dome

53. Structural and physiographic features in North Dome

54. West flank of North Dome

55. East flank of North Dome

56. West flank of northern Middle Dome

57. Northern Middle Dome

Fradre 1. Map showing location of Kettleman Hills with reference to other features in the Coalinga and other nearby areas

2. Sections of lower part of Tulare formation and upper part of San Joaquin formation on east flank of northern North Dome.

3. Sections showing fossiliferous layers in Neverita zone of San Joaquin formation on east flank of North Dome

4. Lower part of Neverita zone of San Joaquin formation on ridge southeast of Arroyo Torcido, southwestern part of sec. 6 , T. 22 S., R. 18 E.

5. Sections showing fossiliferous layers in Neverita zone of San Jorquin formation on west flank of North Dome

6. Generalized section of strata in lower part of San Joaquin formation and in upper part of Etchegoin formation in northern North Dome

7. Stratigraphic relations of Cascajo conglomerate member of San Joaquin formation in Arroyo Delgado, on west flank of North Dome..-

8. Reconstruction of strata exposed in Arroyo Ramoso and on El Lobo under interpretation that blue sandstone and conglomerate at both localities represent Cascajo conglomerate member of San Joaquin formation.............

9. Sections of Littorina zone of Etchegoin formation and immediately underlying strata on west and east flanks of North Dome.

10. Generalized section of upper part of Etchegoin formation of Middle Dome

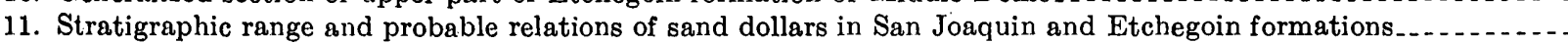

12. Sketch map of California and southern Oregon showing principal areas of marine Pliocene formations . . . . . . . .

13. Suggested correlation of upper part of Etchegoin formation and San Joaquin formation in Kettleman Hills with subsurface section in southern San Joaquin Valley . . . . .

14. Inferred chronologic relations of Miocene formations on west side of southern San Joaquin Valley ...........

15. Sketch map showing location of anticlines in Kettleman Hills with relation to other anticlines along west border

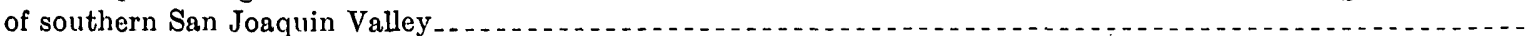

\section{INSERTS}




\title{
GEOLOGY OF THE KETTLEMAN HILLS OIL FIELD, CALIFORNIA STRATIGRAPHY, PALEONTOLOGY, AND STRUCTURE
}

\author{
By W. P. Woodring, Ralph Stewart, and R. W. Richards
}

\begin{abstract}
The Tiettleman Fills oil field came into prominence in 1928, when the completion of the discovery well indicated a rich supply of oil and gas in a region that had long been considered prospective oil territory. The Kettleman Hills, 30 miles long and 4 to 5 miles wide, consist of three northwestward-trending anticlines-North Dome, Middle Dome, and South Dome-which lie in echelon alinement along the west side of southern San Joaquin Valley. Although a part of the foothills of the Coast Ranges, they are separated from the mountains by the synclinal Kettleman Plain. South Dome is the northern part of the anticline that is overlapped by the alluvium of San Joaquin Valley. Ten miles southeast of South Dome, Lost Hills rise above the alluvium either as a part of the same anticline or as another one of the anticlines in a line extending southeastward from Anticline Ridge in the Diablo Range through the Kettleman Hills.
\end{abstract}

Stratigraphy and paleontology of exposed formations.-The exposed strata and those penetrated by wells have a thickness of about 14,000 feet and range in age from Pliocene and Pleistocene (?) to Eocene. Those exposed at the surface have a thickness of about 6,000 feet and are of Pliocene and Pleistocene (?) age. They represent in descending order the Tulare, San Joaquin, and Etchegoin formations. The Tulare formation has an exposed thickness of 1,700 to 3,500 feet. It is nonmarine and consists principally of sandstone and conglomerate and toward the base of fine-grained rocks in which fresh-water mollusks and fresh- and brackish-water diatoms are abundant. The San Joaquin formation has a thickness of 1,200 to 1,800 feet. It consists of silt and clay, in most of which marine fossils are apparently absent, alternating with silt, sandstone, and conglomerate, many strata of which contain marine fossils. Four marine faunal zones in the San Joaquin formation, the conglomerate at the base of the formation, and other less persistent lithologic and faunal units were mapped. The Pecten zone, a little above the middle of the formation, is the most widespread and most readily recognized. The San Joaquin formation is divided at the base of the Pecten zone into an upper and a lower part. The base of the San Joaquin formation is drawn at the base of the Cascajo conglomerate member. It is suggested that the Cascajo conglomerate is to be correlated with a conglomerate that lies unconformably on Miocene shale along the southwest border of San Joaquin Valley near McKittrick. The Pecten zone and Cascajo conglomerate correspond probably to marine zones recognized in the subsurface section of southern San Joaquin Valley and appear to represent the most extensive marine invasions during San Joaquin time. The exposed part of the Etchegoin formation has a thickness of about 700 feet in North Dome and an estimated exposed thickness of about 600 feet in Middle Dome. Apparently a considerably greater thickness, estimated as 1,800 feet, is represented in South Dome. With the exception of fresh-water beds near the top of the formation in North Dome, the Etchegoin consists of marine deposits, principally sandstone, conglomerate, and silt. Five faunal zones were mapped in the Etchegoin of North Dome. The structure contour lines showing the structure of the exposed formations are drawn on the Littorina zone, the highest of the five zones in North Dome, and its essential equivalent-the Pseudocardium-Anadara zone-in Middle and South Domes. One faunal zone and several generally discontinuous lithologic units in the Etchegoin formation were mapped in both Middle and South Domes, where fossils are relatively rare.

Volcanic debris is abundant in the exposed formations with the possible exception of the upper part of the Tulare formation. The material examined by M. N. Bramlette has the composition of augite andesite, hornblende andesite, and hypersthene andesite. A partial chemical analysis of a pumice tuff from the upper part of the San Joaquin formation indicates that it is dacitic. The Lassen Peak district at the south end of the Cascade Range in northern California and the region in the Coast Ranges north of San Francisco Bay appear to be the most likely source of this volcanic material. Most of the coarse-grained sandstones in the Etchegoin formation and in the basal part of the San Joaquin formation are characterized by a blue color due to a film of undetermined composition on the grains. According to Bramlette the film is probably a chloritic or clay mineral, and he suggests that there may be a relation between this mineral and tuffaceous material of the composition of hypersthene andesite, which appears to be characteristic of the blue sandstones.

Sand dollars (echinoids) of the genus Dendraster are perhaps the most abundant of the stratigraphically important fossils in the San Joaquin and Etchegoin formations. The D. gibbsii group, which is characterized by a markedly eccentric apical system, occurs in the Etchegoin and in the lower part of the San Joaquin; the D. coalingaensis group, which has a less eccentric apical system, is abundant in the upper part of the San Joaquin. The $D$. coalingaensis group also occurs in the lower part of the San Joaquin, and one member of the group is found in the upper Pseudocardium zone in the upper part of the Etchegoin. Merriamaster, treated as a subgenus of Dendraster, is characterized by inflated margins of the test, large spine bases, and open petals. Sand dollars assigned to Merriamaster were found only in the upper part of the San Joaquin formation.

The Acila zone fauna in the upper part of the San Joaquin formation lived probably in deeper water than any other fauna in the San Joaquin or Etchegoin formation. The upper Mya zone-the youngest of the marine zones in the San Joaquinrepresents probably less saline water than the other marine zones. During the deposition of the Pecten zone of the San Joaquin formation the water was apparently warmer than during the deposition of the other zones and also was apparently warmer than the present coastal water north of Point Conception. Perhaps the inland San Joaquin Valley sea may have joined the open ocean south of Point Conception during the deposition of the Pecten zone and north of Point Conception at other times. Arnold and other writers considered certain species from the upper $M y a$ zone and other beds indicative of cold water. It is more probable that these forms indicate estuarine conditions. 
The Tulare formation is assigned to the upper Pliocene and Pleistocene (?), the San Joaquin formation to the upper Pliocene, and the Etchegoin formation to the middle Pliocene. Principally on the occurrence of Merriamaster the part of the San Diego formation exposed at Pacific Beach, near San Diego, is correlated with the San Joaquin formation. Strata in the eastern part of the Ventura Basin that have been correlated with the Pecten zone of the San Joaquin are considered older, more probably the equivalent of the Etchegoin.

Stratigraphy and paleontology of formations penetrated by wells and exposed nearby.-The unexposed part of the Etchegoin formation and the underlying Jacalitos formation are not differentiated in the subsurface section. The undifferentiated Etchegoin and Jacalitos have a thickness of 3,600 to 4,500 feet and consist chiefly of sandy shale, clay shale, and sand. The Jacalitos formation, which is assigned to the lower Pliocene, is underlain by the upper Miocene Reef Ridge shale-the caving shale or heaving shale of drillers. The Reef Ridge shale has an average thickness of 500 feet and is made up of shale, sandy shale, and tuffaceous sand. Foraminifera from the subsurface Reef Ridge shale and from the lower part of the formation at the foot of Reef Ridge, along the mountain front west of the Kettleman Hills, are referred by R. M. Kleinpell to his Bolivina obliqua zone. After passing through the Reef Ridge shale wells enter a hard siliceous shale representing a type of Miocene lithology characteristic of the Monterey shale of the Coast Ranges. This shale, which is called the brown shale by drillers and is here designated the McLure shale member of the Monterey shale, has an average thickness of 1,300 feet in North Dome and thickens southward to 2,500 feet in South Dome. Near the base of the McLure shale one to three beds of bentonite have been found in most wells. Bentonite of the same character also occurs near the base of the McLure at the outcrop on Reef Ridge. The bentonite is readily recognized in core and ditch samples and is used as a key bed. Foraminifera from the basal part of the McLure shale exposed on Reef Ridge are assigned by Kleinpell to a horizon in the lower part of the upper Miocene of current Coast Range chronology. This horizon is identified 3,500 to 4,000 feet below the top of the 7,000-foot section of Monterey shale on Chico Martinez Creek, along the front of the Coast Ranges 40 miles southeast of the Kettleman Hills.

The oil-bearing Temblor sandstone, which has a thickness of about 2,000 feet and is considered of lower and middle Miocene age, underlies the McLure shale. It consists of productive zones of sand and sandy shale and barren zones of shale, shaly sand, and sand. In North Dome the following productive and barren zones are recognized. The productive zones are numbered in consecutive order downward.

Driller's names used for subdivisions of Temblor sandstone in North Dome

First zone.

Upper variegated zone.

Second zone.

600 -foot shale.

Third zone.

800 -foot shale.

\section{Fourth zone.}

Lower variegated zone.

Fifth zone.

Felix siltstone.

Whepley shale.

Sixth zone.

The lower part of the First zone is characterized by the abundance of serpentine and the green garnet uvarovite and is designated the serpentine zone by Bramlette. This zone and probably also the underlying upper variegated zone are the equivalent of the Big Blue serpentinous member at the top of the Temblor sandstone exposed on Anticline Ridge, northwest of the Kettleman Hills. On the basis of its Foraminifera the 600 -foot shale is correlated by R. M. Kleinpell with the Gould shale, which represents his Siphogenerina branneri zone. The Gould shale is the lowest member of the 7,000-foot section of Monterey shale exposed on Chico Martinez Creek. According to this correlation and the correlation of the basal part of the McLure shale, the part of the Temblor sandstone in the Kettleman Hills subsurface section overlying the 600 -foot shale is the equivalent of a considerable thickness of Monterey shale in the Chico Martinez Creek section, for it is improbable that there are discontinuities of any magnitude in either section. A thin mineral zone, designated by Bramlette the orthoclase-anhydrite zone, occurs at the top of the Fifth zone and apparently also in the lower part of the lower variegated zone. Most of the Fifth zone represents Bramlette's andesitic sand zone, characterized in the well material by the abundance of hornblende and by the presence of other ferromagnesian minerals.

Several wells in North Dome have been drilled through the Temblor sandstone into the Kreyenhagen shale, which has a thickness of 1,000 to 1,150 feet. The Kreyenhagen shale is a shale of Monterey type. At the outcrop it is of Eocene age or of Eocene and Oligocene age. As the age relations of the Kreyenhagen in the Kettleman Hills subsurface section are uncertain, it is designated Oligocene (?) and Eocene. Deep wells at the extreme north end of North Dome penetrated the Kreyenhagen shale and entered the McAdams sand, which may represent the middle Eocene Avenal sandstone of the Reef Ridge outcrop section.

Structure.-North Dome is much longer and 400 feet higher structurally than Middle Dome. South Dome is evidently part of an anticline that is wider than North and Middle Domes. As the structure of South Dome is interpreted, it is 800 feet higher structurally than North Dome. The southward extent of South Dome is uncertain owing to the overlap of alluvium. but South Dome may be the north end of the Lost Hills anticline structurally the highest part of which is about 10 miles south of South Dome.

Two sets of normal faults are recognized in North Dome: (1) strike faults that are about parallel to the strike of the strata, and (2) diagonal faults that in general trend slightly east of north at angles of about $60^{\circ}$ to the strike of the strata. The faults of both sets have average dips of about $60^{\circ}$. The strike faults have displacements ranging from a few feet to about 300 feet. Most of the strike faults dip toward the axis of the anticline. Striae observed on a few strike-fault planes are almost invariably parallel to the dip of the fault planes. The axis of the middle part of the anticline lies in a complex fault trough limited by strike faults. The diagonal faults have displacements of less than 100 feet. Most of the diagonal faults on and near the plunging ends of the anticline dip in the direction of plunge. In the central part of the anticline, where the axis is essentially horizontal, eastward-and westward-dipping diagonal faults are about equally numerous. The trend and angle of inclination of striae were measured on many diagonal faults. With only a few exceptions the striae are oblique to the strike and dip of the fault planes, lie at angles of about $60^{\circ}$ to the strike, and are inclined toward the axis of the anticline.

Middle Dome consists of three parts, the main part and a faulted minor dome at each plunging end. The axis of the anticline is bent sharply between the middle part and each of the minor domes. Most of the faults in Middle Dome are roughly radial or slightly diagonal. Strike faults were recognized only near the ends of the anticline close to the base of down-faulted wedges that point toward the concave sides of the bends in the axis. The strike faults dip toward the axis of the anticline. The radial and diagonal faults have the greatest displacement at the border of the down-faulted wedges or in wedges in the minor domes, the maximum displacement being generally about 150 feet. On the east limb most of the radial and diagonal faults in the central part of the anticline and in the area adjoining the minor dome at the north end dip westward; most of those on the west limb as far south as the minor dome at the south end dip eastward. 


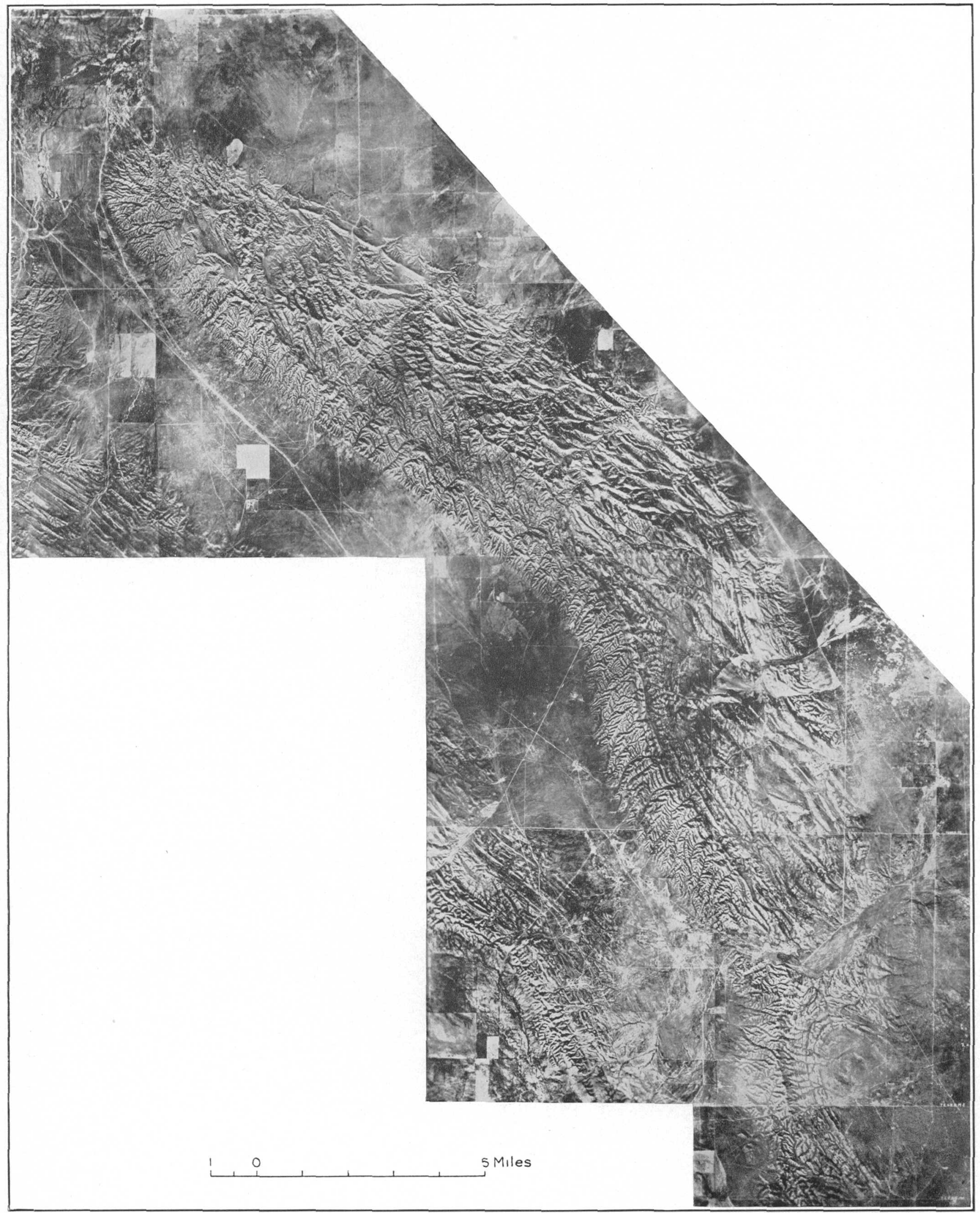




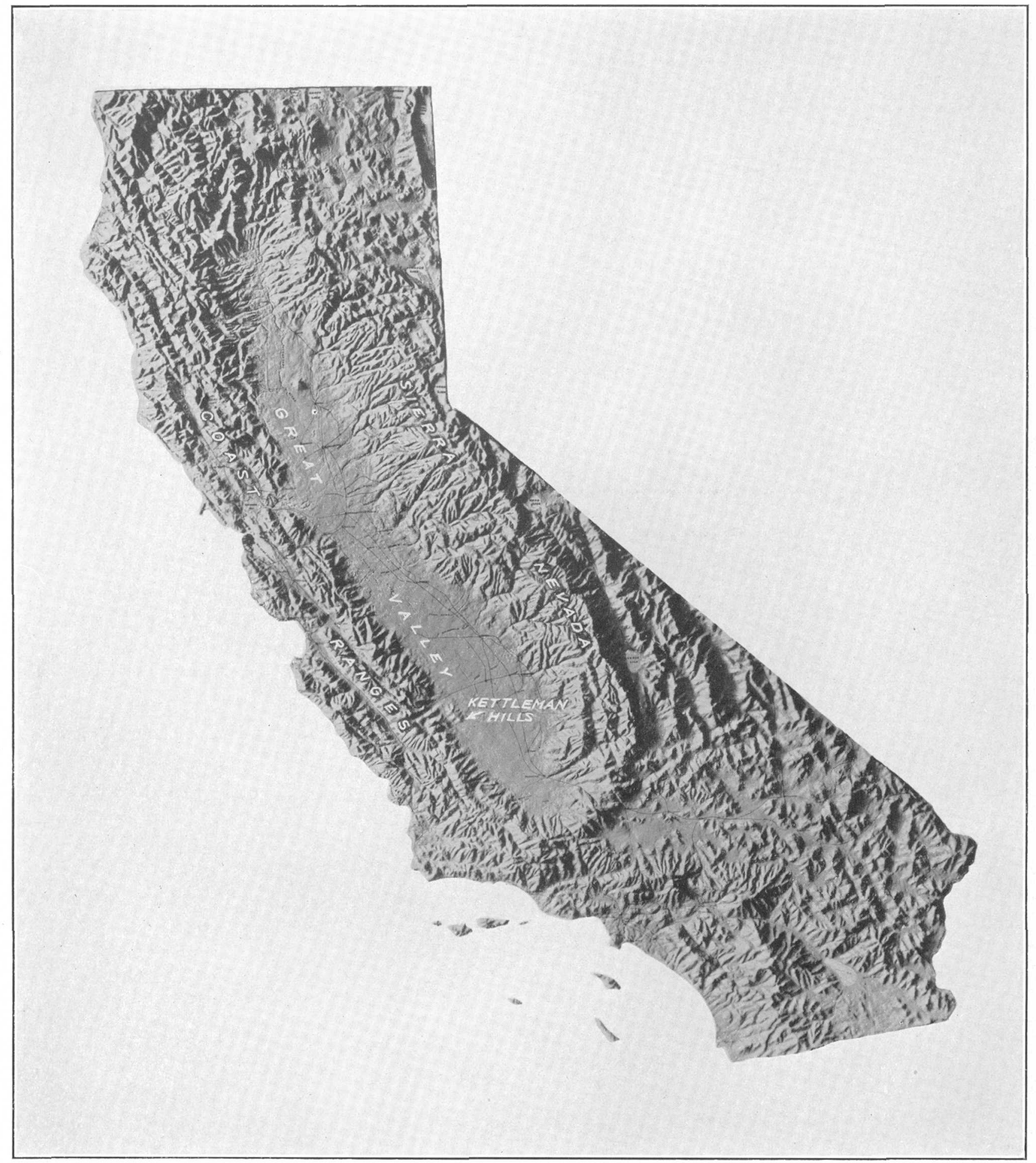

RELIEF MAP OF CALIFORNIA. 
In South Dome only minor diagonal or approximately radial faults were recognized. The axis of the anticline appears to rise southward as far as the south end of the hills.

The deformation of the Kettleman Hills is attributed to north-south compression applied to a northwestward-trending zone of weak strata in which echelon anticlines were formed. The upward squeezing of incompetent material lifted and folded the strata; the faulting is attributed to shearing that accompanied differential vertical stresses in competent strata overlying the rising incompetent material. The strike faults of the fault trough of North Dome formed after the strata had been lifted nbove the levels of direct influence of the north-soutl. compression, but inasmuch as they dip toward the axis of the anticline there was evidently enough compression on the flanks to localize the movement on such faults. The diagonal faults appear to have been formed before the strata had been raised entirely above the levels of the effect of the north-south compression. The oblique striae of the diagonal faults appear to have been formed in a stage intermediate between the formation of the diagonal and the strike faults. Greater pressure on the flanks of Middle Dome than of North Dome may account for the absence of an axial fault trough in Middle Dome and for the general strike of the faults almost at right angles to the axis. On South Dome the dimensions of the incompetent material may have been such as to balance the horizontal and vertical stresses in the overlying competent rocks during the uplifting of the strata; under these conditions no axial fault trough would be formed.

Physiography.-The Kettleman Hills represent land forms carved from a deformed surface of low relief developed across folded strata of the Tulare (upper Pliocene and Pleistocene (?)) and older formations. The deformation of this surface is attributed to renewed arching along the axis of the Kettleman Hills anticline presumably during late Pleistocene time. A nearly flat surface at El Prado, near the north end of North Dome, truncates strata in the upper part of the San Joaquin formation. This surface has such low relief and covers such a large area that it evidently was formerly much more extensive than it now is and presumably covered the Kettleman Hills, but it has not been traced with certainty beyond its present limits. A surface truncating the lower part of the San Joaquin formation on La Palomera in southern North Dome may be a remnant of the surface at El Prado, but it seems to lie below the probable projection of that surface. Dissected surfaces on Las Alturas, in Middle Dome, and on Las Colinas, in South Dome, probably correspond to one or the other of the North Dome surfaces. The southward decrease in altitude from North Dome to South Dome may be explained by a southward tilt relative to the surrounding alluvium.

The lowest of the dissected erosion surfaces, representing a stage in the recent uplift of the hills, is the most conspicuous because of the older alluvium associated with it. La Vega, in northern North Dome, shows this surface and the accompanying older alluvium very well. Gravel lying above the floor of Avenal Gap, between Middle and South Domes, may have been deposited at about the same time as the older alluvium at La Vega and elsewhere.

\section{INTRODUCTION}

\section{PREVIOUS WORK}

The geology of the Coalinga district, which includes the Kettleman Hills, was first described by Watts ${ }^{1}$ and F. M. Anderson. ${ }^{2}$ Ralph Arnold and Robert

I Watts, W. L., The gas and potroleum yielding formations of the central valley of Oalifornis: Callfornia State Min. Bur. Bull. 3, pp. 53-68, 1894.

- Anderson, F. M., A stratlgraphic study in the Mount Diablo Range of California: Callfornis Acrd. Scl. Proc., 3d ser., vol. 2, pp. 155-248, pls. 12-35, 1905. $152100-41-2$
Anderson mapped this district under the auspices of the Geological Survey, and the results of their work were published in final form in Bulletins $396^{3}$ and $398 .^{4}$ The Kettleman Hills constitute only a small part of the Coalinga district-a relatively minor part so far as the preparation of Bulletin 398 was concerned. Only the youngest strata of the Coalinga district are exposed in the Kettleman Hills, but data on the remainder of the Tertiary section, described in Bulletin 398 and other publications, are essential in interpreting the subsurface section in the Kettleman Hills.

Unpublished studies in 1924-25 by R. D. Reed, W. D. Kleinpell, Chester Cassel, and D. D. Hughes, under the auspices of the Marland Oil Co., played an important part in guiding drilling operations that resulted in the discovery of an oil field in the Kettleman Hills. After the discovery well was completed in 1928 the Kettleman Hills were studied by many geologists, and many reports on the general geology of the area or on particular aspects of the geology have been published, the most comprehensive of which are those by Gester and Galloway ${ }^{5}$ on the general geology and by Goudkoff ${ }^{6}$ on the subsurface stratigraphy.

\section{SCOPE OF REPORT}

The Kettleman Hills embrace a considerable acreage of public lands. An estimate of the potentialities of the field showed that unrestricted development would not only result in a great waste of natural resources but would also be ruinous to the oil industry. This investigation of the geology of the Kettleman Hills was undertaken by the Geological Survey primarily to furnish data for the administration of the public lands with the view of cooperating with leaseholders and holders of private lands so as to conserve and utilize the resources to the greatest possible extent. This publication makes the results of the investigation available to anyone interested in the geology of the Kettleman Hills, including those having an interest in small holdings, for whom the expense of geologic work is prohibitive.

In addition to publishing material of immediate interest to oil operators in the Kettleman Hills, this report makes data available for investigations in oil geology in nearby regions. The Coalinga district has an unusually full succession of fossiliferous Pliocene deposits. In working out the stratigraphy and structure particular attention was given to the zonal paleontology of the part of this Pliocene section that crops out in the Kettleman Hills. The zonal distribution of the fossils is described, most of the species are illus-

A Arnold, Ralph, Paleontology of the Coalinga district, Fresno and Kings Counties, Calif.: U. S. Geol. Survey Bull. 396, 173 pp., 30 pls., 1909 [1910].

4 Arnold, Ralph, and Anderson, Robert, Geology and oil resources of the Coalinga district, Calif.: U. S. Geol. Survey Bull. 398, 354 pp., 52 pls., 9 figs., 1910.

- Gester, G. C., and Galloway, John, Geology of Kettleman Hills oil fleld, Calif.: Am. Assoc. Petroleum Geologists Bull., vol. 17, pp. 1161-1193, 6 figs., 1933.

- Goudkoff, P. P., Subsurface stratigraphy of Kettleman Hills oil field, Calif.: Idem., vol. 18, pp. 435-475, 8 figs., 1934. 
GEOLOGY OF THE KETTLEMAN HILLS OIL FIELD, CALIFORNIA

trated, and the distribution and affinities of the stratigraphically important species are discussed. Many of the stratigraphically important fossils are recognized by field geologists, and the usefulness of fossils in field work in the Coast Ranges, where lithologic features are frequently unreliable, has long been realized. The results of this work on the paleontology of the Kettleman Hills may also be useful in interpreting the stratigraphy of subsurface sections in the San Joaquin Valley. The paleontology of the subsurface section in the Kettleman Hills is considered as far as practicable. The Foraminifera of the principal fossiliferous beds in the subsurface section, supplemented by material from the same horizons at nearby outcrop localities, are illustrated and discussed. The work on the mineralogy, of the sandstones indicates that such investigations may yield fruitful results in working out the stratigraphic relations of the oil-bearing sands.

Details of the structure of the Kettleman Hills that are presented may not have a direct bearing on oil development but may be of interest to geologists in considering the geometric aspects of crustal deformation.

Of more general interest is the purpose of contributing data for the interpretation of the geologic history of the Coast Ranges. The paleontologic data on the outcrop section may be of some assistance in studying the stratigraphy of other Pliocene basins and in attempting to establish correlations. The discussion of stratigraphic classification and nomenclature, particularly with reference to the Miocene formations, may stimulate consideration of the principles underlying a subject that is especially troublesome in the Coast Ranges.

\section{FIELD WORK}

The field work that furnished the basis for this report was begun in 1930 and was continued at intervals until 1934. The anticlinal character of the Kettleman Hills is apparent to even the casual observer, but the many structural complications due to an intricate network of minor faults, at least in North Dome and Middle Dome, are much less obvious. Though it is improbable that these faults have any relation to the occurrence of oil, an attempt was made to map them, not only to represent the structure adequately but also because the stratigraphy could not be understood if they were neglected. Faunal zones were particularly useful in mapping. On the other hand, some lithologic units proved to be more persistent than had been expected. The two sets of features-fossils and lithology-served as checks on each other.

The mapping was done by W. P. Woodring and Ralph Stewart, assisted by J. C. Miller, G. F. Taylor, and C. L. Gazin. J. C. Miller mapped the Amnicola zones in the Tulare formation, the base of the Tulare formation, the upper Mya zone, and the oyster-bearing sandstones in the upper part of the San Joaquin formation. Ralph Stewart mapped the Acila zone, the
Trachycardium and Pecten zones, and the interior of North Dome below the Neverita zone. W. P. Woodring mapped the Neverita zone, contributed data on minor units between the Pecten and Neverita zones and immediately below the Neverita zone, and mapped the interior of Middle and South Domes below the Pecten zone. G. F. Taylor measured sections in the Tulare formation and contributed other data. C. L. Gazin assisted in mapping the boundary between the upper and lower parts of the Etchegoin formation in Middle Dome. R. W. Richards gathered information on the subsurface stratigraphy and on the occurrence of oil, gas, and water.

The fossil zones and lithologic units were mapped by tracing along the strike. This procedure yielded more complete information for selected parts of the section than for intervening parts. Intervening parts of the section were examined at intervals, and it is improbable that important fossil zones or lithologic units have been completely overlooked. Not all the units that were recognized are shown on the geologic map and a great many more could be recognized, for the number of units mapped in an area like this depends principally on the length of time that can be devoted to field work.

The formations that are penetrated by wells are exposed at nearby localities. They were not studied at the outcrop localities as carefully as may be desirable. Information assembled by M. N. Bramlette in bis study of the Monterey shale of the Coast Ranges, undertaken in collaboration with K. E. Lohman and R. M. Kleinpell, and the results of K. E. Lohman's work on the Temblor sandstone of Anticline Ridge are, however, available. Two sections of the Temblor sandstone measured on Reef Ridge by W. P. Woodring and the late H. R. Farnsworth before the Kettleman Hills project was started are included in this report. After the project was under way M. N. Bramlette investigated the mineralogy of the sandstones of the subsurface section, and in connection with this work W. P. Woodring and M. N. Bramlette made a brief examination of the upper part of the Temblor sandstone at localities on Reef Ridge and Anticline Ridge.

\section{ADVANCE EDITION OF GEOLOGIC MAP}

An advance edition of the geologic map, including the formation boundaries, structure contour lines showing the structure of the exposed formations, generalized stratigraphic sections, and structure sections was issued in July 1934 in order to make the data available prior to the completion and publication of the present report. The structure contours of the exposed formations and the structure sections are reproduced on plate 51 . The generalized stratigraphic sections, somewhat modified, are shown on plates 3 and 51 .

Since the advance edition was published the boundary between the San Joaquin and Etchegoin formations has been shifted about 100 feet higher in the 
North Dome section. On the advance edition the boundary was drawn at the datum plane used for the contour lines. The datum plane is now designated the Littorina zone of the Etchegoin formation in North Dome and the Pseudocardium-Anadara zone of the Etchegoin formation in Middle and South Domes. The boundary between the San Joaquin and Etchegoin is now placed at the base of the Cascajo conglomerate member of the San Joaquin.

\section{PRESENTATION OF DATA}

The stratigraphy is described in the order in which the formations are penetrated, or would be penetrated, in drilling operations, beginning with the youngest formation.

The stratigraphy and paleontology of the exposed formations is described by W. P. Woodring and Ralph Stewart, each of whom deals with the strata and areas he has mapped. These two authors also discuss the "Environment suggested by fossils" (pp. 99-102) and "Age and correlation of exposed formations" (pp. 102-114). W.P. Woodring describes the stratigraphy and paleontology of the part of the section mapped by J. C. Miller and discusses the possible source of the volcanic material. $\mathrm{He}$ also describes the stratigraphy and paleontology of the formations penetrated by wells, with the exception of the matter dealing with the thickness and lithology of the subsurface formations, which was prepared by R. W. Richards. W. P. Woodring and Ralph Stewart describe the structure of the exposed formations, and Ralph Stewart discusses the origin of the structure and physiography. The discussion of the subsurface stratigraphy is based on development to the end of 1936 but includes, however, an outline of the deep formations penetrated by Kenda wells 4-18-J and 67-20-J, which were not completed until 1938.

Lists of fossils under the heading "Stratigraphy of exposed formations" show the geographic distribution of fossils collected from the different faunal zones and lithologic units. Only brief comments are made on the character of each fauna and on the fossils that may be particularly useful to stratigraphers. A discussion of the character of the faunas may be found under the heading "Environment suggested by fossils," and discussions of the stratigraphically important fossils are included under the heading "Paleontology of exposed formations." Not all the collections of fossils that were made are included in the fossil lists, as it seems unnecessary to duplicate records at nearby localities. On the other hand, some important occurrences are recorded in the lists on the basis of field determinations of fossils that were not collected. The fossil localities are plotted on the geologic map (pl. 3) and are described on pages 156-166. The report numbers for the localities were assigned before the collections were determined, so some of the collections are not in numerical stratigraphic sequence.
The fossil lists are arranged systematically. An alphabetical arrangement, which was used by Arnold in his reports on the Coalinga district, has many advantages, but it has also disadvantages. The chief disadvantage is the separation of closely allied genera belonging to the same family. This disadvantage is even more marked now than at the time when Arnold prepared his lists, for former broadly conceived genera are now generally dismembered. As an extreme example, the Coalinga Pliocene Pectenidae, which were all listed by Arnold under Pecten, are listed in the present report under Pecten, Aequipecten, Chlamys, Hinnites, Patinopecten, and Lyropecten.

\section{ACKNOWLEDGMENTS}

Many geologists and engineers generously assisted in gathering the data. Special acknowledgment is due to L. C. Decius and J. H. Jenkins, of the Associated Oil Co.; D. T. Hoenshell, of the Kettleman Hills North Dome Association, and A. S. Hayes, C. L. Clark, and S. S. Siegfus, formerly of the same organization; H. H. Dievendorf, of the Petroleum Securities Co.; Max Birkhauser, of the Shell Oil Co.; E. G. Gaylord, G. C. Gester, G. M. Cunningham, John Galloway, W. F. Barbat, J. M. Bugbee, and J. H. Sargent, of the Standard Oil Co. of California; W. A. English and R. C. Ward, of the Superior Oil Co.; R. D. Reed, of the Texas Co. (California); D. B. Myers and L. N. Waterfall, of the Union Oil Co.; R. D. Bush, State oil and gas supervisor; H. V. Dodd, of the California Division of Oil and Gas; R. C. Patterson, John Anderson, and Larry Blessing, of the Conservation Branch of the Geological Survey; D. D. Hughes and Boris Laiming, of the Texas Co. (California), who gave access to an unpublished report on the Foraminifera of the Kreyenhagen shale; and P. P. Goudkoff, of Los Angeles.

Many members of the Geological Survey contributed directly to this report. M. N. Bramlette studied the mineralogy of sandstones in the subsurface section and in corresponding parts of the outcrop section on Reef Ridge and furnished notes on the mineralogy of rock specimens from the Kettleman Hills outcrop section. He also supplied stratigraphic sections of Miocene formations cropping out on Reef Ridge, Chico Martinez Creek, and Zemorra Creek. K. E. Lohman identified the diatoms, wrote the discussions of the diatom floras, and contributed stratigraphic sections of the Temblor formation on Carneros Creek and Anticline Ridge. R. M. Kleinpell, formerly of the Geological Survey, identified Foraminifera from core material and from outcrop localities on Reef Ridge, Zemorra Creek, and Chico Martinez Creek, prepared the discussion of the foraminiferal faunas, and made suggestions concerning the chronology and correlation of the subsurface formations. R. W. Brown identified the land plants. The porosity of samples of oil sand and the character of the bentonite in the McLure shale member were 
determined by P. G. Nutting. A sample of pumice tuff was examined by C. S. Ross and a partial chemical analysis of this tuff was made by R. C. Wells. Other members of the Geological Survey contributed through frequent discussions and by reviewing parts of the report. Special acknowledgment is due to A. A. Baker, James Gilluly, T. A. Hendricks, W. W. Rubey, and P. D. Trask. H. D. Miser, under whose direction this project was planned, enthusiastically supported and encouraged this protracted investigation. The writers are also under obligations to the members of the editorial staff and of the section of illustrations.

Dr. H. A. Pilsbry, of the Academy of Natural Sciences of Philadelphia, generously gave much advice in the identification of the fresh-water mollusks of the Tulare and San Joaquin formations. The bryozoans and ostracodes were examined by Dr. R. S. Bassler and a decapod crustacean by Dr. M. J. Rathbun, both of the United States National Museum. The land mammals were identified by Dr. C. L. Gazin, of the United States National Museum, and Prof. Chester Stock, of the California Institute of Technology; the marine mammals by Dr. Remington Kellogg, of the United States National Museum. Dr. W. K. Gregory, of the American Museum of Natural History, exanined a collection of "bulbous fish growth" from the Tulare formation. A slab of calcareous algae from the Tulare formation was examined by the late Dr. M. A. Howe, of the New York Botanical Garden.

Finally the writers wish to express their gratitude to Ralph Arnold and Robert Anderson, who in their work in the Coalinga district laid a foundation for the study of the geology of one of the most interesting regions in the Coast Ranges.

\section{BIBLIOGRAPHY}

The following bibliography is intended to cover literature dealing with the geology of the Kettleman Hills and nearby regions. It does not include many reports dealing exclusively with the occurrence of oil and gas and other economic aspects.

1894. Watts, W. L., The gas and petroleum yielding formations of the central valley of California: California State Min. Bur. Bull. 3, 100 pp., 7 unnumbered pls., 5 unnumbered figs.

The Kettleman Hills are described on pp. 54-55, and a structure section is shown on p. 67. So far as known this is the earliest usage of the name "Kettleman Hills" in geologic literature.

1894. Cooper, J. G., On some Pliocene fresh-water fossils of California: California Acad. Sci. Proc., 2d ser., vol. 4, pp. 166-172, pl. 14 .

Includes species from strata in Kettleman Hills now referred to Tulare formation.

1905. Anderson, F. M., A stratigraphic study in the Mount Diablo Range of California: California Acad. Sci. Proc., 3d ser., vol. 2, pp. 155-248, pls. 12-35.

The pioneer work on the geology of the Coalinga district. Most of the formation names now in use were proposed in this account.
1908. Anderson, F. M., A further stratigraphic study in the Mount Diablo Range of California: Idem, 4th ser., vol. 3, pp. 1-40.

An amplification and correction of the preceding account.

1908. Arnold, Ralph, and Anderson, Robert, Preliminary report on the Coalinga oil district, Fresno and Kings Counties, Calif.: U. S. Geol. Survey Bull. 357, 142 pp., 2 pls. 1 fig.

A preliminary report on the area covered by Bulletin 398. Cited in the present report only for new formation names.

1910. Arnold, Ralph, Paleontology of the Coalinga district, Fresno and Kings Counties, Calif.: U. S. Geol. Survey Bull. 396, 173 pp., 30 pls., 1909 [1910].

Lists and discusses fossils from formations in the Coalinga district, including the Kettleman Hills, and describes and illustrates many of the species. The lists, discussions, and illustrations were reproduced in Bulletin 398. Bulletin 396 bears the date 1909 but was issued January 15, 1910.

1910. Arnold, Ralph, and Anderson, Robert, Geology and oil resources of the Coalinga district, Calif.: U. S. Geol. Survey Bull. 398, 354 pp., 52 pls., 9 figs.

The standard work on the geology of the Coalinga district, including the Kettleman Hills.

1910. Arnold, Ralph, and Johnson, H. R., Preliminary report on the McKittrick-Sunset oil region, Kern and San Luis Obispo Counties, Calif.: U. S. Geol. Survey Bull. 406, 225 pp., 5 pls., 2 figs.

Geology of the region south of the area covered by Bulletin 398 .

1911. Kellogg, Louise, Fossil beaver from the Kettleman Hills, Calif.: California Univ., Dept. Geology, Bull., vol. 6, pp. 401-402, 1 fig.

Castor californicus, based on a molar tooth from an indefinite locality and horizon in the northern part of the Kettleman Hills. This species was found in the Pecten zone of the San Joaquin formation during the field work for the present report. (See Stirton, 1935.)

1912. Hannibal, Harold, A synopsis of the Recent and Tertiary fresh-water Mollusca of the Californian Province: Malacol. Soc. London Proc., vol. 10, pp. 112-211, pls. 5-8.

Includes descriptions of species from the Tulare formation of the Kettleman Hills.

1915. Clark, W. B., and Twitchell, M. W., The Mesozoic and Cenozoic Echinodermata of the United States: U. S. Geol. Survey Mon. 54, 341 pp., 108 pls.

Includes descriptions of species from the Kettleman Hills and other parts of the Coalinga district.

1915. Merriam, J. C., Tertiary vertebrate faunas of the North Coalinga region of California: Am. Philos. Soc. Trans., new ser., vol. 22, pp. 191-234, 49 figs.

Description of land vertebrates from a Miocene zone and several Pliocene zones at localities a few miles north of the crest of Anticline Ridge. The Jacalitos and Etchegoin formations, heretofore assigned to the upper Miocene, are referred to the Pliocene.

1915. Anderson, Robert, and Pack, R. W., Geology and oil resources of the west border of the San Joaquin Valley north of Coalinga, Calif.: U. S. Geol. Survey Bull. 603, 220 pp., 14 pls., 5 figs.

Geology of an extensive area north of Anticline Ridge.

1916. Nomland, J. O., Relation of the invertebrate to the vertebrate faunal zones of the Jacalitos and Etchegoin formations in the north Coalinga region, Calif.: California Univ., Dept. Geology, Bull., vol. 9, pp. 77-88, pl. 7. 
Relation of Pliocene marine invertebrate zones to Pliocene land vertebrate zones described by Merriam from localities a few miles north of Anticline Ridge.

1916. Nomland, J. O., Fauna from the lower Pliocene at Jacalitos Creek and Waltham Canyon, Fresno County, Calif.: California Univ., Dept. Geology, Bull., vol. 9, pp. 199-214, pls. 9-11.

Fossils from the type region of the Jacalitos formation are listed, and some of the species are described.

1917. Nomland, J. O., The Etchegoin Pliocene of middle California: California Univ., Dept. Geology, Bull., vol. 10, pp. 191-254, pls. 6-12, 2 figs.

Stratigraphy and lithology of the Etchegoin formation (including the Jacalitos formation) principally in the Jacalitos Hills and the Kreyenhagen Hills; lists fossils and describes and figures some of the species, including an Anodonta from the Kettleman Hills.

1917. Nomland, J. O., Fauna of the Santa Margarita beds in the north Coalinga region of California: California Univ., Dept. Geology, Bull., vol. 10, pp. 293-326, pls. 14-20, 2 figs.

Stratigraphy of Santa Margarita sandstone north of Anticline Ridge; lists the fossils and describes and figures some of the species.

1920. Kew, W. S. W., Cretaceous and Cenozoic Echinoidea of the Pacific coast of North America: California Univ., Dept. Geology, Bull., vol. 12, pp. 23-236, pls. 3-42, 5 figs.

Includes descriptions of species from the Coalinga district.

1921. English, W. A., Geology and petroleum resources of northwestern Kern County, Calif.: U.'S. Geol. Survey Bull. 721,48 pp., 2 pls., 2 figs.

Geology of the northern part of the area covered by Bulletin 406 (1910).

1921. Vander Leck, Lawrence, Petroleum resources of California with special reference to unproved areas: California State Min. Bur. Bull. 89, 186 pp., 6 pls., 12 figs.

The Kettleman Hills are considered on pp. 174-175.

1924. Reed, R. D., Role of heavy minerals in the Coalinga Tertiary formations: Econ. Geology, vol. 19, pp. 730749 , figs. $71-72$.

Study of heavy minerals in Tertiary formations in Coalinga district.

1925. Hanna, G. D., The age and correlation of the Kreyenhagen shale in California: Am. Assoc. Petroleum Geologists Bull., vol. 9, pp. 990-999.

The Kreyenhagen of Reef Ridge is considered Eocene; the Kreyenhagen of Anderson and Pack on Anticline Ridge and northward is considered Oligocene, or more probably Miocene.

1926. Reed, R. D., Aragonite concretions from the Kettleman Hills, Calif.: Jour. Geology, vol. 34, pp. 829-833, 2 figs.

Description of aragonite concretions from sand or silt 20 feet below Pecten zone of the San Joaquin formation on the west side of South Dome.

1927. Hanna, G. D., The lowest known Tertiary diatoms in California: Jour. Paleontology, vol. 1, pp. 103-127, pls. 17-21.

The fossils described are from the Kreyenhagen shale, including localities on Anticline Ridge and Domengine Ranch, and are considered of Miocene age.

1929. Hanna, G. D., and Grant, W. M., Brackish-water diatoms from the Etchegoin formation of central California: Jour. Paleontology, vol. 3, pp. 87-100, pls. 11-14.

Describes diatoms from white clay, referred in the present report to the base of the Tulare formation.
1929. Beal, C. H., and Heller, A. H., The Kettleman Hills oil field: Oil Bull., vol. 15, no. 12, pp. 1289-1295, 5 figs.

Describes the geology and oil development.

1929. McCullough, E. H., Kettleman Hills oil field, Calif.: Am. Assoc. Petroleum Geologists Bull., vol. 13, pp. 14791483, 1 fig.

Describes the geology and oil development.

1929. Musser, E. H., Preliminary report on the Kettleman Hills oil field: California Oil Fields (California Div. Mines and Mining), vol. 14, no. 5, pp. 5-17, 2 pls., 1928 [1929].

Describes the subsurface stratigraphy, occurrence of oil, and technology.

1930. Matthew, W. D., A Pliocene mastodon skull from California, Pliomastodon vexillarius n. sp.: California Univ., Dept. Geol. Sci., Bull., vol. 19, pp. 335-348, 4 pls., 2 figs.

Description of a mastodon from the San Joaquin formation of North Dome.

1930. Condit, D. D., Age of Kreyenhagen shale in Cantua CreekPanoche district, Calif.: Jour. Paleontology, vol. 4, pp. 259-262.

Stratigraphy of the Kreyenhagen shale north of the Coalinga district is described and Foraminifera and other fossils are recorded.

1930. Henny, Gerard, McLure shale of the Coalinga region, Fresno and Kings Counties, Calif.: Am. Assoc. Petroleum Geologists Bull., vol. 14, pp. 403-410, 3 figs.

Discussion of shale of Monterey type exposed on Reef Ridge and nearby regions.

1930. Von Estorff, F. E., Kreyenhagen shale at type locality, Fresno County, Calif.: Idem., pp. 1321-1336, 5 figs.

Lithology and paleontology of the Kreyenhagen shale in the type region on Reef Ridge. Also includes a list of fossils from the Avenal sandstone, which is referred to the Domengine.

1931. Galliher, E. W., Collophane from Miocene brown shales of California: Am. Assoc. Petroleum Geologists Bull., vol. 15, pp. 257-269, 10 figs.

Description of pyritized phosphatic pellets from brown shale of the Kettleman Hills and North Belridge fields.

1931. Goudkoff, P. P., Age of producing horizon at Kettleman Hills, Calif.: Idem, pp. 839-842.

Concludes that the upper 700 feet of producing sand is younger than the top of the Temblor formation in the type region.

1931. Lynton, E. D., Some results of magnetometer surveys in California: Idem, pp. 1351-1370, 7 figs.

The Kettleman Hills are considered on pp. 1364-1370. South Dome is considered part of Lost Hills anticline.

1931. Jenkins, O. P., Stratigraphic significance of the Kreyenhagen shale of California: Mining in California, vol. 27 , no. 2 , pp. 141-186, 1 pl., 10 figs.

Summary of the stratigraphy and paleontology of the Kreyenhagen shale, and an annotated bibliography.

1931. Hanna, G. D., Diatoms and silicoflagellates of the Kreyenhagen shale: Idem, pp. $187-201,5$ pls.

Includes descriptions of species from localities on Anticline Ridge and Domengine Ranch. They are considered of probable Eocene age.

1931. Church, C. C., Foraminifera of the Kreyenhagen shale: Idem, pp. 202-213, 3 pls.

Includes consideration of species from the Coalinga district. Foraminifera of the middle and lower parts of the Kreyenhagen north of Coalinga are considered of probable upper Eocene age. 
1931. Grant, U. S., IV, and Gale, H. R., Catalogue of the marine Pliocene and Pleistocene Mollusca of California: San Diego Soc. Nat. History Mem., vol. 1, 1036 pp., 32 pls., 15 figs.

Includes discussion of the Pliocene section in the San Joaquin Valley (pp. 51-53) and consideration of Pliocene mollusks recorded from the Kettleman Hills and other parts of the Coalinga district.

1932. Cunningham, G. M., and Barbat, W. F., Age of producing horizon at Kettleman Hills, Calif.: Am. Assoc. Petroleum Geologists Bull., vol. 16, pp. 417-421.

Contrary to Goudkoff's conclusion, it is concluded that the uppermost part of the producing sand is of the same age as the sandstone at the top of the Temblor formation in the type region.

1932. Barbat, W. F., Age of producing horizon at Kettleman Hills, Calif.: Idem, pp. 611-612.

Typographic error in preceding account is corrected and Gould shale, which is assigned to Temblor formation, is defined.

1932. Galliher, E. W., Organic structure in sediments: Jour. Sedimentary Petrology, vol. 2, pp. 46-47, 2 figs.

The pyritized phosphatic pellets previously described (1931) are considered fecal pellets of some unknown invertebrate.

1932. Dodd, H. J., Recent developments in the Kettleman Hills field: California Oil Fields (California Div. Oil and Gas), vol. 17, no. 1, pp. 5-44, 13 pls., 1931 [1932].

Discussion of the subsurface section and occurrence and character of oil, gas, and water.

1933. Reed, R. D., Geology of California, 355 pp., 60 figs., Tulsa, Am. Assoc. Petroleum Geologists.

Includes descriptions of the stratigraphy and lithology of formations in the Kettleman Hills and discussion (pp. 217-220) of the age of producing sand.

1933. Gester, G. C., and Galloway, John, Geology of Kettleman Hills oil field, Calif.: Am. Assoc. Petroleum Geologists Bull., vol. 17, pp. 1161-1193, 6 figs.

Stratigraphy and structure of the Kettleman Hills, and occurrence of oil and gas.

1934. Barbat, W. F., and Johnson, F. L., Stratigraphy and Foraminifera of the Reef Ridge shale, upper Miocene, Calif.: Jour. Paleontology, vol. 8, pp. 3-17, 1 pl., 1934.

The Reef Ridge shale - one of the units in the Kettleman Hills subsurface section-is defined and described, and the Foraminifera are described.

1934. Goudkoff, P. P., Subsurface stratigraphy of Kettleman Hills oil field, Calif.: Am. Assoc. Petroleum Geologists Bull., vol. 18 , pp. $435-475,8$ figs.

A description and interpretation of Kettleman Hills subsurface section.

1934. Barbat, W. F., and Galloway, John, San Joaquin clay, Calif.: Idem, pp. 476-499, 2 figs.

F. M. Anderson's name "San Joaquin clay" is revived for the upper part of the Etchegoin of Arnold and Anderson, and its occurrence in the Kettleman Hills and in the subsurface section in the southern part of the San Joaquin Valley is described.

1934. Cunningham, G. M., and Kleinpell, W. D., Importance of unconformities to oil production in the. San Joaquin Valley, Calif.: Problems of petroleum geology, pp. 785-805, 5 figs., Tulsa, Am. Assoc. Petroleum Geologists.

Includes data on the geologic history of the Kettleman Hills and other parts of the Coalinga district.

1934. Woodring, W. P., Stewart, Ralph, and Richards, R. W., Geologic map of the Kettleman Hills, Calif. (advance edition, scale 1:31.680): U. S. Geol. Survey.
Some features not shown on the advance edition have been added to the map accompanying the present report, and the base of the San Joaquin formation has been shifted from the Littorina zone to the base of the Cascajo conglomerate, about 100 feet higher stratigraphically.

1934. Pilsbry, H. A., Pliocene fresh-water fossils of the Kettleman Hills and neighboring California oil fields: Nautilus, vol. 48 , pp. 15-17.

Most of the species described in this preliminary account are from the Kettleman Hills.

1934. Dodd, H. V., and Kaplow, E. J., Kettleman North Dome and Kettleman Middle Dome fields, progress in development: California Oil Fields (California Div. Oil and Gas), vol. 18 , no. 4, pp. 5-20, 3 pls., 1 table, 1933 [1934].

Brings earlier accounts to date.

1934. Bramlette, M. N., Heavy mineral studies on correlation of sands at Kettleman Hills, Calif.: Am. Assoc. Petroleum Geologists Bull., vol. 18, pp. 1559-1576, 1 fig.

A comparison of heavy mineral data from sandstones in the Kettleman Hills subsurface section and from the outcrop section along Reef Ridge. This work was undertaken as part of the Geological Survey's Kettleman Hills project, and the results are incorporated in the present report.

1935. Pilsbry, H. A., Mollusks of the fresh-water Pliocene beds of the Kettleman Hills and neighboring oil fields, Calif.: Acad. Nat. Sci. Philadelphia Proc., vol. 86, pp. 541-570, pls. 18-23, 2 figs.

Most of the species described are from the Tulare formation of the Kettleman Hills; a few are from the San Joaquin formation of the same region.

1935. Stirton, R. A., A review of the Tertiary beavers: California Univ., Dept. Geol. Sci., Bull., vol. 23, pp. 391-458, 142 figs., map.

Includes a description of teeth (Castor californicus Kellogg) collected from the Pecten zone of the San Joaquin formation during field work for the present report.

1935. Atwill, E. R., Oligocene Tumey formation of California: Am. Assoc. Petroleum Geologists Bull., vol. 19, pp. 1192-1204, 3 figs.

Stratigraphy and paleontology of the Kreyenhagen shale of Anderson and Pack in the region north of Anticline Ridge.

1935. Hoots, H, W., and Herold, S. C., Natural-gas resources of California: Geology of natural gas, pp. 113-220, 36 figs., Tulsa, Am. Assoc. Petroleum Geologists.

Includes discussion of the Kettleman Hills, pp. 128-136.

1935. Bode, F. D., The fauna of the Merychippus zone, north Coalinga district, Calif.: Carnegie Inst. Washington Pub. 453, pp. 65-96, 2 pls., 10 figs.

Describes the fauna of the Merychippus zone and its occurrence on Domengine Creek north of Anticline Ridge. Includes discussion of correlation with the Kettleman Hills subsurface section.

1935. Cushman, J. A., and Siegfus, S. S., New species of Foraminifera from the Kreyenhagen shale of Fresno County, Calif.: Cushman Lab. Foram. Research Contr., vol. 11. pp. 90-95, pl. 14.

Nine new species from Garza Creek area along Reef Ridge are described and other species are recorded. Attention is drawn to the occurrence of Hantkenina and other Eocene forms. 
1938. Grant, U. S., IV, and Hertlein, L. G., The West American Cenozoic Echinoidea: California Univ. Los Angeles, Pub. Math. Phys. Sci., vol. 2, 225 pp., 30 pls., 17 figs. Includes descriptions of species from Kettleman Hills and other parts of Coalinga district. Some of data covering stratigraphic range of species in Kettleman Hills are erroneous.

1938. Kleinpell, R. M., Miocene strotigraphy of California, 450 pp., 22 pls., 14 figs., Tulsa, Am. Assoc. Petroleum Geologists.

Includes discussion of foraminiferal faunas and age of Miocene subsurface formations in Kettleman Hills and of Miocene formations in outcrop section of Coalinga district.

1939. Vokes, H. E., Molluscan faunas of the Domengine and Arroyo Hondo formations of the California Eocene: New York Acad. Sci. Annals, vol. 38, pp. 1-246, pls. 1-22, map (pl. 17).

Includes description of Eocene sandstone exposed on Reef Ridge (pp. 20-21), assigned to Domengine formation, and its mollusks, and of Eocene deposits and mollusks in other parts of Coalinga district.

1939. Seigfus, S. S., Stratigraphic features of Reef Ridge shale in southern California: Am. Assoc. Petroleum Geologists Bull., vol. 23, pp. 24-44, 5 figs.

Discussion of stratigraphy and Foraminifera of Reef Ridge shale at outcrop and subsurface localities.

\section{LOCATION AND GEOGRAPHIC FEATURES}

The Kettleman Hills lie close to the east foot of the Coast Ranges along the west border of southern San Joaquin Valley, about 175 miles northwest of Los Angeles and about the same distance southeast of San Francisco. (See pl. 2.) The greater part of the area is in Kings County, the northern part extends into Fresno County, and the southern part into Kern County. The Kettleman Hills constitute a northwestwardtrending slightly arcuate range, convex eastward, that has a length of 30 miles and an average width of 4 or 5 miles. As shown in figures 1 and 15, this range forms the main part of the isolated outermost foothills of the Coast Ranges extending southeastward from the mountain front along the axis of the Coalinga anticline. The hills comprise three anticlines and the corresponding geographic divisions are called North Dome, Middle Dome, and South Dome. These anticlines lie in echelon alinement and are offset westward in the order named. (See pl. 1.) Eastward from the Kettleman Fills stretches the flat San. Joaquin Valley for a distance of 60 miles to the foot of the Sierra Nevadi. Tulare Lake, a body of shallow water of considerable extent representing the accumulation of flood waters from Kings River and other streams emerging from the Sierra Nevada, formerly lay east of the Kettleman Hills. Except during years of exceptionally heavy rainfall the lake is no longer in existence owing to increased utilization of the water in the Sierran streams and to reclamation by drainage. The former beach line is within a mile of the edge of the hills at the south end of North Dome. Between the Kettleman Hills and the foot of the Coast Ranges proper lies Kett]eman Plain.
The names North Dome, Middle Dome, and South Dome that are in use for the three divisions of the Kettleman Hills are based on structural features but are applied to geographic divisions. The designation South Dome is inappropriate as regards structure. North Dome and Middle Dome are doubly plunging anticlines, whereas South Dome-or rather the part of South Dome that is visible-plunges northwestward and is overlapped at the south end of the hills by the alluvium of San Joaquin Valley. The geographic name "South Dome" has, however, come into general use. To some geologists accustomed to the usage of the term "dome" for essentially quaquaversal anticlines, the designation of elongate anticlines, such as North Dome and Middle Dome, as domes would also appear inappropriate. The three anticlines in the Kettleman Hills are part of a northwestward-trending line of folds extending from Anticline Ridge to Lost Hills, a distance of 70 miles.

South Dome and Middle Dome are separated by alluvium-floored Avenal Gap, which extends from the Kettleman Plain to the San Joaquin Valley. No feature of this kind separates North Dome and Middle Dome, but the change in the trend of the hills reflects the change in structure, and a southward decrease in ruggedness marks the boundary between them. (See pls. 56,57 .)

North Dome rises to a considerably greater altitude than Middle and South Domes and is more rugged. La Cima, the highest point in North Dome, has an altitude of 1,366 feet above sea level, and rises about 600 feet above the edge of the Kettleman Plain and about 900 feet above the border of the San Joaquin Valley.

Coalinga is 10 miles northwest of the north end of the Kettleman Hills. It is the center for the oil industry operating in the Coalinga fields and for the livestock and agricultural industries of the surrounding region. Avenal, founded after oil development began in the Kettleman Hills, is in the Kettleman Plain west of North Dome. Three public roads extend across the Kettleman Hills. A road along the crest of North Dome and one to the center of Middle Dome were constructed by oil companies. From these main roads many secondary roads and trails branch off, making almost all parts of the hills readily accessible.

Before the establishment of the oil industry a cattle ranch in Avenal Gap was the only permanent habitation in the Kettleman Hills. A sheep ranch at La Porteria, on the east side of Middle Dome, is occupied at intervals. South Dome, the southern part of Middle Dome, and adjoining parts of the Kettleman Plain and San Joaquin Valley are used for grazing cattle. During parts of the year sheep graze in Middle and North Domes. Oil camps have been built in North Dome, and several gasoline plants in North Dome and one in Middle Dome are handling wet gas. 
The Coalinga oil fields are on the Coalinga anticline (Anticline Ridge) and on the monocline on the southwest limb of the adjoining Coalinga syncline. Southeast of the Kettleman Hills lie the Lost Hills, North Belridge, and Belridge fields, all of which are on low anticlinal hills or on the floor of San Joaquin Valley some distance from the mountains. Still farther southeast are the McKittrick and Elk Hills fields and the great area included in the Sunset-Midway field. These fields, or the structural features determining their location, are shown in figure 15.

The San Joaquin Valley and adjoining foothills are characterized by hot summers, mild winters, and low precipitation (almost all of which falls during the

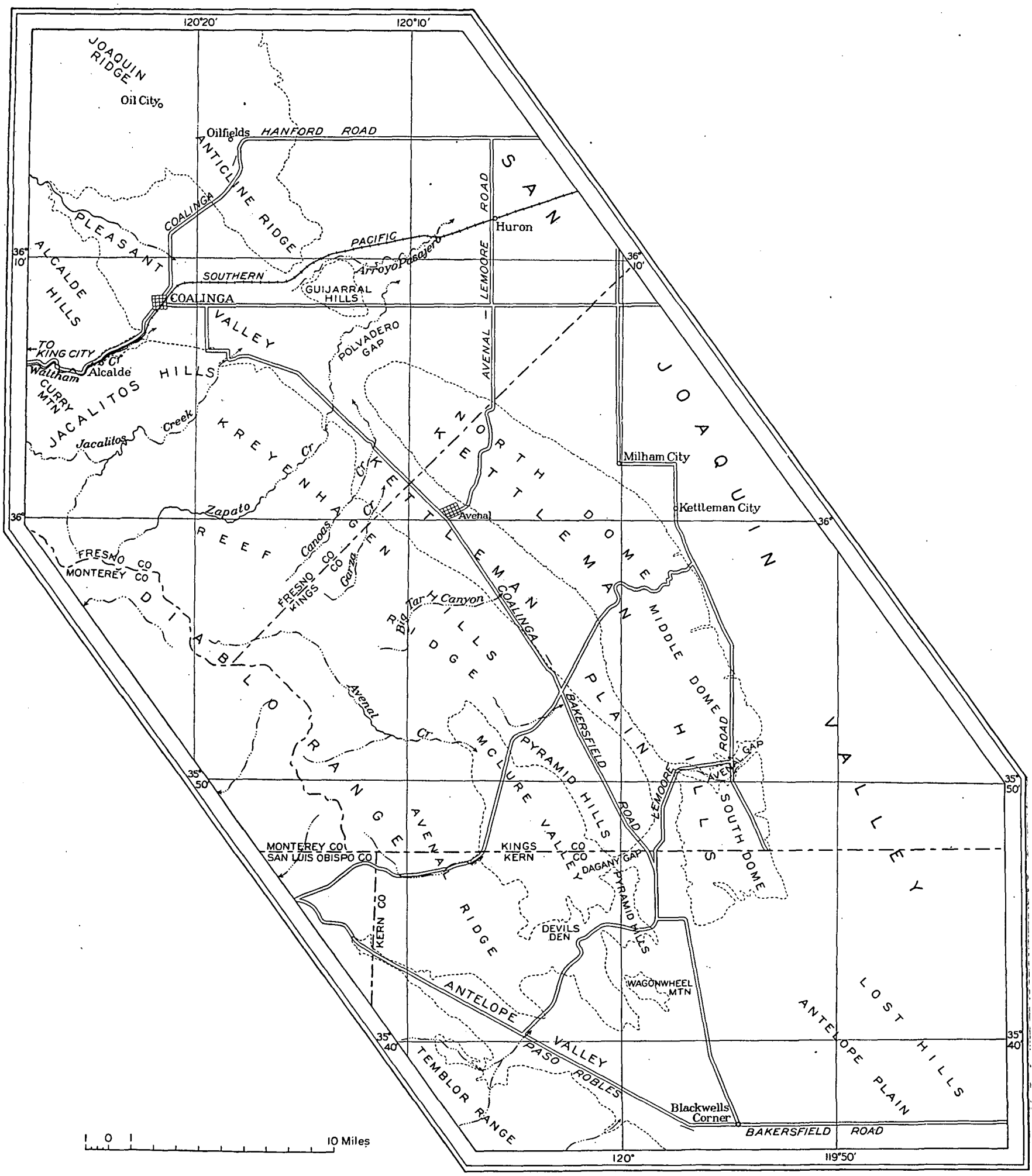

FIGURE 1-Map showing location of Kettleman Hills with reference to other features in the Coalinga and other nearby areas. Dotted line represents edge of alluvium. Adapted from U. S. Geological Survey Bulletins 398 and 721. 
winter) ${ }^{2}$ - the hot desert climate of the modified Köppen classification used by Russell. ${ }^{8}$ The mean annual rainfall decreases southward from 9.2 inches at Fresno to 5.6 inches at Bakersfield and 5.5 inches at Maricopa. (See Bakersfield and Maricopa on fig. 15. Fresno is on the east side of San Joaquin Valley 50 miles northeast of Corlinga.) During the 18-year period from 1912 to 1930 the mean annual rainfall at Coalinga was 6.5 inches, 90 percent of which fell between November 1 and April 30. The summers are virtually rainless. During the same 18-year period Coalinga had a mean annual temperature of $62.9^{\circ}$. During midsummer the temperature frequently rises above $100^{\circ}$, and the average maximum for July and August is a little over $100^{\circ}$. In winter the temperature at times drops below the freezing point, but temperatures below $20^{\circ}$ are rare. The ground fogs that frequently blanket San Joaquin Valley after the winter rains begin extend at times as far west as the Kettleman Hills and rise above them.

The Kettleman Hills support no natural vegetation larger than sagebrush, and except along the deeper arroyos the growth of sagebrush is generally sparse. As in the San Joaquin Valley proper, ${ }^{\theta}$ the vegetation is characterized by weedy annuals, among which brome grasses, alfileria (locally known as filaree), wild oats, and bur clover are abundant. During the winter rains these annuals mature rapidly and produce a green cover, which is luxuriant in years of exceptionally heavy rainfall. Showy flowering plants, particularly lupine, California poppy, and yellow composites, add color to the winter vegetation. After the rains cease these annuals dry up and remain as a dead cover the rest of the year. At the time the field work was in progress the sagebrush in deep sandy soil in Middle and South Domes was dead, probably the result of the period of low rainfall culminating in the year 1928-29, when only 2.1 inches was recorded at Coalinga. The 18-year record at Coalinga shows 3 years in which the annual rainfall was less than 3 inches. These years of exceptionally low rainfall were separated by 5 -year periods of heavier rainfall. The difference in vegetation growing on sandy soil and on clayey soil is well shown in Middle Dome. Sagebrush (Artemisia) is virtually confined to sandy soil, which has also an open cover of relatively large annuals, among which rockcress (Arabis), fiddle-neck (Phacelia), tarweed (Hemizonia), and spikeweed (Centromadia) are conspicuous. Scattered dense clusters of low-growing peppergrass (Lepidium) are characteristic of clayey soil.

\section{OUTLINE OF STRATIGRAPHY}

A generalized stratigraphic section of North Dome, representing exposed formations and those penetrated

7 U. S. Dept. Agr., Weather Bur., Climatic summary of the United States, sec. 17, Contral California, 63 pp., map, 1934.

8 Russcll, E. J., Dry climates of the United States: 1, Climatic map: California Univ. Pub. Gcography, vol. 5, pp. 1-41. 8 figs., map, 1931.

- Shantz, H. L., and Zon, Raphael, Natural vegetation: U. S. Dept. Agr., Atlas Am. Agr., pt. 1, sec. E, pp. 17-18, 1824. by wells-a total thickness of about 14,000 feet-is shown on plate 51 . Aside from differences in thickness, in details of lithology, and in depth of penetration of wells, this section is also representative of Middle and South Domes.

The exposed formations are of Pliocene, or of Pliocene and Pleistocene (?), age, disregarding alluvium deposited since the period of strong deformation. The youngest of these formations, the Tulare formation, consists of nonmarine deposits, principally poorly consolidated or unconsolidated sandstone and conglomerate. The lower part of the Tulare generally embraces thinbedded sandstone, clay, limestone, and tuffaceous material. Underlying the upper Pliocene and Pleistocene (?) Tulare formation is the upper Pliocene San Joaquin formation. It consists of silt and clay, in which marine fossils are generally absent, alternating with beds of sandstone and conglomerate, many of which contain marine or nonmarine fossils. At least some of the deposits of the San Joaquin formation that lack marine fossils appear to be nonmarine. The Middle Pliocene Etchegoin formation, which underlies the San Joaquin, consists principally of marine deposits, but the upper part embraces beds containing freshwater fossils. Sandstone, conglomerate, silt, and tuffaceous material are the prinicpal constituents of the Etchegoin formation. Apparently a considerably greater thickness of Etchegoin is exposed in South Dome than in North or Middle Domes, but the base of the formation is not exposed in the Kettleman Hills.

The formations penetrated by wells range in age from Pliocene to Eocene. The subsurface Etchegoin is not differentiated from the underlying lower Pliocene Jacalitos formation. Both formations consist of sandstone, sandy shale, and shale. Three Miocene formations are recognized. The youngest is the upper Miocene Reef Ridge shale - the caving shale of drillers. It consists of shale, silty shale, and tuffaceous sandstone. Underlying the Reef Ridge shale is the upper Miocene McLure shale member of the Monterey shale, a hard siliceous shale called the brown shale by drillers. The Temblor sandstone, of middle and lower Miocene age, underlies the McLure and embraces oil-bearing zones consisting principally of sand and barren zones made up chiefly of shale. The deepest wells drilled so far penetrate the underlying Kreyenhagen shale, which at the outcrop is of Eocene age, or embraces both Oligocene and Eocene deposits, and enter the McAdams sand, the probable equivalent of the middle Eocene Avenal sandstone, of the Reef Ridge outcrop section.

\section{STRATIGRAPHY OF EXPOSED FORMATIONS}

Generalized stratigraphic sections of the formations exposed in the three anticlines constituting the Kettleman Hills, omitting alluvium, are shown on plate 3 . The total maximum thickness of the exposed formations is about 7,000 feet. The greatest thickness in any 
area, however, does not exceed 6,000 feet, and over much of the region it is not more than 5,000 feet.

The names that are in use for the three exposed formations were proposed many years ago by Anderson ${ }^{10}$ during the course of his pioneer work on the geology of the Coalinga district. The boundaries of these formations have been placed at different horizons, however, by different geologists, depending on individual preferences. This varying usage is a reflection of the absence of unequivocal discontinuities of major magnitude. There is no unconformity (angular discordance) in the entire section, nor is there evidence of disconformities (major discontinuities without angular discordance) of demonstrable major magnitude. The entire section is full of discontinuities; in fact, evidence of discontinuity is apparent at the base of almost any bed composed of material having a larger grain size than the underlying bed. These discontinuities are considered of minor magnitude, for it has not been demonstrated that a considerable thickness of strata was removed during their formation, nor that a considerable thickness of strata, represented elsewhere, was deposited during their formation. Minor discontinuities have been called diastems. ${ }^{11}$ The discontinuities in the Kettleman Hills are considered of diastem rank.

Under these circumstances it is a matter of no great importance at what horizons the formation boundaries are drawn, so long as it is understood where they are placed and so long as a particular horizon is consistently used. It is naturally advantageous to choose horizons that can be recognized with reasonable certainty over as large an area as possible, as such horizons are likely to represent the greatest changes in geologic events. In the present report the base of the Tulare formation is drawn immediately above the youngest widespread marine deposits. This division places some brackishwater beds in the lower part of the Tulare formation which otherwise consists of deposits interpreted as lake and stream deposits. The boundary between the San Joaquin and Etchegoin formations is placed at the base of conglomerate or sandstone correlated on the basis of fossils with conglomerate that rests unconformably on Miocene shale farther south along the west side of San Joaquin Valley. Conglomerate has not been recognized at this horizon everywhere throughout the Kettleman Hills, but it is represented at many localities. This classification places most of the alternating marine and apparently nonmarine deposits in the San Joaquin formation, but leaves in the Etchegoin formation the earliest beds that contain fresh-water fossils. On the advance edition of the geologic map

\footnotetext{
${ }^{10}$ Anderson, F. M., A stratigraphic study in the Mount Diablo Range of California: California Acad. Sci. Proc., 3d ser., vol. 2, pp. 178-182, 1905.

11 Barrell, Joseph, Rhythms and the measurements of geologic time: Geol. Soc. A merica Bull., vol. 28, p. 794, 1917. Eaton, J. E., The bypassing and discontinuous deposition of sedirrentary materials: Am. Assoc. Petroleum Geologists Bull., vol. 13, p. $728,1829$.
}

issued in 1934 the base of the San Joaquin formation was drawn at the base of the earliest bed containing fresh-water fossils. The faunal and lithologic features of this bed are recognizable, however, only in North Dome.

The clay and silt throughout the exposed section are hard rocks when fresh and dry. The rocks made up of coarser constituents present every gradation from loose sand and gravel to hard sandstone and conglomerate. Unconsolidated or imperfectly consolidated rocks are more abundant than firmly cemented rocks, and geologists accustomed to working with older rocks would use terms implying unconsolidation for most of the material. In the descriptions that follow there may be a tendency to favor the use of terms for consolidated rocks.

Pyroclastic material is abundant in the entire exposed section, with the possible exception of the coarse detrital deposits of the Tulare formation, which were not examined for this constituent. Some of this material consists of quite fresh water-laid tuff made up of unaltered glass. Beds of white clay, in which glass shards are still recognizable, represent probably altered tuff. Many of the sandstones are notably tuffaceous or contain notable quantities of material that represents probably an alteration product of volcanic glass.

\section{PLEISTOCENE AND RECENT SERIES}

\section{YOUNGER ALLUVIUM AND EOLIAN DEPOSITS}

The alluvium now being deposited along arroyos in the Kettleman Hills and in the adjoining plains, or recently deposited, is designated younger alluvium. The contact between this alluvium and the deformed strata is more evident along the west flank of North Dome and northern Middle Dome than elsewhere. The younger alluvium extends up flat-floored narrow arroyos for a distance of a mile or more from the edge of the surrounding plains, particularly on the west flank of North Dome. In the low-lying saddle between North and Middle Domes the alluvium extends up wide arroyos several miles from the edge of the San Joaquin Valley. Along Avenal Gap, in the saddle between Middle and South Domes, it forms a relatively wide band entirely across the hills.

The younger alluvium consists chiefly of silt and silty sand. At La Salida, on the east side of Middle Dome, half a mile west of the edge of the San Joaquin Valley, it has a thickness of about 25 feet. Its thickness in the plains surrounding the hills is not known. The younger alluvium is presumably mainly of Recent age. Its physiographic aspects are discussed under the heading "Physiography."

Areas of Recent eolian sand on the east flank of the North Dome-Middle Dome saddle, principally on the leeward (east) side of ridges composed chiefly of sand and sandstone, were mapped. Small areas of eolian deposits in North Dome, mostly derived from older 
alluvium, are shown on the geologic map (pl. 3) by the same pattern as that used for older alluvium.

\section{OLDER ALLUVIUM}

Dissected alluvial deposits lying above the floors of present streams are designated older alluvium. The older alluvium is generally 25 to 150 feet above present strenm beds. The largest areas mapped are on the east flank of North and Middle Domes mainly on the outcrop of the San Joaquin formation. Scattered patches, however, are found at higher altitudes on the outcrop of the Etchegoin formation. This older alluvium consists principally of silty sand. At many places it contains fossils derived from strata cropping out in the Kettleman Hills, notably Pseudocardium and sand dollars.

Gravel occurs at maximum altitudes of 100 to 150 feet above the floor along both flanks of Avenal Gap. Small patches of similar gravel farther south in central and eastern South Dome consist of volcanic rocks, brown sandstone, and red, green, and black chert. Conglomerates in deformed strata that crop out in the Kettleman Hills display similar constituents. The cobbles in the gravel, however, are generally larger than those observed in bedrock conglomerates. On Boulder Hill, where the largest area of gravel is exposed, some of the cobbles are 8 inches long. They decrease in size southward in South Dome.

Silty alluvium 10 to 25 feet above the floor of Avenal Gap is younger than the gravel.

The boundaries of the older alluvium are generally indefinite. The surface on which it rests, bevelling the deformed strata, was observed at only a few places. The older alluvium was deposited since the main erosion of the hills and is presumably of late Pleistocene age. The age, however, depends upon the uncertain dating of the upper part of the Tulare formation and the equally uncertain dating of the physiographic development of the hills. The origin of the older alluvium is discussed under the heading "Physiography."

\section{PLEISTOCENE (?) AND PLIOCENE SERIES}

\section{TULARE FORMATION}

The youngest folded strata in the Kettleman Hills constitute the Tulare formation. They were first noticed by Watts, ${ }^{12}$ and the formation was named by F. M. Anderson..$^{13}$ No type locality was designated, but the Kettleman Hills have been regarded as the type region, ${ }^{14}$ as the exposures there were the only ones described, and the name was derived from Tulare Lake, the shore of which at that time lay close to the east

12 Watts, W. L., Tho gas- and petroleum-yielding formations of the central valley of Californin: California State Min. Bur. Bull. 3, p. 55, fig. on p. 67, 1894.

18 Anderson, F. M. A stratigraphic study in the Mount Diablo Range of California: Californla Acad. Scl. Proc., 3d ser., vol. 2, pp. 181-182, 1905.

14 Arnold, Ralph, and Anderson, Robert, Geology and oil resources of the Coalinga distrist, Calif.: U. S. Crool. Survoy Bull. 398, p. 143, 1910. Anderson, Robert, and Pack, R. W., Creology and oll resources of the west border of the San Joaquin Valley north of Coalinga, Callf: U. S. Geol. Survey Bull, 603, p. 101, 1915. edge of North Dome. It is suggested that the section on La Ceja, on the east side of northern North Dome, which is probably the section examined by Watts and Anderson, be considered the type section, though here, owing to the overlap of alluvium, only the lower part of the formation is exposed.

The Tulare formation consists principally of sandstone, much of which is cross-bedded, silty, and pebbly, and conglomerate, apparently representing stream deposits. Most of this material is poorly consolidated or unconsolidated. At the base of the formation and also at higher horizons in the lower part are thin-bedded, fine-grained sediments-clay, silt, fine-grained sandstone, tuff, and limestone-that are interpreted as lake deposits. Pyroclastic material is abundant in the lower part of the formation. The upper part of the formation was not examined for this constituent. Less information was gathered concerning details of the stratigraphy and lithology of the Tulare formation, except for the basal part, than for the remainder of the exposed section, as the structural features of the anticlines are revealed by the underlying formations. In most of North and Middle Domes the Tulare can roughly be divided into two unequal parts. In these areas beds of conglomerate are generally numerous above a horizon 200 to 600 feet above the base of the formation and at most places are rare or absent below this horizon. At the north end of North Dome-the only place where the conglomerates were mapped-the base of the conglomeratic part represents a zone of interfingering beds. Moreover, on the west side of South Dome conglomerates are as abundant in the lower part of the formation as at higher horizons. It appears improbable that these conglomerates along the west side of South Dome represent an overlap of the upper part of the Tulare, for the marine beds immediately underlying the base of the Tulare elsewhere are recognized in part of this region, and other conglomerates underlie these marine beds at horizons where conglomerate is absent elsewhere.

The base of the Tulare formation is drawn just above the youngest widespread marine deposits constituting the upper Mya zone of the San Joaquin formation. In North Dome the upper Mya zone is overlain by a diatomaceous white silty clay that has been prospected for fuller's earth. This clay, therefore, is considered the basal bed of the Tulare formation. It varies considerably in thickness and in the proportion of detrital constituents. At places it is so diluted with detrital material that it is unrecognizable or it is replaced by other sediments. Where this bed consists principally of white clay it forms a light-co ored band and can readily be traced. Even though the clay could be traced only intermittently, the boundary on the map between the San Joaquin and Tulare formations was drawn at the top of the upper Mya zone, which was recognized more or less continuously throughout the 
hills. This is an arbitrary division of sediments representing a change from a marine environment to an environment of lakes, swamps, and streams. No evidence of a major discontinuity was found at this horizon or at any other in this part of the section. The change in environment was probably due to deformation in the adjoining mountains that may represent an important event in the geologic history of the region, but it is not known whether this event corresponds to a chronologic division, such as the division between Pliocene and Pleistocene time. This horizon was chosen because it seems to represent the greatest environmental change and because the upper Mya zone could be traced with a reasonable degree of assurance. It has also the further cartographic advantage of showing by means of one line the boundary between the Tulare and San Joaquin formations and the outcrop of the upper Mya zone, which can be recognized in the field by its fossils. If the base of the conglomerates represented the same horizon throughout the hills, it would be advantageous to choose that horizon as the base of the Tulare. The conglomerates represent a change in erosional and depositional history, and the base of the Tulare along most of the mountain front may lie at a higher horizon than the white clay and other fine-grained rocks in the Kettleman Hills. The boundary between the Tulare and the San Joaquin has been placed at other horizons by other geologists: at the top of the white clay ${ }^{15}$ and also higher-at the base of the fossiliferous sandy and limy beds here designated the lower Amnicola zone. ${ }^{16}$

The conformable relation between the Tulare and San Joaquin formations in the Kettleman Hills is exceptional. Along the border of much of the Temblor Range and along the greater part of the Diablo Range the Tulare rests with discordance on Pliocene or older formations. These relations seem to indicate that the Kettleman Hills lie near the trough of the basin in which the late San Joaquin and Tulare sediments were laid down. The Tulare has been described as resting disconformably on the San Joaquin in the Kettleman Hills. ${ }^{17}$ This interpretation appears to be based on assignment of Amnicola-bearing beds, which are at a lower horizon than the base of the lower Amnicola zone elsewhere, to the lower Amnicola zone. It seems to be doubtful, however, whether the presence of Amnicola and other fossils is sufficient evidence to determine the stratigraphic relations.

The overlap of recent alluvium covering San Joaquin Valley conceals a large part of the Tulare formation on the east side of the Kettleman Hills. The greatest

\footnotetext{
15 Arnold, Ralph, and Anderson, Robert, op. cit. (Bull. 398), p. 144.

16 Reed, R. D., Geology of California, fig. 52 (op. p. 254), Tulsa, Am. Assoc. Petroleum Geologists, 1933. Gester, G. C., and Galloway, John, Geology of Kettleman Hills oil field, Calif.: Am. Assoc. Petroleum Geologists Bull., vol. 17, pp. 11721173, fig. 3 (p. 1169), 1933. Barbat, W. F., and Galloway, John, San Joaquin clay, California: Idem., vol. 18, pp. 480, 481, 1934.

${ }_{17}$ Gester, G. C., and Galloway, John, op. cit. Barbat, W. F., and Galloway, John, op. cit.
}

exposed thickness on the east side is in southern North Dome, where the thickness is 1,700 feet. On the west side of the hills the exposed thickness increases from 1,700 feet in northern North Dome to 2,600 feet in southern North Dome, rises to a maximum of 3,500 feet in central Middle Dome, and decreases to 2,400 feet in South Dome. These figures are based on map computations that are not everywhere adequately controlled. The only fairly complete section that was measured in the field shows a thickness of 1,958 feet (see pp. 21-22) on the west side of southern North Dome, but this section does not include several hundred feet of poorly exposed beds near the edge of the hills. Though the overlap of alluvium makes estimates uncertain, the formation is probably thickest on the west side of central Middle Dome, where the greatest thickness is exposed, and thins northward, southward, and eastward.

\section{STRATIGRAPHY AND IITHOLOGY \\ EAST FLANK OF NORTH DOME}

The diatomaceous white silty clay mapped as the base of the Tulare formation is exposed almost continuously from the north end of North Dome southward to the south end of La Ceja. Farther south it was recognized at scattered localities, but in this region it is diluted with sand and at many places is not recognizable. The thickness of the clay and the percentage of detrital constituents vary from place to place (fig. 2). A prospect pit on the north line of sec. 35, T. 21 S., R. 17 E., near the Avenal-Lemoore road, exposes a thickness of 12 feet. In a nearby trenched section a thickness of 16 feet was measured. The clay exposed in the prospect pit is dirty white and is stained yellowish brown by small ferruginous concretions that lie along bedding planes. Thin laminae contain scattered sand grains. A layer half a foot from the top yielded a fragmentary leaf imprint and an impression of a fresh-water mussel. The clay is overlain along a sharp minutely irregular contact by rather dirty fine-grained sand that becomes cleaner upward. Narrow burrows filled with this sand extend down into the clay. A sample of the clay from this locality examined by M. N. Bramlette contains glass shards, indicating that it is an altered tuff. According to a preliminary examination by P. G. Nutting, this clay fails to qualify as a commercial bleaching clay, though when treated with acid its bleaching quality is superior to that of a clay in the upper part of the Etchegoin formation of Middle Dome, which has also been prospected.

The beds between the white clay and the lower Amnicola zone consist principally of sand and clay, which are generally poorly exposed. West of the fault running through the gap traversed by the road in the northeastern part of sec. 28 , T. 21 S., R. 17 E., a fresh tuff overlies the white clay (fig. 2 , column 2). The tuff, which has a maximum thickness of 15 inches, and an overlying limy sandstone, 3 to 6 feet thick, contain 
NW.

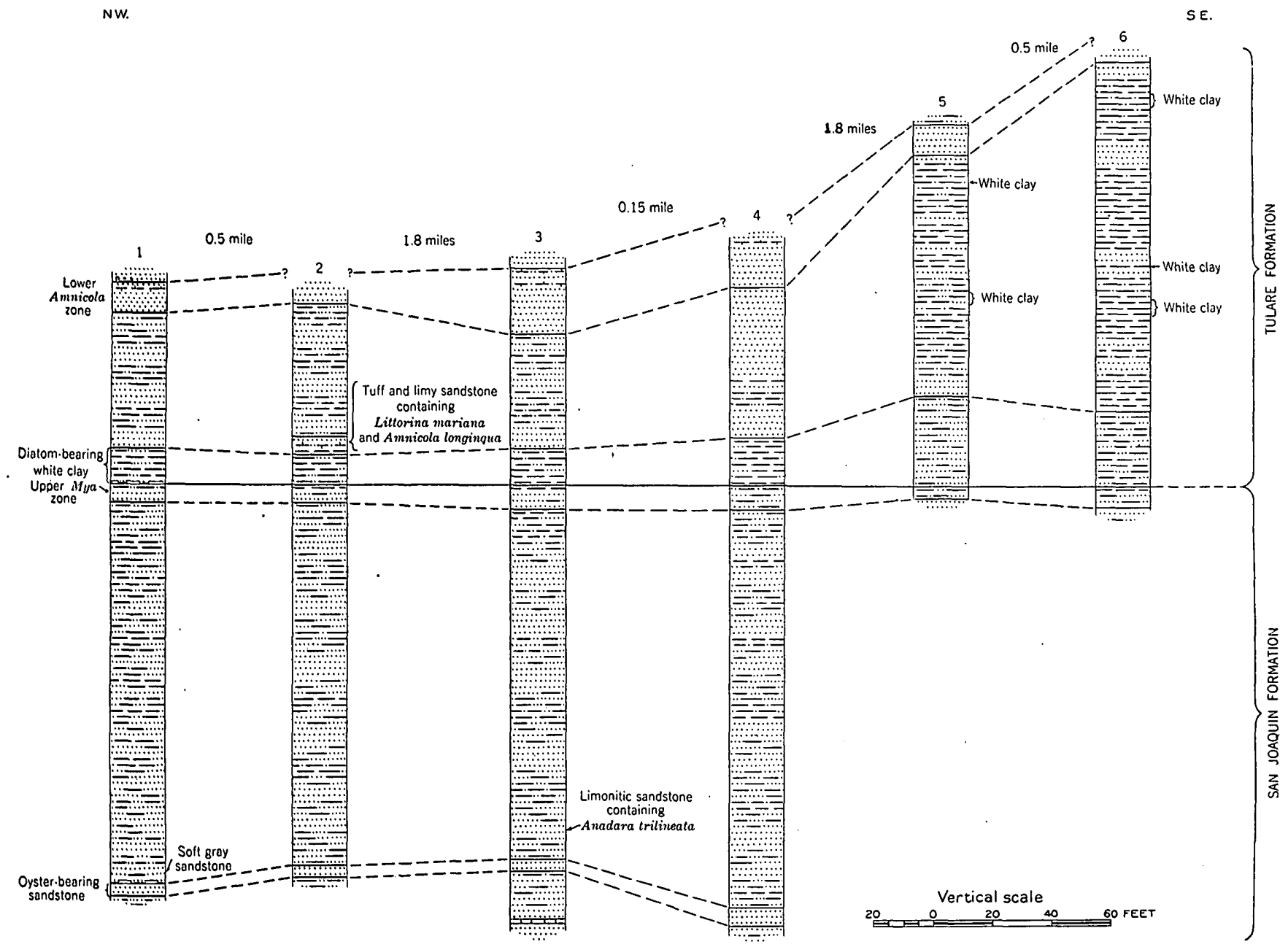

Fiouri 2.-Sections of lower part of Tulare formation and upper part of San Joaquin formation on east flank of northern North Dome. Figures between columns represent distances between sections.

1. Half a millo southeast of Arroyo Vadosa, sec. 28, T. 21 S., R. 17 E.

2. Spur west of road, northenstern part of sec. $28, T$, 21 S., R. 17 E. (locality 3).

3. La Ceja, a quarter of a mile southeast of Avenal-Lemoore road, sec. 35, T. $21 \mathrm{~S}$.,

R. 17 E. (localities 5, 6, 7, 29, 51).

4. La Cojn, 750 leet southeast of proceding soction.

Littorina and Amnicola (locality 3).18 Both beds also contain molds, representing probably fresh-water mussels. These beds extend northwestward along the strike for a distance of about 150 feet and lens out. According to Bramlette, the tuff consists principally of glass, which has an index of refraction of about 1.50 and contains much biotite, some andesine, and a little augite and hornblende.

Beds that apparently underlie the lower Amnicola zone are well exposed on the east side of Arroyo Largo. At that locality a ledge-making Amnicola-bearing sandstone, which forms the crest of the ridge to the southeast where it was mapped as the base of the lower Amnicola zone, is the highest bed exposed. Cross-bedded and evenly bedded sand, sandstone, silty sandstone, and

18 The fossil localities are plotted on the geologic map, plate 3, and are described on pages $150-160$.
5. Near Arroyo Torcido, 350 feet along strike southeast of north line of sec. 6, T. 22 S., R. $18 \mathrm{E}$.

6. Near Arroyo Torcido, northern part of sec. 6, T. 22 S., R. 18 E., 2,500 teet along strike southeast of preceding section.

limy sandstone, representing a thickness of about 50 feet, underlie the ledge-making bed. A ferruginous brown sandstone, which is 30 feet below the ledgemaking sandstone and is crowded with Amnicola, is particularly prominent. Weathered outcrops of Amnicola-bearing sandstone are found farther southeast between Arroyo Largo and the Avenal-Lemoore road at a horizon between the white clay and the ledge-making sandstone. The presence of Amnicola-bearing beds so low in the section may point to an erosional disconformity at the base of the lower Amnicola zone, but it seems probable that these fossiliferous beds are the lateral equivalent of beds elsewhere barren of fossils.

The following section of the lower part of the Tulare formation was measured by trenching on La Ceja a quarter of a mile northwest of Arroyo Bifido (fig. 2, column 4): 
Section of basal part of Tulare formation on La Ceja, a quarter of a mile northwest of Arroyo Bifido, sec. 35, T. 21 S., R. 17 E.

[Measured by G. F. Taylor]

Tulare formation:

Hard brown ferruginous sandstone, many Amnicola, taken as base of lower Amnicola zone; but may correspond to unit $5 \mathrm{c}$ of section on page 17 .

Medium-grained gray sand......................

Fine-grained, concretionary gray sandstone. . . . . . .

Fine-grained gray sand .........

Fine-grained, concretionary gray sandstone. . . . . . -

Fine-grained gray sand .............................

Dirty white silty clay . . . . . . . . . . . . . . . . . .

Fine-grained gray sand, stained yellowish brown....

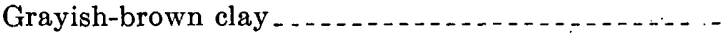

Fine-grained gray sand........................

Grayish-brown silty clay -........

Fine-grained gray sand .............................

Dirty white silty and sandy clay

Thickness of Tulare formation below base of lower

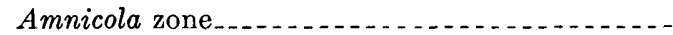

San Joaquin formation, upper Mya zone:

Silt, clay, and silty clay:

Grayish-brown silty clay, probably representing upper part of upper $M y a$ zone that elsewhere contains small oysters.....................

Grayish-brown silt and clay, sandy toward base; contains Calyptraea, Ostrea, Saxidomus, Mya.

Two sections measured farther southeast near Arroyo Torcido at localities 2,500 feet apart along the strike are as follows (fig. 2, columns 5, 6):

Section of basal part of Tulare formation near Arroyo Torcido, 350 feet along strike southeast of north line of sec. 6, T. 22 S., R. 18 E.

Tulare formation:

$$
\text { [Measured by G. F. Taylor] }
$$

Grayish-brown mudstone.

Lower Amnicola zone:

Brownish-gray to gray sandstone, many Amnic-

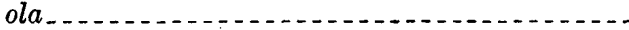

Hard brown ferruginous sandstone, Amnicola

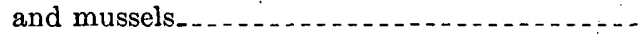

Brown ferruginous sand, few Amnicola .......

Hard brown ferruginous sandstone, Amnicola, Sphaerium, and mussels.................

Beds below lower Amnicola zone:

Gray sand

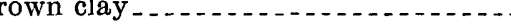

Clay and silty clay:

Grayish-brown silty clay...............

Grayish-brown clay .....................

Yellowish-brown sand

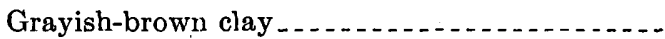

Yellowish-brown sand .....................

Grayish-brown clay .........................

Yellowish-brown sand

Clay and silty clay:

Gray silty clay

Grayish-brown clay .........................

Dirty white silty clay, stained yellow
Section of basal part of Tulare formation near Arroyo Torcido, 350 feet along strike southeast of north line of sec. 6, T. 22 S., $R$. 18 E.-Continued.

Tulare formation-Continued.

Beds below lower Amnicola zone-Continued.

Clay and silty clay:

Light-gray clay grading downward into un-

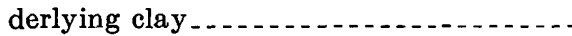

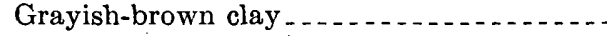

Grayish-brown silty clay ...................

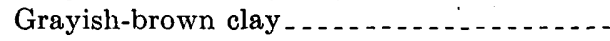

Grayish-brown sandy clay .................

Yellowish-brown sand . . . . . . . . . . . . . . . .

Silty and sandy clay and silty sand:

Dirty white silty and sandy clay .........

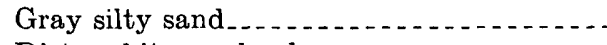

Dirty white sandy clay .....................

Gray silty sand $\ldots$

Thickness of Tulare formation below lower Amnicola zone...............

San Joaquin formation, upper Mya zone:

Grayish-brown silty clay representing upper part of upper Mya zone; contains oysters.

Section of lower part of Tulare formation near Arroyo Torcido, northern part of sec. 6, T. 22 S., R. 18 E., 2,500 feet along strike southeast of locality of preceding section

Tulare formation:

[Measured by G. F. Taylor]

Gypsiferous hard brown sandstone, Amnicola and Feet mussels (base of lower Amnicola zone)

Yellowish-brown sand ........................ 4

Clay:

Grayish-brown clay .................... 7

Dirty white clay ......................... 3

Gypsiferous grayish-brown clay.............. 13

Gypsiferous yellowish-brown sand.............. 8

Gypsiferous grayish-brown clay _................. 27

Gypsiferous yellowish-brown sand .............. 3

Dirty white clay, stained yellow .............. 2

Gray to grayish-brown sand.................... 2

Clay:

Gypsiferous grayish-brown clay

Dirty white clay.

$\begin{array}{rr}\text { Grayish-brown clay } \ldots \ldots & 10\end{array}$

Grayish-brown clay

Gray sand . .

Grayish-brown clay ................. 14

Dirty white sandy clay................... 25

Thickness of Tulare formation below base of lower

Amnicola zone........................... 139

San Joaquin formation, upper Mya zone:

Grayish-brown clay .......................... 3

Grayish-brown sandy clay, contains oysters....... 4

On Arroyc Estrecho, at the south end of North Dome, an Amnicola-bearing sandstone lies about 30 feet above the base of the formation, but in that area the base of the lower Amnicola zone is not clearly defined (see section, p. 18). 
The lower Amnicola zone embraces beds in which fresh-water fossils are abundant, particularly small snails of the genus Amnicola. One or more hard ferruginous or limy sandstones, which are oolitic on the east side of Middle Dome, also serve to identify the zone at many places. These hard sandstones stand in marked contrast to the sand and soft sandstone that make up the bulk of the lower part of the Tulare. In the absence of good exposures the lowest of the hard sandstones was mapped as the base of the zone. On the east side of northern North Dome the base of the lower Amnicola zone is 50 to 150 feet above the base of the formation, and the thickness of beds embraced in the zone, as determined by the lower and upper limits of abundant fossils, ranges from 10 to 25 feet (fig. 2). Farther south the zone is thicker and the base is generally about 150 feet above the base of the formation, but at some localities fossiliferous beds occur at a horizon about 50 feet above the base. The varying position of the base and top may be due to thickening and thinning of the lower part of the formation, to the lensing of fossiliferous beds, to a combination of these changes, or to an erosional discontinuity. In view of the uncertainty that the base and top represent the same horizons in different regions, the observed relations are probably the result of changes in thickness and of lensing. The base of this zone is considered by some geologists as the base of the Tulare formation, but its doubtful stratigraphic quality and the uncertainty of its recognition in parts of the hills make it an unsatisfactory horizon at which to place a major stratigraphic division.

The following section of the lower Amnicola zone, embracing a thickness of about 10 feet, was measured half a mile southeast of Arroyo Vadosa (fig. 2, column 1):

Section of lower Amnicola zone in lower part of Tulare formation half a mile southeast of Arroyo Vadosa, northeastern part of sec. 28, T. 21 S., R. $17 \mathrm{E}$.

Coarse sandstone forming crest of ridge farther west, includes lenses of conglomerate.....................

Lower Amnicola zone:

Ferruginous limy sandstone, molds of mussels _... 3

Ferruginous sand . . .

Speckled grayish-olive sand and polished spherules of brown iron oxide; 4 - to 5-inch layer near top contains paired mussels......................

Ferruginous sand.

Ferruginous poorly cemented sand; contains Amnicola

Thickness of lower Amnicola zone........

Ft. in. 13 $\stackrel{1}{=}$ 3 23 111 11 18 $9 \quad 11$

The most readily accessible exposures of the lower Amnicola zone are on La Ceja, southeast of the AvenalLemoore road, in the strata suggested as the type section of the Tulare formation. The following section was measured on La Ceja (fig. 2, column 3):
Section of basal part of Tulare formation on La Ceja, a quarter of a mile southeast of Avenal-Lemoore road, sec. 35, T. 21 S., R. 17 E.

Lower Amnicola zone:

10. Ferruginous concretionary dirty sand

9. Limestone and marl:

c. Hard ledge-making limestone, molds of mussels and Sphaerium.................

b. Soft marl

a. Impure limestone, molds of mussels and

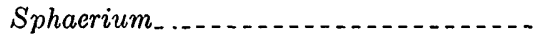

8. Ferruginous concretionary dirty sand $\ldots . .$.

7. Sand:

e. Hydrobia-bearing sand . ............

d. Speckled grayish-olive sand, many polished spherules of brown iron oxide of about same size as sand grains; 3 -inch layer at top contains mussels; collection of fossils (locality 7 ) represents

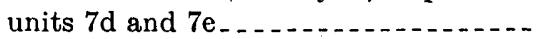

c. Ferruginous dirty sand; ferruginous concretions at top.....................

b. Amnicola-bearing sand...........

a. Ferruginous sand.......................

6. Unexposed; probably same material as unit $7 a$

5. Sand:

d. Poorly cemented brown sand, few Amnicola

c. Hard brown sandstone, Amnicola concentrated at base and scattered through-

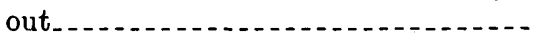

b. Poorly cemented brown sand; $1 / 2$-inch mudstone layer at top containing many Amnicola.........................

a. Cross-bedded brown sandstonc, scattered Amnicola.............

4. Sand:

b. Amnicola-bearing sand; lower 21 inches crowded with Amnicola; 8 inches below top layer of ferruginous concretions contains at top "bulbous fish growths" (see p. 97) ........

a. Brown dirty sand, molds of mussels; 3 inches above base layer of ferruginous concretions contains at top "bulbous fish growths" and Amnicola (locality 6) .

3. Ferruginous dirty sand, many Amnicnla

Maximum thickness of lower Amnicola

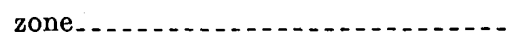

Beds below lower Amnicola zone:

2. Unexposed, except few inches of gray sand immediately overlying unit 1...........

1. Dirty white silty clay containing fresh-water diatoms (locality 5)

Thickness of Tulare formation below lower Amnicola zone....... . ........ $49 \quad 6$

Unit $7 \mathrm{~d}$ of this section and also unit 3 of the preceding section, measured near Arroyo Vadosa, are made up of about equal amounts of sand grains and polished 
spherules of brown iron oxide. The spherules have the same size range as the sand grains-from a little less than half a millimeter to a little more than a millimeter. Though they are dark brown, they give the sand a speckled olive-green color. These spherules are apparently an oolitic form of iron oxide. The lower Amnicola zone throughout the hills contains more iron oxide than other parts of the formation. Unit 8 of the section on La Ceja has lavender blotches attributed to manganese oxide. The iron and manganese oxides are interpreted as representing bog deposits that accumulated in swamps on the edge of the lake in which these fine-grained sediments were laid down. In addition to the fresh-water snails and mussels, "bulbous fish growths" (described on p. 97) are conspicuous fossils in certain beds at this and other localities.

Along part of the east flank of North Dome-near Arroyo Torcido, and southward from Arroyo Doblegado-Amnicola-bearing sandstones are at two horizons separated by 50 to 150 feet of beds apparently barren of fossils. The beds at the lower horizon, 50 to 150 feet above the base of the formation, correspond to those just described. Those at the upper horizon are less persistent. Both sets of fossiliferous sandstones are referred to the lower Amnicola zone. On Arroyo Estrecho, where the following section was measured, Amnicola-bearing sandstones are scattered through the lower 300 feet of the formation, and a division into two horizons is not apparent. A 10 -inch bed of white clay, partly altered to siliceous shale, is conspicuous in this section.

Section of lower part of Tulare formation on Arroyo Estrecho, NE1/4 sec. 6, T. 23 S., R. 19 E.

[Measured by G. F. Taylor]

Tulare formation:

Sandstone and sand:

Hard grayish-brown sandstone, many Amnicola (top of lower Amnicola zone) .........

Grayish-brown sand ..................

Hard grayish-brown sandstone, uppermost 6 inches contains Amnicola

Grayish to yellowish-brown sand, Amnicola in some layers. . . . . . . . . . . . . . . . .

Hard grayish-brown sandstone.

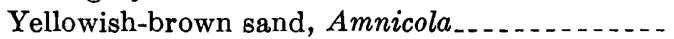

Hard grayish-brown sandstone.....

Yellowish-brown cross-bedded sand, Amnicola.

Hard yellowish-brown standstone, Amnicola

Yellowish-brown cross-bedded sandstone, Amnicola _...

White clay partly altered to siliceous shale...-

Yellowish-brown cross-bedded sand, Amnicola

Hard grayish-brown sandstone..............

Poorly exposed yellowish-brown sand, hard grayish-brown sandstone, and brown clay; some beds contain Amnicola............. 200士

Hard grayish-brown sandstone, Amnicola.....

Poorly exposed yellowish-brown sand and clay.-

Thickness of Tulare formation measured. . . $300 \pm$ San Joaquin formation, upper Mya zone.
The uppermost Amnicola-bearing bed on the ridge between Arroyo Robador and Arroyo Pino may correspond to the upper Amnicola zone recognized in Middle Dome and on the west side of southern North Dome.

Most of the conglomeratic upper part of the Tulare formation is overlapped by alluvium on the east side of North Dome. In the area between Arroyo Vadosa and Arroyo Largo the lowest thick zone of conglomerate, 375 feet above the base of the Tulare, forms a low ridge or disconnected low hills. The conglomerate is composed principally of cobbles of brown sandstone that have a maximum length of about 6 inches. Heavy conglomerates, like those just described, form a discontinuous ridge between Arroyo Bifido and Arroyo Torcido, but at this locality they are 500 to 625 feet above the base of the formation. Several hundred feet of cross-bedded channeled coarse-grained sandstone underlying the conglomerates is well exposed on Arroyo Torcido. Farther southeast on Arroyo Hondo no heavy conglomerates were observed in the exposed part of the formation. On Arroyo Doblegado the Tulare above the lower Amnicola zone is made up almost entirely of massive or thinly bedded, cross-bedded, or evenly bedded sandstone, much of which is channeled. Small pebbles and chips of white siliceous shale are common in some beds. Amnicola and Sphaerium were observed on Arroyo Degollado in a sandstone about 600 feet above the base of the formation, and an Amnicolabearing sandstone at about the same horizon, or higher, is exposed on Arroyo Estrecho. At the south end of North Dome, east of La Lomica, is a conglomerate ridge 575 feet above the base of the formation. The material, which consists of pebbles less than half an inch long and a few cobbles as much as 6 inches long, represents lava, granitic and basic intrusives, chert, and sandstone. In this region about 1,200 feet above the base of the formation is a thicker zone of conglomerates. Small oysters, Littorina, and a fresh-water snail, identified in the field as Amnicola but possibly representing Fluminicola, occur together in sandstone that includes also lenses of conglomerate at the top of this zone (locality 13).

\section{EAST FLANK OF MIDDLE DOME}

The white clay at the base of the Tulare was not recognized south of the north end of Middle Dome. The base of the lower Amnicola zone along the east flank of Middle Dome is 100 to 150 feet above the base of the formation. The zone has a maximum thickness of at least 120 feet and embraces several conspicuous beds of fossiliferous sandstone and limestone, some of the latter oolitic. The following section, which probably represents virtually the full thickness of the zone, though the base is not exposed, was measured at La Salida, where Arroyo Culebrino is deeply entrenched. 


\section{PLATE 4}

Figures 1, 2. Valvata virens platyceps Pilsbry. Paratypes. Locality 19, upper Amnicola zone.

1. Height $3.8 \mathrm{~mm}$., width $3.6 \mathrm{~mm}$. U. S. Nat. Mus. 495198.

2. Height $2 \mathrm{~mm}$., width $2.1 \mathrm{~mm}$. U. S. Nat. Mus. 495199.

3. Valvata humeralis californica Pilsbry. Height $2.5 \mathrm{~mm}$., width $3.7 \mathrm{~mm}$. Locality 20, lower Amnicola zone. U. S. Nat. Mus. 495200.

4-6. Littorina mariana Arnold. Locality 3, below lower Amnicola zone.

4. Height (incomplete) $10 \mathrm{~mm}$., width $6.6 \mathrm{~mm}$. U. S. Nat. Mus. 495201.

5. Height (incomplete) $13 \mathrm{~mm}$., width $11 \mathrm{~mm}$. U. S. Nat. Mus. 495202.

6. Height (incomplete) $10.3 \mathrm{~mm}$., width $9.1 \mathrm{~mm}$. U. S. Nat. Mus. 495203.

7-9. Fluminicola cf. F. spiralis Pilsbry. Locality 4732, lower Amnicola zone.

7. Height $3.7 \mathrm{~mm}$., width $2.6 \mathrm{~mm}$. U. S. Nat. Mus. 495204 .

8. Height $3.1 \mathrm{~mm}$., width $2.4 \mathrm{~mm}$. U. S. Nat. Mus. 495205 .

9. Height $2.8 \mathrm{~mm}$., width $1.9 \mathrm{~mm}$. U. S. Nat. Mus. 495206.

10, 11. Fluminicola ef. F. spiralis Pilsbry. Locality 19, upper Amnicola zone.

10. Height $4.5 \mathrm{~mm}$., width $3.1 \mathrm{~mm}$. U. S. Nat. Mus. 495207.

11. Height 3.1 mm., width $2.6 \mathrm{~mm}$. U. S. Nat. Mus. 495208 .

12. Fluminicola ef. F. yatesiana (Cooper). Length $3.1 \mathrm{~mm}$., width $2.2 \mathrm{~mm}$. Locality 8 , lower Amnicola zone. U. S. Nat. Mus. 495209

13-16. Pyrgulopsis vincta Pilsbry. Locality 20, lower Amnicola zone.

13. Height $3.7 \mathrm{~mm}$., width $2.2 \mathrm{~mm}$. U. S. Net. Mus. 495210.

14. Height $3.8 \mathrm{~mm}$., width $2.2 \mathrm{~mm}$. U. S. Nat. Mus. 495211.

15. Height about $3.0 \mathrm{~mm}$., width $1.8 \mathrm{~mm}$. U. S. Nat. Mus. 495212 . (Specimen broken after drawing was made.)

16. Height $4 \mathrm{~mm}$., width $2 \mathrm{~mm}$. U. S. Nat. Mus. 495213.

17, 18. Calipyrgula carinifera Pilsbry. Paratypes. Locality 7, lower Amnicola zone.

17. Height $3 \mathrm{~mm}$., width $1.3 \mathrm{~mm}$. U. S. Nat. Mus. 495215.

18. Height $3.4 \mathrm{~mm}$., width (incomplete) $1.3 \mathrm{~mm}$. U. S. Nat. Mus. 495216.

19. Calipyrgula ellipsostoma Pilsbry. Height (incomplete) $2.9 \mathrm{~mm}$., width $1.2 \mathrm{~mm}$. Locality 10, lower Amnicola zone.

U. S. Nat. Mus. 495217.

20, 21. Calipyrgula stewartiana Pilsbry. Topotypes. Locality 14, lower Amnicola zone.

20. Height $2.5 \mathrm{~mm}$., width $1.4 \mathrm{~mm}$. U. S. Nat. Mus. 495219.

21. Height $3.1 \mathrm{~mm}$., width $1.7 \mathrm{~mm}$. U. S. Nat. Mus. 495220.

22. Littoridina woodringi Pilsbry. Paratype. Height $3 \mathrm{~mm}$., width $1.7 \mathrm{~mm}$. Locality 19, upper Amnicola zone.

U. S. Nat. Mus. 495222.

23-27. Amnicola longinqua Gould. Lower Amnicola zone.

23. Height $4 \mathrm{~mm}$., width $2.4 \mathrm{~mm}$. Locality 20. U. S. Nat. Mus. 495223.

24. Height $3.9 \mathrm{~mm}$., width $2.7 \mathrm{~mm}$. Locality 20. U. S. Nat. Mus. 495224.

25. Height $4 \mathrm{~mm}$., width $2.4 \mathrm{~mm}$. Locality 20. U. S. Nat. Mus. 495225.

26. Height $3.9 \mathrm{~mm}$., width $2.3 \mathrm{~mm}$. Locality 18. U. S. Nat. Mus. 495226 .

27. Height $3.3 \mathrm{~mm}$., width $2 \mathrm{~mm}$. Locality 18. U. S. Nat. Mus. 495227 .

28-34. Hydrobia andersoni (Arnold). Lower Amnicola zone.

28. Holotype. Height $4.2 \mathrm{~mm}$., width $2.4 \mathrm{~mm}$. Locality 4732 . U. S. Nat. Mus. 165505.

29. Topotype. Height $3.3 \mathrm{~mm}$., width $2.3 \mathrm{~mm}$. Locality 4732 . U. S. Nat. Mus. 495228.

30. Topotype. Height $3.4 \mathrm{~mm}$., width $2.2 \mathrm{~mm}$. Locality 4732 . U. S. Nat. Mus. 495229.

31. Topotype. Height $3 \mathrm{~mm}$., width $1.8 \mathrm{~mm}$. Locality 4732 . U. S. N乞t. Mus. 495230.

32. Height $3 \mathrm{~mm}$., width $1.9 \mathrm{~mm}$. Locality 7. U. S. Nat. Mus. 495231.

33. Height $2.9 \mathrm{~mm}$., width $1.9 \mathrm{~mm}$. Locality 7. U. S. Nat. Mus. 495232.

34. Height $3.5 \mathrm{~mm}$., width $1.8 \mathrm{~mm}$. Locality 7. U. S. Nat. Mus. 495233.

35-38. Brannerillus physispira Hannibal. Lower Amnicola zone.

35, 36. Height $3.2 \mathrm{~mm}$., width $2.8 \mathrm{~mm}$. Locality 8. U. S. Nat. Mus. 495234.

37, 38. Height $2.7 \mathrm{~mm}$., width $3.1 \mathrm{~mm}$. Locality K14 (U. S. G. S. 13380). U. S. Nat. Mus. 495235.

39-50. Brannerillus involutus Pilsbry. Lower Amnicola zone.

39, 40. Height $3 \mathrm{~mm}$., width $2.2 \mathrm{~mm}$. Locality 21. U. S. Nat. Mus. 495236.

41, 42. Height $4 \mathrm{~mm}$., width $2.8 \mathrm{~mm}$. Locality 21. U. S. Nat. Mus. 495237.

43, 44. Height $3 \mathrm{~mm}$., width $2.2 \mathrm{~mm}$. Locality 21. U. S. Nat. Mus. 495233 .

45, 46. Height $3.3 \mathrm{~mm}$., width $2.6 \mathrm{~mm}$. Locality 21. U. S. Nat. Mus. 495239.

47, 48. Height $2.7 \mathrm{~mm}$., width $2.2 \mathrm{~mm}$. Locality 21. U. S. Nat. Mus. 495240 .

49, 50. Height $1.9 \mathrm{~mm}$., width $1.7 \mathrm{~mm}$. Locality K14 (U. S. G. S. 13380). U. S. Nat. Mus. 495241.

51, 52. Goniobasis kettlemanensis woodringi Pilsbry. Locality 17, lower Amnicola zone.

51. Height (incomplete) $27.5 \mathrm{~mm}$., width (incomplete) $10.5 \mathrm{~mm}$. U. S. Nat. Mus. 495245.

52. Height (incomplete) $23.8 \mathrm{~mm}$., width (incomplete) $9.9 \mathrm{~mm}$. U. S. Nat. Mus. 495246.

53, 54. Goniobasis arnoldiana Pilsbry. Locality 27, below lower Amnicola zone.

53. Height (virtually complete) $22.4 \mathrm{~mm}$., width $10 \mathrm{~mm}$. U. S. Nat. Mus. 495247.

54. Height $16.1 \mathrm{~mm}$., width $7.6 \mathrm{~mm}$. U. S. Nat. Mus. 495248. 

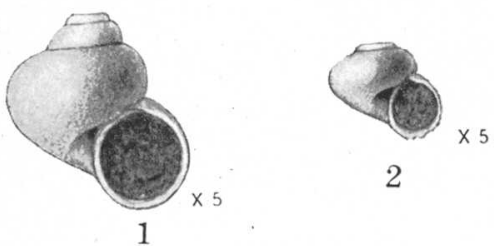

2

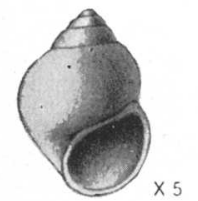

7.

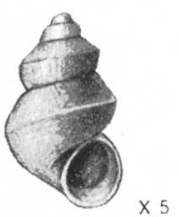

14

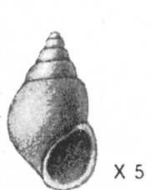

22

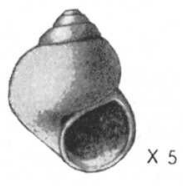

8

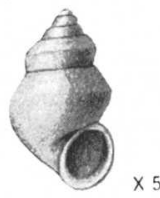

15

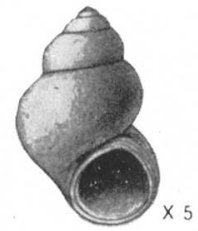

23

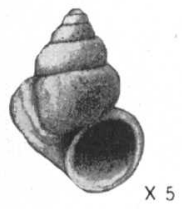

29

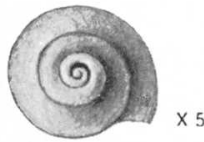

36

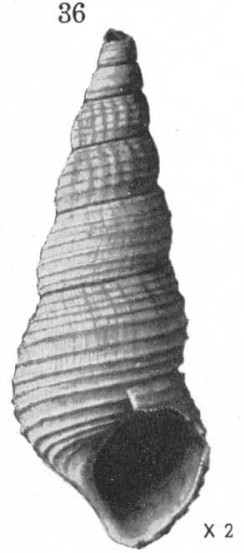

51

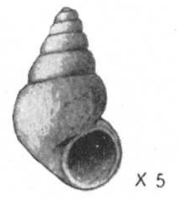

30

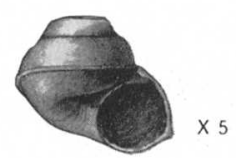

37

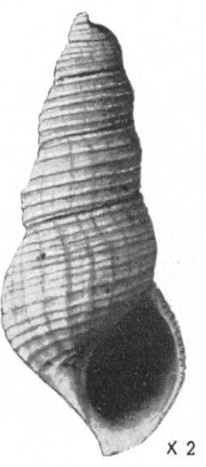

52

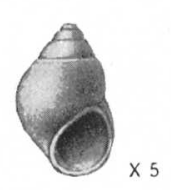

9

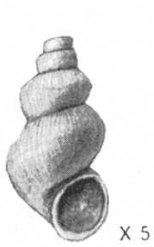

16

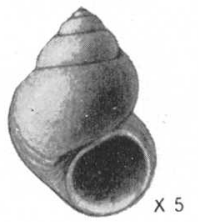

24

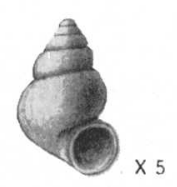

31

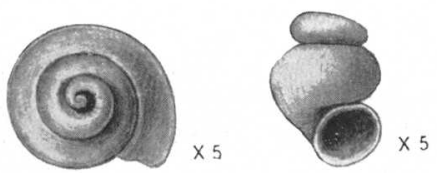

39
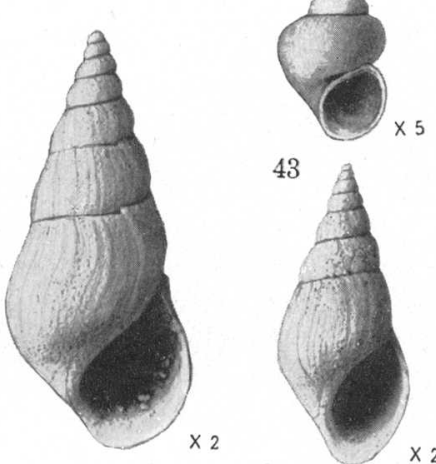

54

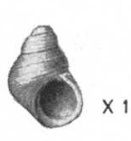

4

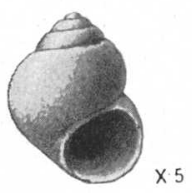

11

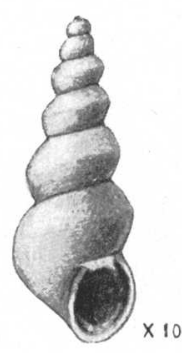

18

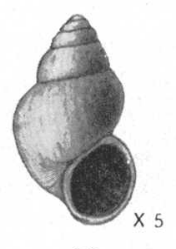

26

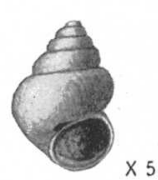

33

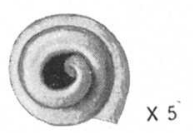

40

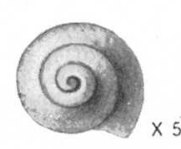

44

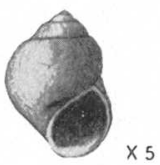

47
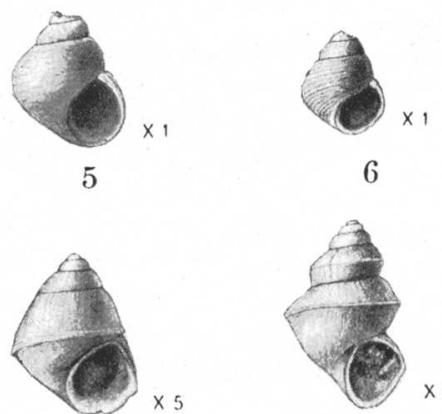

12

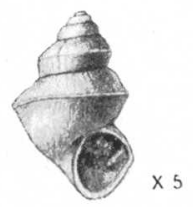

13
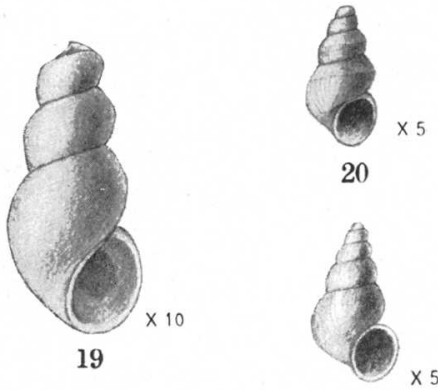

21

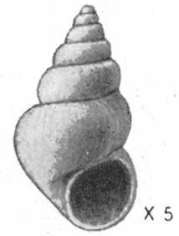

28

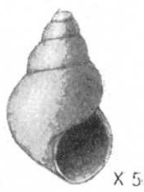

27
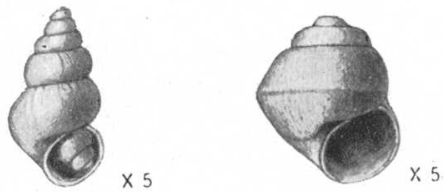

34

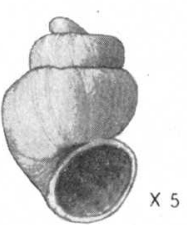

35

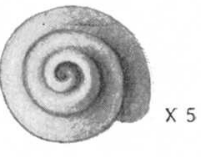

42

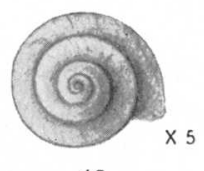

46
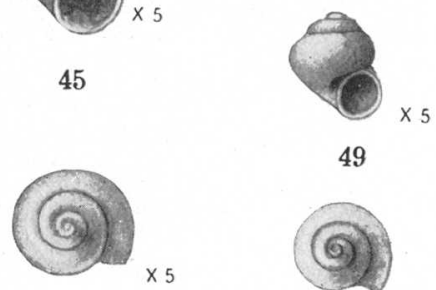

49

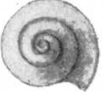

48

FOSSILS FROM TULARE FORMATION. 


\section{PLATE 5}

Figures 1-3. Brannerillus involutus Pilsbry. Apparently sinistral, actually ultradextral, form. Locality 21, lower Amnicola zone.

1. Height $2 \mathrm{~mm}$., width $2.3 \mathrm{~mm}$. U. S. Nat. Mus. 495242 .

2, 3. Height $1.7 \mathrm{~mm}$., width $2.8 \mathrm{~mm}$. U. S. Nat. Mus. 495243 .

4-6. Carinifex sanctaeclarae marshalli Arnold. Height $2.6 \mathrm{~mm}$., width $4.2 \mathrm{~mm}$. I.ocality 19, upper Amnicola zone. U. S. Nat. Mus. 495249.

7-9. Menetus centervillensis (Tryon). Specimen glossed with thin oolitic coat. Height $1.3 \mathrm{~mm}$., width $2.8 \mathrm{~mm}$. Locality 18, lower Amnicola zone. U. S. Nat. Mus. 495250.

10-15. Menetus vanvlecki (Arnold). Topotypes. Locality 7, lower Amnicola zone.

10-12. Height $1.7 \mathrm{~mm}$., width $3.6 \mathrm{~mm}$. U. S. Nat. Mus. 495251.

13-15. Height $2 \mathrm{~mm}$., width $4.9 \mathrm{~mm}$. U. S. Nat. Mus. 495252.

16, 17. Physa wattsi Arnold. Height $10 \mathrm{~mm}$., width $8 \mathrm{~mm}$. Locality 19, upper Amnicola zone. U. S. Nat. Mus. 495253.

18, 19. Physa humerosa Gould. Height $6.5 \mathrm{~mm}$., width $4.3 \mathrm{~mm}$. Locality 27, below lower Amnicola zone. U. S. Nat. Mus. 495254.

20. Parapholyx cf. P. effusa (Lea). Height $3.4 \mathrm{~mm}$., width $4 \mathrm{~mm}$. Locality 21, lower Amnicola zone. U. S. Nat. Mus. 495255.

21-24. Sphaerium kettlemanensis Arnold. Topotypes. Locality 7, lower Amnicola zone.

21, 22. Length $7.7 \mathrm{~mm}$., height $6.5 \mathrm{~mm}$., thickness $1.9 \mathrm{~mm}$. U. S. Nat. Mus. 495256 .

23, 24. Length $7.4 \mathrm{~mm}$., height $6.6 \mathrm{~mm}$., thickness $1.7 \mathrm{~mm}$. U. S. Nat. Mus. 495257.

25-28. Sphaerium n. sp.? Locality 17, lower Amnicola zone.

25, 26. Length $7.2 \mathrm{~mm}$., height $6.5 \mathrm{~mm}$., thickness $2.2 \mathrm{~mm}$. U. S. Nat. Mus. 495258 .

27, 28. Length $7 \mathrm{~mm}$., height $6.2 \mathrm{~mm}$., thickness $2.5 \mathrm{~mm}$. U. S. Nat. Mus. 495259 .

29-34. Sphaerium cooperi Arnold.

29. Length $13.9 \mathrm{~mm}$., height $10.5 \mathrm{~mm}$., thickness $4 \mathrm{~mm}$. Locality 26, below lower Amnicola zone. U. S. Nat. Mus. 495260.

30. Length $12.6 \mathrm{~mm}$., height $10.5 \mathrm{~mm}$, thickness $3.8 \mathrm{~mm}$. Locality 27, below lower Amnicola zone. U. S. Nat. Mus. 495261.

31. Length $12.6 \mathrm{~mm}$., height $10.1 \mathrm{~mm}$., thickness $3.5 \mathrm{~mm}$. Locality 27, below upper Amnicola zone. U. S. Nat. Mus. 495262

32. Length $10.8 \mathrm{~mm}$., height $8.6 \mathrm{~mm}$, thickness $3.2 \mathrm{~mm}$. Locality 27, below upper Amnicola zone. U. S. Nat. Mus. 495263.

33, 34. Length $6.9 \mathrm{~mm}$., height $5.6 \mathrm{~mm}$., thickness $2 \mathrm{~mm}$. Locality 21, lower Amnicola zone. U. S. Nat Mus. 495264.

35-38. Pisidium compressum praecompressum Pilsbry. Locality 10, lower Amnicola zone.

35. Length $2.3 \mathrm{~mm}$., height $2.1 \mathrm{~mm}$., thickness $0.6 \mathrm{~mm}$. U. S. Nat. Mus. 495265 .

36. Length $1.8 \mathrm{~mm}$., height $1.6 \mathrm{~mm}$., thickness $0.6 \mathrm{~mm}$. U. S. Nat. Mus. 495266 .

37. Length $1.8 \mathrm{~mm}$., height $1.7 \mathrm{~mm}$., thickness $0.6 \mathrm{~mm}$. U. S. Nat. Mus. 495267 .

38. Length $1.4 \mathrm{~mm}$., height $1.3 \mathrm{~mm}$., thickness $0.5 \mathrm{~mm}$. U. S. Nat. Mus. 495268 .

39-42. Pisidium sp. Locality 20, lower Amnicola zone.

39. Length $1.6 \mathrm{~mm}$., height $1.3 \mathrm{~mm}$., thickness $0.5 \mathrm{~mm}$. U. S. Nat. Mus. 495269.

40. Length $1.6 \mathrm{~mm}$., height $1.3 \mathrm{~mm}$., thickness $0.5 \mathrm{~mm}$. U. S. Nat. Mus. 495270 .

41. Iength $1.7 \mathrm{~mm}$., height $1.5 \mathrm{~mm}$., thickness $0.5 \mathrm{~mm}$. U. S. Nat. Mus. 495271 .

42. Length $1.9 \mathrm{~mm}$., height $1.7 \mathrm{~mm}$., thickness $0.7 \mathrm{~mm}$. U. S. Nat. Mus. 495272.

43-46. Pisidium cf. P. insigne Gabb. Locality 8, lower Amnicola zone.

43. Length $1.3 \mathrm{~mm}$., height $1 \mathrm{~mm}$., thickness $0.4 \mathrm{~mm}$. U. S. Nat. Mus. 495273.

44. Length $1.5 \mathrm{~mm}$., height $1.1 \mathrm{~mm}$., thickness $0.4 \mathrm{~mm}$. U. S. Nat. Mus. 495274.

45. Length $1.6 \mathrm{~mm}$., height $1.3 \mathrm{~mm}$., thickness $0.5 \mathrm{~mm}$. U. S. Nat. Mus. 495275 .

46. Length $1.4 \mathrm{~mm}$., height $1.2 \mathrm{~mm}$., thickness $0.4 \mathrm{~mm}$. U. S. Nat. Mus. 495276.

47, 48. Pisidium ef. P. abortivum exiguum Sterki. Locality 21, lower Amnicola zone.

47. Length $1.8 \mathrm{~mm}$., height $1.4 \mathrm{~mm}$., thickness $0.6 \mathrm{~mm}$. U. S Nat. Mus. 495277.

48. Length $1.7 \mathrm{~mm}$., height $1.3 \mathrm{~mm}$., thickness $0.5 \mathrm{~mm}$. U. S. Nat. Mus. 495278. 


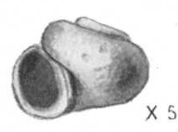

1

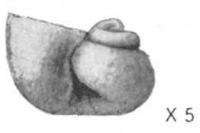

2

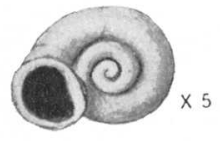

3

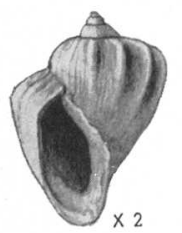

16

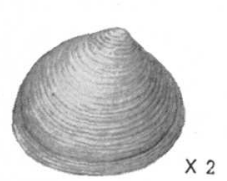

21

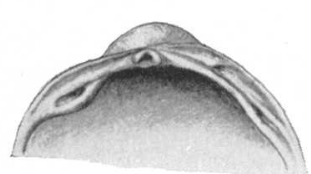

26

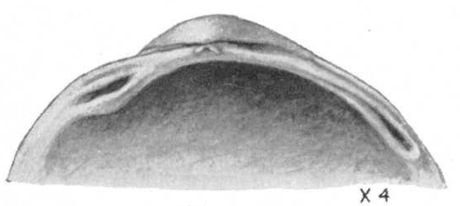

31

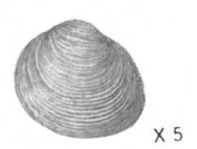

35

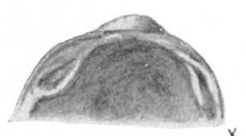

37

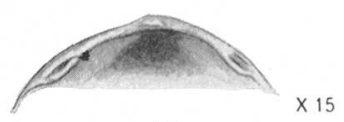

43
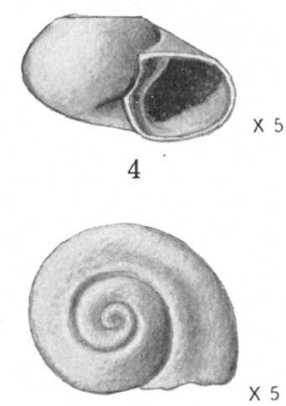

5
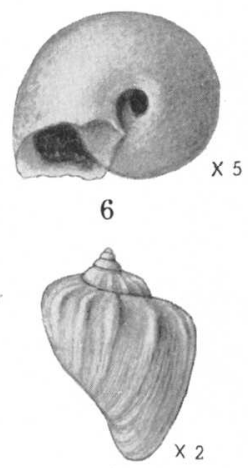

17

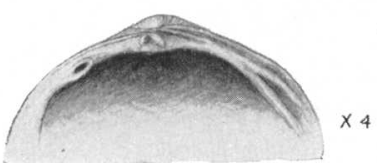

22

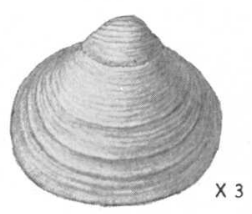

27
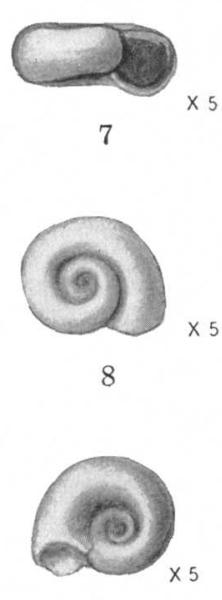

9
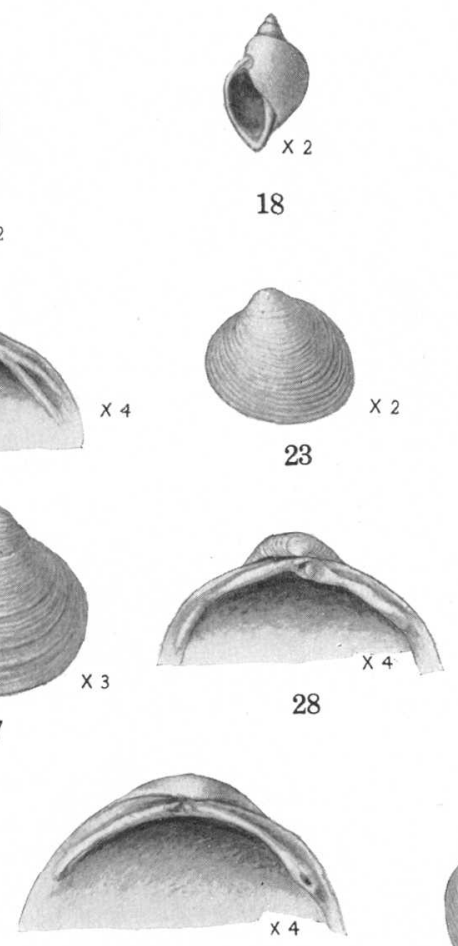

32

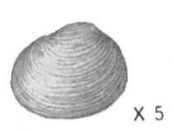

36

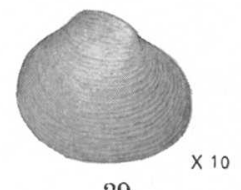

39

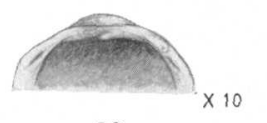

38

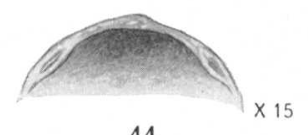

44
8

23

28

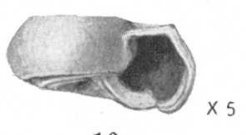

10

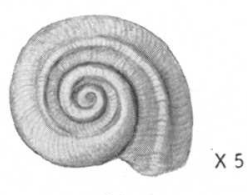

11

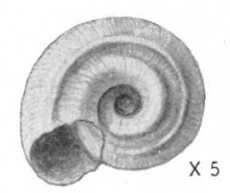

12

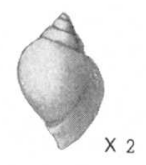

19
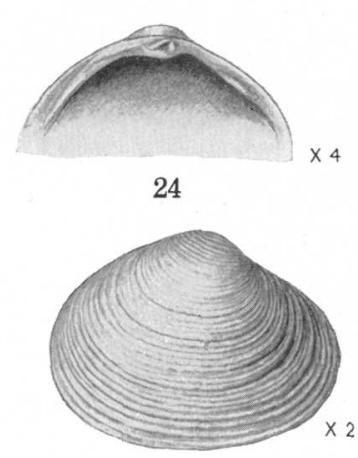

29

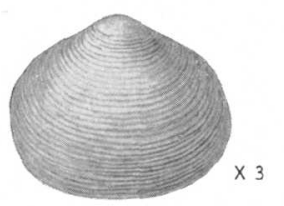

33

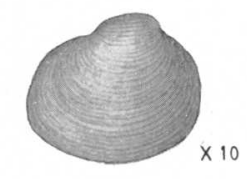

40

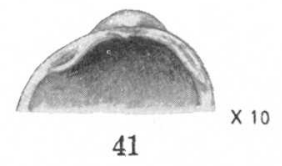

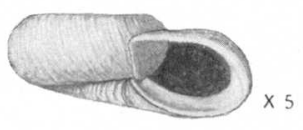

13

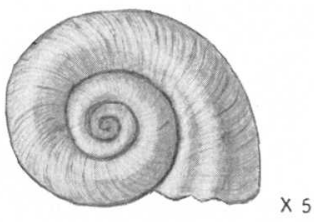

14

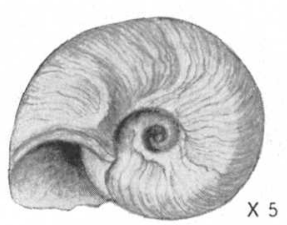

15

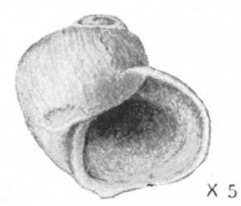

20

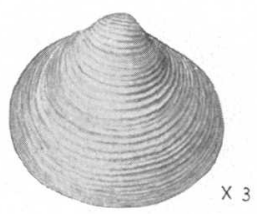

25

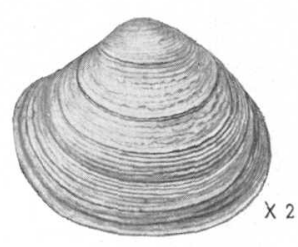

30
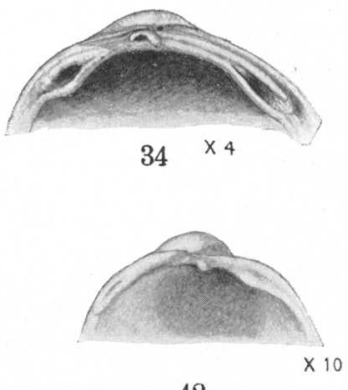

42

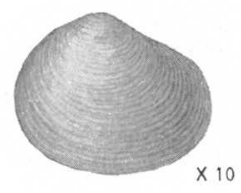

47

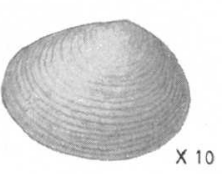

48

FOSSILS FROM TULARE FORMATION. 


\section{PLATE 6}

[Figures natural size]

Frgures 1-3. Anodonta kettlemanensis Arnold. Lower Amnicola zone.

1, 2. Short form. Length $64 \mathrm{~mm}$., height $42 \mathrm{~mm}$., thickness $13 \mathrm{~mm}$. Locality 10. U. S. Nat. Mus. 495279.

3. Elongate, strongly inflated form. Length $72.8 \mathrm{~mm}$., height $42.8 \mathrm{~mm}$., thickness of both valves $30 \mathrm{~mm}$. Locality 8. U. S. Nat. Mus. 495280.

4-9. Gonidea coalingensis Arnold.

4. Strongly inflated, high-beaked form. Length $68 \mathrm{~mm}$., height $35.5 \mathrm{~mm}$., thickness $14 \mathrm{~mm}$. Locality 27 , below lower Amnicola zone. U. S. Nat. Mus. 495281.

5, 6. Length $65.5 \mathrm{~mm}$., height $29.2 \mathrm{~mm}$., thickness $8.4 \mathrm{~mm}$. Locality 10, lower Amnicola zone. U. S. Nat. Mus. 495282.

7, 8. Length $69.2 \mathrm{~mm}$., height $31 \mathrm{~mm}$., thickness $8 \mathrm{~mm}$. Locality 10, lower Amnicola zone. U. S. Nat. Mus. 495283.

9. High-beaked large form. Length $88.7 \mathrm{~mm}$., height $42.7 \mathrm{~mm}$., thickness $12 \mathrm{~mm}$. Locality 20 , lower Amnicola zone. U. S. Nat. Mus. 495284. 


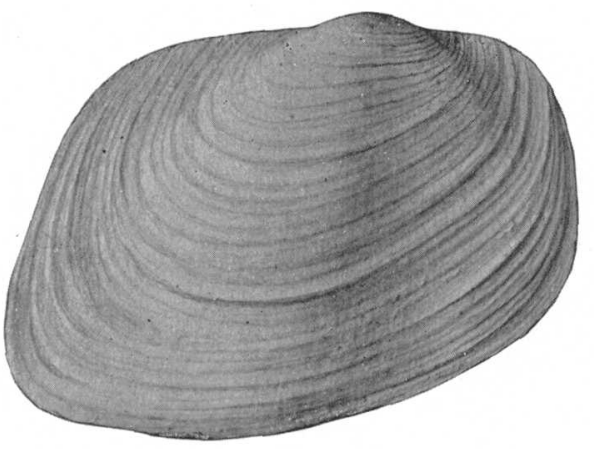

1

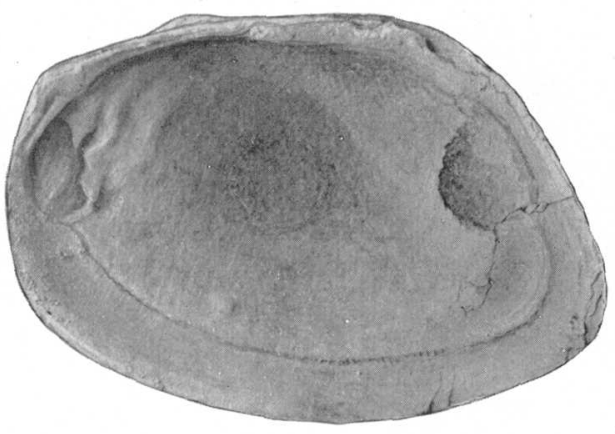

2

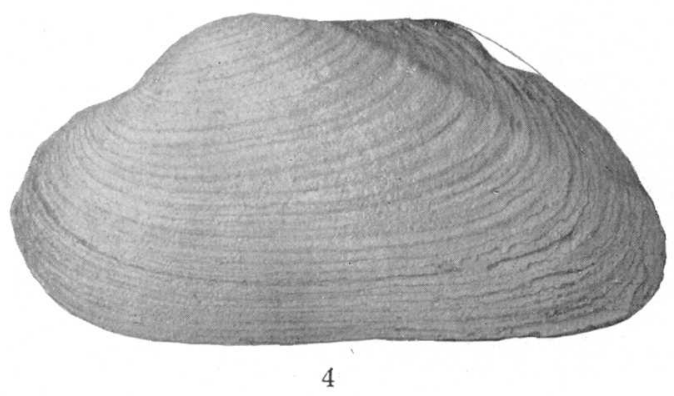

4

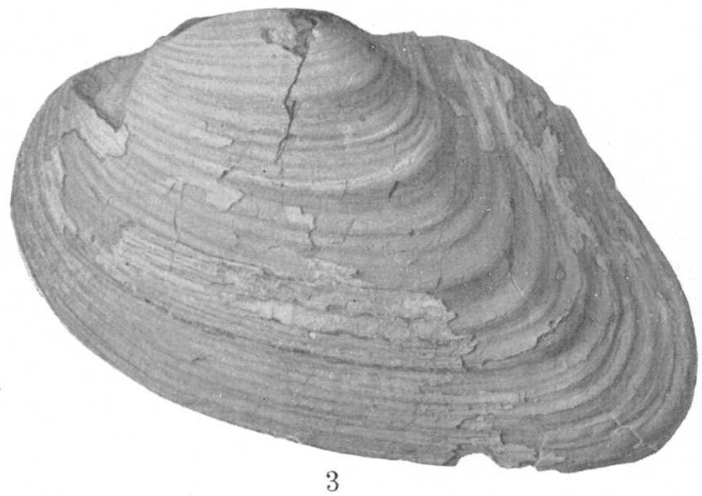

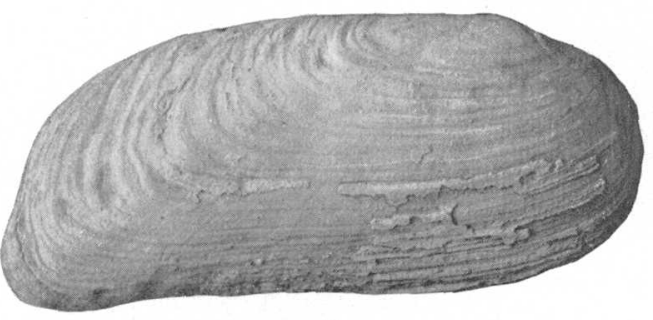

5

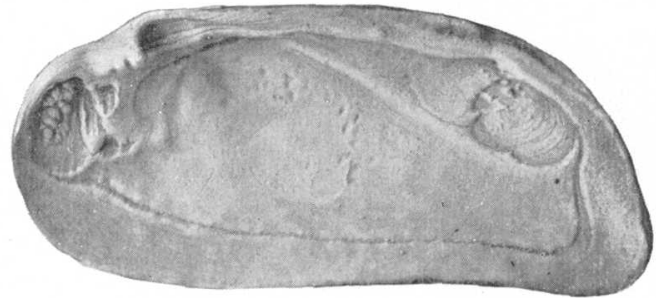

6
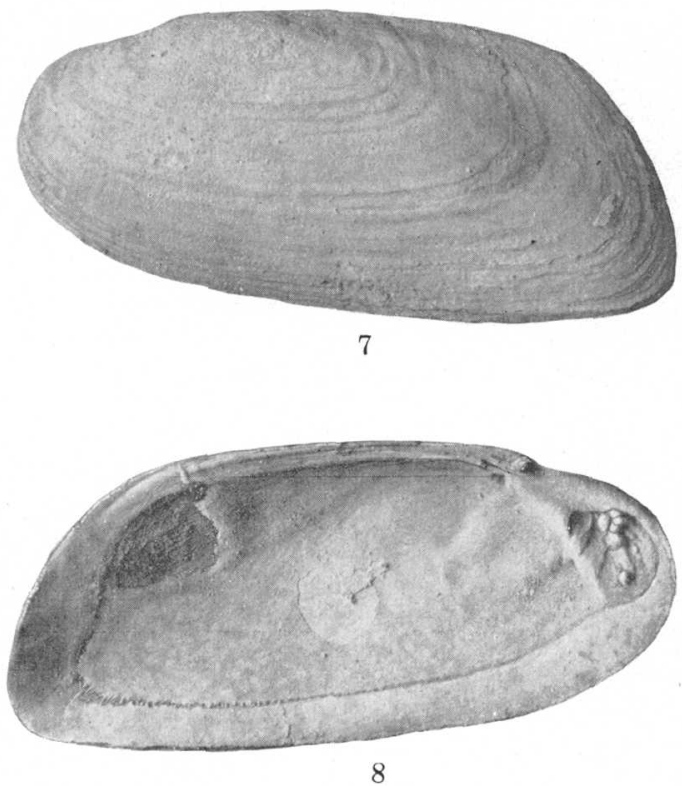

8

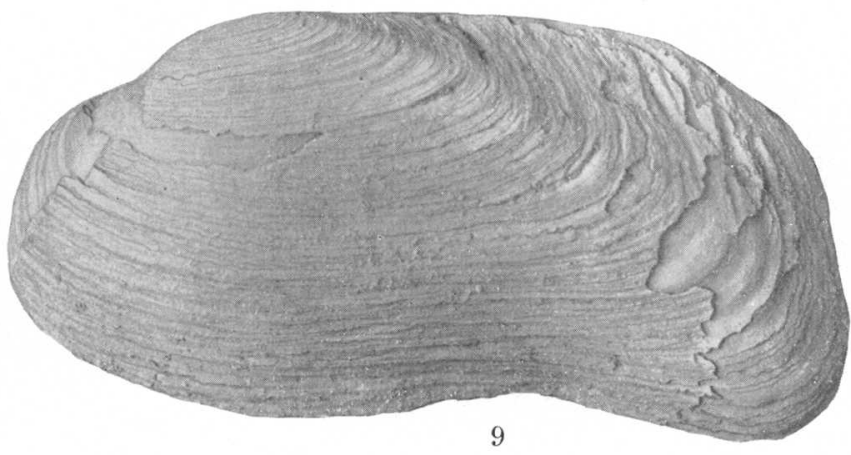

9

FOSSILS FROM TLLARE FORMATION. 


\section{PLATE 7}

FIgORE 1. Surirella utahensis Grunow. Length $0.030 \mathrm{~mm}$., width $0.024 \mathrm{~mm}$. Locality 11, white clay at base of formation. U. S. G. S. diatom catalog No. 1520-4.

2. Stephanodiscus carconensis Grunow. Diameter $0.040 \mathrm{~mm}$. Locality 5 , white clay at base of formation. U. S. G. S. diatom catalog No. 1602-5.

3. Epithemia zebra (Ehrenberg) Kützing var. saxonica (Kützing) Grunow. Length $0.058 \mathrm{~mm}$., width $0.010 \mathrm{~mm}$. Locajity 11, white clay at base of formation. U. S. G. S. diatom catalog No. 1520-3.

4. Rhopalodia gibba (Ehrenberg) Müller. Length $0.083 \mathrm{~mm}$., width $0.022 \mathrm{~mm}$. Locality 16, lower Amnicola zone. U. S. G. S. diatom catalog No. 1512-1.

5. Hyalodiscus schmidtii Frenguelli. Diameter $0.039 \mathrm{~mm}$. Locality 11, white clay at base of formation. U. S. G. S. diatom catalog No. 1518-1.

6. Eunotia robusta Ralfs var. tetraodon (Ehrenberg) Ralfs. Length $0.034 \mathrm{~mm}$., width $0.011 \mathrm{~mm}$. Locality 5, white clay at base of formation. U. S. G. S. diatom catalog No. 1602-7.

7. Melosira granulata var. curvata Grunow. Diameter $0.009 \mathrm{~mm}$. Locality 5 , white clay at base of formation. U. S. G. S. diatom catalog No. 1602-3.

8. Melosira granulata (Ehrenberg) Ralfs. Length (two frustules) $0.047 \mathrm{~mm}$., diameter $0.013 \mathrm{~mm}$. Locality 5 , white clay at base of formation. U. S. G. S. diatom catalog No. 1602-2.

9. Melosira ambigua (Grunow) Müller. Length (two frustules and two valves) $0.069 \mathrm{~mm}$., diameter $0.016 \mathrm{~mm}$. Locality 5, white clay at base of formation. U. S. G. S. diatom catalog No. 1602-4.

10. Diploneis smithii (Brebisson) Cleve. Length $0.060 \mathrm{~mm}$., width $0.033 \mathrm{~mm}$. Locality 11, white clay at base of formation. U. S. G. S. diatom catalog No. 1518-2.

11. Nitzschia etchegoinia Hanna and Grant. Length $0.096 \mathrm{~mm}$., width $0.034 \mathrm{~mm}$. Locality 11 , white clay at base of formation. U. S. G. S. diatom catalog No. 1520-5.

12. Nitzschia punctata (W. Smith) Grunow. Length $0.045 \mathrm{~mm}$., width $0.017 \mathrm{~mm}$. Locality 5 , white clay at base of formation. U. S. G. S. diatom catalog No. 1602-11.

13. Navicula marina Ralfs. Length $0.066 \mathrm{~mm}$., width $0.035 \mathrm{~mm}$. Locality 11 , white clay at base of formation. U. S. G. S. diatom catalog No. 1519-1.

14. Cymbella mexicana (Ehrenberg) Cleve. Length $0.095 \mathrm{~mm}$., width $0.023 \mathrm{~mm}$. Locality 11, white clay at base of formation. U. S. G. S. diatom catalog No. 1520-2.

15. Cymbella prostrata (Berkeley) Cleve. Length $0.048 \mathrm{~mm}$., width $0.017 \mathrm{~mm}$. Locality 5 , white clay at base of formation. U. S. G. S. diatom catalog No. 1602-9. 


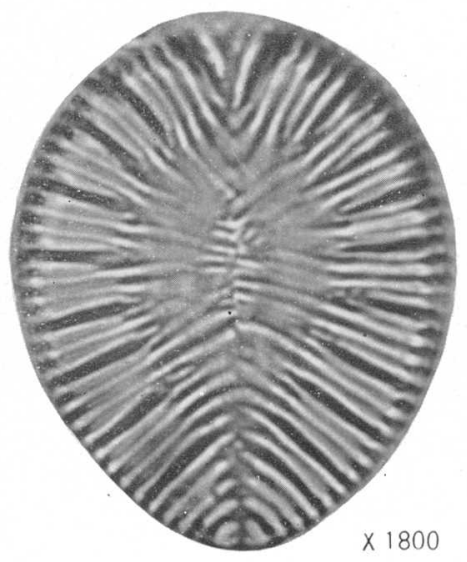

$\times 1800$

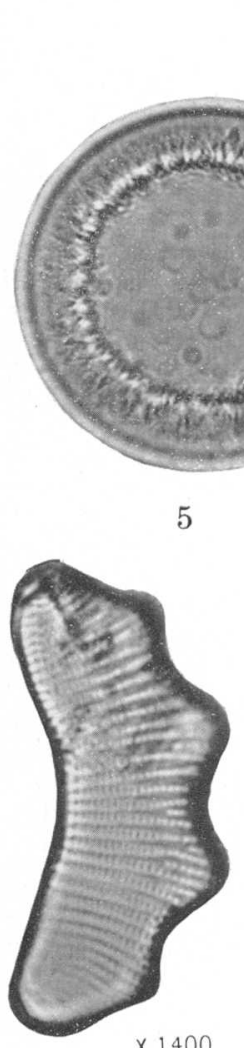

1

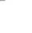

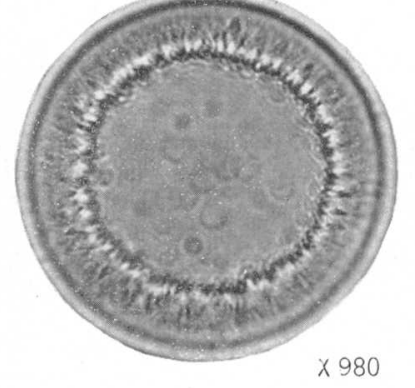

5

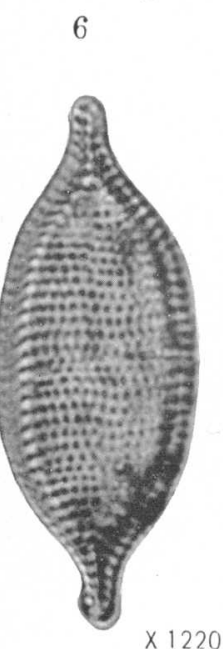

11

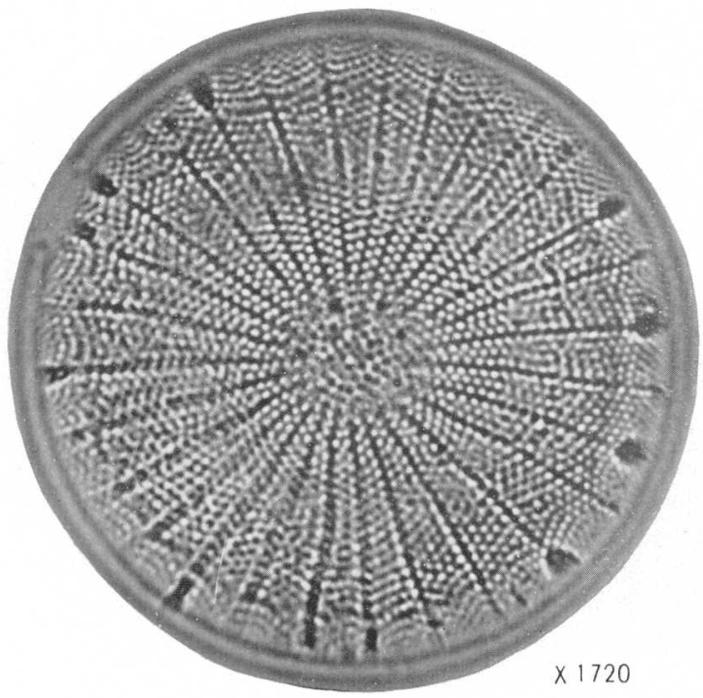

2

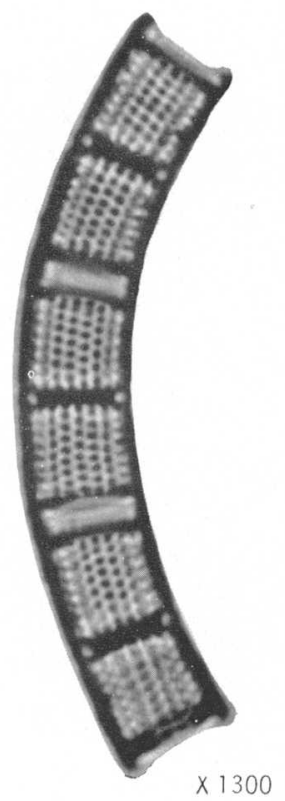

7

9

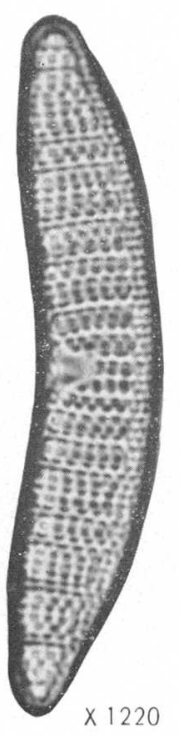

3

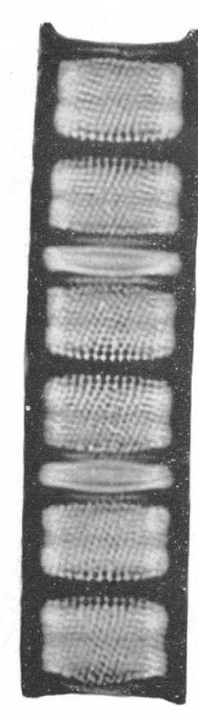

$\times 1000$
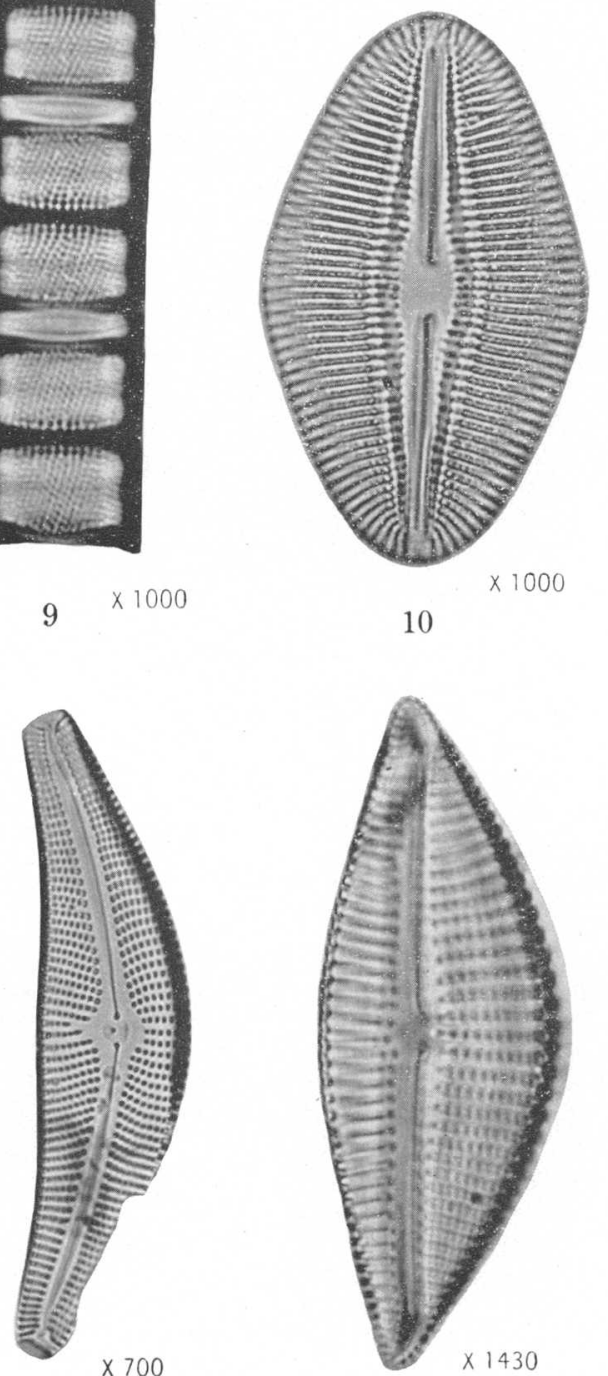

14

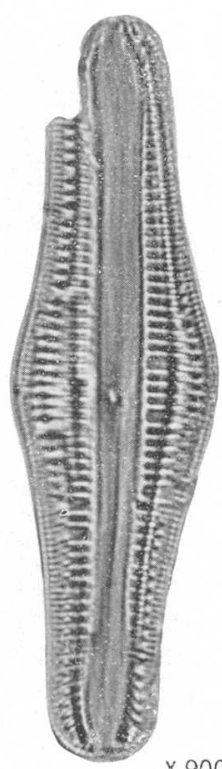

4

$\times 900$ $\times 700$
10

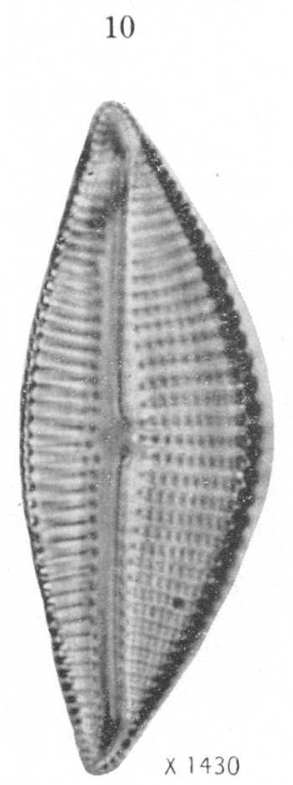

15

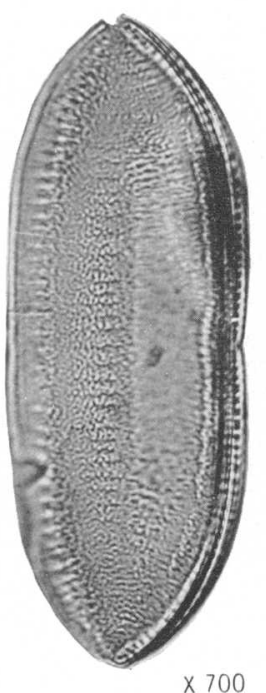

12

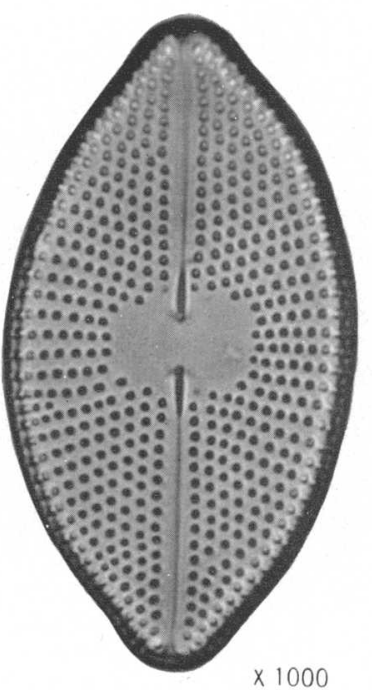

13

DIATOMS FROM TULARE FORMATION. 
Section of lower Amnicola zone of Tulare formation at La Salida on east side of northern Middle Dome, sec. 17, T. 23 S., R. $19 \mathrm{E}$.

8. Thin-bedded gray iron-stained fine-grained sandstone and silt; top not exposed ..... Lower Amnicola zone:

7. Cross-bedded gray sand containing scattered mussels. Several discontinuous, hard and flaggy ferruginous layers. Ferruginous nodules arranged along other layers. Much of the sand contains small flat pebbles of white siliceous shale. Black chert pebbles as much as $3 \frac{1}{2}$ inches long form a thin bed 33 inches below top. The sand between this layer of pebbles and top of bed contains scattered Amnic-

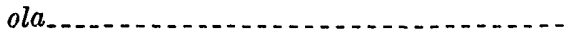

6. Tuff and sandy tuff:

b. Thin-bedded sandy tuff, fine sandstone, and silt. The silt contains brackish-water diatoms (Iocality 16).

a. Fresh tuff, consisting of glass with an index of refraction of about 1.51....

5. Grayish-olive silt and fine-grained sandstone, poorly exposed except at intervals in bottom of arroyo. ...................

4. Sand:

b. Ferruginous sand; some layers have ferruginous cement; Amnicola and mussels scattered throughout. At base a 2-inch layer of cross-bedded sand containing Amnicola is overlain by a 1-inch layer containing many mussels. At the base of a 6 -inch layer lying 2 feet below top are mussels and "bulbous fish growths"-..-

a. Cross-bedded gray sand, surface ironstained. Includes four discontinuous hard layers. A thin layer 35 inches below top contains broken mussels _..........................

3. Thin-bedded, fine-grained gray sand with mud partings. Includes three discontinuous layers of hard, ferruginous flaggy sandstone 1 foot or less thick. Many layers contain small pebbles and an occasional 2- or 3-inch pebble of white sili-

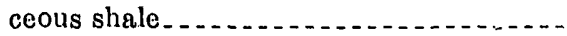

2. Limestone and sand:

e. Amnicola- and mussel-bearing sand. Mussels most abundant at base, middle, and top................

d. Limestone, made up of Amnicola and calcareous oolites; contains few mussels_.............................

c. Ferruginous, oolitic sand; many calcareous oolites, scattered Amnicola, and a few Calipyrgula, ostracodes and otoliths (locality 15) ..........

b. Limestone, made up of Amnicola and calcareous oolites; few mussels. Resembles unit 2d. Between algal heads it rests on unit $1 \mathrm{~b}$. May be absent above thick algal heads.......

a. Discontinuous layer of flat heads of calcareous algae that have a mammillary upper surface. Penetrates cracks in unit $1 \mathrm{~b}$.
Section of lower Amnicola zone of Tulare formation at La Salida on east side of northern Middle Dome, sec. 17, T. 2S S., $R$. 19 E.-Continued.

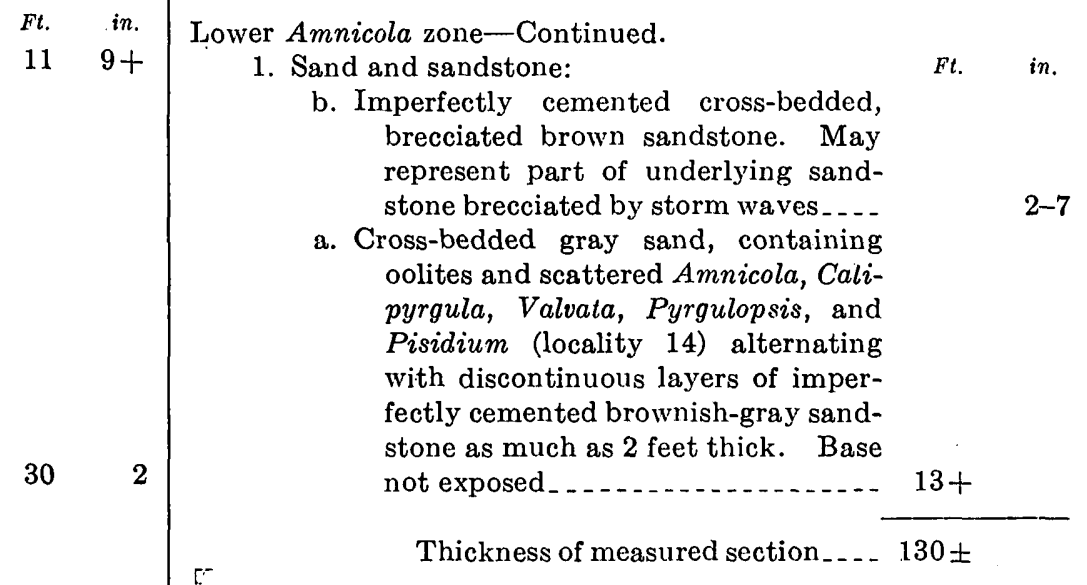

The tuff in unit $6 \mathrm{a}$ of the preceding section is fresher than volcanic material observed elsewhere in the Tulare formation. The oolites in unit 2 consist of thin layers of calcareous material enveloping sand grains of varying size and bits of clay. On many of the sand grains the calcareous material is thin and is partly worn off. Oolitic limestone or limy sandstone extends southward along the north half of Middle Dome. Near the west line of sec. 21 , T. 23 S., R. 19 E., two beds of oolitic sandstone, each of which has a thickness of about a foot, are separated by 10 feet of fine-grained rocks.

Fossils strewn along soil-covered outcrops reveal the presence of the lower Amnicola zone at places in the low hills on the east side of the saddle between Middle Dome and South Dome.

A higher Amnicola zone, designated the upper Amnicola zone, was mapped at localities on the east side of Middle Dome. It is 350 feet above the base of the formation and consists of one or two soft fossiliferous sandstones. The southernmost locality may represent a different horizon, as it is apparently 275 feet above the base of the formation.

At La Salida the base of the stratigraphically lowest conglomerate represents a horizon 750 feet above the top of the lower Amnicola zone. This conglomerate is a lens in coarse-grained sandstone and consists principally of flat pebbles of siliceous shale that have a maximum length of 5 inches. Carinifex shells occur at the top of an overlying layer of smaller pebbles in this exposure. Farther down the arroyo a miniature box canyon is cut in conglomerate and massive sandstone.

\section{WEST FLANK OF NORTH DOME}

The white clay at the base of the Tulare formation forms conspicuous exposures around the north end of

0-31/2 North Dome and southward on the west flank, but toward the south end of the anticline it is less prominent, owing apparently to a greater admixture of brown 0-2 clay. The white clay has been prospected on Arroyo 
GEOLOGY OF THE KETTLEMAN HILLS OIL FIELD, CALIFORNIA

del Camino, where it consists in ascending order of 4 feet of white clay, 8 feet of grayish-brown clay, and 14 inches of white clay. Near the north line of sec. 30, T. $21 \mathrm{~S}$., R. $17 \mathrm{E}$., the upper part of the clay consists of hard siliceous shale that resembles the Monterey (Miocene) type of siliceous shale.

The lower Amnicola zone was recognized along virtually the entire west side of North Dome. Near the north end of the anticline the base of the zone is 30 feet above the top of the white clay, or 45 feet above the base of the formation. Farther south it is 100 to 200 feet above the base. An Amnicola-bearing sandstone less than 50 feet above the base of the formation near the south end of the anticline is considered to represent a horizon below the lower Amnicola zone, as on the east flank. Between Arroyo Corto and La Cañada Simada a 2-foot fine-grained fresh tuff lies in the lower Amnicola zone about 50 feet above its base. The index of refraction of the glass constituting this tuff, as determined by M. N. Bramlette, is about 1.50 . At places, for example locality 22, the tuff contains Amnicola. Southward from Arroyo Somero hard Amnicola-bearing sandstones exposed at two horizons in the lower Amnicola zone, as on part of the east flank, are separated by 85 to 150 feet of poorly exposed, apparently barren beds. At many places where there are no actual exposures the soil formed from these beds is marked by a brown ferruginous crust. On both sides of the main western branch of Arroyo Conchoso a 4-foot white sandy clay crops out about 100 feet above a hard brown limy sandstone in the upper part of the lower Amnicola zone. The following section of beds below the lower Amnicola zone was measured on Arroyo Conchoso.

Section of basal part of Tulare formation on Arroyo Conchoso, sec. 30, T. 22 S., R. $18 \mathrm{E}$.

[Measured by G.F. Taylor]

Tulare formation:

Hard brown ferruginous sandstone, Amnicola and mussels; base of lower Amnicola zone.

Unexposed.....................................

Dark brown clay and silt, poorly exposed........ 80 Clay:

Yellowish-white clay

Dark-brown clay _._-_........ 8

Light-grayish-yellow clay . .

Dark-grayish-brown clay ...................

Grayish-brown clay, stained yellowish; upper part sandy

Thickness of Tulare formation below lower Amnicola zone.................... 154

San Joaquin formation, upper Mya zone:

Dark gray clay; contains oysters.

The following section of the lower part of the Tulare formation was measured on Arroyo Delgado.
Section of basal part of Tulare formation on Arroyo Delgado, sec. 39, T. 22 S., R. $18 \mathrm{E}$.

[Measured by G. F. Taylor]

Alternating sandstone and silty clay.

Ft. in.

Lower Amnicola zone:

Cross-bedded yellowish-gray sandstone, Amnic-

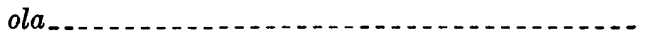

Hard dark yellow limy sandstone, few Amnicola.

Moderately coarse yellowish-gray sandstone, many small clay pellets.............

Brownish-gray iron-stained sandy clay and silt.

Fine-grained cross-bedded yellowish-gray sandstone, scattered Amnicola................

Dark-gray to brownish-gray sandy clay and silt, many Amnicola and mussels..............

Beds below lower Amnicola zone:

Fine-grained cross-bedded light-yellow sandstone

Grayish-brown sandy clay and silt.........

Alternating sandstone and clay, poorly exposed; some beds contain few Amnicola and mussels.

White clay at base of Tulare formation; thickness uncertain.

Thickness of measured section

$63 \pm$

This section shows Amnicola-bearing beds lower than a horizon considered the base of the lower Amnicola zone. On branches of the first main arroyo north of Arroyo Raso Amnicola and other fossils were collected less than 50 feet above the base of the Tulare (localities $26,27)$. In the section measured on the first arroyo south of Arroyo Raso (see pp. 21-22) fossiliferous beds referred to the lower horizon in the lower Amnicola zone are 135 feet above the base of the formation and the upper horizon is 85 feet higher. A higher Amnicolabearing sandstone, 330 feet above the base of the formation, is at essentially the same horizon as the upper Amnicola zone of the east side of Middle Dome, which also appears to be represented at a few localities from Arroyo Somero southward to Arroyo Raso. At the head of the first main arroyo south of the Paso RoblesHanford road grayish-brown sandstone that contains Amnicola and mussels and represents the lowest observed fossiliferous beds in the lower Amnicola zone is 100 feet above the base of the Tulare.

At the north end of North Dome the upper part of the Tulare consists of many discontinuous beds of conglomerate, some of which are imperfectly cemented, interbedded with sandstone, much of which is poorly consolidated. The lowest beds of conglomerate are 200 to 275 feet above the base of the formation, not far above the lower Amnicola zone. Where the strike of the beds bends southward along the west side of the anticline the base of the main conglomerate zone is 425 to 500 feet above the base of the formation. On the first arroyo north of La Cañada Simada scattered beds of conglomerate begin at a horizon 200 feet above the base of the formation and extend up through the 
section. In this area the pebbles and cobbles are smaller than in the conglomerates farther south. Brown sandstone is the most abundant rock in the conglomerate, though granitic rocks, red chert, and lavas were noted. On Arroyo Somero and also on the first arroyo south of Arroyo Mellado conglomerate is absent, except thin lenses of small pebbles. A coarse, pebbly, massive brown sandstone near the edge of the hills on Arroyo Chico, 1,800 feet above the base of the formation, contains small oysters.

The following section, in which the lithologic description is generalized, was measured on the first main arroyo south of Arroyo Raso, three-quarters of a mile northwest of the Paso Robles-Hanford road. This section does not include an estimated thickness of 700 feet of poorly exposed beds near the edge of the hills.

\section{Section of Tulare formation on arroyo three-quarters of a mile northwest of Paso Robles-Hanford road}

[Measured by G. F. Taylor]

Conglomerate, contains oyster fragments .............

Grayish-brown slightly cross-bedded sandstone; contains

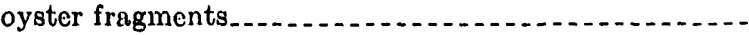

Conglomerate; contains fragments of mussels . . . . . . . .

Grayish-brown sandstone with mudstone partings........

Conglomerate; contains oyster fragmeuts..............

Grayish-brown sandstone; contains small oysters.......

Hard conglomerate; contains small oysters.............

Grayish-brown sandstone; contains small oysters.......

Grayish-brown muddy sandstone .....................

Grayish-brown sandstone; contains small oysters.......

Hard conglomerate; contains small oysters..............

Grayish-brown sandstone; contains small oysters . . . ....

Conglomerate; contains small oysters . . . . . . . ........

Grayish-brown sandstone............................

Hard conglomerate; many pebbles of siliceous shale; con-

tains small oysters. . . . . . . . . . . . . . . . . . . . . .

Grayish-brown sandstone; contains small oysters . .......

Conglomerate made up of large cobbles; contains small oysters...............

Grayish-brown sandstone including occasional conglomerate lenses and oysters; upper 125 feet poorly exposed..

Poorly sorted coarse-grained, pebbly gray sandstone; contains small oysters. . . . . . . . . . . . . . . . . . . . . .

Grayish-brown pebbly sandstone, poorly exposed .......

Poorly sorted pebbly gray sandstone . . . . . . . . . . .

Coarse-grained grayish-brown sandstone...............

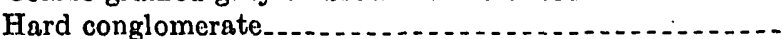

Grayish-brown sandstone including conglomerate lenses..

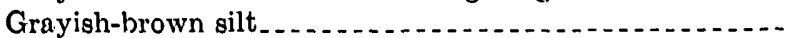

Grayish-brown sandstone including conglomerate lenses..

Grayish-brown silt. .....................

Grayish-brown sandstone including conglomerate lenses

Hard cross-bedded grayish-brown sandstone............

Cross-bedded soft light-grayish-brown sandstone.......

Poorly bedded muddy grayish-brown sandstone..........

Conglomerate; siliceous shale pebbles abundant . . . . . . .

Cross-bedded yellowish-gray sandstone . . . . . . . . . . . . .

Poorly bedded silty grayish-brown sandstone............

Cross-bedded yellowish-gray sandstone . . . . . . . . . . . . .

Poorly bedded muddy grayish-brown sandstone..........

Cross-bedded yellowish-gray sandstone . . . . . . . . . . . . .

Yellowish-gray silt

Grayish-brown sandstone 109
Section of Tulare formation on arroyo three-quarters of a mile northwest of Paso Robles-Hanford road-Continued

Hard cross-bedded grayish-brown sandstone............. Poorly exposed grayish-brown sandstone including thin conglomerate lenses and thin beds of silt.

Hard coarse-grained gray sandstone..................

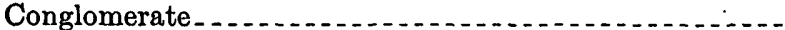

Grayish-brown sandstone including few conglomerate lenses . . . . .

Conglomerate consisting almost entirely of siliceous shale

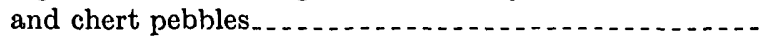

Silt

Silty grayish-brown sandstone including few conglomerate lenses...

Poorly sorted rudely bedded coarse sand and pebbles.... Coarse-grained grayish-brown sandstone including conglomerate lenses.

Conglomerate. . - 2.

Grayish-brown sandstone

Poorly sorted rudely stratified coarse sand and pebbles; pebbles composed principally of siliceous shale.........

Coarse-grained grayish-brown sandstone including many conglomerate lenses . . . . . . . . . . . . . . . . . . .

Hard grayish-brown sandstone . . . . . . . . . . . . .

Cross-bedded yellowish-gray sandstone; contains many small pebbles and chips of siliceous shale about $1 / 8$ inch long.

Coarse-grained cross-bedded pebbly conglomerate lenses

Conglomerate; well-rounded chert cobbles abundant....

Coarse-grained cross-bedded yellowish-gray sandstone...

Conglomerate ..... . . . . . . . . . . . . . . . . . . . . . .

Cross-bedded dark-gray sandstone . . . . . . . . . . . . . . .

Hard conglomerate made up of pebbles to large cobbles..

Coarse-grained yellowish-gray pebbly sandstone including

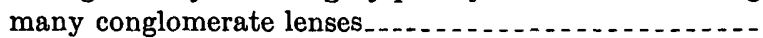

Hard grayish-brown pebbly sandstone. Conglomerate; siliceous shale pebbles abundant.........

Coarse-grained yellowish-gray sandstone including many conglomerate lenses . . . . .

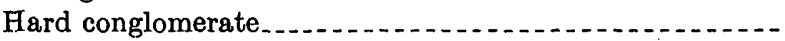

Coarse-grained yellowish-gray sandstone including few conglomerate lenses . . . .

Hard conglomerate. Coarse-grained poorly bedded yellowish-brown sandstone

Hard grayish-brown sandstone. . . . .

Massive gray sandstone . . . . . . . . . . . . . . . . . . .

Hard gray sandstone; contains many Amnicola, Goniobasis, Sphaerium, and other fossils (locality 28); represents upper Amnicola zone.................................

Massive yellowish-gray sandstone................... Hard gray sandstone. . . . . . . . . . . . . . . . . . .

Massive yellowish-gray sandstone

Conglomerate. ... . . . .

Hard gray sandstone $\ldots \ldots \ldots \ldots$

Yellowish-gray sandstone $\ldots \ldots \ldots$

Yellowish-gray sandstone; contains Amnicola and mussels. This bed and underlying bed assigned to upper horizon in lower Amnicola zone......................

Yellowish-gray sandstone; contains Amnicola........

Hard gray sandstone...... Massive yellowish-gray sandstone

Hard gray sandstone. . . Massive yellowish-gray sandstone.................... Gray sandstone; small pebbles of siliceous shale abundant. Well-bedded gray sandstone.......... Hard gray sandstone. 120 
Section of Tulare formation on arroyo three-quarters of a mile northwest of Paso Robles-Hanford road-Continued

Massive gray sandstone. Feet

Hard grayish-brown sandstone; contains many Amnicola and mussels at base. Assigned to lower horizon in lower

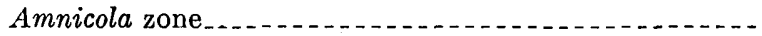
Poorly exposed sandstone and clay White clay

Poorly exposed sandstone and clay; soil has ferruginous crust and "bulbous fish growths." Base of lower $A m$ nicola zone in this interval. Underlain by upper Mya zone of San Joaquin formation ...................

Thickness of measured section

1,958

In this section the base of the conglomerate zone is 434 feet above the base of the formation, though there is a 1-foot conglomerate bed 177 feet lower. Small oysters were observed in a sandstone 1,636 feet above the base of the formation and upward to the top of the measured section through a thickness of 322 feet of sandstone and conglomerate.

\section{WEST FLANK OF MIDDLE DOME}

The exposed part of the Tulare formation is about 3,500 feet thick on the west flank of Middle Dome and is thicker in this region than elsewhere in the Kettleman Hills. Fossiliferous beds representing the lower Amnicola zone were mapped for only short distances at the north and south ends of the anticline. Fossils identifying the zone could doubtless be found elsewhere on soil-covered slopes. At several places beds of dirty white sandy clay, representing probably altered tuff, are exposed about 250 feet above the base of the formation and also closer to the base. A few small oysters and one specimen of Littorina were found in pebbly sandstone in the upper part of the Tulare near the edge of the hills on Arroyo Menudo and the first arroyo to the north.

\section{WEST FLANK OF SOUTH DOME}

The location of the contact between the Tulare and San Joaquin formations is doubtful along the greater part of the west flank of South Dome. The lower Amnicola zone was not found in this region, and the upper Mya zone was identified by its fossils only at the north end of the anticline and near the south end of the Kettleman Hills. Two loose specimens of Olivella were picked up at localities corresponding to an estimated stratigraphic position within 50 feet of the base of the Tulare. This genus is not known to occur in the upper Mya zone nor at any other horizon in the San Joaquin formation above the Pecten zone. It is quite certain that these specimens are not Tulare fossils. They may represent detrital constituents weathered out of a conglomerate in the Tulare, though they are not badly worn, or they may have been dropped by Indians. ${ }^{19}$

19 For the extensive use of Olivella by California Indians see Kroeber, A. L., Handbook of the Indians of California: Bur. Am. Ethnology Bull. 78, p. 826, 1925 .
Conglomerates-or rather gravels, for most of the material is unconsolidated - are abundant throughout the Tulare formation on the west flank of South Dome, even at the base of the formation. In many of these beds the pebbles consist almost entirely of flat, crudely elliptical pieces of white siliceous shale, derived presumably from the McLure shale member of the Monterey shale exposed on Reef Ridge and in the Pyramid Hills and probably also from the Kreyenhagen shale of Reef Ridge. Although these beds are rarely exposed in the low rolling hills on the west side of South Dome, the pieces of siliceous shale cover the ground along their strike. These gravels also contain cobbles and poorly rounded pieces of buff limestone, which, like limestone concretions in the McLure shale of Reef Ridge, contain diatoms. Other rocks are represented in the gravels, such as fossiliferous Temblor sandstone, containing Aequipecten andersoni, and hard brown sandstone like that in concretions in Eocene and Cretaceous formations back of Reef Ridge. One of the Temblor boulders in gravel about 20 feet above the base of the Tulare measured 18 by 13 inches.

\section{FOSSILS}

At many places fossils, consisting principally of freshwater snails, mussels, and diatoms, are abundant in the lower part of the Tulare formation, particularly in the beds assigned to the lower and upper Amnicola zones. The fossils aside from diatoms are listed on page 23 , and the diatoms are listed on pages 24-25. The freshwater mollusks, representing the largest known Pliocene fresh-water fauna on the Pacific coast, have recently been described by Pilsbry. ${ }^{20}$ They are illustrated on plates 4 to 6 .

Shells were collected from beds regarded as underlying the lower Amnicola zone at three localities. At locality 3, near the north end of North Dome, a sandy tuff overlying the white clay at the base of the formation contains Littorina mariana (pl. 4, figs. 4-6) and a small form of Amnicola longinqua-an association of a freshwater genus with a marine genus that tolerates water of low salinity. The Littorina is represented by 23 specimens, some of which are well-preserved and have color markings. The condition of the material and the absence of other marine fossils suggest that these shells are not detrital, and their presence points to a temporary connection with the sea at the time when the tuff was laid down. The other two collections are from adjoining localities on the west side of southern North Dome (localities 26, 27). Goniobasis arnoldiana (p). 4 , figs. 53,54 ) was found only at these localities but was collected by Arnold and Anderson at their locality 4732 [Goniobasis "nigrina?"], which represents the lower Amnicola zone near locality 21. The Amnicola

${ }^{20}$ Pilsbry, H. A., Mollusks of the fresh-water Pliocene beds of the Kettleman Hills and neighboring oil flelds, Calif.: Acad. Nat. Sci. Philadelphia Proc., vol. 86, pp. 541-570, pls. 18-23, 2 figs., 1935. 


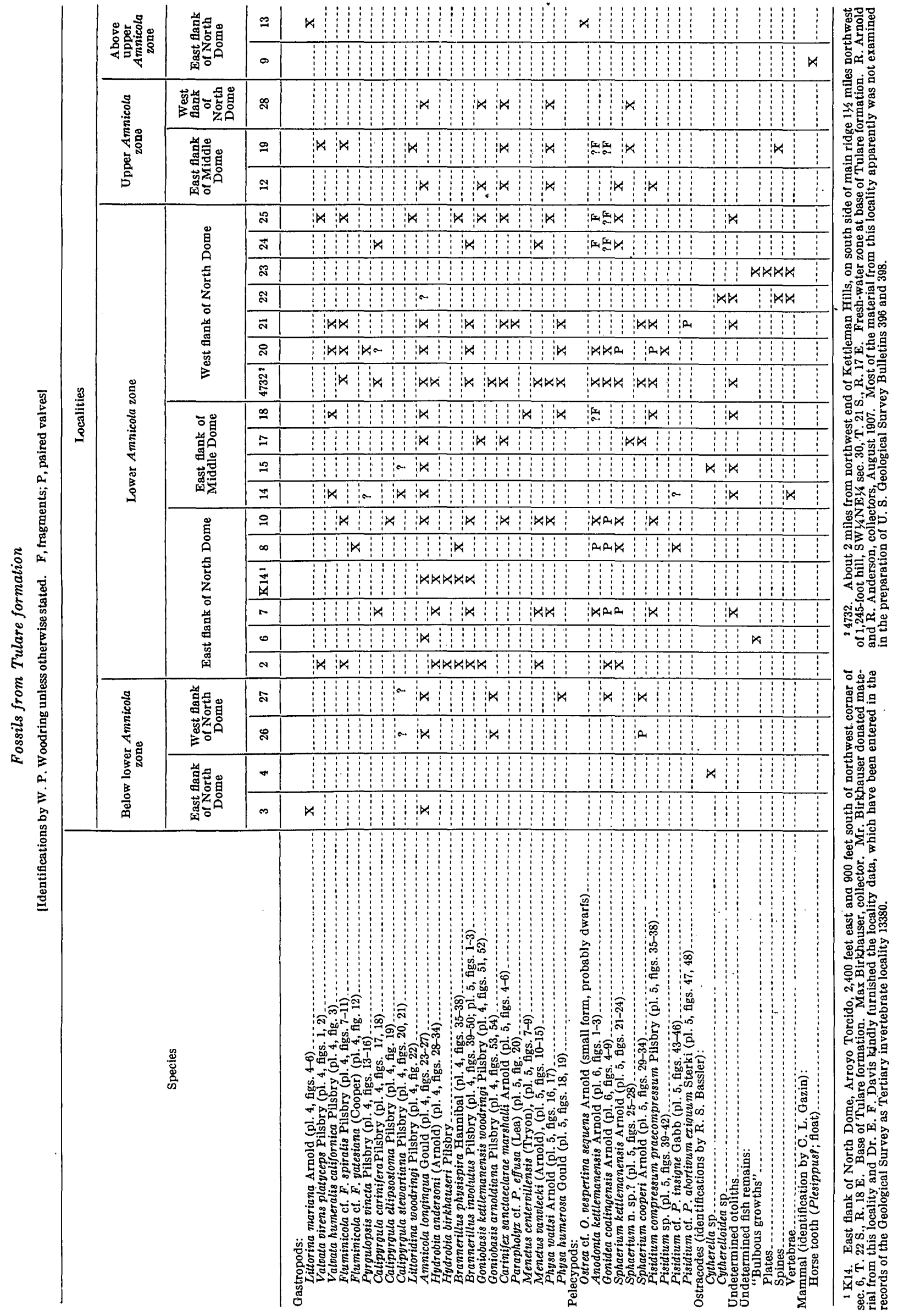


Species

Melosira sulcata (Ehrenberg) Kützing

Melosira sol (Ehrenberg) Küzing.

Melosira undulata (Ehrenberg) Kützing var. normanii Arnott_.

Melosira solida Eulenstein

Melosira distans Kützing var. lirata (Ehrenberg) Bethge

Melosira granulata (Ehrenberg) Ralfs (pl. 7, fig. 8)

Melosira granulata var. curvata Grunow (pl. 7, fig. 7)

Melosira granulata var. australiensis Grunow.

Melosira granulata var. muzzanensis (Meister) Bethge

Melosira ambigua (Grunow) Müller (pl. 7, fig. 9)

Melosira crenulata Kützing var. semilaevis Grunow.

Podosira stelliger (Bailey) Mann.

Hyalodiscus schmidtii Frenguelli (pl 7, fig 5)

Stephanopyxis turris (Greville and Arnott) Ralfs var. cylindrus Grunow

Thalassiosira decipiens (Grunow) Joergensen

Cyclotella meneghiniana Kützing.

Cyclotella compta (Ehrenberg) Kützing var. pliocaenica.Krasske.

Cyclotella iris Brun and. Heribaud.

Cyclotella pygmaea Pantocsek.

Stephanodiscus dubius (Fricke) Hustedt

Stephanodiscus astraea (Ehrenberg) Grunow

Stephanodiscus carconensis Grunow (pl. 7, fig. 2)

Stephanodiscus carconensis var. pusilla Grunow

Coscinodiscus excentricus Ehrenberg-

Coscinodiscus kützingii Schmidt

Actinoptychus undulatus Ehrenberg.

Xanthiopyxis ovalis Lohman.

Triceratium uncinatum Schmidt

Biddulphia cf. B. pulchella Gray

Terpsonoe americana (Bailey) Ralfs

Tetracyclus lacustris Ralfs.

Tetracyclus japonicus (Petit) Hustedt

Grammatophora cf. G. maxima Grunow

Meridion circulare Agardh

Fragilaria construens (Ehrenberg) Grunow

Fragilaria construens var. subsalina Hustedt

Fragilaria construens var. venter (Ehrenberg) Grunow

Fragilaria harrissonii W. Smith

Fragilaria harrissonii var. dubia Grunow

Synedra ulna (Nitzsoh) Ehrenberg

Synedra ulna var. amphirhynchus (Ehrenberg) Grunow

Eunotia robusta Ralfs var. tetraodon (Ehrenberg) Ralfs (pl. 7, fig. 6)

Eunotia praerupta Ehrenberg

Eunotia tenella (Grunow) Hustedt.

Eunotia pectinalis (Kützing) Rabenhorst

Eunotia pectinalis var. minor (Kützing) Grunow

Eunotia pectinalis var. undulata (Ralfs) Rabenhorst

Eunotia pectinalis var. ventralis (Ehrenberg) Hustedt.

Eunotia lunaris (Ehrenberg) Grunow

Eunotia cf. E. gracilis (Ehrenberg) Rabenhorst

Eunotia formica Ehrenberg

Eunotia cf. E. didyma Grunow var. curta Hustedt

Eunotia trigibba Hustedt.

Eunotia serpentina Ehrenberg

Cocconeis placentula Ehrenberg.

Cocconeis placentula var. lineata (Ehrenberg) Cleve

Cocconeis scutellum Ehrenberg var. minutissima Grunow

Cocconeis sp. (indeterminable) .

Rhoicosphenia curvata (Kützing) Grunow

Mastogloia elliptica Agardh.

Gyrosigma attenuatum (Kützing) Rabenhorst

Gyrosigma kützingii (Grunow) Cleve.

Caloneis formosa (Gregory) Cleve var. rostrata Frenguelli

Caloneis silicula (Ehrenberg) Cleve var. kjellmaniana (Grunow) Cleve

Caloneis trinodis (Lewis) Meister.

Diploneis elliptica (Kützing) Cleve

Diploneis advena (Schmidt) Cleve.

Diploneis smithii (Brebisson) Cleve (pl. 7 , fig. 10)

Stauroneis phoenicenteron Ehrenberg.
Localities

White clay at base of formation

Lower $A m$

East flank of Middle Dome

16

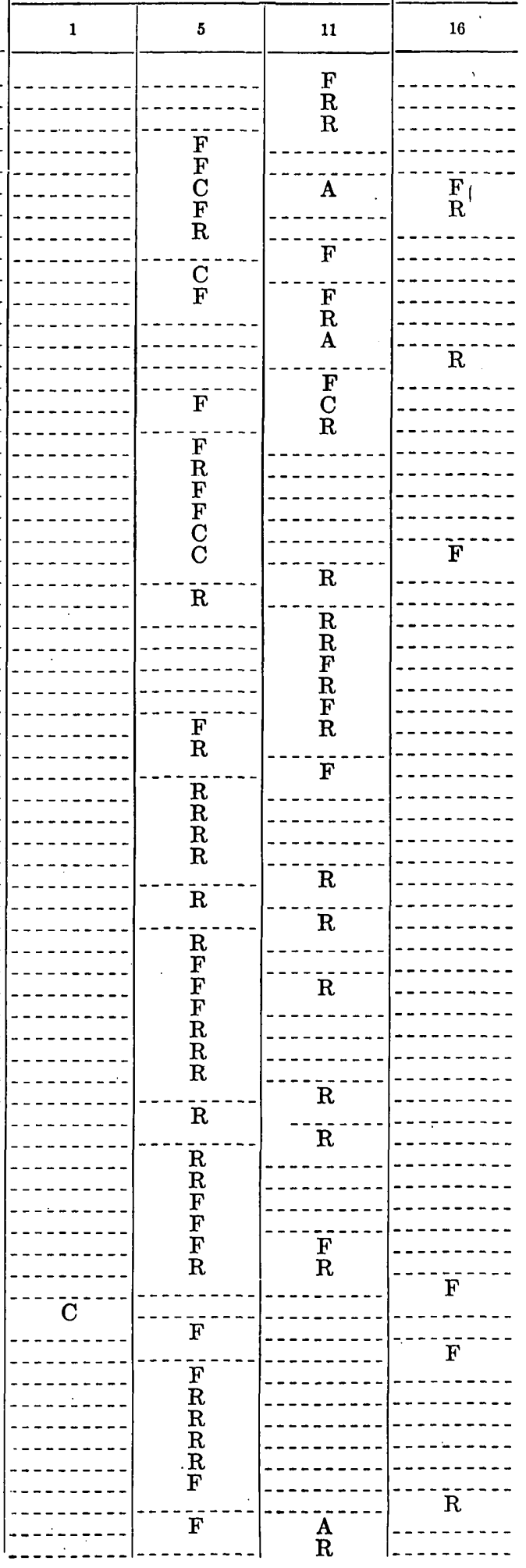


Diatoms from Tulare formation-Continued

[Identifications by K. E. Lohman. R, rare; F, few; C, common; A, abundant]

\begin{tabular}{|c|c|c|c|c|}
\hline \multirow{4}{*}{ Species } & \multicolumn{4}{|c|}{ Localities } \\
\hline & \multirow{2}{*}{\multicolumn{3}{|c|}{ White clay at base of formation }} & $\begin{array}{c}A m- \\
\text { zone }\end{array}$ \\
\hline & & & & $\begin{array}{l}\text { East flank of } \\
\text { Middle Dome }\end{array}$ \\
\hline & 1 & 5 & . 11 & 16 \\
\hline 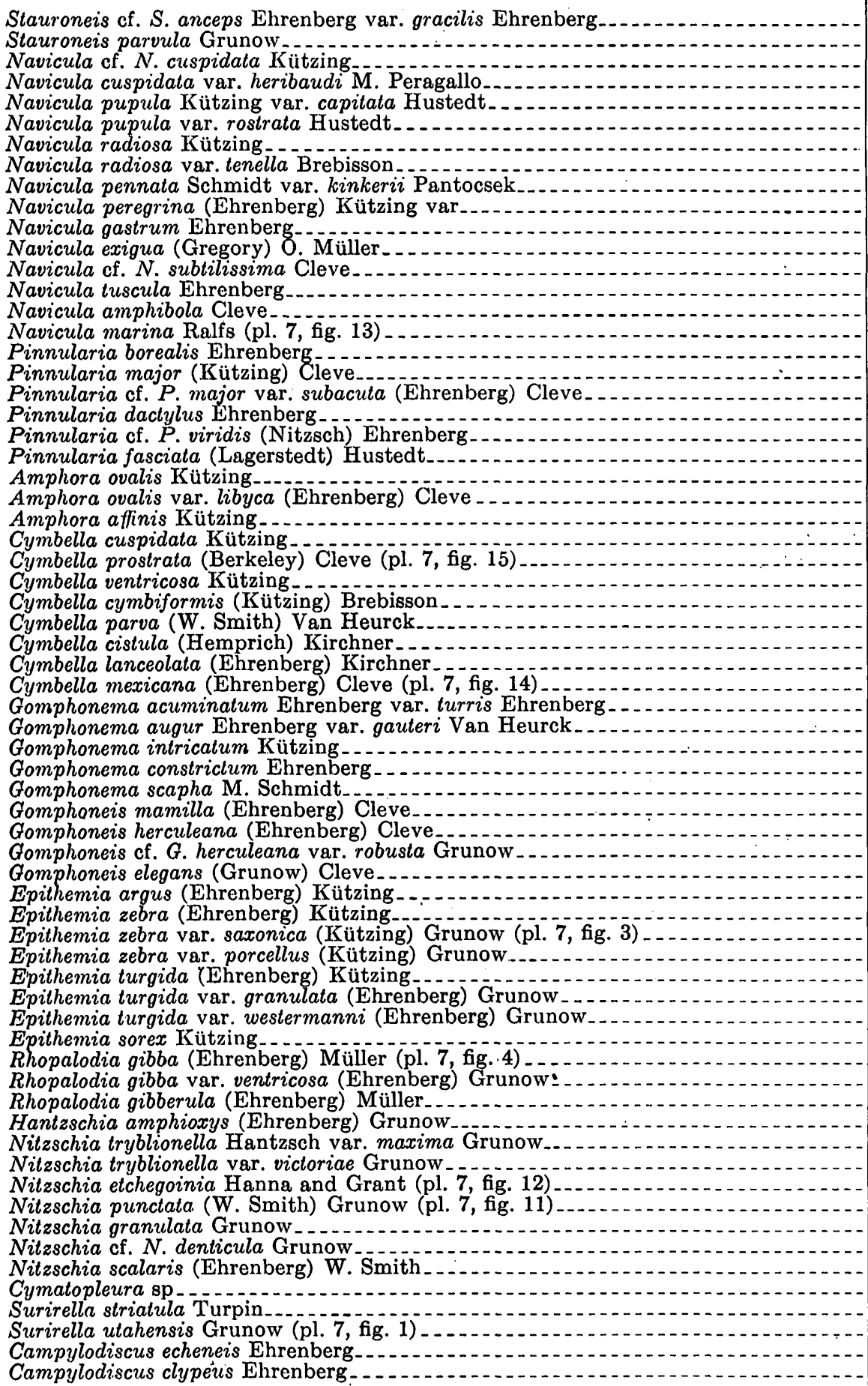 & \begin{tabular}{|l}
-1 \\
-1 \\
-1
\end{tabular} & 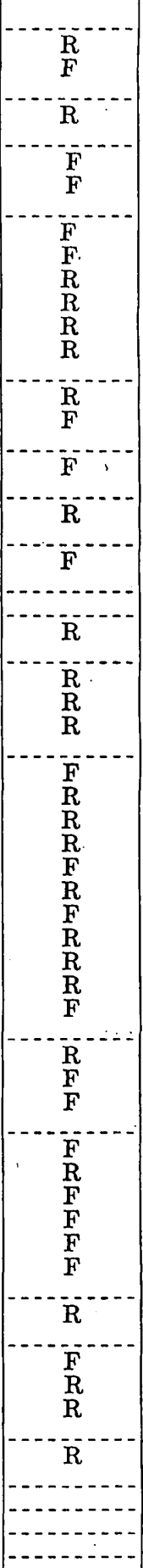 & 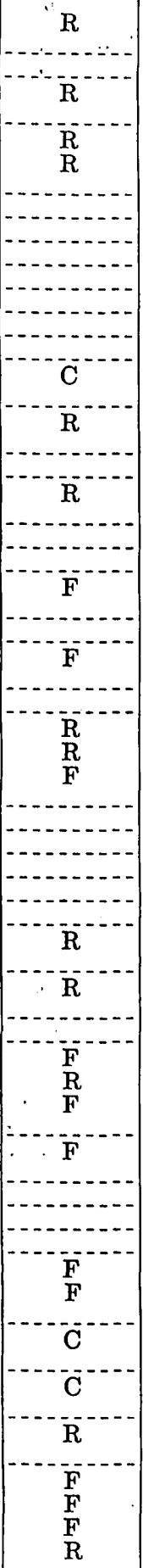 & 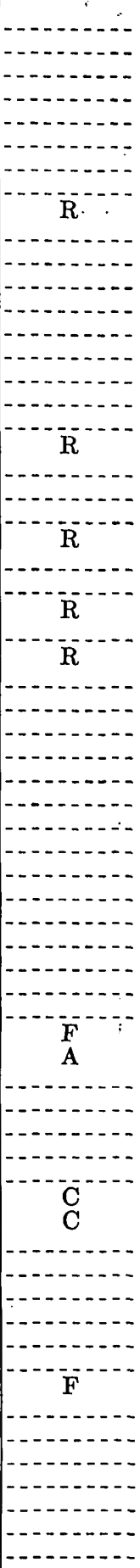 \\
\hline
\end{tabular}


GEOLOGY OF THE KETTLEMAN HILLS OIL FIELD, CALIFORNIA

in these two collections is a slender form of $A$. longinqua that has slightly inflated whorls, also found in the lower Amnicola zone. The thick-shelled strongly inflated high-beaked form of Gonidea coalingensis (pl. 6, fig. 4) represented at locality 27 was not found at other horizons.

Most of the Tulare fossils are from the lower Amnicola zone, characterized by the abundance of Amnicolidae (Fluminicola, Pyrgulopsis, Calipyrgula, Littoridina, Amnicola, Hydrobia, and Brannerillus).

The fossils in the upper Amnicola zone, from which collections were made at only three localities, also occur in the lower Amnicola zone. Pyrgulopsis, Calipyrgula, Hydrobia, and Brannerillus, however, were not found in the upper zone, so far as these few collections go, whereas Valvata, Fluminicola, and Littoridina are more abundant in the upper zone, though represented at only one locality. The apparent differences between the two zones are probably due to habitat control or to insufficient collecting.

Amnicola-bearing beds at horizons above the upper Amnicola zone were seen at several places, but the only shells collected are from a locality on the east side of southern North Dome, where Littorina mariana, a small oyster referred to Ostrea cf. O. vespertina sequens, and molds of part of the body whorl of a small snail occur in sandstone about 1,200 feet above the base of the formation (locality 13). The small snail was identified in the field as Amnicola; the material collected is indeterminable but more probably represents Fluminicola. Small oysters were seen also on the west side of North Dome and on the west side of Middle Dome. At the latter locality, which was recorded by Arnold and Anderson, ${ }^{21}$ they are accompanied by Littorina: The possible significance of these fossils is discussed under the heading "Environment suggested by fossils."

Diatoms were collected from the white clay at the base of the Tulare along the east side of North Dome and from the lower Amnicola zone at La Salida, on the east side of Middle Dome. This material was examined by K. E. Lohman, of the Geological Survey, who identified the species listed on pages 24-25. Some of the characteristic species are shown on plate 7. According to Lohman, the flora from locality 5 , which yielded the largest number of species, represents fresh or slightly brackish water. Most of the species from locality 11 also represent fresh and brackish water, but the considerable number of marine species suggests deposition near tide level. The flora from locality 16 indicates brackish water.

\section{PLIOCENE SERIES}

\section{CLASSIFICATION AND NOMENCLATURE}

There is no general agreement in the classification and nomenclature of the Pliocene strata underlying the

${ }^{21}$ Arnold, Ralph, and Anderson, Robert, Geology and oil resources of the Coalinga district, Calif.: U. S. Geol. Survey Bull. 398, pp. 147, 150, 1910.
Tulare formation. F. M. Anderson ${ }^{22}$ originally divided them into two units, the San Joaquin clays and the Etchegoin sands, but he also used the name Etchegoin in a group sense (Etchegoin beds) for both. Arnold and Anderson ${ }^{23}$ divided this part of the section into two formations: Etchegoin formation and Jacalitos formation, the latter embracing part of the original Coalinga beds of F. M. Anderson. This division was based essentially on the overlap of Pliocene beds onto Cretaceous rocks in the White Creek syncline, in the Diablo Range northwest of Coalinga, and an attempt was made to draw the boundary between the two formations at a horizon corresponding to the base of the overlapping beds. ${ }^{24}$ This overlap doubtless represents an important event in the geologic history of the region, but it is not yet known how successful the attempt was to use it as a basis for stratigraphic classification in more complete sections. In the work undertaken by Arnold and Anderson no attempt could be made to trace individual beds or thin zones throughout the Jacalitos Hills and Kreyenhagen Hills. The boundary on their map between Etchegoin and Jacalitos consequently was based on paleontologic data supplemented by the prevalence of blue sandstone in the Etchegoin formation and its absence in the Jacalitos formation throughout most of the area. This classification has the disadvantages of subdividing an essentially similar lithologic sequence on paleontologic grounds. Notable differences between Jacalitos and Etchegoin fossils are apparent, and detailed mapping may reveal lithologic features that could be used in mapping the beds containing these different faunas and perhaps in recognizing smaller divisions. However that may be, the current practice of the Geological Survey in the separation of Etchegoin and Jacalitos is left unchanged, as the Jacalitos formation is not exposed in the Kettleman Hills.

Mapping in the Kettleman Hills and work in the Kreyenhagen Hills show the desirability of recognizing as a separate unit the upper part of the Etchegoin formation of Arnold and Anderson. As this unit corresponds to F. M. Anderson's San. Joaquin clay, that nqame has recently been revived. ${ }^{25}$ As there is general agreement concerning the desirability of recognizing this unit and only minor differences of opinion concerning its limits, the name in the form San Joaquin formation is here adopted. There is no uniformity, however, in the nomenclature for the remainder of the Pliocene section. Nomland, ${ }^{26}$ Barbat and Galloway, ${ }^{27}$

22 Anderson, F. M., A stratigraphic study in the Mount Diablo Range of California: California Acad. Sci., 3d ser., vol. 2, pp. 178-181, 1905.

23 Arnold, Ralph, and Anderson, Robert, op. cit. (Bull. 398), pp. 75-79, 96-140.

24 Idem, pp. 98, 114.

${ }^{25}$ Barbat, W. F., and Galloway, John, San Joaquin clay, California: Am. Assoc. Petroleum Geologists Bull., vol. 18, pp. 476-499, 2 flgs., 1934. See also Gester, G. C., and Galloway, John, Geology of the Kettleman Hills oil field, Calif.: Am. Assoc. Petroleum Geologists Bull., vol. 17, pp. 1171-1173, 1933.

${ }_{26}$ Nomland, J. O., The Etchegoin Pliocene of middle California: California Univ., Dept. Geology, Bull., vol. 10, pp. 195-197, 1917.

${ }^{27}$ Op. cit. 
and Gester and Galloway ${ }^{28}$ extended the name Etchegoin to embrace the Jacalitos formation-that is, they adopted F. M. Anderson's revised nomenclature, ${ }^{29}$ with the exception that Etchegoin was not used in a group sense. Reed ${ }^{30}$ raised Etchegoin to group rank and extended the name Jacalitos to include Arnold and Anderson's Etchegoin minus the San Jonquin. As the usage of the same name for a group and a formation within the group is confusing, the simplest solution so far as the Kettleman Hills are concerned would be to raise Etchegoin to group rank and to propose a new

\section{${ }^{83}$ Op. cit.}

20 Anderson, F. M., A further stratigraphic study in the Mount Diablo Range of California: Callfornia Acad. Sci. Proc., 4th ser., vol. 3, pp. 28-31, 1908.

so Reod, R. D., Geology of California, pp. 235-236, Tulsa, Am. Assoc. Petroleum Geologists, 1033. name for the formation underlying the San Joaquin. This action would result in the virtual elimination of the well-known name Etchegoin in this region, and even if the new unit were adopted by other geologists its base would have to be found elsewhere. In view of the conflicting opinions and the undesirable features of other schemes, a compromise involving the restriction of the name Etchegoin to Arnold and Anderson's Etchegoin minus the San Jorquin is adopted-a solution independently reached by Goudkoff. ${ }^{31}$ This restriction is unfortunate inasmuch as Etchegoin has been widely used in the broader sense, but it has the advantage of retaining both Etchegoin and Jacalitos as

31 Goudkoff, P. P., Subsurface stratigraphy of Kettleman Hills oil field, Calif. Am. Assoc. Petroleum Geologists Bull., vol. 18, pp. 438-439, 1934.

Classification and nomenclature of Pliocene formations underlying Tulare formation in Coalinga district

\begin{tabular}{|c|c|c|c|c|c|c|c|}
\hline \multicolumn{2}{|c|}{ F. M. Anderson, 1905, 1008} & $\begin{array}{l}\text { Arnold and R. Ander- } \\
\text { Son, } 1910\end{array}$ & \multicolumn{2}{|r|}{ Reod, 1933} & $\begin{array}{l}\text { Gester and Galloway, } \\
\text { 1933; Barbat and }\end{array}$ & Goudkoff, 1934 & This roport \\
\hline \multirow{2}{*}{ 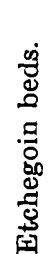 } & San Joaquin clays. & \multirow{2}{*}{$\begin{array}{l}\text { Etchegoin for- } \\
\text { mation. }\end{array}$} & \multirow{2}{*}{ 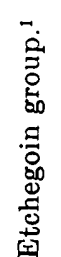 } & $\begin{array}{l}\text { San Joaquin } \\
\text { clay. }\end{array}$ & $\begin{array}{l}\text { San Joaquin } \\
\text { clay. }\end{array}$ & $\begin{array}{l}\text { San Joaquin } \\
\text { clay. }\end{array}$ & $\begin{array}{l}\text { San Joaquin } \\
\text { formation. }\end{array}$ \\
\hline & Etchegoin sands. & & & $\begin{array}{l}\text { Jacalitos forma- } \\
\text { tion. }\end{array}$ & Etchegoin sand. & $\begin{array}{l}\text { Etchegoin for- } \\
\text { mation. }\end{array}$ & $\begin{array}{l}\text { Etchegoin forma- } \\
\text { tion. }\end{array}$ \\
\hline
\end{tabular}

1 The Reol Ridgo shale, which seoms to be Miocene, was also Included tn the Etchegoln group.

formation names. The different classifications proposed and the one here adopted are diagrammatically shown below.

\section{SAN JOAQUIN FORMATION}

The name San Joaquin formation is adopted for the greater part of the apparently nonmarine and marine strata underlying the nonmarine Tulare formation. No type locality was designated in the original description of the San Joaquin clays, but the Kettleman Hills were mentioned, and the section in sec. 23, T. $22 \mathrm{~S}$., R. 18 E., on the east side of North Dome has been recently suggested as the type section. ${ }^{32}$ The section exposed along Arroyo Hondo on the east side of North Dome may be a more satisfactory standard section.

The preponderance of fine-grained rocks-fine-grained silty sandstone, silt, and clay-is the most apparent lithologic feature of the San Joaquin formation. Weathered outcrops give the impression that clay is the principal constituent, but fresh exposures show that much of the material is silt and silty sandstone and that a large part of the clay is silty. Some of these finegrained rocks appear to be nonmarine; at least marine fossils have not been found in many of them, and the remains of land plants and fresh-water shells have been found in some. Beds of sand or sandstone and of gravel or conglomerate are interbedded with the fine-grained

\footnotetext{
st Barbat. W. F., and Galloway, John, op. cit., pp. 478-480.
}

rocks. Many of these coarse-grained beds contain marine fossils, and a few contain nonmarine fossils. Thin lenses of limestone occur at several horizons in the upper half of the formation. Fresh tuff is rare in the San Joaquin formation, but volcanic material, or material regarded as an alteration product of volcanic glass, makes up a considerable part of some beds. On account of the lack of a prevailing type of lithology the original name San Joaquin clays is changed to San Joaquin formation.

Many of the marine beds have characteristic suites of fossils, apparently representing different animal communities, that can be recognized in the field. The zonul nomenclature introduced by Arnold and Anderson for some of these marine beds is adopted in an expanded and modified form. The largest marine faunas are generally found in sand, sandstone, and conglomerate. Such beds are distinctive not only on account of their fossils but also on account of their lithology, for they lie between rocks that are for the most part fine-grained. As most of them show more or less change in lithology along the strike and as their recognition depends principally on the fossils, a zonal nomenclature appears preferable to member names. The only member name proposed is the one for the conglomerate and sandstone at the base of the formation-the Cascajo conglomerate member. 
The base of the San Joaquin formation is drawn at the base of the Cascajo conglomerate member. As interpreted in this report, this member is recognized in the three anticlines of the Kettleman Hills. It is probably the equivalent of the conglomerate that rests unconformably on Miocene shale near McKittrick, farther south on the west border of the San Joaquin Valley. On the advance edition of the geologic map of the Kettleman Hills, issued in 1934, the base of the San Joaquin formation was placed at the base of the Littorina zone, which is now assigned to the Etchegoin formation. In North Dome the Littorina zone is about 100 feet below the Cascajo member. The Littorina zone embraces a layer of oolite and the earliest freshwater fossils. The oolite is the most reliable stratigraphic datum plane in North Dome, but no oolite or fresh-water fossils have been found at this horizon in Middle Dome or South Dome. The base of the Cascajo conglomerate is considered a more satisfactory horizon for a major stratigraphic division, as it is believed to be recognizable over a larger area and is apparently the equivalent of conglomerate that elsewhere marks a transgression following deformation in the adjoining Coast Ranges.

Barbat and Galloway ${ }^{33}$ placed the boundary between the San Joaquin and Etchegoin formations at the base of a lenticular bluish-gray sandstone that rests on the upper Mulinia zone (designated the upper Pseudocardium zone in the present report). The equivalent of the upper Pseudocardium zone of North Dome has not been certainly recognized, however, in Middle and South Domes. Evidence indicating discontinuity is apparent at the base of the sandstone that at places lies on the upper Pseudocardium zone, as at the base of other sandstones and conglomerates.

The San Joaquin formation is thickest on the west flank of southern North Dome and northern Middle Dome and thins eastward across the hills. The approximate thickness of the principal faunal and litho-

s3 Barbat, W. F., and Galloway, John, op. cit., pp. 480 (table), 482.

Approximate thickness, in feet, of San Joaquin formation

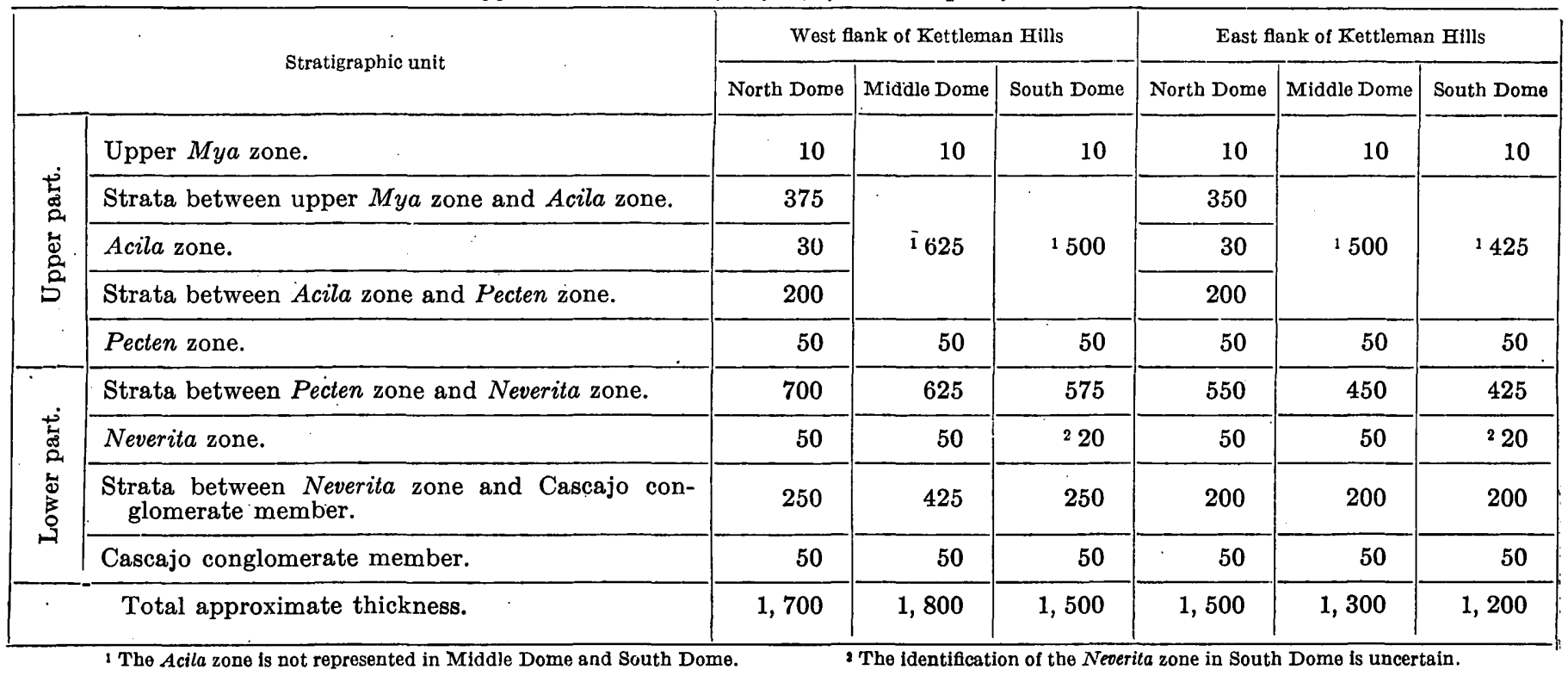

logic units and of the entire formation is shown in the following table.

The generalized stratigraphic sections on plate 3 represent graphically the character of the San Joaquin formation in the three anticlines. These sections show the stratigraphic position and map symbol of the mapped faunal and lithologic units, including minor units not shown in the preceding table. The mapped lines represent the base of the units, but some of the units are so thin that the width of the line exceeds the width of outcrop of the unit.

The Pecten zone is the most distinctive and most widespread faunal unit in the San Joaquin formation. In order to show the base of the Pecten zone more clearly, the formation is divided into a lower part and an upper part at the base of this zone, and the two parts are shown by a separate pattern on the geologic map (pl. 3). This subdivision also corresponds to a major faunal subdivision based on the sand dollars or echinoids. On the greater part of the east flank of Middle Dome, where the Pecten zone is not well developed, the division is made at the base of the Trachycardium zone, which might be considered the upper part of the Pecten zone.

\section{UPPER MYA ZONE}

STRATIGRAPHY AND LITHOLOGY

The upper Mya zone, first briefly described by Arnold ${ }^{34}$ constitutes the uppermost part of the San Joaquin formation. It has an observed thickness of 6 to 7 feet. A fossiliferous sand, in which $M y a$ generally is the most abundant fossil, is the most conspicuous.

3rnold, Ralph, Paleontology of the Coalinga district, Fresno and Kings Coun. ties, Calif.: U. S. Geol. Survey Bull. 396, p. 42, 1909 [1910]. 
part of the zone. At places the sand is overlain by silty clay that is nonfossiliferous or contains small oysters regarded as dwarfs. The silty clay was observed only in fresh exposures and may not be widespread. A thin limestone that underlies the sand at some localities is included in the zone. In the absence of exposures the upper Mya zone was mapped by following the narrow band of fossils and the narrow band of thin sandy soil.

Arnold and Anderson ${ }^{35}$ defined the upper Mya zone as embracing a thickness of 300 to 400 feet of sand and clay in the Kreyenhagen Hills and a thickness of 200 to 300 feet in the Kettleman Hills. As both areas were mentioned and no type region was designated, it is suggested that Las Alturas, on the west side of nothern. Middle Dome, be considered the type region of the upper Mya zone as here restricted. The term upper Mya zone is restricted to the uppermost part of the original zone. Geologists working in this region have informally made this restriction in view of the absence of Mya in other parts of the original upper Mya zone, at least in the Kettleman Hills. The upper Mya zone as here defined is separated from the next underlying Mya-bearing zone by beds whose minimum thickness is 875 feet. The lower Mya zone of Arnold ${ }^{36}$ probably corresponds to the Littorina zone of the Etchegoin formation. So many $M y a$-bearing beds have been recognized, however, in the lower part of the San Joaquin and in the upper part of the Etchegoin that the term lower Mya zone is inappropriate. Nevertheless, the retention of the name upper Mya zone for the zone at the top of the San Joaquin is appropriate, as it is the highest Mya zone.

East flank of Kettleman Hills.-The upper Mya zone is exposed at intervals on the east flank of North Dome and was recognized at other places by its fossils. The following section was measured in an arroyo 500 feet west of Arroyo Bifido. At this locality the fossils are poorly preserved.

Section of upper Mya zone of San Joaquin formation in arroyo 500 feet west of Arroyo Bifido, sec. 35, T. 21 S., R. 17 E.

Tulare formation:

Dirty white silty clay.

San Joaquin formation, upper Mya zone:

Olive-gray silty clay, fragments of dwarf oysters

and barnacles.

Fossiliferous sand:

Fine-grained dirty sand containing many molds of $M y a$; upper surface minutely irregular and iron-strained.................

Muddy sand; many Mytilus..............

Fine-grained sand; many molds of $M y a_{-. . .--~}$

Fine-grained dirty iron-stained sand containing mudstone pellets at base; molds of clams (base of upper Mya zone). Underlain by olive-gray silty clay . . . . . .

Thickness of upper Mya zone._._._._._. 61 ${ }^{86}$ Arnold, Ralph, and Anderson, Robert, op. cit. (Bull. 398), pp. 119, 121, 1910. so Idem, pp. 121, 123. See also Bull. 396, p. 42.
The following section is exposed on Arroyo Robador:

Section of upper Mya zone of San Joaquin formation on Arroyo Robador, sec. 25, T. 22 S., R. 19 E.

Tulare formation:

Ft. in.

Dirty white clay containing brackish-water diatoms (locality 11).

San Joaquin formation, upper Mya zone:

Broken dwarf oysters in matrix of olive-green silty clay. Contact with overlying bed sharply defined and marked by gypsiferous layer.......

Shells and shell fragments in matrix of clean gray sand. Most abundant shells represent $M y a$, mostly single valves lying in various attitudes. In upper half of bed small and medium-sized single-valved Anadara, Calyptraea, and a few small fragments of Mytilus. Grades downward into nonfossiliferous gray sand.....

Thickness of upper Mya zone........... 77

On a tributary of Arroyo Estrecho near the north end of Los Viejos, at the south end of North Dome, the exposed part of the zone, representing a thickness of $2 \frac{1}{2}$ feet, consists of a mass of shells and shell fragments in a matrix of clean gray sand (locality 35).

Along the east side of Middle Dome and of the saddle between Middle and South Domes the zone was traced by following the narrow band of fossils, the most abundant of which are fragments of Mya and Macoma.

West flank of Kettleman Hills.-On Arroyo Conchoso and farther south a hard, dirty, white, sandy, limestone 3 to 8 inches thick immediately underlies the fossiliferous sand and is included in the upper Mya zone. At places the limestone contains molds of Mya. The following section was measured on Arroyo Conchoso, where the clay containing dwarf oysters makes up the bulk of the zone.

Section of upper Mya zone of San.Joaquin formation on Arroyo Conchoso, sec. 30, T. 22 S., R. $18 \mathrm{E}$.

[Measured by G. F. Taylor]

Tulare formation: Ft. in.

Grayish-brown clay, stained yellowish, upper part sandy (see section, p. 20).

San Joaquin formation, upper Mya zone:

Dark gray clay; many dwarf oysters . . . . . . . . . . 6

Yellowish-gray sand ......................... 1

Limestone containing molds of $M y a_{\ldots \ldots \ldots} \ldots \ldots$

Thickness of upper Mya zone.

The limestone underlying the fossiliferous sand crops out at places along the west side of Middle Dome. It is generally less than a foot thick but has a maximum thickness of 2 feet. In this region the limestone contains indeterminable molds of broken shells. The overlying sand is very fossiliferous in northern Middle Dome and is exposed at many localities along the crest and west slope of Las Alturas (localities 38-43).

At the north end of South Dome Littorina is particularly abundant in the upper Mya zone (localities 44, 45). A few float fossils, principally dwarf oysters, were 
observed on the soil-covered eastern slope of Las Colinas. Farther south no indication of the zone was found, with the exception of float dwarf oysters in the northeastern part of sec. 9, T. 25 S., R. 19 E. (locality 46).
FOSSILS

The fossils collected from the upper Mya zone are listed in the following table, and the abundant and characteristic species are shown on plates 8 and 9 .

Fossils from upper Mya zone of San Joaquin formation

[Identifications by W. P. Woodring unless otherwise stated. F, Fragments; P, paired valves]

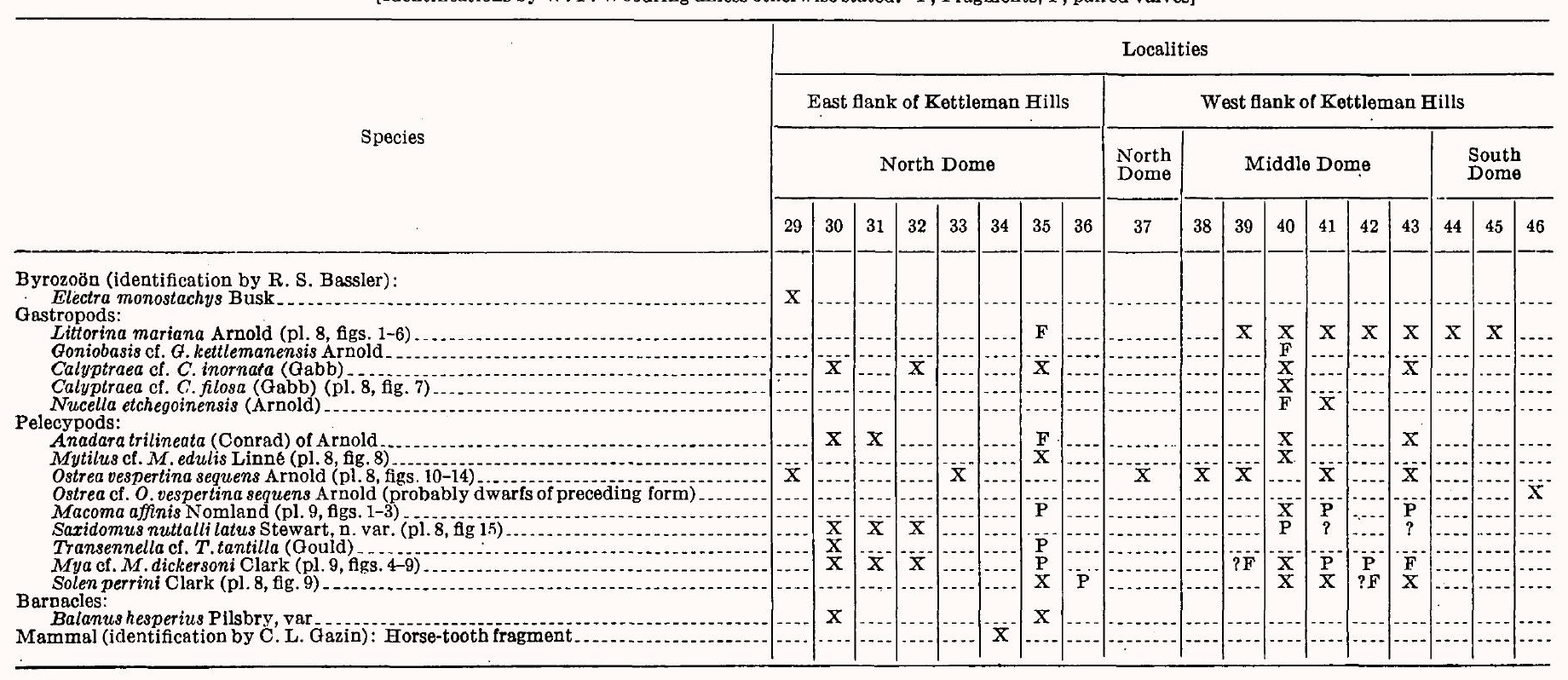

The fauna of the upper Mya zone embraces only a few species. It consists of marine forms, but the most abundant species represent genera that thrive in brackish water (Littorina, Ostrea, Macoma, Mya). Fragmentary remains of a fresh-water snail (Goniobasis) and of a horse tooth may have weathered out of the Tulare formation. Burrowing pelecypods (Macoma, Saxidomus, Mya, Solen) and attached pelecypods (Mytilus, Ostrea) are the most widespread fossils. Calyptraea is the only widespread gastropod, but Littorina is abundant on the west side of northern South Dome.

The species in the upper Mya zone were found at other horizons in the Kettleman Hills. Mytilus cf. $M$. edulis is more common in the upper Mya zone than at other horizons and was not observed in beds more than 200 feet below the upper Mya zone. The association of Mya cf. M. dickersoni, Ostrea lurida sequens, Macoma affinis, Saxidomus nuttalli latus, and Calyptraea cf. $C$. inornata, and the absence of species associated with these at other horizons are characteristic of the upper Mya zone. Strata in Arnold's upper Mya zone in the Kreyenhagen Hills have the same faunal association. These beds may represent the chronologic equivalent of the upper Mya zone of the Kettleman Hills, or they may represent the same environmental conditions at an earlier or later date. It is improbable that the Mya zone underlying the Tulare formation north of Anticline Ridge is the equivalent of the upper Mya zone in the Kettleman Hills, for Glycymeris is recorded in this Mya zone north of Anticline Ridge, and Pseudocardium occurs immediately below it. ${ }^{37}$

\section{STRATA BETWEEN. UPPER MYA ZONE AND ACILA ZONE STRATIGRAPHY AND LITHOLOGY}

In North Dome the strata between the upper Mya and the Acila zones embrace a thickness of 350 to 375 feet. These beds consist principally of sand, silty sand, and silty clay. A few thin beds of hard sandstone and hard limestone are conspicuous. The Acila zone was not recognized in Middle Dome and South Dome. The strata in these two anticlines corresponding to those between the upper Mya and Acila zones in North Dome are similar to North Dome strata in general features. On the west side of Middle Dome and South Dome, however, they include a considerable thickness of conglomerate.

Near the north end of North Dome sand dollars were found in silty sand about 115 feet below the upper Mya zone on both flanks of the anticline (localities $49,50)$. This is the highest horizon at which sand dollars were observed in the Kettleman Hills. A soft gray tuffaceous sandstone about 30 feet above the sand-dollar-bearing sand at locality 49 was examined by M. N. Bramlette, who found that it contains some fresh glass, abundant hypersthene and andesine, and some augite and hornblende.

${ }^{37}$ Nomland, J. O., Relation of the invertebrate to the vertebrate faunal zones of the Jacalitos and Etchegoin formations in the north Coalinga region, Calif.: California Univ., Dept. Geology, Bull., vol. 9, pp. 83, 85 (table), 1916. 
The small oysters in the oyster-bearing sandstones are the most abundant fossils in this part of the section. They are smaller and are generally more elongate and less strongly plicate than the oysters in the sand of the upper Mya zone. The small variety of Dendraster coalingaensis that has slightly raised petals is also found in the Acila zone. The smaller variety that has flat petals occurs also in the Neverita zone and in the Cascajo conglomerate member.

\section{ACILA ZONE}

\section{STRATIGRAPHY AND LITHOLOGY}

The Acila zone is about halfway between the top of the San Joaquin formation and the Pecten zone, 300 to 400 feet below the top of the San Joaquin and 200 to 300 feet above the Pecten zone. It consists of fossiliferous brownish or greenish muddy sand or silt interbedded with clay. The sand and clay appear to vary in thickness and in stratigraphic position relative to each other. The observed thickness of strata assigned to the zone is about 30 feet. Outcrops of the zone are inconspicuous, and the zone generally is recognizable only by the presence of fossils on weathered or soilcovered outcrops. With few exceptions the solid lines showing the outcrop of the zone on the geologic map (pl. 3) indicate the presence of Acila zone fossils at the surface.

An artificial cut along the Avenal-Lemoore road on the west flank of North Dome is selected as the type locality of the Acila zone. (See section, pp. 32-33.) Anadara is more abundant in the zone than Acila. The zone is called the Acila zone, however, as Acila was not found in the San Joaquin formation below this zone and is known from only two localities above it, whereas Anadara is found at many horizons in the San Joaquin.

The Acila zone is known in North Dome but was not recognized in Middle Dome or South Dome. This lateral change occurs roughly in the saddle between North and Middle Domes and is comparable to the lateral change in the Pecten zone in about the same area.

East flank of North Dome.-The following section was measured in a pit excavated for drilling mud near Arroyo Hondo.

Section of strata in upper part of San Joaquin formation, including Acila zone, in mud pit near Arroyo Hondo, SW1/4 sec. 5, T. 22 S., R. 18 E. (locality 58)

Strata overlying Acila zone:

Thinly laminated clay and sand streaked gray and blue. Four to five feet above base are 1-inch sandstone layers, the base of aach layer marking a discontinuity. Contact at base abrupt. Top not exposed
Section of strata in upper part of San Joaquin formation, including Acila zone, in mud pit near Arroyo Hondo, $S W 14$ sec. 5. T. 22 S., R. 18 E. (locality 58)-Continued

Acila zone:

Brownish-gray sand with yellowish-brown lenticles less than 1 inch thick. Large Anadara and a few scattered pebbles in lower 18 inches. Clay partings near top and a few Anadara near top in a 3inch sand layer separated from underlying clay parting by discontinuity. Discontinuity at base; contact abrupt; fragments of clay above contact; 1-inch sand-filled boreholes in underlying clay...-

Blue clay, excavated for drilling mud. Contact at base not observed...............................

Muddy sand containing some pebbles, Acila, small Anadara, Calyptraea, and other fossils (locality 58). Contact at base abrupt (?) Strata below Acila zone:

Greenish-gray, iron-stained, fine-grained sandstone, irregular clay partings; contains sand dollars. (The sand dollars are listed with the Acila zone fossils.) Contact at base abrupt and irregular, sand-filled boreholes in underlying silt. The numerous holes obscure the contact, but it represents a discontinuity ..........................

Laminated bluish-green-gray and brown silt; 2-inch limy lens 3 feet below top; base not exposed......

The southernmost locality of the Acila-Anadara association is on a low ridge on the west side of Los Viejos, about 1 1 $\frac{1}{2}$ miles south of Arroyo Estrecho. A bed containing Anadara, exposed just south of Arroyo Culebrino, is in the approximate stratigraphic position of the Acila zone and is correlated with it. Farther south the zone or its equivalents were not recognized.

West flank of North Dome.-The section below was measured at the type locality of the Acila zone on the Avenal-Lemoore road.

Section of strata in upper part of San Joaquin formation, including Acila zone, in cut on Avenal-Lemoore road, sec. 10, T. 22 S., R. $17 \mathrm{E}$.

Strata overying Acila zone:

9. Poorly exposed gray sand. Contact at base abrupt. Top not exposed......

8. More or less laminated gray clay. Contact at

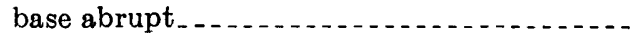
Acila zone:

7. Greenish-gray muddy sand. One fragment of Anadara observed. Chert pebbles as much as half an inch long near top. Contact at base apparently abrupt; unworn fragments of clay in basal part.................. 11

6. Laminated sandy clay. Contact at base abrupt, obscured by gypsum crystals ........ 14

5. Grayish-green muddy sand. Contact at base abrupt; sand-filled boreholes in underlying clay:

c. Abundant and somewhat scattered Acila and small Anadara; few Calyptraea . $_{3}$

b. Nonfossiliferous . . . . . . . . . . . . . . 1

a. Large Anadara $\ldots \ldots \ldots$
Ft. in. $6+$ $31 / 2$

1

3


Section of strata in upper part of San Joaquin formation, including Acila zone, in cut on Avenal-Lemoore road, sec. 10, T. 22 S., R. 17 E.-Continued

Strata underlying Acila zone:

Ft. in.

4. Laminated blue clay, weathering light gray, and some lenses of sand

3. Gray sand similar to unit 2 , but containing more

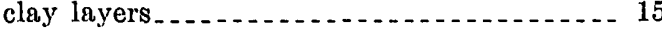

2. Irregularly bedded, fine-grained gray sand containing small clay pellets. Contact at base abrupt; sand-filled borings in underlying mud . . . . . . . . . . . . . . . . . 17

1. Irregularly bedded light-gray sand; iron concretions and thin mud layers near and at top. Base not exposed. (Probably corresponds to sand containing sand dollars in other sections.) (-2.

In this section a layer containing large Anadara underlies a layer containing small Anadara and Acila, and the layers are not separated by a discontinuity, whereas in the section measured on the east flank of the anticline the stratigraphic relations are reversed and the layers are separated by a discontinuity.

The Acila-Anadara association was found on a knoll on the steep east slope of Las Alturas, just east of El Paso, the southernmost locality at which the Acila zone was recognized on the west flank of the Kettleman Hills. It is quite possible that the zone may extend farther southward, for its stratigraphic position would place it on the steep eastern slope of Las Alturas, where exposures are rare. In La Zanja, farther south on the west flank of Middle Dome, conglomerates and an occasional limestone layer occur in this part of the section, and it is reasonably certain that the Acila zone is not present as a fossil zone.

FossiLs

Fossils from the Acila zone are listed in the following table, and some of the species are illustrated on plates $11,39,41,45$, and 46 .

Fossils from Acila zone of San Joaquin formation and underlying sand

[Identiflcations by Ralph Stewart. F, fragments; P, paired valves; S, small specimens; W, worn specimens]

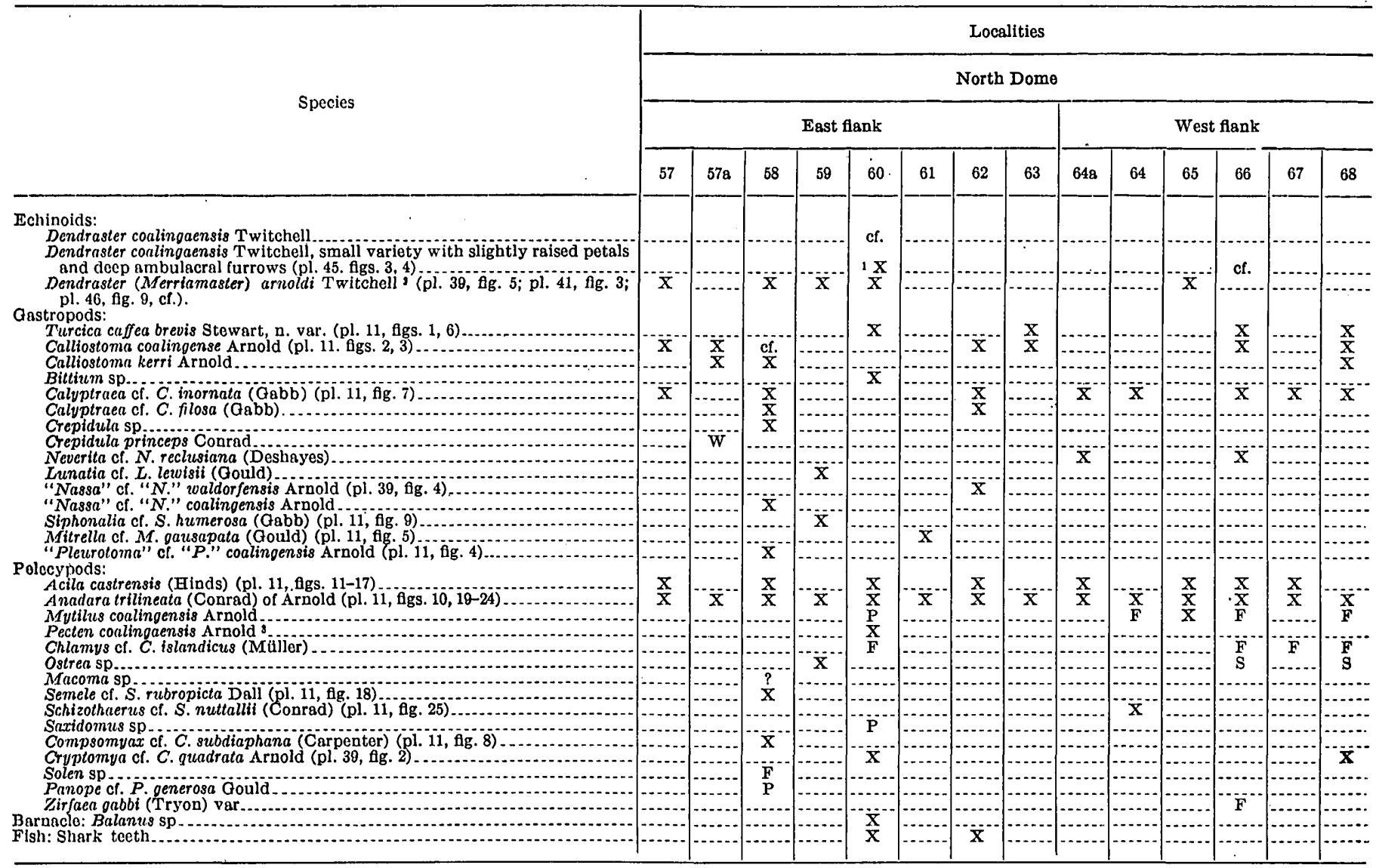

About 300 fect southeast of locality 60 , from a 2-foot gray sand just above the layer of silt containing Acila and evidently part of the Acila zone.

- From sand a few feet below Acila zone.

Anadara and Acila are the most abundant fossils, and the association of these two genera is a characteristic feature of this zone. A specimen of Acila was found on the steep western slope of La Ceja, on the west side of Arroyo Largo. This specimen may have come from the upper Mya zone or more probably from strata about
25. feet lower, in which a medium-sized Anadara was found on the east side of Arroyo Largo. A more satisfactory occurrence of Acila above the Acila zone was found by Dr. Max Birkhauser. This locality is farther southeast on the east flank of North Dome on the south branch of Arroyo Torcido (NW/4 $\mathrm{SW} / 4 \mathrm{NE} / 1 / 4$ sec. 6, T. 
22 S., R. 18 E.), where Acila and Anadara occur in fine-grained sand or sandy silt about 30 feet below the upper Mya zone. Aside from these two localities, Acila was not found in the San Joaquin formation outside the Acila zone.

Calyptraea is the only abundant gastropod. The other fossils are rare. The fragments of Chlamys are the highest stratigraphically and therefore the last of the Pectinidae yet found in the Kettleman Hills.

Most of the sand dollars included in the list of Acila zone fossils occur in sand a few feet below the Acila zone. (See section, p. 32.) In the sand underlying the Acila zone is the highest horizon at which Merriamaster was found (pl. 39, fig. 5 ; pl. 41, fig. 3 ; pl. 46, fig. 9). The variety of Dendraster coalingaensis with slightly raised petals (pl. 45, figs. 3,4 ) that occurs in the Acila zone itself also was found in strata about 250 feet higher stratigraphically.

\section{STRATA BETWEEN ACILA ZONE AND PECTEN ZONE}

In North Dome the strata between the Acila and the Pecten zones are about 200 feet thick. They consist chiefly of muddy silt and sand. In Middle and South Domes, where the Acila zone was not recognized, beds of conglomerate occur in the corresponding part of the section. These beds of conglomerate are more numerous on the west flank of the Kettleman Hills than on the east.

On the east flank of North and Middle Domes and on the west flank of North Dome are marine fossils in sand at a horizon generally 125 to 150 feet above the base of the Pecten zone, about halfway between the Acila zone and the Pecten zone. The faunal zone is designated the Trachycardium zone. On account of the similarity of its fauna to that of the Pecten zone it is described with the Pecten zone.

A conspicuous white fresh pumice tuff crops out on the north bank of Arroyo Doblegado, 100 feet west of the east line of sec. 16, T. 22 S., R. 18 E., at a horizon about 125 feet above the base of the Pecten zone. The tuff is in the form of a lens that has a maximum thickness of 10 feet. It overlies cross-bedded bluish-gray sandstone, the uppermost part of which has pellets and stringers of tuff, and is overlain by a 2-foot layer of cross-bedded tuff and bluish-gray sandstone in thin stringers. The tuff consists of lumps of pumiceous glass that have a diameter of 2 to 5 millimeters. The index of refraction of the glass, as determined by M. N. Bramlette, is 1.50. A partial chemical analysis is given below.

Partial chemical analysis of pumice tuff from upper part of San Joaquin formation

[R. C. Wells, analyst]

$\begin{array}{ccr}\text { [R. C. Wells, analyst] } & \begin{array}{r}\text { Percent } \\ \mathrm{SiO}_{2}\end{array} \mathrm{Ka}_{2} \mathrm{O} \\ \mathrm{Na}_{2} \mathrm{O} & & 1.9 \\ & & 2.4 \\ \end{array}$

\section{S. Ross comments on the analysis as follows:}

The analysis shows that in the norm the plagioclase feldspar would be sodic, near oligoclase in composition, and would exceed the potash feldspar orthoclase. There would also be a considerable proportion of normative quartz. A rock of this composition would be a dacite, a type of rock that commonly forms pumice tuff.

It is not known whether similar tuff occurs elsewhere at the same horizon.

On the west flank of southern Middle Dome worn fragments of Aequipecten, Pseudocardium?, Trachycardium?, Mya, and horse-tooth fragments were found in conglomerate at locality 136 . On an assumption of an average dip of $20^{\circ}$ this conglomerate is about 400 feet above the horizon regarded as the base of the Pecten zone in this region and about 250 feet below the upper Mya zone, or about in the stratigraphic position of the Acila zone. Elsewhere Pseudocardium occurs at much lower horizons; and Aequipecten and Trachycardium were not observed above the Trachycardium zone. The worn condition of these fossils leaves little doubt that they were transported into the gravel as fossils or as dead shells. According to available information, it seems more likely that they were derived as fossils from earlier strata than that they are worn fragments of shells that lived in this region when the gravel was deposited. If they were transported as fossils, they were presumably derived from strata cropping out west of the Kettleman Hills.

\section{PECTEN ZONE AND TRACHYCARDIUM ZONE}

STRATIGRAPHY AND LITHOLOGY

The Pecten zone is about 200 feet below the Acila zone and from 425 to 625 feet below the upper $M y a$ zone. As typically developed it consists of sand and silty sand that has an average thickness of about 50 feet and includes fossiliferous layers. Locally the zone is as much as 175 feet thick, but it is not fossiliferous throughout such thickness. The base of the sand is generally pebbly. In general the sand in the upper part of the zone is silty and locally contains many sand dollars. A thin limestone layer is present at the base of the zone at some localities, particularly on the west flank of Middle and South Domes. On the west flank of Middle Dome thick beds of conglomerate occur in the zone. Conglomerate is less abundant on the east flank of Middle Dome. On the east flank of South Dome the zone consists of silty sediments. The character and thickness of the zone at localities on the east flank of North Dome and on the west flank of Middle and South Domes are shown on plate 12.

The Pecten zone contains a peculiar and therefore easily recognized marine fauna. On the basis of its fossils this zone is correlated with Arnold's typical Pecten coalingaensis zone of the Kreyenhagen Hills, ${ }^{38}$

${ }^{38}$ Arnold, Ralph, op. cit. (Bull. 396), p. 42. Arnold, Ralph, and Anderson, Robert, op. cit. (Bull. 398 ), pp. 119, 137. 


\section{PLATE 8}

Figures 1-6. Littorina mariana Arnold.

[Figures natural size]

1. Height (incomplete) $22.7 \mathrm{~mm}$., width $17.8 \mathrm{~mm}$. Locality 41 . U. S. Nat. Mus. 495285.

2. Height $14.3 \mathrm{~mm}$., width $10.7 \mathrm{~mm}$. Locality 44 . U. S. Nat. Mus. 495286.

3. Height (incomplete) $19.8 \mathrm{~mm}$., width $13 \mathrm{~mm}$. Locality $44 . \quad$ U. S. Nat. Mus. 495287.

4. Height $15.5 \mathrm{~mm}$., width $10.6 \mathrm{~mm}$. Locality 44. U. S. Nat. Mus. 495288.

5. Height (almost incomplete) $13.5 \mathrm{~mm}$, width $9.5 \mathrm{~mm}$. Locality 44 . U. S. Nat. Mus. 495289.

6. Height $19.3 \mathrm{~mm}$., width $12 \mathrm{~mm}$. Locality 44. U. S. Nat. Mus. 495290.

7. Calyptraea ef. C. filosa (Gabb). Height $9.8 \mathrm{~mm}$., greatest diameter $1.7 \mathrm{~mm}$. Locality 40 . U. S. Nat. Mus. 495291.

8. Mytilus cf. M. edulis Linné. Greatest length $54.2 \mathrm{~mm}$., width $26.8 \mathrm{~mm}$., thickness $8.2 \mathrm{~mm}$. Locality 40 . U. S. Nat. Mus. 495293.

9. Solen perrini Clark. Length (incomplete) $53.8 \mathrm{~mm}$., height $22.5 \mathrm{~mm}$., thickness $8.1 \mathrm{~mm}$. Locality 40 . U. S. Nat. Mus. 495294.

10-14. Ostrea vespertina sequens Arnold.

10. Left valve. Length $51.5 \mathrm{~mm}$., height $42 \mathrm{~mm}$., thickness about $12 \mathrm{~mm}$. Locality 33 . U. S. Nat. Mus. 495295.

11. Left valve. Length $58 \mathrm{~mm}$., height $63.8 \mathrm{~mm}$., thickness about $14.5 \mathrm{~mm}$. Locality 33 . U. S. Nat. Mus. 495296.

12. Right valve. Length $47.5 \mathrm{~mm}$., height $59.5 \mathrm{~mm}$., thickness about $5 \mathrm{~mm}$. Locality 33 . U. S. Nat. Mus. 495297.

13. Left valve. Length $40.5 \mathrm{~mm}$, height $54.5 \mathrm{~mm}$, thickness about $15 \mathrm{~mm}$. Iocality 37 . U. S. Nat. Mus. 495298.

14. Right valve. Length $36 \mathrm{~mm}$., height $59.5 \mathrm{~mm}$., thickness about $6 \mathrm{~mm}$. Locality 37 . U. S. Nat. Mus. 495299.

15. Saxidomus nuttalli latus Stewart, n. var. Length $85.5 \mathrm{~mm}$., height $62 \mathrm{~mm}$., thickness $21 \mathrm{~mm}$. Locality $31 . \quad$ U. S. Nat. Mus. 495300. 


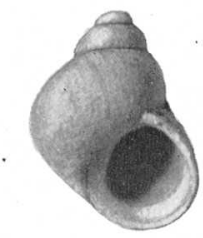

1

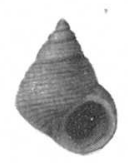

2

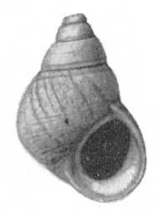

3

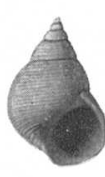

4

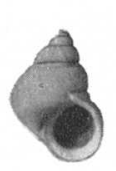

5

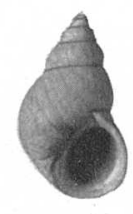

6
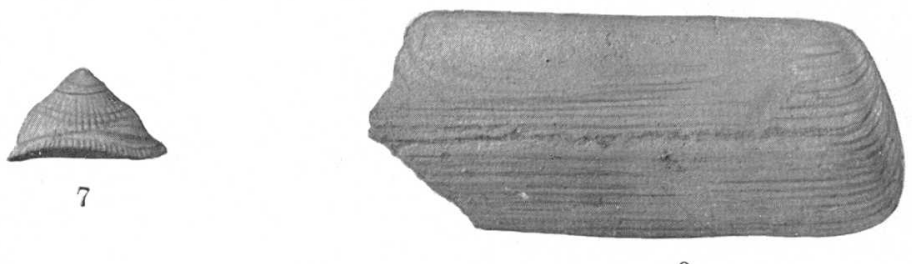

9

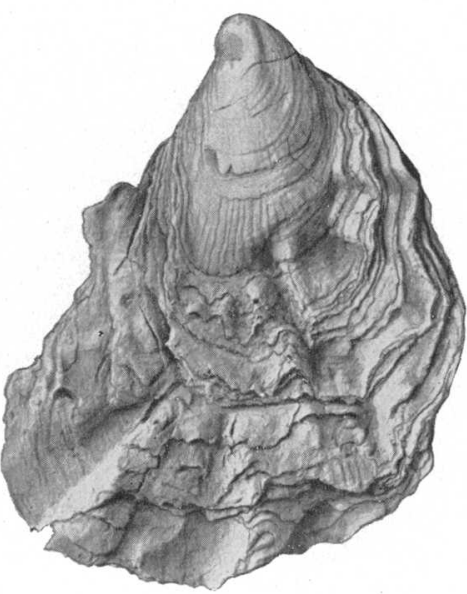

12

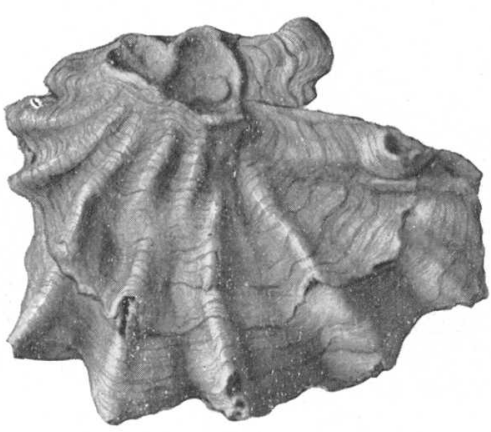

10

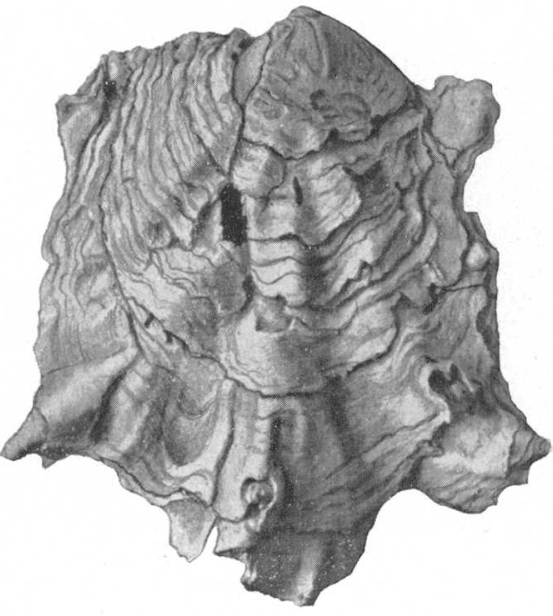

11

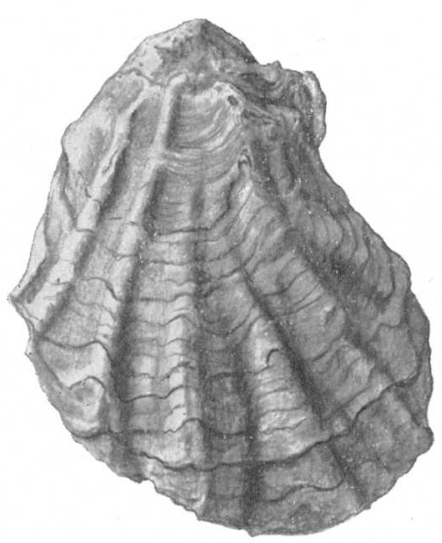

13

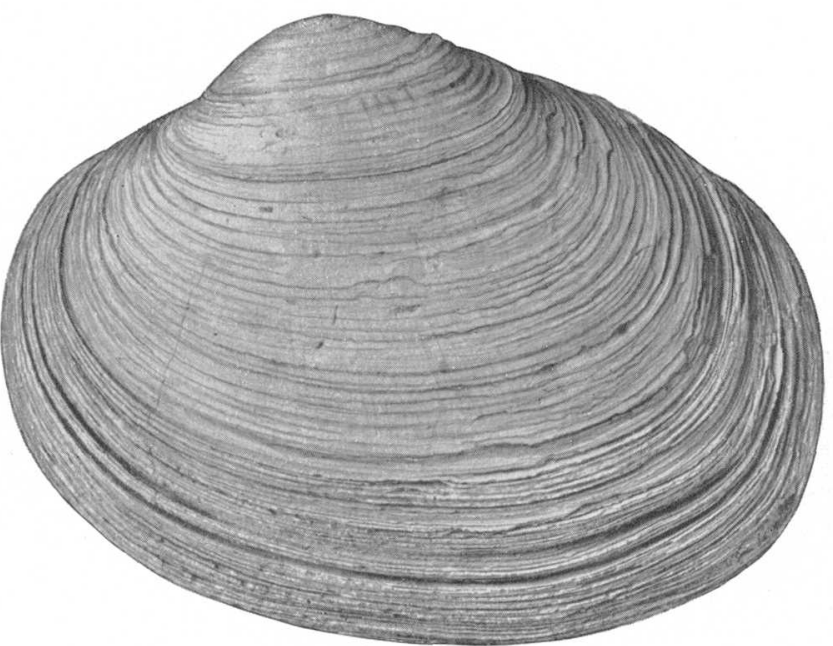

15

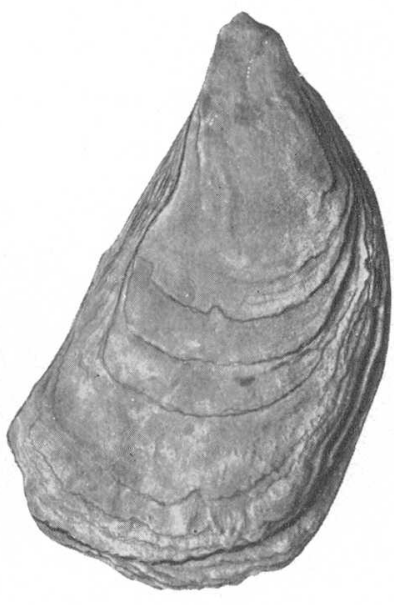

14

FOSSILS FROM UPPER MYA ZONE OF SAN JOAQUIN FORMATION. 


\section{PLATE 9}

[Figures natural size]

Figures 1-3. Macoma affinis Nomland. Locality 41.

1. Length $56 \mathrm{~mm}$., height $44 \mathrm{~mm}$., thickness of both valves $17.5 \mathrm{~mm}$. U. S. Nat. Mus. 495301 .

2. Length $62.5 \mathrm{~mm}$., height $48 \mathrm{~mm}$., thickness of both valves $20.5 \mathrm{~mm}$. U. S. Nat. Mus. 495302 .

3. Length $50 \mathrm{~mm}$., height $40 \mathrm{~mm}$., thickness $9.5 \mathrm{~mm}$. U. S. Nat. Mus. 495303 .

4-9. Mya ef. M. dickersoni Clark.

4. Length $78 \mathrm{~mm}$., height $40.5 \mathrm{~mm}$., thickness (not including chondrophore) $12.8 \mathrm{~mm}$. Locality 42 . U. S. Nat. Mus. 495305.

5. Length (virtually complete) $62.2 \mathrm{~mm}$., height $46.2 \mathrm{~mm}$., thickness $19 \mathrm{~mm}$. Locality 30 . U. S. Nat. Mus. 495306.

6, 7. Length $95.5 \mathrm{~mm}$., height $58.5 \mathrm{~mm}$., thickness (not including chondrophore) $20.5 \mathrm{~mm}$. Locality 31 . U. S. Nat. Mus. 495304.

8, 9. Length $74.5 \mathrm{~mm}$., height $49 \mathrm{~mm}$., thickness $20 \mathrm{~mm}$. Locality 31 . U. S. Nat. Mus. 495307. 
GEOLOQGICAL SURVEY

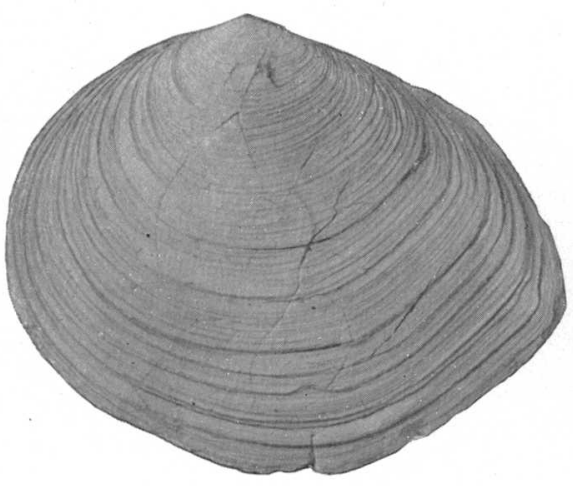

1

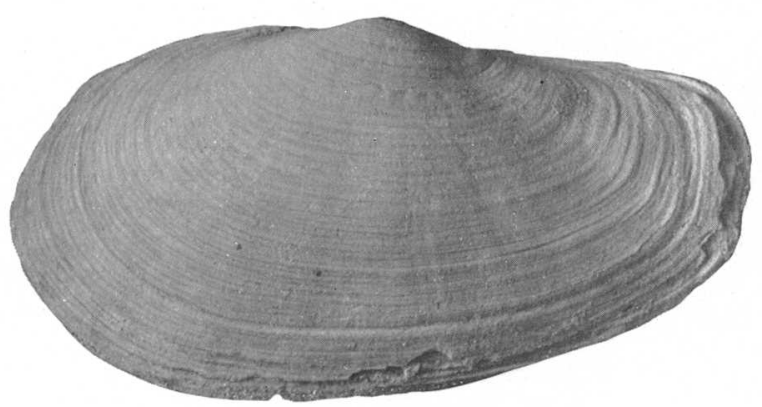

4

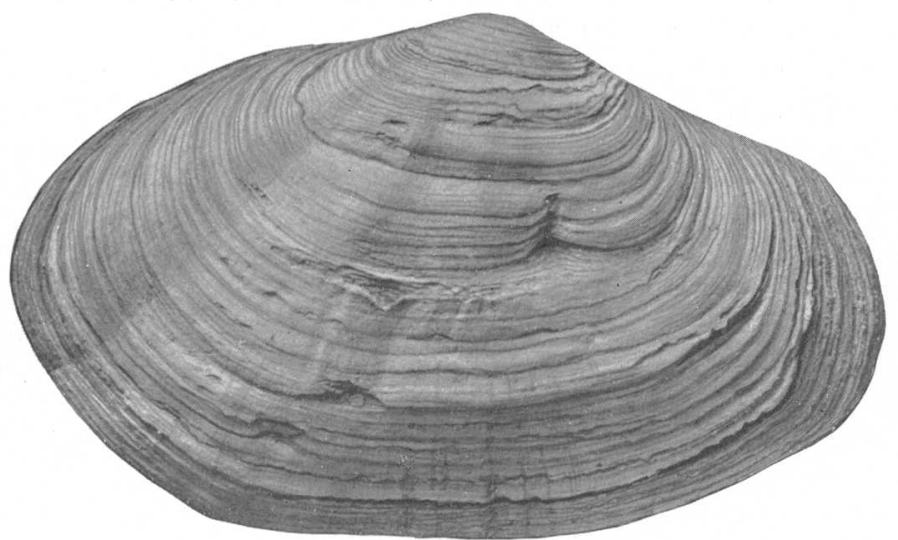

6

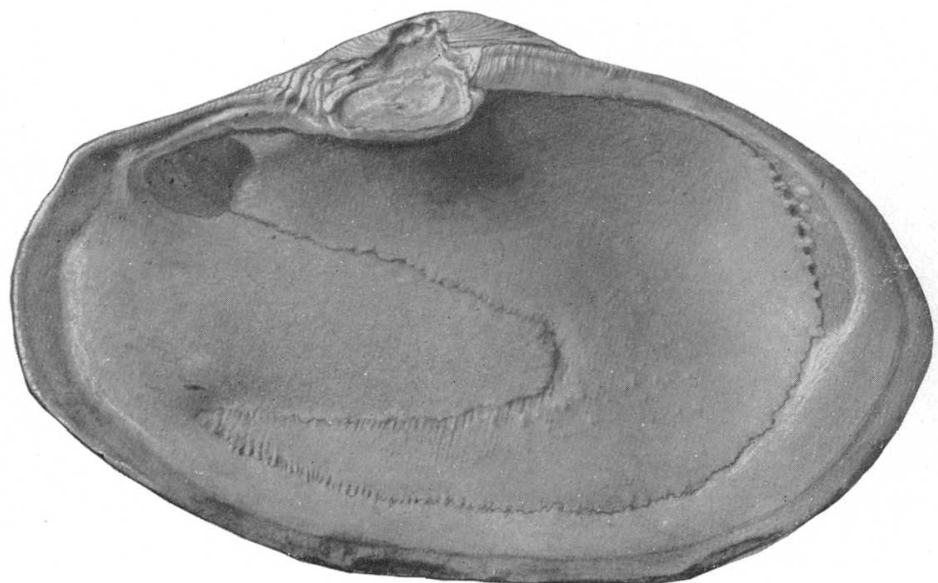

7

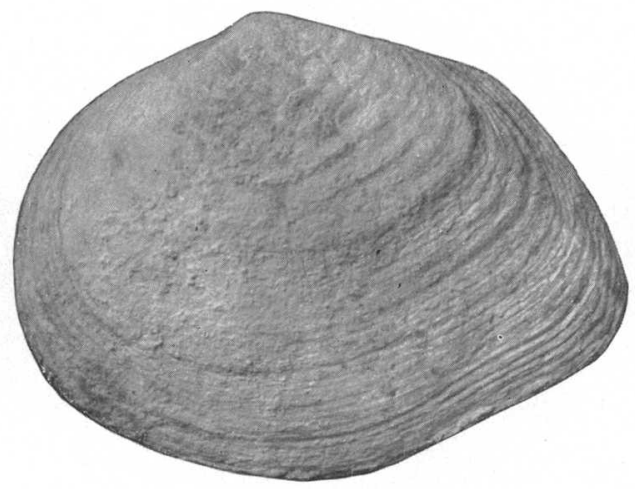

2
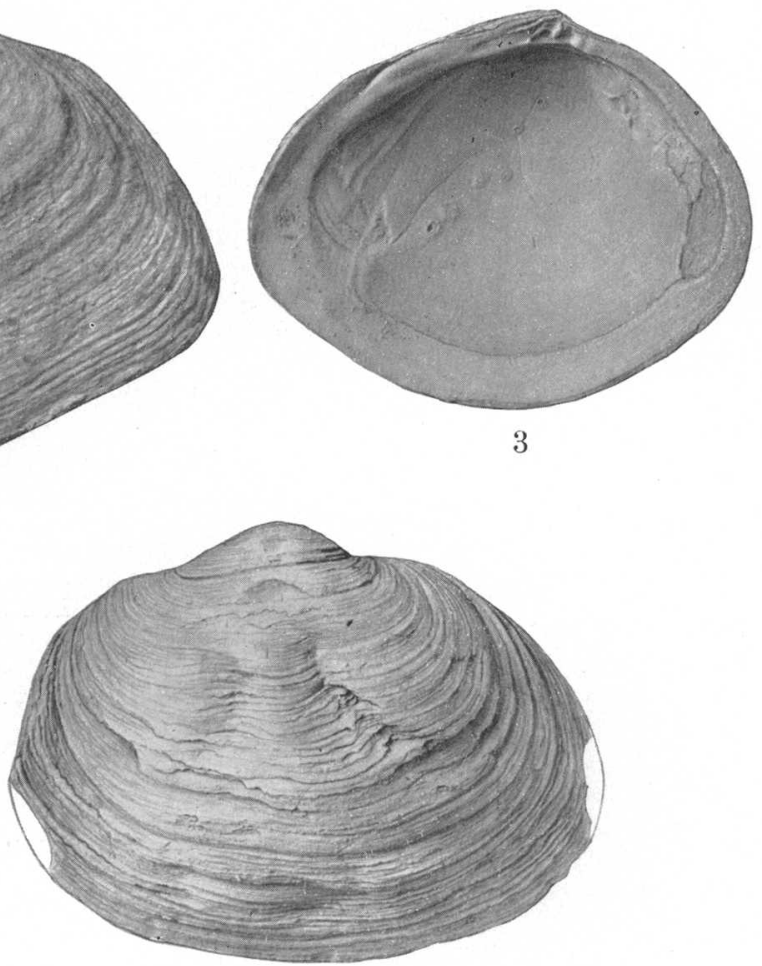

5

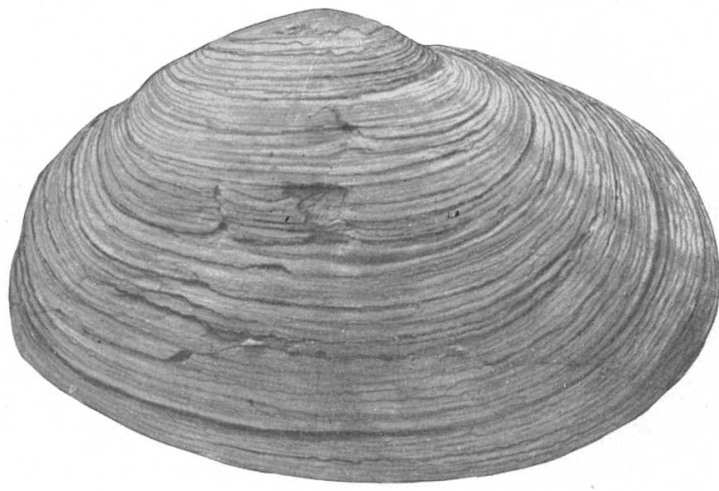

8

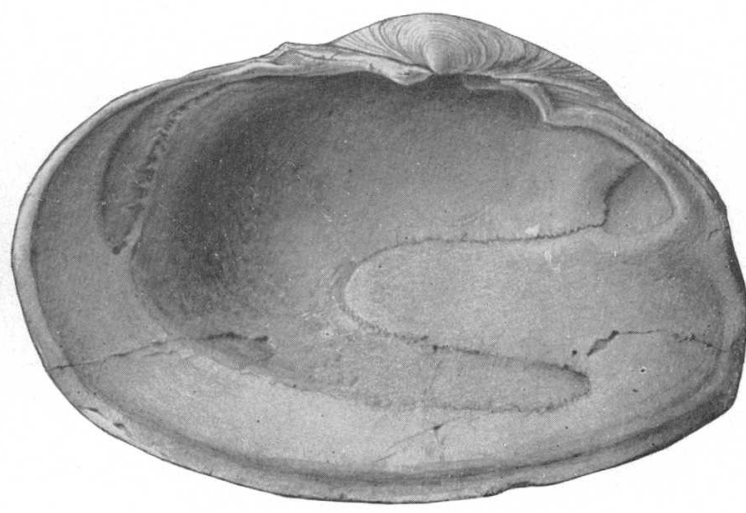

FOSSILS FROM UPPER MYA ZONE OF SAN JOAQUIN FORMATION. 


\section{PLATE 10}

[Figures natural size unless otherwise designated]

Figures 1-5. Ostrea vespertina sequens Arnold.

1. Right valve. Length $24 \mathrm{~mm}$., height $27.5 \mathrm{~mm}$., thickness about $4.5 \mathrm{~mm}$. Locality 52 . U. S. Nat. Mus. $495307 \mathrm{a}$.

2. Right valve. Length $20.5 \mathrm{~mm}$., height $37.5 \mathrm{~mm}$., thickness about $2.5 \mathrm{~mm}$. Locality 52 . U. S. Nat. Mus. 495308.

3. Left valve. Length $32 \mathrm{~mm}$., height $34.5 \mathrm{~mm}$., thickness about $9 \mathrm{~mm}$. Locality 52 . U. S. Nat. Mus. 495309.

4. Left valve. Length $22 \mathrm{~mm}$., height $40 \mathrm{~mm}$., thickness about $5 \mathrm{~mm}$. Locality 52 . U. S. Nat. Mus. 495310 ,

5. Left valve. Length $28 \mathrm{~mm}$., height $43.5 \mathrm{~mm}$., thickness about $14 \mathrm{~mm}$. Locality 55 . U. S. Nat. Mus. 495311 .

6-9. Dendraster coalingaensis Twitchell, small var. with slightly raised petals, and deep ambulacral furrows.

6. Length $31.6 \mathrm{~mm}$., width $33 \mathrm{~mm}$., height $7 \mathrm{~mm}$. Locality 50. U. S. Nat. Mus. 495312 .

7. Length $33.2 \mathrm{~mm}$., width $34.8 \mathrm{~mm}$., height $7.8 \mathrm{~mm}$. Locality 50 . U. S. Nat. Mus. 495313.

8. Length $39.7 \mathrm{~mm}$., width $40.8 \mathrm{~mm}$., height $7.7 \mathrm{~mm}$. Locality 50 . U. S. Nat. Mus. 495314 .

9. Length $20.7 \mathrm{~mm}$., width $24 \mathrm{~mm}$., height $4 \mathrm{~mm}$. Locality 49 . U. S. Nat. Mus. 495315.

10-12. Dendraster coalingaensis Twitchell, small var. with flat petals. Locality 56 .

10. Form with marginal periproct. Length $26.4 \mathrm{~mm}$., width $28.5 \mathrm{~mm}$., height $4 \mathrm{~mm}$. U. S. Nat. Mus. 495316.

11. Form with supramarginal periproct. Length $18.3 \mathrm{~mm}$., width $19.9 \mathrm{~mm}$., height $3.4 \mathrm{~mm}$. U. S. Nat. Mus. $495316 \mathrm{a}$

12. Form with periproct at margin of oral surface. Length $20.5 \mathrm{~mm}$., width $23.8 \mathrm{~mm}$., height $3.3 \mathrm{~mm}$. U. S. Nat. Mus. 495317. 


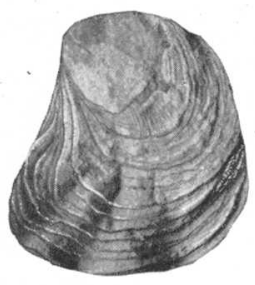

1

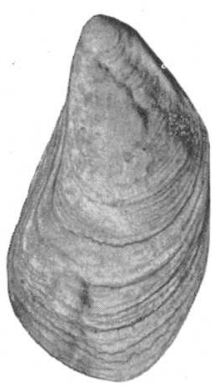

2

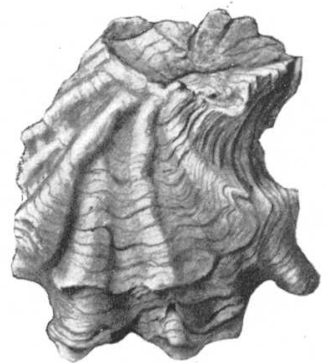

3
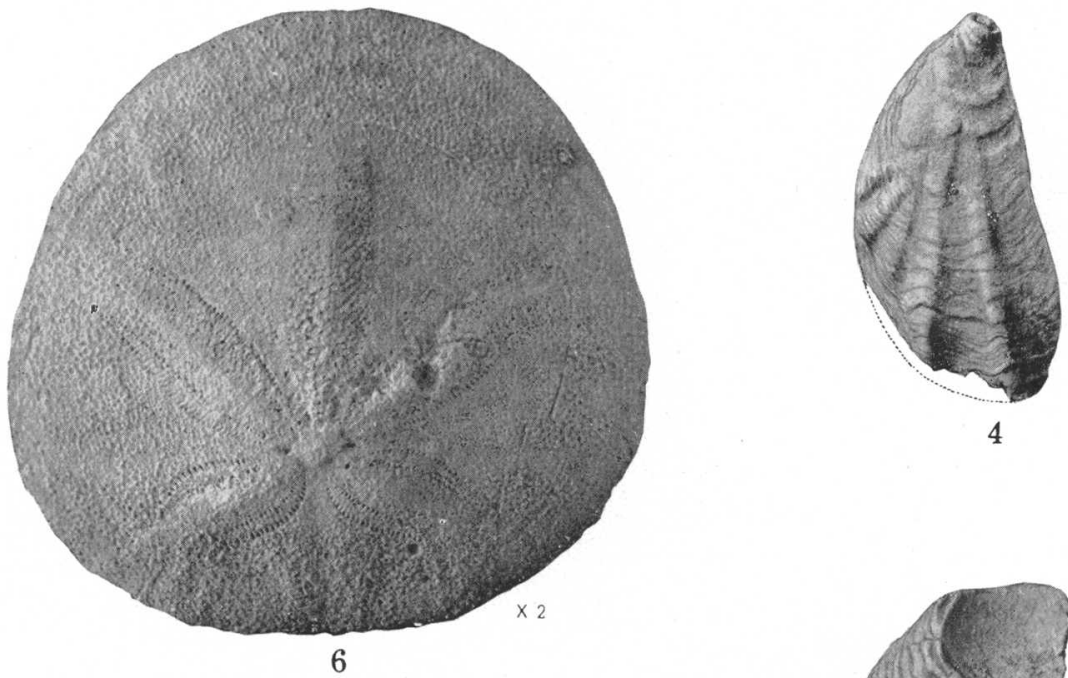

4

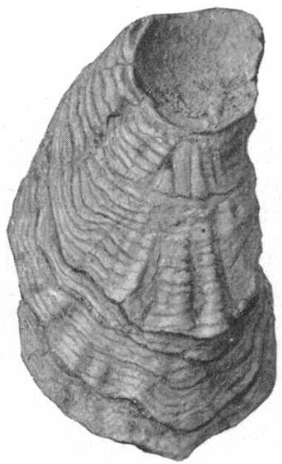

5
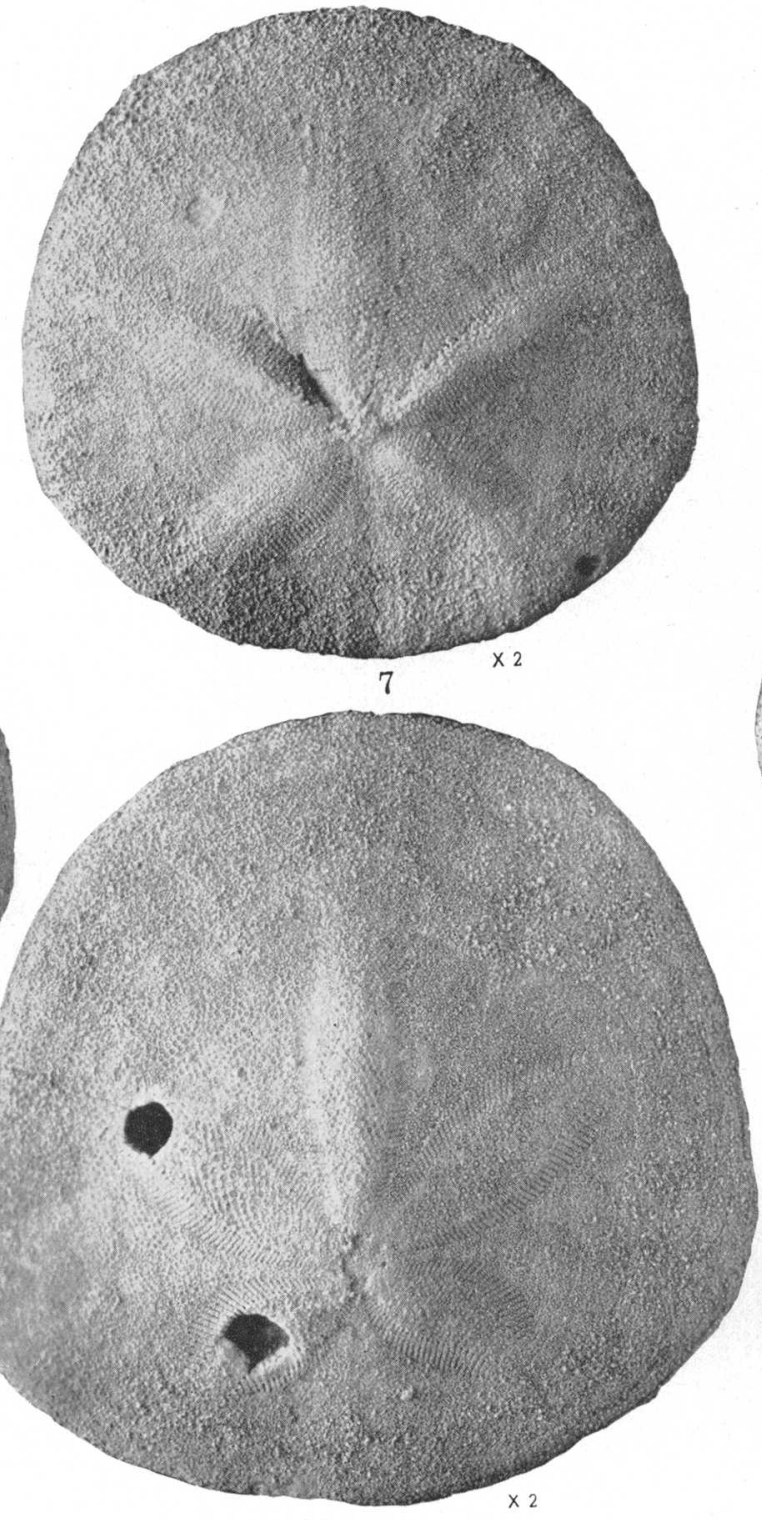

8

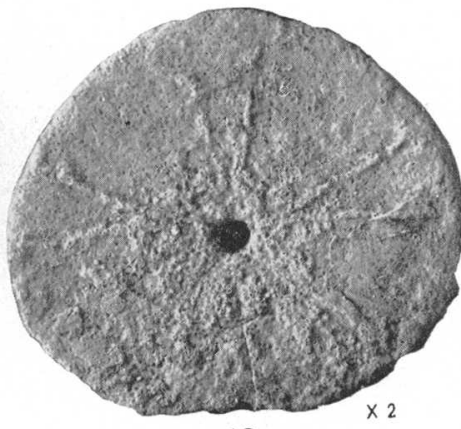

12

FOSSILS FROM STRATA IN SAN JOAQUIN FORMATION BETWEEN UPPER MYA AND ACILA ZONES. 


\section{PLATE 11}

[Figures natural size unless otherwise designated]

Figdre 1. Turcica caffea brevis Stewart, n. var. Height (incomplete) $20.5 \mathrm{~mm}$., width (incomplete) $18 \mathrm{~mm}$. Locality 68. U. S. Nat. Mus. 495709.

2, 3. Calliostoma coalingense Arnold. Height $11.5 \mathrm{~mm}$., width $15.6 \mathrm{~mm}$. Locality 57. U. S. Nat. Mus. 495710.

4. "Pleurotoma" cf. "P." coalingensis Arnold. Height (incomplete) $10.2 \mathrm{~mm}$., width (incomplete) $4.6 \mathrm{~mm}$. Locality 58. U. S. Nat. Mus. 495711.

5. Mitrella cf. M. gausapata (Gould). Height (incomplete) $8.3 \mathrm{~mm}$., width $4.1 \mathrm{~mm}$. Locality 62 . U. S. Nat. Mus. 495712.

6. Turcica caffea brevis Stewart, n. var. Holotype. Height (incomplete) $24.1 \mathrm{~mm}$., width $21.2 \mathrm{~mm}$. Locality 58. U. S. Nat. Mus. 495713.

7. Calyptraca cf. C. inornata (Gabb). Height $25 \mathrm{~mm}$., greatest diameter $26 \mathrm{~mm}$. Locality 58 . U. S. Nat. Mus. 495714.

8. Compsomyax cf. C. subdiaphana (Carpenter). Length (incomplete) $33 \mathrm{~mm}$., height $30 \mathrm{~mm}$. Locality 58 . U. S. Nat. Mus. 495715.

9. Siphonalia cf. S. humerosa (Gabb). Height (incomplete) $58 \mathrm{~mm}$., width (incomplete) $34 \mathrm{~mm}$. Locality 59 . U. S. Nat. Mus. 495716.

10. Anadara trilineata (Conrad) of Arnold. Length $61.5 \mathrm{~mm}$., height (almost complete) $46.5 \mathrm{~mm}$. , thickness $18 \mathrm{~mm}$. Locality 57. U. S. Nat. Mus. 495717.

11-17. Acila castrensis (Hinds). Locality 60. U. S. Nat. Mus. 495718.

11. Length (incomplete) $6.5 \mathrm{~mm}$., width $5.6 \mathrm{~mm}$., thickness $2 \mathrm{~mm}$.

12. Length $10.6 \mathrm{~mm}$., height $8.3 \mathrm{~mm}$., thickness $3.3 \mathrm{~mm}$.

- 13. Length $11.9 \mathrm{~mm}$., height $9.3 \mathrm{~mm}$., thickness $3.4 \mathrm{~mm}$.

14. Length $13.1 \mathrm{~mm}$., height $11 \mathrm{~mm}$., thickness $4.3 \mathrm{~mm}$.

15. Length $8.4 \mathrm{~mm}$., height $6.7 \mathrm{~mm}$., thickness $2.3 \mathrm{~mm}$.

16. Length $10.3 \mathrm{~mm}$., height $8.4 \mathrm{~mm}$., thickness $2.6 \mathrm{~mm}$.

17. Length $12 \mathrm{~mm}$., height $10.4 \mathrm{~mm}$., thickness $3.6 \mathrm{~mm}$.

18. Semele cf. S. rubropicta Dall. Incomplete specimen. Length $29 \mathrm{~mm}$., height $24 \mathrm{~mm}$. , thickness $6.5 \mathrm{~mm}$. Locality 58. U. S. Nat. Mus. 495719.

19-24. Anadara trilineata (Conrsd) of Arnold.

19. Length $69 \mathrm{~mm}$., height $55 \mathrm{~mm}$., thickness $20 \mathrm{~mm}$. Locality 57 . U. S. Nat. Mus. 495720.

20. Length $65 \mathrm{~mm}$., height $56 \mathrm{~mm}$., thickness of both valves $37.5 \mathrm{~mm}$. Locality 57 . U. S. Nat. Mus. 495721 .

21. Length $79.5 \mathrm{~mm}$., height $70 \mathrm{~mm}$., thickness $25 \mathrm{~mm}$. Locality 57 . U. S. Nat. Mus. 495722 .

22. Length $39 \mathrm{~mm}$., height $31 \mathrm{~mm}$., thickness $10 \mathrm{~mm}$. Locality 58 . U. S. Nat. Mus. 495723.

23. Length $7.5 \mathrm{~mm}$., height $6.3 \mathrm{~mm}$., thickness of both valves $4.4 \mathrm{~mm}$. Locality 62 . U. S. Nat. Mus. 495724 .

24. Length $20.5 \mathrm{~mm}$., height $16 \mathrm{~mm}$, thickness $5 \mathrm{~mm}$. Locality 62 . U. S. Nat. Mus. 495725 .

25. Schizothaerus cf. S. nuttallii (Conrad). Length $61 \mathrm{~mm}$., height $48.5 \mathrm{~mm}$., thickness of both valves (not completely closed) $31 \mathrm{~mm}$. Locality 64 . U. S. Nat. Mus. 495726. 

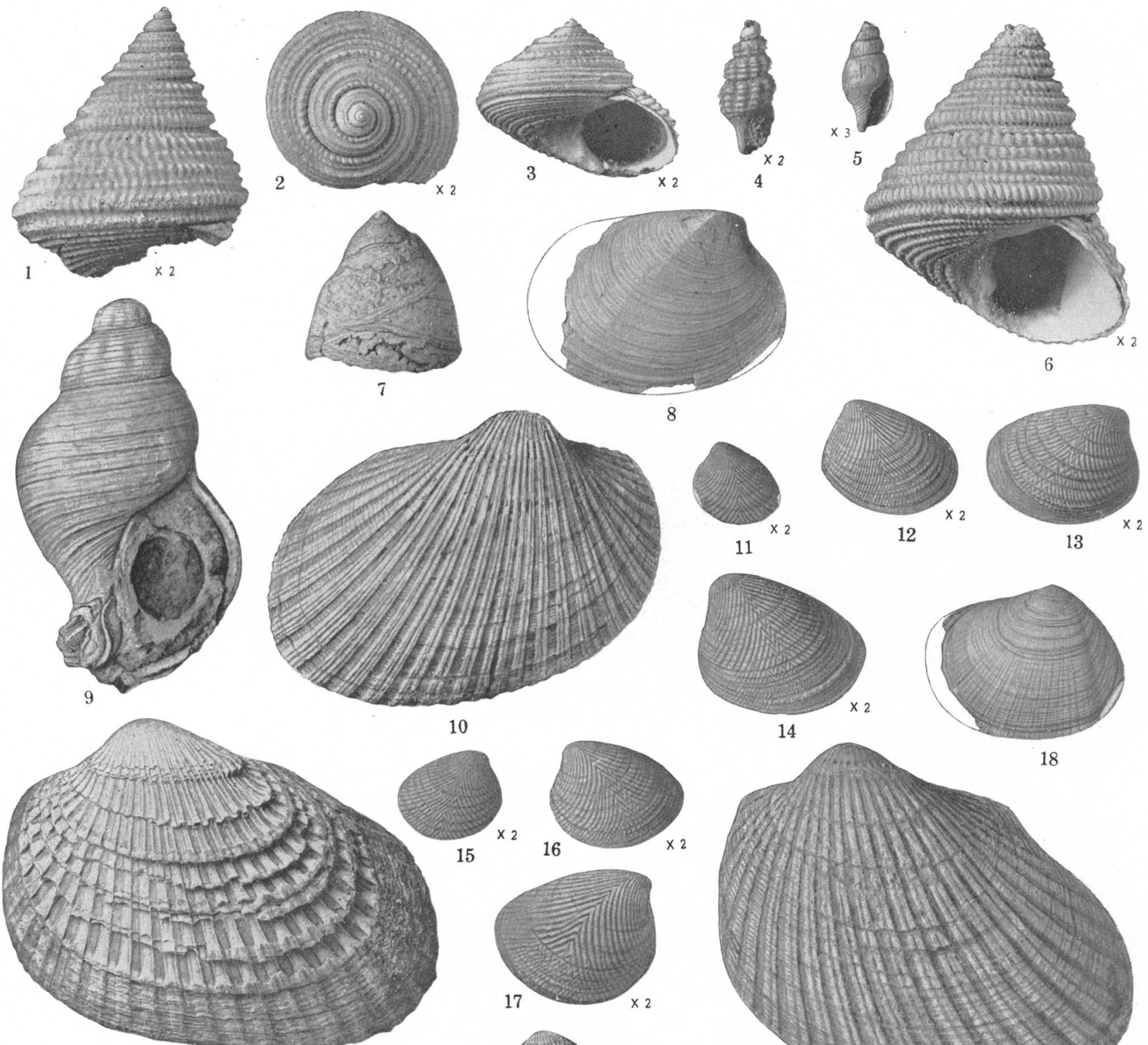

10
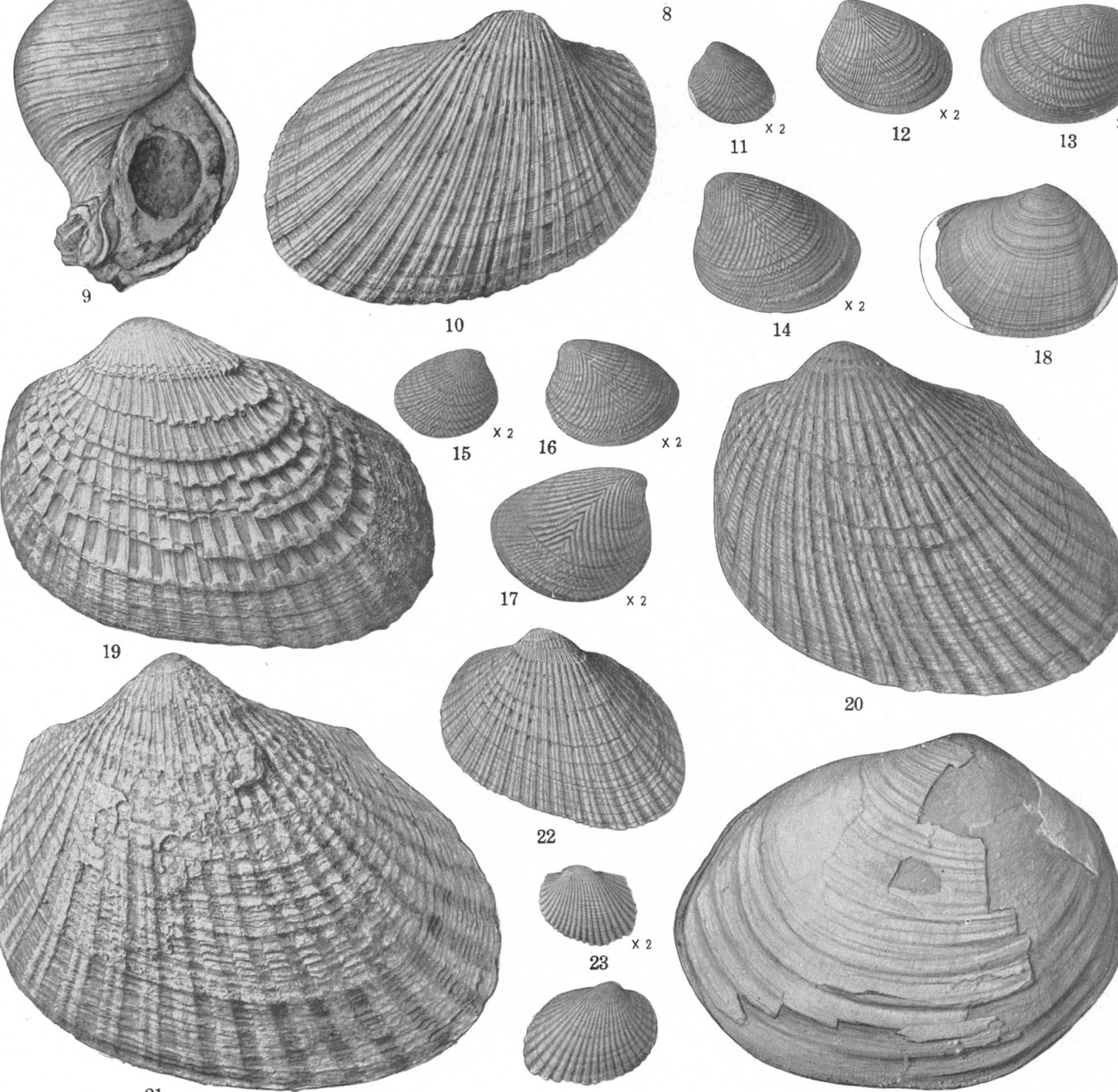

21

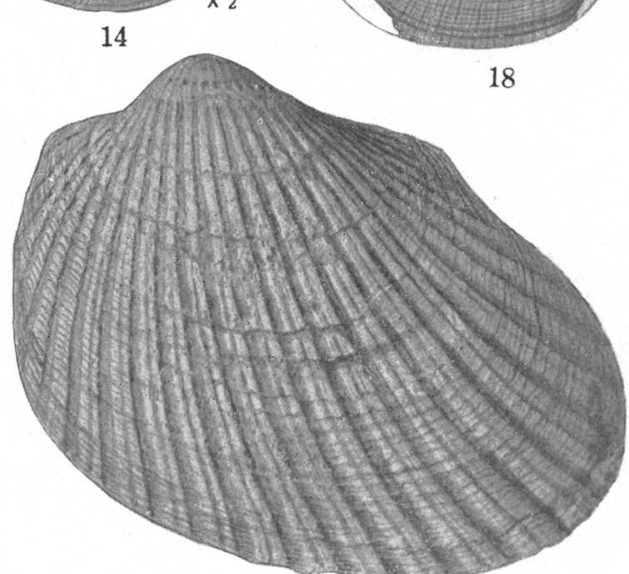

20

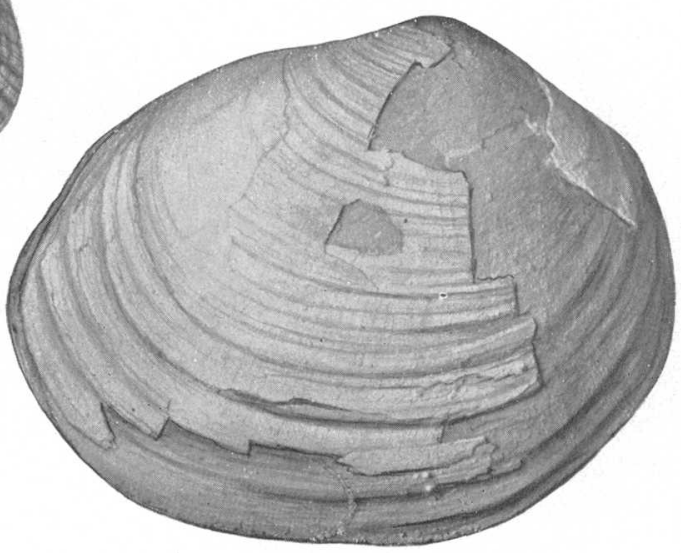

25

FOSSILS FROM ACILA ZONE OF SAN JOAQUIN FORMATION. 


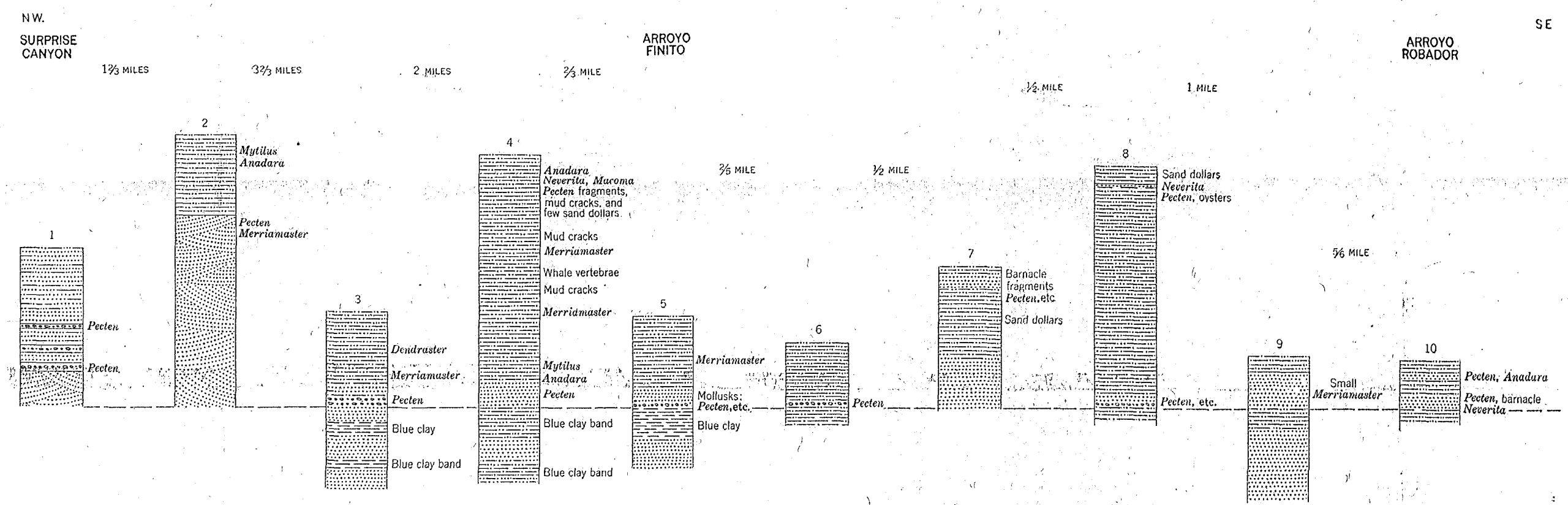

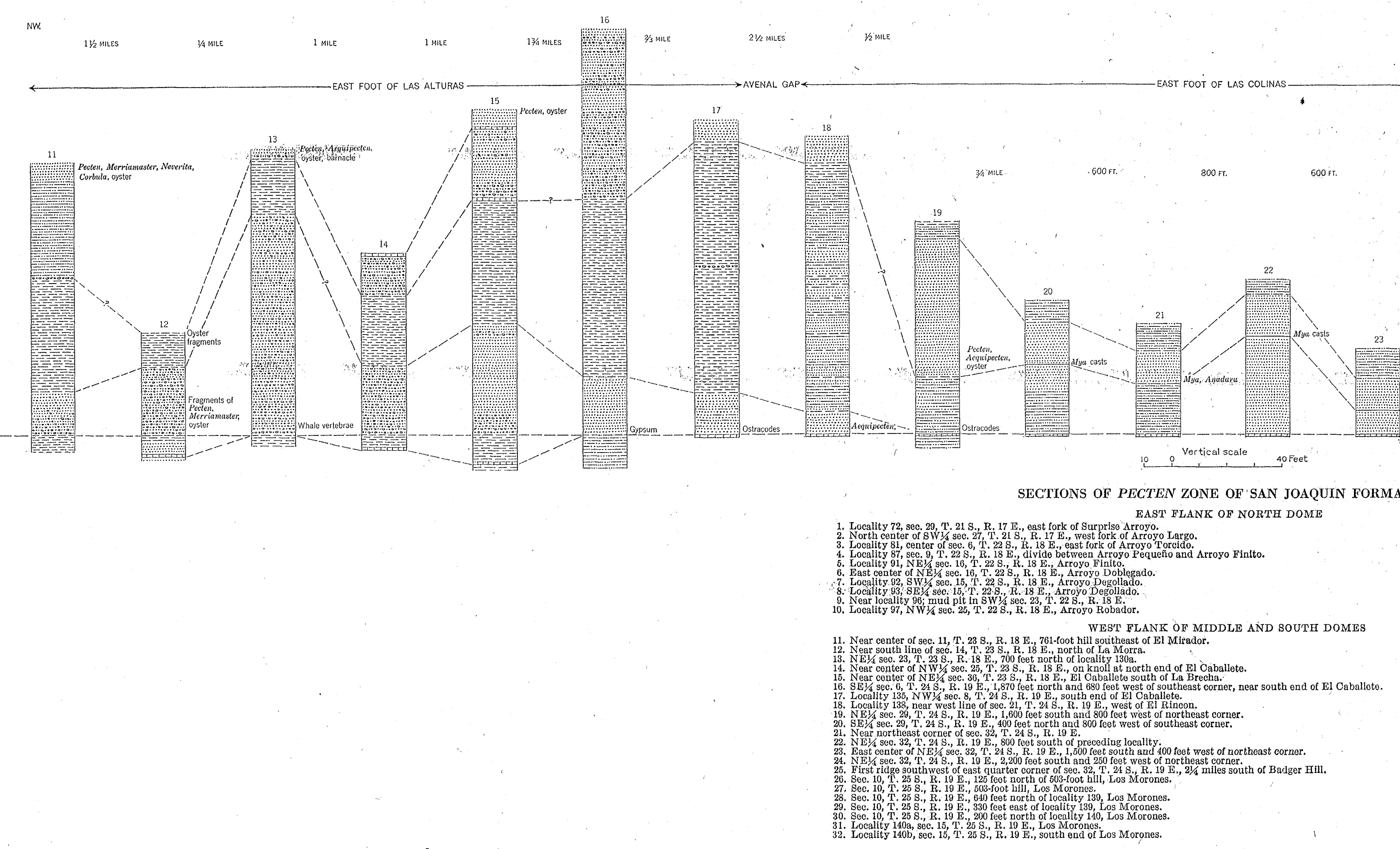




\section{PLATE 13}

Figures natural size unless otherwise designated]

Figures 1,2 . Pecten coalingensis Arnold.

1. Length $42 \mathrm{~mm}$., height $38 \mathrm{~mm}$., thickness $13 \mathrm{~mm}$. Locality 79 . U. S. Nat. Mus. 495727 .

2. Length $20 \mathrm{~mm}$., height $18.6 \mathrm{~mm}$., thickness $2 \mathrm{~mm}$. Locality 91 . U. S. Nat. Mus. 495728 .

3, 4. Aequipecten circularis impostor (Hanna). Locality 101.

3. Length $16.6 \mathrm{~mm}$., height $17.7 \mathrm{~mm}$., thickness $3.7 \mathrm{~mm}$. U. S. Nat. Mus. 495729 .

4. Jength $16.4 \mathrm{~mm}$., height $17.2 \mathrm{~mm}$., thickness $3.5 \mathrm{~mm}$. U. S. Nat. Mus. 495730.

5. Chlamys etchegoini (Anderson). Length $33.6 \mathrm{~mm}$., height $40.5 \mathrm{~mm}$., thickness $8 \mathrm{~mm}$. Locality $71 . \quad$ U. S. Nat. Mus. 495731 .

6-9. Aequipecten circularis impostor (Hanna). Locality 101.

6. Length $43.6 \mathrm{~mm}$., height $41.5 \mathrm{~mm}$., thickness $9 \mathrm{~mm}$. U. S. Nat. Mus. 495732 .

7. Length $31 \mathrm{~mm}$., height $31.5 \mathrm{~mm}$., thickness $6.4 \mathrm{~mm}$. U. S. Nat. Mus. 495733.

8. Length $26.5 \mathrm{~mm}$., height $27 \mathrm{~mm}$., thickness $5 \mathrm{~mm}$. U. S. Nat. Mus. 495734 .

9. Length $46.5 \mathrm{~mm}$., height $42.6 \mathrm{~mm}$., thickness $11 \mathrm{~mm}$. U. S. Nat. Mus. 495735.

10-13. Venerupis grata tarda Stewart, n. var. Locality 111.

10. Length $10.3 \mathrm{~mm}$., height $9.3 \mathrm{~mm}$., thickness $3.7 \mathrm{~mm}$. U. S. Nat. Mus. 495736 .

11. Length $12 \mathrm{~mm}$., height $12 \mathrm{~mm}$., thickness $4.5 \mathrm{~mm}$. U. S. Nat. Mus. 495737.

12, 13. Holotype. Length $14.6 \mathrm{~mm}$., height $14.6 \mathrm{~mm}$., thickness $6 \mathrm{~mm}$. U. S. Nat. Mus. 495738.

14. Botula? sp. J.ength (incomplete) $24.6 \mathrm{~mm}$., height $6 \mathrm{~mm}$., thickness of both valves $6 \mathrm{~mm}$. Locality 82 . U. S. Nat. Mus. 495739.

15. Volsella cf. V. recta (Conrad). Length $88 \mathrm{~mm}$., width $36.4 \mathrm{~mm}$., thickness of both valves $25 \mathrm{~mm}$. Locality 75 . U. S. Nat. Mus. 495740.

16. Caudal spine of sting ray. Length (incomplete) $27.5 \mathrm{~mm}$., width $9 \mathrm{~mm}$. Locality 86 . U. S. Nat. Mus. 495741 .

17, 18. Pecten coalingensis Arnold.

17. Length $73.9 \mathrm{~mm}$., height $68.5 \mathrm{~mm}$., thickness about $21 \mathrm{~mm}$. Locality 82 . U. S. Nat. Mus. 495742.

18. Length $69.4 \mathrm{~mm}$., height $60 \mathrm{~mm}$., thickness about $5 \mathrm{~mm}$. Locality $75 \mathrm{a}$. U. S. Nat. Mus. 495743. 

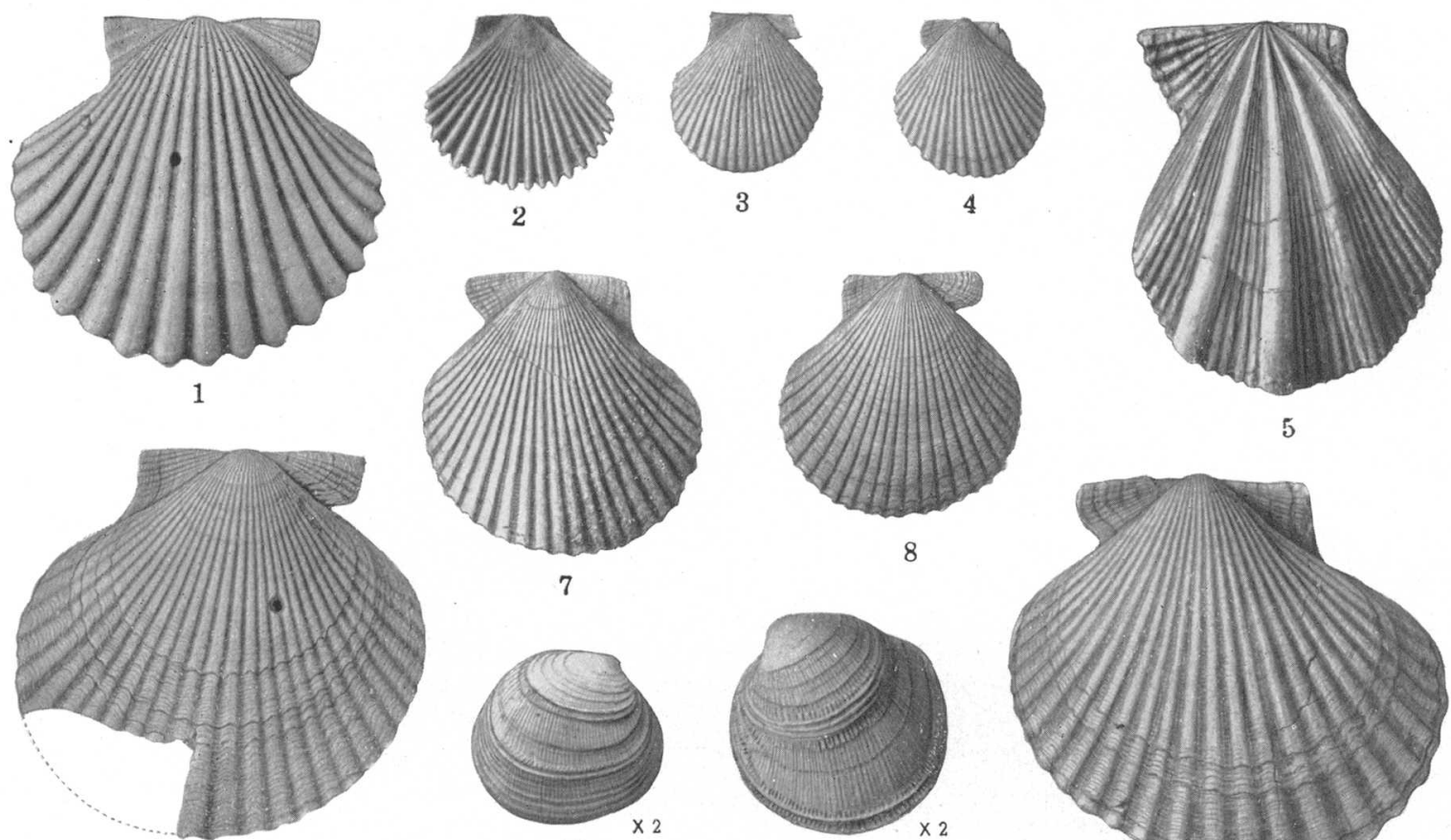

6
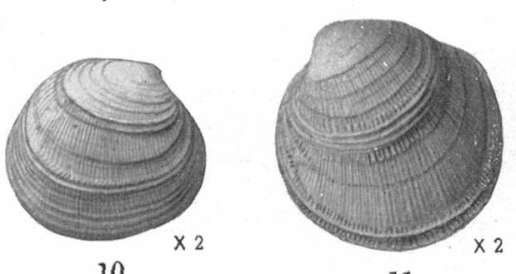

11
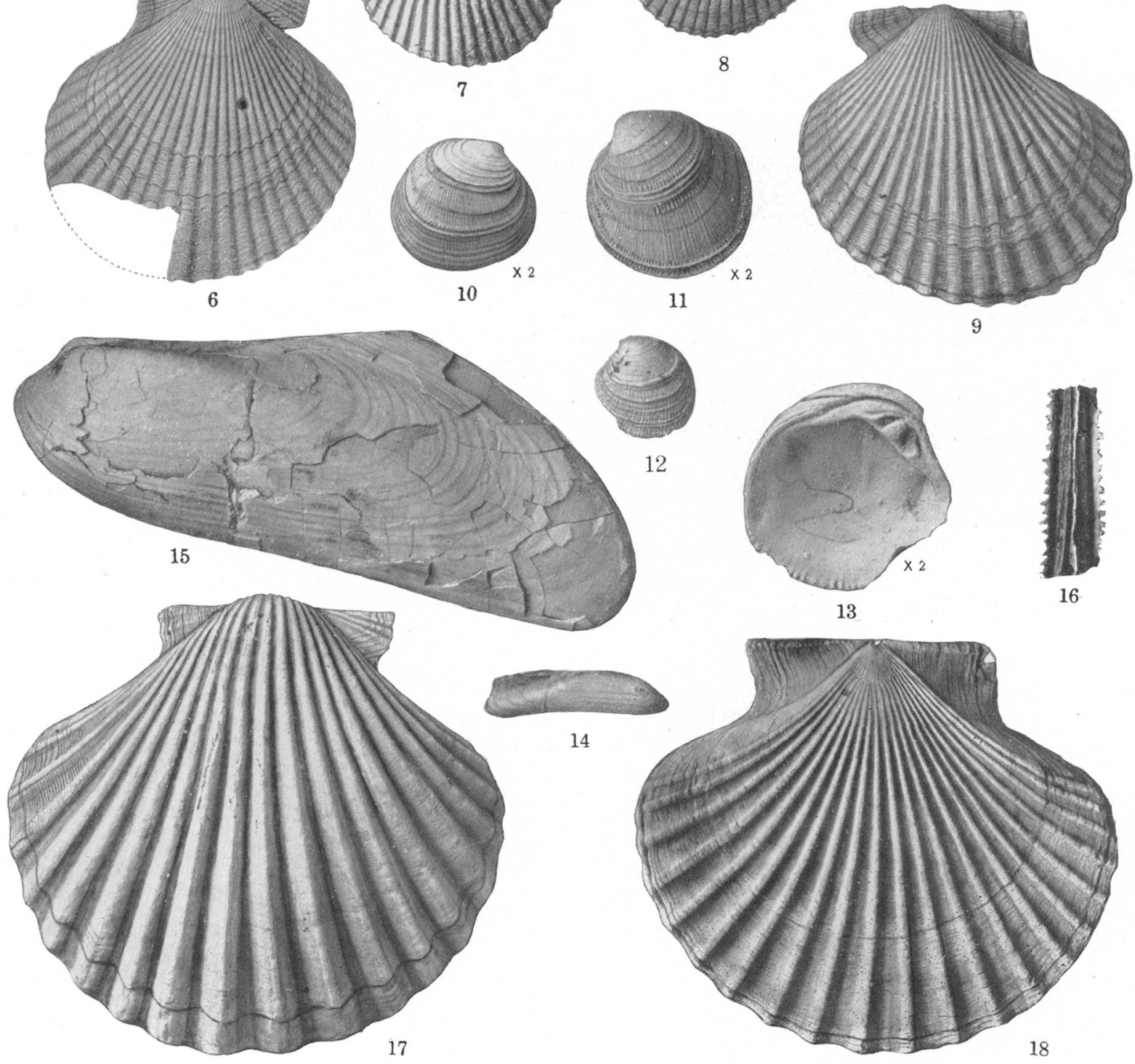

FOSSILS FROM PECTEN ZONE OF SAN JOAQUIN FORMATION. 


\section{PLATE 14}

Figures 1-4. Chama pellucida Broderip.

[Figures natural size]

1. Length of both valves $73 \mathrm{~mm}$. Locality 87. U. S. Nat. Mus. 495744.

2. Length $36.5 \mathrm{~mm}$., height $42 \mathrm{~mm}$., thickness of both valves $30 \mathrm{~mm}$. Locality 119 . U. S. Nat. Mus. 495745 .

3. Length $47 \mathrm{~mm}$., height $39 \mathrm{~mm}$., thickness $15 \mathrm{~mm}$. Locality 102 . U. S. Nat. Mis. 495746.

4. Length $34 \mathrm{~mm}$., height $31 \mathrm{~mm}$., thickness $10 \mathrm{~mm}$. Locality 91 . U. S. Nat. Mus. 495747.

5. Macoma cf. M. nasuta (Conrad). Length $50 \mathrm{~mm}$., height $45 \mathrm{~mm}$., thickness of both valves $14.5 \mathrm{~mm}$. IJocality 75 . U. S. Nat. Mus. 495748.

6. Pholadidea ovoidea (Gould), short var. Length (practically complete) $35 \mathrm{~mm}$., height $26.7 \mathrm{~mm}$., thickness of both valves about $26 \mathrm{~mm}$. Locality 119 . U. S. Nat. Mus. 495749.

7. Anadara trilineata (Conrad) of Arnold, elongate flat var. Length $41.3 \mathrm{~mm}$., height $26.6 \mathrm{~mm}$., thickness of both valves $18 \mathrm{~mm}$. Locality 75 . U. S. Nat. Mus. 495750.

8. Tellina ? cf. T. ? oldroydi Wiedey. Length $84.4 \mathrm{~mm}$., height $53 \mathrm{~mm}$., thickness of both valves $23.8 \mathrm{~mm}$. $\quad$ Locality 75 . U. S. Nat. Mus. 495751.

9. Ostrea vespertina Conrad. Length $66.5 \mathrm{~mm}$., height $55 \mathrm{~mm}$., thickness about $18 \mathrm{~mm}$. Locality $130 . \quad$ U. S. Nat. Mus. 495752 .

10. Chama pellucida Broderip. Length $36 \mathrm{~mm}$., height $58.5 \mathrm{~mm}$., thickness $19 \mathrm{~mm}$. Locality $87 . \quad$ U. S. Nat. Mus. 495753 .

11. Panope cf. P. generosa Gould. Length (almost complete) $103 \mathrm{~mm}$., height $70 \mathrm{~mm}$., thickness of both valves $45 \mathrm{~mm}$. Locality 87. U. S. Nat. Mus. 495754. 

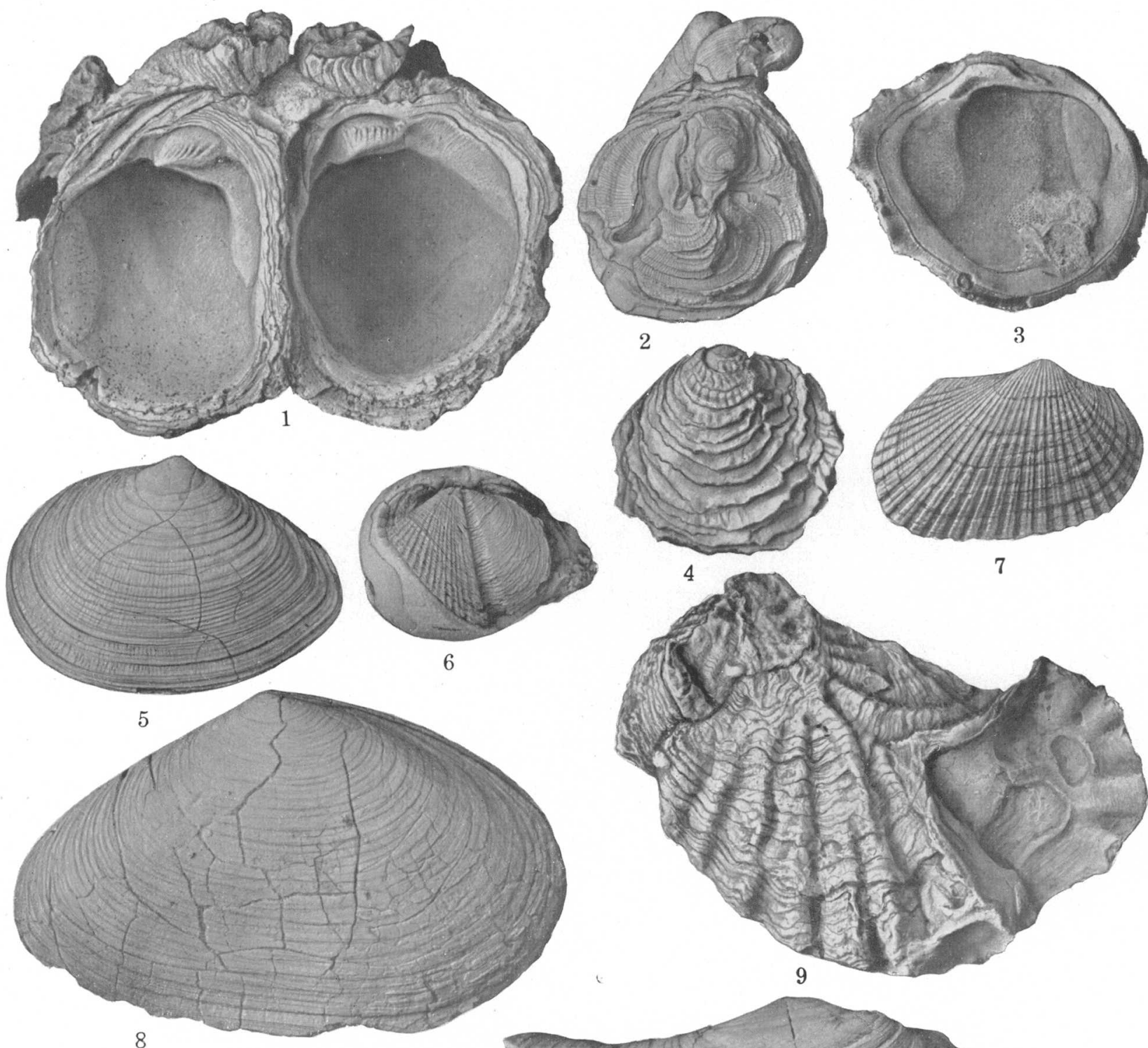

8

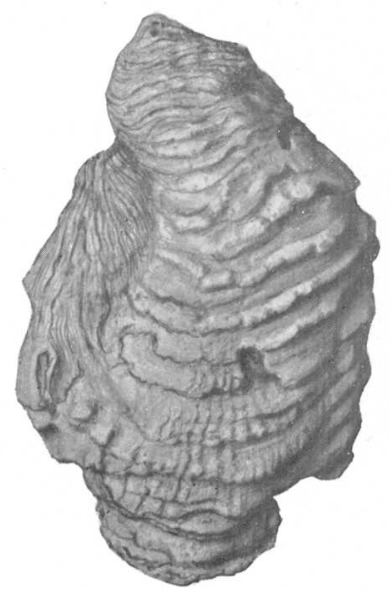

10

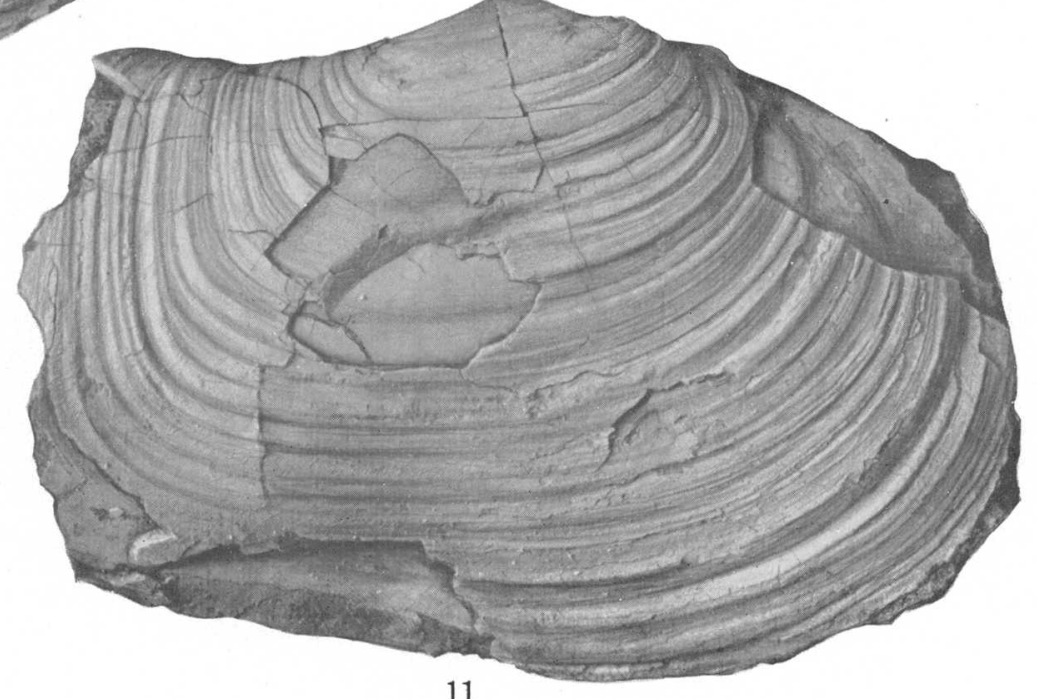

11

FOSSILS FROM PECTEN ZONE OF SAN JOAQUIN FORMATION. 


\section{PLATE 15}

[Figures natural size unless otherwise designated]

Figures 1, 7. Cancellaria rapa Nomland. Height (almost complete) $73 \mathrm{~mm}$., width (almost complete) $38 \mathrm{~mm}$. Locality 75. U. S. Nat. Mus. 495755.

2. Jaton cf. J. festivus (Hinds). Height (incomplete) $29.5 \mathrm{~mm}$., width (incomplete) $18.5 \mathrm{~mm}$. Locality $87 . \quad$ U. S. Nat. Mus. 495756.

3. "Nassa" coalingensis Arnold. Height $33 \mathrm{~mm}$., width $16 \mathrm{~mm}$. Locality 94. U. S. Nat. Mus. 495757.

4. Progabbia sp. Height (incompiete) $30.5 \mathrm{~mm}$., width $17 \mathrm{~mm}$. Locality 82 . U. S. Nat. Mus. 495758.

5, 6. Goniobasis kettlemanensis Arnold.

5. Height (incomplete) $27.5 \mathrm{~mm}$., width (almost complete) $11 \mathrm{~mm}$. Locality 98 . U. S. Nat. Mus. 495759.

6. Height (incomplete) $21.4 \mathrm{~mm}$., width $8.8 \mathrm{~mm}$. Locality 140. U. S. Nat. Mus. 495760.

8. Lunatia cf. L. lewisii (Gould). Height $68.5 \mathrm{~mm}$., width $63 \mathrm{~mm}$. Locality 75. U. S. Nat. Mus. 495761.

9. Jaton festivus (Hinds), n. var. Height (incomplete) $38.7 \mathrm{~mm}$., width (almost complete) $24 \mathrm{~mm}$. Locality 102. U. S. Nat. Mus. 495762.

10. Calyptraea cf. C. inornata (Gabb). Height (incomplete) $13 \mathrm{~mm}$., diameter $26 \mathrm{~mm}$. Locality 104. U. S. Nat. Mus. 495763. May be a worn specimen of C. cf. C. filosa (Gabb).

11. Neverita reclusiana (Deshayes). Height $36.6 \mathrm{~mm}$., width $29 \mathrm{~mm}$. Locality 120, Trachycardium zone. U. S. Nat. Mus. 495764.

12. Tritonalia ef. T. lurida (Middendorf). Height (ineomplete) $22 \mathrm{~mm}$., width $11.4 \mathrm{~mm}$. Locality،106. U. S. Nat. Mus. 495765.

13. Macoma affinis Nomland, small var. cf. M. a. plena Stewart, n. var. Length $36.5 \mathrm{~mm}$., height (almost complete) $27.5 \mathrm{~mm}$., thckness $7 \mathrm{~mm}$. Locality 126, between Pecten and Neverita zones. U. S. Nat. Mus. 495766.

14. Goniobasis kettlemanensis Arnold. Height (incomplete) $12 \mathrm{~mm}$., width $5 \mathrm{~mm}$. Locality 140. U. S. Nat. Mus: 495767.

15, 16. Calliostoma coalingense Arnold. Height $19 \mathrm{~mm}$., width $19 \mathrm{~mm}$. Locality 81. U. S. Nat. Mus. 495768.

17, 18. Forreria magister munda Stewart, n. var. Locality 102.

17. Height (almost complete) $75 \mathrm{~mm}$., width (incomplete) $43 \mathrm{~mm}$. U. S. Nat. Mus. 495769.

18. Holotype. Height (incomplete) $59 \mathrm{~mm}$., width $42 \mathrm{~mm}$. U. S. Nat. Mus. 495770.

19, 20. Neverila reclusiana (Deshayes). Locality 120, Trachycardium zone.

19. Short variety. Height (practically complete) $26.6 \mathrm{~mm}$., width $26.4 \mathrm{~mm}$. U. S. Nat. Mus. 495771.

20. Height $33.8 \mathrm{~mm}$., width $30 \mathrm{~mm}$. U. S. Nat. Mus. 495772.

21. Calliostoma kerri Arnold. Height (almost complete) $29.5 \mathrm{~mm}$., width (almost complete) $22 \mathrm{~mm}$. Locality 87. U. S. Nat. Mus. 495773.

22, 23. Calliostoma ef. C. gemmulatum Carpenter. Locality 102a.

22. Height (incomplete) $17.5 \mathrm{~mm}$., width $20 \mathrm{~mm}$. U. S. Nat. Mus. 495774.

23. Height $13.5 \mathrm{~mm}$., width $13 \mathrm{~mm}$. U. S. Nat. Mus. 495775. 


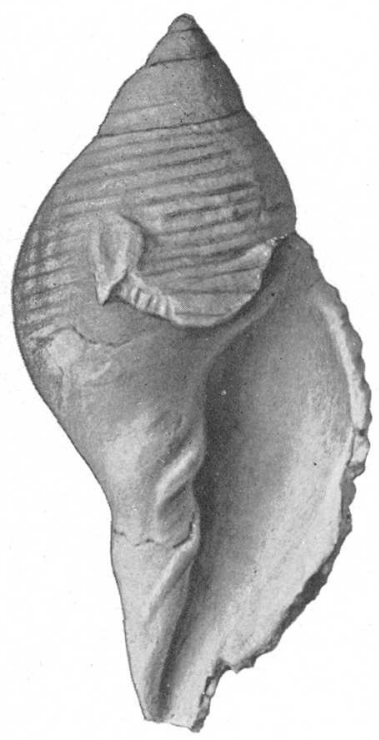

1

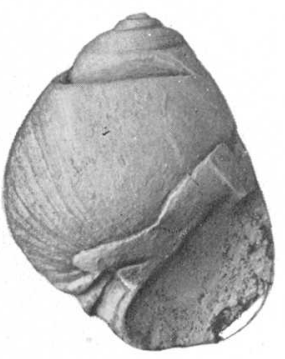

11

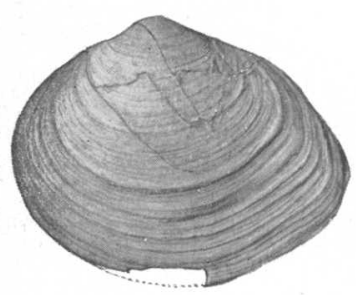

13

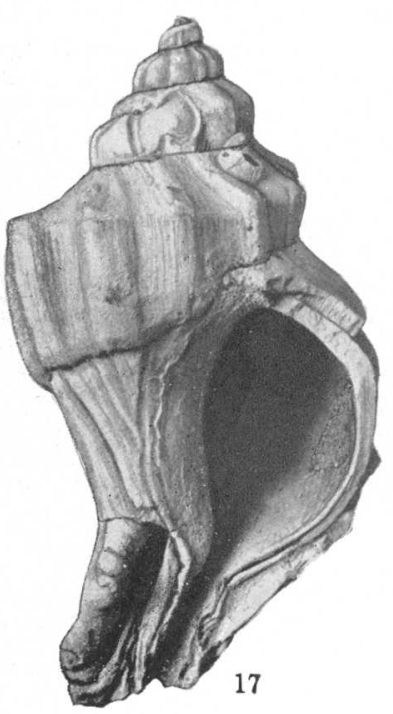

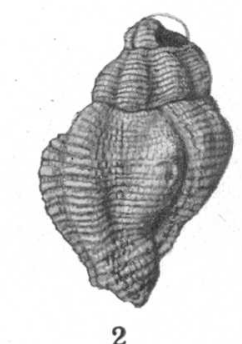
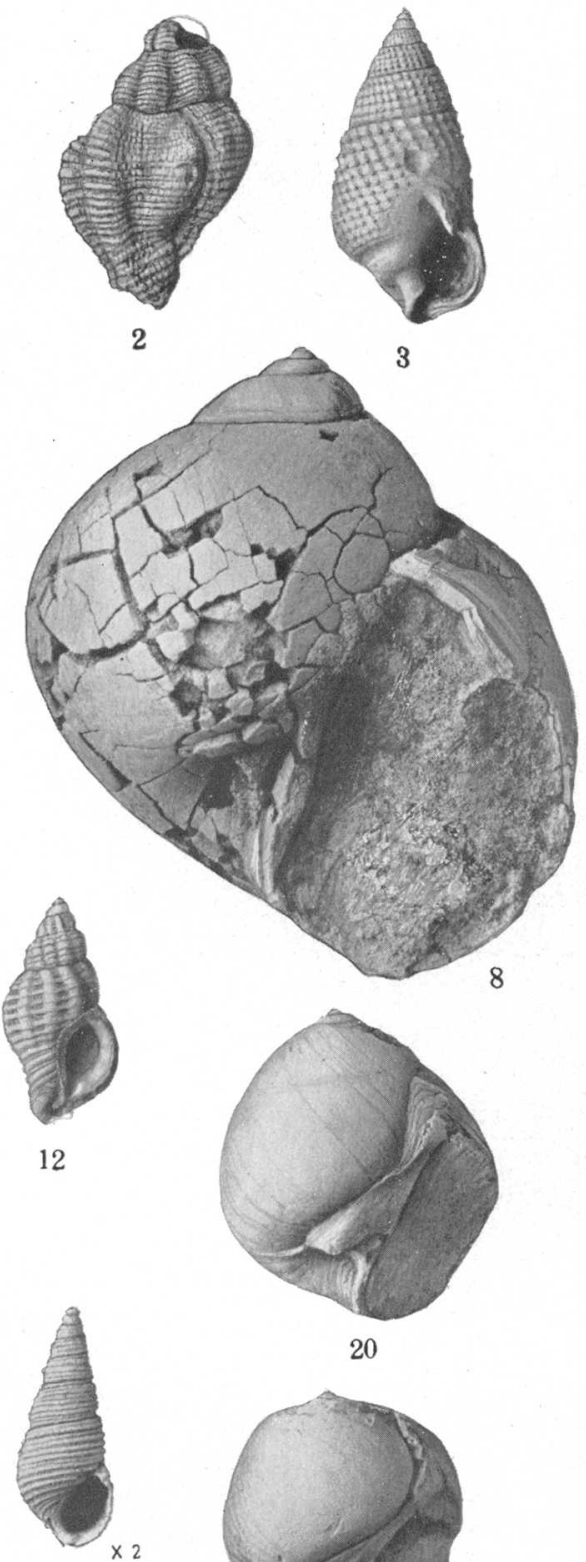

20

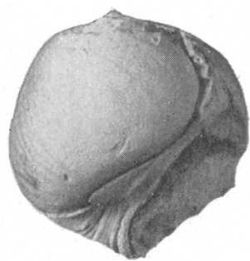

19

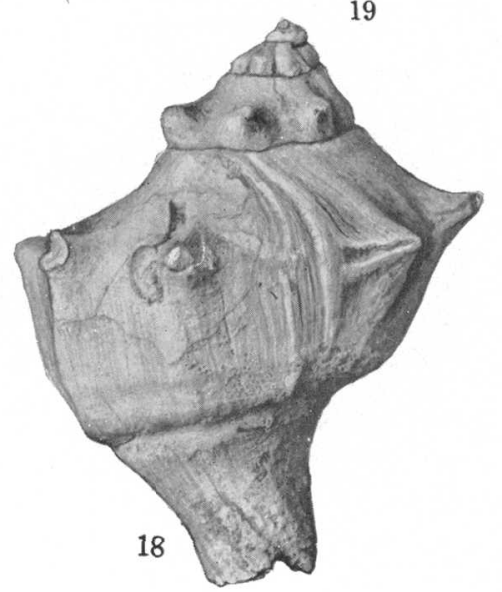

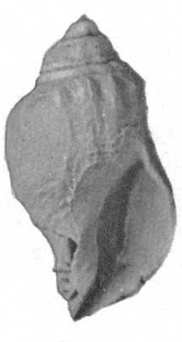

4
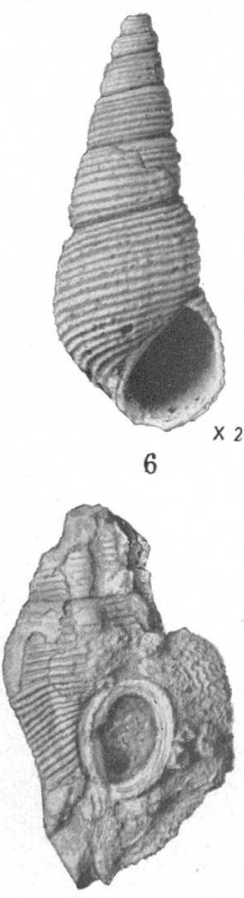

9

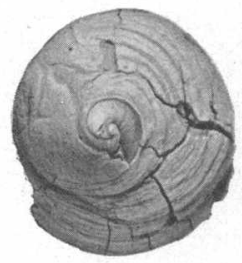

10

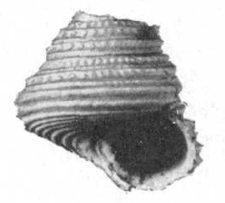

22

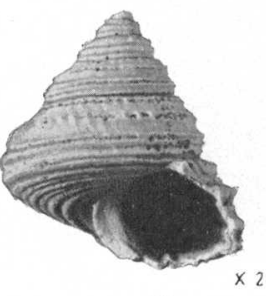

23

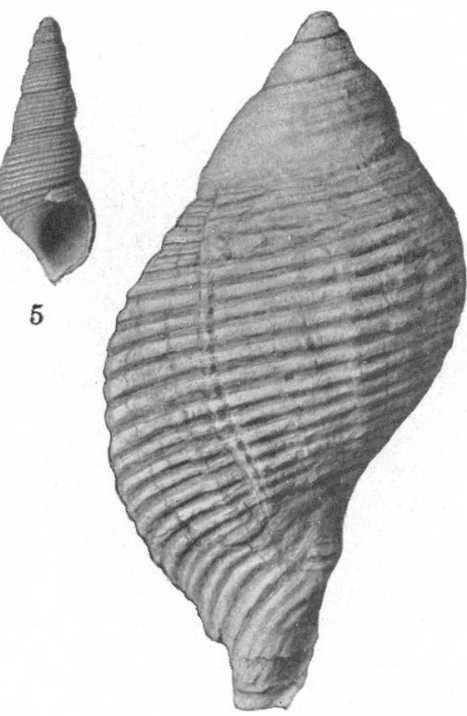

7
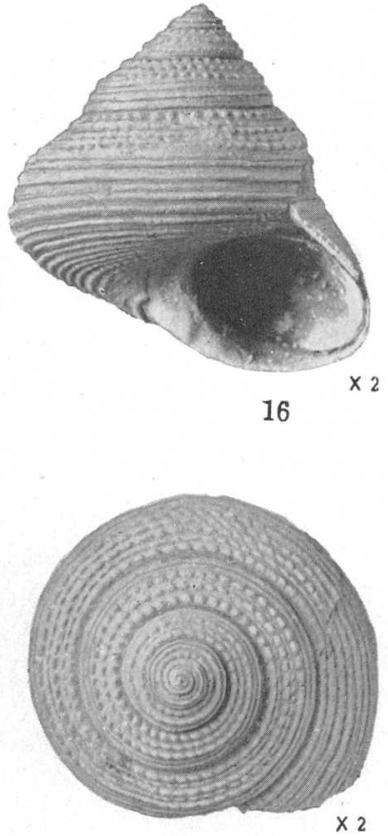

15

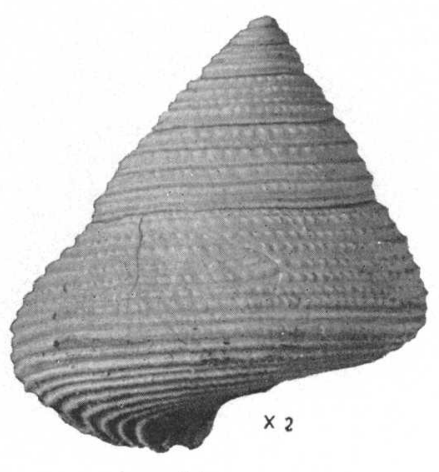

21

FOSSILS FROM PECTEN AND TRACHYCARDIUM ZONES OF SAN JOAQUIN FORMATION AND FROM STRATA IN SAN JOAQUIN FORMATION BETWEEN PECTEN AND NEVERITA ZONES. 


\section{PLATE 16}

[Figures natural size unless otherwise designated]

Figure 1. Macoma ef. M. secta (Conrad). Length $72.5 \mathrm{~mm}$., height $51.3 \mathrm{~mm}$. Locality 135 . U. S. Nat. Mus. 495776.

2. Trachycardium cf. T. quadragenarium (Conrad). Length $58 \mathrm{~mm}$., height $52 \mathrm{~mm}$., thickness about $20 \mathrm{~mm}$. Locality 71. U. S. Nat. Mus. 495777.

3. Volsella cf. V. capax (Conrad). Greatest length (incomplete) $78 \mathrm{~mm}$., width $46 \mathrm{~mm}$., thickness of right valve about $25 \mathrm{~mm}$. Locality 87. U. S. Nat. Mus. 495778.

4. Pecten coalingaensis Arnold. Internal view of flatter valve. Length $61.5 \mathrm{~mm}$., height $53 \mathrm{~mm}$. Locality $79 \mathrm{a}$. U. S. Nat. Mus. 495779.

5, 6. Terebratalia cf. T. smithi Arnold. Height $22.3 \mathrm{~mm}$., width $18 \mathrm{~mm}$., thickness of both valves $10 \mathrm{~mm}$. Locality 79 a. U. S. Nat. Mus. 495780.

7. Astrangia coalingensis Vaughan. Fragment of colony. Length $63.5 \mathrm{~mm}$., width $46.5 \mathrm{~mm}$. Locality 79 . U. S. Nat. Mus. 495781.

8. Saxidomus nuttallii latus Stewart, n. var. Holotype. Length $111 \mathrm{~mm}$., height $82 \mathrm{~mm}$., thickness of both valves 53.5 mm. Locality 87 . U. S. Nat. Mus. 495782. 

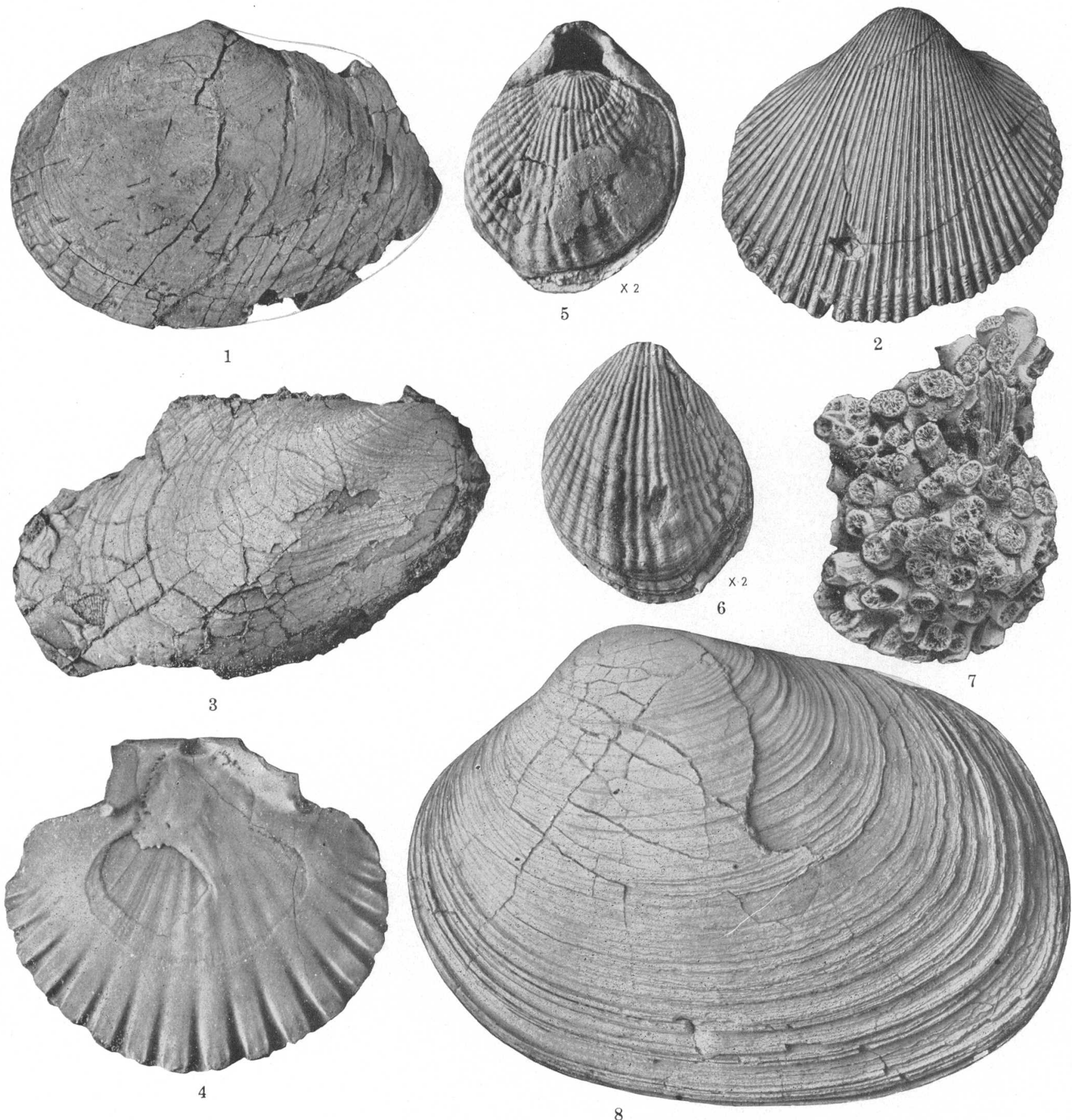

FOSSILS FROM PECTEN ZONE OF SAN JOAQUIN FORMATION. 
a correlation already made by Arnold and Anderson. ${ }^{38 a}$ Inasmuch as $P$. coalingaensis is the only Pecten, in the restricted sense, recognized in the Kettleman Hills, there should be no ambiguity in referring to the Pecten coalingaensis zone as the Pecten zone. The abbreviated name is appropriate for the zone, as Pecten was not found at other horizons.

The base of the zone is generally well-defined in areas where exposures are adequate. At many localities evidence for discontinuity is apparent at the base. The discontinuity may be of no greater physical significance than discontinuities found at the base of many other beds of sand and sandstone in the San Joaquin formation. At a few localities, however, fossiliferous sand appears to grade downward into nonfossiliferous sand, and it is difficult to determine the exact base of the zone. On the west flank of South Dome the zone is absent for a distance of 213 miles.

Because the Pecten zone was identified over a larger area than any other faunal zone in the San Joaquin formation and because its fauna is so readily recognized, the San Joaquin formation is divided into lower and upper parts at the base of this zone-a subdivision corresponding to a faunal subdivision based on the sand dollars.

On the east flank of southern North Dome and Middle Dome and on the west flank of southern North Dome marine fossils occur in sand and pebbly sand, generally 125 to 150 feet above the base of the Pecten zone, about halfway between the Pecten and the Acila zones. This zone is designated "the Trachycardium zone." The type locality is on the north side of Arroyo Conchoso (locality 121, NE1/4 sec. 30, T. 22 S., R. 18 E.), where the zone is about 20 feet thick. The strata between the Pecten and the Trachycardium zones consist chiefly of nonfossiliferous muddy silt. The fossils in the Trachycardium zone occur also in the Pecten zone. The Trachycardium zone might, therefore, be considered as the upper Pecten zone, but Pecten was not found in it. The name of the zone is not entirely satisfactory, because Trachycardium is also present in the Pecten zone. This genus, however, is a common fossil in the Trachycardium zone and has not been found at horizons above that zone or below the Pecten zone, with the exception of the conglomerate fossils mentioned under the heading "Strata between Acila zone and Pecten zone."

The Trachycardium zone is an important aid in interpreting the geology of the saddle between North and Middle Domes, where the Pecten zone is in some places obscure. On the east flank of Middle Dome the Trachycardium zone is generally only about 50 to 60 feet above the base of the Pecten zone. In part of this region the division between the upper and lower parts of the San Joaquin formation is for convenience placed at the base of the Trachycardium zone, for the Pecten

18a Op. cit. (Bull. 398), p. 121.

$152190-40-4$ zone is not well exposed and its base was recognized at only a few places.

The Trachycardium zone was generally recognized by the occurrence of large marine shells in the soil or in a ledge that interrupts smooth slopes. Details of the stratigraphy of the zone are not available except in artificial excavations.

East flank of North Dome.-Sections of the Pecten zone on the east flank of North Dome are shown on plate 12. The zone consists of coarse-grained sand and silty sand about 40 to 65 feet thick, both of which contain fossils. The stratigraphic relations and faunal content of different layers appear to change from place to place. In much of this region the stratigraphic position of the zone may be recognized by thin layers of dark-blue or .black clay-mentioned by Arnold and Anderson-that immediately underlie the zone ${ }^{39}$ The layers of dark-colored clay may be only an inch thick, but weathered outcrops of silt associated with them form conspicuous bluish-black bands barren of vegetation. The beds of sand that lie between the layers of silt and clay are much thicker than indicated by weathered outcrops. The sand forming the base of the Pecten zone contains small pebbles, generally consisting of chert. This sand rests on underlying strata with an irregular contact and penetrates cracks or borings in the underlying strata. The base of the zone is generally more sharply defined than the top, which is placed at the top of fossiliferous sand. Typical Pecten-bearing sand is exposed in an excavation at Standard oil well 65-29-J (locality 72, sec. 29, T. 21 S., R. 17 E.; column 1, pl. 12), where the following section was measured.

Section of Pecten zone of San Joaquin formation at locality 72 , sec. $29, T .21 \mathrm{~S} ., \mathrm{R} .17 \mathrm{E}$.

7. Laminated somewhat irregularly bedded silt and silty sand; some persistent silt layers 1 inch thick........

6 . Sand similar to unit 4, but containing more limy nodules, ehert pebbles, and silt fragments; few fossils (bone, Chama?, Peclen). This bed rises across the strata 51 inches in a horizontal distance of 24 feet, crossing the normal stratification at an angle of about $7^{\circ}$

Feet 23

5. Dirty sand containing Pecten; increases in thickness

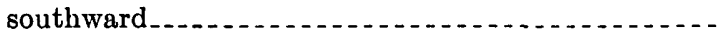

4. Sand similar to unit 2 , but containing iron concretions, limy nodules, and scattered corals..............

3. Coarse-grained sand .

2. Sand containing small angular chert pebbles and silt fragments. Pecien abundant, mostly fragments of large specimens; small specimens $3 \mathrm{~cm}$. long.unbroken 1. Coarse-grained cross-bedded sand. Base not exposed _ $9+$ Thickness of Pecten zone........... $41+$

Sand dollars are more abundant in silty sand in the upper part of the zone than in the cleaner and coarsergrained sand containing Pecten and other fossils (pl.

30 Arnold, Ralph, and Anderson, Robert, op. cit. (Bull. 398), p. 121. 
12 , columns $3,4,5,7,8)$. In the northern part of the anticline a layer containing large fossils (MytilusAnadara layer) appears to be at different horizons above the base of the zone (pl. 12, columns 2,4). At locality 92, near Arroyo Doblegado, a brown grit containing barnacle fragments and shells is near the top of the zone (pl. 12, column 7). For a distance of about a quarter of a mile along the strike northwest and southeast of locality 98, between Arroyo Robador and Arroyo Pino, fresh-water fossils (Goniobasis and Anodonta) were found at the surface with the marine fauna of the Pecten zone. The fresh-water layer is presumably a lens near the base of the zone if not actually forming the base. Perhaps the Anodonta layer near locality 96 , in sec. 23 , T. 22 S., R. $18 \mathrm{E}$. (pl. 12, column 9) is part of the same fresh-water bed.

Just south of the Paso Robles-Hanford road an important faunal change in the Pecten zone is evident. Only a few fragments of Pecten, mostly fragments of large specimens of the flat valve possibly transported after death, were found. Another pecten, Aequipecten, is abundant (locality 101). Farther south at La Lomica the gastropods Forreria and Jaton are exceptionally abundant (locality 102). South of Arroyo del Poso fresh-water shells occur above a conglomerate that contains 3-inch yellow limestone cobbles (locality 103). Farther southeast along the strike at locality 103a fragments of marine fossils were found in the conglomerate, which is considered to represent the base of the Pecten zone.

An oyster bed is exposed at locality 100 , south of Arroyo Pino, about 125 feet above the base of the Pecten zone. This bed, which contains fragments of Trachycardium and other fossils in addition to oyster shells and fragments, is assigned to the Trachycardium zone. Strata north and south of Arroyo del Paso, 100 feet or less above the base of the Pecten zone, also are assigned to the Trachycardium zone.

East flank of Middle Dome.-The Pecten zone is not well-exposed along the east flank of Middle Dome and may be poorly developed. A fossiliferous sand traced with some degree of certainty from a locality just south of La Salida southward to La Porteria and beyond is assigned to the Trachycardium zone, though it is only 50 or 60 feet above strata referred to the base of the Pecten zone. The section in this area is evidently thinner than farther north. At places Trachycardium is found in the Trachycardium zone, which is very fossiliferous at locality 106, just west of La Porteria. A conglomerate 50 or 60 feet lower in the section is regarded as the base of the Pecten zone. Pecten and Aequipecten occur in sand assigned to the Pecten zone about 50 feet below the Trachycardium zone 1,000 feet southeast of locality 108, and at other places Aequipecten occurs in sand in a similar stratigraphic position. A fossiliferous layer in or just beneath clay and above a layer of silt at the south end of Middle Dome is con- sidered as the Pecten zone, but in the area where exposures are poor and fossils are scarce it is difficult to distinguish between the Pecten and Trachycardium zones. Mya occurs in this layer at locality 110 , on the south slope of Boulder Hill-the only locality where Mya was observed in the Pecten or the Trachycardium zones on the east flank of the Kettleman Hills.

East flank of. South Dome.-A wide band of silt in Las Perillas is identified as the Pecten zone. Fragments of Pecten? were found at the south line of sec. 15, T. 24 S., R. 19 E., and Aequipecten occurs at several places in secs. 22 and 26 . Locality 111 is the southernmost locality at which the zone was identified on the east flank of the Kettleman Hills. A bed of conglomerate about 20 feet thick near the southeast corner of sec. 22 is thought to overlie the Pecten zone. It is suggestive of conglomerates that overlie the zone on the west flank of South Dome. At locality 112, near the edge of the alluvium of San Joaquin Valley, the fresh-water snail Goniobasis occurs in a layer possibly 75 feet below the Pecten zone. It is probably the layer referred to by Arnold and Anderson, ${ }^{40}$ who suggested that it may represent the Pecten coalingaensis zone.

West flank of North Dome.-The Pecten zone increases in thickness from about 50 feet on the west flank of northern North Dome to about 100 feet in the saddle between North and Middle Domes. North of the Avenal-Lemoore road the zone may be identified as sand and silt overlying bands of blue clay, as on the opposite side of the anticline, but fossils are less abundant than on the east flank and at many places are absent. Farther south the zone is more fossiliferous. As on the east flank, sand dollars are abundant in silty sand overlying sand containing Pecten. The large-shelled Mytilus-Anadara layer was not found on the west flank.

In Arroyo Mellado (locality 117) and between Arroyo Mellado and Arroyo Chico a grit containing barnacle fragments seems to be about 50 feet above the base of the zone. It corresponds in stratigraphic position to a similar bed on the east flank near Arroyo Doblegado. At locality 119, near Arroyo Conchoso, where the base of the Pecten zone consists of coarse-grained fossiliferous sand overlying a thin bed of limy clay, pholad borers in the clay are oriented siphon end upward in life position, and the borings are filled with sand like that of the overlying Pecten zone. Nearby at locality $119 a$ fresh-water shells, Goniobasis and Anodonta, occur in a bed that may be the equivalent of the limy clay at locality 119. Between Arroyo Ramoso and Arroyo Delgado (locality 122) fresh-water shells occur in a sandstone that may be considered the base of the Pecten zone. This sandstone overlies blue clay and underlies greenish-gray clay, which was traced with reasonable certainty southward almost to Middle Dome.

${ }^{10}$ Arnold, Ralph, and Anderson, Robert, op. cit., p. 138. 
South of the Paso Robles-Hanford road cross-bedded sand containing a few pebbles and a few fossils form the basal part of the zone. Pecten and sand dollars occur in sand about 100 feet higher in the section (pl. 12, column 11). The zone is underlain by a thin lnyer of limestone and a conspicuous layer of bentonitic (?) clay, which extend southward for a distance of 2 miles. Farther south of locality 129 conglomerate at the base of the zone contains pebbles, 2 inches or less long, of black chert and igneous rocks and a few pebbles of yellow limestone. The number and size of the yellow limestone pebbles increase southward.

The Trachycardium zone was recognized near the west branch of Arroyo Conchoso and at localities extending southward to the saddle between North and Middle Domes. At the type locality on the slope west of Arroyo Conchoso (locality 121) it consists of 20 feet of fossiliferous sand about 125 feet above the base of the Pecten zone. Between Arroyo Raso and the Paso Robles-Hanford road the Trachycardium zone consists of a prominent cross-bedded grit or coarsegrained sand containing shell fragments. In a cut on the Paso Robles-Hanford road it overlies silty clay and underlies cross-bedded sand and consists in ascending order of 6 feet of regularly bedded fossiliferous sand, irregularly bedded less fossiliferous sand, and a fossiliferous layer a foot thick that nearby contains sand dollars. At this locality the Trachycardium zone is about 250 feet above the base of the Pecten zone. There is evidently a pronounced thickening of the strata between these two zones as contrasted with the thinning on the east flank between southern North Dome and Middle Dome. The thickening of the strata between the Trachycardium and Acila zones is not so pronounced.

West flank of Middle Dome.-Strata assigned to the Pecten zone are thicker on the west flank of Middle Dome than elsewhere, the thickness reaching a maximum of 175 feet (pl. 12, column 16). The increased thickness appears to be due principally to thick beds of conglomernte. The conglomerate mapped as the base of the zone is exposed at places along the foot of Las Alturas and in the northern part of El Caballete (pl. 12, columns 11-15). The conglomerate contains 3 -inch cobbles of yellow limestone and white siliceous shale and is as much as 80 feet thick. Fossils are not abundant in this conglomerate, but at places Pecten and other fossils are present. Fresh-water fossils found at the surface with marine fossils in sec. 14, T. $23 \mathrm{~S}$., R. 18 E., presumably come from a thin lens of freshwater strata near the base of the zone. Farther south along El Caballete the base of the zone is placed at the base of gray sand or sandy silt (pl. 12, columns 16, 17), which are poorly exposed and are apparently nonfossiliferous.
Several thin beds of limestone, generally about 2 inches thick, occur in or below the Pecten zone. The lowest bed is in clay underlying the zone (pl. 12, columns 12, 14, 15). Along the crest of El Caballete southward from La Brecha a layer of limestone immediately underlies the conglomerate referred to the base of the zone (pl. 12, column 17). Locally it is gypsiferous and at locality 134, in sec. 8, T. 24 S., R. 19 E., it contains ostracodes. The line on the map (pl. 3) representing the base of the Pecten zone is the outcrop of this limestone, as the overlying sand and sandy silt into which the conglomerate appears to grade southward are not well exposed. In sec. 36 , T. 23 S., R. 18 E., south of La Brecha, two beds of limestone are in the upper part of the zone (pl. 12, column 15). The upper limestone is generally platy. Farther south only one limestone is present in the upper part of the zone, and it disappears southward (pl. 12, column 16). At locality 132, in sec. 6, T. 24 S., R. 19 E., fragments of fossils occur in white sand and conglomerate overlying the one bed of limestone in this part of the section. The white sand and conglomerate correspond to the unit shown in column 16 , plate 12 . White siliceous shale pebbles, derived presumably from the Miocene McLure shale member of the Monterey to the west, are abundant in this conglomerate. Siliceous shale pebbles in such abundance were not observed below the Pecten zone. Fossiliferous sand and conglomerate at this horizon, more than 100 feet above the inferred base of the zone, were traced with a fair degree of certainty southward almost to Avenal Gap. In secs. 8 and 17, T. 24, S., R. 19 E., Pecten fragments, Aequipecten, and other fossils occur at this horizon.

West flank of South Dome.-Sections of the Pecten zone on the west flank of South Dome are shown on plate 12,. At Badger Hill (locality 137) a thin limestone containing ostracodes (?) is correlated with the limestone just below the base of the zone in southern Middle Dome. This limestone was traced southward with few gaps to the south end of the Kettleman Hills. It is a satisfactory horizon marker and forms a conspicuous outcrop, particularly when viewed from the south (pl. 18, $C$ ). At sume outcrops it is gypsiferous and at others it consists of two beds about 5 feet apart stratigraphically.

In sec. 20, T. 24 S., R. 19 E., Aequipecten occurs in an 8 -foot sand immediately above the limestone. This sand is overlain by about 90 feet of silt or clay, above which is a 30 -foot white sand also contrining Aequipecten (locality 138; pl. 12, column 18). In the adjoining sec. 29, Pecten and Aequipecten were found on the surface of sand about 20 feet above the limestone (pl. 12, column 19).

Southward from Badger Hill the Pecten zone thins and finally disappears, the upper part first. The sec- 
GEOLOGY OF THE KETTLEMAN HILLS OIL FIELD, CALIFORNIA

tions in columns 18 to 26 on plate 12 , show the gradual southward thinning in the stretch of $2 \frac{1}{4}$ miles south of Badger Hill. As the thickness of the zone decreases typical Pecten zone fossils are replaced by Mya. Farther south for a distance of $2 \frac{1}{3}$ miles there is no Pecten zone, and the mapping is based on the limestone that immediately underlies the zone farther north. The absence of Pecten zone sand and conglomerate may be due to an erosional discontinuity or a nondepositional discontinuity. In view of the evident lenticularity of strata in the San Joaquin formation, however, the nonfossiliferous silt and clay overlying the limestone may have been deposited at the same time as sand and gravel farther north, and the absence of Pecten zone fossils may be due to the different environment.

On Los Morones the Pecten zone again appears (pl. 12, columns 27-32). At the north end of Los Morones the zone is represented by a ledge of limy mudstone containing many shell fragments. At its northern extremity this ledge is in contact with the underlying limestone layer, but southward the two beds are separated by silt and sand. A sandy bed in this interval, which locally contains fresh-water shells, appears to grade northward into a thin lens of limestone. The presence of Mya in the zone on Los Morones suggests a facies similar to that $2 \frac{1}{2}$ miles to the north, but there are also fresh-water layers and a marine fauna fairly typical of the Pecten zone, including abundant Aequipecten and fragments of Pecten (localities 139, 140, 140a, 140b). The fresh-water fossils at Los Morones were assigned to the Tulare formation by Arnold. ${ }^{41}$

\section{FOSSILS}

The fossils of the Pecten and Trachycardium zones are listed in the table opposite this page and the characteristic and abundant species are shown on plates $13-16,39,45,46$. The Pecten zone contains a relatively large marine fauna, larger than any other fauna in the San Joaquin and Etchegoin formations. Many species and genera of this fauna were not found at other horizons. Fossils are abundant in North Dome, less so in Middle Dome, and still less in South Dome except on Los Morones at the south end of the hills. The fauna of the Trachycardium zone is similar to that of the Pecten zone. The speciès in the Trachycardium zone occur in the Pecten zone, but many Pecten zone fossils are absent in the Trachycardium zone.

Pecten coalingaensis (pl. 13, figs. 1, 2, 17, 18; pl. 16, fig. 4) is a common fossil in the Pecten zone in North Dome but is rare farther south. This genus is not known to occur at other horizons. The specimen listed under the Acila zone was probably derived from older alluvium. Another member of the Pectinidae, Aequipecten circularis impostor (pl. 13, figs. 3, 4, 6-9),

\footnotetext{
$"$ Arnold, Ralph, op. cit. (Bull. 396), pp. 47, 48 (locality 4715). Arnold, Ralph, and Anderson, Robert, op. cit. (Bull. 398), p. 153 (locality 4715).
}

is abundant in the Pecten zone at localities in Middle Dome and South Dome and on the east flank of North Dome south of the Paso Robles-Hanford road but was not found north of Arroyo Pino. It also occurs in the Trachycardium zone. Chama pellucida (pl. 14, figs. 1-4, 10), Jaton cf. J. festivus (pl. 15, figs. 2, 9), the coral Astrangia coalingensis (pl. 16, fig. 7), and other less abundant species represent genera not found outside the Pecten zone. Relatively large oysters that have a strongly plicate upper valve, Ostrea vespertina (pl. 14, fig. 9), occur in the Pecten and Trachycardium zones but were not certainly identified at other horizons. Neverita reclusiana (pl. 15, figs. 11, 19, 20), which has an extensive stratigraphic range in the San Joaquin and Etchegoin formations, is particularly abundant in the Pecten zone at localities 93 and 117 and in the Trachycardium zone at locality 121.

Dendraster coalingaensis in its typical form (pl. 45, fig. 2 ) and the variety gibbosus (pl. 45, figs. 5, 6) occur in the Pecten zone and at lower horizons in the San Joaquin. Merriamaster, treated as a subgenus of Dendraster, is abundant in the Pecten and Trachycardium zones and was not found at lower horizons. One species, $D$. (M.) perrini (pl. 46, figs. 1, 2, 4, 7, 10, 12), appears to be confined to the Pecten and Trachycardium zones; another, $D$. (M.) arnoldi (pl. 46, figs. 3, $5,6,8,11,13$ ), also occurs in the Acila zone.

The Pecten zone also contains a relatively large number of mammalian remains, generally isolated teeth and bones. Teeth of the extinct beaver Castor californicus were not found outside this zone. They are particularly abundant at locality 118 .

\section{OCCURRENCE ELSEWHERE IN SAN JOAQUIN VALLEY}

The type region of the Pecten coalingaensis zone is in the Kreyenhagen Hills, which form the Coast Range foothills west of the Kettleman Hills. According to Arnold and Anderson, ${ }^{42}$ the zone in the Kreyenhagen Hills is 300 to 400 feet below the top of their Etchegoin formation. Arnold and Anderson cited their locality 4712 as typical of the zone. ${ }^{43}$ The fauna from their locality 4710 is more like that in the Kettleman Hills. In the Kreyenhagen Hills the zone has been traced from Zapata Creek southeastward for a distance of about 10 miles to a locality south of Big Tar Canyon.44 (For locations see fig. 1.) The importance of the Pecten zone in the foothill region and the short stratigraphic range of its fauna were emphasized by Nomland, ${ }^{45}$ who recognized it on Anticline Ridge in beds traceable to the type locality of the Etchegoin selected by Arnold and Anderson. The zone has also been identified in

\footnotetext{
12 Arnold, Ralph, and Anderson, Robert, op. cit. (Bull. 398), p. 119.

43 Idem, p. 137.

" Kleinpell, W. D., in Reed, R. D., Geology of California, p. 240, fig. 47, Tulsa, Am. Assoc. Petroleum Geologists, 1933.

${ }^{3}$ Nomland, J. O., The.Etchegoin Pliocene of middle California: California Univ., Dept. Geology, Bull., vol. 10, pp. 213-214, 1917.
} 


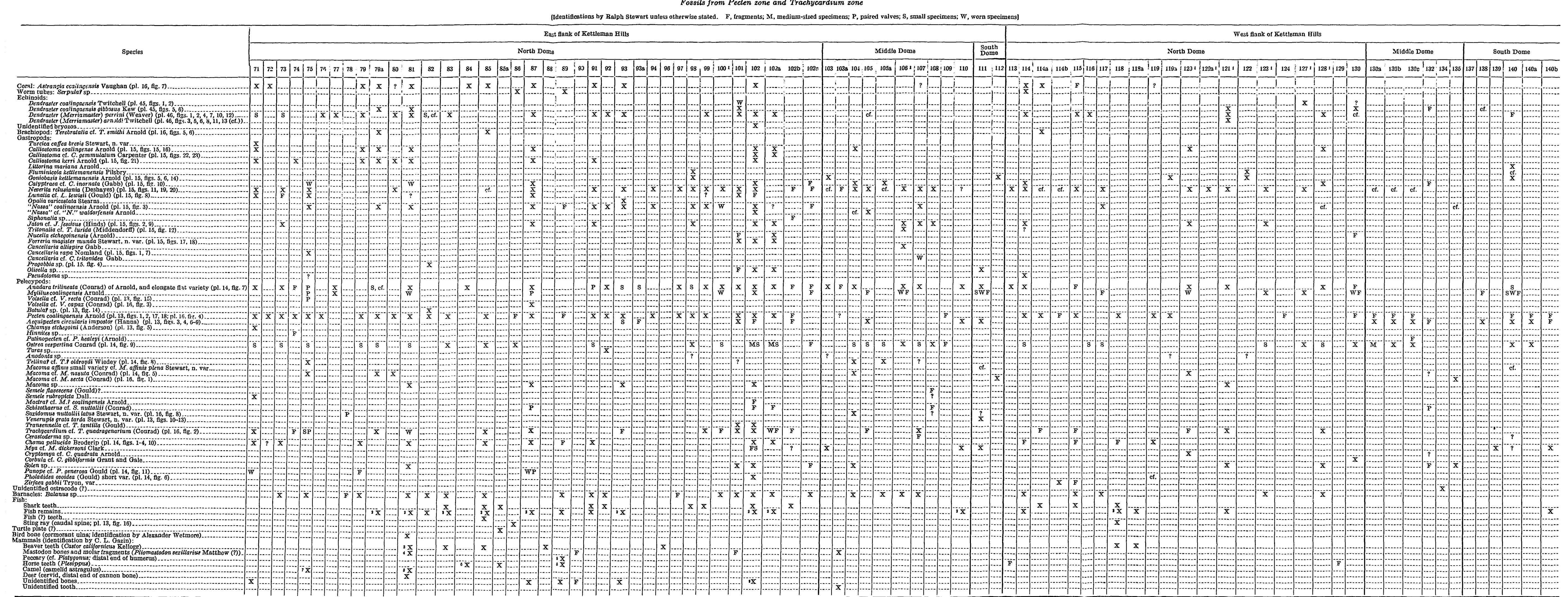

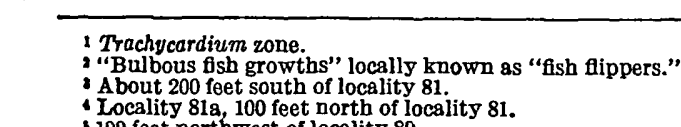


Priest Valley, in the Coast Ranges 35 miles northwest of North Dome. ${ }^{46}$

In view of its widespread outcrop the Pecten zone may be expected to occur as a marine zone in the San Joaquin Valley subsurface section. According to Barbat and Galloway, ${ }^{47}$ a marine zone containing Corbula and "Laevicardium" centifilosum is present in the subsurface section. Barbat and Galloway correlated this zone with strata in North Dome that appear to represent the Acila zone. Inasmuch as the species in the subsurface zone are compatible with the Pecten zone fauna and inasmuch as the Pecten zone is known to have a more widespread outcrop than the Acila zone, a correlation with the Pecten zone is more probable. (See fig. 13.) This subsurface zone is presumably the same as that from which Corbula gibbiformis was described. ${ }^{48}$

S'TRA'TA BE'TWEEN PECTEN ZONE AND NEVERITA ZONE

STRATIGRAPHY AND LITHOLOGY

The strata between the Pecten and Neverita zones have a thickness of 450 to 700 feet. They are made up principally of buff and olive-gray sandy silt and gritty or pebbly sand. Clay is generally a minor constituent but at places is conspicuous.

The clay, silt, and sand immediately underlying the Pecten zone are described with that zone. In North Dome these strata include the layers of dark-colored clay that are useful in locating the Pecten zone, and on the west flank of Middle and South Domes a thin limestone serves the same purpose.

The aragonite concretions described by Reed ${ }^{49}$ occur on Los Morones, at the south end of the Kettleman Hills, about 20 feet stratigraphically below the Pecten zone. According to Reed, they are found in poorly washed sand or silt and might have been formed under conditions similar to those on the floor of the Black Sea.

A band of olive-gray silty clay about 100 feet below the Pecten zone was mapped around the north end of North Dome. The mastodon remains described by Matthew ${ }^{50}$ were collected on Elephant Hill from strata overlying this clay, not from a horizon 100 feet above the upper Mulinia zone (upper Pseudocardium zone of present report), as Matthew was informed.

Mya occurs in silty clay or silty sandstone about halfway between the Pecten and Neverita zones on both flanks of southern North Dome (localities 125, 126, 141),

is Pack, R. W., and English, W. A., Geology and oil prospects of Waltbam, Priest, Bitterwater, and Peachtree Valleys, Calif.: U. S. Geol. Survey Bull. 581, p. 158, 1914. Nomland, J. O., op. cit.

"Barbat, W. F., and Galloway, John, San Joaquin clay, California: Am. Assoc. Petroleum Ceologlsts Bull., vol. 18, p. 486, fig. 1 (p. 488), 1934.

is Grant, U. S., IV, and Gale, H. R., Catalogue of the marine Pliocene and Pleistoceno Moliusca of Callfornia: San Dlogo Soc. Nat. History Mem., vol. 1, p. 420, 1931.

- Reod, R. D., Aragonito concretions from the Kettleman Hills, Calif.: Jour. Geology, vol. 34, pp. 829-833, 2 figs., 1020.

so Matthow, W. D., A Pliocono mastodon skull from California, Pliomastodon vexillarius n. sp.: Californla Univ., Dept. Geol. Sci., Bull., vol. 19, pp. 335-348, pls. 41-44, 2 figs., 1030. Osborn, .F. F., Proboscidea, vol. 1, pp. 161-163, figs. 106-108, 110, Now York, 1938. on the west flank of the saddle between North and Middle Domes, and on the west flank of northern South Dome. The fossiliferous layers are probably at different horizons in different regions; in fact, at locality 141, a quarter of a mile north of the Paso Robles-Hanford road on the east flank of North Dome, there appear to be four Mya layers ${ }^{51}$ in a thickness of 90 feet. On the west flank of the North Dome-Middle Dome saddle a Mya layer crops out on the crest of the first row of low knolls east of the foot of Las Alturas. Toward the south it grades into nonfossiliferous sandstone. Also on the west flank of northern North Dome Myabearing sandstone is replaced southward by barren sandstone.

At about the same horizon or closer to the Pecten zone fresh-water fossils and leaves were found in silty clay and sandy silt at scattered localities in the three anticlines (localities 95, 125a, 131, 142).

At the north end of North Dome, where fossils were not found, sand and sandstone appear to be more abundant in this part of the section. Olive-buff, ironstained dirty sandstone, similar to sandstone in the Neverita zone, crops out on a branch of Arroyo Largo on the north line of sec. 34, T. 21 S., R. 17 E. (pl. 17, $A$ ). The sandstone is 4 feet thick and is riddled with borings, some of which extend downward from the upper surface and are filled with sand like that in the overlying bed. The sandstone is overlain by olive-brown coarsegrained cross-bedded sand containing small pebbles of red, green, and black chert, also shown on plate $17, A$. The angle between cross-bedded laminae and the normal dip is as much as $20^{\circ}$. An excavation at Standard oil well 21-33-J (sec. 33, T. 21 S., R. 17 E.) exposes similar sandstone and sand, possibly the same beds (pl. 17, B). In this excavation the cross-bedded sand cuts across the sandstone, reducing its thickness from $2 \frac{1}{2}$ feet to a foot in a horizontal distance of 50 feet.

A light-gray tuffaceous sandstone is the most conspicuous lithologic unit in North Dome in the interval between the Pecten and Neverita zones. It is lower in the section than the strata already described, about 50 to 75 feet above the top of the Neverita zone. It is shown at places on the geologic map (pl. 3), but it could be mapped over a larger area, especially on the west flank. The sandstone has an observed thickness of 15 to 25 feet. It is soft but generally forms a low cliff. Fresh glass shards were recognized wherever the sandstone was examined, and at places the shards are so abundant that the rock is virtually a sandy tuff. This sandstone generally contains molds of small Anadara and Solen and at places molds of Olivella. Diatoms were collected from laminae of silt in the sandstone and from silty clay a few feet below the sandstone (localities 143, 144). A section of the tuffaceous sand-

"These layers, of course, do not consist wholly of $M y a$ shells. The term "Mya layer" is, however, a convenient designation for such beds and is less stilted than the term "Mya-bearing bed." The term "Mya bed," which is frequently used, conflicts with the usage of the term "bed" in formal stratigraphic nomenclature. 
stone and immediately overlying and underlying beds was measured in a cut on the Paso Robles-Hanford road.

Section of strata in lower part of San Joaquin formation between Pecten and Neverita zones including gray tuffaceous sandstone, measured in cut on Paso Robles-Hanford road west of Arroyo Estrecho, northwestern part of sec. 6, T. 2S S., R. 19 E. (locality 143)

Strata overlying gray tuffaceous sandstone:

8. Massive fine-grained olive-brown sand with thin layers of laminated silt and dirty sand. Basal part contains clay pellets. Ironstained layer 13 inches above base. Top not exposed...........................

7. Thin-bedded silty clay, silt, and silty sandstone. The silty clay contains a few corroded diatoms. Borings filled with overlying sand extend down from top for an observed maximum distance of 7 inches..-

6. Moderately coarse grained olive-brown sand, and, especially in lower half, thin layers of cross-bedded silty sand and laminae of

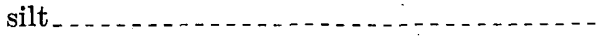

Gray tuffaceous sandstone:

5. Gray, iron-stained tuffaceous sandstone, abundant glass shards in thin layers; includes laminae of fine-grained sand and diatomaceous silt. The sandstone has a few molds of small specimens of Anadara and Solen and is riddled with burrows filled with fine sand. Base not clearly exposed.
Section of strata in lower part of San Joaquin formation between Pecten and Neverita zones including gray tuffaceous sandstone, measured in cut on Paso Robles-Hanford road west of Arroyo Estrecho, northwestern part of sec. 6, T. 2S S., R. 19 E. (locality 143 --Continued

Strata underlying gray tuffaceous sandstone:

Ft. in.

4. Silty clay and silt; may represent basal part of overlying sandstone. Contains diatoms (locality 143). Base not exposed.......

3. Unexposed . . . . . . . . . . . .

2. Moderately coarse grained olive-brown sand Top not exposed..........................

1. Laminated silty clay and silt. Silty clay contains diatoms. (Locality $143 a$ represents lowest exposed part.) Base not exposed.

Fossils

The mollusks and leaves collected from strata between the Pecten and Neverita zones are listed in the following table. The mollusks consist chiefly of Mya and other marine forms that occur in brackish water and of freshwater species. The $M y a$ shells are generally cracked and broken and at places are replaced by gypsum. At locality 141 , however, they include paired specimens. The gastropod operculum from locality 142 is of special interest, for it is the first specimen of Scalez recorded from an outcrop locality.

Fossils from strata in lower part of San Joaquin formation between Pecten zone and Neverita zone

Mollusks from localities 125, 125a, 126, and 131 identifled by Ralph Stewart; those from localities 141 and 142 identifled by W. P. Woodring. Plants identifled by R. W. Brown. P, paired ralves]

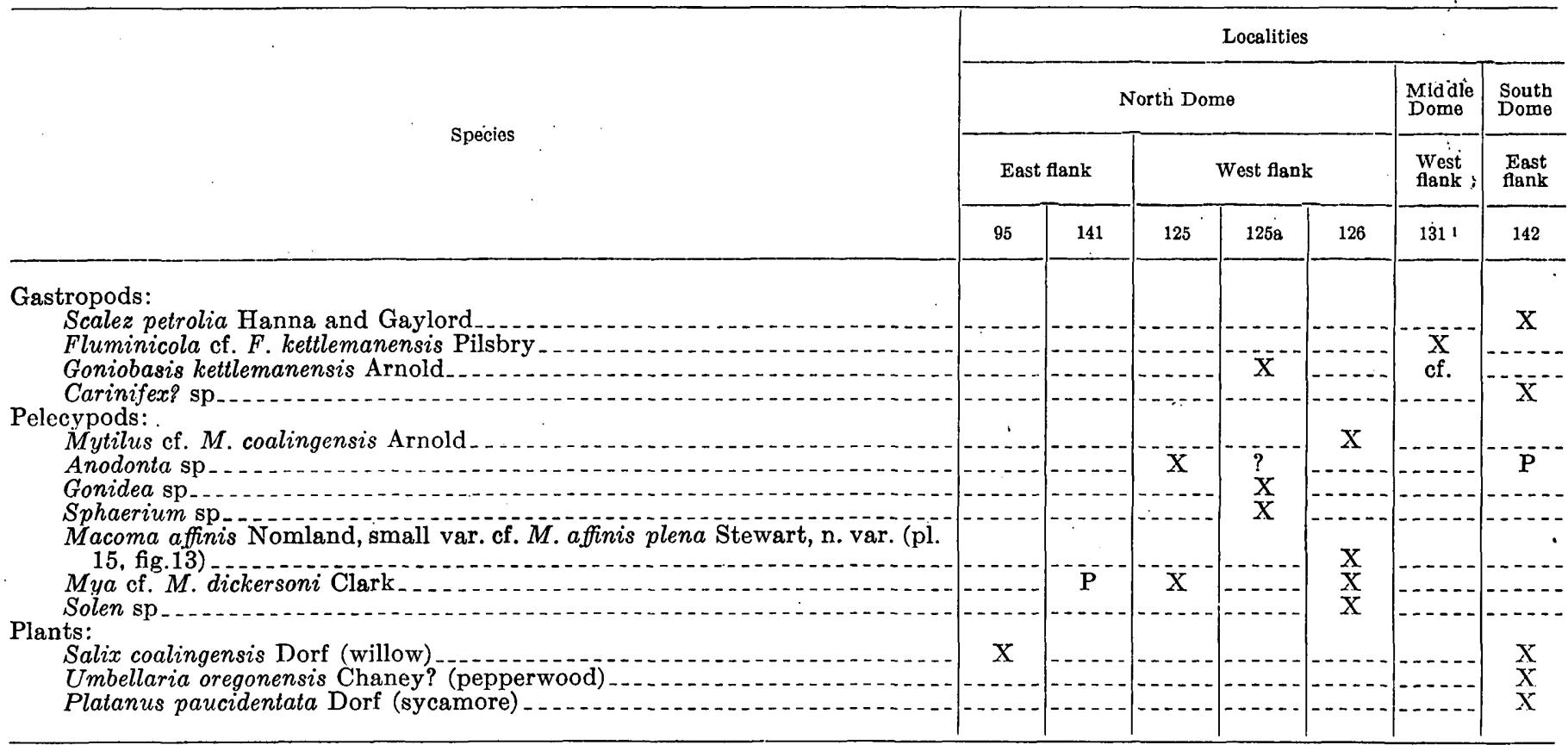

1 Fossils observed but not collected.

The diatoms listed in the following table were identified by $\mathrm{K}$. E. Lohman in collections from the gray tuffaceous sandstone and immediately underlying strata. Some of the species are shown on plates 22 and 23. According to Lohman, the flora is marine and includes many pelagic species. 
Diatoms from strata in lower part of San Joaquin formation between Pecten and Neverita zones

[Identifications by K. E. Lohman. R, rare; F, few; C, common; A, abundant]

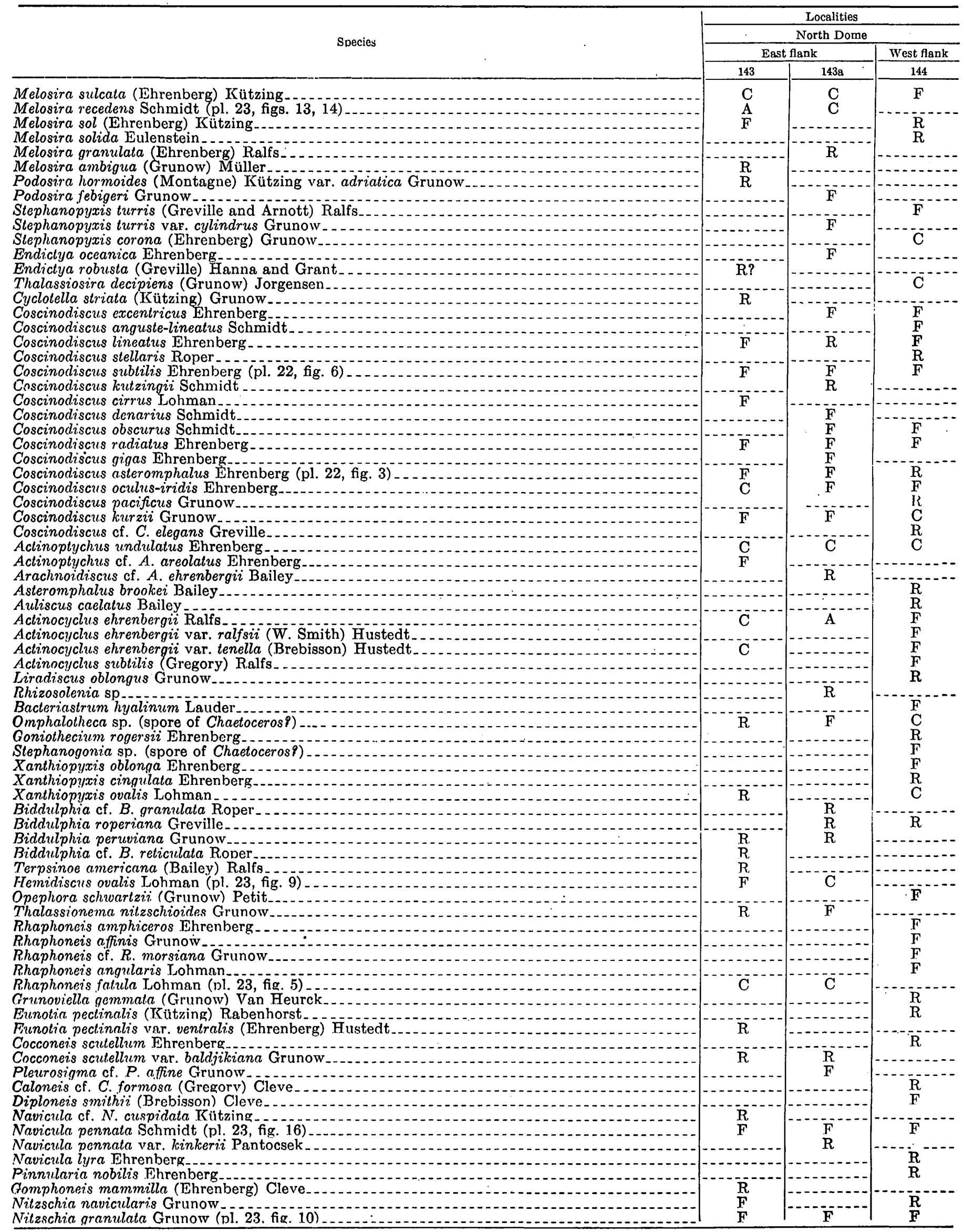




\section{NEVERITA ZONE \\ STRATIGRAPHY AND LITHOLOGY}

The Neverita zone is 450 to 700 feet below the Pecten zone. It consists of sandstone and sand and in North Dome, where it is best exposed, it has an average thickness of 50 to 75 feet. At places the zone is as much as 100 feet thick, and toward the south end of Middle Dome it decreases to about 30 feet. In South Dome a sand doubtfully identified as the Neverita zone is 20 feet thick.

The type locality of the Neverita zone is on the east side of Arroyo Bifido northward from the south line of sec. 35 , T. 21 S., R. 17 E. (pl. 18, $A$ ). The name of the zone is unsatisfactory, for Neverita occurs at various horizons in the San Joaquin formation, and at places it is more abundant in the Pecten and Trachycardium zones than in the Neverita zone itself. Nevertheless, this genus is common in the Neverita zone and it is not known to occur at lower horizons in the San Joaquin formation except in the Cascajo conglomerate member, which contains broken and worn specimens. Moreover, the faunal association characteristic of the Neverita zone was not found at other horizons. The Neverita zone has been informally designated the Natica-Mya zone by some field geologists.
The Neverita zone includes two lithologic types: (1) sandstone and (2) a much thicker loose sand. (1) The sandstone is buff, iron-stained, mediumgrained, poorly sorted, and dirty. Though uncemented, aside from lumps that have a ferruginous or calcareous cement, it is firm enough to form low cliffs on steep slopes. It is generally massive; at some places, however, it has discontinuous silt partings and at others it includes thin beds of olive-brown sand. The sandstone contains small pebbles, consisting principally of black chert and white quartz, that are scattered or are concentrated in lenses, particularly at the base. Layers of fossils occur in the sandstone at different horizons at one locality or apparently at the same horizon at different localities, representing different faunal associations. (2) The sand is coarsegrained, relatively well sorted and clean, and olive brown. Ferruginous cement forms irregular lumps. The sand also contains pebbles and is locally crossbedded. Much of the sand is barren of fossils, but sand dollars are more abundant in the sand, especially near the base, than in the sandstone. The approximate mineral composition of a sample of sandstone and sand, as determined by M. N. Bramlette, is given below.

Approximate mineral composition of sand and sandstone in Neverita zone of San Joaquin formation

[Determined by M. N. Bramlette]

\begin{tabular}{|c|c|c|c|c|c|}
\hline Mineral groups & Relative abundance & Sand 1 & & Sandstone 2 & \\
\hline \multirow{3}{*}{ Heavy minerals. } & Abundant. & $\begin{array}{l}\text { Magnetite. } \\
\text { Green hornblende. } \\
\text { Augite. } \\
\text { Brown hornblende. }\end{array}$ & \multirow{3}{*}{ 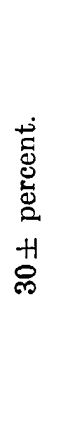 } & $\begin{array}{l}\text { Magnetite. } \\
\text { Augite. } \\
\text { Green hornblende. } \\
\text { Brown hornblende. }\end{array}$ & \multirow{3}{*}{ 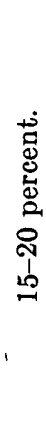 } \\
\hline & Common. & $\begin{array}{l}\text { Epidote. } \\
\text { Titanite. } \\
\text { Apatite. }\end{array}$ & & $\begin{array}{l}\text { Epidote. } \\
\text { Actinolite. }\end{array}$ & \\
\hline & Rare. & $\begin{array}{l}\text { Zircon. } \\
\text { Glaucophane. }\end{array}$ & & $\begin{array}{l}\text { Titanite. } \\
\text { Garnet. } \\
\text { Apatite. } \\
\text { Zircon. } \\
\text { Glaucophane. } \\
\text { Tourmaline. }\end{array}$ & \\
\hline \multirow{3}{*}{ Light minerals. } & Abundant. & $\begin{array}{l}\text { "Zeolitic" mineral. } \\
\text { Andesine. } \\
\text { Quartz. }\end{array}$ & \multirow{3}{*}{ 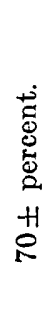 } & $\begin{array}{l}\text { "Zeolitic" mineral. } \\
\text { Fresh, zoned andesine. } \\
\text { Labradorite. } \\
\text { Quartz. }\end{array}$ & \multirow{3}{*}{ 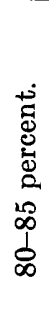 } \\
\hline & Common. & $\begin{array}{l}\text { Orthoclase. } \\
\text { Serpentine. } \\
\text { Microcrystalline rock aggre- } \\
\text { gates. }\end{array}$ & & $\begin{array}{l}\text { Orthoclase. } \\
\text { Serpentine. } \\
\text { Chlorite. } \\
\text { Clay minerals. }\end{array}$ & \\
\hline & Rare. & & & & \\
\hline
\end{tabular}




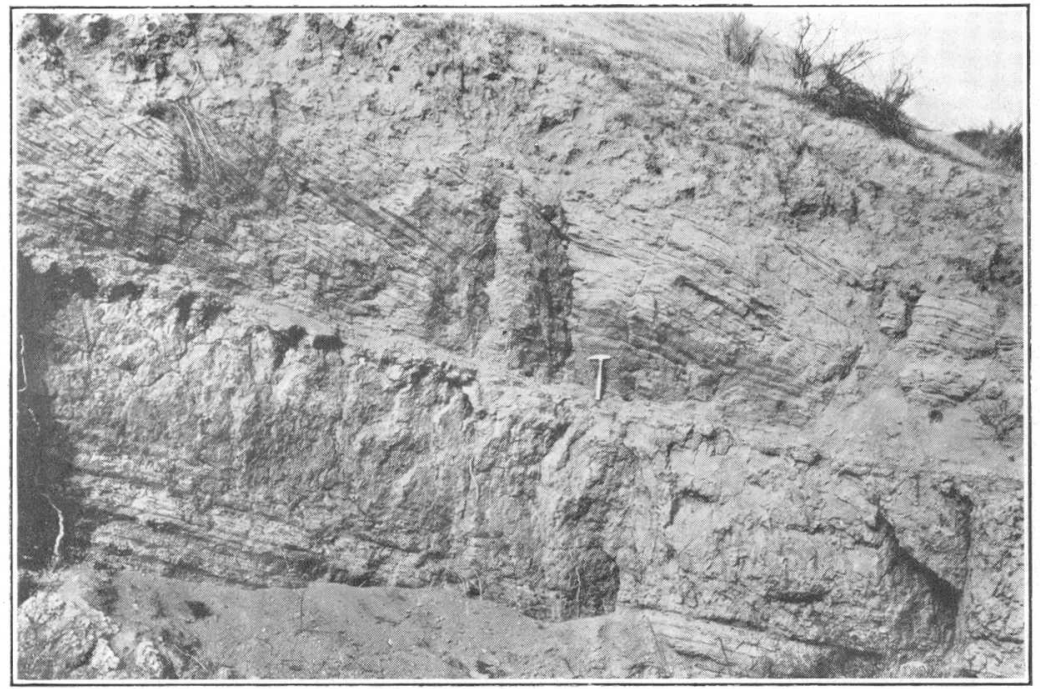

A. SANDSTONE AND CROSS-BEDDED SAND OF SAN JOAQUIN FORMATION ON BRANCH OF ARROYO LARGO AT NORTH LINE OF SEC. 34, T. 21 S., R. 17 E.

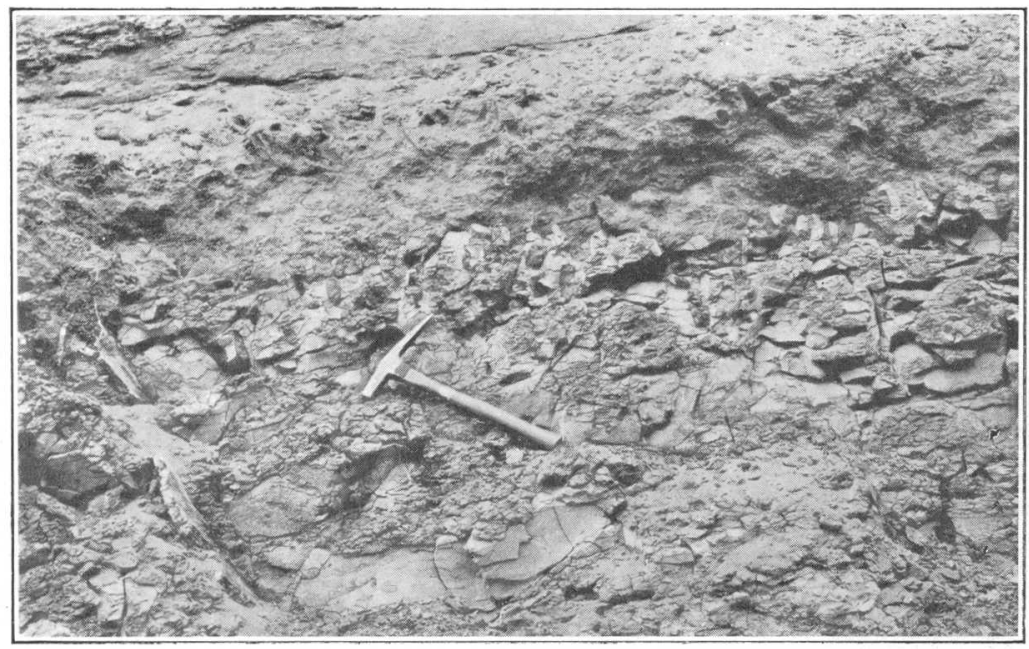

B. SANDSTONE OF SAN JOAQUIN FORMATION RIDDLED WITH BORINGS. EXCAVATION AT STANDARD WELL 21-33-J, SEC. 33, T. 21 S., R. 17 E.

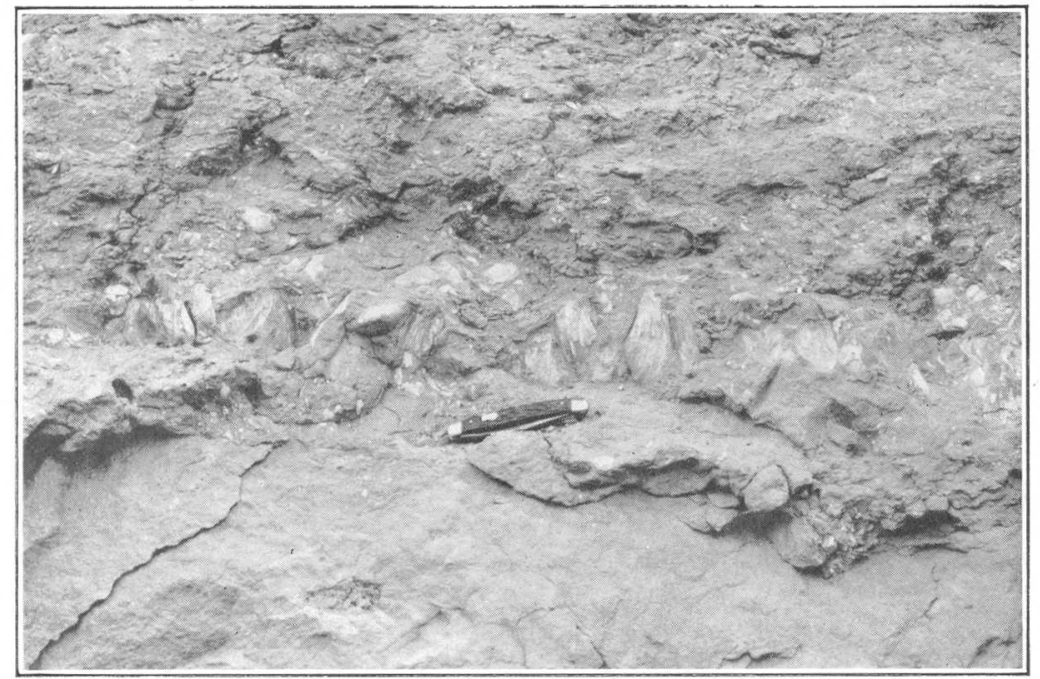

C. SECOND MYA LAYER ABOVE LITTORINA ZONE OF ETCHEGOIN FORMATION ON ROAD NORTHWEST OF DOUBLE HILL IN SEC. 2 , T. 22 S., R. 17 E. 


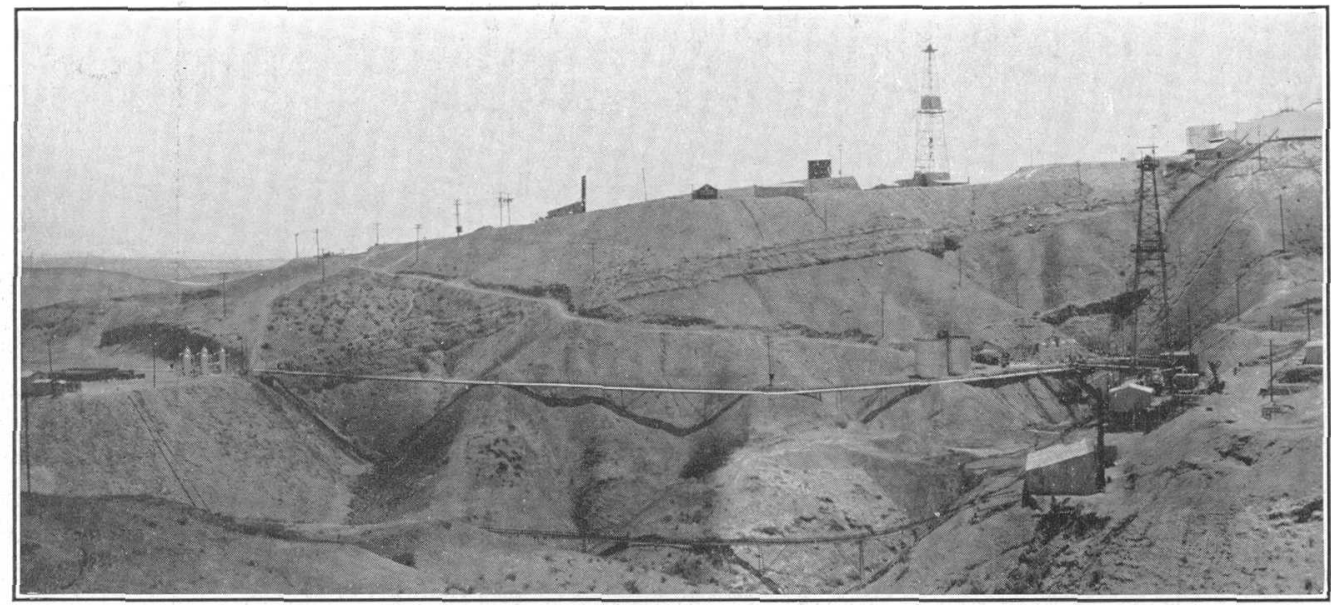

A. NEVERITA ZONE AT TYPE LOCALITY ON EAST SIDE OF ARROYO BIFIDO, SEC. 35, T. 21 S., R. 17 F. Basal sandstone and lower part of overlying sand form low cliff under derrick on skyline.

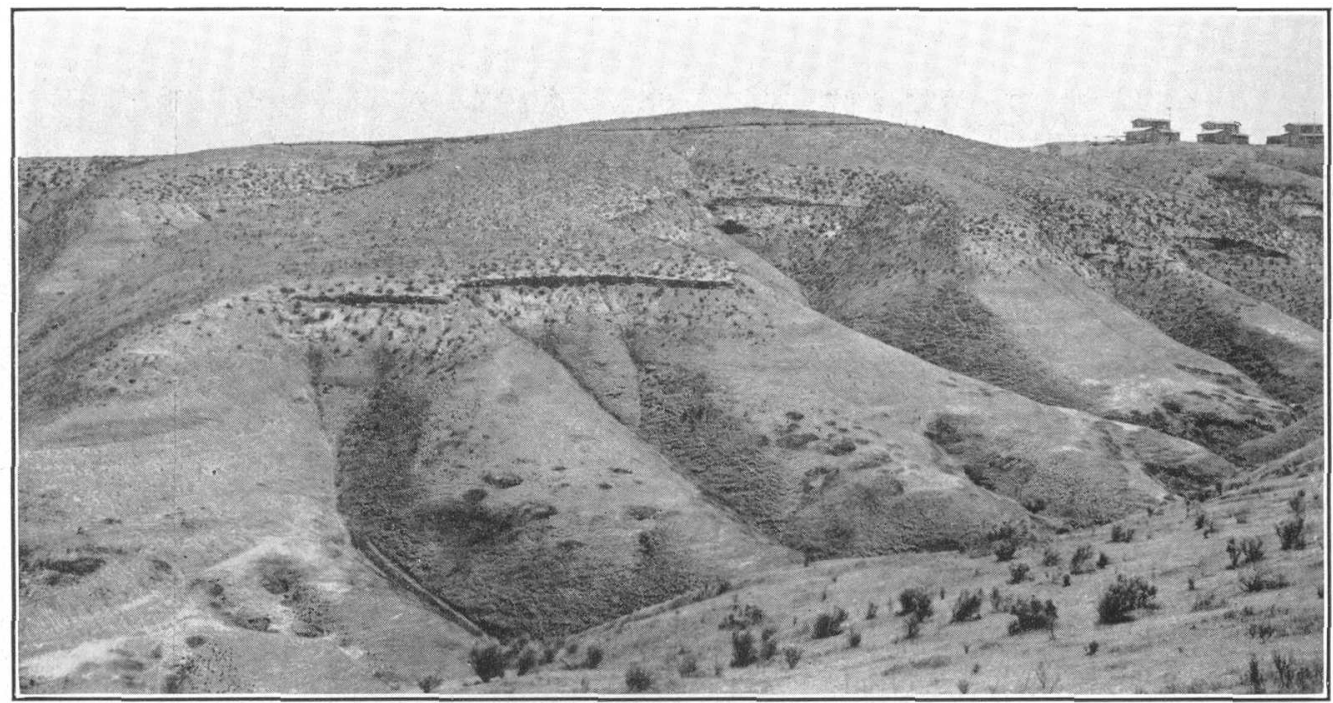

B. NEVERITA ZONE ON EAST SIDE OF BRANCH OF ARROYO LARGO IN WESTERN PART OF SEC. 3 , T. 22 S., R. 17 E. Basal sandstone forms low cliff; overlying sand extends to top of ridge.

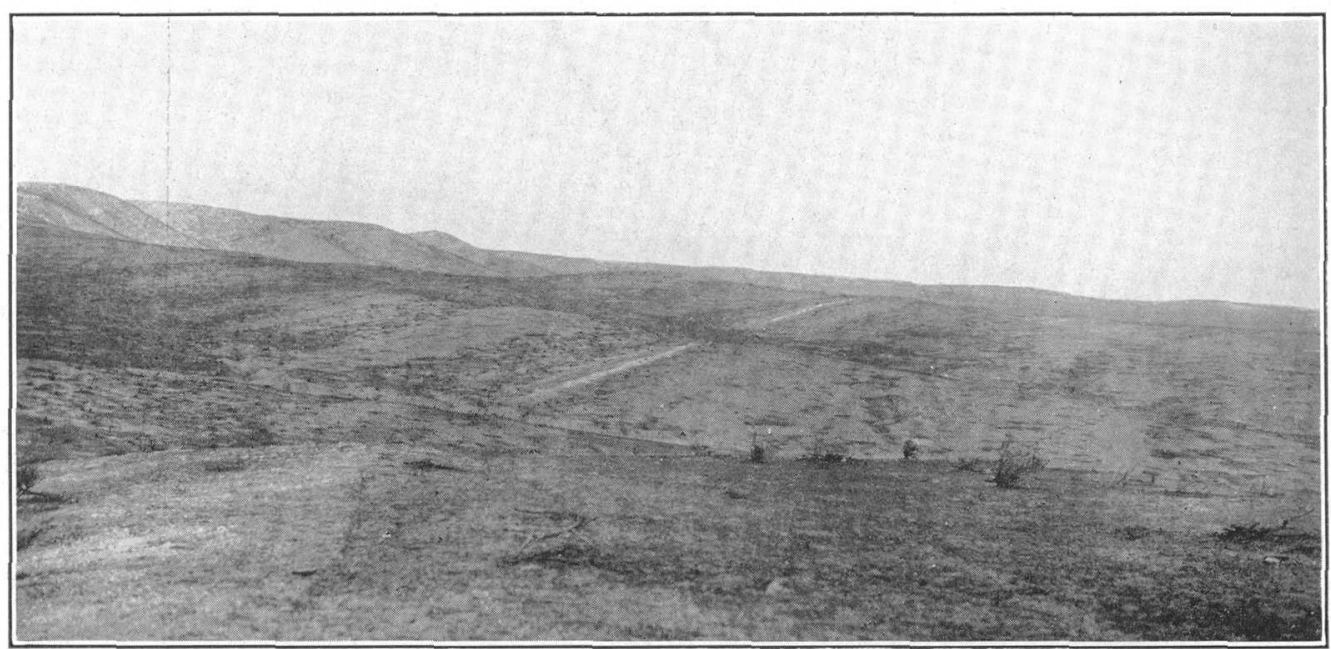

C. VIEW ON WEST FLANK OF SOUTH DOME LOOKING NORTHWARD FROM SOUTH LINE OF SEC. 20 , T. 24 S., R. 19 E. The narrow white band marks the outcrop of a thin bed of limestone immediately underlying the Pecten zone. 


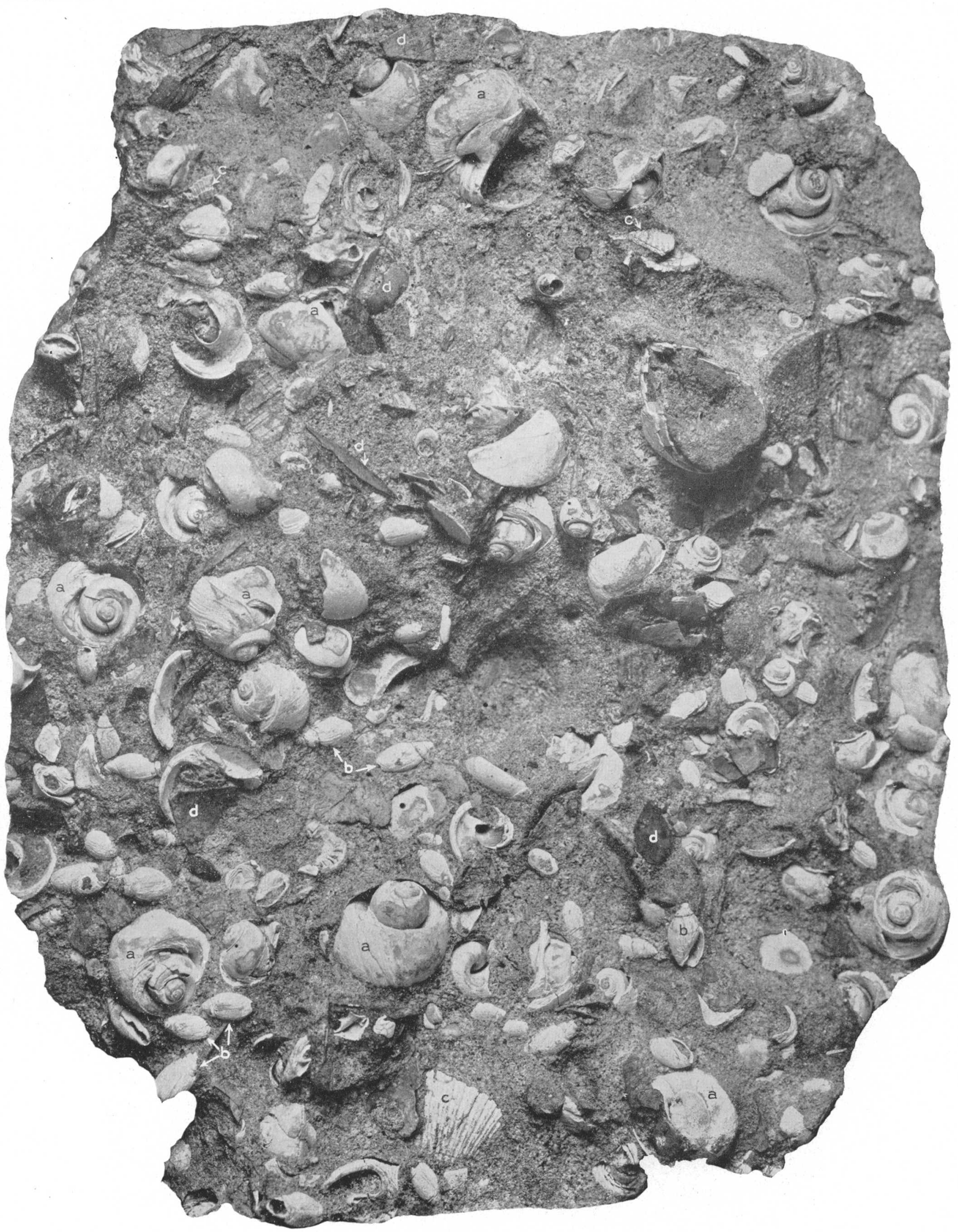

LIMY SANDSTONE FROM NEVERITA LAYER OF BASAL SANDSTONE OF NEVERITA ZONE SHOWING CHARACTERISTIC FAUNAL ASSOCIATION.

From butte in southeastern part of sec. 33 , T, 21 S., R. 17 E., locality 163 . Natural size. 


\section{PLATE 20}

[Figures natural size unless otherwise designated]

Figures 1-5. Neverita reclusiana (Deshayes).

1. Exfoliated specimen. Height (incomplete) $32.5 \mathrm{~mm}$., width (incomplete) $31 \mathrm{~mm}$. Locality 148a. U.S. Nat. Mus. 495318.

2. Variety. Height (virtually complete) $36 \mathrm{~mm}$., width (almost complete) $33 \mathrm{~mm}$. Locality $171 . \quad$ U. S. Nat. Mus. 495319.

3. Height $34.6 \mathrm{~mm}$., width $29.8 \mathrm{~mm}$. Locality 171 . U. S. Nat. Mus. 495320.

4. Variety. Height $23 \mathrm{~mm}$., width (almost complete) $21.8 \mathrm{~mm}$. Locality 152 . U. S. Nat. Mus. 495321.

5. Height (incomplete) $23.2 \mathrm{~mm}$., width (incomplete) $20.8 \mathrm{~mm}$. Locality 149. U. S. Nat. Mus. 495322.

6. Calyptraea cf. C. inornata (Gabb). Height about $18 \mathrm{~mm}$., greatest diameter $26 \mathrm{~mm}$. Locality $155 . \quad$ U. S. Nat. Mus. 495324.

7. Mitrella gausapata (Gould). Height (incomplete) $10.5 \mathrm{~mm}$., width (almost complete) $5.8 \mathrm{~mm}$. Locality 165. U. S. Nat. Mus. 495323.

8, 9. Olivella ef. O. pedroana (Conrad). Locality 145.

8. Height (incomplete) $13.2 \mathrm{~mm}$., width $7.3 \mathrm{~mm}$. U. S. Nat. Mus. 495325.

9. Height $12 \mathrm{~mm}$., width $5.5 \mathrm{~mm}$. U. S. Nat. Mus. 495326.

10, 11. Dendraster gibbsii (Rémond), small var. Locality 164.

10. Length $35.1 \mathrm{~mm}$., width $42.3 \mathrm{~mm}$., height $7.7 \mathrm{~mm}$. (also shown on pl. 22, fig. 3). U. S. Nat. Mus. 495335.

11. Length $39.6 \mathrm{~mm}$., width $42.9 \mathrm{~mm}$., height $7.9 \mathrm{~mm}$. (also shown on pl. 22, fig. 5). U. S. Nat. Mus. 495336.

12. Macoma cf. $M$. nasuta (Conrad). Length $49.8 \mathrm{~mm}$., height $34.7 \mathrm{~mm}$., thickness of both valves about $14 \mathrm{~mm}$. Locality 161. U. S. Nat. Mus. 495327.

13, 14. Volsella cf. V. recta (Conrad).

13. Greatest length $61.9 \mathrm{~mm}$., width $27 \mathrm{~mm}$., thickness of both valves $19.9 \mathrm{~mm}$. Locality 148 . U. S. Nat. Mus. 495330.

14. Greatest length (almost complete) $86 \mathrm{~mm}$., width $34.8 \mathrm{~mm}$., thickness of both valves $26.7 \mathrm{~mm}$. Locality 153. U. S. Nat. Mus. 495328.

15-17. Anadara trilineata (Conrad) of Arnold.

15. Elongate flat variety. Length $40.9 \mathrm{~mm}$., height $26.4 \mathrm{~mm}$., thickness $9.7 \mathrm{~mm}$. Locality 154 . U. S. Nat. Mus. 495329.

16. Elongate flat variety. Length $41 \mathrm{~mm}$., height $27 \mathrm{~mm}$., thickness $10 \mathrm{~mm}$. Locality 154 . U. S. Nat. Mus. 495331.

17. Length $67.5 \mathrm{~mm}$., height $52.5 \mathrm{~mm}$., thickness $22 \mathrm{~mm}$. Locality 161 . U. S. Nat. Mus. 495332. 


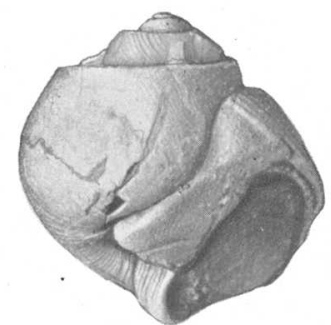

1

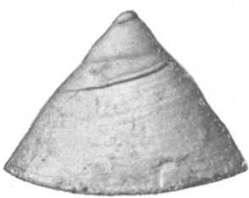

6

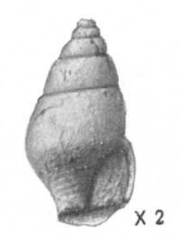

7
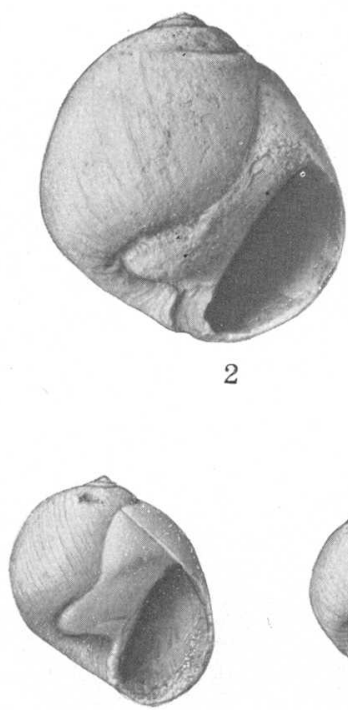

4

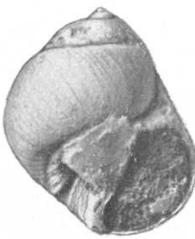

5

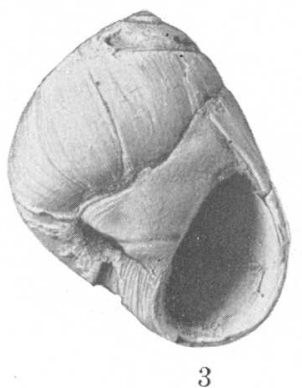

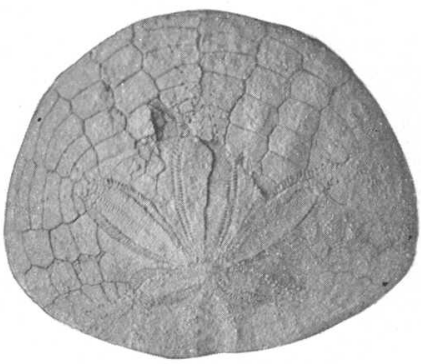

10

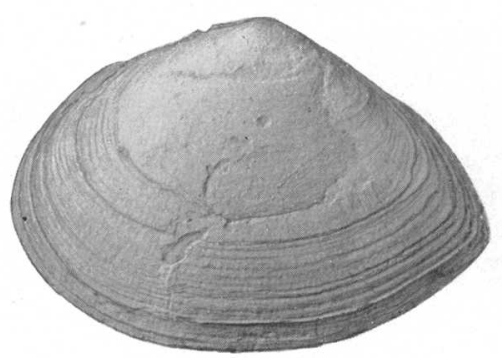

12

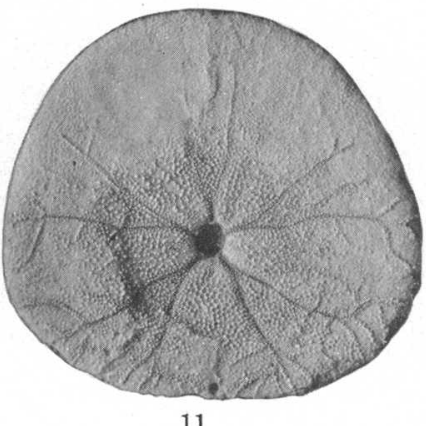

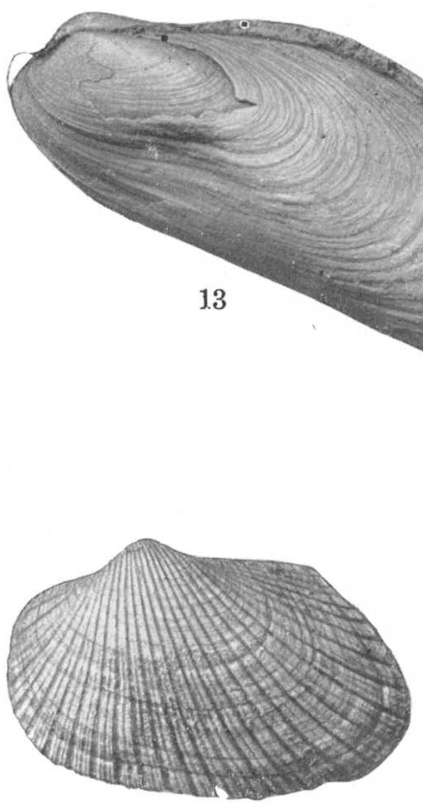

15

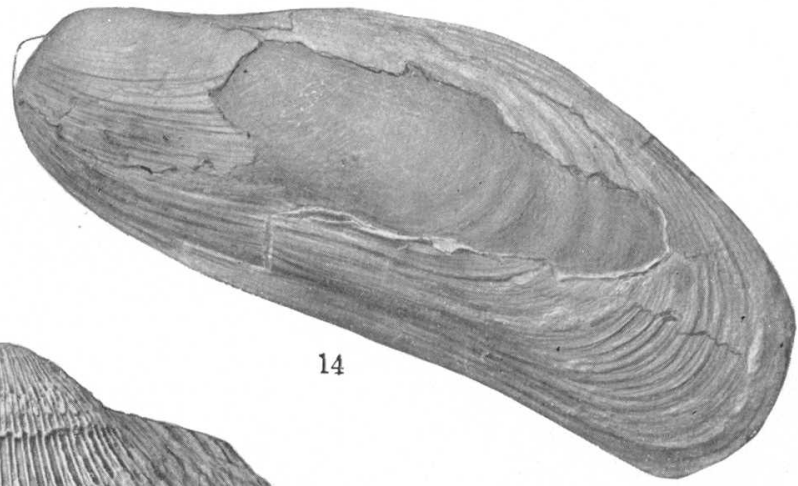

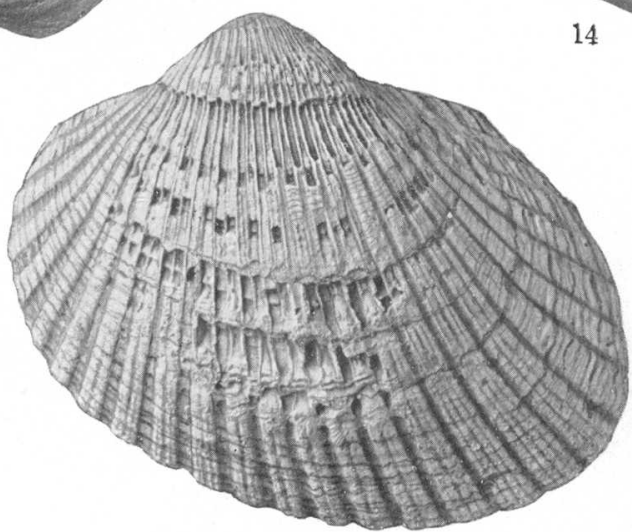

17
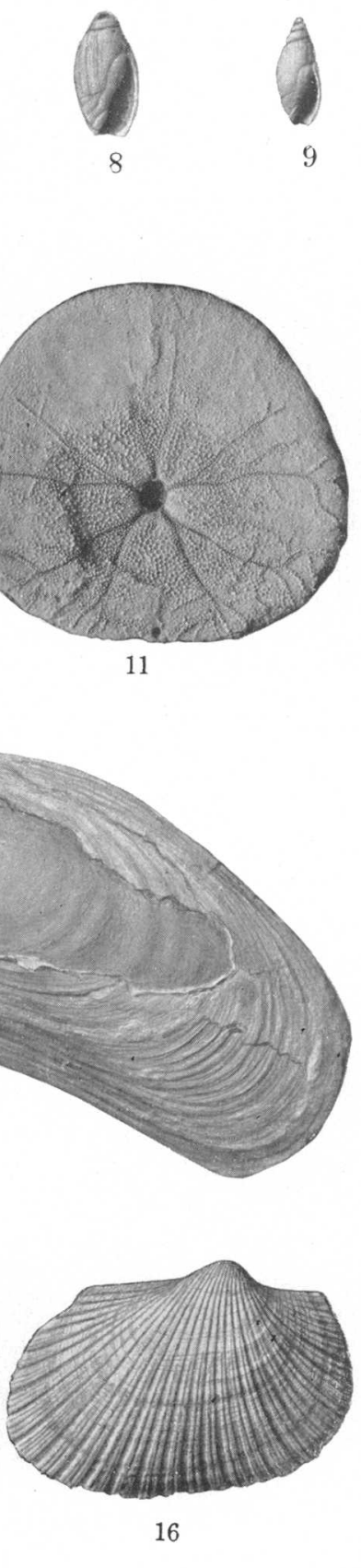

FOSSILS FROM NEVERITA ZONE OF SAN JOAQUIN FORMATION. 


\section{PLATE 21}

[Figures natural size unless otherwise designated]

Figures 1, 2. Platyodon colobus Woodring, n. sp. Locality 151.

1. Type. Length (incomplete) $66.8 \mathrm{~mm}$., height (almost complete) $51.5 \mathrm{~mm}$., thickness of both valves about $40 \mathrm{~mm}$. U. S. Nat. Mus. 495333.

2. Length (incomplete) $67 \mathrm{~mm}$., height $55.5 \mathrm{~mm}$., thickness about $29 \mathrm{~mm}$. U. S. Nat. Mus. 495334 .

3-6. Dendraster gibbsii (Rémond), small var.

3. Length $35.1 \mathrm{~mm}$., width $42.3 \mathrm{~mm}$., height $7.7 \mathrm{~mm}$. (also shown on pl. 21, fig. 10). Locality $164 . \quad$ U. S. Nat. Mus. 495335.

4, 5. Length $39.6 \mathrm{~mm}$., width $42.9 \mathrm{~mm}$., height $7.9 \mathrm{~mm}$. (also shown on pl. 21, fig. 11). Locality 164 . U. S. Nat. Mus. 495336.

6. Length $34 \mathrm{~mm}$., width $38.5 \mathrm{~mm}$., height (crushed) $6.5 \mathrm{~mm}$. Locality 163a. U. S. Nat. Mus. 495337. 

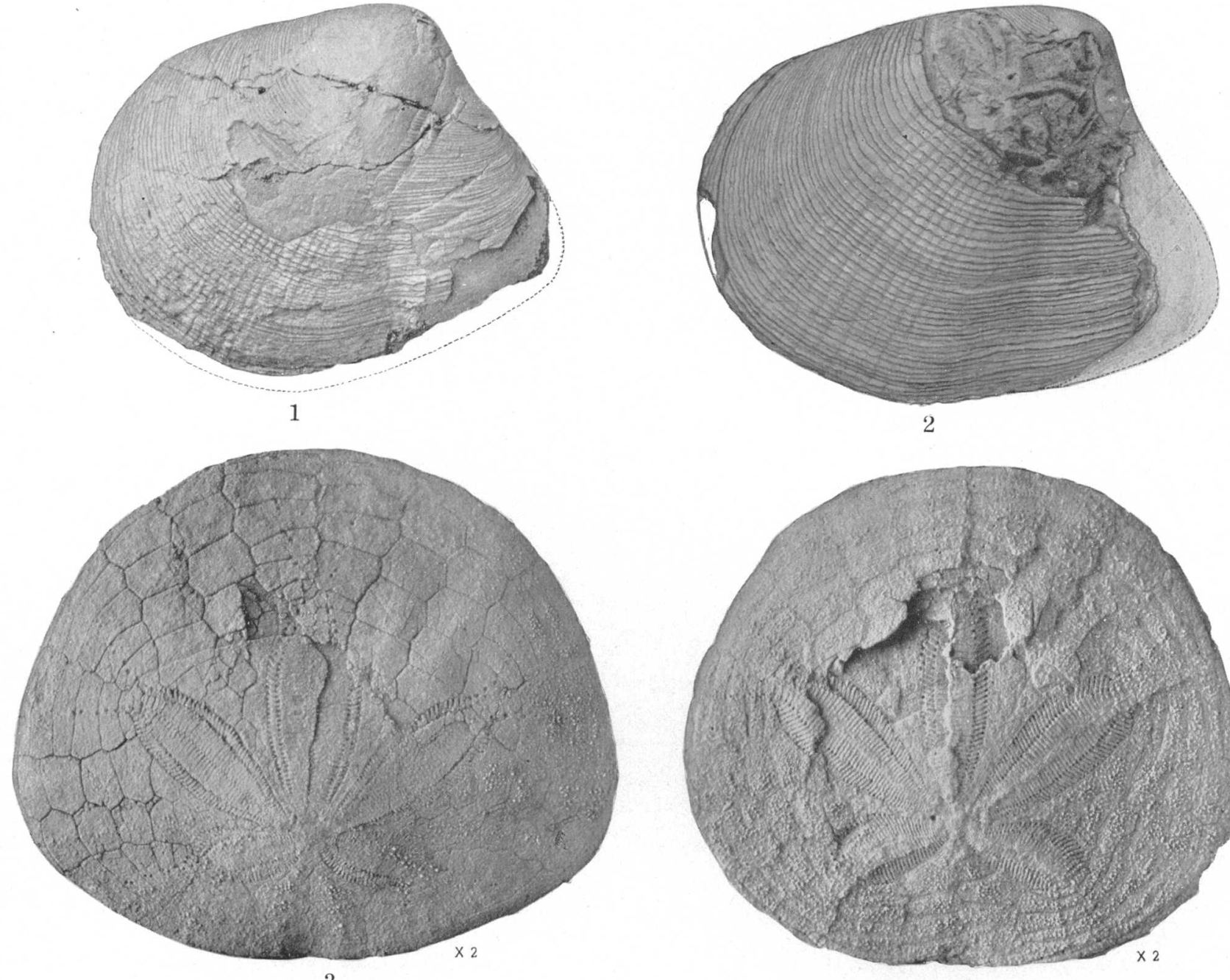

2

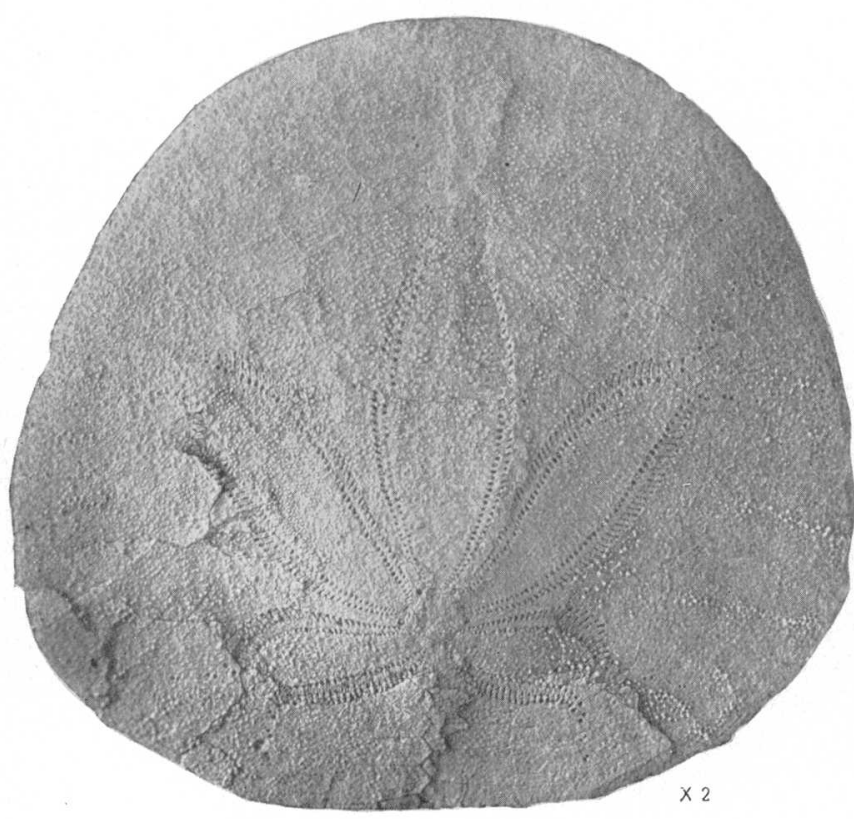

4

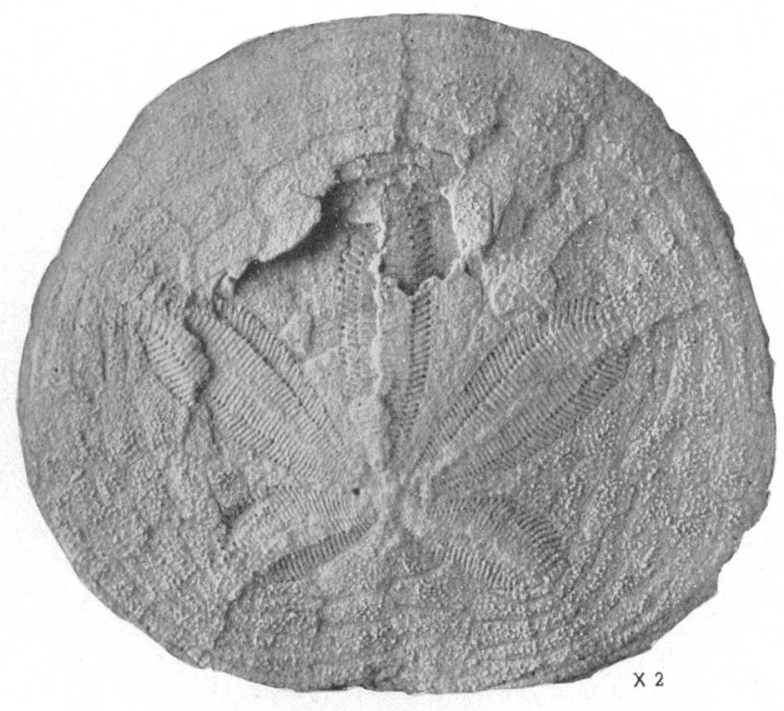

6

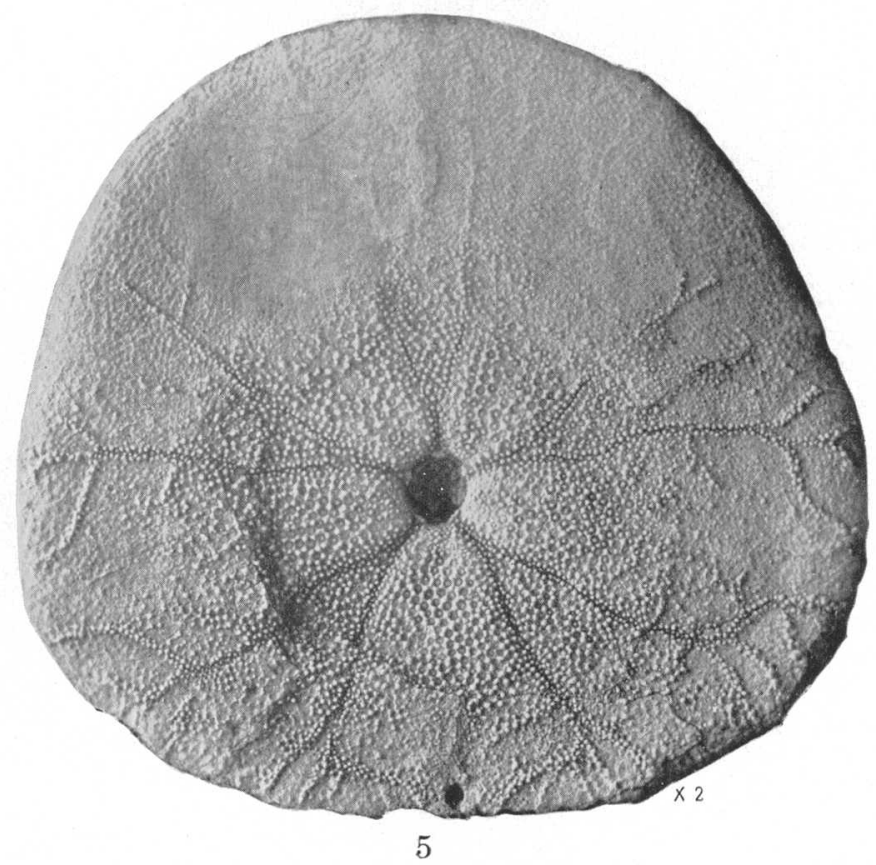

FOSSILS FROM NEVERITA ZONE OF SAN JOAQUIN FORMATION. 


\section{PLATE 22}

Figdre 1. Coscinodiscus obscurus Schmidt. Diameter $0.118 \mathrm{~mm}$. Locality 168, Neverita zone. U. S. G. S. diatom catalog No. 1524-7.

2. Coscinodiscus kurzii Grunow. Diameter $0.105 \mathrm{~mm}$. Locality 173, Neverita zone. U. S. G. S. diatom catalog No. $1630-3$.

3. Coscinodiscus asteromphalus Ehrenberg. Diameter $0.170 \mathrm{~mm}$. Locality 143a, clay underlying tuffaceous sandstone between Pecten and Neverita zones. U. S. G. S. diatom catalog No. 1508-4.

4. Coscinodiscus cirrus Lohman. Holotype. Diameter $0.121 \mathrm{~mm}$. Locality 173, Neverita zone. U. S. G. S. diatom catalog No. 1630-1.

5. Coscinodiscus excentricus Ehrenberg. Diameter $0.066 \mathrm{~mm}$. Locality 173 , Neverita zone. U. S. G. S. diatom catalog No. 1630-2.

6. Coscinodiscus subtilis Ehrenberg. Diameter $0.071 \mathrm{~mm}$. Locality 144, tuffaceous sandstone, between Pecten and Neverita zones. U. S. G. S. diatom catalog No. 1507-1. 

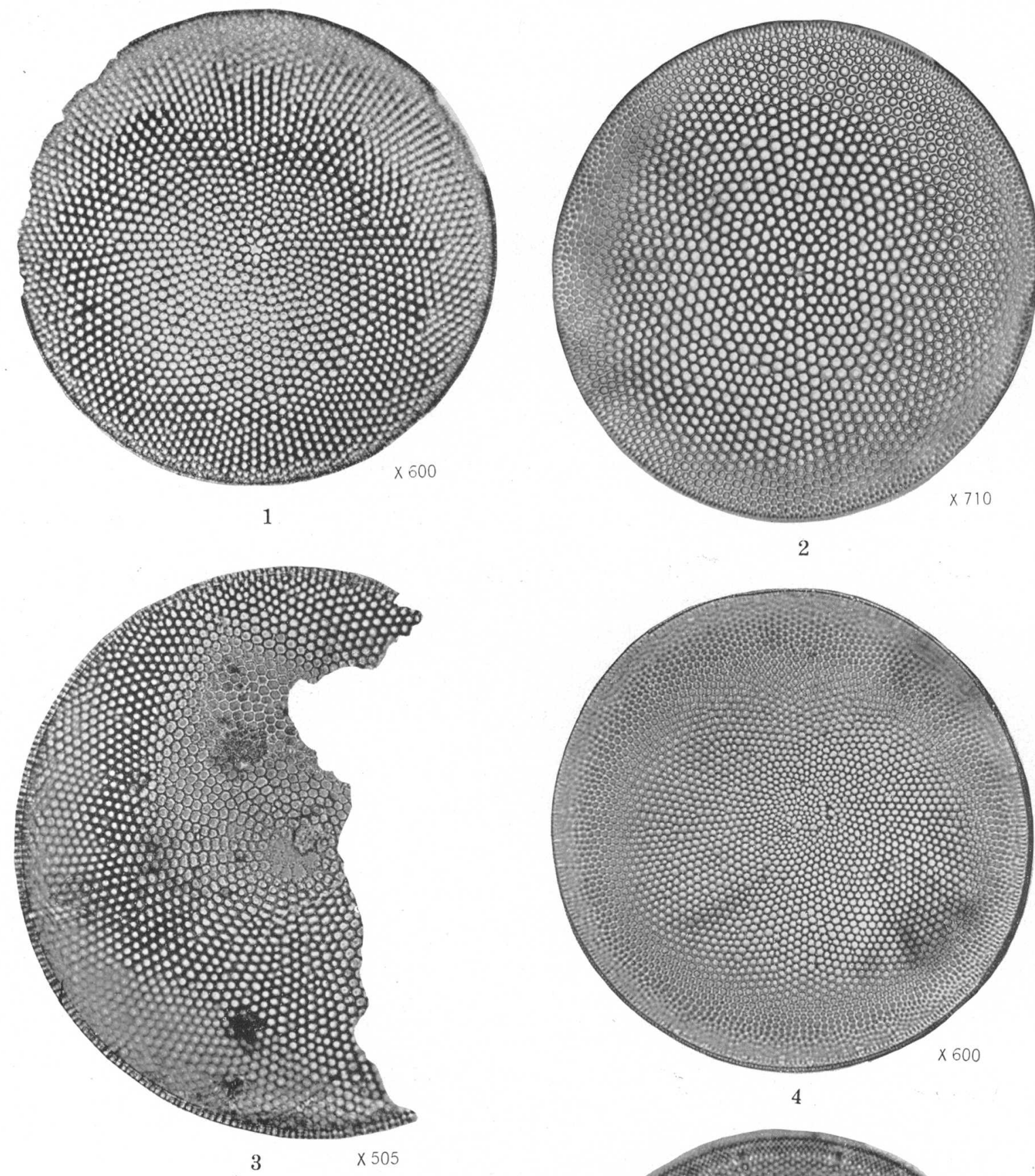

4

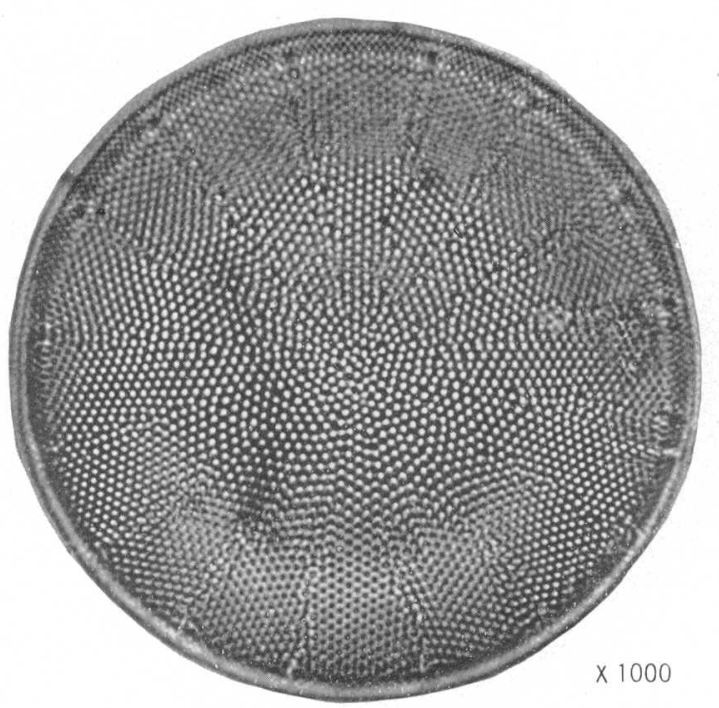


PLATE 23

Frgure 1. Actinocyclus ehrenbergii Ralfs. Diameter $0.063 \mathrm{~mm}$. Locality 173 , Neverita zone. U. S. G. S. diatom catalog No. 1630-4.

2. Stephanopyxis corona (Ehrenberg) Grunow. Diameter $0.037 \mathrm{~mm}$. Locality 168, Neverita zone. U. S. G. S. diatom catalog No. 1524-6.

3. Actinoptychus undulatus Ehrenberg. Diameter 0.065. Locality 168, Neverita zone. U. S. G. S. diatom. catalog No. 1524-4.

4. Epithemia turgida (Ehrenberg) Kützing. Length $0.091 \mathrm{~mm}$., width $0.019 \mathrm{~mm}$. Locality 168, Neverita zone. U. S. G. S. diatom catalog No. 1524-8.

5. Rhaphoneis fatula Lohman. Holotype. Length $0.046 \mathrm{~mm}$., width $0.008 \mathrm{~mm}$. Locality 143a, clay underlying tuffaceous sandstone, between Pecten and Neverita zones. U. S. G. S. diatom catalog No. 1508-3.

6-8. Rhaphoneis angularis Lohman. Locality 168, Neverita zone.

6. Holotype. Length $0.142 \mathrm{~mm}$., width $0.020 \mathrm{~mm}$. U. S. G. S. diatom catalog No. 1524-1.

7. Paratype. Length $0.119 \mathrm{~mm}$., width $0.020 \mathrm{~mm}$. U. S. G. S. diatom catalog No. 1524-2.

8. Paratype. Length $0.066 \mathrm{~mm}$., width $0.020 \mathrm{~mm}$. U. S. G. S. diatom catalog No. $1524-3$.

9. Hemidiscus ovalis Lohman. Holotype. Length $0.028 \mathrm{~mm}$., width $0.021 \mathrm{~mm}$. Locality 143a, clay underlying tuffaceous sandstone, between Pecten and Neverita zones. U. S. G. S. diatom catalog No. 1508-1.

10. Nitzschia granulata Grunow. Length $0.038 \mathrm{~mm}$., width $0.016 \mathrm{~mm}$. Locality 143 , tuffaceous sandstone, between Pecten and Neverita zones. U. S. G. S. diatom catalog No. 1522-1.

11. Nitzschia navicularis Grunow. Length $0.033 \mathrm{~mm}$., width $0.012 \mathrm{~mm}$. Locality 168 , Neverita zone. U. S. G. S. diatom catalog No. 1524-9.

12. Xanthiopyxis ovalis Lohman. Holotype, Length $0.021 \mathrm{~mm}$., width $0.015 \mathrm{~mm}$. Locality 168, Neverita zone. U. S. G. S. diatom catalog No. 1517-1.

13, 14. Melosira recedens Schmidt. Locality 143, tuffaceous sandstone, between Pecten and Neverita zones.

13. Valve view. Diameter $0.017 \mathrm{~mm}$. U. S. G. S. diatom catalog No. 1522-3.

14. Zone view, four frustules and two valves. Diameter $0.011 \mathrm{~mm}$., length over all $0.032 \mathrm{~mm}$. U. S. G. S. diatom catalog No. 1522-2.

15. Melosira sulcata (Ehrenberg) Kützing. Diameter $0.023 \mathrm{~mm}$. Locality 168 , Neverita zone. U. S. G. S. diatom catalog No. 1524-5.

16. Navicula pennata Schmidt. Length $0.090 \mathrm{~mm}$., width $0.017 \mathrm{~mm}$. Locality 144 , tuffaceous sandstone, between Peclen and Neverita zones. U. S. G. S. diatom catalog No. 1507-2. 

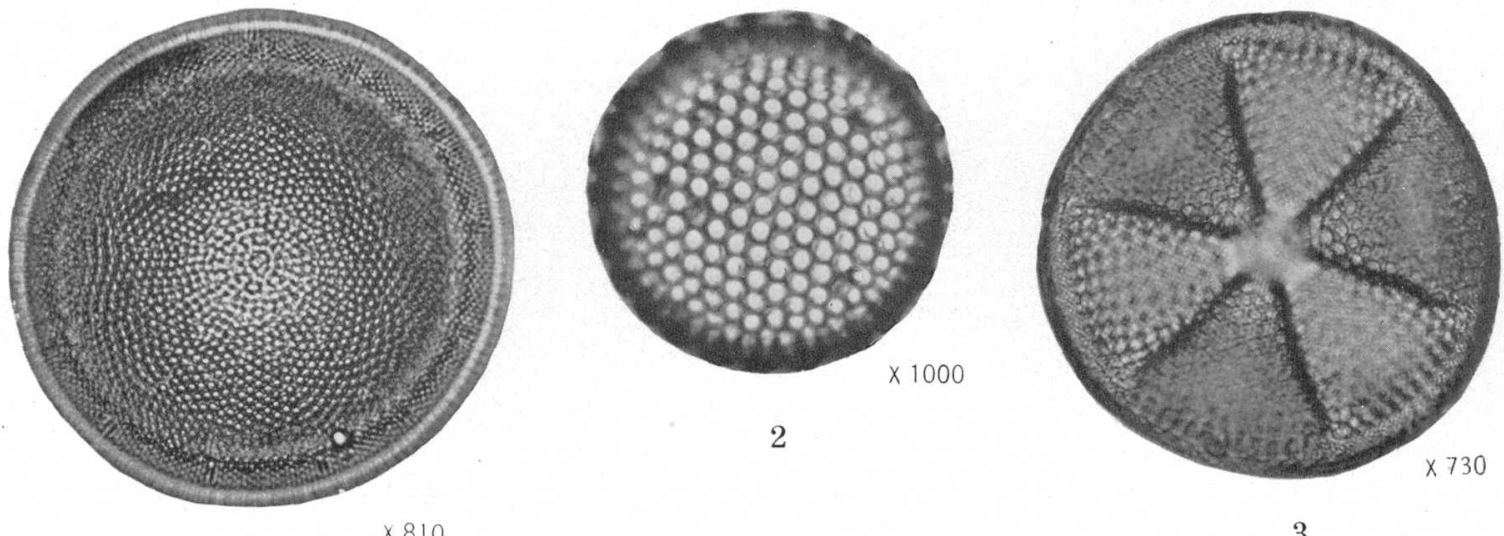

1

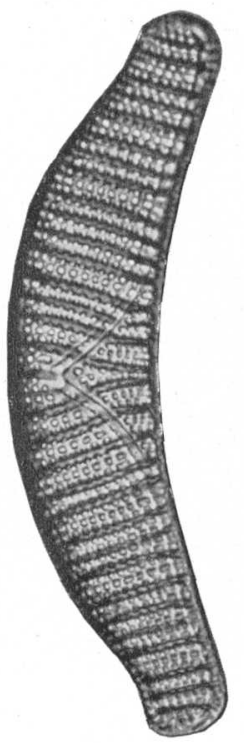

$4 \times 810$

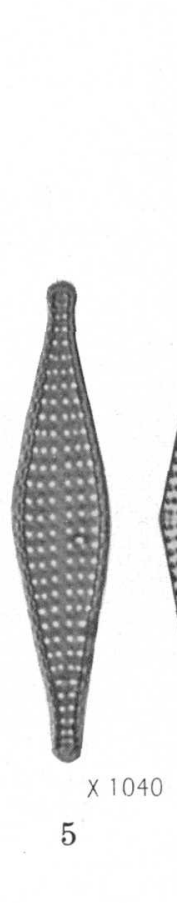

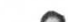

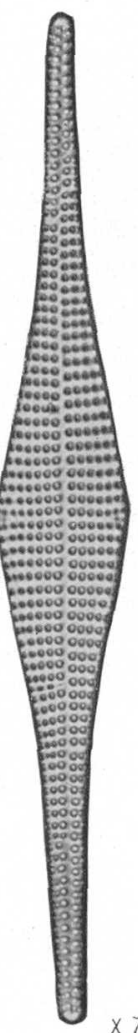

6

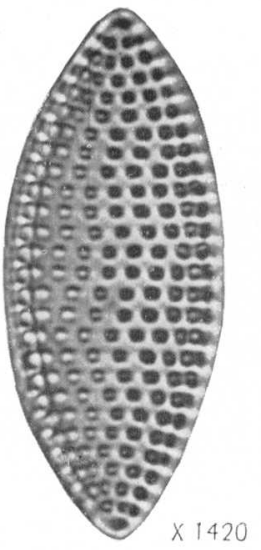

10

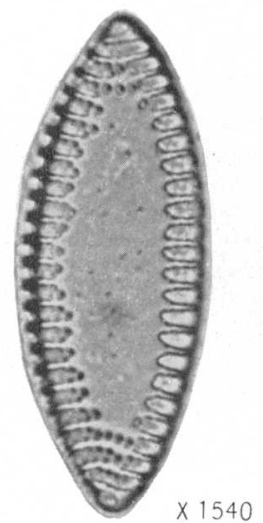

11
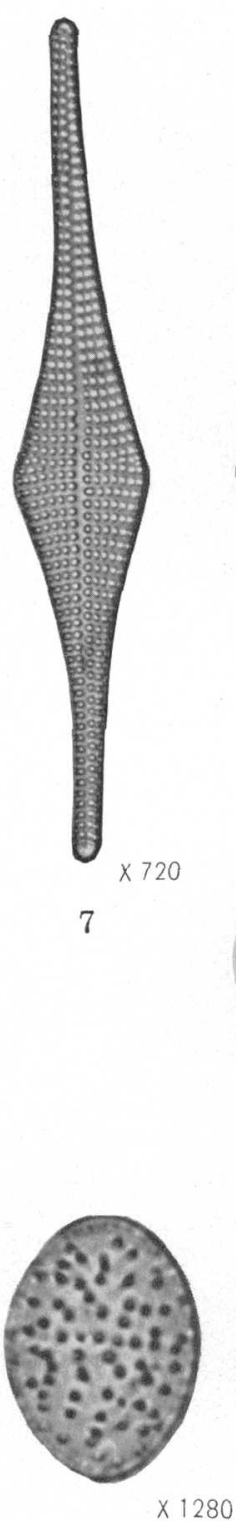

12
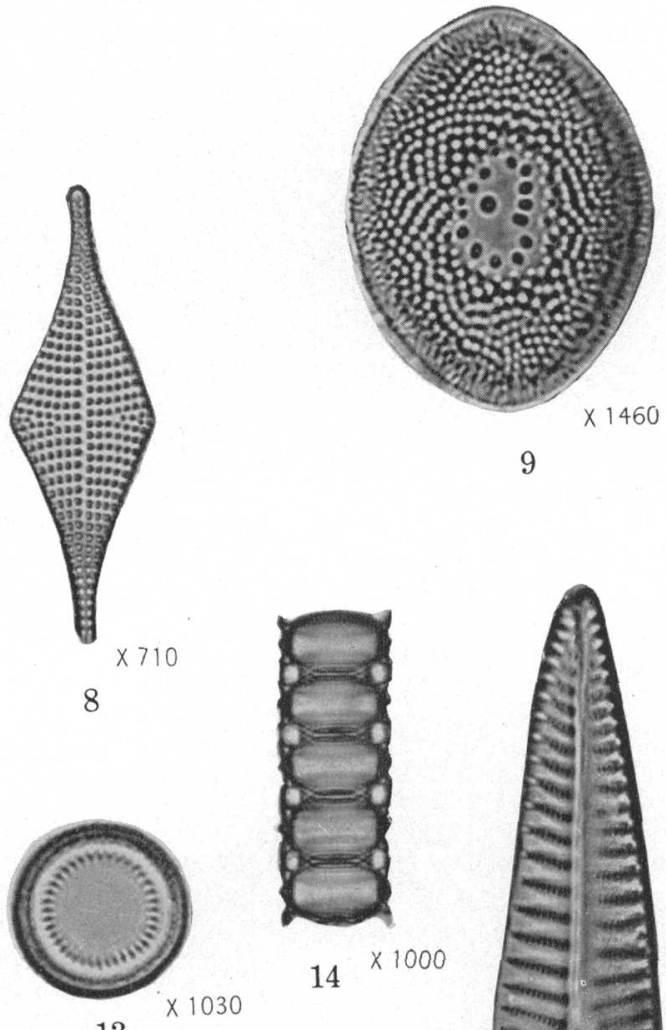

14

$\times 1000$

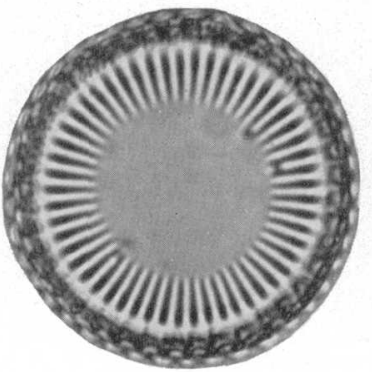

15
3

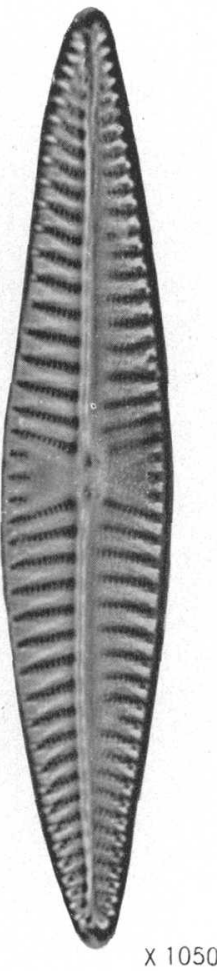

16 


\section{PLATE 24}

[Figures natural size unless otherwise designated]

Figure 1. Solen perrini Clark. Length (incomplete) $57 \mathrm{~mm}$., height $21 \mathrm{~mm}$., thickness $7.3 \cdot \mathrm{mm}$. I.ocality 175 , upper oolite of San Joaquin formation. U. S. Nat. Mus. 495338.

2. Mya cf. $M$. dickersoni Clark. Length $74.5 \mathrm{~mm}$., height $47 \mathrm{~mm}$., thickness (not including clırondophore) $14 \mathrm{~mm}$. Locality 175, upper oolite of San Joaquin formation. U. S. Nat. Mus. 495339.

3. Macoma affinis plena Stewart, n. var. Length $36.4 \mathrm{~mm}$., height $30 \mathrm{~mm}$., thickness $8 \mathrm{~mm}$. Locality 175, upper oolite of San Joaquin formation. U. S. Nat. Mus. 495340.

4-6. Psephidia n. sp.? Locality 175, upper oolite of San Joaquin formation.

4. Length $3.9 \mathrm{~mm}$., height $4 \mathrm{~mm}$., thickness of both valves $2.4 \mathrm{~mm}$. U. S. Nat. Mus. 495341 .

5. Specimen partly covered with oolitic coat. Length $3.1 \mathrm{~mm}$., height $3.1 \mathrm{~mm}$., thickness of both valves $1.8 \mathrm{~mm}$. U. S. Nat. Mus. 495342.

6. Length $2.6 \mathrm{~mm}$., height $2.5 \mathrm{~mm}$., thickness $0.9 \mathrm{~mm}$. U. S. Nat. Mus. 495343.

7. Anadara trilineata (Conrad) of Arnold, var. cf. canalis (Conrad). Length $55.5 \mathrm{~mm}$., height $44.5 \mathrm{~mm}$., thickness $18 \mathrm{~mm}$. Locality 178, Cerastoderma-bearing sandstone of San Joaquin formation. U. S. Nat. Mus. 495344.

8, 9. Cerastoderma ef. C. meekianum (Gebb). Length $57.6 \mathrm{~mm}$., height $59.6 \mathrm{~mm}$., thickness about $22.5 \mathrm{~mm}$. Locality 178 , Cerastoderma-bearing sandstone of San Joaquin formation. U. S. Nat. Mus. 495345.

10-13. Aequipecten circularis eldridgei (Arnold). Locality 214, Cascajo conglomerate member of San Joaquin formation.

10. Length $18.4 \mathrm{~mm}$, height $19.9 \mathrm{~mm}$., thickness $5.3 \mathrm{~mm}$. U. S. Nat. Mus. 495346.

11. Length $14.9 \mathrm{~mm}$., height $16.6 \mathrm{~mm}$., thickness $3.7 \mathrm{~mm}$. U. S. Nat. Mus. 495347.

12. Length $9.3 \mathrm{~mm}$., height $9.6 \mathrm{~mm}$., thickness $2.5 \mathrm{~mm}$. U. S. Nat. Mus. 495348.

13. Length $17.8 \mathrm{~mm}$., height $18.1 \mathrm{~mm}$., thickness $5.7 \mathrm{~mm}$. U. S. Nat. Mus. 495349.

14, 15. Pseudocardium densatum (Conrad) of Arnold, vars. Locality 203, Cascajo conglomerate member of San Joaquin formation.

14. Right valve. Length $33.2 \mathrm{~mm}$., height (almost complete) $32 \mathrm{~mm}$., thickness $13 \mathrm{~mm}$. U. S. Nat. Mus. 495350 .

15. Right valve. Length $40 \mathrm{~mm}$., height $30 \mathrm{~mm}$., thickness $12.8 \mathrm{~mm}$. U. S. Nat. Mus. 495351 .

16-18. Nucella etchegoinensis (Arnold). Cascajo conglomerate member of San Joaquin formation.

16. Height (incomplete) $38.7 \mathrm{~mm}$., width $26 \mathrm{~mm}$. Locality 209 . U. S. Nat. Mus. 495352.

17. Height (incomplete) $52 \mathrm{~mm}$., width $28.6 \mathrm{~mm}$. Locality $204 . \quad$ U. S. Nat. Mus. 495353.

18. Height (incomplete) $43 \mathrm{~mm}$., width $25 \mathrm{~mm}$. Locality $203 . \quad$ U. S. Nat. Mus. 495354.

19, 20. Pseudocardium densatum (Conrad) of Arnold, medium-sized var. Pseudocardium-Anadara zone of Etchegoin formation.

19. Right valve. Length $46 \mathrm{~mm}$., height $38.7 \mathrm{~mm}$., thickness $17.5 \mathrm{~mm}$. Locality 345 . U. S. Nat. Mus. 495355.

20. Right valve. Length $40.9 \mathrm{~mm}$., height $34.8 \mathrm{~mm}$., thickness $15 \mathrm{~mm}$. Locslity 344 . U. S. Nat. Mus. 495356.

21. Mya cf. M. dickersoni Clark. Length (almost complete) $62 \mathrm{~mm}$., height (incomplete and somewhat crushed) $32.3 \mathrm{~mm}$., thickness (not including chondrophore) $10 \mathrm{~mm}$. Locality 346. Pseudocardium-Anadara zone of Etchegoin formation. U. S. Nat. Mus. 495357. 


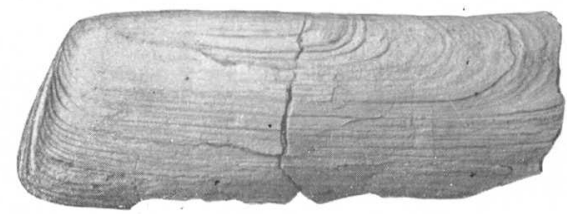

1

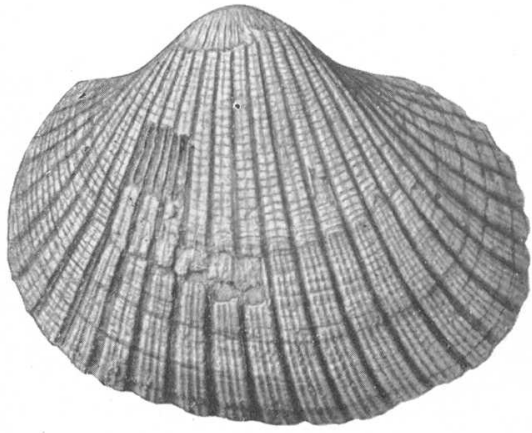

7

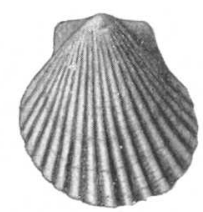

10

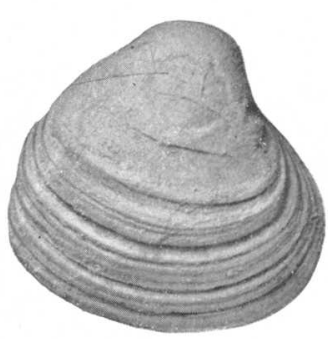

14
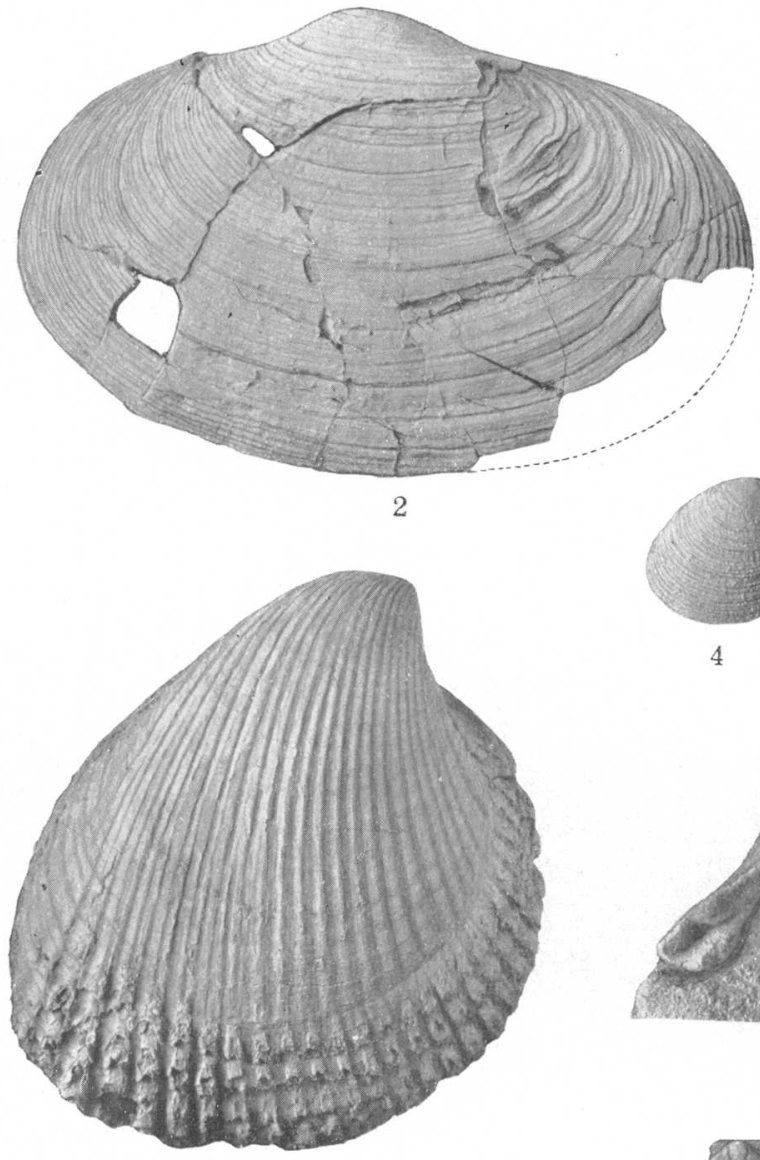

8
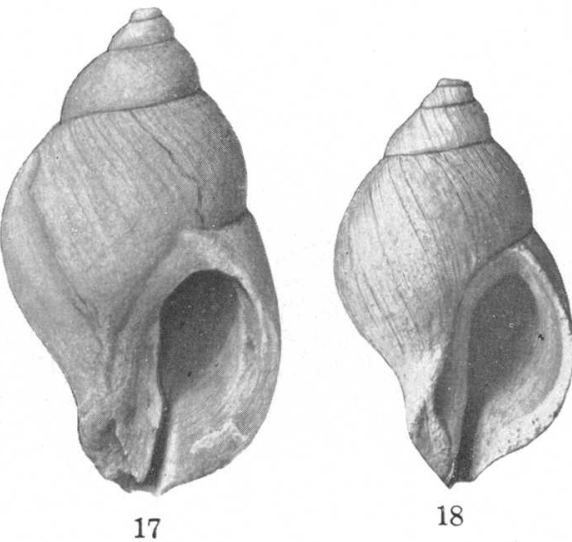

18
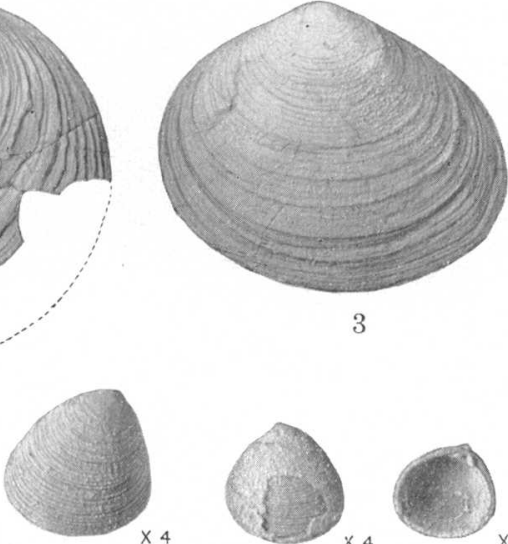

3
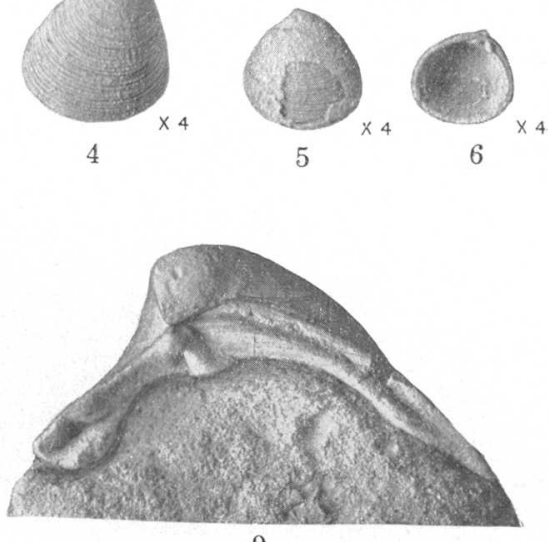

9

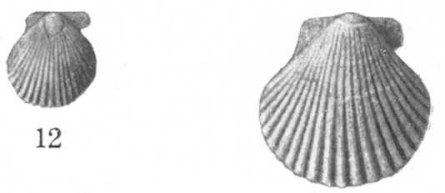

13
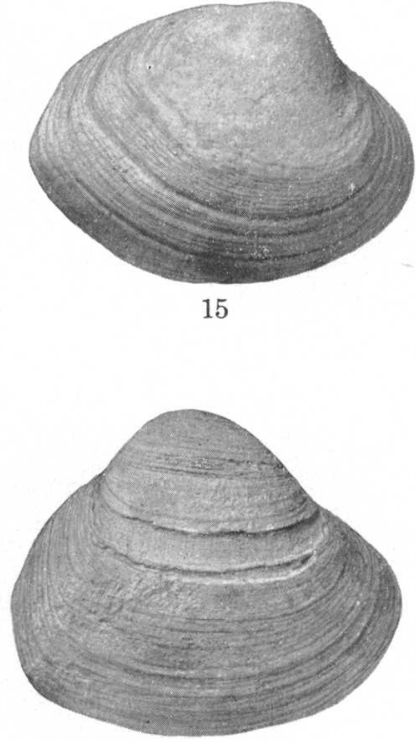

20

19

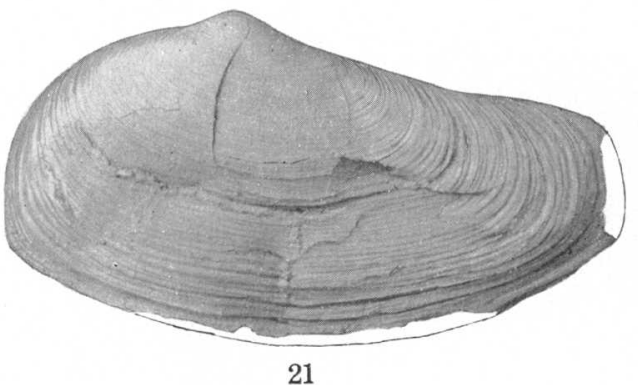

FOSSILS FROM LOWER PART OF SAN JOAQUIN FORMATION AND UPPER PART OF ETCHEGOIN FORMATION. 


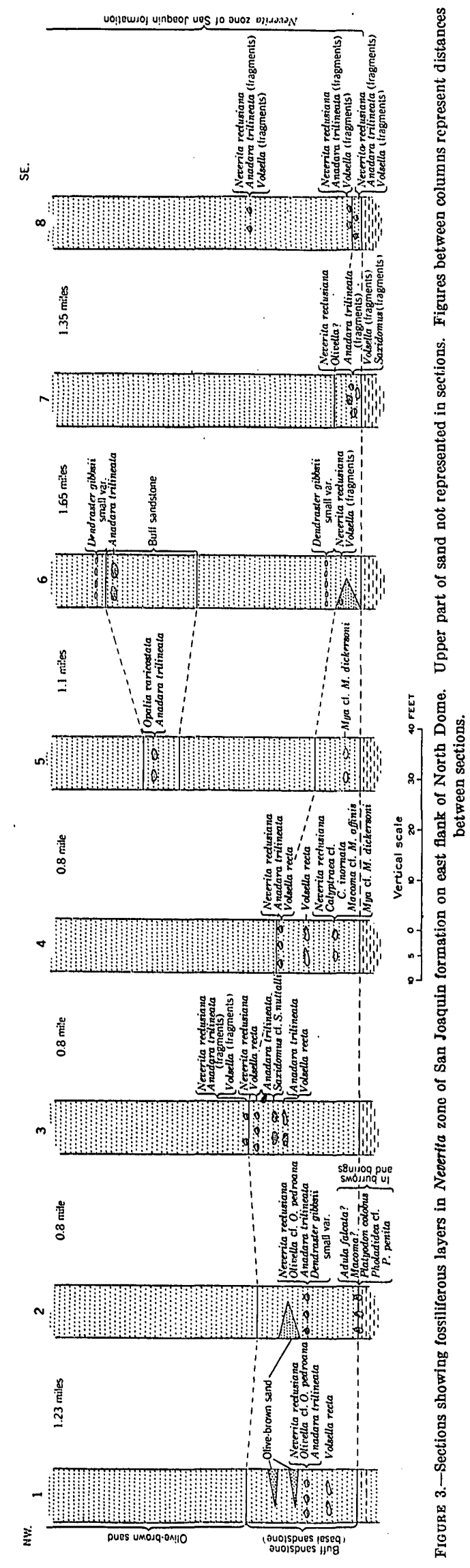

According to Bramlette, the greater percentage of heavy minerals in the sand and the greater abundance of the "zeolitic" mineral in the sandstone constitute the principal differences in mineral composition. Both kinds of rock contain pyroclastic debris of the composition of augite andesite and hornblende andesite, though volcanic glass was not recognized in either. The "zeolitic" mineral is probably an alteration product of glass and appears to be one of the heulanditeclinoptilolite group. The matrix of the sandstone consists of a feltlike mass of this mineral in fine crystals about 0.02 millimeter long. This mineral gives the sandstone the dirty appearance that in the field was attributed to silt and clay. It also serves as a binder for the sand grains.

North Dome.-On the east flank of North Dome a fossiliferous sandstone, designated the basal sandstone, generally lies at the base of the Neverita zone. (See fig. 3.) The basal sandstone has an observed thickness of 5 to 25 feet. It contains one or more layers of fossils, a Neverita layer in the upper part generally being the most conspicuous. The basal sandstone rests on clay or silty sandstone. Where the base is well exposed the contact is sharp and slightly irregular. At several localities burrowing and boring fossils were found in living positions penetrating the underlying stratum (fig. 3 , column 2 ).

On the ridge southeast of Arroyo Torcido a lens of coarse-grained cross-bedded blue sandstone that rapidly thickens to 15 feet appears in the basal sandstone, as shown in figure 4. The blue sandstone fills channels 5 feet deep.

Across Arroyo Doblegado and nearby the basal sandstone is absent, but a similar fossiliferous sandstone, in which Neverita was not found, occurs at a horizon 30 feet or more above the base of the Neverita zone (fig. 3, columns 5, 6). Farther southeast the basal sandstone again appears (fig. 3, columns 7,8). Toward the south end of the anticline exposures are poor in the area where the zone would be expected to occur, and the zone was not recognized.

On the west flank of North Dome the basal sandstone has generally only one layer of fossils, a Neverita layer. (See fig. 5.) The layer is near the base of the sandstone except at the north end of the anticline, where it is near the top. The basal sandstone and the lower part of the overlying sand are well exposed on the two little buttes in the soutbeastern part of sec. 33, T. 21 S., R. 17 E. (fig. 5, column 2), and on the east side of the branch of Arroyo Largo in the western part of sec. 3, T. 22 S., R. 17 E. (pl. 18, B; fig. 5, column 3). The section below was measured at the latter locality. 


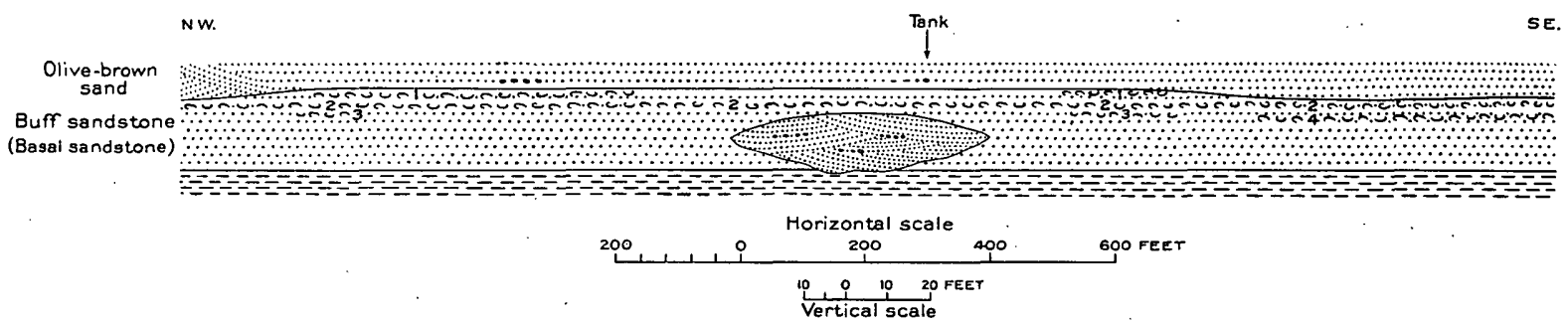

FIGURE 4.-Lower part of Neverita zone of San Joaquin formation on ridge southeast of Arroyo Torcido, southwestern part of sec. 6 , T. 22 S., R. 18 E. Nos. 1 to 4 indicate fossiliferous layers. The broad shallow channels at the top of the basal sandstone were not observed but are based on the position of the base of the overlying sand with reference to fossiliferous layers in the basal sandstone.

NW.

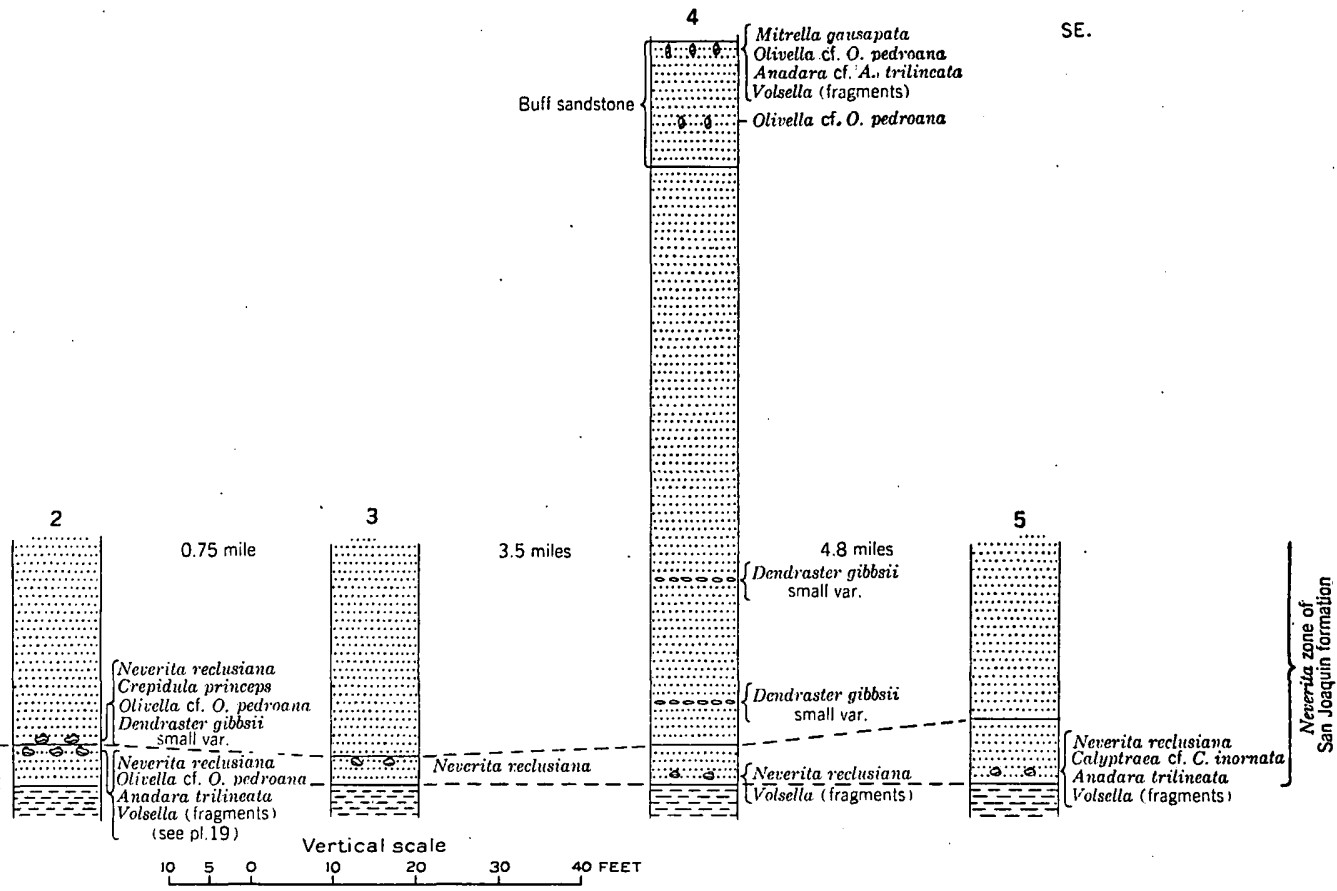

FIGURE 5.-Sections showing fossiliferous layers in Neverita zone of San Joaquin formation on west flank of North Dome. Full thickness of sand represented only In column 4. Figures between columns represent distances between sections.

1. Branch of Arroyo Vadosa, northeastern part of sec. 33, T. 21 S., R. 17 E.

2. Butte in southeastern part of sec. 33, T. 21 S., R. 17 E. (localities 163, 163a).

3. Branch of Arroyo Largo, western part of sec. 3, T. 22 S., R. $17 \mathrm{E}$

4. Branch of Arroyo Mellado near north line of sec. 24, T. 22 S., R. 17 E. (localities 164, 164a, 165).

5. Southern part of sec. 34, T. 22 S., R. 18 E.

Neverita zone of San Joaquin formation and underlying strata at head of branch of Arroyo Largo in western part of sec. 3, T. - Q2 S., R. 17 E.

Neverita zone:

6. Coarse-grained cross-bedded olive-brown sand; base sharply defined. Only few feet at base clearly exposed; total thickness estimated.

5. Medium-grained poorly sorted apparently dirty, cliff-making buff sandstone (basal sandstone). Contains few scattered Neverita 6 inches to a foot below top. Small pebbles having a maximum length of half an inch and consisting principally of black chert abundant in lower half. Rests with sharp irregular contact on underlying bed. Pebbles or pellets several inches long of silt like that in underlying bed at contact. Borings filled with sand and pebbles extend down from contact; cross sections of borings as much as 10 inches below contact....
Ft.

in.

(String

Strata underlying Neverita zone:

4. Gray silt and fine-grained silty sand ........

3. Very coarse grained, pebbly cross bedded olive-brown sand, silty partings in upper part. Channels and sand-filled borings 2 inches long extend down from sharp irregular contact at base................

2. Greenish-gray silt and fine silty sand.......

1. Moderately coarse grained, cross-bedded, olive-brown sand. Base not exposed; underlain by clay and silt farther down arroyo.

Ft. in.

6

18

$3+$

The basal sandstone seems to be absent for a distance of $1 \frac{1}{2}$ miles northwestward from Arroyo Delgado, opposite the region on the east side of the anticline where it is missing. At the south end of the anticline the zone is not well exposed. It can be recognized, 3 
tered clusters of Neverita, accompanied at a few places by Anadara, both apparently weathered out of the basal sandstone.

At the north end of the anticline a buff sandstone, similar to the basal sandstone and containing Neverita, is exposed for a short distance at the head of the arroyo northeast of the center of sec. 33, T. 21 S., R. 17 E., at a horizon 15 feet above the basal sandstone (fig. 5, column 1). On Arroyo Mellado and its first tributary to the southeast a fossiliferous buff sandstone lies at the very top of the zone, 70 feet above the basal sandstone (fig. 5, column 4).

Middle Dome.-On the east side of the North DomeMiddle Dome saddle the Neverita zone consists of a basal sandstone 2 to 3 feet thick overlain by sand. The basal sandstone contains a Neverita layer near the top. Between Arroyo Conejo and the branch of Arroyo Culebrino in the northeastern part of sec. 19, T. 23 S., R. 19 E., the zone was not recognized. Farther south the zone forms a narrow band of sandy soil containing scattered Neverita and other fossils. At locality 168, in sec. 33 , T. 23 S., R. 19 E., corresponding to a stratigraphic position 25 feet above the base of the zone, diatomaceous white silty clay was collected from debris at the mouths of rodent burrows. This material presumably represents thin layers in the sand but was not seen in outcrop.

On the west flank of Middle Dome fossils occur in a sandstone at the base of the zone that resembles the buff sandstone of North Dome or is light gray, coarsergrained, cleaner, and lime-cemented. At locality 171, in sec. 24 , T. 23 , S., R. 18 E., the specimens of Neverita are in better condition than at any other locality representing the zone. For a distance of $1 \frac{1}{2}$ miles south of the nortbern part of sec. 25 , T. 23 S., R. 18 E., a coarsegrained, poorly sorted, ferruginous, nonfossiliferous sandstone that forms a narrow band of sandy soil was identified as the Neverita zone. The zone was not recognized in Pepper Grass Valley. Farther south a band of sandy soil, on which specimens of Neverita were found in the southern part of sec. 5, T. 24 S., R. 19 E., was mapped as the Neverita zone. Southward from sec. 25, T. 23 S., R. 18 E., the sandy soil contains angular chips and pebbles of white siliceous shale, presumably derived from the Miocene McLure shale member of the Monterey shale of Reef Ridge: At locality 173, in sec. 8, T. 24 S., R. 19 E., diatomaceous white silty clay was collected from rodent-burrow debris at a position corresponding to a horizon 10 feet above the base of the zone. In this region the zone is about 30 feet thick, unless the dip is steeper than supposed. The zone was not identified in the area of meager exposures at the south end of the anticline.

South Dome.-A sand about 20 feet thick, forming a band of sandy soil around the north end of South Dome, may represent the Neverita zone. It is at about the horizon of the zone, but no fossils were found other than diatoms in rodent-burrow debris, a feature in which this sand resembles sand in the Neverita zone of southern Middle Dome.

\section{FossiLs}

Fossils from the Neverita zone are listed in the following table. The characteristic and abundant species are shown on plates 19-21.

The fauna of the Neverita zone consists of marine forms. The modern analogs of some of the species, however, live also in brackish water.

A Neverita layer in the basal sandstone, in which Neverita reclusiana (pl. 20, figs. 1-5), Olivella cf. $O$. pedroana (pl. 20, figs. 8, 9), Anadara trilineata (pl. 20, figs. 15-17), and Volsella cf. V. recta (pl. 20, figs. 13, 14) are the most abundant fossils, contains the most characteristic and widespread faunal association. This association is shown on plate 19 , a photograph of a slab of limy sandstone from the Neverita layer in the basal sandstone at locality 163 . All these species occur in the Pecten zone but not in the same limited faunal association. At places this association occurs in the sand overlying the basal sandstone. Platyodon colobus (pl. 21, figs. 1,2) is the only species of the zone that was not found at other horizons. A Volsella layer, a Saxidomus-Anadara layer, a Mya-Calyptraea layer, and a Mya layer occur also at places in the basal sandstone. The Mya layer, which may represent brackish water, occurs at or near the base of the zone.

The species in sandstones above the basal sandstone occur also in the basal sandstone, except Opalia varicostata.

Sand dollars are more abundant in the sand than in the sandstone. The most common form is a small variety of Dendraster gibbsii (pl. 20, figs. 10, 11; pl. 21, figs. 3-6). No form of $D$. gibbsii has been recognized at higher horizons. 


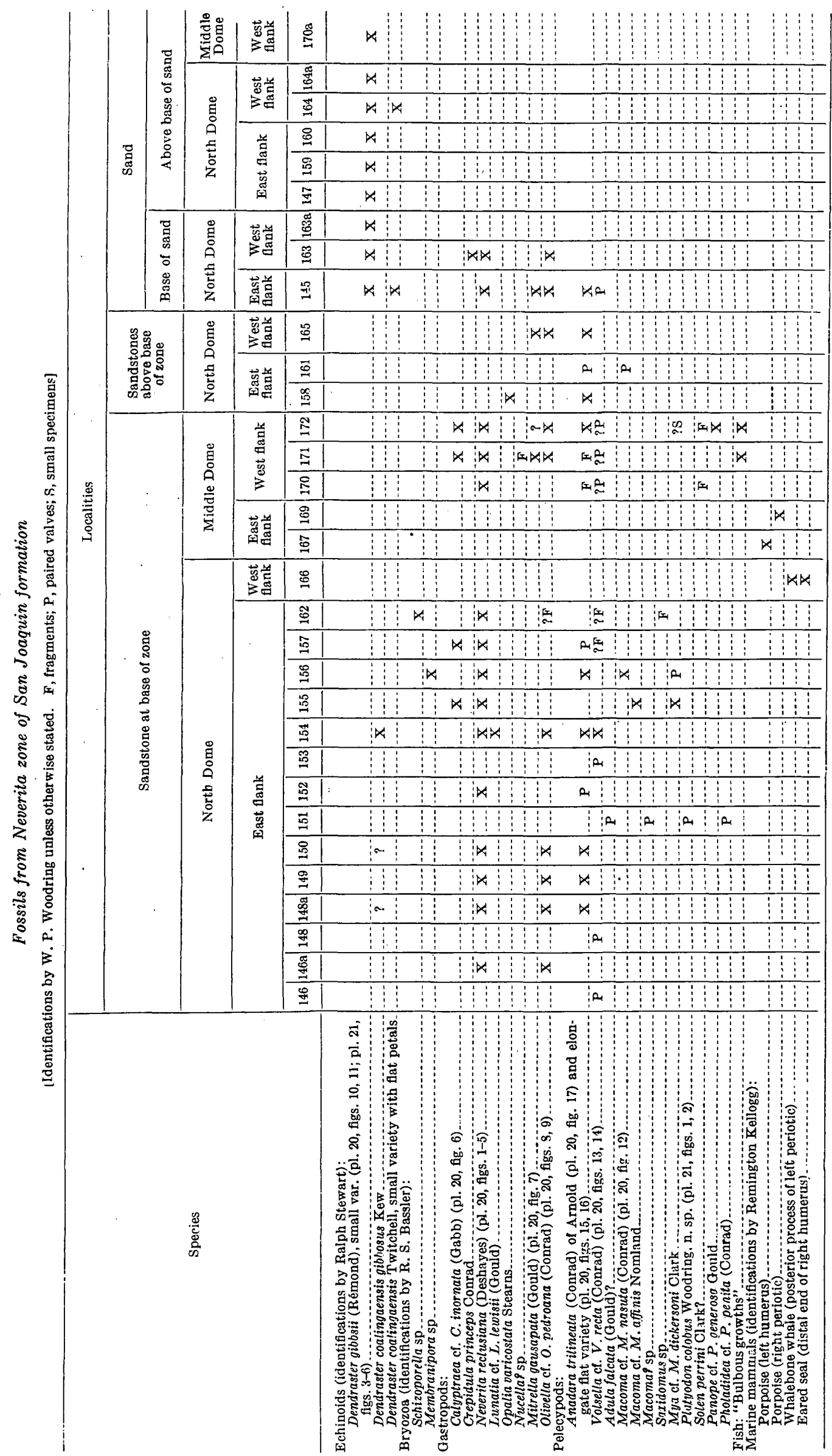


Diatoms identified by K. E. Lohman from material collected in southern Middle Dome are listed in the following table. Lohman states that the flora is

dominantly marine but includes a few fresh-water and brackish-water forms. The characteristic species of this flora are shown on plates 22 and 23 .

Diatoms from Neverita zone of San Joaquin formation in Middle Dome

[Identiflcations by K. E. Lohman. R, rare; F, few; C, common; A, abundant]

\begin{tabular}{|c|c|c|}
\hline Species & East flank & West flank \\
\hline 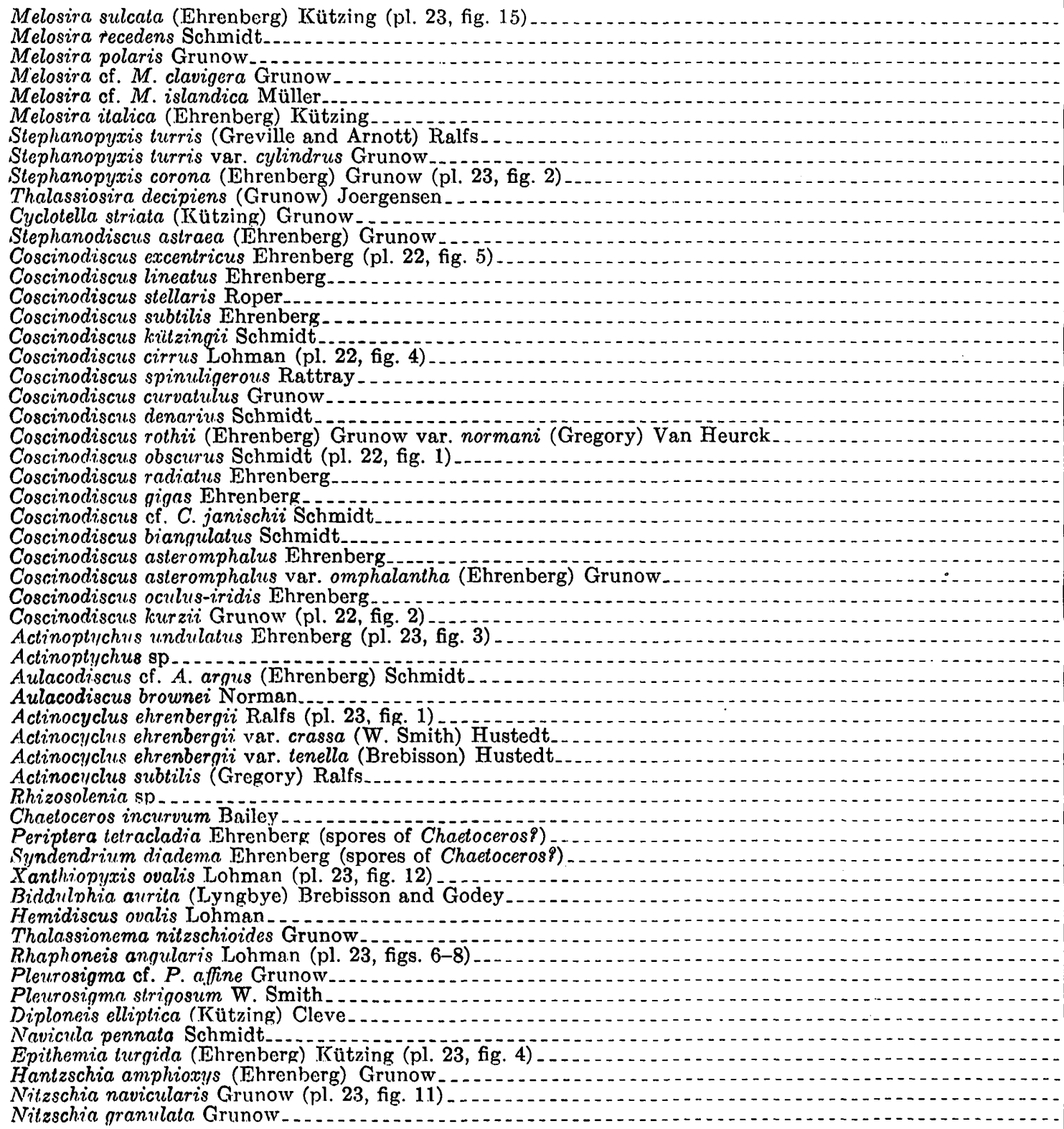 & $\begin{array}{l}\mathrm{F} \\
\mathrm{R} \\
\mathrm{R} \\
\mathrm{R} \\
\mathrm{R} \\
\mathrm{R} \\
\mathrm{F} \\
\mathrm{F} \\
\mathrm{R} \\
\mathrm{R} \\
\mathrm{C} \\
\mathrm{F} \\
\mathrm{R} \\
\mathrm{F} \\
\mathrm{C} \\
\mathrm{F}\end{array}$ & \begin{tabular}{l}
$\mathrm{C}$ \\
$\mathrm{F}$ \\
$\mathrm{R}$ \\
$\mathrm{R}$ \\
$\mathrm{F}$ \\
$\mathrm{F}$ \\
$\mathrm{C}$ \\
$\mathrm{F}$ \\
$\mathrm{F}$ \\
$\mathrm{F}$ \\
$\mathrm{C}$ \\
$\mathrm{R}$ \\
$\mathrm{F}$ \\
$\mathrm{F}$ \\
$\mathrm{C}$ \\
$\mathrm{R}$ \\
$\mathrm{C}$ \\
$\mathrm{C}$ \\
$\mathrm{F}$ \\
$\mathrm{F}$ \\
$\mathrm{A}$ \\
\hdashline $\mathrm{R}$ \\
$\mathrm{F}$ \\
$\mathrm{F}$ \\
$\mathrm{C}$ \\
$\mathrm{R}$ \\
$\mathrm{F}$ \\
$\mathrm{R}$ \\
$\mathrm{F}$ \\
$\mathrm{F}$ \\
$\mathrm{F}$ \\
$\mathrm{F}$ \\
$\mathrm{F}$ \\
$\mathrm{F}$ \\
$\mathrm{R}$ \\
\end{tabular} \\
\hline
\end{tabular}

GTRATA BETWEEN NEVERITA ZONE AND CASCAJO CONGLOMERATE MEMBER

BTRATIGRAPHY AND LITHOLOGY

The strata between the Neverita zone and the Cascajo conglomerate, consisting chiefly of silt, sand, sandstone, and clay, have a thickness of 200 to 425 feet. Thin beds of tuff and oolite are minor but conspicuous constituents.

At scattered localities on both flanks of North Dome a Mya layer is about 20 feet below the Neverita zone. In North Dome it is convenient to number the Mya layers near the base of the San Joaquin formation and 
near the top of the Etchegoin formation in their stratigraphic order above the Littorina zone of the Etchegoin-the most reliable stratigraphic datum plane. This Mya layer near the base of the Neverita zone is, accordingly, designated the fourth $M y a$ layer above the Littorina zone. (See North Dome stratigraphic column; pl. 3, and fig. 6.) At the south end of North Dome a tuff is in the same stratigraphic position. At places Mya molds occur at the base of the tuff or immediately below it. The tuff is light-colored and is 2 or 3 feet thick. According to M. N. Bramlette, it consists principally of fresh glass and contains a little andesine, hornblende, and augite. Near the plunging crest of the anticline the tuff is more readily traced than the Neverita zone.

Along the west flank of northern North Dome from La Cumbre (sec. 10, T. 22 S., R. 17 E.) southward to a branch of Arroyo Chico in sec. 13, T. 22 S., R. 17 E., another Mya layer-the third $M y a$ layer above the Littorina zone-lies 150 to 175 feet below the Neverita zone. At places it is overlain by blue sandstone. At scattered localities on the east flank of the anticline northward from a branch of Arroyo Doblegado a Mya layer at a horizon about 100 feet below the Neverita zone is correlated with the third Mya layer on the opposite flank.

The following section of strata between the Neverita zone and a blue sandstone doubtfully identified as the Cascajo conglomerate, somewhat generalized owing to incomplete exposures, was measured in a road cut near the southwest corner of sec. 6 , 'T. 22 S., R. 18 E.

Section of strata in lower part of San Joaquin formation between Neverita zone and Cascajo conglomerate member (8) in road cut near southwest corner of sec. 6, T. 22 S., R. $18 \mathrm{E}$.

Neverita zone.

Sandy silt, including lens of blue sandstone at base..... -

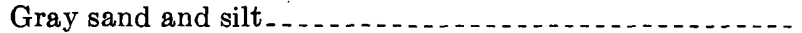

Green clay and silt. Probably includes equivalent of third Mya layer above Littorina zone of Etchegoin formation

Brown sand and grit with some pebbles and thin layers of

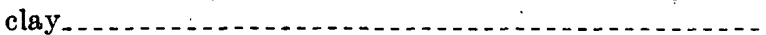

Alternating brown sand and silt. ... . . . . . . . . . . .

Cascajo conglomerate member (?). Coarse-grained cross-

bedded blue sandstone with layers of pebbles........

Thickness of strata between Neverita zone and Cascajo conglomerate (?)

Feet

50

35 .

15

30

60

20

A thin bed of oolite crossing Arroyo Robador in sec. 22, T. 22 S., R. 18 E., and extending southward for a distance of half a mile, is the essential equivalent of the third Mya layer, for it also is about 100 feet below the Neverita zone. This oolite is designated the upper oolite to distinguish it from the oolite in the Littorina zone of the Etchegoin formation. It has a thickness of 4 or 5 feet and consists of oolites, shell fragments, and shells. The oolites are made up of sand grains and also apparently of bits of clay coated with calcareous layers of varying thickness. Many of the sand grains forming the cores have angular edges, but the oolites are subspherical or subelliptical. Mya is the most common fossil. Farther south on the east slope of Broken Hill and on the east side of North Dome-Middle Dome saddle oolite containing broken Mya shells is correlated with the oolite on Arroyo Robador.

An oolite in Middle Dome is also correlated with the upper oolite on Arroyo Robador. On the east flank of the anticline, where the section is relatively thin, the oolite is about 60 feet below the Neverita zone. Between Arroyo Culebrino and the foot of Parejo Hill the apparent equivalent of the oolite is a buff silt containing fragments of Mya. Oolites are progressively more abundant southward from the fault at the south end of Parejo Hill, and in sec. 33, T. 23 S., R. 19 E., the bed of oolite is well developed, though it also contains uncoated sand grains. At a locality on the west slope of the ridge in sec. 33 blocks of oolite are embedded in the soil at three levels, possibly owing to slumping. Southward from the south line of T. 23 the oolite bed is replaced by nonfossiliferous buff silt and clay.

On the west flank of Middle Dome oolite was observed at the north end of the anticline in the northern part of sec. 13, T. 23 S., R. 18 E. It seems to grade southward into Mya-bearing silty clay, which is about 150 feet below the Neverita zone. South of Arroyo Culebrino the equivalent of the $M y a$-bearing clay appears to be included in nonfossiliferous clay that forms a prominent strike ridge. On weathered exposures this clay is buff, but in fresh exposures at least part of it is olive gray. It is about 200 feet below the Neverita zone and is considered the essential equivalent of the oolite on the east flank that is only 60 feet below the Neverita zone. The entire San Joaquin formation thins across the anticline, but no other part of the formation thins so much.

On a branch of Arroyo Hondo (locality 177) and on a branch of Arroyo Doblegado (locality 178) - both on the east flank of North Dome-a sandstone containing large specimens of Cerastoderma is exposed about 60 feet below the Mya layer that is correlated with the third Mya layer. At locality 177 the fossils are in a 4-inch lens of hard pebbly sandstone in soft gray dirty sandstone. At locality 178 they also occur in a hard layer in soft olive-brown sandstone. In the east fork of Arroyo del Camino-on the west flank of North Domeabout 50 feet below the third Mya layer is a pebbly sandstone containing Cerastoderma in the same part of the section.

\section{FOSSILS}

Fossils from the third Mya layer, the upper oolite, and the Cerastoderma-bearing sandstone are listed in the following table. Some of the species are shown on plate 24. 
Fossils from strata in lower part of San Joaquin formation between Neverita zone and Cascajo conglomerate member

[Identifications by W. P. Woodring un]ess otherwise stated. F. fragments; P, paired valves

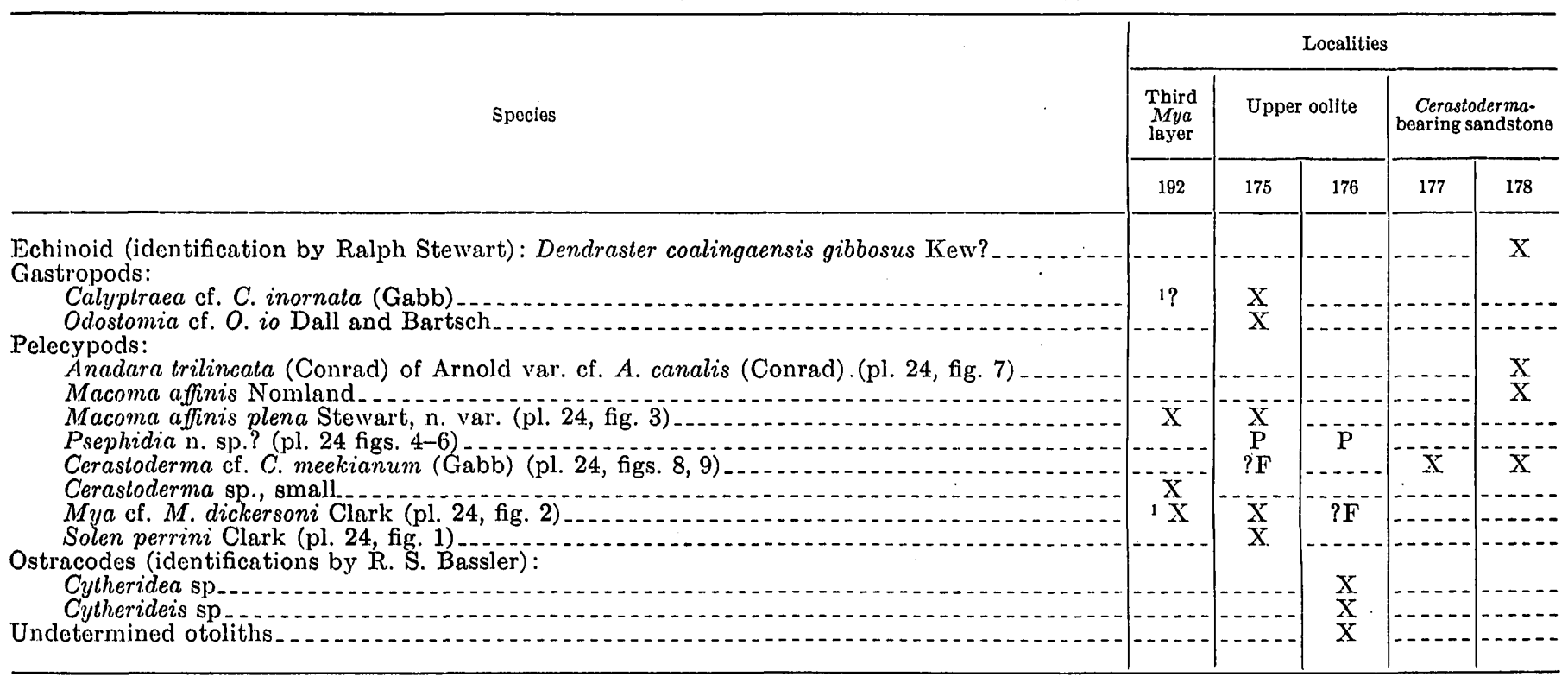

1 Obsorved but not collected.

Odostomia was not found at horizons other than the upper oolite. The small venerid Psephidia (pl. 24, figs. 4-6) occurs in the upper oolite and in the Cascajo conglomerate. The absence of Littorina and Amnicolalike fresh-water gastropods also serves to distinguish the upper oolite from the oolite in the Littorina zone of the Etchegoin formation. The form of Anadara trilineata in the Cerastoderma-bearing sandstone has more centrally located beaks than forms at higher horizons in the San Joaquin formation and is similar to a variety from the Etchegoin formation.

In addition to the fossils listed, others were observed or collected in this part of the section. Leaves occur in clayey silt exposed in a cut at Standard well 47-35-J, sec. T. 21 S., R. 17 E., at a horizon about 50 feet below the Neverita zone. The leaf-bearing bed is 10 feet below a layer containing Volsella and immediately above a 2-foot bed of blue silty clay. A fragment of an upper cheek tooth of a horse, collected a few feet below the Neverita zone at locality 174, represents, according to C. L. Gazin, Pliohippus or Plesippus. An ear bone from locality 169 , representing a horizon 35 feet above the upper oolite, is identified by Remington Kellogg as belonging to an extinct porpoise.

\section{CASOAJO CONGLOMERATE MEMBER}

STRATIGRAPHY AND LITEOLOGY

The base of the San Joaquin formation is placed at the base of a unit consisting of conglomerate and sandstone, generally blue, here designated the Cascajo conglomerate member. Cascajo Hill, on the west flank of South Dome, is the type locality of the Cascajo conglomerate. The average thickness of the Cascajo is 50 feet, but at places it is considerably greater. Throughout the Kettleman Hills the Cascajo and underlying sandstones are relatively resistant rocks and form a series of hills and ridges.

In northern South Dome the Cascajo contains the small pecten Aequipecten circularis eldridgei. On the basis of the occurrence of this fossil, which has not been found at other horizons in the outcrop section, it is suggested that the Cascajo is equivalent to sand and gravel that unconformably overlie Miocene shale near McKittrick, ${ }^{52}$ on the west border of the San Joaquin Valley 50 miles southeast of the Kettleman Hills, the type locality of $A$. circularis eldridgei. If this correlation is correct, the widespread deposition of gravel in the Kettleman Hills at the horizon of the Cascajo appears to be the result of deformation in the adjoining Coast Ranges. Should this small pecten be found at other horizons the suggested correlation would be less certain. Even in that event the base of the Cascajo might be considered an appropriate horizon for drawing the base of the San Joaquin formation in the Kettleman Hills.

The Cascajo conglomerate disappears below the surface in the saddles between the three anticlines in the Kettleman Hills and the correlation of strata assigned. to this member in the three anticlines is not entirely satisfactory. The correlation rests on the occurrence of sandstone and conglomerate in an appropriate part of the section and on the occurrence of fossils at scattered localities. The fossils in Middle and North Domes do not include, however, $A$. circularis eldridgei but do include fragments of a larger Aequipecten, probably related to $A$. circularis impostor of the Pecten zone. In North. Dome sandstone and conglomerate

"s Arnold, Ralph, and Johnson, H. R., Preliminary report on the McKittrickSunset oil region, Kern and San Luis Obispo Counties, Calif.: U. S. Geol. Survey Bull. 406, p. 80, 1910. Pack, R. W., The Sunset-Midway oil field, Calif., pt. 1, Geology and oil resources: U. S. Ceol. Survev Prof. Paper 116, p. 46, 1920. 
assigned to the Cascajo cut across underlying strata and may be interpreted as resting on successively older beds. Scour discontinuities of this character are not unusual in the San Joaquin and Etchegoin formations. The interpretation of exceptionally deep local scouring at the base of conglomerate assigned to the Cascajo is aided by the presence in the underlying strata of several recognizable faunal and lithologic units within a short stratigraphic distance. Along the greater part of the east flank of North Dome and along the south part of the west flank conglomerate and sandstone are present at the inferred horizon of the Cascajo, but a mappable boundary was not recognized. For this reason throughout North Dome the San JoaquinEtchegoin boundary is shown on the geologic map (pl. 3) at the base of a lower apparently more persistent tuffaceous blue sandstone designated the first blue sandstone above the Littorina zone of the Etchegoin formation, except at places on the west flank where the first blue sandstone appears to have been cut out by the Cascajo. This cartographic representation of the boundary should present no serious difficulty, for the stratigraphic thickness involved is not more than about 100 feet. Within this thickness the beds of conglomerate and sandstone may occur as irregular lenses rather than as continuous layers.

The Cascajo and the underlying blue sandstones are the highest relatively persistent blue sandstones and conglomerates. Lenses of blue sandstone occur at higher horizons, particularly in the interval between the Pecten and Neverita zones. Downward in the section from the Cascajo throughout the Etchegoin formation many of the coarse-grained sandstones are blue. These blue sandstones are a noteworthy feature in the Kettleman Hills and other parts of the Coalinga region. It has been recognized that the blue color is due to a film on the sand grains, and the suggestion has been made that the film consists of vivianite, ${ }^{53}$ of opal or chalcedony, fine volcanic dust, or clayey material. ${ }^{54}$ Samples from several blue sandstones in the Kettleman Hills were examined by M. N. Bramlette, who found that the mineral forming the film has a mean index of refraction of 1.56 , nearly parallel extinction, and negative elongation. It is soft and can readily be scraped off the grains and is slightly soluble in hydrochloric acid. According to Bramlette, these properties indicate that the mineral is neither vivianite nor opal. He suggests that it is probably a chloritic or clay mineral and that there seems to be a relation between the film-forming mineral and hypersthene andesite tuff. The blue sandstones examined contain a notable quantity of pyroclastic material of this composition, whereas pyroclastic material in sandstones of the San

\footnotetext{
${ }^{63}$ Arnold, Ralph, and Anderson, Robert, op. cit. (Bull. 398), p. 97.

34 Anderson, Robert, and Pack, R. W., Geology and oil resources of the west border of the San Joaquin Valley north of Coalinga, Calif.: U. S. Geol. Survey Bull. 603, pp. 82-83, 1915 .
}

Joaquin and Etchegoin formations that are not blue consists of augite or hornblende andesitic tuff.

North Dome.-The stratigraphic relations of sandstone and conglomerate assigned to the Cascajo in North Dome were interpreted by the occurrence of these

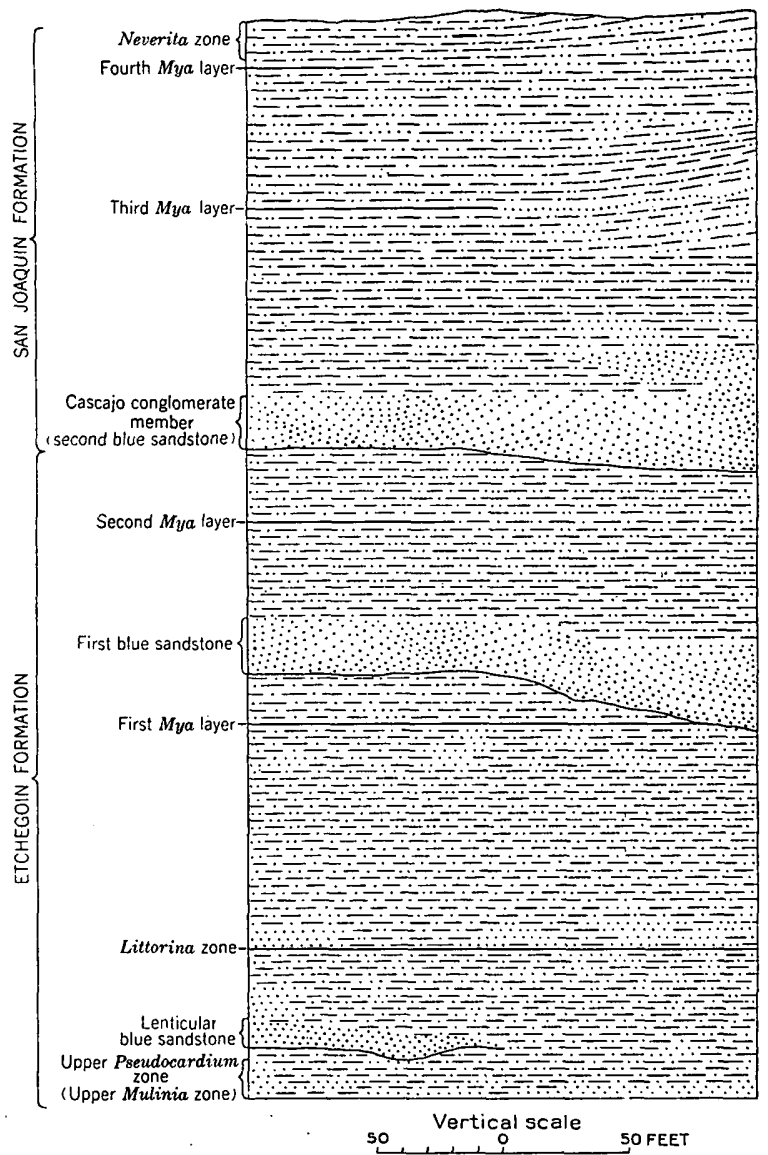

FIGURE 6.-Generalized section of strata in lower part of San Joaquin formation and in upper part of Etchegoin formation in northern North Dome.

strata with reference to the Littorina zone of the underlying Etchegoin formation and to the following units in Etchegoin strata overlying the Littorina zone, designated in the order of their position above the Littorina zone, first Mya layer, first blue sandstone, second Mya layer. These units are shown in figure 6. The Cascajo normally overlies the second Mya layer in the regions where this $M y a$ layer occurs and is normally the second blue sandstone above the Littorina zone. As stated above, for the purpose of clearer cartographic representation the San Joaquin-Etchegoin boundary is shown on plate 3 at the base of the first blue sandstone, except locally on the west flank where the first blue sandstone is thought to be cut out by the Cascajo. The differentiation of the first blue sandstone and Cascajo, however, is uncertain at places.

The succession shown in figure 6 is well developed at the north end of North Dome. Coarse-grained cross-bedded blue sandstone and grit containing layers of pebbles are assigned to the Cascajo. The pebbles consist chiefly of black chert. On the north side of 
Double Hill sandstone of this character is 33 feet above the second Mya layer. (See section, p. 57.) At many places on the east flank southward from Double Hill sandstone that may be assigued to the Cascajo is not well exposed or is distinguished with difficulty from the first blue sandstone. At scattered localities coarsegrained blue sandstone and conglomerate that probably represent the Cascajo occur in about the same stratigraphic position. These occurrences may be exposures of a continuous stratum or they may represent separate lenses in slightly different parts of the section. At locality 194 worn shells and small sand dollars were directly overlies the first Mya layer and locally cuts across it.

At the head of Arroyo Delgado on the west side of Cerro Alto blue sandstone, considered the Cascajo, cuts across the first blue sandstone (pl. 25, B). At locality 185, in Arroyo Delgado, the blue sandstone contains fossils, including fragments of Aequipecten and the small cup-shaped brachiopod Discinisca. Near the head of the arroyo the base of the blue sandstone is about 60 feet above the Littorina zone. Down the arroyo 600 feet away the base of the sandstone is 170 feet above the downward projection of the Littorina

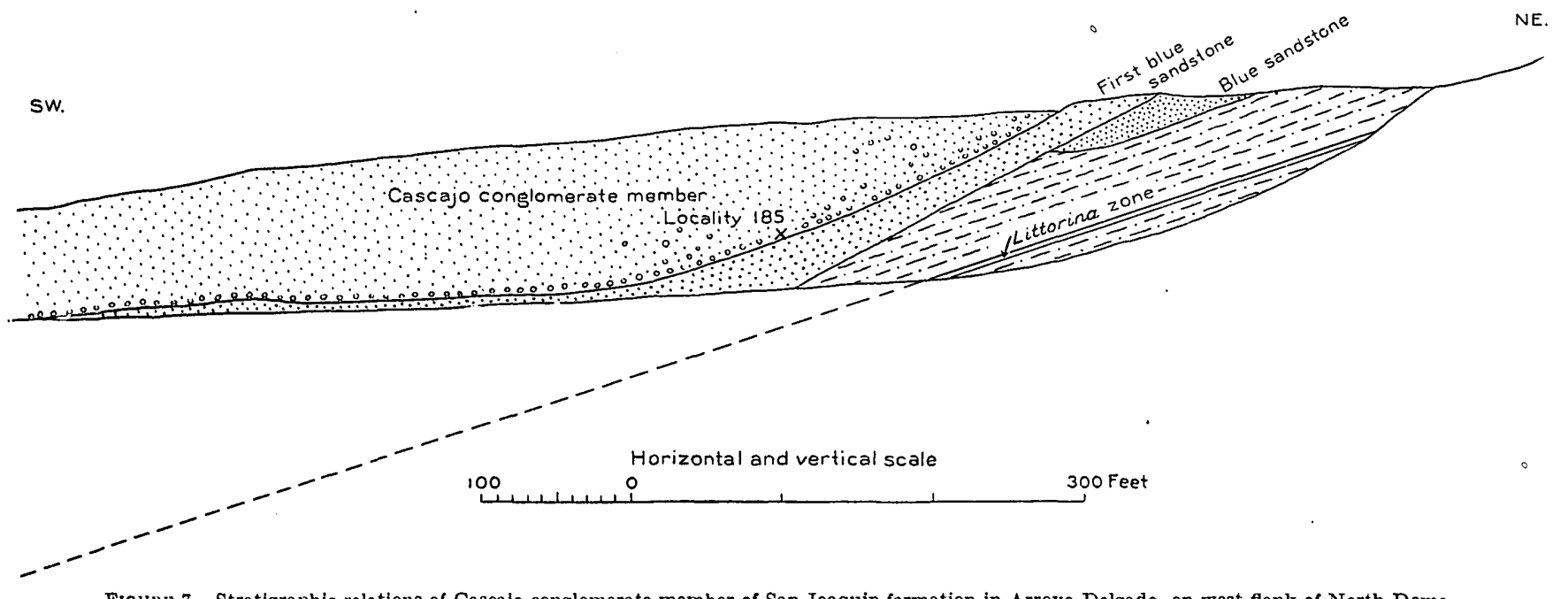

Fiqune 7.-Stratigraphic relations of Cascajo conglomerate member of San Joaquin formation in Arroyo Delgado, on west flank of North Dome.

collected from irregularly bedded blue and gray coarsegrained sandstone corresponding in stratigraphic position to the Cascajo. Sandstone in about the same stratigraphic position at other localities on the east flank contains worn fragments of Anadara.

At the north end of the west flank conglomerate and sandstone identified as the Cascajo overlie the second Mya layer. The irregular contact at the base of the conglomerate is well exposed along the road to Standard well 41-3-P, near the north line of sec. 3, T. 22 S., R. $17 \mathrm{E}$. (pl. 25, A). At this locality the base of the conglomernte is 7 feet above the second $M y a$ layer. Five hundred feet to the east the base is 20 feet above the second Mya layer and a Macoma layer occurs in the intervening silt. On the west slope of the ridge northeast of La Cumbre pebbly blue sandstone, assigned to the Cascrjo, rests on the first blue sandstone with an irregular contact having a relief of 5 feet. At locality 191, near Arroyo Somero, poorly preserved sand dollars occur in coarse-grained blue sandstone 50 feet above the first Mya layer. On the divide between Arroyo Somero and Arroyo Chico blue conglomerate is just above the first Mya lnyer. On the south slope of El Chichon blue conglomerate rests on strata below the first Mya layer, but 400 feet to the west in the bottom of a tributary of Arroyo Chico it again is 50 feet above the first Mya layer. South of El Piso a blue sandstone zone. The stratigraphic relations at this locality, shown in figure 7 , are apparently due to subaqueous erosion and lenticular deposition. If the lenticular blue sandstone underlying the first blue sandstone shown in figure 7 is represented at other localities where the relations to the first blue sandstone are not known, it would be difficult to distinguish it from the Cascajo.

At the head of a branch of Arroyo Delgado (locality 184) the contact between the sandstone identified as the Cascajo and sandy silt overlying the first blue sandstone is well exposed. Between localities 184 and 183 the first blue sandstone appears to be cut out by blue sandstone assigned to the Cascajo. At locality 183 , on the south side of Cerro Ultimo, cross-bedded blue sandstone and grit contain fossils, including fragments of Aequipecten and Discinisca. Farther south blue sandstone and conglomerate assignable to the Cascajo are not well exposed.

The summit of El Lobo, east of the outcrops just described and separated from them by faults, is formed of coarse-grained blue sandstone and grit. Discinisca was found at the base of this sandstone (locality 186). On the west side of El Lobo the blue sandstone is about 25 feet above the Littorina zone. On the east side it is about 25 feet above a Mya-Pseudocardium layer. The Littorina zone may grade laterally into the 
Mya-Pseudocardium layer, but on the basis of stratigraphic relations near the type locality of the Littorina zone the Mya-Pseudocardium layer is thought to be 20 feet below the Littorina zone. The blue sandstone on El Lobo may be the Cascajo, or it may correspond to the lenticular blue sandstone underlying the first blue sandstone shown in figure 7 , despite the occurrence of the brachiopod.

The stratigraphic relations at the scattered exposures of blue sandstone and conglomerate on the west flank of North Dome may be interpreted as indicating that the Cascajo conglomerate formed a continuous stratum. Under this interpretation the same conglomerate is 20 feet above the second Mya layer at the north end of the anticline and soutbward cuts across the second Mya layer, the first blue sandstone, the first $M y a$ layer, and down to the Littorina zone. Figure 8 is a sw.

Arroyo Ramoso

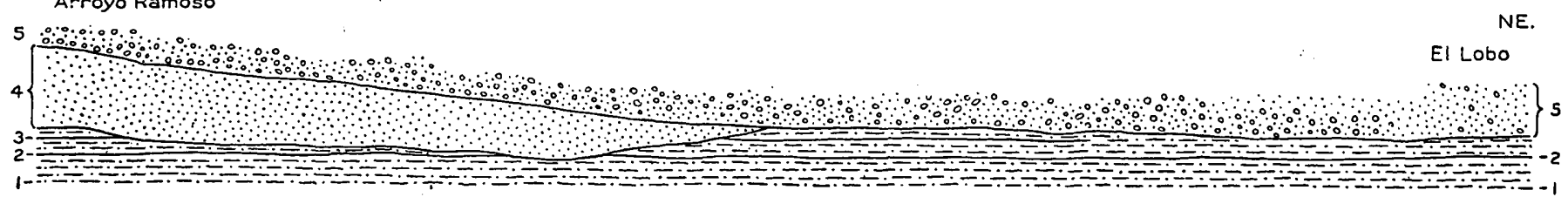

Horizontal and vertical scale

100 Horizontal and vertical scale 300 Feet

Frgure 8.-Reconstruction of strata exposed in Arroyo Ramoso and on El Lobo under interpretation that blue sandstone and conglomerate at both localities represent Cascajo conglomerate member of San Joaquin formation. 1, Upper Pseudocardium zone; 2, Mya-Pseudocardium layer; 3, Mya layer (?=Littorina zone); 4, First blue sandstone; 5, Cascafo conglomerate member of San Joaquin formation (blue sandstone and conglomerate).

reconstruction under this interpretation of the strata exposed in Arroyo Ramoso and on El Lobo. An equally plausible or perhaps more plausible interpretation is that the exposures of blue sandstone and conglomerate represent lenses not only in different parts of the section above the first blue sandstone but also below the first blue sandstone. There is no doubt that blue sandstone and conglomerate mapped as the Cascajo cut across underlying strata, for such relations can be seen in single outcrops. It is not certain, however, that as much as 100 to 150 feet of strata were removed at places during, or before, the deposition of the sand and gravel.

Middle Dome.-At the north end of South Dome the Cascajo conglomerate overlies the readily recognized Pseudocardium-Anadara zone in the Etchegoin formation. The Cascajo conglomerate in Middle Dome is identified by its stratigraphic relation to this zone and by the fossils that occur in the conglomerate. Most of these fossils are represented in the Cascajo of South Dome. If the tuffaceous blue sandstone, designated the first blue sandstone above the Littorina zone in North Dome, occurs in Middle Dome, it was doubtless mapped as part of the Cascajo. The bluish-gray leafbearing sandstone exposed on Arroyo Culebrino at the north end of Middle Dome (see section, p. 71) is probably equivalent to the first blue sandstone. In view of the rather uniform stratigraphic interval between the Pseudocardium-Anadara zone and the base of sandstone and conglomerate identified as the Cascajo, it is doubtful whether in Middle Dome the stratigraphic relations of the Cascajo to underlying beds are as complex as they appear to be in parts of North Dome. The apparent simplicity may, however, be due to less satisfactory exposures than in North Dome.

The soft sandstone cropping out on the ridge east of La Bajada, on the east side of the saddle between North and Middle Domes, may be part of the Cascajo or part of the first blue sandstone of North Dome. The Pseudocardium-Anadara zone, however, was not recognized in this region, and the identification of the sandstone is uncertain. The structure in this area of meager exposures may be more complicated than supposed. Two strike faults of unknown displacement dip westward, and other faults may be present.

On the east side of Middle Dome the Cascajo as mapped consists of soft sandstone, hard sandstone, and conglomerate. Its thickness of 50 to 75 feet is only a rough estimate, as the upper part generally is not exposed and forms the sand-covered dip slope of strike ridges. The sandstone and conglomerate form the crest of Parejo Hill, but south of Arroyo Recodo they crop out far down on the east slope of the ridge forming the continuation of Parejo Hill.

The soft sandstone is blue or bluish gray and at places may correspond to the first blue sandstone of North Dome. At the north end of the anticline soft sandstone contains a few imprints of leaf fragments. The hard sandstone is gray, medium-grained, and weathers out in small rectangular blocks. This kind of sandstone is a conspicuous feature at the north and south ends of Parejo Hill. The conglomerate, which occurs as lenses or makes up the greater part of the member, consists of small pebbles, mostly black chert, that have an average length of about a quarter of an inch. At places the conglomerate has hardly any sand matrix. At the north end of the anticline conglomerate lenses contain "bulbous fish growths" and silicified wood. Fossils, including Aequipecten, were found in conglomerate at two localities on the east side of the anticline (localities 197, 198), and fragments of $M y a$ shells were observed in the northern part of section 4, T. 24 S., R. 19 E., near the south end of the anticline. 
On the west side of Middle Dome the Cascajo as mapped consists principally of sandstone, much of which has lenses of small pebbles. The thickness apparently increases southward from about 50 feet at the north end to a maximum of 140 feet in the southern part of section 31, T. 23 S., R. 19 E., and then rapidly decreases to 50 feet or less. The change in thickness is apparently due to lensing in the upper part of the sandstone. Hard, blocky sandstone like that already described crops out near the top of the sandstone at many places. Fossils, including Aequipecten, were collected at localities 199, 200, and 202. Silt that appears to form a lens in the sandstone and conglomerate mapped as the Cascajo extends northwestward for a distance of about a mile beginning at a place about 1,000 feet northwest of locality 202. Anadara and Venerupis shells, replaced by gypsum, occur in the upper part of the silt.

South Dome.-The type locality of the Cascajo conglomerate is on Cascajo Hill on the west side of South Dome, where the conglomerate is about 50 feet thick. Northward from Cascajo Hill the conglomerate forms a curving row of low ridges, El Arco. In this region the pebbles are a little larger than in Middle Dome. Most of them are three-quarters of an inch to an inch long, but some are $1 \frac{1}{2}$ inches. Black, red, and green chert and white quartz are the most abundant constituents. East of the crest of the anticline the Cascajo is thinner and is not so conspicuous topographically. Aequipecten and other fossils were collected at localities extending northward from Cascajo Hill to the crest of the anticline and eastward to the highway near the east edge of the hills. East of this highway a soft sandstone was mapped as the Cascajo.

Pobbles are less abundant south of Cascajo Hill. Toward the south end of the hills soft gray sandstone that contains hard ferruginous masses and scattered pebbles was identified as the Cascajo. Two broken pumice pebbles were found on the outcrop of the sandstone. "Bulbous fish growths" and bone fragments are the only fossils observed south of Cascajo Hill.

\section{FossiLs}

Marine fossils were found in the Cascajo conglomerate of northern South Dome and at a few places in the conglomerate and sandstone identified as the Cascajo in Middle and North Domes. These fossils are listed in the following table, and a few of the species are shown on plates 24 and 39 .

Most of the fossils are worn, and many of them consist of worn fragments. Probably all the specimens were transported for some distance before burial and many of them may have been transported as fossils. Transported dead shells that occur in conglomerate cannot be satisfactorily distinguished, however, from shells transported as fossils. It is improbable that the forms of Aequipecten occurring in the Cascajo were transported as fossils, for this genus is not known to occur in underlying Pliocene strata in the Kettleman Hills or in the foothills to the west. Other species represented by complete or virtually complete specimens, particularly those belonging to genera that live among stones-such as Nucella etchegoinensis (pl. 24, figs. 16-18)-or are attached to solid objects, were probably transported as dead shells.

The small Aequipecten circularis eldridgei (pl. 24, figs. 10-13) was found only at the north end of South Dome. Fragments of a larger Aequipecten, identified as Aequipecten cf. A. circularis impostor, were collected in the three anticlines. Varieties of Pseudocardium densatum occur in the Cascajo of South and Middle Domes and are abundant on Cascajo Hill. Worn fragments of thick-shelled specimens were doubtless transported as fossils. Complete specimens may also have been transported as fossils. A short trigonal form of this species (pl. 24, fig. 14) is similar to forms in the underlying Pseudocardium-Anadara zone: An elongate form (pl. 24, fig. 15), however, is rare in the underlying strata. The brachiopod Discinisca (pl. 39, figs. 1, 6) was collected at three localities in North Dome, but it is uncertain whether locality 186 represents the same horizon as the other two.

\section{OCCURRENCE ELSEWHERE IN SAN JOAQUIN VALLEY}

Pebbles in the Cascajo conglomerate member consist of rocks similar to those cropping out in the adjoining Coast Ranges. If the material was derived from the Coast Ranges, similar conglomerate would be expected to occur in the Kreyenhagen Hills, at the foot of the Coast Ranges west of the Kettleman Hills. According to observations by Ralph. Stewart, conglomerate occurs in a corresponding part of the section at least locally in Jacalitos Dome and along Canoas Creek, overlying a Mya zone that probably corresponds to the Littorina zone of the Kettleman Hills. This Mya zone overlies the upper Pseudocardium zone (upper Mulinia zone of Arnold and Anderson).

The proposed correlation of the Cascajo conglomerate with sand and gravel containing Aequipecten circularis eldridgei near McKittrick suggests that a marine zone corresponding to the Cascajo may occur in the subsurface section of southern San Joaquin Valley. Barbat and Galloway ${ }^{55}$ recorded a PectenMytilus zone, which contains "Pecten" eldridgei, in the subsurface section 100 feet above the upper Mulinia zone and immediately overlying the fresh-water lower Scalez zone. In view of its stratigraphic position and fossils the Pecten-Mytilus zone is considered the equivalent of the Cascajo. (See fig. 13.)

\footnotetext{
65 Barbat, W. F., and Galloway, John, San Joaquin clay, California: Am. Assoc. Petroleum Geologists Bull., vol. 18, p. 486, 1934.
} 


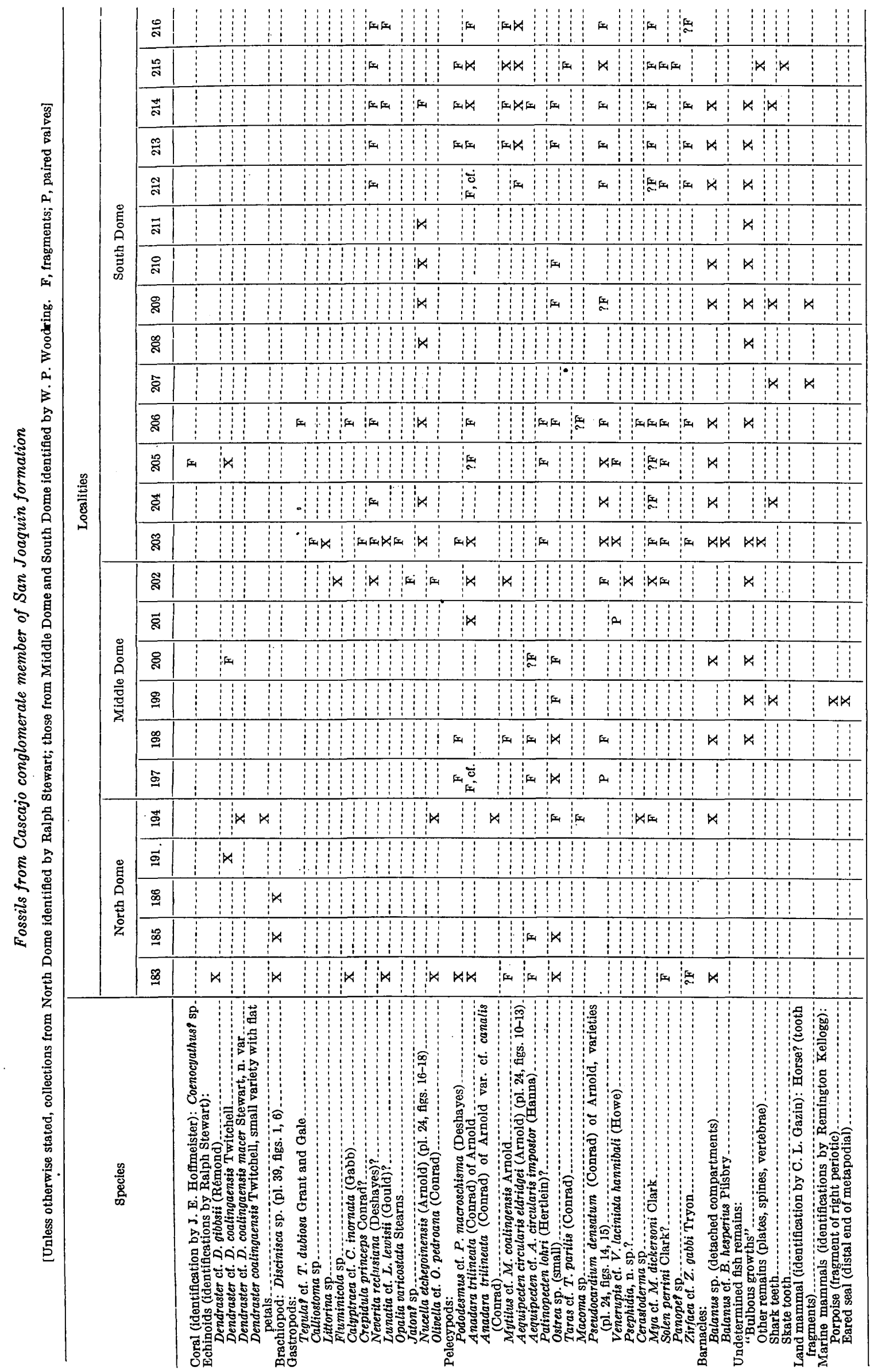




\section{ETCEEGOIN FORMATION}

When the Etchegoin "beds" were named ${ }^{56}$ no type locality was designated. The name was derived from the Etchegoin Ranch, formerly located about 3 miles north of Anticline Ridge, ${ }^{57}$ in the foothills northwest of the Kettleman Hills. Arnold and Anderson established a type locality for the Etchegoin formation on Anticline Ridge and defined the formation in the type region as consisting of sand, gravel, and clay above the base of the Glycymeris zone. ${ }^{58}$ In the type region Arnold and Anderson's Etchegoin formation evidently includes the San Joaquin formation, but the San Joaquin formation has not yet been differentiated on Anticline Ridge. According to Barbat and Galloway's identification of the upper Mulinia zone (upper Pseudocardium zone of present report) on Anticline Ridge, ${ }^{59}$ the Glycymeris zone is not far below the upper Mulinia zone and may be the stratigraphic equivalent of the Siphonalia zone of North Dome. Perhaps part of the nonmarine formation on Anticline Ridge mapped by

soAnderson, F. M., A stratigraphic study in the Mount Diablo Range of California: Callfornir Acad. Scl. Proc., 3d ser., vol. 2, p. 178, 1905.

"Arnold, Ralph, and Anderson, Robert, op. cit. (Bull. 398), p. 113.

ss Idem, pp. 113-114.

so Barbat, W. F., and Galloway, John, op. cit. (Am. Assoc. Petroleum Geologists Bull., vol. 18), p. 484
Arnold and Anderson as the Jacalitos formation ${ }^{60}$ may be the equivalent of some of the marine Etchegoin in the Kettleman Hills.

On the advance edition of the geologic map of the Kettleman Hills issued in 1934 the designation "Etchegoin sandstone" was used. In view of the absence of a prevailing type of lithology in North Dome and in the upper part of the formation in Middle and South Domes the designation "Etchegoin formation" is preferable.

The Etchegoin formation embraces the oldest strata cropping out in the Kettleman Hills. In North Dome the formation has an exposed maximum thickness of about 700 feet; in Middle Dome the estimated exposed thickness is about 600 feet; and in South Dome the exposed Etchegoin has the considerably greater estimated thickness of about 1,800 feet. The Etchegoin of North Dome consists chiefly of silty sand, silt, and sandstone. In Middle and South Domes the formation consists predominantly of sandstone, but the upper part of the formation also includes silt, clay, and conglomerate. The stratigraphic units recognized in the Kettleman Hills and their thickness are given below.

00 Arnold, Ralph, and Anderson, Robert, op. cit. (Bull 398), pp. 107-108.

Stratigraphic units in Etchegoin formation of Kettleman Hills

\begin{tabular}{|c|c|c|c|c|c|c|c|c|c|c|}
\hline \multicolumn{3}{|c|}{ North Dome } & \multicolumn{4}{|c|}{ Middle Dome } & \multicolumn{4}{|c|}{ South Dome } \\
\hline Unit & Lithology & $\begin{array}{c}\text { Thick- } \\
\text { ness } \\
\text { (feet) }\end{array}$ & & Unit & Lithology & $\begin{array}{l}\text { Thick- } \\
\text { noss, } \\
\text { (feot) }\end{array}$ & & Unit & Lithology & $\begin{array}{l}\text { Thick- } \\
\text { ness } \\
\text { (feet) }\end{array}$ \\
\hline $\begin{array}{l}\text { Strnta overiying Littorina } \\
\text { zono, including first Mya } \\
\text { layor, second Mya layer, } \\
\text { and first bluo sandstone. }\end{array}$ & $\begin{array}{l}\text { Sllty sand, sandy silt, } \\
\text { and blue tuffaceous } \\
\text { sandstone. }\end{array}$ & 100 & \multirow{5}{*}{ 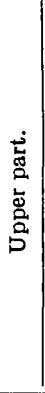 } & $\begin{array}{l}\text { Strata overlying } \\
\text { Pseudocardium- } \\
\text { Anadara zone. }\end{array}$ & $\begin{array}{l}\text { Sandy silt, silty } \\
\text { clay, and lenses } \\
\text { of sandstone. }\end{array}$ & 50 & \multirow{5}{*}{ 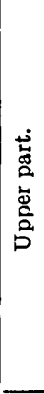 } & $\begin{array}{l}\text { Strata overlying } \\
\text { Pseudocardium- } \\
\text { Anadara zone. }\end{array}$ & $\begin{array}{l}\text { Sandy silt and } \\
\text { silty clay. }\end{array}$ & 50 \\
\hline Littorina zone. & $\begin{array}{l}\text { Oolitic } 1 \text { im os t o ne, } \\
\text { brown sandistone. }\end{array}$ & 5 & & $\begin{array}{l}\text { Pseudocardium- } \\
\text { Anadara zone. }\end{array}$ & Silty sandstone. & 10 & & $\begin{array}{l}\text { Pseudocardium- } \\
\text { Anadara zone. }\end{array}$ & Silty sandstone. & 10 \\
\hline $\begin{array}{l}\text { Strata botwcen I.ittorina } \\
\text { zono and upper Pseudo- } \\
\text { cardium zono. }\end{array}$ & $\begin{array}{l}\text { Silt, sand, and local blue } \\
\text { sandstones. }\end{array}$ & 60 & & \multirow{3}{*}{$\begin{array}{l}\text { Strata underlying } \\
\text { Pseudocardium- } \\
\text { Anadara zone. }\end{array}$} & \multirow{3}{*}{$\begin{array}{l}\text { Sandy silt, silty } \\
\text { clay, sandstone, } \\
\text { and conglomer- } \\
\text { ate. }\end{array}$} & \multirow{3}{*}{350} & & \multirow{3}{*}{$\begin{array}{l}\text { Strats underlying } \\
\text { Pseudocardium- } \\
\text { Anadara zone. }\end{array}$} & \multirow{3}{*}{$\begin{array}{l}\text { Sandy silt, silty } \\
\text { clay, and sand- } \\
\text { stone. }\end{array}$} & \multirow{3}{*}{300} \\
\hline Upper Pseudocardium zono. & Sand, silty sand. & 25 & & & & & & & & \\
\hline $\begin{array}{l}\text { Strata betwoon uppor Pseu- } \\
\text { docardium zone and Si- } \\
\text { phonalia zone. }\end{array}$ & $\begin{array}{l}\text { Sandy silt and local hlue } \\
\text { conglomerate. } \\
\text {. }\end{array}$ & 70 & & & & & & & & \\
\hline Siphonalia zono. & $\begin{array}{l}\text { Brown sandy silt, silty } \\
\text { sand, and local blue } \\
\text { sandstones. }\end{array}$ & 150 & \multirow{4}{*}{\multicolumn{2}{|c|}{ Lower part. }} & \multirow{4}{*}{$\begin{array}{l}\text { Soft sandstone; } \\
\text { near top light- } \\
\text { colored tuffa- } \\
\text { ceous silt. }\end{array}$} & \multirow{4}{*}{200} & \multirow{4}{*}{\multicolumn{2}{|c|}{ Lower part. }} & \multirow{4}{*}{$\begin{array}{l}\text { Soft sandstone, } \\
\text { hard sand: } \\
\text { stone, and con- } \\
\text { glomoratic } \\
\text { sandstone. }\end{array}$} & \multirow{4}{*}{1,500} \\
\hline Macoma zone. & $\begin{array}{l}\text { Light-colornd tuffaceous } \\
\text { silt and gonerally a } \\
\text { blue sandstone. }\end{array}$ & 50 & & & & & & & & \\
\hline Patinopecten zono. & $\begin{array}{l}\text { Brown sandy silt and } \\
\text { silty sand. }\end{array}$ & 100 & & & & & & & & \\
\hline $\begin{array}{l}\text { Strata underlying Patino. } \\
\text { pecten zono. }\end{array}$ & $\begin{array}{l}\text { Brown silt and sand, } \\
\text { lonses of blue sand. } \\
\text { stone. }\end{array}$ & 100 & & & & & & & & \\
\hline A pproximate total exp & osed thickness............... & 700 & \multicolumn{3}{|c|}{ Approximate total exposed thickness...- } & 600 & \multicolumn{3}{|c|}{$\begin{array}{l}\text { Approximate total exposed thick- } \\
\text { ness. }\end{array}$} & 1,800 \\
\hline
\end{tabular}


As shown in the preceding table, the North Dome faunal zones were not recognized in Middle and South Domes, where fossils are far less abundant than in North Dome. In the description of the Etchegoin, North Dome is treated as a unit and Middle and South Domes as another unit.

\section{NORTH DOME}

The upper part of the Etchegoin formation of North Dome above the Siphonalia zone is divided into thin faunal zones (Littorina and upper Pseudocardium zones) and strata that are nonfossiliferous or contain relatively few fossils. In fact, the division is similar to that adopted for the San Joaquin formation. The remaining three zones (Siphonalia, Macoma, and Patinopecten zones) are different from the overlying zones, as they embrace a considerable thickness of strata containing several or many fossiliferous layers. These three zones are not so easily recognized as the Littorina and upper Pseudocardium zones. Indefinite as they are, the three zones were useful in mapping the structure of the axial region of the anticline. The position of faults was inferred from the distribution of the zones, and subsequent search for the fault planes was successful at so many localities that considerable confidence in the zones is justified. Where all three zones are present in a section they are usually recognizable as two units of brown strata separated by a unit of light-colored strata. The Siphonalia zone consists mostly of brown sandy silt, though in some sections it includes blue sandstones; the Macoma zone is made up of light-gray to white tuffaceous silt and generally includes a blue sandstone; and the Patinopecten zone consists chiefly of brown silty sand. If the light-colored Macoma zone is not present, the abundance of Patinopecten usually distinguishes the Patinopecten zone from the Siphonalia zone. At the base of the Patinopecten zone in some sections is a layer containing large barnacles, assigned to Tamiosoma. The barnacles locally. occur upright, in the position in which they lived, forming clusters of varying size that may appropriately be called barnacle reefs (pl. 27, $A$ ). Similar barnacle reefs are present in the Macoma zone at the north end of the anticline and in strata underlying the Patinopecten zone. Barnacles and barnacle fragments are abundant in the Siphonalia zone, but reefs were not found in this zone. The sand dollar Dendraster gibbsii is abundant in the Siphonalia, Macoma, and Patinopecten zones. In fact, these three zones might be designated the Dendraster gibbsii zone, for this sand dollar is rare, if present at all, in overlying Etchegoin strata in North Dome. This species may also occur, however, in the underlying Jacalitos formation, and a form of it is present in the lower part of the San Joaquin.

The interval between the Macoma and Littorina zones appears to increase in thickness in the north part of North Dome. This may be due to an increase in thickness of the strata of the Siphonalia zone or to misidentification of the Macoma zone in the northern outcrops. The Macoma zone was not traced continuously from the north end to the type locality, and it is possible that the Macoma zone of the north end corresponds to tuffaceous strata 50 feet below the type Macoma zone. However, no indication of the typical Macoma zone above strata identified as the Macoma zone was recognized in the northern part of the anticline.

A representative section of the Etchegoin is exposed on the ridge extending soutbward from El Rascador on the east flank of the anticline, where the formation has an exposed thickness of about 550 feet (pl. 26, $A$; pl. 28, column 9). On the top of El Rascador is a blue sandstone identified as the Cascajo conglomerate member of the San Joaquin formation. Downward in the section is a thin-bedded blue sandstone (first blue sandstone) followed in order by the five faunal zones shown in the table on page 55. The lowest strata exposed are in the bottom of the north fork of Arroyo Doblegado, where blue sandstone and brown silty sand containing Pseudocardium underlie the Patinopecten zone.

The most satisfactory horizon indicator in the Etchegoin is the Littorina zone, which is near the top of the formation. Consequently the Littorina zone is taken as the datum plane for comparison of sections and for correlations, and the accuracy of the correlations tends to diminish as the stratigraphic distance from the Littorina zone increases. Sections of Etchegoin strata below the Littorina zone are shown on plate 28 .

\section{STRATA OVERLYING LITTORINA ZONE}

Stratigraphy and lithology.-The Etchegoin strata overlying the Littorina zone consist of sandy silt, silty sand, and a relatively persistent tuffaceous blue sandstone. The thickness of the strata varies, especially on the west flank of North Dome, apparently owing to the cutting out of beds by conglomerate identified as the Cascajo conglomerate member of the San Joaquin. Under the interpretation shown in figure 8 the Cascajo rests virtually on the equivalent of the Littorina zone at El Lobo. The average thickness of the Etchegoin above the Littorina zone is, however, about 100 feet. At the north end of North Dome the thickness is fully twice as great, as shown in figure 6 . This 200 -foot section at the north end of the anticline includes the following three mappable units, named in succession above the Littorina zone: first Mya layer, first blue sandstone, second Mya layer. The following section showing these units was measured in a road cut on the north side of Double Hill. The road is not shown on the topographic base of plate 3 . 
Section of strata in Etchegoin formation above Littorina zone exposed in road cut on north side of Double Hill, north of center of sec. 2, T. 22 S., R. $17 \mathrm{E}$.

Sain Joaquin formation, Casćajo conglomerate member: Feet Cross-bedded blue sandstone containing some pebbles and 1-foot fragments of green clay at base. Scour discontinuity at base

Etchegoin formation:

Cross-bedded gray sand with few clay partings. Contact at base abrupt.........................

Gray sand and silt; some ferruginous concretions and lighter-colored layers. Numerous discontinuities within this unit. Contact at base abrupt........

Gray pebbly silt. Contact at base abrupt......... Greenish gravel with pebbles as much as 2 inches long and some shale partings. Contact at base abrupt.

Greenish-gray sand and silt with concretionary layers. Contact at base abrupt..........

Brownish-gray pebbly silt with scattered pebbles as much as 2 inches long. Contact at base abrupt and marked by 1-inch borings 1 foot long.......

Gray poorly sorted sand. Contact at base abrupt.-

Greenish clay. At base a gradational mixture of clay and sand; borings 1 inch in diameter, extending 20 inches into underlying sand

Second Mya layer. Greenish-gray massive sand. Shells in living positions and fragments of shells near top. Contact at base abrupt.............

Light-gray sand and silt. Contact at base abrupt. -

Grayish-green silt with two dark clay streaks near top. Contact at base fairly distinct..........

Dark-green clay. Contact at base gradational.....

Gray sand. Contact at base gradational .........

Dark-gray sand with some lighter layers of finer material. Contact not observed..................

Greenish clay with some darker streaks; somewhat silty near top. Contact at base abrupt........

Cross-bedded greenish sand. Contact at base ab-

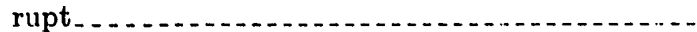

Gray sand with streaks of lighter material. Contact

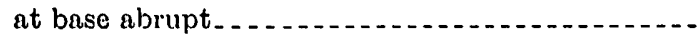

First blue sandstone:

Fine-grained, well sorted blue sandstone; some layers cross-bedded . . . . . . . . . . . . . . . . . . . .

Fine-grained, laminated bluish sand with some light-colored clay (?) layers............

First Mya layer. Gray silty sand containing small

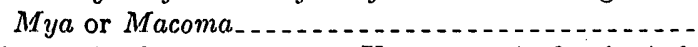

Fine-grained gray sand. Upper part laminated; lower 4 feet massive. Contact at base abrupt....

Green clay. Contact at base abrupt.............

Gray massive sand. Mya casts near middle. Con-

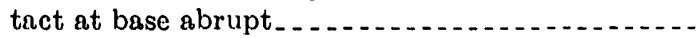

Gray tough clay. Borings filled with overlying

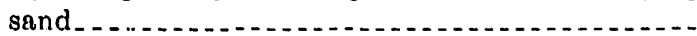

Gray tough clay. Contact at base fairly distinct. .

Coarse-grained green sand. Clay layers near top. Scour discontinuity at base ..................

Laminated light-gray clay. Contact at base abrupt.

Soft gray sand containing Mya in living positions about 1 foot from top. Base not exposed. Base of section about 20 feet above Littorina zone......

Thickness of Etchegoin strata overlying Littorina zone. . .

The second Mya layer was observed only around the north end of the anticline from La Cumbre to
Double Hill. Its absence farther south on the east flank is attributed mainly to different environmental conditions during deposition, but its absence on the west flank is assumed to be due to removal of strata before the deposition of blue conglomerate identified as the Cascajo conglomerate. The presence of large Mya shells, standing upright in the position of living shells, usually distinguishes the second Mya layer (pl. 17, C) from the first $M y a$ layer.

The first blue sandstone is a cliff-forming blue or grayish blue thin-bedded, fine-grained tuffaceous sandstone, generally 10 to 25 feet thick. Part of the sandstone is locally cross-bedded. The lighter-colored or $31 / 3$ almost white layers presumably contain more volcanic $71 / 2$ material than the darker layers. At some outcrops the sandstone is separated from underlying sandy silt by a scour discontinuity, but in general it appears $2 \frac{1}{3}$ to be a more sandy facies of the underlying silt. This 2 sandstone was mapped around North Dome, and for the most part its base is shown on the geologic map (pl. 3) as the San Joaquin-Etchegoin boundary. Though it is more persistent than other sandstones in this part of the section, lenticular sandstones at slightly different horizons may have been mapped as the same bed, and at places the separation from the overlying Cascajo conglomerate is uncertain. Along part of the west flank the first blue sandstone appears to be cut by blue sandstone and conglomerate identified as the Cascajo.

The following section of the upper part of the Etchegoin, including the first blue sandstone, was measured in a road cut near the southwest corner of sec. $6, \mathrm{~T}$. 22 S., R. 18 E., in a region where the second $M y a$ layer is not present. This section, a continuation of the section on page 48 , is somewhat generalized owing to incomplete exposures.

Section of strata in Etchegoin formation overlying Littorina zone in road cut near southwest corner of sec. 6, T. 2Q S., R. 18 E.

San Joaquin formation, Cascajo conglomerate member (?). Coarse-grained, cross-bedded blue sandstone with layers of pebbles.

Etchegoin formation:

Gray sand ...

Gray silt with some green clay. Probably includes equivalent of second Mya layer.................

Cross-bedded blue sandstone.

Sandy silt . - . . .

Blue sandstone. . .

Laminated silt

Blue sandstone. . . . . . . .

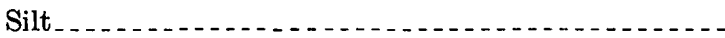

First blue sandstone. Gritty blue sandstone......

Tuffaceous (?) silt. . . . . . . . . . . . .

First Mya layer

Grav silt. . . . . .

Blue sandstone. Lens about $1 / 4$ mile long . . . . . .

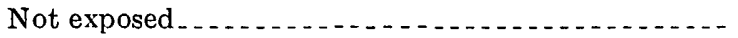

Littorina zone.

Thickness of Etchegoin strata overlying Littorina zone 
At locality 196, in a branch of Arroyo Robador, leaf imprints occur at the base of the first blue sandstone. Leaf imprints also were found in the first blue sandstone at the south end of the anticline on the east side of El Collado and near the north end of the ridge between the forks of Arroyo del Paso.

The first Mya layer, consisting of fragments of shells and small shells in silty sand, was traced from the north end of the anticline southward to a locality east of El Taco on the east flank and as far as La Cima on the west flank. It may extend farther south on the east flank, for a $M y a$ layer on the west flank of Arroyo Hondo may be the first Mya layer, and this layer may also be present just under the first blue sandstone on the south side of Arroyo Doblegado. At places on the west flank blue conglomerate assigned to the Cascajo rests on the first $M y a$ layer or cuts across it, and the absence of the layer in part of this area may be interpreted as the result of deeper scouring. The first Mya layer is immediately below the first blue sandstone or a few feet below it. It is too close to the first blue sandstone to be shown on a map of the scale of plate 3 .

A section of the strata below the first Mya layer, measured in a road cut on the east side of the first hill east of Double Hill, is shown below. The road is not shown on plate 3 .

Section of strata in upper part of Etchegoin formation betwecn first Mya layer and Littorina zone exposed in road cut on east side of first hill east of Double Hill, sec. 2, T. 2Q S., R. $17 \mathrm{E}$.

Light gray tuffaceous sand. Contact at base distinct but not well exposed.

First Mya layer. Greenish sand; Mya shells in living positions and numerous small shells. Contact at base apparently a thin gradational zone..................

Rather fine grained blue sand. Contact at base abrupt, at least locally.

Grayish sand with light-gray clay or silt layers, particularly in upper part. Fossil leaves 8 inches below top (locality 193b). Contact at base abrupt..........

Bluish-gray clay stained yellow, including a 9-inch layer of concretionary sand containing small clay fragments.

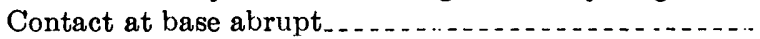

Greenish sand. Scour discontinuity (?) at base........

Grayish-brown sand. A 2-inch layer contains scattered casts of fresh-water gastropods (Amnicola?) ..........

Greenish sand. A layer of $M y a$ shells in living positions 10 inches above base and a 4-inch concretionary layer 6 inches above Mya layer. Contact at base locally

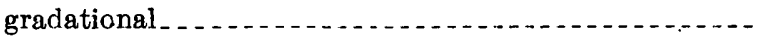

Greenish sand with streaks of gray and brown sand......

Bluish laminated silt; gray and brown and more sand in upper part. Contact at base marked by 1-inch layer of sand penetrating underlying clay 6 inches along cracks

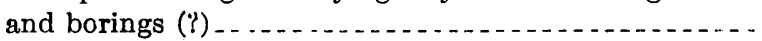

Greenish clay. A 1-inch dark purple layer 3 feet above base and a $1 / 4$-inch pink layer 8 inches higher. Upper 18 inches lighter-colored and sandy. Contact at base marked by two $1 / 4$-inch brown layers 2 inches apart....

Bluish clay about $1 \frac{1}{2}$ feet thick grading upward into laminated silt. Contact at base abrupt. .............
Section of strata in upper part of Etchegoin formalion between first $M y$ layer and Littorina zone exposed in road cut on east side of first hill east of Double Hill, sec. 2, T. 22 S., R.17 E.-Continued

Gray-green clay with coarser-grained layers about a foot apart. Contact at base abrupt..................

Gray sand grading upward into silt. Base about 20 feet

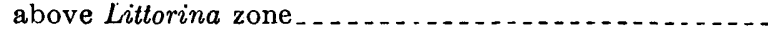

Approximate thickness of strata between first $M y a$ layer and Littorina zone

Fossils.-The leaves collected from the first blue sandstone at locality 196 and those from a horizon below the first Mya layer at locality 193a represent a willow, identified by R. W. Brown as Salix coalingensis Dorf.

In addition to the Mya shells in the first and second Mya layers, Mya occurs at lower horizons above the Littorina zone, as shown in the sections on pages 57 and 58. In the section measured on the first hill east of Double Hill fresh-water snails occur 35 feet below the first Mya layer. At locality 189, on the west flank of the anticline near Arroyo Conchoso, the fresh-water mussel Anodonta was found a foot above the first Mya layer. Half a mile to the northwest at locality $189 \mathrm{a}$ Anodonta is present at about the same horizon. Ten feet lower in the section Solen and Mya occur, and 25 feet still lower are fresh-water snails (Amnicola?). Fresh-water fossils Anodonta and Amnicola also occur on the east side of La Tusa, in the faulted axial region of the anticline in the southern part of sec. 12 , T. $22 \mathrm{~S}$., R. $17 \mathrm{E}$. This fresh-water horizon is 40 feet above the Littorina zone. Nomland ${ }^{61}$ described Anodonta nitida from this locality and assigned it to a stratigraphic position below the upper Mulinia zone-a quite reasonable interpretation at that time, as the faulting of North Dome had not been studied. Perhaps this fresh-water bed at La Tusa is the equivalent of the lower freshwater bed at locality 189 a about 50 feet above the Littorina zone, but inasmuch as fresh-water fossils occur at several horizons above the Littorina zone the correlation is uncertain.

\section{LITTORINA ZONE}

Stratigraphy and lithology.-The Littorina zone, generally 5 feet or less in thickness, is normally about 100 feet below conglomerate and sandstone identified as the Cascajo conglomerate member forming the base of the San Joaquin formation, but it may have been removed locally before the conglomerate was deposited. At the north end of the anticline it appears to be 200 feet below the Cascajo (fig. 6). The difference in thickness of the strata separating the Littorina zone and the Cascajo may be interpreted as the result of scouring by currents during, or just preceding, the deposition of the Cascajo, but the measurement may have been exaggerated by possible local misidentification of the Cascajo.

61 Nomland, J. O., The Etchegoin Pliocene of middle California: Californla Univ. Dept. Geology, Bull., vol. 10, pp. 215-216, 231, pl. 9, fg. 2, 1917. 


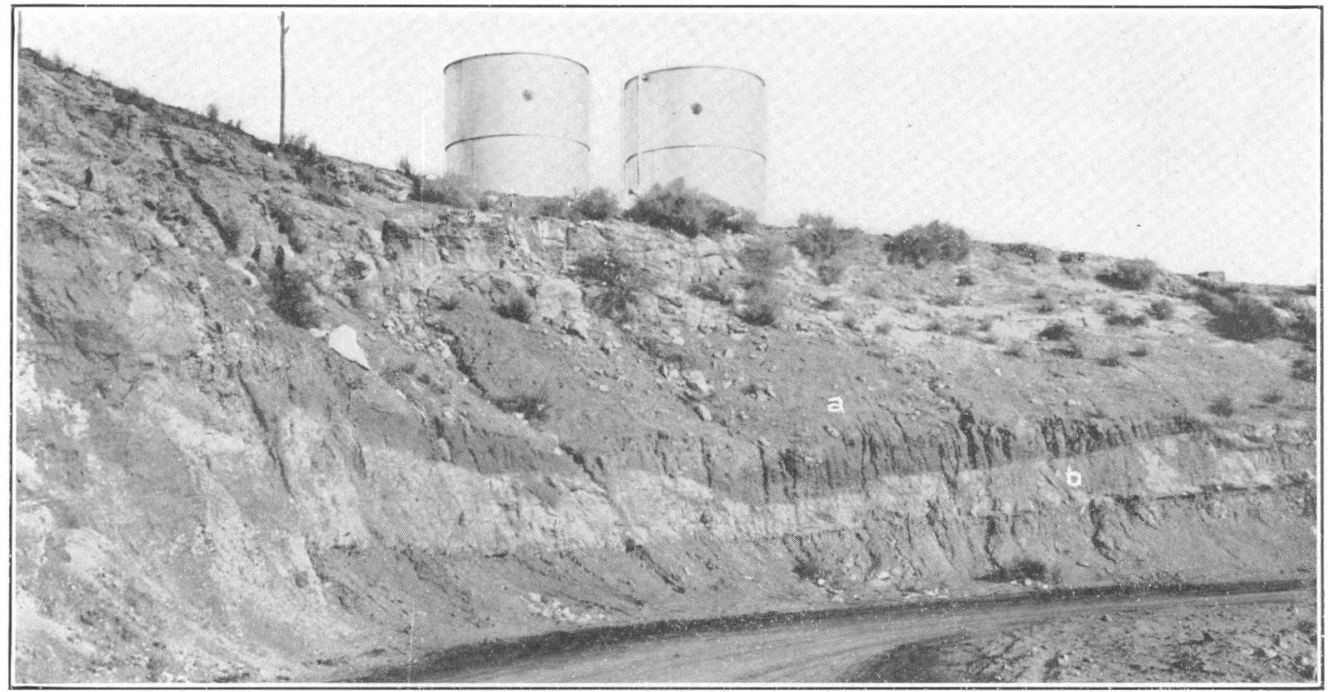

A. CASCAJO CONGLOMERATE MEMBER OF SAN JOAQUIN FORMATION NEAR STANDARD WELL 41-3-P, NEAR NORTH LINE OF SEC. 3, T. 22 S., R. 17 E. a. Cascajo conglomerate. Note irregular contact at hase.

b. Silt and silty sand of Etehegoin formation including second Mya layer.

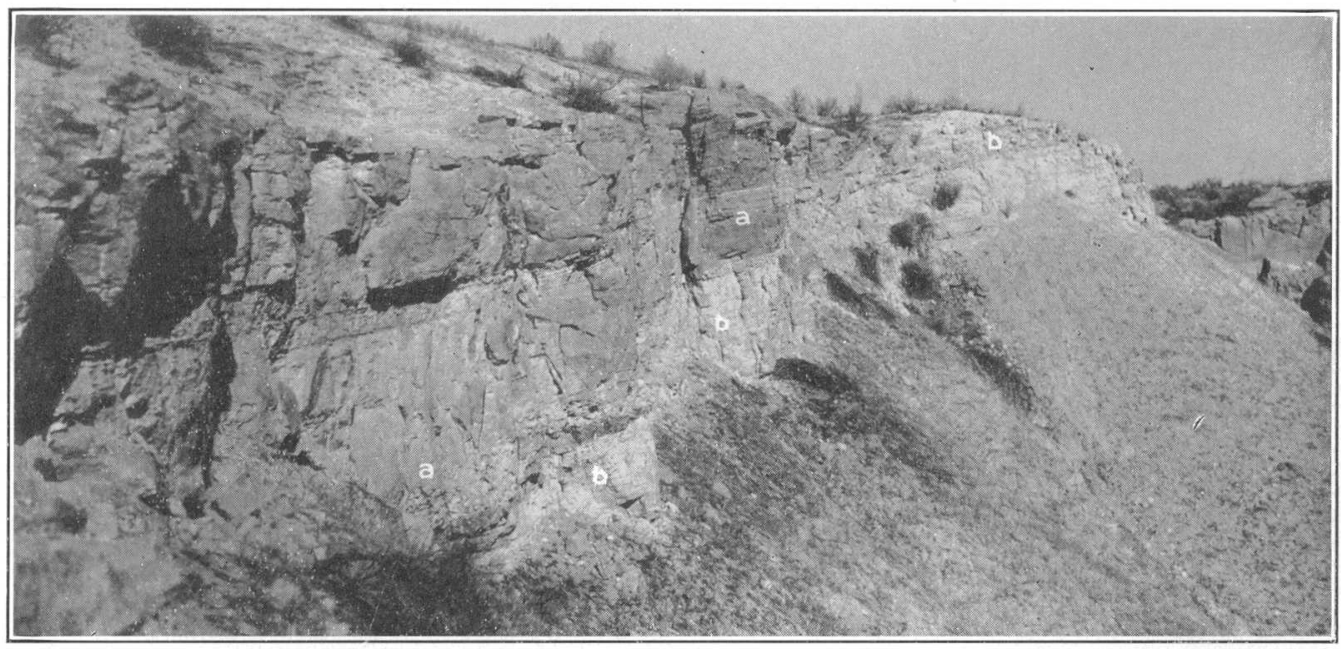

B. BLUE SANDSTONE OF CASCAJO CONGLOMERATE MEMBER OF SAN JOAQUIN FORMATION CUTTING ACROSS FIRST BLUE SANDSTONE OF UNDER. LYING ETCHEGOIN FORMATION AT HEAD OF ARROYO DELGADO ON WEST SIDE OF CERRO ALTO, SEC. 28, T. 22 S., R. 18 E.

a. Cascajo conglomerate.

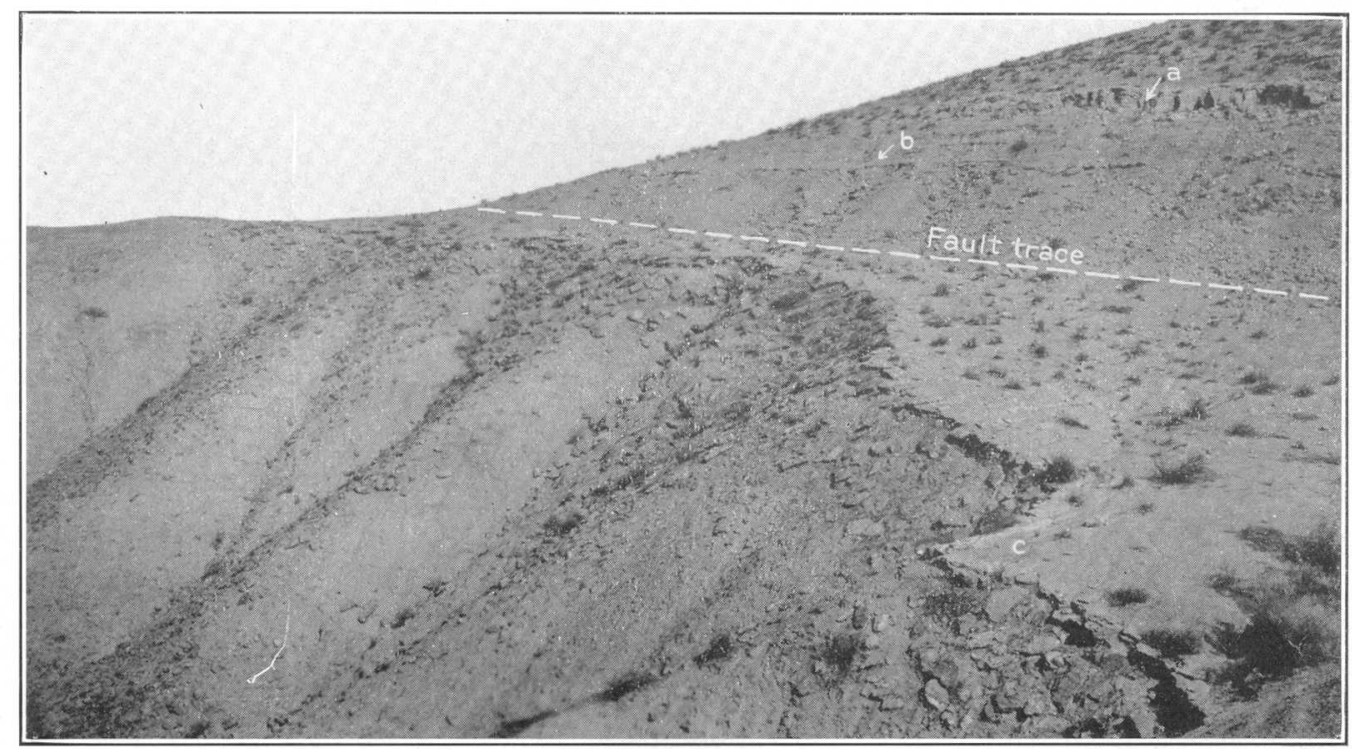

C. TYPE LOCALITY OF LITTORINA ZONE OF ETCHEGOIN FORMATION AT EL PISO, ON WEST SIDE OF LA CIMA, SEC. 19, T. 22 S., R. 18 E. a. First blue sandstone.

. First Mya layer.

The first Mya layer and first blue sandstone are normally about 100 feet above the Littorina zone. 


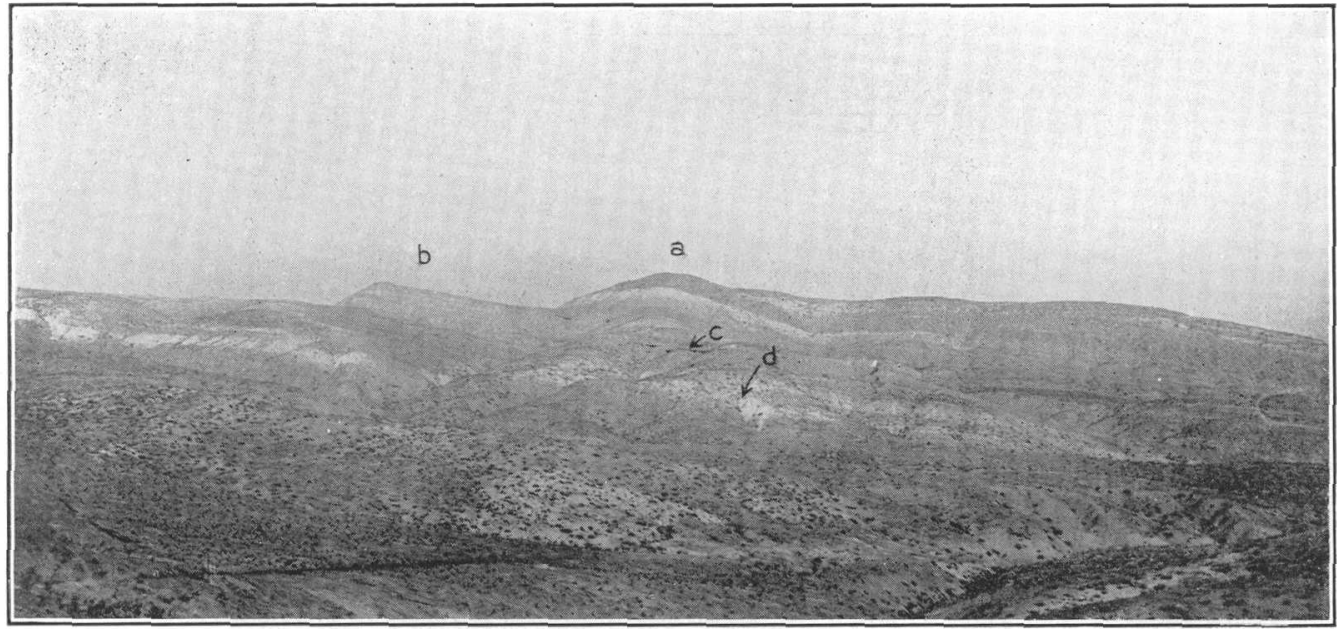

A. VIEW LOOKING NORTHEASTWARD TOWARD EL RASCADOR, IN SEC. 17, T. 22 S., R. 18 E. a. Cascajo conglomerate member of San Joaquin formation.

b. Littorina zone.

c. Mytilus layer in Siphonalia zone.

d. Tuffaceous sand of Macoma zone.

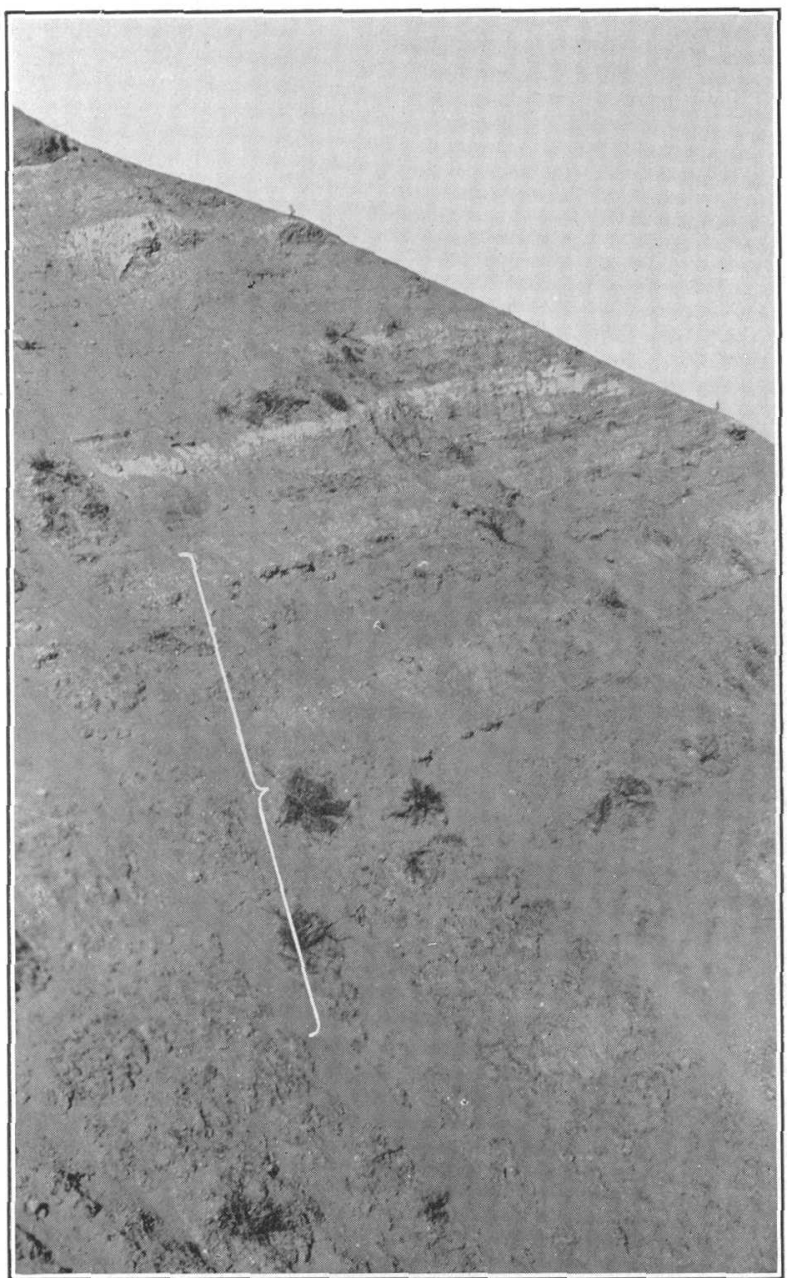

$B$. FOSSILIFEROUS LAYERS IN UPPER PSEUDOCARDIUM ZONE ON EAST SIDE OF EL LEON, SEC. 20, T. 22 S., R. 18 E. The bracket shows the limits of the zone.

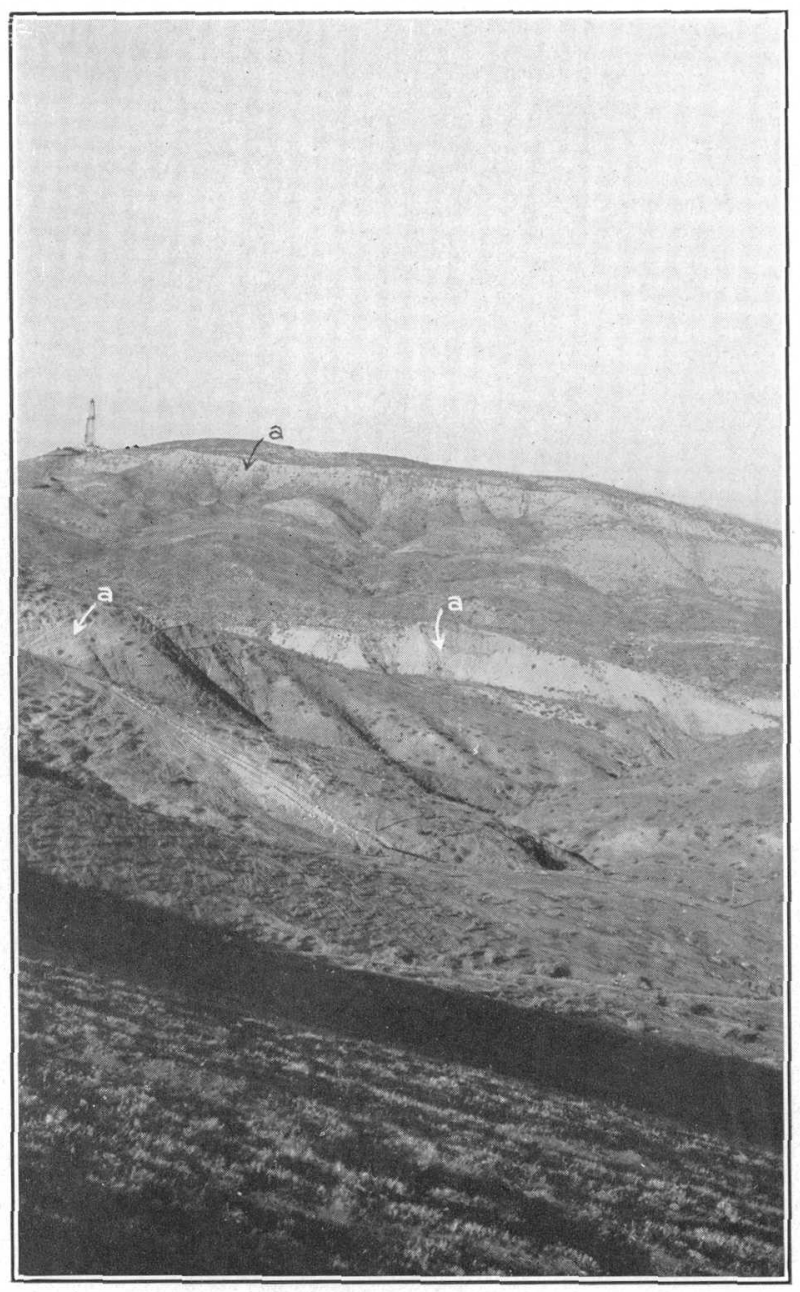

C. VIEW LOOKING NORTHWARD FROM LA ALETA TOWARD LAS PAREDES, IN SEC. 17, T. 22 S., R. 18 E.

Shows three outcrops of white tuffaceous sand of Macoma zone (a) separated by faults. 


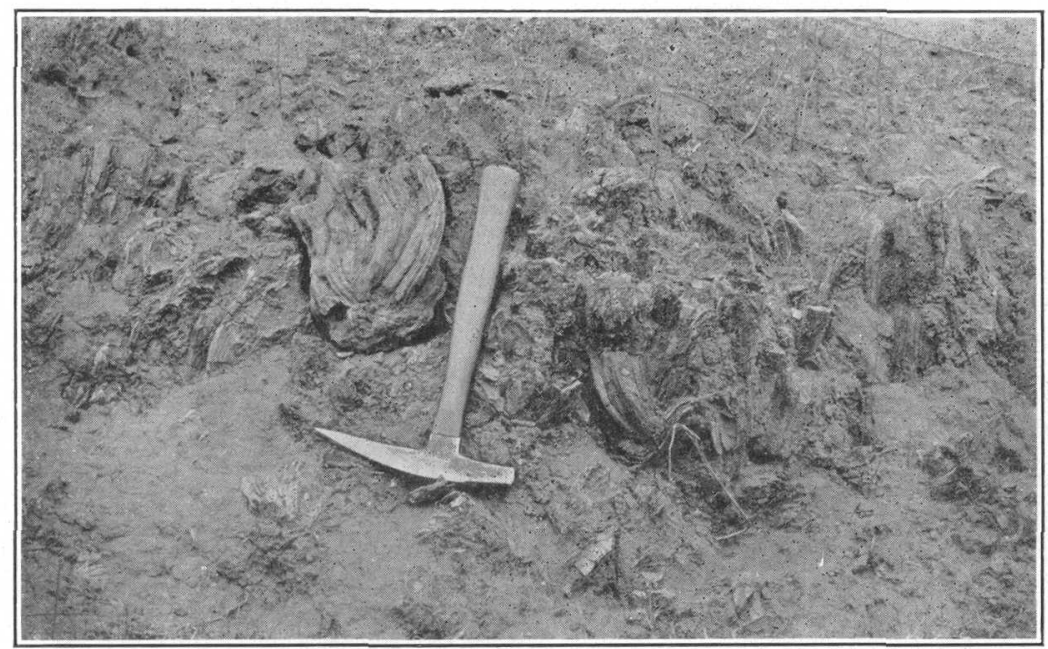

A. BARNACLE REEF UNDERLYing PATINOPECTEN ZONE ON SOUTH SLOPE OF EL TOLETE, SEC. 7, T. 22 S., R 18 E.

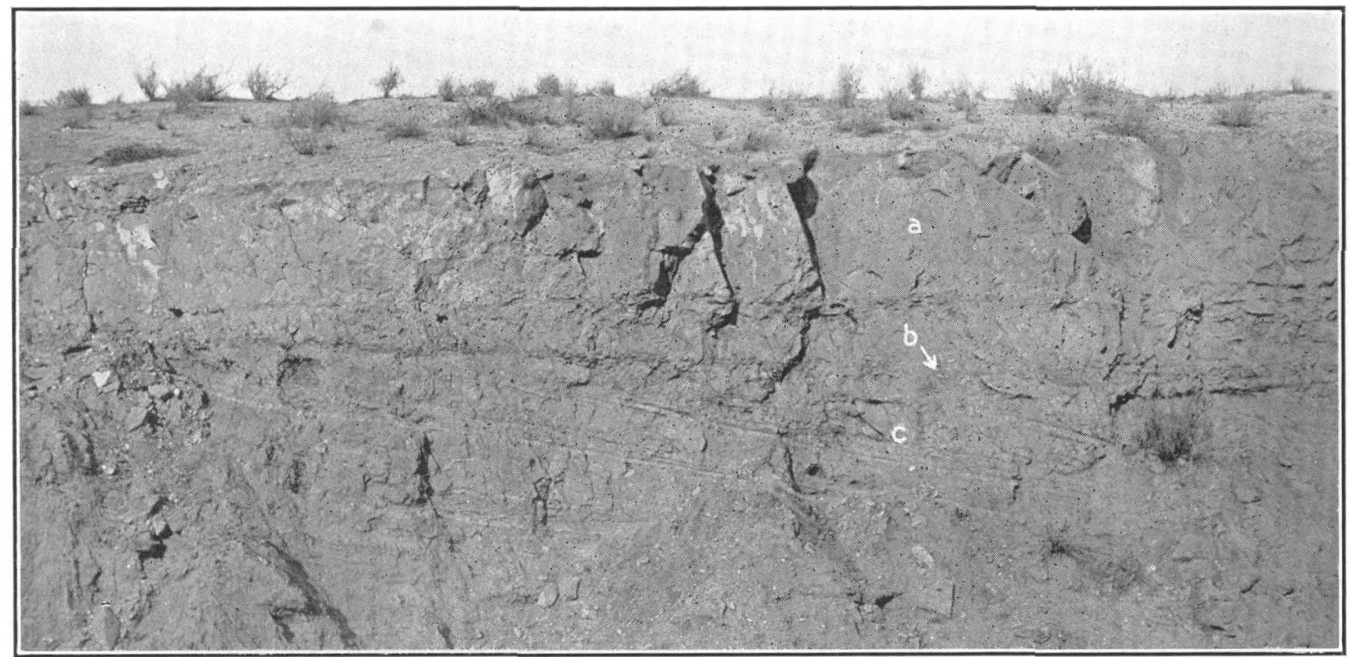

B. IRREGULAR BEDDING IN SIPHONALIA ZONE ON ARROYO ESTRECHO, SW 14 SEC. 35, T. 22 S., R. 18 E. a. Massive sandstone.

c. Sandy silt.

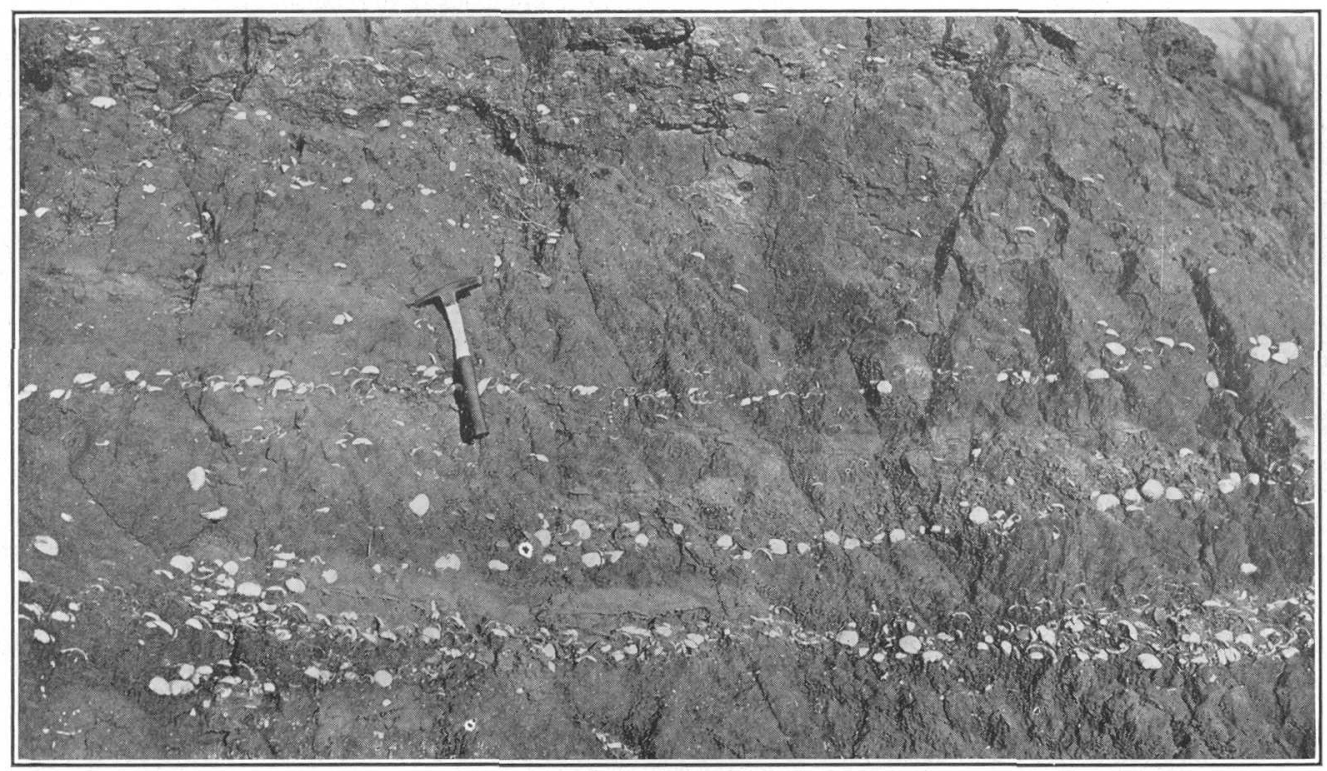

C. PSEUDOCARDIUM IN IRREGULARLY BEDDED SILT IN UPPER PART OF SIPHONALIA ZONE ON NORTH SLOPE OF ARROYO PINO, SE1/19 SEC. 26, T. 22 S., R. $18 \mathrm{E}$. 


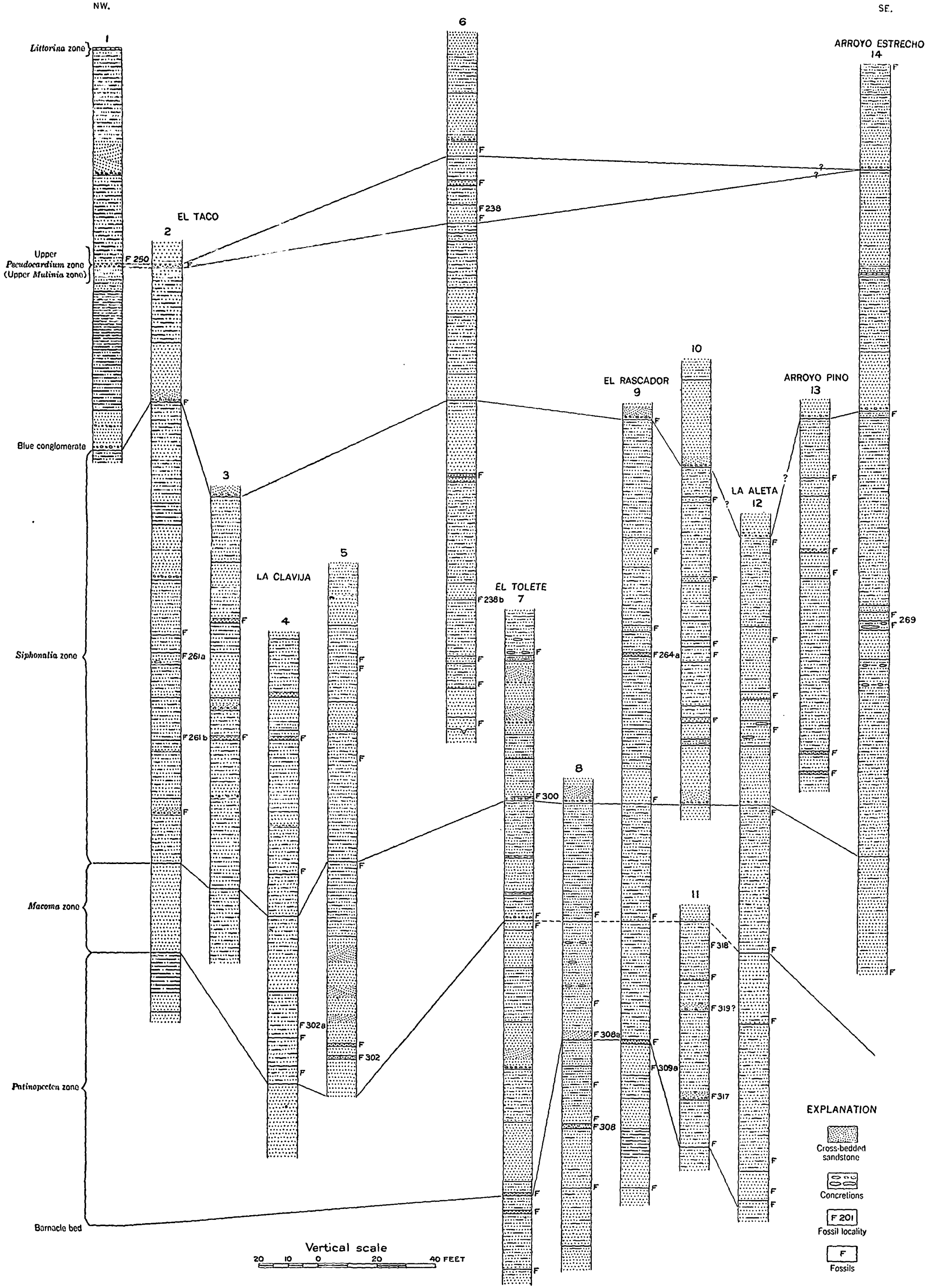

SECTIONS OF STRATA IN ETCHEGOIN FORMATION OF NORTH DOME UNDERLYING LITTORINA ZONE.

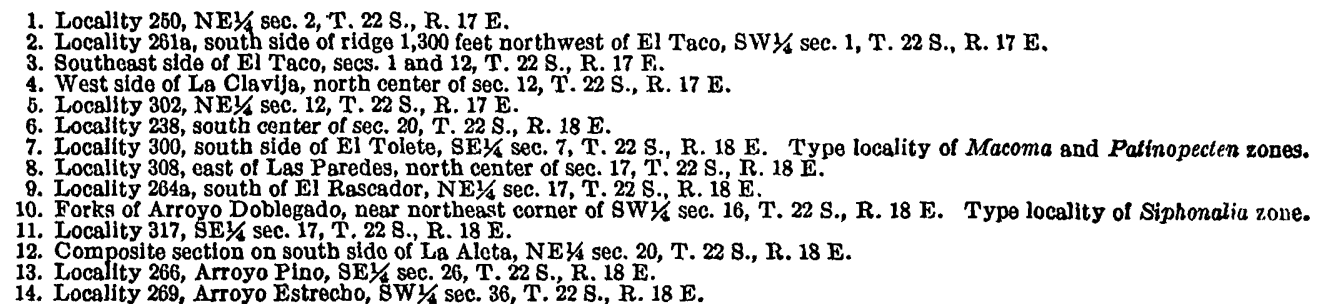


The Littorina zone at many localities may be divided into two parts, an upper part containing a mixture of fresh-water and marine fossils and including a brown oolitic limestone and a lower part containing marine fossils. Aside from the oolitic limestone, the zone consists of gray or brown sandstone. The oolitic limestone is a hard layer 6 inches to a foot thick that weathers out as slabs or forms dip slopes. It has been called the pavement bed or sidewalk bed. It forms a conspicuous layer that is easily traced over the greater part of North Dome. Because it is so thin it permits the most exact correlation of strata on opposite sides of the anticline,

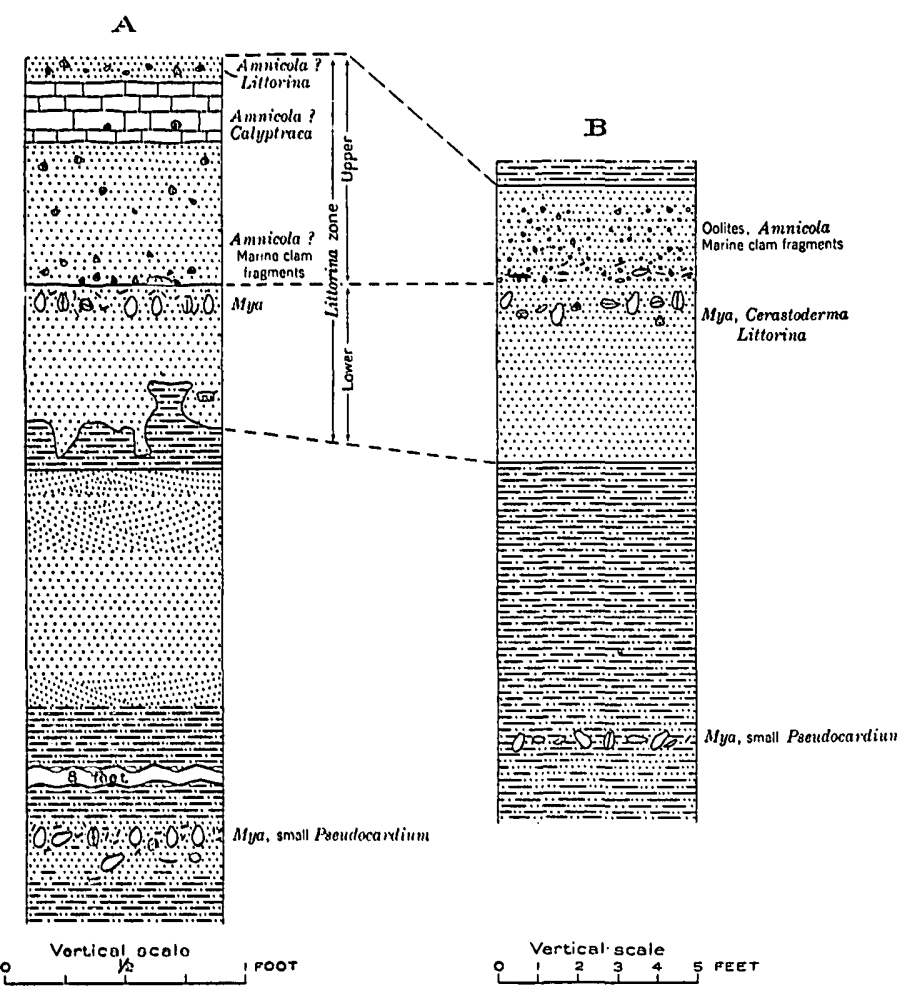

Fiauks 0.-Sections of Littorina zone of Etchegoin formation and immediately undorlylug strata on west and cast flanks of North Dome. The fossils are not drawn to scale, and thoir position is generalized.

A. Wost flank; 400 fect southeast of JI Piso, scc. 19, T. 22 S., R. 17 E.

B. East flank; oxcavation for woll location near southwest corner of sec. 6, T. 22 S., R. 18 E.

and its surface is shown by contours on the geologic structure map (pl. 51). The zone is interbedded with silt and clay between the overlying first blue sandstone and the underlying blue sandstones associated with the upper Pseudocardium zone. Where the oolite layer is absent the exact position of the zone in the interval between the more conspicuous outcrops of the underlying and overlying blue sandstones may be difficult to determine.

Littorina is not confined to this zone, and, therefore, the name of the zone is not ideal. This genus occurs in the underlying upper Pseudocardium zone and also at several horizons in the San Joaquin formation. It is, however, a common fossil in the Littorina zone and at localities where the two parts are present occurs in both the lower marine part and the upper fresh-water $152180-40-5$ part. Fresh-water fossils occur in overlying Etchegoin strata, but Littorina has not been found with them. The marine faunal association in the oolite in the lower part of the San Joaquin formation (described as the upper oolite under the heading "Strata between Neverita zone and Cascajo conglomerate member") resembles that in the lower part of the Littorina zone, but Littorina is absent.

At El Piso, on the west side of La Cima, the type locality of the Littorina zone (locality 218 ; pl. 25, C), the upper part of the zone consists of the hard oolite, half a foot thick, overlain by pebbly cross-bedded sandstone, one foot of which is exposed. The sandstone also contains some oolites. Some indication of cross-bedding is evident in the oolite layer, which contains at least some sand grains. The oolites are brown and smooth, many have concentric layers, and some are hollow. In the lower part of the zone is a gray sandstone, a foot of which is exposed. The upper part of the gray sandstone is very fossiliferous, and the lower part is silty.

Sections of the Littorina zone and immediately underlying strata are shown in figure 9. The following section, which includes the zone, was measured at the locality represented in figure $9, \mathrm{~B}$ :

Section of strata in upper part of Etchegoin formation, including Littorina zone, exposed in excavation for well location near southwest corner of sec. 6, T. 2Q S., R. $18 \mathrm{E}$.

Strata overlying Littorina zone:

Thin-bedded gray sand. Discontinuity at base... -

Laminated silty clay weathering greenish gray. Numerous brown streaks and seams of gypsum half an inch to 2 inches wide cutting bedding or parallel to it. Discontinuity at base........... Littorina zone:

Greenish-gray oolitic and fossiliferous sandstone. Discontinuity at base....................... Strata underlying Littorina zone:

Gray laminated silt. $\quad M y a$ in living positions a foot above base and few small Pseudocardium. Discontinuity at base .......

Greenish-gray rather massive silt. May correspond to greenish band beneath Littorina zone at some weathered outcrops. Contact at base grada-

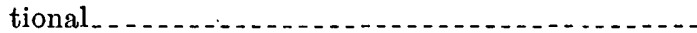

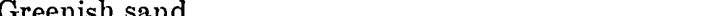

The zone was traced with little difficulty except on the west flank of the anticline between Cerro Alto and El Leon and at the extreme north and south ends of the anticline.

In the area between the north slope of Cerro Alto and El Leon the typical Littorina zone was not recognized along the main outcrop west of the strike faults, and the observations seem to indicate that in parts of the area at least the zone was eroded away before or during the deposition of the Cascajo conglomerate (?) or the first blue sandstone. In part of this region a layer containing $M y a$ and shell fragments, locally truncated by a blue sandstone, is thought to represent the Littorina 
zone Locally an inconspicuous layer containing Mya and small Pseudocardium is about 20 feet lower in the section. In view of the faunal association this $M y a-$ Pseudocardium layer, rather than the overlying Mya layer, is considered the equivalent of the Mya-Pseudocardium layer that at places on both flanks of the anticline is 7 to 10 feet below the base of the Littorina zone. (See fig. 9.)

Localities near the northwest corner of sec. 2, T. $22 \mathrm{~S}$., R. $17 \mathrm{E}$. , and in the bottom of Arroyo Bifido half a mile to the east are the northernmost observed occurrences of the zone, but oolites were not recognized at these localities. At locality 224, farther south near Cerro Lodoso, the oolite layer, which is practically horizontal, appears to grade westward in a distance of 10 to 15 feet into a limy clay containing $M y a$ and Pseudocardium. The continuity of the strata was not established, but it is evident that at this locality Pseudocardium occurs in the Littorina zone or just below it. Farther to the west and across a fault a layer with $M y a$ and Pseudocardium appears to represent the Littorina zone.

No oolites were observed in the zone toward the south end of the anticline. The zone was reasonably well identified as far south as Broken Hill on the east flank and Drillers Ridge on the west flank. Farther south a layer containing $M y a$, "Pseudocardium, and Anadara at localities 226 and $238 \mathrm{a}$ and a $M y a$ layer at locality 228 were mapped as the Littorina zone. The fossiliferous strata at these localities may correspond to the Mya-Pseudocardium layer about 10 feet below the
Littorina zone shown in figure 9, but the Littorina zone was not found above them. However, a Littorina zone association was found still farther south on the Paso Robles-Hanford road just west of the Arroyo del Paso crossing. At that locality Littorina, Mya, and Calyptraea occur in a 2-inch layer of silt containing some grit and gypsum. As no complete exposures were found in this region, it is quite possible that both the MyaPseudocardium layer and at least the lower part of the Littorina zone may be present.

The faulted outcrops of the Littorina zone afford the most conspicuous evidence for the troughlike structure of the crest of North Dome. The most striking example of the repetition of the zone by faulting is on the south slope of Las Paredes. At this locality the oolite layer, with the upper Pseudocardium zone 40 feet below it, caps a hill and is about 300 feet lower stratigraphically than the main outcrop at the foot of El Rascador. Similar faulting on the west side of La Muralla is more accessible. North of La Cima the Littorina zone, including the oolite layer, is repeated four times. An assumption that these outcrops represent as many Littorina zones in different stratigraphic positions is made untenable not only by observations on some of the fault planes but also by the repetition of other identifiable strata in the separate fault blocks.

Fossils.-Fossils from the Littorina zone are listed in the following table, and three of the species are shown on plates 29 and 39 .

Fossils from Littorina zone of Etchegoin formation

[Identifications by Ralph Stewart. F, fragments; P, paired valves; $S$, small specimens]

\begin{tabular}{|c|c|c|c|c|c|c|c|c|c|}
\hline \multirow{2}{*}{ Species } & \multicolumn{9}{|c|}{ Localities } \\
\hline & 218 & 219 & 221 & 223 & 225 & 226 & 227 & 229 & $238 \mathrm{a}$ \\
\hline $\begin{array}{l}\text { Gastropods: } \\
\text { Littorina mariana Arnold (pl. 29, figs. 8, 9) } \\
\text { Amnicola? sp. } \\
\text { Calyptraea cf. C. inornata (Gabb) } \\
\text { Pelecypods: } \\
\text { Anadara sp } \\
\text { Macoma affinis plena Stewart n. var. (pl. 29, fig. 12) } \\
\text { Pseudocardium sp. } \\
\text { Cerastoderma cf. C. meekianum (Gabb) small var. (pl. 29, fig. } \\
\text { 3) } \\
\text { Mya cf. } M \text {. dickersoni Clark. } \\
\text { Solen sp. }\end{array}$ & $\begin{array}{l}\mathrm{X} \\
\mathrm{X} \\
\mathbf{X} \\
\mathbf{X} \\
\mathbf{P} \\
\mathbf{P}\end{array}$ & 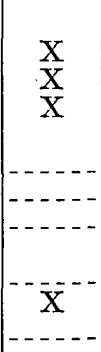 & 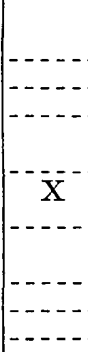 & $\begin{array}{c}\mathrm{X} \\
\mathrm{F} \\
\stackrel{\mathrm{P}}{\mathrm{P}} \\
\mathrm{P}\end{array}$ & \begin{tabular}{c}
$\mathrm{X}$ \\
$\mathrm{X}$ \\
\hdashline$-\cdots$ \\
\hdashline $\mathrm{X}$ \\
\hdashline \\
\hdashline \\
\hdashline
\end{tabular} & 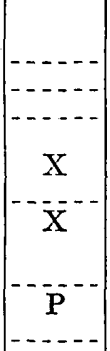 & 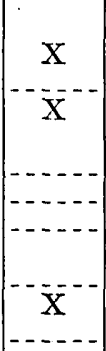 & $\begin{array}{c}x \\
X \\
X \\
X\end{array}$ & $\begin{array}{c}X \\
-P^{-} \\
-S\end{array}$ \\
\hline
\end{tabular}

Where the Littorina zone consists of an upper part and a lower part fresh-water fossils were not found in the lower part; that is, they do not occur below the oolite. Many of the marine fossils in the lower part are in living positions and may have been killed by freshening of the water. Littorina mariana (pl. 29, figs. 8, 9), Mya .cf. $M$. dickersoni, the small Macoma affinis plena (pl. 29, fig. 12), and a small variety of
Cerastoderma cf. C. meekianum (pl. 29, fig. 3) are the most abundant fossils in the lower part of the zone or in the fossiliferous layers of the zone at localities where the upper part is not present. The fresh-water snail in the upper part of the zone, identified as Amnicola?, is abundant, but the specimens are not well enough preserved to be identified with certainty. It is reasonably certain, however, that they represent a fresh-water form. 
The marine fossils associated with the fresh-water snails consist of fragments of clams, aside from the gastropods Littorina and Calyptraea. These marine fossils may be accounted for by assuming that they were derived from the underlying part of the zone. Some of the marine fossils in the upper part of the zone, however, notably Littorina, may have been able to survive in brackish or almost fresh water.

Anadara was not found in the Littorina zone itself but in the Mya-Pseudocardium layer mapped as the zone toward the south end of North Dome.

Though Pseudocardium is abundant in strata only about 60 feet below the Littorina zone, its absence from the Littorina zone is very striking and is characteristic of the whole area of North Dome with but few known possible exceptions. These exceptions represent localities near the extremities of the anticline, where the oolite was not observed. At these localities poorly preserved medium-sized specimens of Pseudocardium associated with Mya occur in a layer mapped as the Littorina zone. It seems likely, however, that the layer containing Pseudocardium near the south end of the anticline is not the exact equivalent of the Littorina zone, and perhaps the similar layer near the north end is also not the exact equivalent. In Arroyo Largo (locality 246) at the northwest end of the anticline an isolated outcrop contains fresh-water snails and Pseudocardium. This outcrop may represent the Littorina zone, but it was mapped as the upper Pseudocardium zone.

\section{STRATA BETWEEN LITTORINA ZONE AND UPPER PSEUDOCARDIUM ZONE}

The strata between the Littorina and Pseudocardium zones have a thickness of 40 to 70 feet. They consist chiefly of sandy silt and silty clay, but at some localities include a considerable thickness of sand and sandstone. On the south side of La Palomera a thin lens of practically pure tuff, consisting principally of volcanic glass, occurs about 20 feet above the upper Pseudocardium zone. The Mya-Pseudocardium layer occurring locally about 10 feet below the Littorina zone is mentioned under the heading "Littorina zone" and is shown in figure 9. About 500 feet south of the type locality of the Littorina zone this layer contains Calyptraea and Macoma? as well as Mya and Pseudocardium.

At some localities a pebbly blue sandstone or conglomerate overlies the upper Pseudocardium zone and locally cuts across the upper part of the zone. In fact, at places near the north end of North Dome and in the entire area at the south end of the anticline the upper Pseudocardium zone is cut out by conglomerate in this part of the section, or the zone grades laterally into conglomerate. Barbat and Galloway ${ }^{62}$ placed the San Joaquin-Etchegoin boundary at this horizon-at the base of lenticular blue sandstone overlying the upper

02 Barbat, W. F., and Galloway, John, San Joaquin clay, Ca!ifornla: Am. Assoc. Potroleum Goologists Bull., vol. 18, pp. 480 (table), 482, 1934.
Pseudocardium zone. Barbat and Galloway's classification has the advantage of drawing the boundary immediately above the upper limit of abundant Pseudocardium. It has also the further advantage of placing in the San Joaquin formation the earliest fresh-water deposits occurring in the Littorina zone and overlying strata. Their classification, however, is difficult to apply in Middle and South Domes unless the term "upper Pseudocardium zone" is loosely used, as, in fact, it may be in other areas.

The following section of strata between the Littorina and upper Pseudocardium zones was measured at the southeast end of El Leon.

Section of strata in upper part of Etchegoin formation between Littorina and upper Pseudocardium zones at southeast end of El Leon (locality 298)

Littorina zone: Greenish-gray sandstone, many shells in upper part-Littorina, Mya (in living positions), and small Macoma...................................

Greenish-gray sand with some indurated purplish-brown layers and a 2-foot pebble bed at base. Pebbles consisting of chert and quartz mostly less than half an inch long. Scour discontinuity at base................

Grayish-blue and purple clayey silt with a light-gray clay about 2 feet thick at top and a purplish sand about a

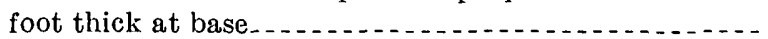

Dark-gray sand, weathering light gray ............... Poorly exposed gray sandy silt . . . . . . . . . . . . . . .

Coarse-grained sandstone, greenish in upper part, bluish in lower part. Pebbles and laminated sandstone near

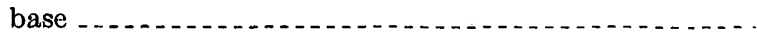
Upper Pseudocardium zone (see continuation of section p. 62).

Thickness of strata between Littorina and upper Pseudocardium zones.......................

Sycamore and willow leaves, identified by R. W. Brown as Platanus paucidentata and Salix coalingensis, were found at locality 271a, near the south end of the anticline, in blue sandstone estimated to be just above the horizon of the upper Pseudocardium zone.

UPPER PSEUDOCARDIUM ZONE (UPPER MULINIA ZONE)

Stratigraphy and lithology.-The upper Pseudocardium zone is about 175 feet below the top of the Etchegoin formation. It consists generally of fossiliferous sandstone containing abundant large Pseudocardium but at places also includes nonfossiliferous silty sand and silty clay. The thickness is variable. At localities where the zone is well developed it is about 25 feet thick.

This zone essentially marks the upper limit of Pseudocardium in North Dome. It roughly corresponds to the upper Mulinia zone of Arnold and Anderson, ${ }^{63}$ who indicated the upper Mulinia zone on their geologic map of the Kettleman Hills by a red line. ${ }^{64}$ Arnold and Anderson's upper Mulinia zone evidently included more than the upper Pseudocardium, however, for they cited a thickness of 150 feet for

${ }^{63}$ Arnold, Ralph, and Anderson, Robert, op. cit. (Bull. 398), pp. 119, 122, 123. 136 or Idem, pl. 1. 
their zone in North Dome. ${ }^{65}$ Both the Kreyenhagen Hills and Kettleman Hills were mentioned in the description of the upper Mulinia zone, and no type locality has been designated. Unless better sections are found in the Kreyenhagen Hills, it is suggested that the south end of El Leon (locality 238) be considered the type locality of the upper Pseudocardium zone.

The name of the zone is changed because the species for which it is named, Mulinia densata, is now assigned to Pseudocardium. The change in nomenclature is not so drastic as it may appear to be, for the fossil has been cited as Pseudocardium gabbi ${ }^{66}$ and as Mactra (Pseudocardium) densata. ${ }^{67}$

The upper Pseudocardium zone was not examined in detail because of its proximity to the Littorina zone, which is usually more easily mapped. It was examined and mapped, however, at many localities. At the south end of North Dome it appears to be absent, and at the extreme north end the facies is not typical.

The standard section of the upper Pseudocardium zone in North Dome is exposed at locality 238 at the south end of El Leon, where the following section was measured (pl. 26, $B$ ).

Section of upper Pseudocardium zone of Etchegoin formation at south end of El Leon (locality 238)

Upper Pseudocardium zone. Overlain by coarsegrained sandstone; (For upward continuation of section, see p. 61):

Gray fossiliferous sandstone with bed of Pseudocardium forming prominent 2-foot layer. Large and small Pseudocardium and a few small sand dollars. Contact at base abrupt, sand filling borings penetrating underlying

Gray sandy clay. Contact at base not well exposed

Gray silty sandstone with three fossiliferous layers. Contact at base abrupt:

More or less barren.....

Upper fossiliferous layer.

Large thin sand dollars. (Some Pseudocardium, Cerastoderma, and Gilycymeris farther south) ............

More or less barren ................

Middle fossiliferous layer.

Mytilus, Saxidomus, Anadara, and oysters.

(Probably represented at locality 237a, 800 feet south, by a bed containing oysters, Anadara, Saxidomus, and Pseudocardium)

Ft. in. 8

1

${ }^{65}$ Arnold, Ralph, and Anderson, Robert, op. cit. (Bull. 398), p. 122.

${ }_{68}$ Pack, R. W., The Sunset-Midway oil field, Calif., pt. 1, Geology and oil resources: U. S. Geol. Survey Prof. Paper 116, p. 45, 1920.

97. Grant, U. S., IV, and Gale, H. R., Catalogue of the marine Pliocene and Pleistocene Mollusca of California: San Diego Soc. Nat. History Mem., vol. 1, p. 403, 1931.

Section of upper Pseudocardium zone of Etchegoin formation at south end of El Leon (locality 238)-Continued

Upper Pseudocardium zone-Continued.

Gray silty sandstone with three fossiliferous layers-Continued.

$F t$.

More or less barren.....................

Lower fossiliferous layer. Medium-sized Pseudocardium, Cerastoderma, Saxidomus, a few fragments of sand dollars, and oysters. (About 200 feet to the south the Saxidomus are in living positions with their posterior ends pointing upward)

Barren.......

Thickness of upper Pseudocardium zone_ $29+$

In this section the zone is 29 feet thick and the top is 58 feet below the Littorina zone. This stratigraphic position for the upper Pseudocardium zone, about 60 feet below the Littorina zone, is fairly consistent along the greater part of the west flank of the anticline. A readily accessible locality is on the south side of the Skyline road east of El Chichon (locality 240), where the following section was measured. In this section the zone is only 5 feet thick and consists of buff silty sandstone containing three fossiliferous layers, probably corresponding to the 15 -foot gray silty sandstone at the base of the section on El Leon.

Section of upper Pseudocardium zone of Etchegoin formation on south side of Skyline road east of El Chichon (locality 240)

Barren buff silty sandstone. Locally cut out by over- Ft. in. lying coarse-grained pebbly blue sandstone._._._._. 14

Fossiliferous layer. Mostly broken Pseudocardium -..- 10

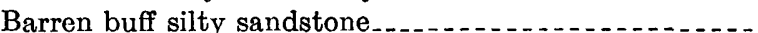

Fossiliferous layer. Scattered Pseudocardium.........

Barren buff silty sandstone

Main fossiliferous layer (locality 240). Pseudocardium,

Anadara, Venerupis, Solen, oysters, and thin sand

dollars

Thickness of upper Pseudocardium zone........

5

Another accessible locality where the zone is well exposed is on the southwest end of Discovery Ridge, on the top of a small hill just abovie the road (locality 242). At this locality the zone is closer to the axis of the anticline owing to displacement by faults. At locality 243, northeast of Cerro Lodoso, the zone is marked by two fossiliferous layers 15 feet apart:

At the north end of the anticline, in Arroyo Largo and its tributaries, the upper Pseudocardium zone, like the Littorina zone, is not easily mapped, partly owing to poor exposures but also apparently owing to a change in facies. Several layers in this region containing Pseudocardium and other fossils probably represent the zone. The most notable feature in this region is the occurrence in some layers of great numbers of the small pelecypod Transennella. 
At locality 250, on the east flank of the anticline east of Double Hill, the zone, represented by a 1 -foot brown silty sandstone containing Pseudocardium, is 72 feet below the Littorina zone. It is unlikely that this 1 -foot fossiliferous sandstone is the equivalent of the 29-foot section on IEl Leon. The 1-foot sandstone may be the equivalent of the basal part of the $\mathrm{El}$ Leon section and the 30 feet of nonfossiliferous brown silty sandstone overlying the 1-foot sandstone may corre'spond to the remainder of the $\mathrm{El}$ Leon section. The nonfossiliferous silty sandstone is overlain by cross-bedded pebbly blue sandstone.

The zone was not definitely recognized south of the south branch of Arroyo Robador on the east flank of the anticline and south of a locality east of Cerro Ultimo on the west flank. Strata in the estimated stratigraphic position of the zone around the south end of the anticline are apparently nonfossiliferous. A conglomerate that forms the northeastward-trending row of hills just south of Arroyo Estrecho and east of Pipe Hill is thought to be in the stratigraphic position of the zone. Possibly the zone is cut out by this conglomerate. If so, the conglomerate corresponds to the pebbly blue sandstone overlying the zone at localities farther north.

In the faulted trough of the anticline near the axis the upper Pseudocardium zone is represented by a Pseudocardium-Mya layer 40 feet below the Littorina zone south of Las Paredes, and by a sandstrone containing Pseudocardium and thin sand dollars also 40 feet below the Littorina zone west of La Muralla. A bed containing small Anadara, oysters, and fragments of Pseudocardium on top of the knoll 500 feet south of the north quarter corner of sec. 18, T. 22 S., R. 18 E., is correlated with the upper Pseudocardium zone.

Fossils.-The fossils collected from the upper Pseudocardium zone are listed in the following table. The characteristic species are shown on plates $29,30,39$ to 41 .

Fossils from upper Pseudocardium zone (upper Mulinia zone) of Etchegoin formation

[Identiflcations by Ralph Stewart. F, fragments; P, paired valves; S, small specimens]

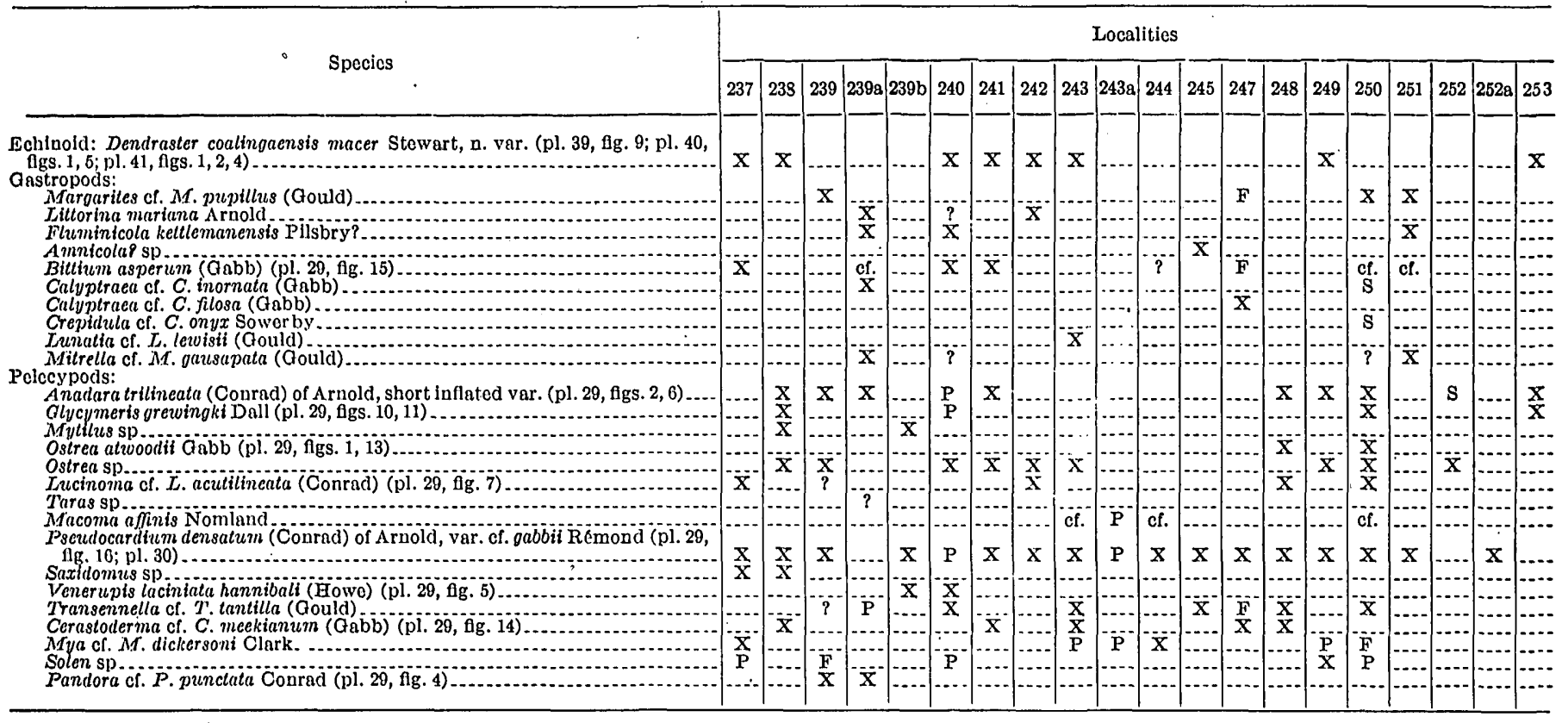

The fauna of the upper Pseudocardium zone is a small marine fauna. Fresh-water snails were found with the marine fossils at several localities in the northern part of the anticline. Petrified wood occurs in the zone, particularly on the east flank of the anticline near the north end. Remains of land mammals are, however, rare. Fragments of a horse tooth at locality 243a may have come from the zone.

The upper Pseudocardium zone is usually identified by the great abundance of Pseudocardium densatum.
This species is also abundant at lower horizons, but at these lower horizons Mya is very scarce. The usual form of Pseudocardium densatum in the upper Pseudocardium zone (pl: 29, fig. $16 ; \mathrm{pl} .30$ ) is similar to the varicty gabbii. The thin sand dollar Dendraster coalingaensis macer (pl. 39, fig. 9; pl. 40, figs. 1, 5; pl. 41, figs. $1,2,4)$ was found only in this zone. The zone is further characterized by the highest occurrence of Glycymeris grewingki (pl. 29, figs. 10, 11), Ostrea atwoodii (pl. 29, figs. 1, 3), Lucinoma cf. L. acutilineata 
(pl. 29, fig. 7), and Venerupis laciniata hannibali (pl. 29, fig. 5), and by the occurrence of a short inflated form of Anadara trilineata (pl. 29, figs. 2, 6).

Occurrence in San Joaquin Valley subsurface section.The uppermost occurrence of abundant Pseudocardium in the subsurface section in the southern San Joaquin Valley has been correlated with the upper Pseudocardium zone. ${ }^{68}$ According to Barbat and Galloway's composite subsurface section, the subsurface upper Pseudocardium zone underlies fresh-water deposits including the lower Scalez zone. The fresh-water deposits are in the stratigraphic position of the Littorina zone, or of fresh-water strata overlying the Littorina zone, and occur below a marine zone suggested in the present report as the equivalent of the Cascajo conglomerate member at the base of the San Joaquin formation. The succession of zones in the composite subsurface section, therefore, is essentially the same as in a composite North Dome-South Dome section. In subsurface sections that have this succession of zones the correlation of the upper Pseudocardium zone with the upper Pseudocardium zone of North Dome is reasonably certain. In subsurface sections that lack this succession of zones, however, the uppermost occurrence of Pseudocardium may not invariably represent the same horizon. The doubtful stratigraphic quality of the uppermost occurrence of Pseudocardium is illustrated in the Kettleman Hills. In North Dome this genus occurs rarely in, or just below, the Littorina zone. In Middle and South Domes it occurs in the Cascajo conglomerate member of the-San Joaquin formation, possibly as transported fossils, and is abundant in a zone considered the essential equivalent of the Littorina zone. Though the thickness of strata involved in these uppermost occurrences of Pseudocardium in the Kettleman Hills is negligible for purposes of regional correlation, in other sections the thickness may be greater.

\section{STRATA BETWEEN UPPER PSEUDOCARDIUM ZONE AND SIPHONALIA ZONE}

The strata between the upper Pseudocardium and Siphonalia zones have a thickness of 45 to 80 feet, generally about 70 feet. Nonfossiliferous sandy silt and sandstone predominate in this part of the section. At some localities a blue conglomerate immediately overlies the Siphonalia zone and cuts out strata in the zone. Locally the blue conglomerate contains Pseudocardium, sand dollars, and mastodon remains, generally tusk fragments. A section of these strata measured at the south end of El Leon, where the blue conglomerate is not present, is given below (pl. 28, column 6).

${ }^{68}$ Barbat, W. F., and Galloway, John, op. cit. (Am. Assoc. Petroleum Geologists Bull., vol. 18), p. 487, fig. 1 (p. 488).

Section of strata in Etchegoin formation between upper Pseudocardium zone and Siphonalia zone at south end of El Leon (locality 238)

Upper Pseudocardium zone. (For upward continuation of section, see p. 62.)

Laminated sandy silt. Contact at base abrupt......... Light-gray clay, sandy at base Poorly exposed laminated sandy silt Greenish sand, weathering dark brown ............. Dark-gray and some light-gray laminated sandy silt..... Fine-grained dark gray sand. Contact at base abrupt. Probably corresponds to blue conglomerate elsewhere overlying Siphonalia zone..............................

Greenish sand and poorly bedded silt assigned to Siphonalia zone.

Thickness of strata between upper Pseudocardium zone and Siphonalia zone........

\section{3}

3

15

10

20

9

SIPHONALIA ZONE

Stratigraphy and lithology.-Brown silt and fossil iferous brown silty sand and sandstone, 100 to 150 feet thick, are designated the Siphonalia zone. Tha top of the zone is 135 to 200 feet below the Littorina zone. At some localities the Siphonalia zone is overlain by blue conglomerate that cuts across strata in the zone. At localities - where the blue conglomerate is absent the top of the zone is placed at the top of fossiliferous strata, as in the section at the south end of El Leon (pl. 28, column 6). Locally a blue sandstone, at the base of which is a scour discontinuity, forms the base of the zone, and at places lenses of blue sandstone occur in the zone. A layer of tuff less than a foot thick is present near the top of the zone, and a fossiliferous gravel occurs near the base of the zone in the northern part of the anticline.

The type locality of the Siphonalia zone is on Arroyo Doblegado, near the northeast corner of the SW 14 sec. 16, T. 22 S., R. 18 E. At this locality the zone is 113 feet thick, including a blue sandstone at the base, and is overlain by blue conglomerate (pl. 28, column 10). The name of the zone is derived from a large gastropod, Siphonalia kettlemanensis. This species has not been found above the zone, though the genus occurs in the upper part of the San Joaquin formation. The Siphonalia zone is the highest zone in the Etchegoin formation containing large gastropods. Many pelecypods found in the zone are also large, a large Mytilus being one of the most abundant fossils. Sand dollars are abundant in the zone, generally in lenses of sand practically devoid of other fossils. Mastodon remains, generally fragments of tusks and molar teeth but at one locality a skull, occur near the top of the zone as well as in the overlying blue conglomerate. Fossil plants were also found in the upper part of the zone. 
The zone includes several fossiliferous layers. Usually but one main layer is present in a given section, but fossils may be present at intervals through a thickness of more than 100 feet. The main layers are shown locally on the geologic map (pl. 3). The correlation of the lityers has not been attempted, and it is doubtful whether they could be satisfactorily correlated, for the main layer becomes nonfossiliferous when traced laterally a few hundred feet, and it is in different parts of the section at different localities. At some outcrops, where two fossiliferous layers or sets of layers occur about 50 fect apart, the zone may be divided into two parts. At some localities, notably on the west side of La Aleta and in Arroyo Estrecho, the fossiliferous layers or ledges are not parallel to each other or to the general stratification of adjacent strata. At a locality in Arroyo Estrecho, shown on plate 27, B, a Mytilus layer underlying and essentinlly parallel to massive sandstone truncates sandy silt. Irregular bedding of this nature, which is apparently a local phenomenon, was also observed in the Pecten zone of the San Joaquin formation.

Because of the thickness of the zone and the lenticular nature of the fossiliferous layers the Siphonalia zone is not such a satisfactory horizon marker as the Littorina and upper Pseudocardium zones. The apparent complexity of the Siphonalia zone is partly due to its position in faulted strata but may also be due to different conditions of sedimentation. than those of the higher zones.

A section of the Siphonalia zone at the type locality is shown below.

Section of Siphonalia zone of Etchegoin formation at type locality in road cut at forks of Arroyo Doblegado near northeast corner $S W 34$ sec. 16, T. 22 S., R. $18 \mathrm{E}$.

16. Gray silty sand with irregular half-inch layer of clay. Overlain by a 40 -foot blue conglomerate consisting of cross-bedded coarse-grained sandstone with pebbles and clay fragments near base and 15 feet above base. Base of blue conglomerate marked by a discontinuity. Top of Siphonalia zone 65 feet below upper Pseudocardium zone, a 5-foot fossil-

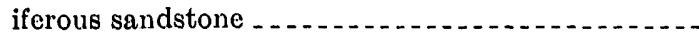

15. Concretionary fossiliferous layer. Mostly Pseudocardium, but some Venerupis and Macoma. Matrix similar to adjacent strata or a little coarser.......

14. Sandy silt. Discontinuity at base

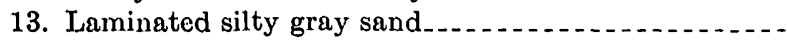

12. Gray sand with pebbles and few fossils. Macoma, large Glycymeris, and small Cerastoderma, the last two represented by paired valves. Discontinuity at base marked by sand penetrating underlying sand in borings.

11. Silty sand similar to unit 13

10. Gray silty fossiliferous sand. Chiefly paired Pseudocardium, which form a layer near top and another near bottom; paired Solen, Venerupis, and small Mytilus just below upper layer................

9. Massive silty sand.
Section of Siphonalia zone of Etchegoin formation at type locality in road cut at forks of Arroyo Doblegado near northeast corner $S W 34$ sec. 16, T. 22 S., R. 18 E.-Continued.

8. Fossiliferous sandstone. Large Mytilus, Pseudocardium, paired Schizothaerus, large Cerastoderma, large "Nassa," Venerupis, Glycymeris, large Anadara. Just above indurated layer sand contains small sand dollars, Glycymeris, and small Crepidula

7. Gray sand similar to unit 8; large Pseudocardium and large and abundant sand dollars in lower 2 feet...

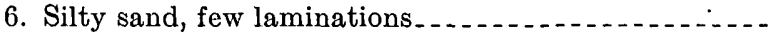

5. Fossiliferous sandstone. Upper part contains many shell fragments. Fauna apparently similar to that of unit 8 .

4. Sand with thin layers of clay at top and bottom. Lowest part of sand bluish.....................

3. Massive coarse-grained blue sandstone. . . . . . . . .

2. Laminated silt. . . . . . . . . . . . . . . . . . .

1. Massive coarse-grained blue sandstone with pebbles chiefly about 5 feet above base. Cross-bedded near base and much finer grained at top. Discontinuity at base. Underlain by laminated grayish-green silt probably representing top of Macoma zone....

Thickness of Siphonalia zone

Feet

In this section there are two main fossiliferous layers 20 feet apart, and large sand dollars are abundant just below the upper layer.

The following section was measured on the south side of La Aleta (locality 283; pl. 28, column 12).

Section of Siphonalia zone of Etchegoin formation on south side of La Aleta, NE1/4 sec. 20, T. 22 S., R. 18 E. (locality 283)

Brownish bedded silt, Pseudocardium near top. Overlain by blue sandstone, conglomeratic at base; base marked by discontinuity ..........................

Fossiliferous sand; Glycymeris, Tellina, Cerastoderma, and

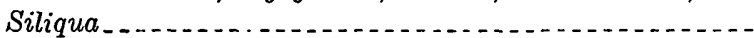

Bluish sand containing abundant Pseudocardium, also Venerupis, Mytilus, and Solen......................

Brown and blue silty sand. Paired Mytilus filled with green clay forms layer near top. Ledges containing barnacles, Mytilus, sand dollars, and oysters, and a 5 -foot bed of blue sand near base. Discontinuity at base

Feet 30 $1 / 6$

Blue sandstone with few pebbles. Discontinuity at base. (Underlain by light gray micaceous silty sand of Macoma zone, containing Macoma and sand dollars near top) . . . .

Thickness of Siphonalia zone.................. $901 \%$

At the south end of El Leon, where the following section (pl. 28, column 6) is exposed, the blue conglomerate overlying the zone is not present.

Incomplete section of Siphonalia zone of Etchegoin formation at south end of El Leon, sec. 20, T. 22 S., R. $18 E$.

Greenish sand and poorly bedded silt. Three feet above base a 3-inch layer containing large Pseudocardium and small "Nassa." Contact at base abrupt. (For upward continuation of section see p. 64) . . . . . . . . . . . . .

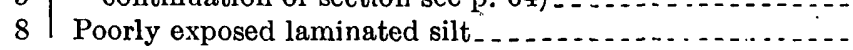

Feet 
Incomplete section of Siphonalia zone of Etchegoin formation at south end of El Leon, sec. 20, T. 22 S., R. 18 E.-Continued

Fine-grained gray sand. Fossiliferous layer near top containing Cerastoderma, Tellina, Calliostoma, large "Nassa," and large Siliqua...........................

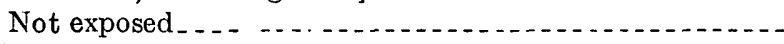

Sandstone ledge containing Pseudocardium, Mytilus, barnacles, and sand dollars. Contact at base abrupt.....

Light-gray sand with some silt in middle. A few oysters, Pseudocardium, and sand dollars near base.......... Light-gray'sand . . . ... . . . . . . . . . . . . . . . . . .

Sandstone ledge containing barnacles and Mytilus resting on gray sand containing numerous fragments of barnacles and Mytilus. The contact is practically parallel to the bedding, but large knobs of the ledge material extend about a foot into underlying sand, evidently filling pits in the surface of the sand. Base of zone not exposed.

Exposed thickness of Siphonalia zone

Feet

6

18

1

9

12

The blue conglomerate overlying the zone seems to be absent also on the west side of Los Jinetes, where the following section is exposed, but it is present 1,500 feet to the northwest on the hill between La Rusa and the Skyline road.

Incomplete section of Siphonalia zone of Etchegoin formation on west side of Los Jinetes, sec. 13, T. 22 S., R. 17 E. (locality 287)

12. Dark-purple sandstone containing Venerupis and Crepidula

11. Irregularly bedded sand and pebbles; Glycymeris, Venerupis, and fragments of a sand dollar near

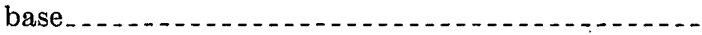

10. Poorly exposed sand and silt, including a lens containing Pseudocardium

9. Poorly exposed sand and silt

8. Fossiliferous sandstone stained purple, containing Macoma, Schizothaerus, and barnacles..........

7. Sand containing barnacles............................

6. Silt.

5. Sand similar to unit 7, but no barnacles observed..--

4. Unexposed, probably silt. . . . . .

3. Silty sand containing Macoma

2. Poorly exposed silt

1. Pebbly sand; poorly preserved shells in concretionlike knobs. Base of zone not exposed.

Exposed thickness of Siphonalia zone.......

The following incomplete section, measured at locality 291, shows only a Pseudocardium layer in the zone.

Incomplete section of Siphonalia zone of Etchegoin formation at locality 291, center of sec. 12, T. 22 S., R. 17 E.

Yellowish sandy silt. Overlain by blue conglomerate, the base of which is marked by a discontinuity ....... Pseudocardium layer in sand.

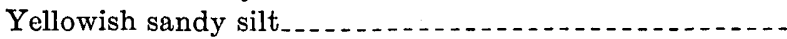

Blue sandstone. Discontinuity at base. Base of zone

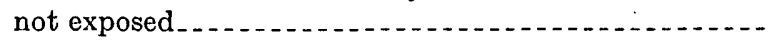

Exposed thickness of Siphonalia zone

Feet

50

1

$\cdot 18$

Fossils.-The characteristic fossils of the Siphonalia zone are shown on plates 31 to $33,39,40$, and 44 . The occurrence of the species is indicated in the accompanying chart.
The fauna of the Siphonalia zone is marine and includes a large proportion of large-shelled forms. Mytilus coalingensis (pl. 32, figs. 3, 4), which occurs at other horizons in the San Joaquin and Etchegoin formations, is one of the largest and most abundant species. Siphonalia kettlemanensis (pl. 31, figs. 1, 7), "Nassa" moranianus, and Forreria magister were not found above the Siphonalia zone. A variety of Forreria magister, however, occurs in the Pecten zone of the San Joaquin formation. Turritella vanvlecki (pl. 31, fig. 2), "Nassa" miser iniqua, Apolymetis cf. A. dombei (pl. 32, fig. 2), and the first Arca of the A. noae group to be recorded from the Coalinga district are not known to occur at other horizons in the Kettleman Hills, but these fossils are rare. An undetermined species of Siliqua (pl. 33, fig. 3) is widespread in the Siphonalia zone and occurs also at lower horizons. The form of Anadara trilineata in the Siphonalia zone (pl. 31, fig. 9) bas more centrally located beaks than $A$. trilineata proper and resembles Conrad's figure of $A$. canalis. A form having a similar outline occurs in the lower part of the San Joaquin formation. At some localities Pseudocardium densatum is as abundant in certain layers as it is in the upper Pseudocardium zone (pl. 27,C). The usual form is a variety similar to $P$. $d$. gabbii, some specimens that have a long anterior end (pl. 39, fig. 8) resemble Conrad's figure of $P$. densatum. The fragments of Lyropecten cf. L. estrellanus found on the surface at locality $282 \mathrm{a}$ probably represent a single valve. As this locality is near a former habitation this pecten may have been transported by man.

The typical form of the sand dollar Dendraster gibbsii (pl. 40, fig. 2) is abundant in the Siphonalia zone and was not found at higher horizons, except possibly in the immediately overlying blue conglomerate, and these specimens may have been derived from strata in the Siphonalia zone during the deposition of the conglomerate. A small sand dollar from the Siphonalia zone, characterized by large spine bases like those of Merriamaster, is considered a variety of $D$. gibbsii- $D$. gibbsii mirus (pl. 44, figs. 4, 5).

\section{M.ACOMA ZONE}

Stratigraphy and lithology.-The Macoma zone consists typically of light-gray massive cliff-forming tuffaceous sand and silt about 50 feet thick. The top of the zone is 250 to 350 feet below the Littorina zone. Owing to its light-gray color the zone is a conspicuous unit between the prevailingly brown Siphonalia and Patinopecten zones. (See pl. 26, $A, C$.) Plate 26, $C$, a view looking northward toward Las Paredes, shows tbree outcrops of the zone separated by faults. Layers containing Macoma more or less characterize the zone, but for the most part fossils are not conspicuous. At places the zone includes lenses of cross-bedded blue sandstone. Though the zone is locally indefinite, it is readily recognized in the central part of North Dome and is useful in determining the structure. 


\section{PLATE 29}

\section{[Figures natural size unless otherwise designated]}

Figure 1. Ostrea atwoodii Gabb. Length $51 \mathrm{~mm}$., height $61 \mathrm{~mm}$., thickness $16 \mathrm{~mm}$. Locality 248, upper Pseudocardium zone. U. S. Nat. Mus. 495783.

2. Anadara trilineata (Conrad) of Arnold, short inflated var. Length $38 \mathrm{~mm}$., height $33 \mathrm{~mm}$., thickness $13 \mathrm{~mm}$. Locality 224, upper Pseudocardium zone. U. S. Nat. Mus. 495784.

3. Cerastoderma cf. C. meekianum (Gabb), small var. Length $41 \mathrm{~mm}$., height $36 \mathrm{~mm}$., thickness about $10 \mathrm{~mm}$. Locality 220, Littorina zone. U. S. Nat. Mus. 495785.

4. Pandora cf. P. punctata Conrad. Length $30 \mathrm{~mm}$., height $19 \mathrm{~mm}$., thickness $4.3 \mathrm{~mm}$. Locality 239a, upper Pseudocardium zone. U. S. Nat. Mus. 495786.

5. Venerupis laciniata hannibali (Howe). Length $47 \mathrm{~mm}$., height $41 \mathrm{~mm}$., thickness $13 \mathrm{~mm}$. Locality 239b, upper Pseudocardium zone. U. S. Nat. Mus. 495787.

6. Anadara trilineata (Conrad) of Arnold, short inflated var. Length $35.5 \mathrm{~mm}$., height $33 \mathrm{~mm}$., thickness $13.6 \mathrm{~mm}$. Locality 250, upper Pseudocardium zone. U. S. Nat. Mus. 495788.

7. Lucinoma cf. L. acutilineata (Conrad). Length $43 \mathrm{~mm}$., height $39.6 \mathrm{~mm}$., thickness of both valves $18.5 \mathrm{~mm}$. Locality 250, upper Pseudocardium zone. U. S. Nat. Mus. 495789.

8, 9. Littorina mariana Arnold. Locality 218, Littorina zone.

8. Height (incomplete) $16 \mathrm{~mm}$., width $12 \mathrm{~mm}$. U. S. Nat. Mus. 495790.

9. Height (incomplete) $10 \mathrm{~mm}$., width $8.2 \mathrm{~mm}$. U. S. Nat. Mus. 495791 .

10, 11. Glycymeris grewingki Dall. Locality 253, upper Pseudocardium zone.

10. Length $33 \mathrm{~mm}$., height $34 \mathrm{~mm}$., thickness $10 \mathrm{~mm}$. U. S. Nat. Mus. 495792 .

11. Length $30 \mathrm{~mm}$., height $30 \mathrm{~mm}$., thickness $8.3 \mathrm{~mm}$. U. S. Nat. Mus. 495793.

12. Macoma affinis plena Stewart, n. var. Length (almost complete) $24.6 \mathrm{~mm}$., height $19 \mathrm{~mm}$., thickness about $6 \mathrm{~mm}$. Locality 218, Littorina zone. U. S. Nat. Mus. 495794.

13. Ostrea atwoodii Gabb. Length $42 \mathrm{~mm}$.; height $40 \mathrm{~mm}$., thickness $12.5 \mathrm{~mm}$. Locality 250, upper Pseudocardium zone. U. S. Nat. Mus. 495795.

14. Cerastoderma cf. C. meekianum (Gabb). Length $63 \mathrm{~mm}$., height $57 \mathrm{~mm}$., thickness $23 \mathrm{~mm}$. Locality 250 , upper Pseudocardium zone. U. S. Nat. Mus. 495796. This specimen has about 28 anterior ribs and a thick internal callus.

15. Bittium asperum (Gabb). Height (incomplete) $13.7 \mathrm{~mm}$., width $5 \mathrm{~mm}$. Locality 239a, upper Pseudocardium zone. U. S. Nat. Mus. 495797.

16. Pseudocardium densatum (Conrad) of Arnold, var. cf. gabbii Rémond. Length $95 \mathrm{~mm}$., height $81 \mathrm{~mm}$., thickness $35 \mathrm{~mm}$. Locality 252a, upper Pseudocardium zone. U. S. Nat. Mus. 495798. 


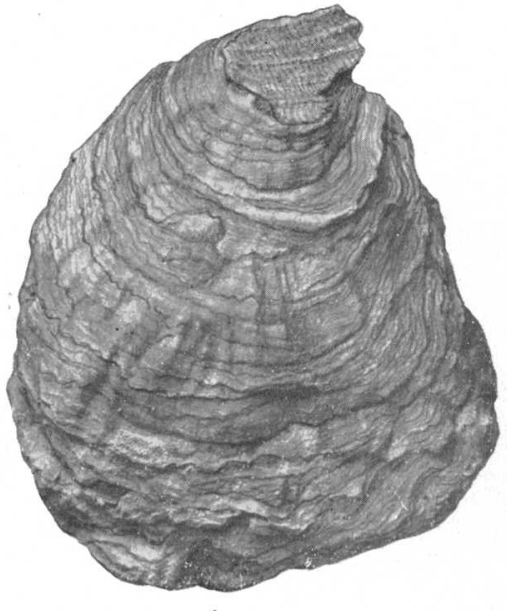

1

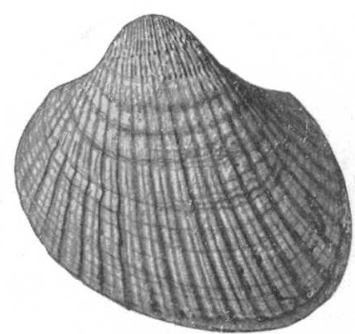

6

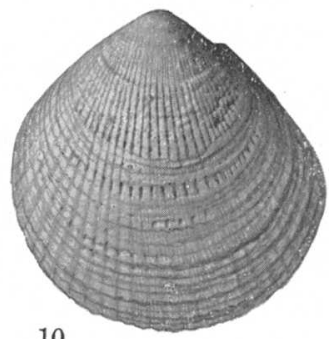

10

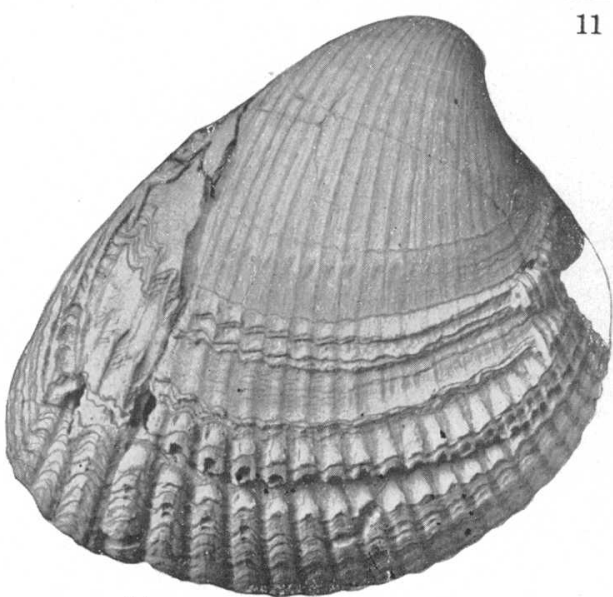

14

7
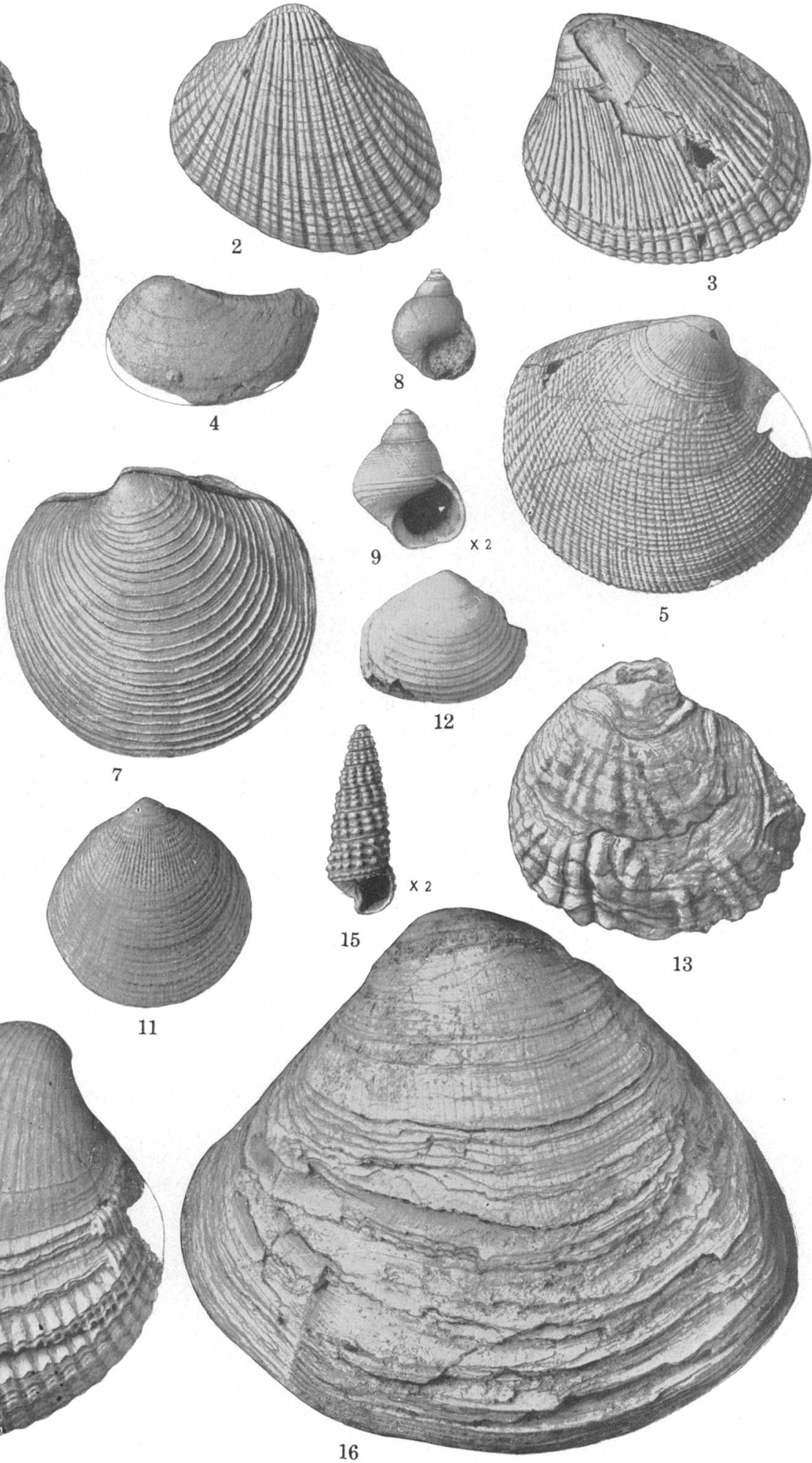

FOSSILS FROM LITTORINA AND UPPER PSEUDOCARDIUM ZONES OF ETCHEGOIN FORMATION OF NORTH DOME. 


\section{PLATE 30}

[Figures natural size]

Figures 1-8. Pseudocardium densatum (Conrad) of Arnold, var. cf. gabbii Rémond. Locality 252a.

1. Length $64 \mathrm{~mm}$., height $58 \mathrm{~mm}$., thickness $20 \mathrm{~mm}$. U. S. Nat. Mus. 495799.

2. Length $54 \mathrm{~mm}$., height $48 \mathrm{~mm}$., thickness $19 \mathrm{~mm}$. U. S: Nat. Mus. 495800 .

3. Length $54 \mathrm{~mm}$., height $44 \mathrm{~mm}$., thickness $17 \mathrm{~mm}$. U. S. Nat. Mus. 495801.

4. Length $29 \mathrm{~mm}$., height $25 \mathrm{~mm}$,, thickness $9.4 \mathrm{~mm}$. U. S. Nat. Mus. 495802 .

5. Length $87 \mathrm{~mm}$., height $73 \mathrm{~mm}$., thickness $27 \mathrm{~mm}$. U. S. Nat. Mus. 495803 .

6. Length $64 \mathrm{~mm}$., height $60 \mathrm{~mm}$., thickness $25 \mathrm{~mm}$. U. S. Nat. Mus. 495804.

7. Length $79 \mathrm{~mm}$., height $73 \mathrm{~mm}$., thickness $33 \mathrm{~mm}$. U. S. Nat. Mus. 495805.

8. Length $92 \mathrm{~mm}$., height $84 \mathrm{~mm}$., thickness $40 \mathrm{~mm}$. U. S. Nat. Mus. 495806 . 


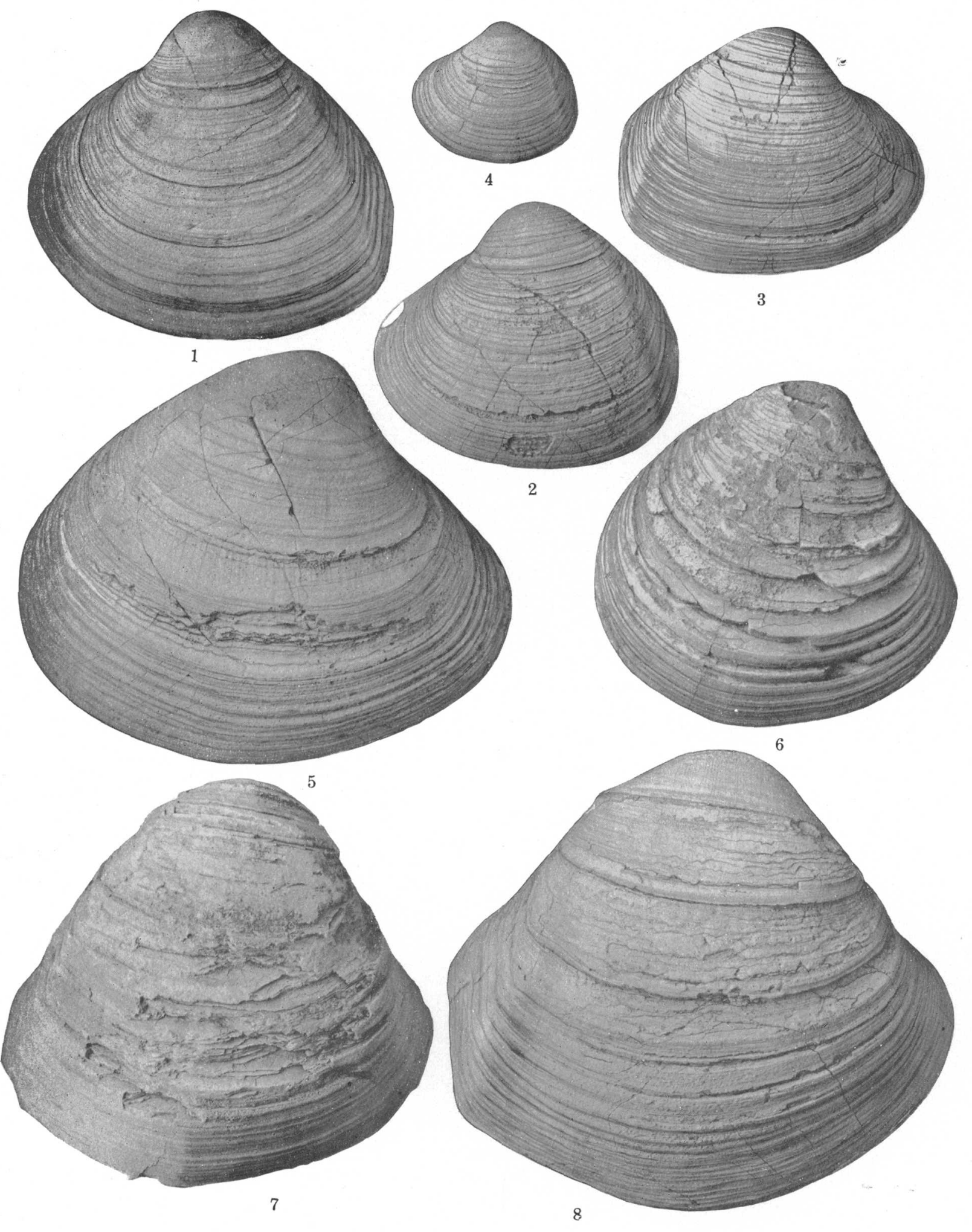

FOSSILS FROM UPPER PSEUDOCARDIUM ZONE OF ETCHEGOIN FORMATION OF NORTH DOME. 


\section{PLATE 31}

[Figures natural size unless otherwise designated]

Figures 1, 7. Siphonalia kettlemanensis (Arnold).

1. Height (incomplete) $83 \mathrm{~mm}$., width (incomplete) $51 \mathrm{~mm}$. Locality 283. U. S. Nat. Mus. 495807.

7. Height (incomplete) $74 \mathrm{~mm}$., width $55 \mathrm{~mm}$. Locality 270 . U. S. Nat. Mus. 495808.

2. Turritella vanvlecki Arnold. Worn specimen. Height (incomplete) $30 \mathrm{~mm}$., width $11 \mathrm{~mm}$. Locality $282 . \quad$ U. S. Nat. Mus. 495809.

3, 4, \$. Hinnites ef. H. crassa Conrad.

3. Length $98 \mathrm{~mm}$., height $104 \mathrm{~mm}$., thickness of both valves $37 \mathrm{~mm}$. Locality 274a. U. S. Nat. Mus. 495810.

4. Length $10.6 \mathrm{~mm}$., height $12.6 \mathrm{~mm}$., thickness $2.3 \mathrm{~mm}$. Locality 282a. U. S. Nat. Mus. 495811.

8. Length $100 \mathrm{~mm}$., height $106 \mathrm{~mm}$., thickness of both valves $37 \mathrm{~mm}$. Locality 274a. U. S. Nat. Mus. 495812 .

5. Lunatia cf. L. lewisii (Gould). Height $47 \mathrm{~mm}$., width $44 \mathrm{~mm}$. Locality 287. U. S. Nat. Mus. 495813.

6. Crepidula ef. C. onyx Sowerby. Worn specimen. Length (incomplete) $23 \mathrm{~mm}$. Locality 287 . U. S. Nat. Mus. 495814 .

9. Anadara trilineata (Conrad) of Arnold, var. cf. canalis (Conrad). Length $48.5 \mathrm{~mm}$., height $37.3 \mathrm{~mm}$., thickness of both valves $29 \mathrm{~mm}$. Locality 264. U. S. Nat. Mus. 495815 

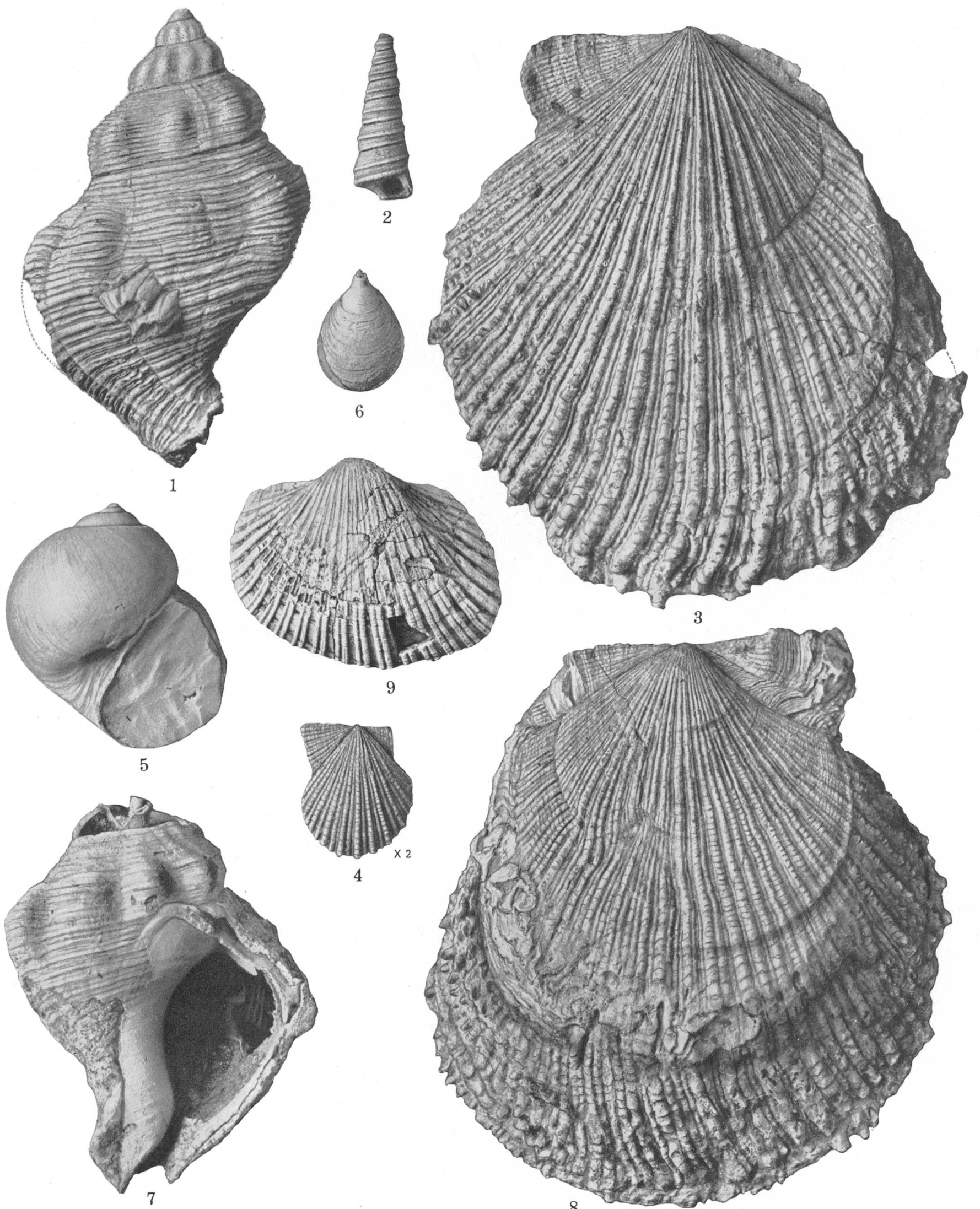

4

FOSSILS FROM SIPHONALIA ZONE OF ETCHEGOIN FORMATION OF NORTH DOME. 


\section{PLATE 32}

[Figures natural size unless otherwise designated]

Figure 1. Chlamys etchegoini (Anderson). Left valve of double-valve specimen. Length $87 \mathrm{~mm}$., height $88 \mathrm{~mm}$., thickness of both valves $38 \mathrm{~mm}$. Locality 279 . U. S. Nat. Mus. 495816.

2. Apolymetis cf. A. dombei (Hanley). Left valve of double-valve specimen. Length $58 \mathrm{~mm}$., height $45 \mathrm{~mm}$., thickness of both valves $22 \mathrm{~mm}$. Locality 264 . U. S. Nat. Mus. 495817.

3, 4. Mytilus coalingensis Arnold. Locality 270.

3. Left valve of double-valve specimen. Greatest length (almost complete) $122 \mathrm{~mm}$., width $58 \mathrm{~mm}$., thickness of both valves $35 \mathrm{~mm}$. U. S. Nat. Mus. 495818.

4. Left valve of double-valve specimen. Greatest length (incomplete) $184 \mathrm{~mm}$., width $75 \mathrm{~mm}$., thickness of both valves $73 \mathrm{~mm}$. U. S. Nat. Mus. 495819 .

5. Calliostoma coalingense privum Stewart, n. var. Type. Height 16.5 mm., width 18.2 mm. Locality 270 . U. S. Nat. Mus. 495820. 


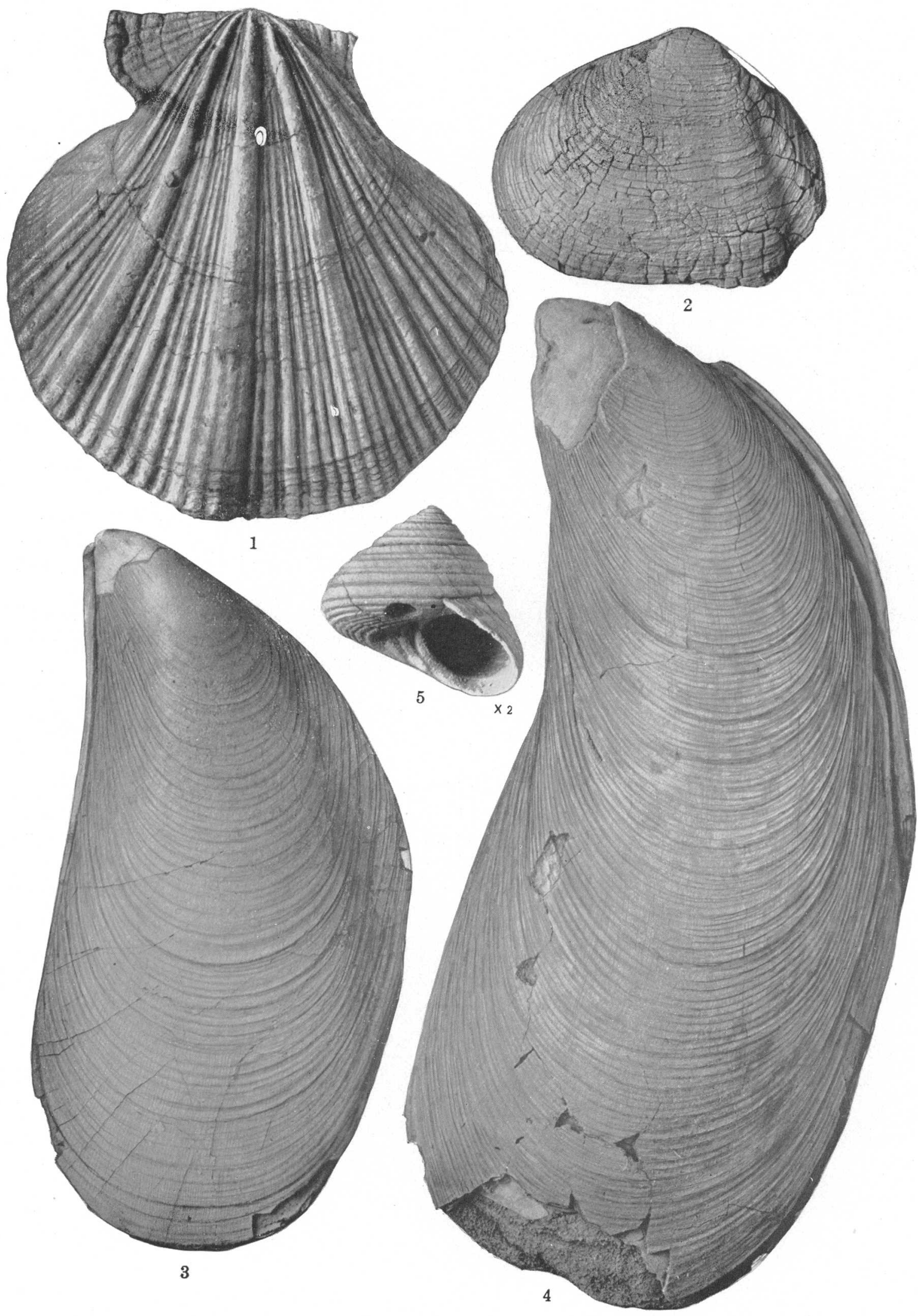

FOSSILS FROM SIPHONALIA ZONE OF ETCHEGOIN FORMATION OF NORTH DOME. 


\section{PLATE 33 \\ [Figures natural size]}

Figdre 1. Mactra? coalingensis Arnold. Right valve. Length $72 \mathrm{~mm}$., height $57 \mathrm{~mm}$., thickness about $12 \mathrm{~mm}$. Locality 263. U. S. Nat. Mus. 495821.

2. Tellina cf. T. bodegensis Hinds. Right valve. Length $64 \mathrm{~mm}$., height $35 \mathrm{~mm}$., thickness about $6 \mathrm{~mm}$. Locality 284 . U. S. Nat. Mus. 4.95822.

3. Siliqua sp. Incomplete right valve. Length $49 \mathrm{~mm}$., height $20 \mathrm{~mm}$., thickness about $3 \mathrm{~mm}$. Locality 294 . U. S. Nat. Mus. 495823.

4. Semele n. sp.? Length $43 \mathrm{~mm}$., height $37 \mathrm{~mm}$., thickness of both valves $18 \mathrm{~mm}$. Locality 272a. U. S. Nat. Mus. 495824. This specimen has concentric lamellae resembling $S$. formosa Sowerby but has a more rounded posterior end.

5. Tellina ? cf. T. ? oldroydi Wiedey. Length (incomplete) $88 \mathrm{~mm}$., height $58 \mathrm{~mm}$., thickness about $12 \mathrm{~mm} . \quad$ Locality 266. U. S. Nat. Mus. 495825.

6. Saxidomus nuttalli latus Stewart, n. var. Length $68 \mathrm{~mm}$., height $48 \mathrm{~mm}$., thickness of both valves (worn) $27 \mathrm{~mm}$. $\mathrm{L}_{\mathrm{O}-}$ cality 287. U. S. Nat. Mus. 495826.

7, 8. Glycymeris grewingki Dall. Locality 266.

7. Length $38 \mathrm{~mm}$., height $36.5 \mathrm{~mm}$., thickness $10 \mathrm{~mm}$. U. S. Nat. Mus. 495827.

8. Length $41.5 \mathrm{~mm}$., height $41 \mathrm{~mm}$., thickness $11 \mathrm{~mm}$. U. S. Nat. Mus. 495828.

9. Schizothaerus cf. S. nuttallii (Conrad). Length $118 \mathrm{~mm}$., height $85 \mathrm{~mm}$., thickness about $18 \mathrm{~mm}$. Locality 287 . U. S. Nat. Mus. 495829. 

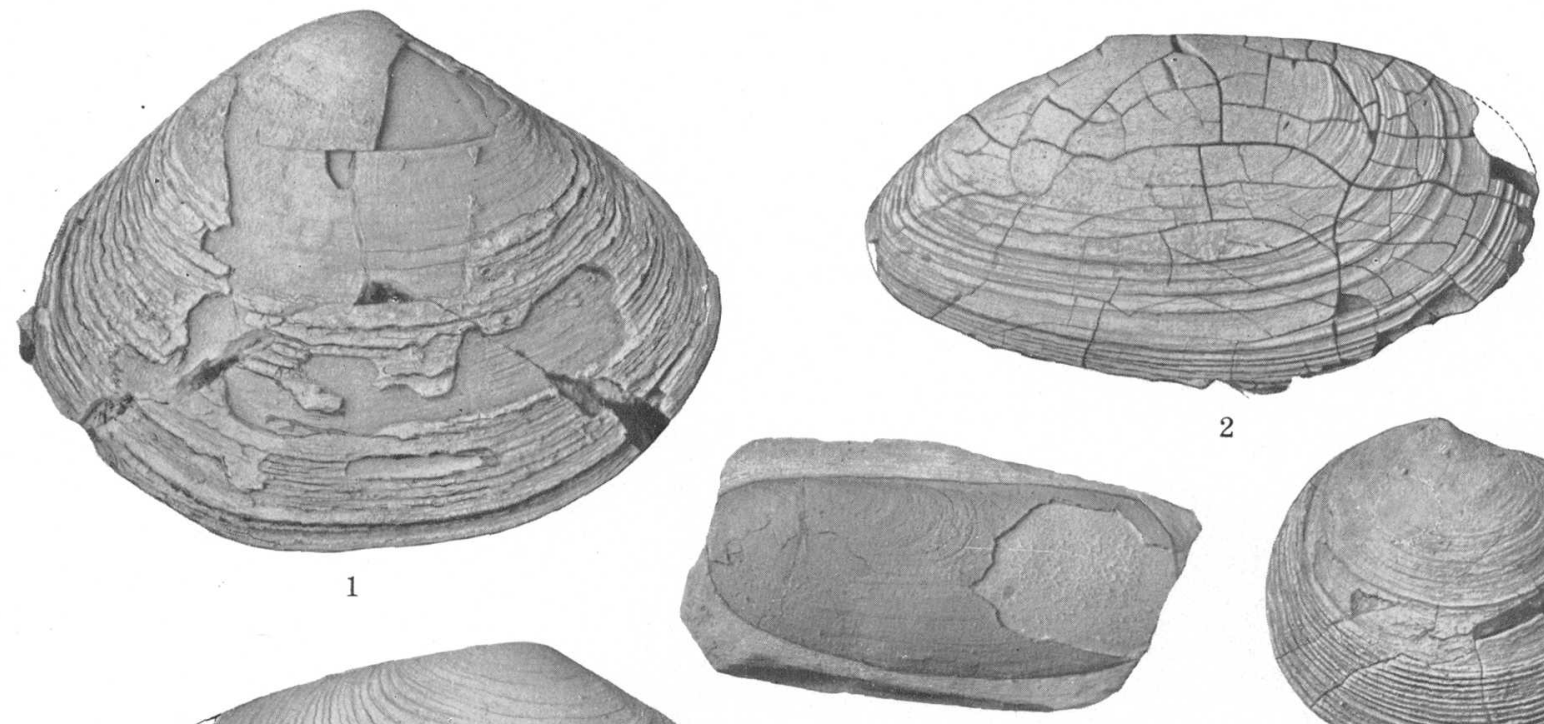

2
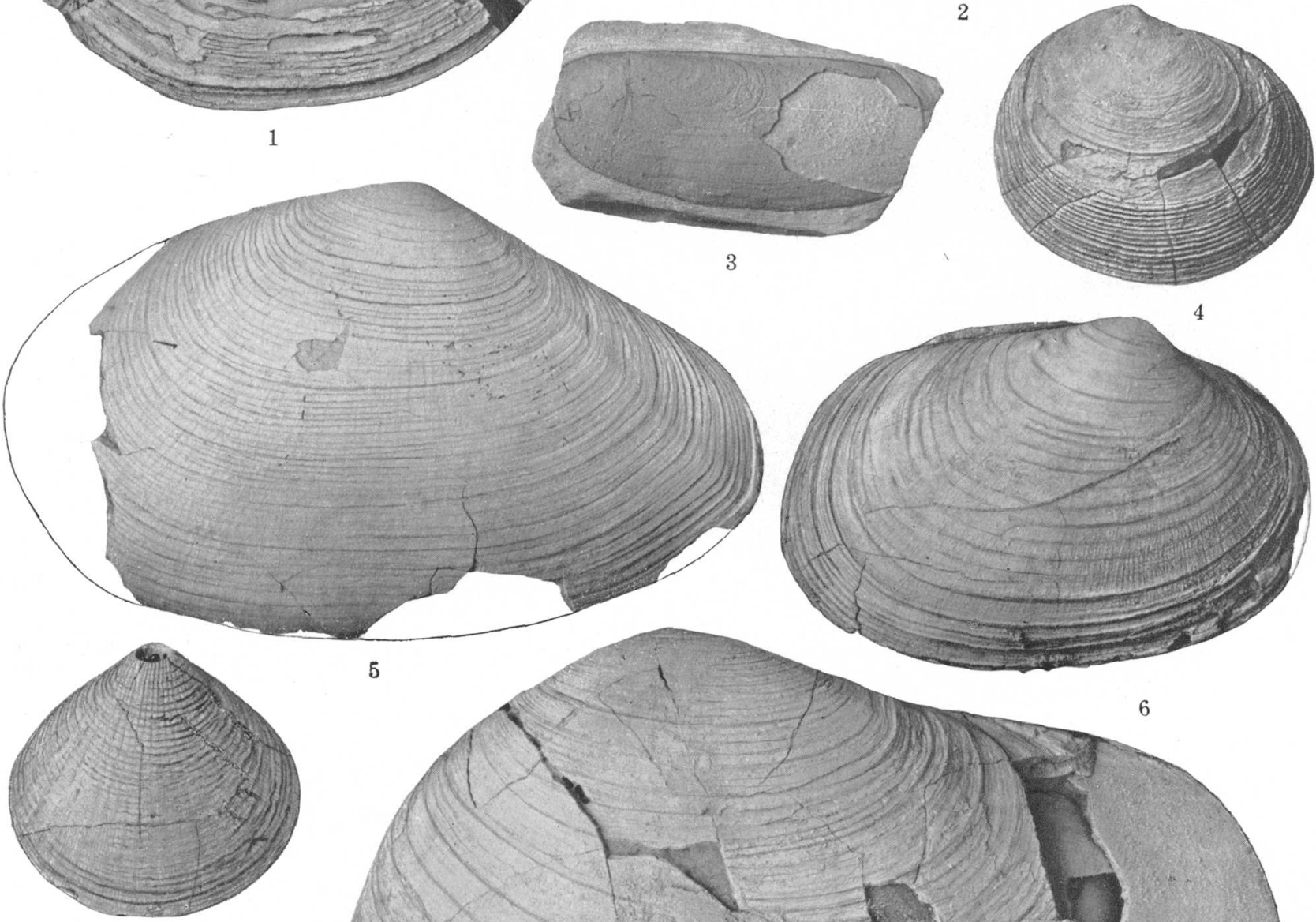

7

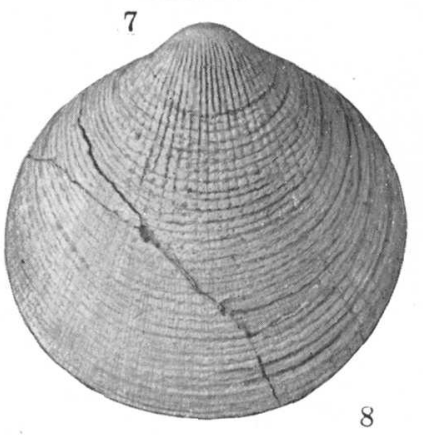

3
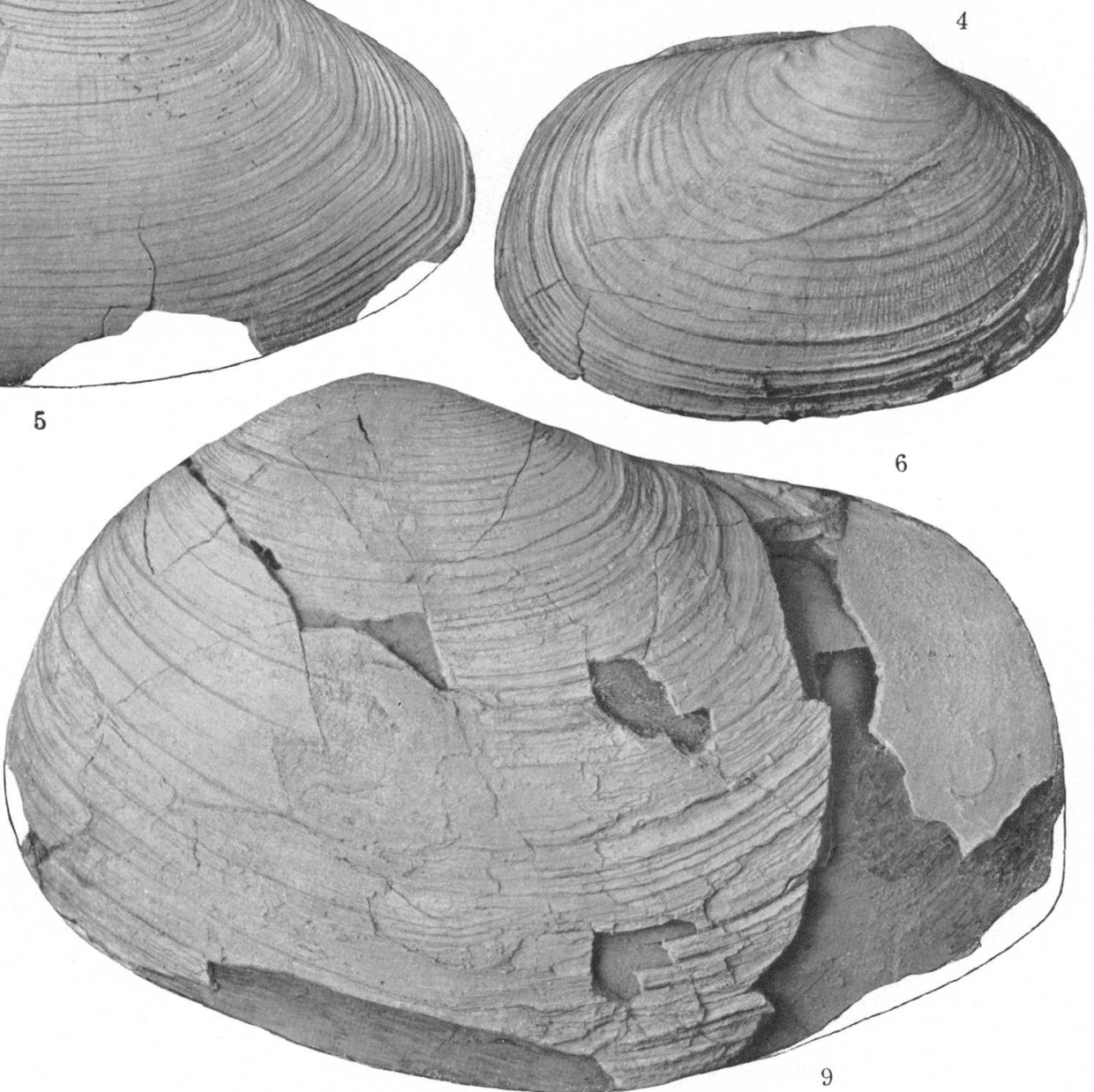

FOSSILS FROM SIPHONALIA ZONE OF ETCHEGOIN FORMATION OF NORTH DOME. 


\section{PLATE 34}

[Figures natural size unless otherwise designated]

Figures 1-4. Macoma affinis Nomland. Locality 306, Macoma zone.

1. Left valve. Length (incomplete) $73.5 \mathrm{~mm}$., height $55.4 \mathrm{~mm}$., thickness $12.5 \mathrm{~mm}$. U. S. Nat. Mus. 495830 .

2. Right valve. Length $75 \mathrm{~mm}$., height $55 \mathrm{~mm}$., thickness $13 \mathrm{~mm}$. U. S. Nat. Mus. 495831 .

3. Right valve. Length $73.5 \mathrm{~mm}$., height $55.4 \mathrm{~mm}$., thickness $13 \mathrm{~mm}$. U. S. Nat. Mus. 495832.

4. Left valve. Length $71 \mathrm{~mm}$., height $54 \mathrm{~mm}$., thickness about $12 \mathrm{~mm}$. U. S. Nat. Mus. 495833.

5, 6. "Nassa" moraniana Martin. Etchegoin formation of North Dome, locality uncertain.

5. Height (incomplete) $28 \mathrm{~mm}$., width $19 \mathrm{~mm}$. U. S. Nat. Mus. 495834.

6. Height (incomplete) $35 \mathrm{~mm}$., width (slightly crushed) $20 \mathrm{~mm}$. U. S. Nat. Mus. 495835 .

8. "Nassa" miser iniqua Stewart, n. var. Type. Height (almost complete) $13.6 \mathrm{~mm}$., width $8 \mathrm{~mm}$. Locality $300 \mathrm{~b}$. Patinopecten zone. U. S. Nat. Mus. 495836.

7. Zirfaea gabbi Tryon, var. Left valve of double-valve specimen. Length (incomplete) $119 \mathrm{~mm} .$, height $70 \mathrm{~mm}$., thickness of both valves $74 \mathrm{~mm}$. Locality 306a, Macoma zone. U. S. Nat. Mus. 495837. 

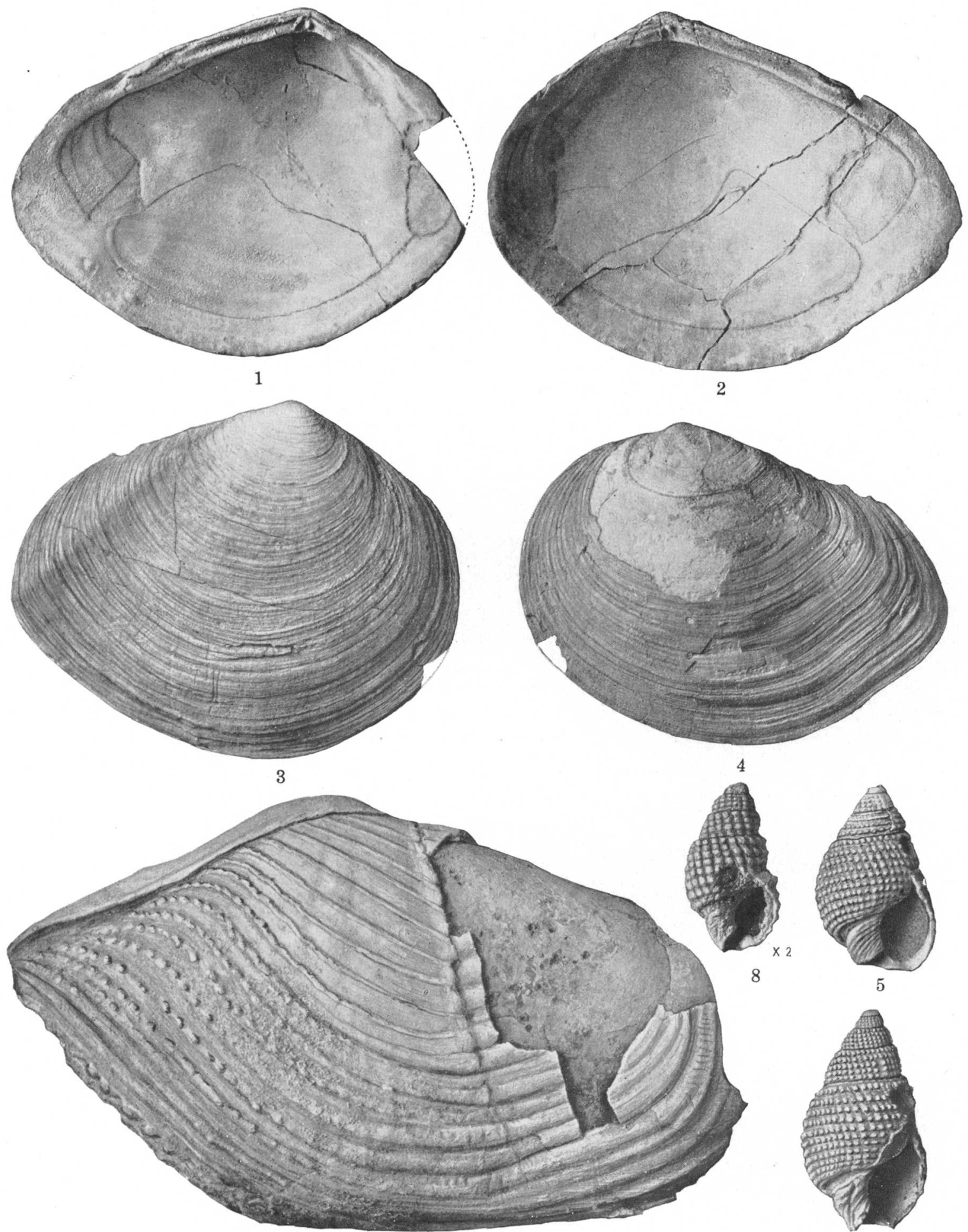

7

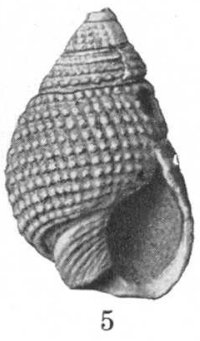

8

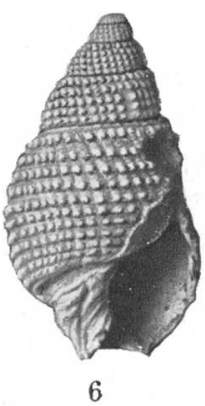

FOSSILS FROM MACOMA AND PATINOPECTEN ZONES OF ETCHEGOIN FORMATION OF NORTH DOME. 


\section{PLATE 35}

[Figures natural size unless otherwise designated]

Figure 1. Macoma cf. M. indentata Carpenter. Left valve of double-valve specimen. Length $51 \mathrm{~mm}$., height $33 \mathrm{~mm}$., thickness of both valves $16 \mathrm{~mm}$. Locality 308 . U. S. Nat. Mus. 495838.

2-5. Patinopecten lohri (Hertlein).

2. Right valve. Length $101 \mathrm{~mm}$., height $97 \mathrm{~mm}$. Locality 317a. U. S. Nat. Mus. 495839.

3. Ieft valve. Length $86 \mathrm{~mm}$., height $86 \mathrm{~mm}$. Locality 320 a. U. S. Nat. Mus. 495840 .

4. Right valve. Length $127 \mathrm{~mm}$., height $114 \mathrm{~mm}$. Locality 316 . U. S. Nat. Mus. 495841.

5. Length $14.8 \mathrm{~mm}$., height $15.8 \mathrm{~mm}$. Locality 308. 'U. S. Nat. Mus. 495842 .

6. Taras ef. T. parilis (Conrad). Left valve of double-valve specimen. Length $35 \mathrm{~mm}$., height $33 \mathrm{~mm}$., thickness of both valves about $15 \mathrm{~mm}$. Locality 316 . U. S. Nat. Mus. 495843. 

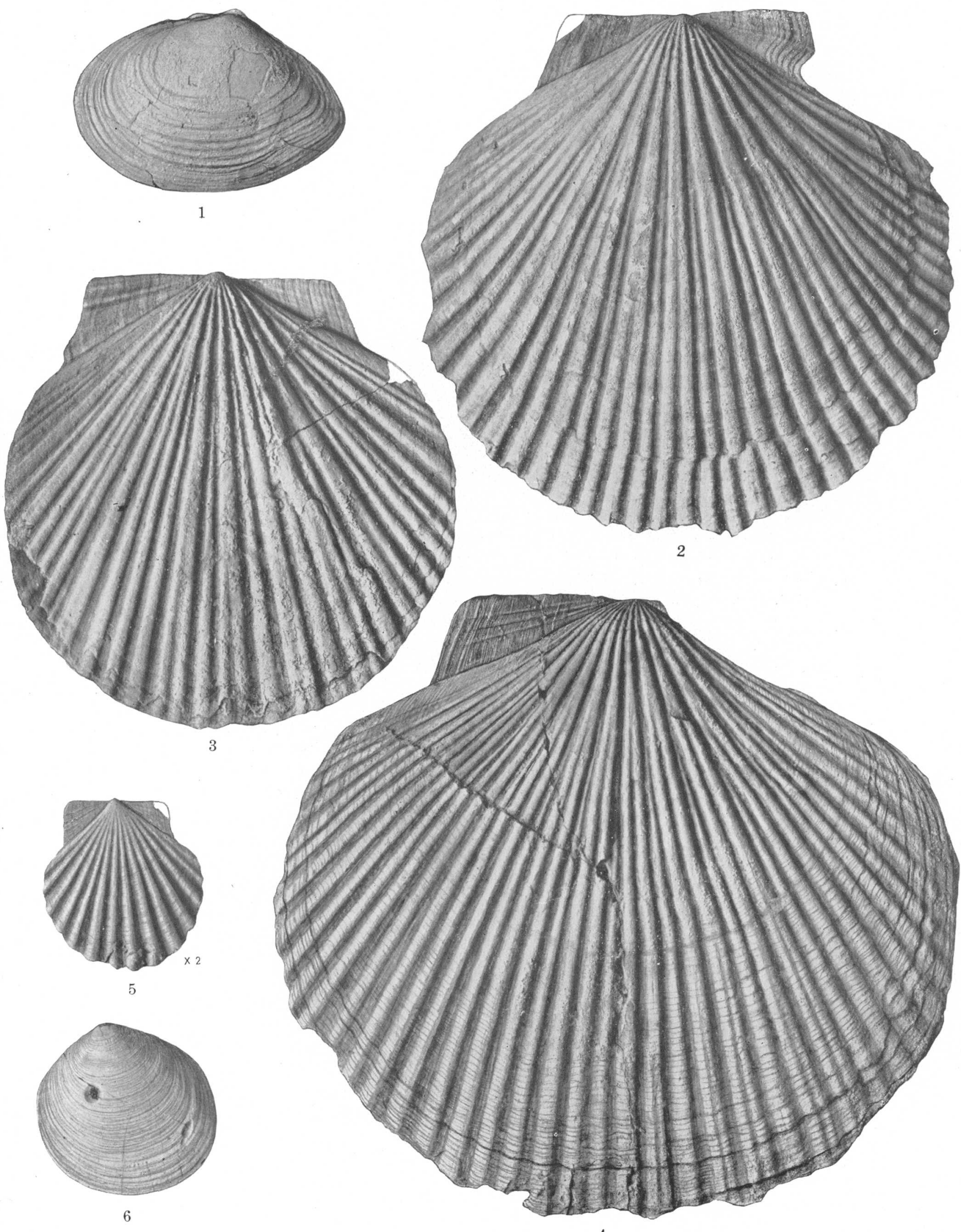

6

FOSSILS FROM PATINOPECTEN ZONE OF ETCHEGOIN FORMATION OF NORTH DOME. 


\section{PLATE 36}

[Figures natural size]

Figures 1, 7. Nucella etchegoinensis (Arnold), ribbed var. Locality 337, Patinopecten zone.

1. Height (incomplete) $73 \mathrm{~mm}$., width $47 \mathrm{~mm}$. U. S. Nat. Mus. 495844 .

7. Height $83 \mathrm{~mm}$., width $47 \mathrm{~mm}$. U. S. Nat. Mus. 495845 .

2-5, 8, 9. Balanus (Tamiosoma). cf. B. (T.) gregarius (Conrad). Locality 300c, strata underlying Patinopecten zone.

2, 3. Scutum. Length $29 \mathrm{~mm}$., width (incomplete) $19.5 \mathrm{~mm}$. U. S. Nat. Mus. 497415.

4, 5. Broken tergum. Length $24 \mathrm{~mm}$., width $15.5 \mathrm{~mm}$. U. S. Nat. Mus. 497416.

8, 9. Scutum. Length (incomplete) $20 \mathrm{~mm}$., width $16 \mathrm{~mm}$. U. S. Nat. Mus. 497414.

6. Opalia varicostata Stearns. Height (incomplete) $52 \mathrm{~mm}$., width $17 \mathrm{~mm}$. Locality 317 , Patinopecten zone. U. S. Nat. Mus. 495846.

10. Sanguinolaria cf. S. nuttallii Conrad. Left valve of crushed double-valve specimen. Length $66 \mathrm{~mm}$., height $48 \mathrm{~mm}$. Locality 308, Patinopecten zone. U. S. Nat. Mus. 495847.

11, 12. Forreria magister (Nomland).

11. Height (incomplete) $94 \mathrm{~mm}$., width $71 \mathrm{~mm}$. Locality 336, Patinopecten zone. U. S. Nat. Mus. 495848.

12. Height (incomplete) $101 \mathrm{~mm}$., width $75 \mathrm{~mm}$. Locality 310 , Patinopecten zone. U. S. Nat. Mus. 495849. Though not shown in the figure, traces of the lower spines are preserved on this specimen. They are not observable on fig. 11 and may not have been present on that specimen. 


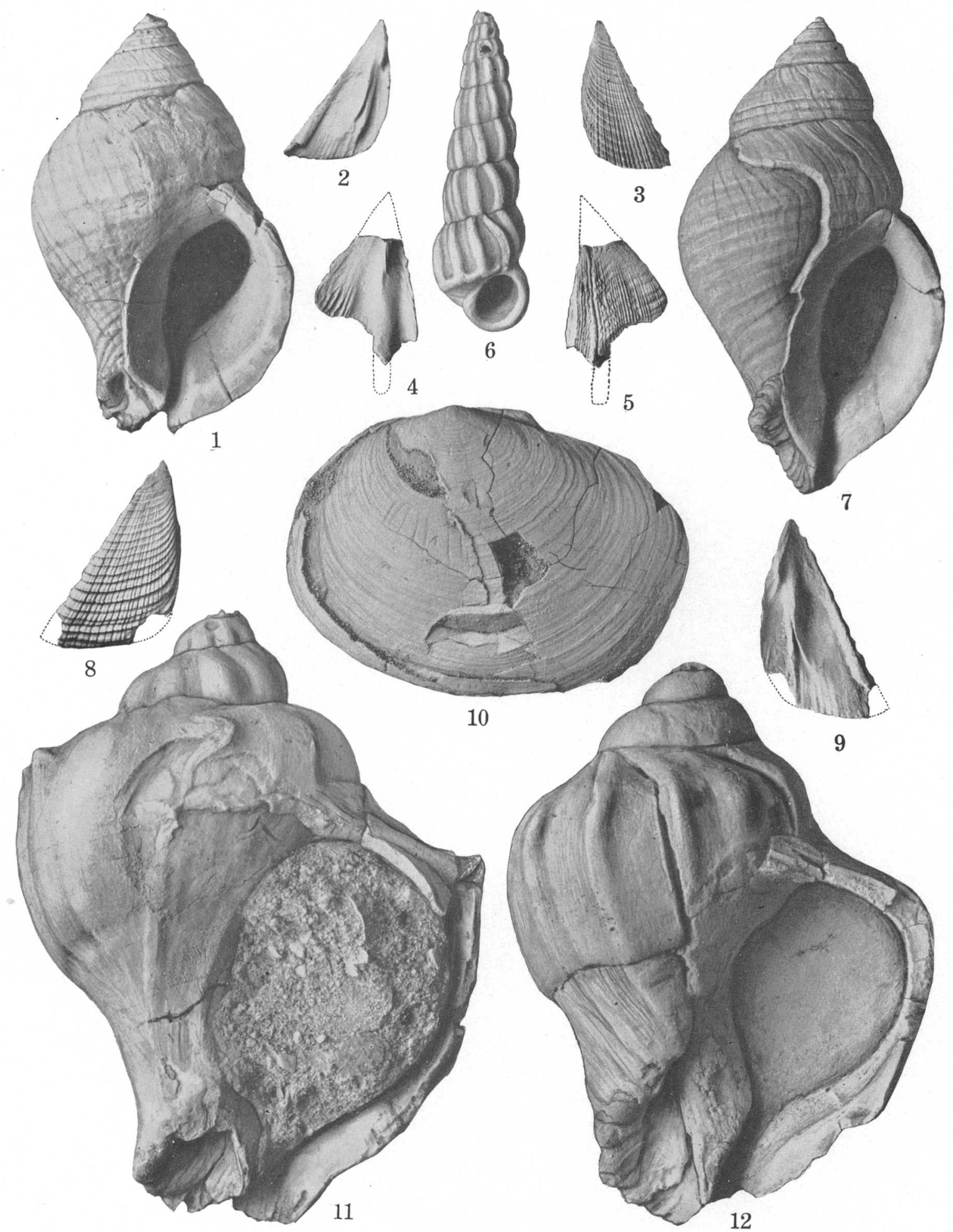

FOSSILS FROM PATINOPECTEN ZONE OF ETCHEGOIN FORMATION OF NORTH DOME AND UNDERLYING STRATA. 


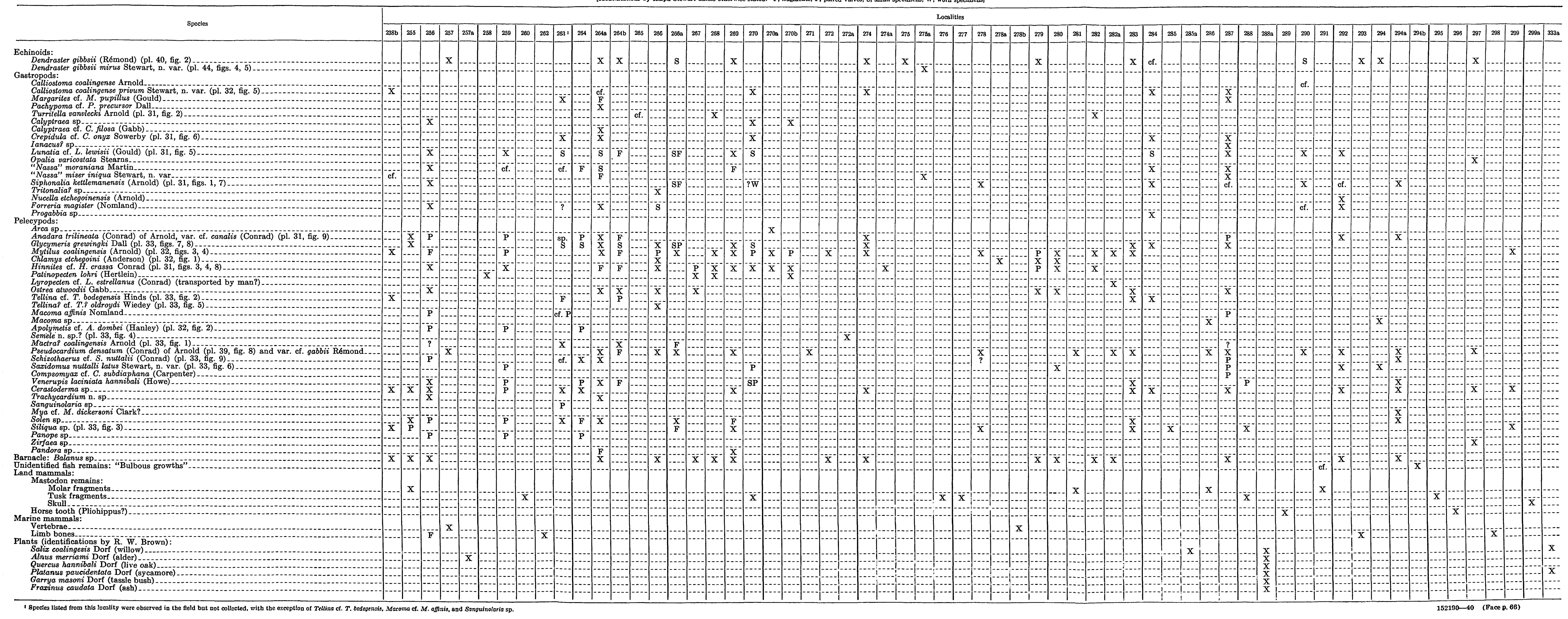


The type locality of the Macoma zone is on the south side of El Tolete, sec. 7, T. 22 S., R. 18 E. (pl. 28, column 7), where the zone is 40 feet thick. The name Macoma zone is unsatisfactory, for Macoma occurs throughout the San Joaquin and Etchegoin formations. This genus is, however, more abundant in the Macoma zone than in the other Etchegoin zones.

Samples from the Macoma zone were examined by M. N. Bramlette, who reports that they contain much andesitic volcanic material. The sands are tuffaceous and contrin andesitic phenocrysts and volcanic glass, though most of the original glass is more or less altered. Thin layers of fine-grained impure tuff, designated clay in the field, have a larger percentage of glass, as much as 50 percent, and also contain diatoms and sponge spicules. The light color of the Macoma zone is apparently due to a larger proportion of volcanic material than in the brown rocks of the Siphonalia and Patinopecten zones.

The section below was measured at the type locality of the Macoma zone, on the south side of El Tolete (pl. 28, column 7).

Section of Macoma zone of Etchegoin formation at type locality on south side of El Tolele, sec. 7, T 22 S., R. 18 E.

Light-gray tuffaceous sand containing few impressions of marine fossils. Contact at base abrupt, marked by borings. Overlain by 14 feet of bluish sand with a 6-inch concretionary fossiliferous layer at base........ .

Light-gray fine-grained volcanic ash. Contact at base

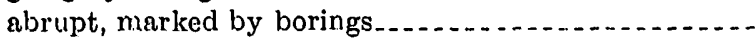

Jight-gray tuffaceous sand. Contact at base abrupt,

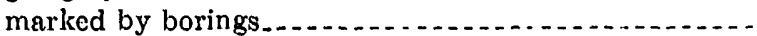

Light-gray fine-grained volcanic ash. Contact at base abrupt, marked by borings............................

Light-gray tuffaceous sand. Small pebbles, Calliostoma, Mytilus, and sand dollars at base. Discontinuity at base. Underlain by laminated slightly tuffaceous

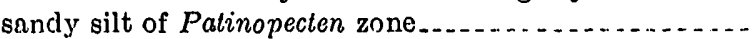

Thickness of Macoma zone

At locality 302, southwest of La Clavija, the Macoma zone is considerably thicker and the base is not exposed (pl. 28, column 5). The greater thickness is due to the presence of cross-bedded blue sandstone, as shown in the following section:

Section of Macoma zone of Etchegorn formation at locality 302, southwest of La Clavija, NE 1/4 sec. 12, T. 2Q S., R. 17 E.

Bluish silty sand and light-colored probably tuffaceous Feet layers. Macoma at top. Overlain by brown sandy silt and blue sandstone of Siphonalia zone............. 25

Cross-bedded blue sandstone ...... . . . . . . . . . . . . . . $4: 0$

Dark reddish-brown sandstone. Pseudocardium and Macoma in lower part............................ 1

Silty sand. Macoma and Pseudocardium near base. Con. tact at base abrupt, marked by fragments of underlying tuff in the sand and by borings penetrating tuff...... $31 / 2$

Fine-grained tuff. Contact at base abrupt............ 1

Light-gray sand containing Macoma. Base not exposed... $6+$

Exposed thickness of Macoma zone $76 \frac{1}{2}+$
On the west side of La Muralla, sec. 21, T. $22 \mathrm{~S}$, R. $18 \mathrm{E}$., the Macoma zone is faulted against the Littorina zone.

Toward the north end of North Dome strata identified as the Macoma zone do not have the characteristic light color. Large fossils (Forreria, Nucella, Mytilus, and barnacles) are more abundant than farther south, and Macoma is less prevalent.

Fossils.--Some of the fossils of the Macoma zone are shown on plates 34 , and 42 to 44 . The species are listed in the table on the following page.

The fauna of the Macoma zone is smaller than that of the Siphonalia zone. Possibly the most important difference between the two faunas is the abundance of Macoma affinis (pl. 34, figs. 1-4) in the Macoma zone. $V e n e r u p i s$ cf. $V$. tenerrima was not found at other horizons.

The following marine diatoms, collected at locality 302, were identified by K. E. Lohman:

Diatoms from Macoma zone of Etchegoin formation at locality S02

Melasira sulcata (Ehrenberg) Kützing.

Coscinodiscus excentricus Ehrenberg.

Coscinodiscus radiatus Ehrenberg.

According to Lohman, the diatoms are badly corroded, suggesting leaching by alkaline solutions. Better specimens and a larger flora may be represented in samples collected later but not yet examined.

\section{PATINOPECTEN ZONE}

Stratigraphy and lithology.-The Patinopecten zone, named for the almost flat circular pecten that is abundant at certain localities, consists of brownish sandy silt and silty' sand generally about 100 feet thick. At places the zone as identified is 40 feet thick. Lithologically these strata resemble those in the Siphonalia zone, but they underlie the light-colored Macoma zone. The top of the Patinopecten zone is about 400 feet below the Littorina zone. At some outcrops sandstone and conglomerate, the base of which is marked by a scour discontinuity, occur about 50 feet below the top of the Patinopecten zone. This may be a logical horizon to separate the Macoma and Patinopecten zones, but the sandstone and conglomerate could not be recognized in all the areas where this part of the Etchegoin formation crops out. Fossiliferous layers, particularly massive silty sand containing a layer of large barnacles or a Mytilus-barnacle layer, are taken as the base of the Patinopecten zone. At many localities the barnacles stand upright and form reefs. The barnacles are generally attached to small Mytilus shells or to Mytilus fragments. At places a Pseudocardium layer appears to be the equivalent of a barnacle layer. The stratigraphic position of the barnacle layer mapped as the base of the zone is not everywhere the same with reference to the Macoma zone, as shown in the sections on plate 28. The barnacle layers are probably at 
Fossils from Macoma zone of Etchegoin formation

[Identifications by Ralph Stewart, unless otherwise stated. P, paired valves; W, worn specimens]

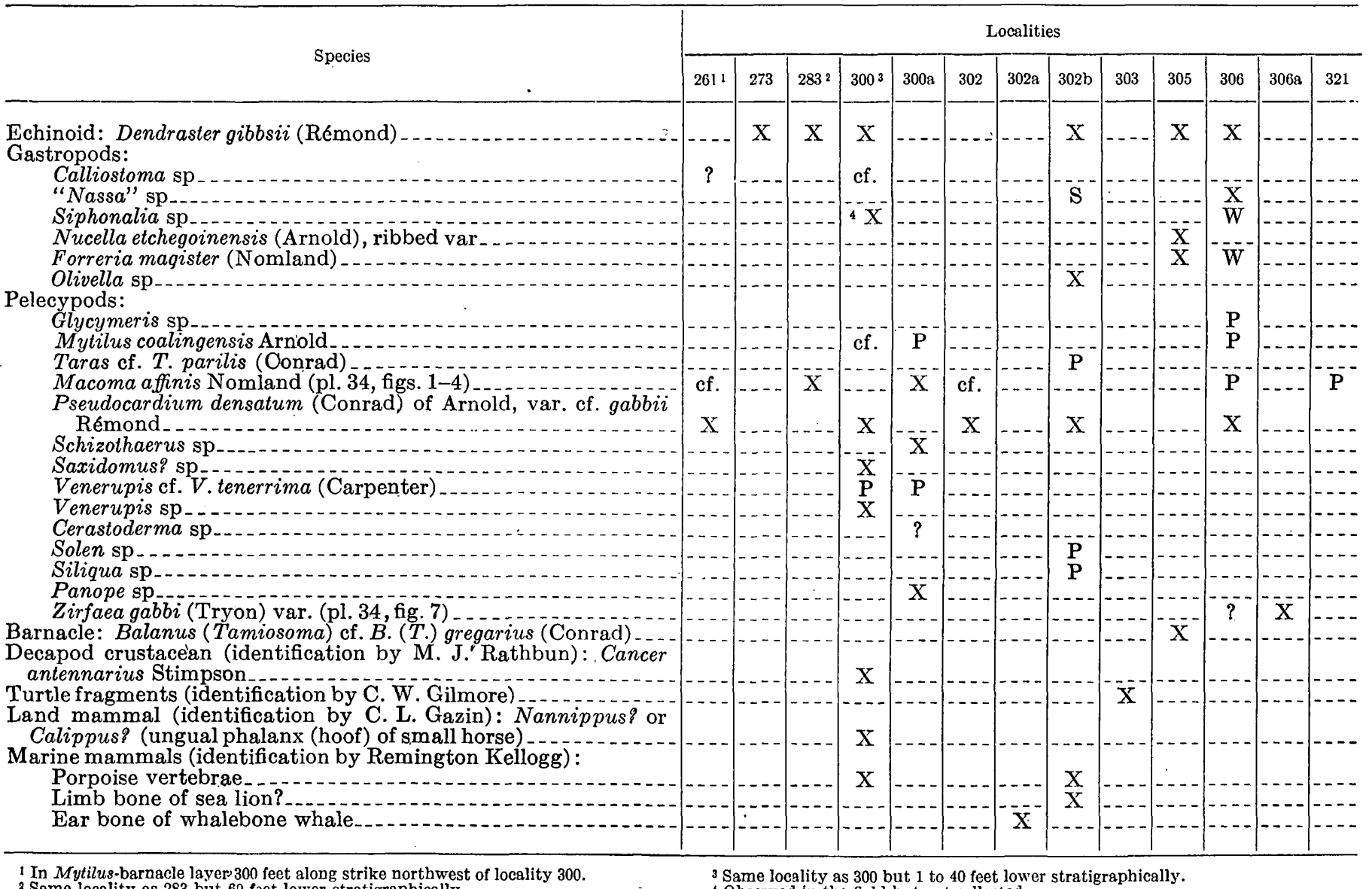

different horizons at different localities and the base of the zone, therefore, is probably not a stratigraphic datum plane. The barnacle layers, however, are easily mapped, and the thickness of strata involved in their stratigraphic position is probably not greater than about 50 feet. In at least one locality a barnacle layer occurs below the base of the Patinopecten zone as mapped.

Fossiliferous layers in the zone and a concretionary sandstone near the top of the zone are shown locally on the geologic map (pl. 3).

The type locality of the Patinopecten zone is on the south side of El Tolete, sec. 7, T. 22 S., R. 18 E., which is also the type locality of the Macoma zone. The name of the zone is not entirely satisfactory, for Patinopecten is found locally in underlying strata, in the Siphonalia zone, and occurs rarely in the Pecten zone and in the Cascajo conglomerate member of the San Joaquin formation. This genus, however, is more abundant in the Patinopecten zone than in other parts of the section and at some outcrops is practically the only fossil in the sandy silt above the barnacle layer mapped as the base of the zone.

The following section (pl. 28, column 7) was measured at the type locality:
Section of Patinopecten zone of Etchegoin formation at type locality on south side of El Tolete; south central part of sec. 7, T. 2Q S., R. $18 \mathrm{E}$.

9. Slightly tuffaceous sandy silt with some pebbles. Overlain by light-gray tuffaceous sand of Macoma zone, the base of which is marked by a discontinuity. (For upward continuation of section see p. 67)

8. Greenish sand, somewhat purplish at top; few small

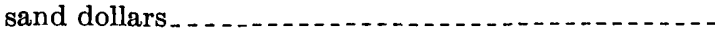

7. Obscurely bedded sand with pebbles and small sand dollars at base. Contact at base abrupt...........

6. Iaminated sandy silt, somewhat concretionary .......-

5. Grayish-green sand with sand dollars; some cross bedding. One-inch pebbles and shell fragments in thin gravel at base. Base marked by scour discontinuity, gravel penetrating underlying silt to depth of 2 feet along cracks and borings. A Panope filled with pebbles from this gravel was observed with posterior end upright.

4. Laminated brown sandy silt with sand dollars and Patinopecten and streaks of altered tuffaceous sandy silt.

3. Concretionary gray sand. One specimen of Tellina observed.

Feet

6

2. Greenish-brown sandy silt with few pebbles..........

1. Brown silty sand with Venerupis and barnacle fragments (Tamiosoma?)

Thickness of Patinopecten zone 
Unit 4 in the preceding section, 50 feet below the top of the zone, includes streaks of light-colored sandy silt similar in field appearance to material in the Macoma zone. According to M. N. Bramlette, a zeolitic mineral that probably represents an alteration product of volcanic glass is abundant in this sandy silt.

At the southerst end of Las Paredes (pl. 28, column 8), south of El Rascador (pl. 28, column 9), and along the west side of La Loba a barnacle layer 40 to 50 feet below the base of the Macoma zone was mapped as the base of the Patinopecten zone. Along the south side of Las Paredes the Patinopecten zone is faulted against the upper Pseudocardium and Iittorina zones. On the south side of La Muralla a Pseudocardium layer about 75 feet below the top of the zone appears to be the equivalent of the barnacle layer farther north and was mapped as the base of the zone. At locality 315 , in a tributary of Arroyo Doblegado, the zone is 84 feet thick, and a barnacle layer occurs at the base (pl. 28, column 12). At $\mathrm{La}$ Cuna the upper part of the zone is characterized by a brown concretionary sandstone. The concretions are cylindrical and are as much as 3 feet long and a foot in diameter. Their long axis is approximately at right angles to the bedding. At localities 328 and 329, on tributaries of Arroyo Murado, a fossiliferous layer probably near the top of the zone contains large, worn specimens of Crepidula. At locality 330 nearby a 1-foot conglomerate 6 feet below a barnacle layer was mapped as the base of the zone. Toward the north end of North Dome a Mytilus-Venerupis lâyer was mapped as the base of the zone.

Fossils.-Fossils from the Patinopecten zone are shown on plates $35,36,40,42,43$. The species are listed in the table on the following page.

The abundance of Patinopecten lohri (pl. 35, figs. 2-5) in the Patinopecten zone is the most apparent difference between the faunas of the Patinopecten and Siphonalia zones. Several species, however-notably Crepidula cf. C. princeps, Pseudotoma sp., Macoma cf. M. vanvlecki, and Macoma cf. $M$. indentata (pl. 35, fig. 1)-were found in the Patinopecten zone but not in the Siphonalia zone. These forms are present in the underlying Jacalitos formation, but the characteristic Jacalitos species are absent.

Large barnacles assigned to Tamiosoma are more abundant in the Patinopecten zone than at other horizons but occur in overlying and underlying Etchegoin strata.

\section{STRATA UNDERLYING PATINOPECTEN ZONE}

The oldest strata exposed in North Dome underlie the Patinopecten zone. They consist of brown silt and sand and lenses of blue sandstone and have a maximum thickness of about 100 feet. The fossils in this part of the section are similar to those in the Patinopecten and Siphonalia żones. Patinopecten is not abundant. Pseudocardium layers occur in this part of the section, as in overlying strata. The burnacle reef shown on plate $27, A$, occurs in a faulted wedge 1,000 feet west of the locality where the section on page 68 was measured. This barnacle reef corresponds to a barnacle layer 40 feet below the base of the Patinopecten zone in the section just mentioned. The opercular valves illustrated on plate 36 , figs. $2-5,8,9$, were collected at the locality shown on plate $27, A$.

\section{MIDDLE DOME AND SOUTH DOME}

The faunal zones in the Etchegoin formation of North Dome were not recognized in Middle and South Domes, where fossils, aside from diatoms, are rare except at horizons in the upper part of the formation. Even in the upper part of the formation Pseudocardium is the only abundant fossil. The difference in relative abundance of fossils is strikingly shown by the absence of sand dollars in Middle and South Domes. It is improbable that the scarcity of fossils in the lower part of the formation is due to the prevalence of nonmarine deposits, for marine diatoms were observed at many places in layers, generally a fraction of an inch thick, and in small fragments of tuffaceous lightcolored silt in the sandstone constituting the lower part of the formation, which otherwise is generally barren. Pelagic species are included in the diatom flora represented in a sample collected from such material. At a few places marine mollusks were found in the sandstone.

In Middle Dome the Etchegoin formation has an estimated exposed thickness of about 600 feet. In South Dome a considerably greater thickness, estimated as about 1,800 feet, appears to be represented. In both anticlines the formation is divided into an upper part, consisting of silty rocks and subordinate beds of sandstone and conglomerate, and a lower part, in which sandstone is the prevailing rock. The Pseudocardium-Anadara zone in the upper part of the formation is a readily recognized thin zone in both anticlines. If a tuffaceous silt near the top of the lower part of the formation in Middle Dome is the equivalent of tuffaceous sand and silt in the Macoma zone of North Dome, the division between the upper and lower parts in. Middle Dome-and presumably also in South Domeis at a horizon about 50 feet above the top of the Macoma zone of North Dome, but this correlation is. uncertain.

\section{OPPER PART OF FORMATION}

STRATA OVERLYING PSEUDOCARDIUM-ANADARA ZONE

Stratigraphy and lithology. - The strata overlying the Pseudocardium-Anadara zone have a thickness of about 50 feet in Middle Dome and perhaps a little less in South Dome. In Middle Dome they consist of buff silt and silty clay and minor lenses of sandstone (fig. 10). At the base is silty clay that forms a narrow layer virtually barren of vegetation. Weathered outcrops in South Dome indicate that silty rocks predominate in the corresponding part of the section there also. 


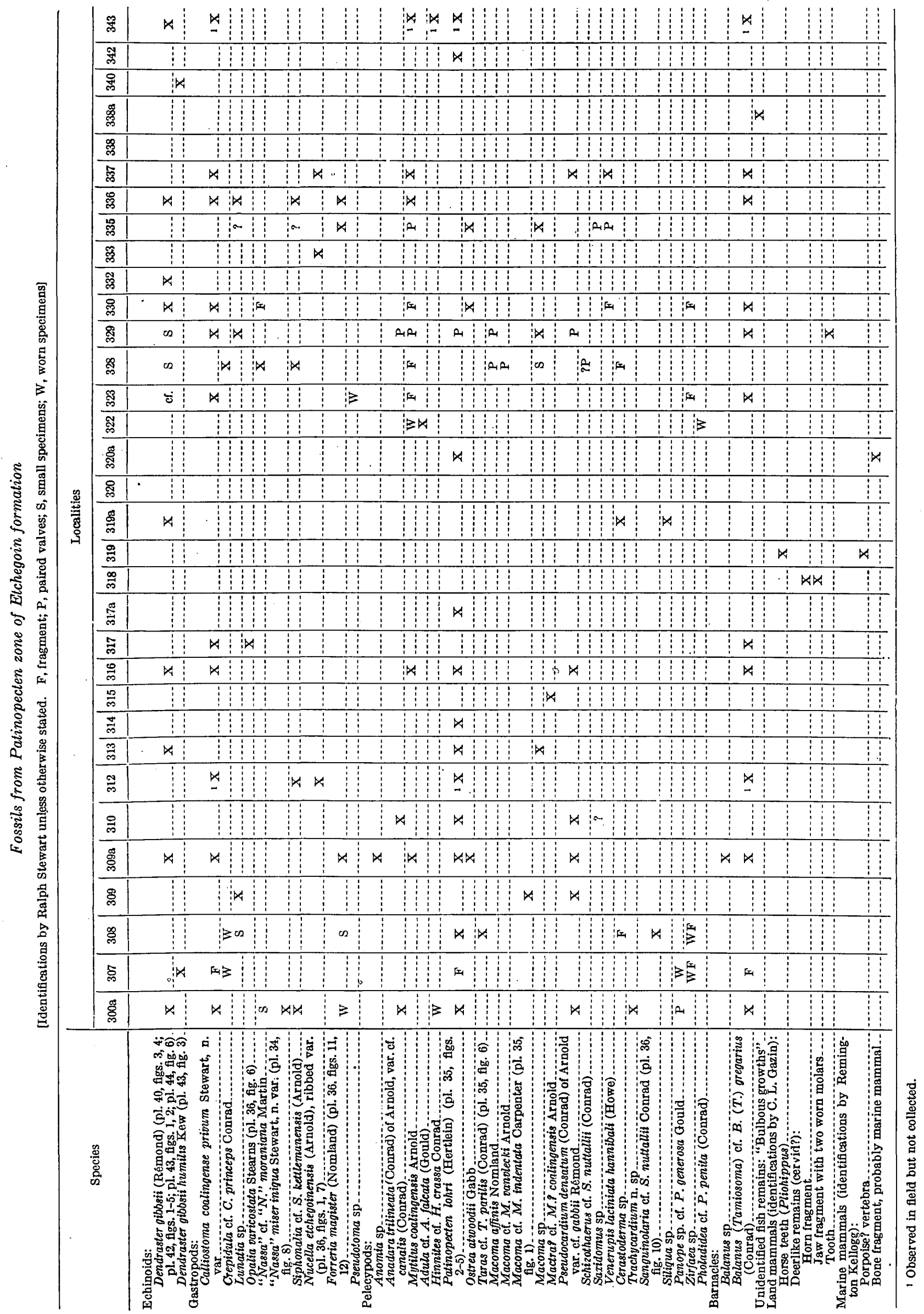




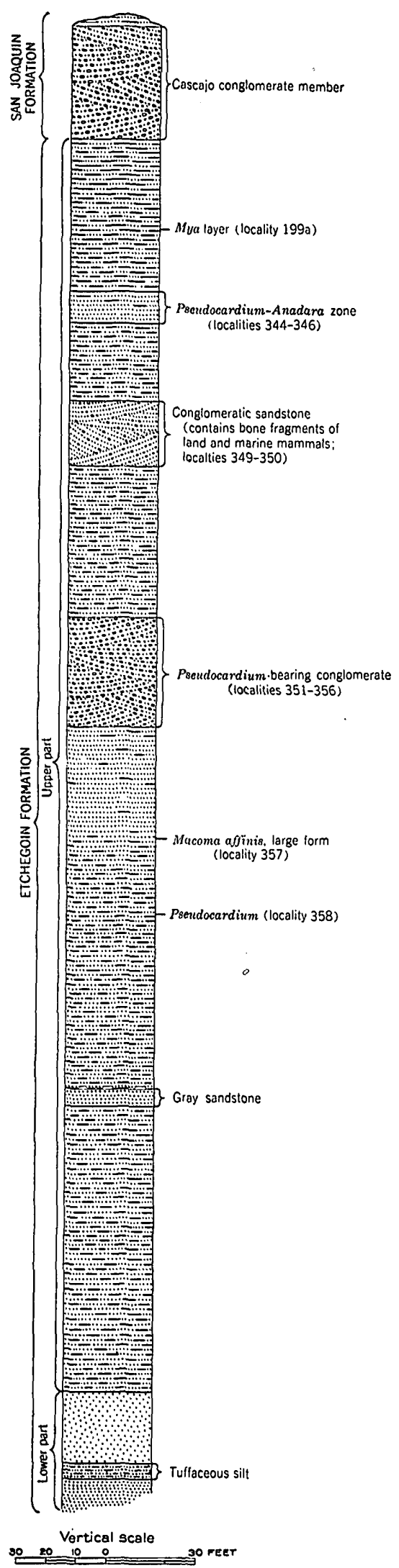

Fiaune 10.-Generalized section of upper part of Etchegoin formation of Middle Dome.

The following section was measured in Middle Dome on the east side of Arroyo Culebrino at the sharp north- ward bend adjoining the south line of sec. 18 , T. 23 S., R. $19 \mathrm{E}$.

Section of strata at base of San Joaquin formation and in upper part of Etchegoin formation on Arroyo Culebrino in southwestern part of sec. 18, T. 29 S., R. 19 E.

San Joaquin formation:

Ft. in.

Cascajo conglomerate member:

Coarse-grained cliff-making bluish-gray sandstone with few imprints of leaf fragments. Possibly corresponds to first blue sandstone of North Dome. Overlain by pebbly sandstone containing worn "bulbous fish growths" and silicified wood. Top not exposed.................. $10+$

Etchegoin formation:

Strata overlying Pseudocardium-Anadara zone:

Poorly exposed buff sandstone.............

Hard gray iron-stained sandstone; lenses out to southeast.........................

Poorly exposed buff silt and clay and soft

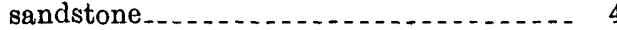

Pseudocardium-Anadara zone:

Gray dirty sandstone containing abundant Pseudocardium and a few Anadara and Mya.

8

A section measured on the ridge south of Arroyo Culebrino in the northeastern part of sec. 24, T. $23 \mathrm{~S}$., R. 18 E., is as follows:

Section of Etchegoin strata overlying Pseudocardium-Anadara zone on ridge south of Arroyo Culebrino in northeastern part of sec. 24, T. 23 S., R. $18 \mathrm{E}$.

Buff silt, clay, and muddy sandstone, the latter contain- Feet ing imperfectly cemented spherical concretions. Thickness estimated. Overlain by Cascajo conglomerate member forming base of San Joaquin formation . .....

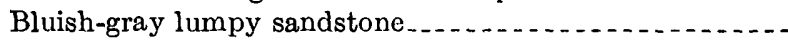

Buff silty clay, including a layer of ironstone concretions 5 feet below top. Underlain by Pseudocardium-Ana:

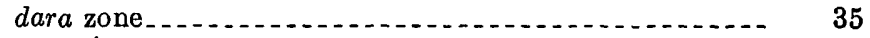

Thickness of Etchegoin strata overlying Pseudocardium-Anadara zone

At locality 199a, along the upper course of Arroyo Culebrino, a Mya layer about 30 feet below the Cascajo conglomerate member forming the base of the San Joaquin formation is exposed on the hanging wall of a fault. This Mya layer may correspond to one of the Mya layers between the Littorina zone and the first Mya layer in the North Dome section. A Mya layer was also found at two other localities on the west side of northern Middle Dome and farther east on Arroyo Culebrino near the south line of sec. 18, T. 23 S., R. 19 E. Mya apparently occurs at about the same horizon at the north end of South Dome, for Myabearing sandstone float was found between the outcrops of the Cascajo conglomerate and PseudocardiumAnadara zone near locality 214.

Fossils.-The fossils collected from the Mya layer at locality 199a are as follows: 
Fossils from Mya layer in Etchegoin strata overlying Pseudocardium-Anadara zone at locality $199 a$

[Identifications by W. P. Woodring]

Macoma affinis Nomland (paired specimen).

Cerastoderma sp. (imperfect specimen).

Mya cf. $M$. dickersoni Clark (paired specimens and single valves).

\section{PSEUDOCARDIUM-ANADARA ZONE}

Stratigraphy and lithology.-The Pseudocardium-Anadara zone consists of 5 to 10 feet of gray or buff silty sandstone about 50 feet below the top of the Etchegoin formation. It is readily recognized by the abundance of a relatively small form of Pseudocardium associated with a few Anadara and Mya, both generally represented by fragments. The zone was mapped in Middle Dome and at the north end of South Dome. The type locality is along Arroyo Culebrino in northern Middle Dome at the place where the section on page 71 was measured.

The zone corresponds probably to the layer containing Mya, Pseudocardium, and Anadara that was mapped as the Littorina zone toward the south end of North Dome. The strata are in the same general part of the section and have the same faunal association. Inasmuch as the Pseudocardium-Anadara zone is the most reliable stratigraphic unit in the Etchegoin formation of Middle and South Domes, it was contoured for the geologic structure map (pl. 51). For practical purposes this datum may be regarded as the equivalent of the datum of the Littorina zone of North Dome. Fossiliferous strata in this part of the section may represent a series of overlapping lenses at slightly different horizons, but the thickness involved is not great enough to affect the representation of the structure.

At many localities in Middle Dome, as on Parejo Hill, the fossils weathered out of the Pseudocardium-
Anadara zone form a band littered with broken Pseudocardium shells, among which may be found a few fragments of Anadara and Mya. At other places the zone is identified by a few fossils strewn in the soil. In such areas, as on the east slope of the ridge in the eastern part of sec. 4, T. 24 S., R. 19 E., the mapping is uncertain. Fresh exposures of the zone were observed at the type locality, at locality 344 , which is farther west on Arroyo Culebrino, and on a tributary of the same stream in the northeastern part of sec. 19, T. 23 S., R. 19 E. At these localities the fossils occur in silty sandstone 5 to 10 feet thick. $M y a$ is generally most abundant at the top of the zone or is confined to the top. Immediately north of the fault 75 feet north of the east quarter corner of sec. 25, T. 23 S., R. $18 \mathrm{E}$., a layer of Mya shells, replaced by gypsum, is exposed at the top of the zone. On the east flank of the anticline southward across the south line of T. 23, Mya is more abundant than elsewhere, and immediately south of the crest of the 520 -foot hill in sec. 4, T. 24 S., R. 19 E., $M y a$ is more abundant than Pseudocardium. A few oolites were recovered from the matrix of fossils collected at locality 346 , in the northern part of the anticline.

In South Dome fossils are not so conspicuous as in Middle Dome, but the same faunal association is represented. According to the width of the band of fossils, the zone is probably not much more than 5 feet thick. On the east side of the anticline the zone was traced almost to the edge of the alluvium covering the San Joaquin Valley; on the west side it appears to grade southward into nonfossiliferous silty sandstone and silt in sec. 33 , T. 24 S., R. 19 E.

Fossils.-Fossils from the Pseudocardium-Anadara zone are listed in the following table, and the Pseudocardium and $M y a$ are shown on plate 24 .

\begin{tabular}{|c|c|c|c|c|c|}
\hline Species & \multicolumn{5}{|c|}{ Lncalities } \\
\hline $\begin{array}{l}\text { Gastropods: } \\
\text { Crepidula princeps Conrad? } \\
\text { Undetermined small gastropod }\end{array}$ & $\mathrm{F}$ & $\mathrm{F}$ & & & 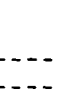 \\
\hline
\end{tabular}

The shells in the Pseudocardium-Anadara zone are generally broken. That this condition is the result of weathering is indicated by the fresh fractures and by the occurrence of whole specimens in unweathered exposures. Pseudocardium densatum, by far the most abundant species, is represented by a variety of small or medium size (pl. 24, figs. 19, 20). This is the highest horizon at which Pseudocardium is abundant in Middle and South Domes, aside from the local occurrence of specimens, possibly of detrital origin, in the Cascajo conglomerate. The Pseudocardium-Anadara zone corresponds approximately to the highest horizon at which 
Pseudocardium occurs in North Dome, and the North Dome occurrences also represent shells generally of small or medium size. Young shells were not found in other beds in Middle Dome or Soutb Dome. A worn unbroken shell from locality 347 , in South Dome, is like thick-shelled specimens from the underlying Pseudocardium-bearing sandstone, and a fragment from locality 345, in Middle Dome, represents a large thick-shelled form like the one in the underlying conglomerate. These shells may be detrital constituents or may be residual from patches of older alluvium removed by erosion.

Anadara trilineata and $M y a$ cf. $M$. dickersoni are generally represented by fragments. A few unbroken small shells of Anadara were collected at locality 347 . The Mya shown on plate 24 , figure 21 , is exceptionally elongate and inequilateral.

The other fossils are represented by single specimens at one locality.

STRATA UNDERLYING PSEUDOCARDIUM-ANADARA ZONE

Stratigraphy and lithology.-In Middle Dome the strata in the upper part of the Etchegoin underlying the Pseudocardium-Anadara zone have a thickness of about 350 feet. They consist principally of silty rocks but include a conglomeratic sandstone and a conspicuous conglomerate. Lenses of blue or gray sandstone occur locally in the silt.

A soft coarse-grained cross-bedded bluish-gray sandstone containing local lenses of small pebbles is about 35 feet below the Pseudocardium-Anadara zone. On Parejo Hill this sandstone has a thickness of 25 feet, but the thickness is variable and at places the sandstone appears to be absent. At localities where this sandstone contains pebbles it resembles a conglomerate lower in the section, though it is generally thinner and less persistent than the conglomerate and has fewer pebbles. The sandstone also apparently lacks the clusters of largo thick-shelled Pseudocardium that occur in the conglomerate. A few isolated specimens of this form of Pseudocardium were found on the outcrop of the sandstone, but none were observed in place. On the east side of the anticline in sec. 33 , T. 23 S., R. $19 \mathrm{E}$. , and in the adjoining part of sec. 4 , T. $24 \mathrm{~S}$., R. $19 \mathrm{E}$., the sandstone is unusually thick and conglomeratic and forms the crest of the ridge extending southeastward from Parejo Hill. In the faulted area on the west side of southern Middle Dome the sandstone is lithologically similar to the underlying conglomerate. This sandstone is in about the same part of the section as the blue sandstone that in parts of North Dome overlies the upper Pseudocardium zone and may represent the base of the San Joaquin formation according to Barbat and Galloway's classification. The upper Pseudocardium zone, however, was not recognized in Middle Dome.
The Pseudocardium-bearing conglomerate about 100 feet below the Pseudocardium-Anadara zone is the most persistent unit in this part of the section in Middle Dome. It is shown on the geologic map (pl. 3), but at places it may have been confused with the overlying sandstone. The conglomerate consists of soft coarsegrained cross-bedded bluish-gray or ferruginous sandstone that has layers or lenses of small pebbles. At most places it contains scattered clusters of a large thick-shelled form of Pseudocardium, generally at the base but locally also above the base. This conglomerate is well exposed on the west slope of Parejo Hill, where it has a thickness of 35 feet. Elsewhere it is fully 50 feet thick, but the thickness is variable and apparently changes within short distances. The specimens of Pseudocardium were probably derived from underlying strata, for they occur in scattered clusters and are not associated with other marine fossils except at two localities where a few molds occur. This conglomerate is probably the equivalent of a blue conglomerate overlying the Siphonalia zone at many localities in North Dome. The conglomerate in North Dome also contains Pseudocardium shells that are probably not in place.

Sandstone and silty sandstone immediately underlying the Pseudocardium-bearing conglomerate are well exposed on the west slope of the hill in the northwestern part of sec. 19, T. 23 S., R. 19 E., where the accompanying section was measured.

Section of strata in Etchegoin formation underlying Pseudocardiumbearing conglomerate on west slope of hill in northwestern part of sec. 19, T. $2 S$ S., R. $19 \mathrm{E}$.

Pseudocardium-bearing conglomerate:

Greatly fractured coarse-grained cross-bedded bluish-gray sandstone. Some layers contain small chert pebbles; others consist of dirty sandstone. No fossils observed. Top not

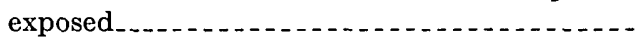

Strata underlying Pseudocardium-bearing conglomerate:

Thin-bedded buff and grayish-buff sandstone and silty sandstone, coarser toward top. Some layers are thick-bedded and a few are cross-bedded. Grades upward into the conglomerate....................................

Iron-stained, grayish-buff sandstone containing small chert pebbles and ferruginous borings. Most of the pebbles are less than half an inch

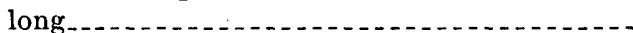

Light-buff to grayish-buff moderately coarse grained sandstone, lower part cross-bedded. Includes cemented masses of irregular shape and varying size. Uppermost foot forms ledge

Soft grayish-buff silty sandstone, massive except near top; $3 \frac{1}{2}$ feet below top a layer of ferruginous concretionary lenses..................

Soft buff sandstone containing scattered large paired Macoma (locality 357) ..............

Poorly exposed soft muddy sandstone and silt.
Ft. In. $24+$ 
At locality 358 and at a few other places the large thick-shelled form of Pseudocardium occurring in the Pseudocardium-bearing conglomerate is abundant in silty sandstone at horizons a few feet to 50 feet below the conglomerate. The similar shells in the conglomerate may have been derived from these strata. At the localities where they occur they are more abundant than in the conglomerate, but they are more widespread in the conglomerate. These fossiliferous strata underlying the conglomerate correspond presumably to the Siphonalia zone of North Dome.

The remainder of the upper part of the Etchegoin in Middle Dome consists of poorly exposed silty rocks. About halfway between the conglomerate and the base of the upper part is a thin gray sandstone recognized along the west side of the anticline and locally on the east side.

In South Dome the strata in the upper part of the Etchegoin underlying the Pseudocardium-Anadara zone have a thickness of about 300 feet. As in Middle Dome, they consist principally of silty rocks. The Pseudocardium-bearing conglomerate and overlying conglomeratic sandstone of Middle Dome were not recognized. At the north end of South Dome a sandstone containing abundant Pseudocardium is 15 to 20 feet below the Pseudocardium-Anadara zone. Fossils are particularly abundant in this sandstone at Oyster Hill (locality 360) and nearby. At Oyster Hill the fossils occur in the uppermost 3 to 5 feet of gray tuffaceous sandstone that is about 25 feet thick and has a middle layer of soft coarse-grained bluish-gray sandstone. A sample of the gray sandstone was examined by M. N. Bramlette, who reported that it contains fresh glass, some of which is brown and has an index of refraction near 1.53, suggesting a more basic composition than that of most of the glass examined from the Kettleman Hills. The sample also contains much andesine and altered biotite, some hypersthene, augite, and hornblende, and a few diatoms and sponge spicules. If the South Dome section is abbreviated, this Pseudocardium-bearing sandstone may correspond roughly to the upper Pseudocardium zone of North Dome, but the form of Pseudocardium is smaller and shorter than that in the upper Pseudocardium zone, and no other fossils were found. Toward the south on both flanks of South Dome the Pseudocardium-bearing sandstone grades into nonfossiliferous strata. A nonfossiliferous gray sandstone at this horizon near the center of sec. 33, T. 24 S., R. 19 E., contains more abundant glass shards than the part of the fossiliferous sandstone sample at Oyster Hill.

South Dome strata in the upper part of the Etchegoin below the horizon of the Pseudocardium-bearing sandstone consist of buff silt and silty clay and lenses of tuffaceous gray sandstone, all of which are generally poorly exposed. Diatoms occur in gray silty clay at scattered localities on the west side of the anticline, principally at horizons close to the base of the upper part of the formation. At locality 361 and elsewhere the diatoms are accompanied by molds of Foraminifera of the genus Elphidium.

Fossils.-Fossils collected from strata in the upper part of the Etchegoin underlying the PseudocardiumAnadara zone are listed in the following table, and the forms of Pseudocardium densatum are shown on plate 37.

The usual form of Pseudocardium densatum in the Pseudocardium-bearing conglomerate and underlying strata in Middle Dome is a variety similar to $P$. $d$.

Fossils from strata in upper part of Etchegoin formation underlying Pseudocardium-Anadara zone

[Identifications by W. P. Woodring unless otherwise stated. F, fragments; M, paired molds; P, paired valves]

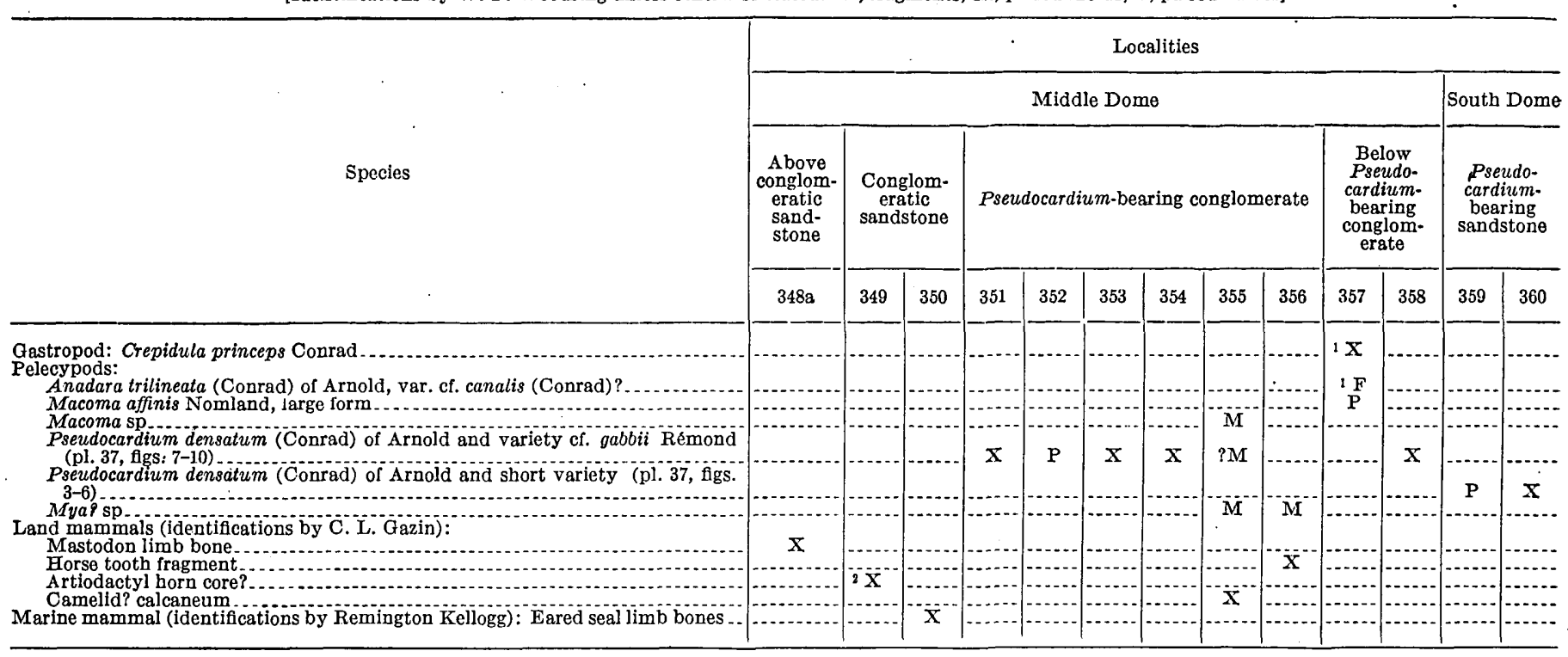

Float specimens.

On surface close to outcrop of Pseudocardium-Anadara zone, but probably weathered out of the conglomeratic sandstone nearby. 


\section{PLATE 37}

[Figures natural size]

Figures 1, 2. Volsella cf. V. modiolus (Linné). Double-valve specimens with crushed anterior end. Locality 368 , lower part of Etchegoin, South Dome.

1. Greatest length (incomplete) $39 \mathrm{~mm}$., width $21.9 \mathrm{~mm}$., thickness of both valves $18.2 \mathrm{~mm}$. U. S. Nat. Mus. 495364.

2. Greatest length (incomplete) $55.3 \mathrm{~mm}$., width $30.8 \mathrm{~mm}$., thickness of both valves $23 \mathrm{~mm}$. U. S. Nat. Mus. 495365.

3. Pseudocardium densatum (Conrad) of Arnold. Left valve. Length $40.7 \mathrm{~mm}$., height $33.7 \mathrm{~mm}$., thickness $12.6 \mathrm{~mm}$. Locality 360, Pseudocardium-bearing sandstone, South Dome.' U. S. Nat. Mus. 495361.

4-6. Pseudocardium densatum (Conrad) of Arnold, short var. Locality 360, Pseudocardium-bearing sandstone, South Dome.

4, 6. Left valve. Length $54.5 \mathrm{~mm}$., height $57 \mathrm{~mm}$., thickness $27 \mathrm{~mm}$. U. S. Nat. Mus. 495362 .

5. Left valve. Length $42 \mathrm{~mm}$., height $47 \mathrm{~mm}$., thickness $20.5 \mathrm{~mm}$. U. S. Nat. Mus. 495363.

7, 8. Pseudocardium densatum (Conrad) of Arnold, var. cf. gabbii Rémond. Right valve; posterior arm of cardinal broken. Length $67.5 \mathrm{~mm}$., height $61 \mathrm{~mm}$., thickness $25 \mathrm{~mm}$. Locality 354, Pseudocardium-bearing conglomerate, Middle Dome. U. S. Nat. Mus. 495358.

9. Pseudocardium densatum (Conrad) of Arnold. Left valve. Length (almost complete) $61.5 \mathrm{~mm}$. ., height (incomplete) $49 \mathrm{~mm}$., thickness $21 \mathrm{~mm}$. Locality 352, Pseudocardium-bearing conglomerate, Middle Dome. U. S. Nat. Mus. 495359.

10. Pseudocardium densatum (Conrad) of Arnold, var. cf. gabbii Rémond. Left valve. Length $74.5 \mathrm{~mm}$., height $70 \mathrm{~mm}$., thickness $31 \mathrm{~mm}$. Locality 358, below Pseudocardium-bearing conglomerate, Middle Dome. U. S. Nat. Mus. 495360 . 


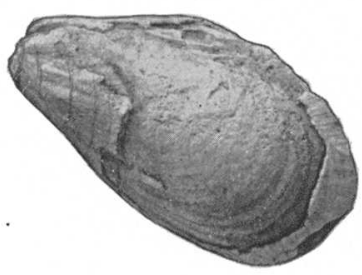

1

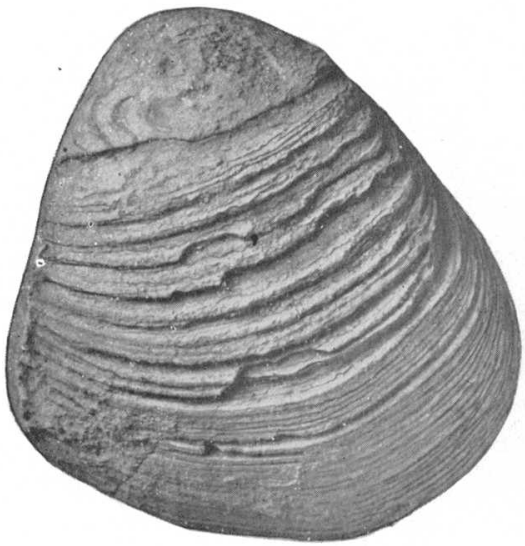

4
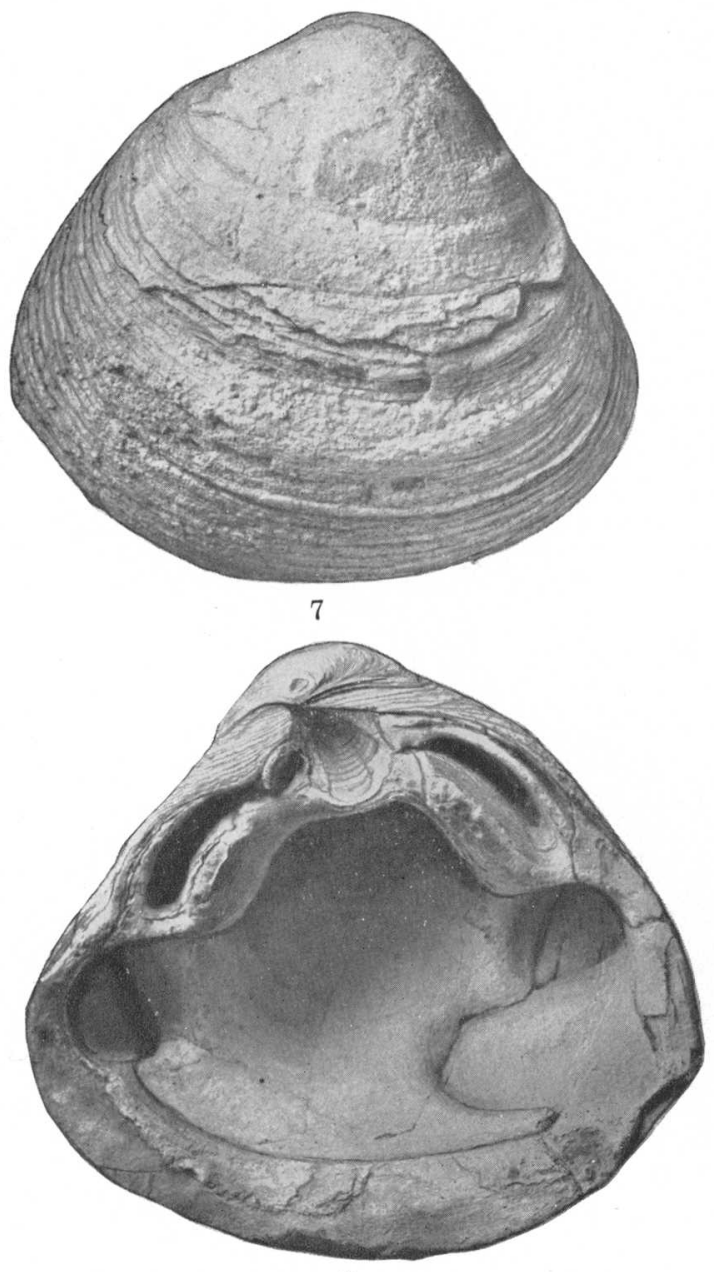
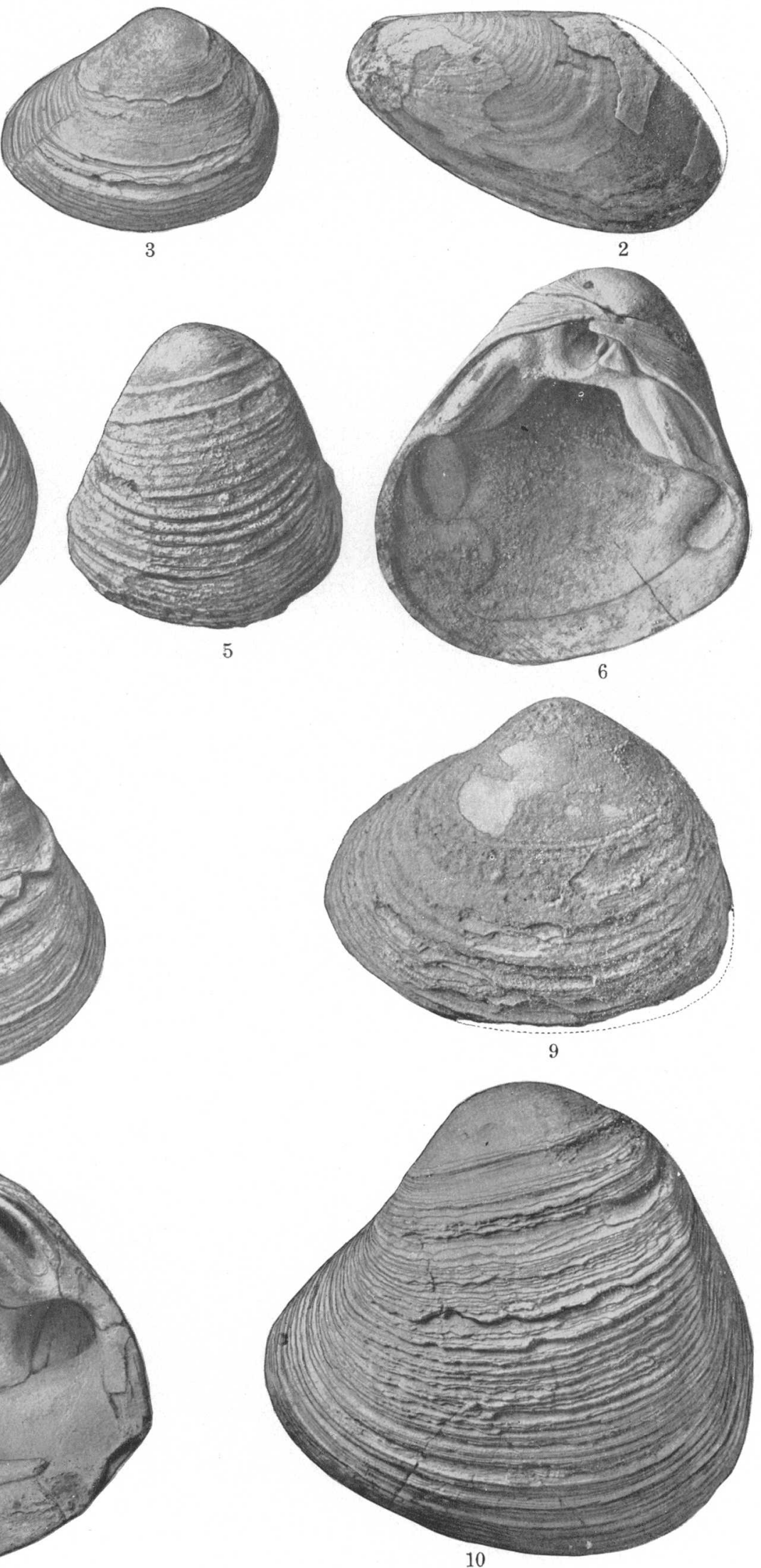

FOSSILS FROM ETCHEGOIN FORMATION OF MIDDLE AND SOUTH DOMES. 


\section{PLATE 38}

Figure 1. Coscinodiscus kurzii Grunow. Diameter $0.135 \mathrm{~mm}$. Locality 364 . U. S. G. S. diatom catalog No. $1515-1$.

2. Coscinodiscus asteromphalus Ehrenberg var. omphalantha (Ehrenberg) Grunow. Diameter $0.266 \mathrm{~mm}$. Locality 361. U. S. G. S. diatom catalog No. 1523-4.

3. Coscinodiscus inclusus Rattray. Diameter $0.040 \mathrm{~mm}$. Locality 361 . U. S. G. S. diatom catalog No. $1523-8$.

4. Endictya robusla (Greville) Hanna and Grant. Diameter $0.057 \mathrm{~mm}$. Locality 361 . U. S. G. S. diatom catalog No. $1523-5$.

5. Coscinodiscus excentricus Ehrenberg. Diameter $0.066 \mathrm{~mm}$. Locality 361 . U. S. G. S. diatom catalog No. $1523-7$.

6. Xanthiopyxis ovalis Lohman. Length $0.027 \mathrm{~mm}$., width $0.018 \mathrm{~mm}$. Locality 364 . U. S. G. S. diatom catalog No. 1515-2.

7. Coscinodiscus vetustissimus Pantocsek. Diameter $0.066 \mathrm{~mm}$. Locality 361. U. S. G. S. diatom catalog No. $1523-6$.

8. Actinoptychus undulatus Ehrenberg. Diameter $0.041 \mathrm{~mm}$. Locality 361. U. S. G. S. diatom catalog No. $1523-5$.

9. Navicula clavata Gregory var. elliptica Schmidt. Length $0.072 \mathrm{~mm}$., width $0.038 \mathrm{~mm}$. Locality 361 . U. S. G. S. diatom catalog No. 1523-9.

10. Slephanodiscus dubius (Fricke) Hustedt. Diameter $0.023 \mathrm{~mm}$. Locality 361. U. S. G. S. diatom catalog No. $1523-3$. 

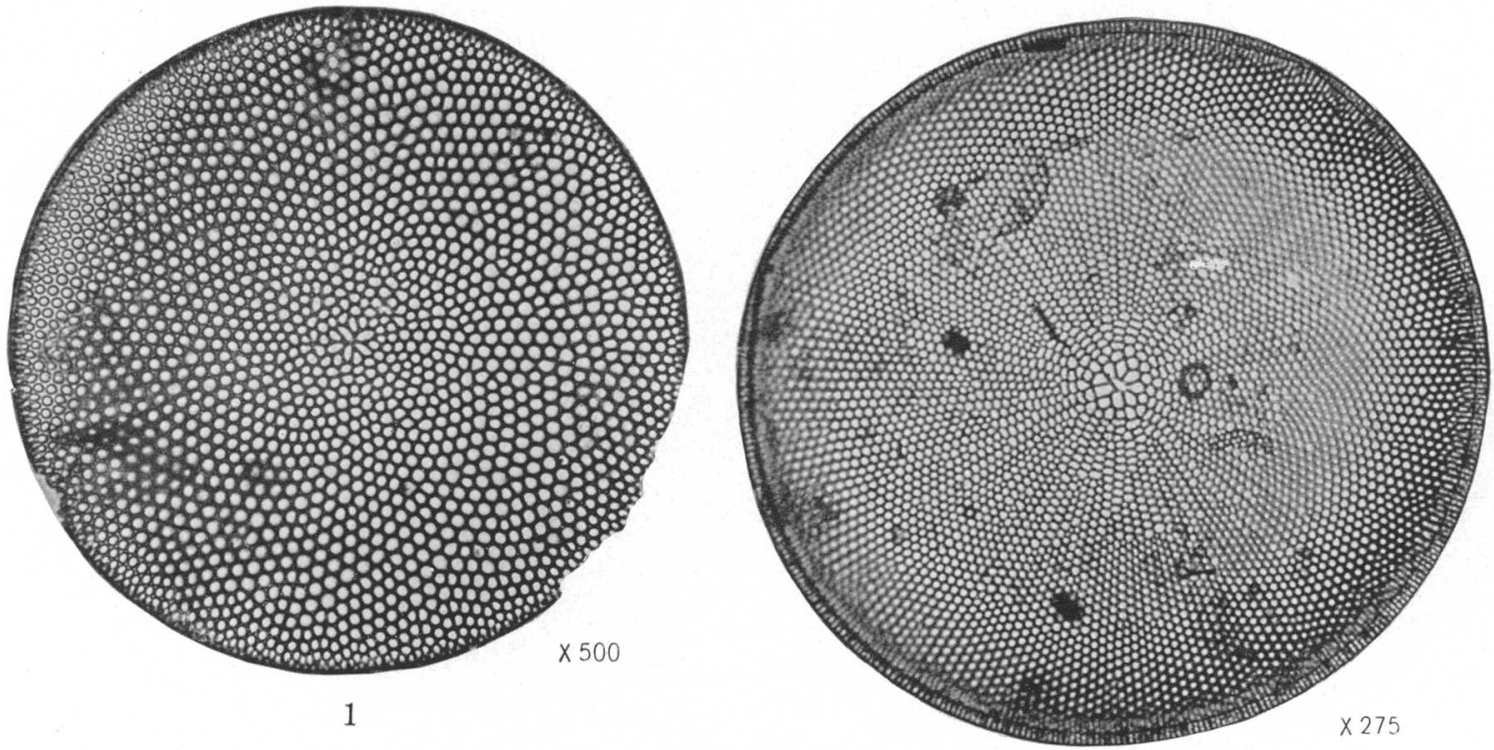

2

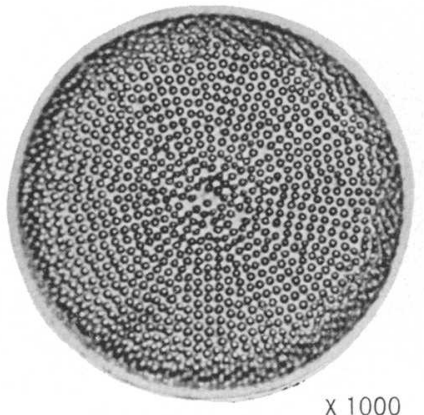

3

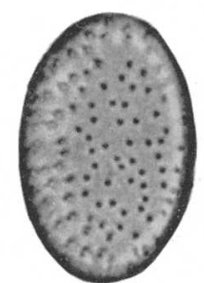

6

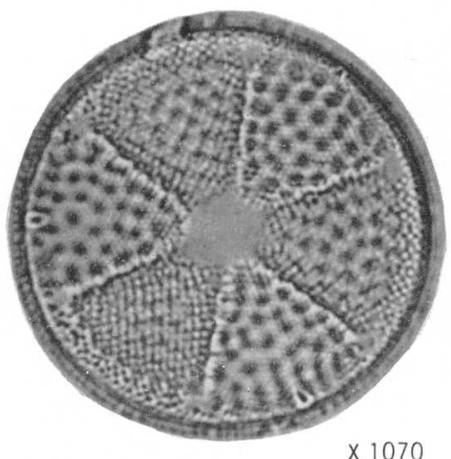

8

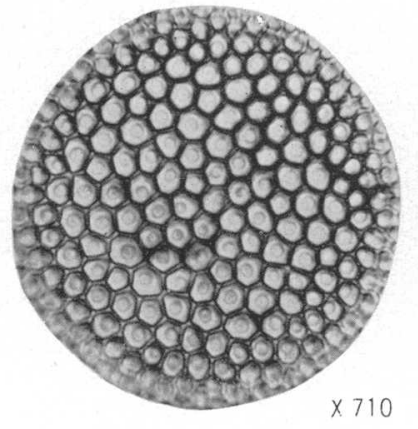

4

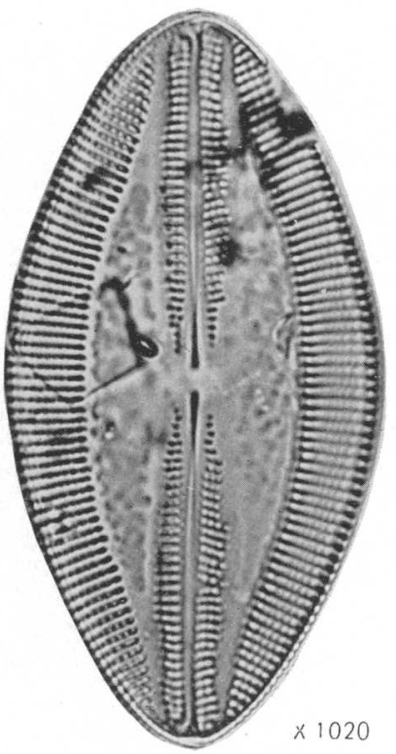

9

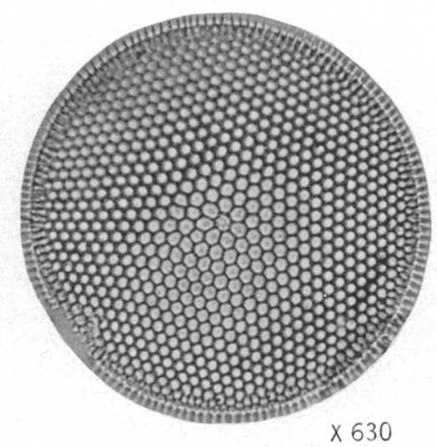

5
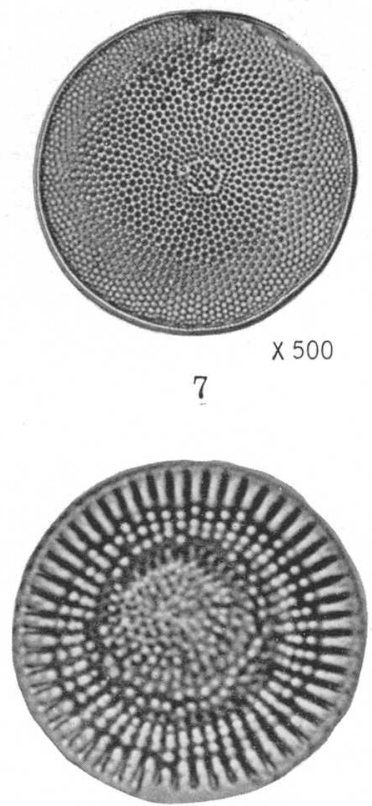

10

DIATOMS FROM ETCHEGOIN FORMATION OF SOUTH DOME. 
gabbii (pl. 37, figs. 7, 8, 10). A few specimens have an elongate anterior end (pl. 37, fig. 9) and resemble Conrad's figure of $P$. densatum. Likewise, the usual form in the Pseudocardium-bearing sandstone of South Dome is a shorter and generally smaller variety (pl. 37 , figs. 4-6), but a few specimens (pl. 37, fig. 3) are similar to Conrad's figure of $P$. densatum. Pseudocardium was not found at lower horizons in either anticline.

The large form of Macoma affinis in strata underlying the Pseudocardium-bearing conglomerate also occurs in the Siphonalia, Macoma, and Patinopecten zones of North Dome.

The following diatoms from locality 361 were identified by K. E. Lohman. Some of the characteristic species are shown on plate 38 . Lohman reports that this flora is dominantly marioe but that it includes a number of fresh-water and brackish-water species, most of which are rare.

Dialoms from upper part of Etchegoin formation at locality 361

[Idontlfications by K. E. Lohman. R, rare; F, fow; C, common; A, abundant]

Melosira sulcata (Ehrenberg) Kützing (R).

Molosira sol (Ehrenberg) Kützing (R).

Melosira solida Eulenstein (R.)

Molosira solida multiformis Frenguelli (R).

Molosira granulata (Ehrenberg) Ralfs (R).

Stophanopyxis turris (Greville and Arnott) Ralfs (R).

Stephanopyxis bruni Schmidt var. (R).

Findictya robusta (Greville) Hanna and Grant (pl. 38, fig. 4) (F). Stephanodiscus dubius (Fricke) Hustedt (pl. 38, fig. 10) (F).

C'oscinodiscus excentricus Ehrenberg (pl. 38, fig. 5) (A).

Coscinodiscus lineatus Ehronberg (F).

Coscinodiscus subtilis Ehrenberg (F).

Coscinodiscus bisculptus Rattray (R).

Coscinodiscus vetustissimus Pantocsek (pl. 38, fig. 7) (F).

Coscinodiscus inclusus Rattray (pl. 38, fig. 3) (R).

Coscinodiscus asteromphalus Ehrenberg omphalantha (Ehren-

berg) Grunow (pl. 38, fig. 2) (F).

Coscinodiscus kntrii Grumow (C).

Actinoptychus undulatus Ehrenberg (pl. 38, fig 8.) (A).

Periptera tetracladia Ehrenberg (F).

Syndendirium diadema Ehrenberg (F). Spores of Chaetoceros?

Dicladia capreolus Ehrenberg (F).

Umphalotheca sp. (R).

Hercotheca cf. H. mammillaris Ehrenberg (F).

Dossoltia sp. (I').

Lithodesmium sp. (R).

Biddulphia roperiana. Greville (R).

T'etracyclus lacustris Ralfs (R).

Thalassionema nitzschioides Grunow (F).

Rhaphoneis amphiceros Lhrenberg (R).

Rhaphoneis angularis Lohman (F).

Cocconeis scutlelum Ehrenberg baldjilerana Grunow (F)

Diploneis elliptica (Kützing) Cleve (R).

Navicula marina Ralfs (I).

Navicula hennedyi $\mathrm{W}$. Smith (R.)

Navicula claratr Gregory elliptica Schmidt (pl. 38, fig. 9) (R).

Pinnularza cf. P. subcapitata Gregory (R).

Pinnularia borealis Ehrenberg (R).

Cymbella lanceolata (Ehrenberg) IKirchner (R).

Cymbella mexicana (Ehrenberg) Cleve $(R)$.

Nitzschia etchegoinia Hanna and Grant (R).

Nitzschia naticularis Grunow (R).

Nitzschia granulata Grunow (F).

\section{LOWER PART OF FORMATION}

Stratigraphy and lithology.-The lower part of the Etchegoin formation of Middle Dome apparently consists almost entirely of sandstone, but exposures are meager, and much of the area of low relief in the interior of the anticline is covered with loose sand. An attempt was made to map the boundary between the upper and lower parts of the formation, but the results are not satisfactory, and at the north end of the anticline normal contacts and faults may have been confused. In areas of simple structure this boundary may be mapped with a reasonable degree of assurance even in the absence of exposures. The soil derived from the sandstone in the lower part of the formation has a heavier growth of vegetation than the soil derived from the silt in the upper part. But because seeds germinate more rapidly in the more impervious silty soil than in the sandy soil, the silty soil takes on a green cover soon after the first rains of the short winter rainy season earlier than the sandy soil.

Two principal kinds of sandstone were observed in the interior of Middle Dome: gray dirty sandstone and bluish-gray cleaner sandstone. Both kinds of sandstone are tuffaceous and much of the gray sandstone has a claylike matrix. Both kinds are soft, aside from imperfectly cemented lumps in gray sandstone, some of which have a ferruginous cement. Hard brown calcareous concretions are characteristic of the uppermost part of the sandstone. A pit near the Bolsa Chica well in sec. 30, T. 23 S., R. 19 E., exposes unconsolidated cross-bedded bluish-gray sandstone that has thin irregular diatom-bearing layers less than an inch thick of tuffaceous sandy silt, and also finer-grained gray sandstone containing fragments of diatom-bearing gray silt and irregular borings filled with coarse sandstone. A sample of gray sandstone from this pit examined by M. N. Bramlette contains fresh volcanic. glass and andesine, some hornblende, augite, and hypersthene, and a few diatoms and sponge spicules. North of the prominent fault near the southwest. corner of sec. 19, T. 23 S., R. 19 E., the upper part of the sandstone is coarse-grained and contains small pebbles. In these features it is similar to the Pseudocardium-bearing conglomerate, but the sandstone is. nonfossiliferous and the conglomerate containing the thick-shelled Pseudocardium is in normal position farther west. Some small pebbles are also present in the upper part of the sandstone on the west slope of the ridge lying west of Parejo Hill. On the east side. of the anticline and also at the north end a tuffaceous fine-grained white silt that has a few diatom impressions. is 30 feet below the top of the sandstone. (See fig. 10.). This silt is probably an altered tuff and may correspond to tuffaceous silt in the Macoma zone of North Dome, but tuffaceous material is so abundant throughout the section that the correlation is uncertain. The tuffaceous silt has been prospected for bleaching clay near 
the north line of sec. 4, T. 24 S., R. 19 E. According to preliminary tests by $\mathrm{P}$. G. Nutting, it is not of commercial grade, but in the natural state has better bleaching properties than the white clay at the base of the Tulare formation.

In contrast with the abundance of fossils in this part of the section in North Dome, the sandstone in Middle Dome appears to be almost barren. Two broken paired molds of Patinopecten that retain a little shell material were seen on the outcrop of the upper part of the sandstone in the north-central part of sec. 30, T. 23 S., R. 18 E. Molds of two small mollusks were collected at locality 362 .

The interior of South Dome is an area of low relief, much of which is covered with loose sand, and exposures are meager. Moreover, fossil zones and distinctive lithologic units that could be followed for a considerable distance are rare. Fossiliferous and nonfassiliferous beds that were traced for any distance are shown on the geologic map (pl. 3). No lithologic unit was traced from one side of the anticline to the other south of the southern part of sec. 27, T. 24 S., R. $19 \mathrm{E}$. If the westward dip is uniform and if there is no duplication by faulting as far east as $\mathrm{El}$ Vejon, the lower part of the Etchegoin of South Dome is about 1,500 feet thickmuch thicker than in North and Middle Domes. An additional thickness of several hundred feet may be represented east of El Vejon. This part of the Etchegoin appears to consist almost entirely of sandstone, but it might include unexposed fine-grained rock. As in Middle Dome, the contact between the two parts of the Etchegoin is drawn at the top of the sandstone. Most of the sandstone is soft, gray, and tuffaceous, but some is hard and some is conglomeratic.

The highest fossiliferous bed shown on the geologic map (pl. 3) is the sandstone on the west side of the anticline in sec. 3 , T. 25 S., R. 19 E., that contains broken specimens of a large Crepidula. At one place there are three Crepidula-bearing sandstones in a stratigraphic thickness of 15 feet. Each of these beds consists of soft gray sandstone containing fossils at the top.

Tuffaceous fine-grained white silt containing a few diatoms is exposed on the ridge in the angle between the highway and the secondary road in the southeastern part of sec. 27, T. 24 S., R. 19 E. This silt may be the equivalent of similar silt in Middle Dome and like it may possibly correspond to tuffaceous silt in the Macoma zone of North Dome.

A hard gray sandstone that forms a series of little cuestas across the plunging north end of the anticline adjoining the east line of sec. 28 , T. 24 S., R. $19 \mathrm{E}$., is found by M. N. Bramlette to be an andesitic tuffaceous sandstone containing phenocrysts of augite, hornblende, and andesine and a little hypersthene. The glass is somewhat altered by the development of zeolite (?) crystals, and some opal (?) cement is present. The hardest rock in South Dome is an olive-gray sand- stone that extends across the plunging crest in the southern part of sec. 27, T. 24 S., R. 19 E., north of Las Lomas. According to M. N. Bramlette it resembles the sandstone just described but is firmly cemented with opal.

Soft tuffaceous gray sandstone containing molds of small specimens of Patinopecten is exposed in a pit in the northern part of sec. 34, T. 24 S., R. 19 E. (locality 363). Gray sandstone, the upper part of which is ironstained and contains a few small pebbles, crops out on the east slope of the 513-foot ridge in the northeastern part of sec. 3, T. 25 S., R. 19 E. Large badly weathered broken bones occur at the base of this sandstone. The gray part of the sandstone contains sand-filled borings and fragments of diatom-bearing gray silt. Layers and fragments of diatom-bearing gray silt occur in tuffaceous gray sandstone in this part of the section, and diatoms were found through an apparent thickness of several hundred feet. Material of this character was collected at locality 364 , which represents a horizon estimated to be almost 1,500 feet below the top of the Etchegoin. At places, as in the upper part of the formation, the diatoms are accompanied by impressions of Elphidium.

Paired specimens of Patinopecten-molds that have a little shell material-occur in hard coarse-grained ferruginous sandstone mapped for a short distance in the southeastern part of sec. 34, T. 24 S., R. 19 E. (locality 365 ), and adjoining parts of sec. 3 . This sandstone, which shows the strike in this region, was unfortunately not recognized on the east side of the anticline.

A zone of sandstone and conglomeratic sandstone, representing a maximum thickness of at least 80 feet, possibly considerably more, is present on the west slope of the ridge lying on the west side of El Vejon. The approximate top and base of this sandstone are shown on the geologic map (pl. 3), but the contacts are not well exposed. Much of this material consists of gray tuffaceous sandstone containing lenses of tuffaceous silt that are generally less than 2 inches thick. At or near the top are lenses of conglomerate in gray ferruginous sandstone. The pebbles have an average length of about a quarter of an inch and a maximum length of half an inch and consist principally of black and green chert, white quartz, and a little white siliceous shale. Thinner lenses of pebbles occur in the sandstone. At the north end of the exposures the sandstone apparently rises in the section through the addition of lumpy gray iron-stained sandstone. Toward the south the pebbles in the upper part of the sandstone disappear. Bone fragments are the only fossils observed in the conglomerate, which was not recognized on the crest or east limb of the anticline. Gray sandstone on the west slope of the 420 -foot hill in the western part of sec. 35 , $T$. 24 S., R. 19 E., contains scattered small pebbles, though they are less abundant than in the sandstone just described. 
Gray tuffaceous sandstone exposed near the south line of T. 24 along the line between secs. 34 and 35, presumably at a horizon below the conglomerate, contains fragments of diatom-bearing silt. Loose blocks of sandstone at the Ohio Smith well near the southwest corner of sec. 35 , T. 24 S., R. 19 E., probably dug up there, have molds of Calyptraea, Anadara, and Patinopecten.

Fossiliferous gray sandstone on the west slope of El Vejon and in nearby areas underlies the conglomerate and appears to represent the lowest part of the outcropping section. Volsella occurs in the upper part of these fossiliferous beds (locality 358). Crepidula is abundant in a gray sandstone that was mapped for a considerable distance and is estimated to be 25 feet lower (locality 369). Arnold and Anderson observed the fossiliferous beds and collected from them. ${ }^{69}$ No exposures were found on the sand-covered east slope of El Vejon. Gray tuffaceous sandstone excavated at the abandoned well in the southwestern part of sec. 1, T. 25 S., R. 19 E. (locality 370 ), has hard fossiliferous calcareous masses and scattered pebbles of chert, quartz, and siliceous shale that have a maximum length of $1 \frac{1}{2}$ inches. This sandstone is assumed to be lower in the section than sandstones on El Vejon.

Fossils.-Fossils from the lower part of the Etchegoin of Middle and South Domes are listed in the following table, and the Volsella from El Vejon is illustrated on plate 37.

${ }^{69}$ Arnold, Ralph, and Anderson, Robert, op. cit. (Bull. 398), pp. 134 (locality 4669), 130 (locality 4857).

Fossils from lower part of Etchegoin formation

[Identiflcations by W. P. Woodring unless otherwise stated. F, fragments; P, paired valves)

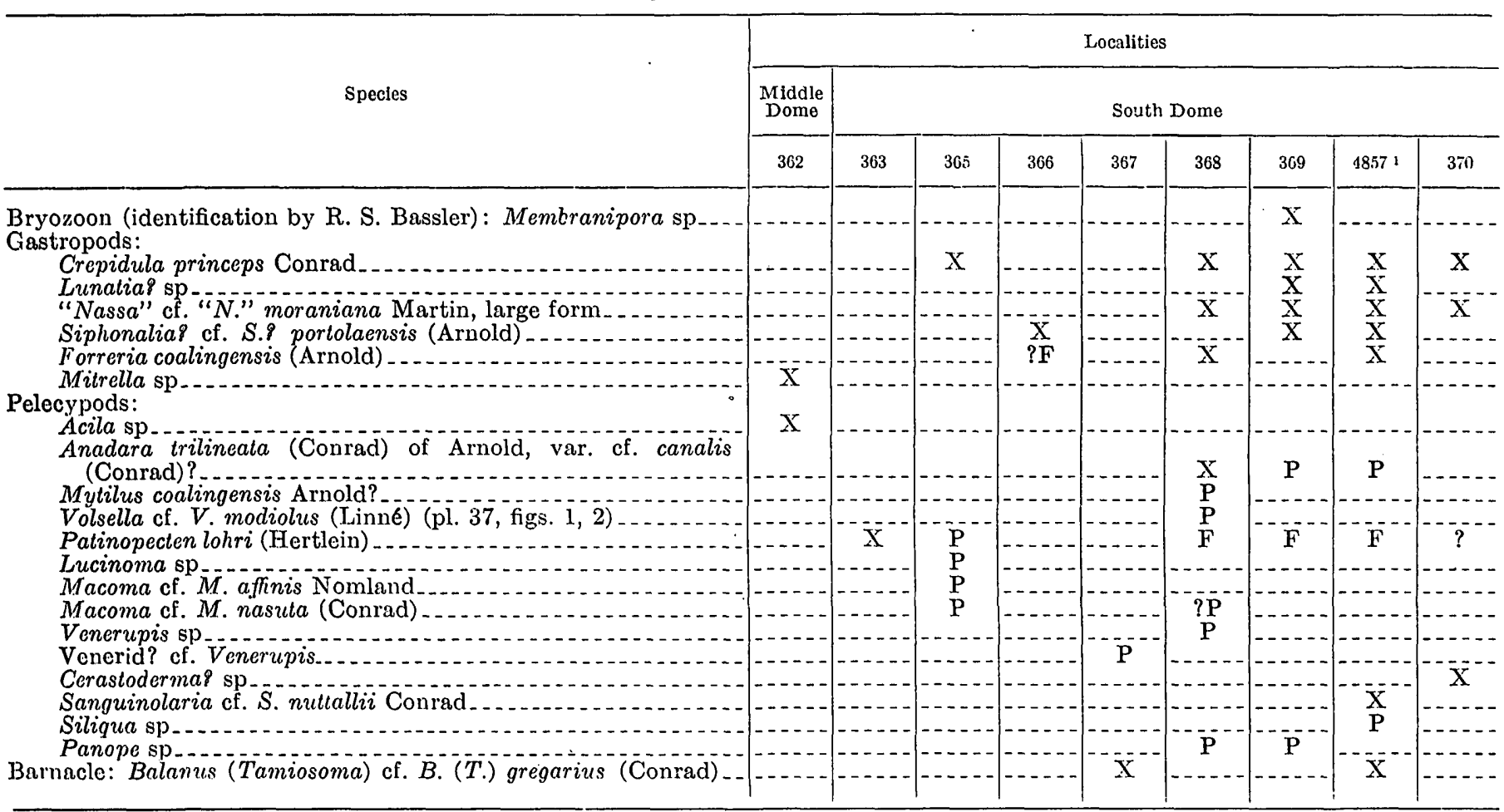

t U. S. G. S. locality 4857. "Extreme southeast end of Kettleman Nills, in secs. 11 and 12, T. 25 S., R. 19 E.; Pecten cweni beds, probably lowcst Etchegoin"; Ralph Arnold, collector.

The molds of Acila from locality 362 are the only specimens of this genus observed in the Kettleman Hills below the Acila zone in the upper part of the San Joaquin formation.

The fossiliferous sandstones on El Vejon and nearby, presumably the oldest strata exposed in the Kettleman Hills, are characterized by a large form of "Nassa" cf. "N." moraniana, Siphonalia? cf. S.? portolaensis, Forreria coalingensis, Volsella of. V. modiolus (pl. 37, figs. $1,2)$, and a large barnacle assigned to Tamiosoma. Siphonalia? cf. S.? portolaensis, Forreria coalingensis, and Volsella cf. $V$. modiolus were not ${ }^{\circ}$ found elsewhere in the Kettleman Hills. "Nassa" cf. "N." moraniana, Sanguinolaria, Siliqua, and Tamiosoma occur in the Etchegoin of North Dome. Forreria coalingensis occurs in the lower part of the Etchegoin in the Kreyenhagen Hills and in the underlying Jacalitos formation. ${ }^{70}$

The diatoms from locality 364 were identified by K. E. Lohman, who prepared the following list and the illustrations on plate 38 .

70 Arnold, Ralph, and Anderson, Robert, op. cit. (Bull. 398), p. 133 (locality 4749) Nomland, J. O., Fauna from the lower Pliocene at Jacalitos Creek and Waltham Canyon, Calif.: California Univ., Dept. Geology, Bull., vol. 9, p. 203, 1916; The Etchegoin Pliocene of middle California: Idem, vol. 10, pp. 213, 221, 1917. 
Diatoms from lower part of Etchegoin formation at locality 364

[Identifleations by K. E. Lohman. R, rare; F, few; C, common; A, abundant]

Melosira solida Eulenstein haitensis Grunow (R).

Melosira granulata (Ehrenberg) Ralfs (R).

Melosira granulata curvata Grunow (R).

Stephanopyxis turris (Greville and Arnott) Ralfs (R).

Coscinodiscus excentricus Ehrenberg (F).

Coscinodiscus subtilis Ehrenberg (F).

Coscinodiscus boliviensis Grunow (F).

Coscinodiscus asteromphalus Ehrenberg (C).

Coscinodiscus asteromphalus omphalantha (Ehrenberg) Grunow (C).

Coscinodiscus oculus-iridis Ehrenberg (F).

Coscinodiscus kurzii Grunow (pl. 38, fig. 1) (F).

Coscinodiscus ef. C. cribrosus Truan and Witt (F).

Actinoptychus splendens (Shadbolt) Ralfs var. (R).

Actinoptychus undulatus Ehrenberg (C).

Actinocyclus ehrenbergii Ralfs (C).

Actinocyclus ehrenbergii tenella (Brebisson) Hustedt (F).

Liradiscus oblongus Grunow (F).

Chaetoceros incurvum Bailey (R).

Periptera tetracladia Ehrenberg (R).

Syndendrium diadema Ehrenberg (F). Spores of Chaetoceros?

Dicladia capreolus Ehrenberg ( $\mathrm{F})$.

Omphalotheca sp. (C).

$X$ anthiopyxis cingulata Ehrenberg (R).

Xanthiopyxis ovalis Lohman (pl. 38, fig. 6) (A).

Lithodesmium cf. L. cornigerum Brun (R).

Thalassionema nitzschiodes Grunow (R).

Pleurosigma cf. P. affine Grunow (R).

Epithemia turgida (Ehrenberg) Kützing (R).

Nitzschia granulata Grunow (R).

Lohman reports that this flora is dominated by marine species and that the large number of pelagic forms suggests fairly open water. The few rare fresh-water and brackish-water species were presumably carried into the sea by streams.

\section{SOURCE OF VOLCANIC MATERIAL IN EXPOSED FORMATIONS}

Volcanic material is abundant throughout the exposed section in the Kettleman Hills, with the possible exception of the upper part of the Tulare formation, which was not examined for this constituent. The tuffaceous material is generally mixed with detrital debris. Relatively pure tuffs, however, occur in the lower Amnicola zone of the Tulare formation on the east side of Middle Dome, about 125 feet above the base of the Pecten zone of the San Joaquin formation on the east side of North Dome, 20 feet below the Neverita zone at the south end of North Dome, and in the Etchegoin formation of North Dome at horizons 20 feet above the upper Pseudocardium zone and near the top of the Siphonalia zone. White tuffaceous silt that apparently represents altered relatively pure tuff occurs at the base of the Tulare formation, in the Macoma zone of the Etchegoin formation of North Dome, and in the Etchegoin of Middle and South Domes. The occurrence of the relatively pure tuffs as lenses of short lateral extent indicates that they are the result of local conditions of sedimentation. The more widespread distribution of white tuffaceous silt at the base of the Tulare and in the Macoma zone of the Etchegoin represents periods of greater volcanic activity or uniform conditions of sedimentation over a larger area.

The tuffs are clearly water-laid, and some of them contain marine fossils. Coarse-grained volcanic material is absent. Inasmuch as no volcanic flows of Pliocene age are known in the Coast Ranges to the windward (westward) of the Kettleman Hills, it is inferred that this volcanic material was derived from a source at a considerable distance and that it represents widespread ash falls resulting from violent explosions. The region in the Coast Ranges north of San Francisco Bay and the Lassen Peak district at the south end of the Cascade Range appear to be the most likely sources. The vents from which the Pliocene volcanic material in the vicinity of San Francisco Bay was derived have not been recognized, but apparently they lay north of the bay, where thick flows of rhyolite, andesite, basalt, and tuff's thin southward. ${ }^{71}$ In this region the Sonoma andesite, which consists of flows and tuffs, interfingers with marine strata containing Pliocene fossils and unconformably overlies the Petaluma formation, which contains Neohipparion. The stratigraphic relations of the Sonoma and Petaluma formations were described by Morse and Bailey. ${ }^{72}$ The tuffs and flows in the Pinole tuff and Orinda formation in the hills east of San Francisco Bay probably represent the same source. These two formations contain Pliocene vertebrates.

The volcanic history of the Lassen Peak district has been described by Williams. ${ }^{73}$ The Tuscan tuff, which extends along the east side of northern Sacramento Valley, west and northwest of the Lassen Peak district, thickens eastward, indicating that the source lay in that direction and that the tuff may have been derived from a vent that was active during the earlier stages of volcanism in this district. ${ }^{74}$ To the west the Tuscan tuff interfingers with the essentially nonvolcanic Tehama formation of Russell and Vander Hoof, which extends southward along the foot of the Coast Ranges on the west side of Sacramento Valley. A dacitic tuffthe Nomlaki tuff of Anderson and Russell-has been recognized in the lower part of both formations, ${ }^{75}$ and

\footnotetext{
7 Osmont, V. C., A geological section of the Coast Ranges north of the Bay of San Francisco: California Univ., Dept. Geology, Bull., vol. 4, pp. 58-76, 84-86, 1905. Dickerson, R. E., Tertiary and Quaternary history of the Petaluma, Point Reyes, and Santa Rosa quadrangles: California Acad. Sci. Proc., 4th ser., vol. 11, pp. 551-559, 1922. Bailey, T. L., The geology of the Potrero Hills and Vacaville region, Solano County, Calif.: California Univ., Dept. Geol. Sci., Bull., vol. 19, pp. 329-330, 1930. Weaver, C. E., Geology of the Coast Ranges immediately north of San Francisco Bay [abstract]: Geol. Soc. America Bull., vol: 41, p. 46, 1930. Weaver, C. E., Geologic cross sections through the Coast Ranges immediately north of San Francisco Bay [abstract]: Geol. Soc. America Bull., vol. 44, p. 155, 1933. Morse, R. R., and Bailey, T. L., Geological observations in the Petaluma district, Calif: Geol. Soc. America Bull., vol. 46, pp. 1441-1451, 1935.

${ }^{72}$ Idem, pp. 1447-1451.

73 Williams, Howel, Geology of the Lassen Volcanic National Park, Calif.: California Univ., Dept. Geol. Sci., Bull., vol. 21, pp. 195-385, 3 maps, 64 figs., 1932.

"Anderson, C. A., The Tuscan formation of northern California with a discussion concerning the origin of volcanic breccias: California Univ., Dept. Geology, Bull., vol. 23, pp. 232-233, 1933.
}

${ }^{7}$ Idem, pp. 219, 234-235. 


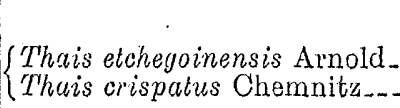

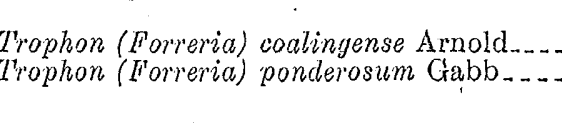

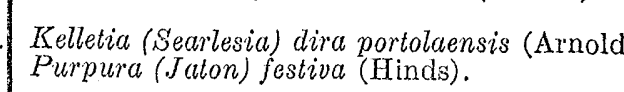

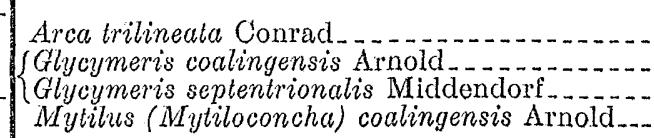

Nucula (Acila) casstrensis Hinds.

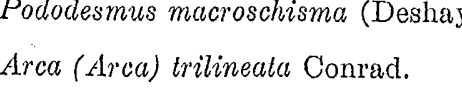

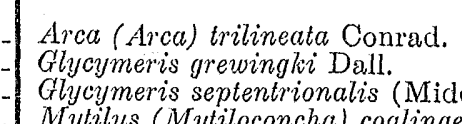

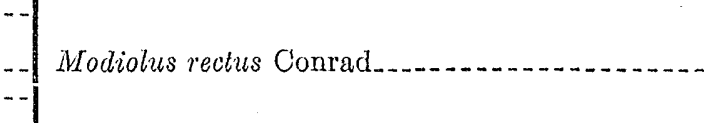

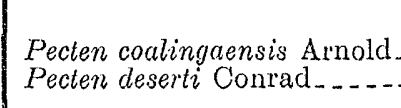

Volsellu recta (Conrad).

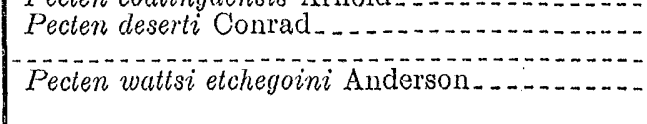

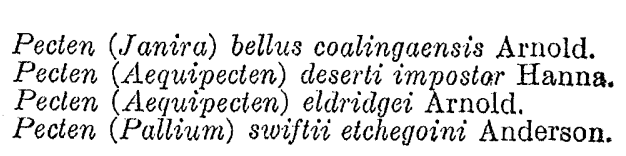

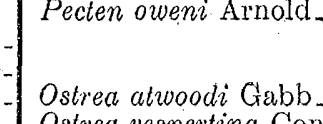

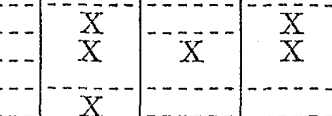

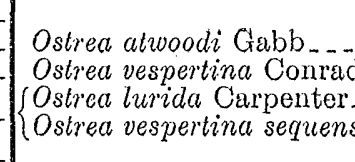

Pecten (Patinopecten) hecleleyi lohri Hertlein.
Ostrea atwoodi Cabb.

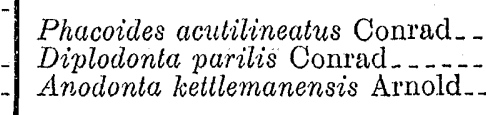

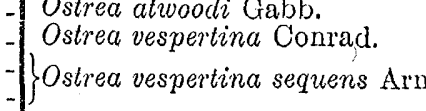

Gonidea coalingensis Arnold.........

Sphearium kettlemannensis Arnold_........-.....

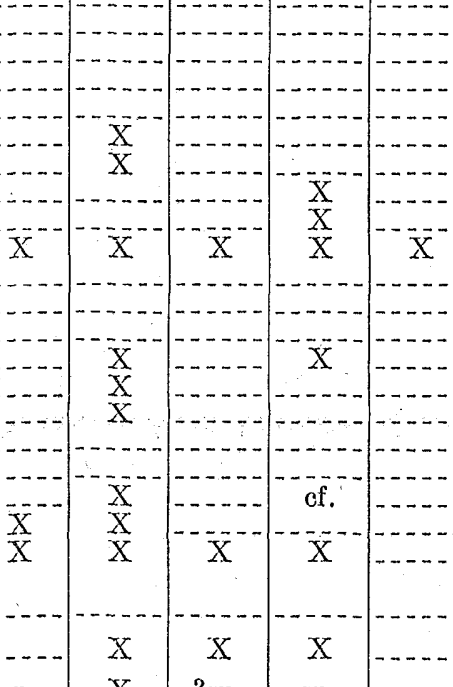

\section{$x$
$x$
0
$x$
$x$}

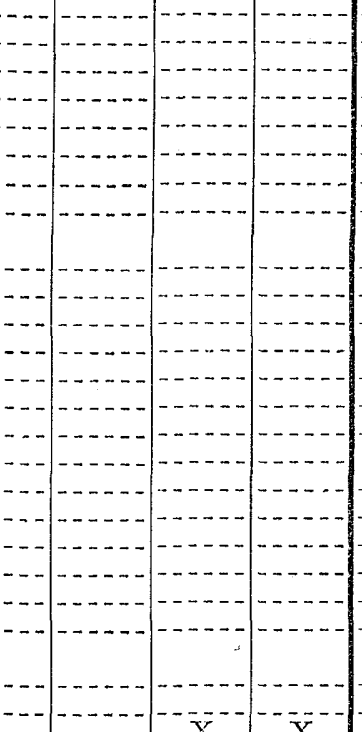

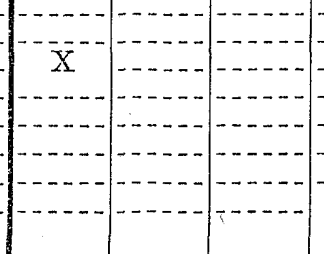

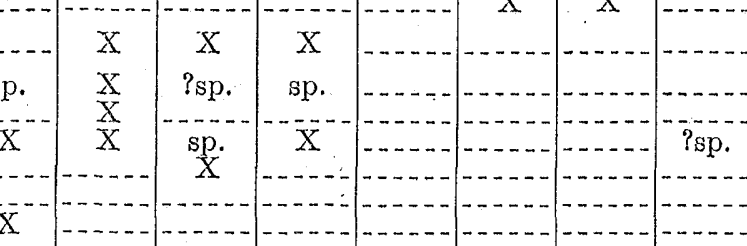

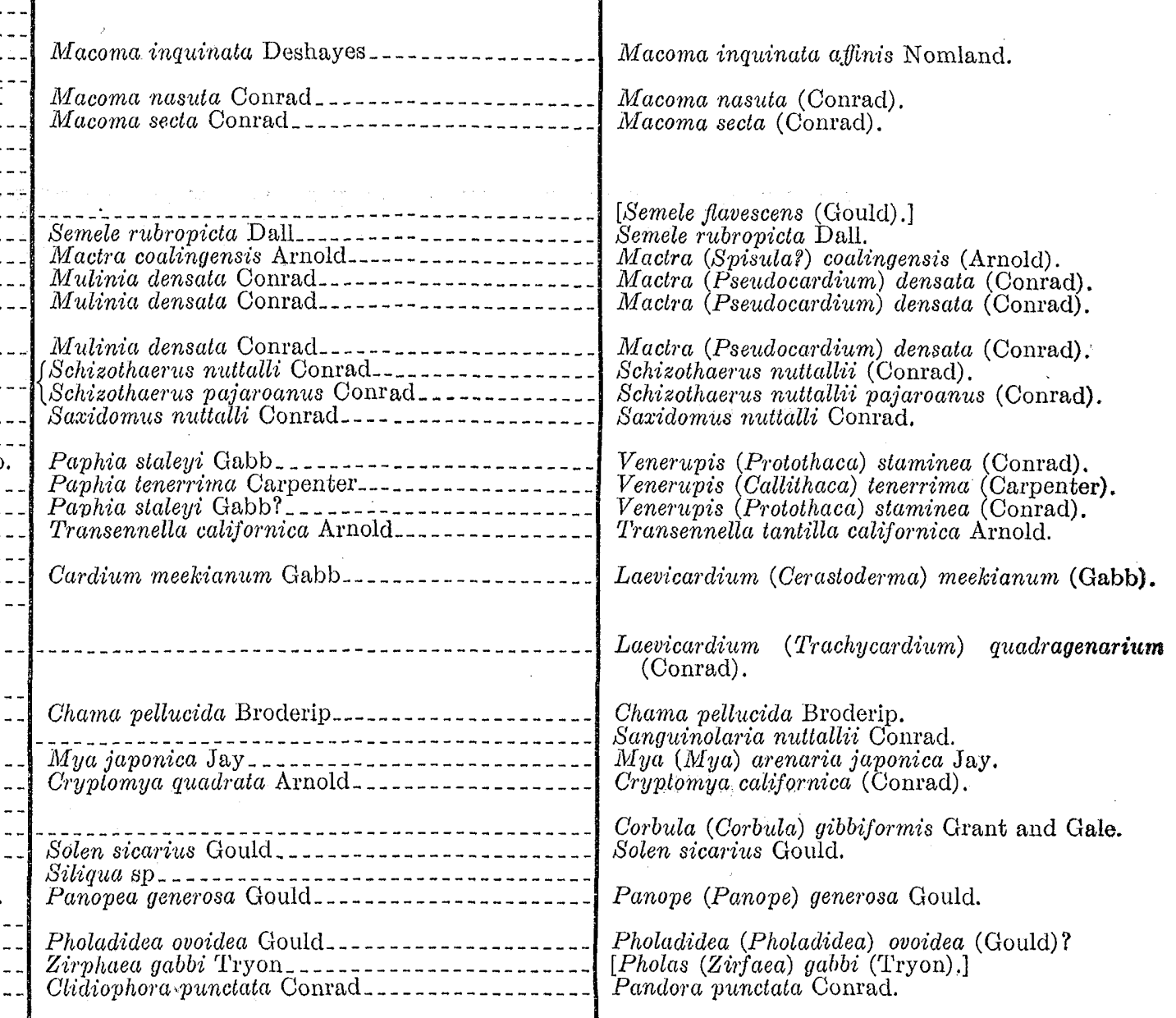

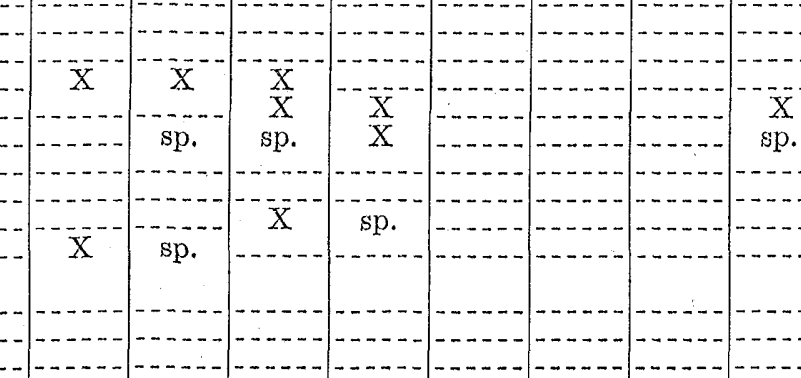

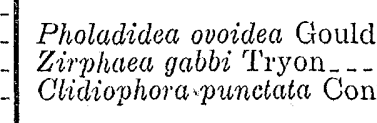


vertebrate remains from beds above the dacitic tuff on the west side of the valley are considered of upper Pliocene age ${ }^{70}$ The dacitic tuff in the Kettleman Hills about 125 feet above the base of the Pecten zone of the San Joaquin formation may possibly correspond to Anderson and Russell's Nomlaki tuff. If the tuffs in the Kettleman Hills were derived from the Lassen Peak region, they may deserve consideration as a possible aid in establishing correlations between the Coast Ranges, the Sierra Nevada, and the Cascade Range.

\section{PALEONTOLOGY OF EXPOSED FORMATIONS}

The table opposite page 78 shows the stratigraphic distribution of fossils from the formations exposed in the Kettleman Fills. In order to correlate the nomenclature of different writers the names used for the fossils by Arnold ${ }^{77}$ in his publications on the Coalinga district, by Kew in his echinoid monograph, ${ }^{78}$ and by Grant and Gale ${ }^{79}$ in their recent catalog of Pliocene and Pleistocene marine mollusks are cited opposite the names used in the present report.

No fossils were collected from Etchegoin strata between the upper Pseudocardium and Siphonalia zones, and collections from Etchegoin strata underlying the Patinopecten zone have not been identified.

For various reasons many of the fossils are indefinitely determined. Most of the indefinitely determined species are represented by inadequate material; the characters of the type material of some species are insufficiently known; and the affinities of other forms have not been worked out. The designation "sp." is used in the species list for undetermined forms-generally incomplete or poorly preserved specimens-that presumably represent some other species than those under the same generic name or that are too imperfect for identification. Some of the "sp.'s" in the species list, however, may be duplications of more completely identified forms. The occurrence of a form. identified as "sp." nt more than one horizon does not necessarily mean that the same form is represented at the different horizons. The designation "sp." is used in the stratigraphic columns for undetermined forms that probably represent the species or variety cited in the species list.

The affinities of the stratigraphically important species and their distribution are discussed under the systematic headings that follow. This treatment was planned with the expectation that it may aid stratigraphers. The sand dollars are discussed by Ralph

70 Russoll, R. D., and Vander Hoof, V. L., A vertebrate fauna from a new Pliocene formation in northorn Californis: Californla Univ., Dept. Geol. Scl., Bull., vol. 20, pp. 11-21, 7 flgs., 1031. Vander Hoof, V. I., Additions to the fauna of the Tehama upper Pliocene of northern California: Am. Jour. Sci., 5th ser., vol. 25, pp. 382-384, 1033.

$"$ Arnold, Ralph, op. clt. (Bull. 396), pp. 71-101, 1909 [1910]. Arnold, Ralph, and Andorson, Robert, op. cit. (Bull. 398), pp. 125-133, 153, 1910.

${ }^{78}$ Kow, W. S. W., Crotaceous and Cenozoic Echinoidea of the Pacific coast of North Amorica: Calilornia Univ., Dept. Ceology, Bull., vol. 12, pp. 113-130, 1920.

70 Grant, U. S., IV, and Gale, H. R., Catalogue of the marine Pliocene and Pleistocono Mollusca of California: San Diego Soc. Nat. History Mem., vol. 1, pp. 109877, 1031.
Stewart and the barnacles are discussed by W. P. Woodring. The matter dealing with the mollusks was written by both authors. As differentiation of authorship is desirable for future citations, initials are added at the end of paragraphs.

Dimensions of figured specimens, including types, and National Museum catalog numbers for these specimens are cited in the explanation of the plates.

The following new names are proposed in the discussions:

Echinoids:

$$
\text { New species and varieties }
$$

Dendraster coalingaensis Twitchell var. macer Stewart, p. 81, pl. 39, fig. 9 ; pl. 40 , figs. 1,5 ; pl. 41 , figs. 1,2 (type), 4

Dendraster gibbsii (Rémond) var. mirus Stewart, p. 80, pl. 44, figs. 4, 5 (type).

Mollusks:

Calliostoma coalingense Arnold var. privum Stewart, p. 84, pl. 32, fig. 5 (type).

Forreria magister (Nomland) var. munda Stewart, p. 88, pl. 15, figs. 17, 18 (type).

Macoma affinis Nomland var. plena Stewart, p. 93, pl. 24, fig. 3 ; pl. 29, fig. 12 ; pl. 39, fig. 3 (type).

"Nassa" miser (Dall) var. iniqua Stewart, p. 87, pl. 34, fig. 8 (type).

Platyodon colobus Woodring, p. 95, pl. 21, figs. 1 (type), 2.

Saxidomus nuttalli Conrad var. latus Stewart, p. 94, pl. 8, fig. 15 ; pl. 16, fig. 8 (type); pl. 33, fig. 6 .

Turcica caffea (Gabb) var. brevis Stewart, p. 84, pl. 11, figs. 1, 6 (type).

Venerupis grata (Say) var. tarda Stewart, p. 94, pl. 13, figs. 10-13 (type).

\section{ECHINOIDS}

Echinoids are represented in the San Joaquin and Etchegoin formations by sand dollars of the genus Dendraster. In addition to Dendraster in the restricted sense, Merriamaster, which is assigned subgeneric rank under Dendraster, occurs in the upper part of the San Joaquin formation. Sand dollars are abundant in some sandy strata in both formations in North Dome, are relatively rare in the San Joaquin formation and apparently absent in the Etchegoin in Middle Dome, and were found in South Dome only in the Pecten zone of the San Joaquin, and at that horizon they are not abundant. In the following discussion citations for Pacific coast species that may be found in Kew's monograph ${ }^{80}$ are omitted, as Kew's work should be available to anyone interested in these fossils.

The Kettleman Hills sand dollars may be classified in three main groups: (1) the Dendraster gibbsii group, characterized by a markedly posterior eccentric apical system; (2) the Dendraster coalingaensis group, characterized by a less eccentric apical system; and (3) the Merriamaster group, characterized by inflated margin of the test, large spine bases, and open petals. The stratigraphic range and probable relations of the different forms of these three groups are shown in figure 11.

Dendraster gibbsii group.-Dendrastergibbsii.(Rémond) is the oldest sand dollar in the Kettleman Hills and is

${ }^{80}$ Kew, W.S.W., op. cit., pp. $23-230$, pls. $3-42,5$ figs. 


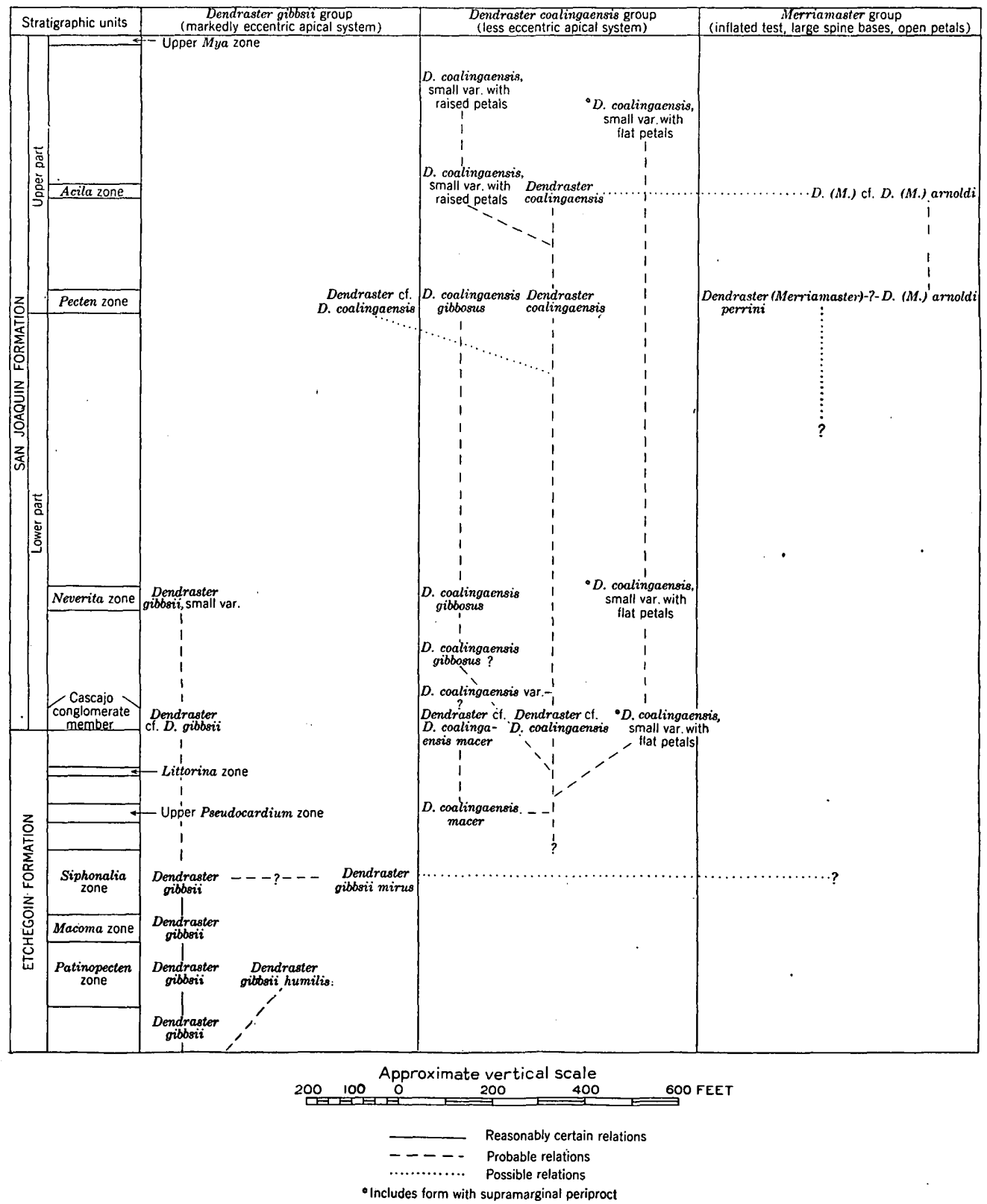

FIGURE 11.--Stratigraphic range and probable relations of sand dollars in San Joaquin and Etchegoin formatsous.

abundant in strata below the Patinopecten zone and in the Patinopecten zone (pl. 40, figs. 3, 4; pl. 42, figs 1-5; pl. 43, figs. 1, 2; pl. 44, fig. 6), the Macoma zone, and the Siphonalia zone (pl. 40, fig. 2). This form has rather inflated margins and a markedly posterior apical system. Specimens that are exceptionally eccentric are assigned to the variety $D$. gibbsii humilis Kew, the type of which was cited from a locality in the Jacalitos Hills west of the Kettleman Hills. The original material of $D$. gibbsii may have been collected in the Kettleman Hills or in the foothills farther west. Rémond's locality, "Kern Lake, Buena Vista County," is clearly erroneous according to current usage; he meant probably Tulare Lake, which is designated Kern Lake on some early maps. Specimen 11050 in the collection of the University of California, labeled "type from C. D. Gibbs, oil region west of Tulare Lake," has been cited as the holotype, ${ }^{81}$ but specimen 11328 is also labeled "type." At one locality in the Siphonalia zone small specimens of $D$. gibbsii have open petals and large spine bases and are almost as inflated as Merriamaster. They are considered abnormal specimens of $D$. gibbsii and are named D. gibbsii mirus Stewart, n. var. (pl. 44, figs. 4,5 ).

A few specimens similar to $D$. gibbsii were found in the Cascajo conglomerate member at the base of the San Joaquin formation. The small variety that is abudant in the Neverita zone of the San Joaquin (pl. 20, figs. 10,$11 ;$ pl. 21 , figs. $3-6$ ) is generally about half as large as the usual $D$. gibbsii. The $D$. gibbsii group has not been recognized at higher horizons in the San 
Juaquin formation, but some specimens in the upper part of the formation, such as the more eccentric forms of $D$. coalingaensis, may possibly be survivors of D. gibbsii.

Dendraster coalingaensis group.-The Dendraster coalingaensis group, with one exception, was found in the San Joaquin formation, particularly in the upper part of the formation. Aside from a few exceptional specimens, the sand dollars of this group have a less eccentric apical system than those of the $D$. gibbsii group.

D. coalingaensis Twitchell occurs in the Pecten zone (pl. 45, figs. 1, 2) and Acila zone, and similar specimens were found in the Cascajo conglomerate member. The variety $D$. coalingaensis gibbosus $\mathrm{Kew}$, which has a high center and is usually wider than long, is present in the Pecten zone (pl. 45, figs. 5, 6) and at lower horizons in the San Joaquin. Some specimens, identified as $D$. cf. $D$. coalingaensis (pl. 39, fig. 7 ), from the Pecten zone have the gencral shape and appearance of $D$. coalingaensis, with which they were found, but have the eccentric apical system of $D$. gibbsii.

A small variety of $D$. coalingaensis that has slightly raised petals and deep ambulacral furrows, occurs in the Acila zone (pl. 45, figs. 3,4 ) and at higher horizons between the Acila and upper Mya zones (pl. 10, figs. 6-9), including the youngest strata in which sand dollars were observed. Another small variety that has flat petals occurs in the Cascajo conglomerate, in the Neverita zone, and at a horizon between the Acila and upper Mya zones (pl. 10, figs. 10-12). The outline of the test and the position of the periproct are variable in this variety; some specimens have an inframarginal or barely inframarginal periproct (pl. 10, fig. 12), others have a marginal periproct (pl. 10, fig. 10), and othersgenerally those with an ovate-pentameral outlinehave a supramarginal periproct (pl. 10, fig. 11).

The thin sand dollar in the upper Pseudocardium zone is the only representative of the $D$. coalingaensis group discovered in the Etchegoin formation. This thin sand dollar is named $D$. coalingaensis macer Stewart n. var. (pl. 39 , fig. 9 ; pl. 40, figs. 1,5 ; pl. 41, figs. 1 , $2,4)$. The opening at the end of the anterior petals is narrower in this variety than in $D$. coalingaensis. A form similar to the variety macer occurs in the Cascajo conglomerate. An exceptional specimen (pl. 44, fig. 3), associated with $D$. coalingaensis gibbosus at a horizon immediately above the Cascajo conglomerate, has the narrow petal openings of the variety macer but is more inflated, having a profile like that of $D$. coalingaensis. It is classified as a variety of that species.

$D$. coalingaensis was described from a Pecten zone locality in the Kreyenhagen Hills, west of the Kettleman Fills. It is probably closely related to $D$. diegoensis Kew, from the San Diego formation, and, as suggested by Twitchell, ${ }^{82}$ may be the ancestor of the living $D$. excentricus (Eschscholtz). D. hesperis Kew, from Priest Valley in the Coast Ranges west of the Coalinga district, appears to be a synonym of $D$. coalingaensis; Kew's D. coalingaensis Twitchell is $D$. (Merriamaster) arnoldi Twitchell. $D$. hesperis gibbosus $\mathrm{Kew}$ is here given priority over $D$. (Calaster) oregonensis gibbosus Kew. ${ }^{83}$

Merriamaster group.-Sand dollars in the Pecten, Trachycardium, and Acila zones are assigned to Merriamaster Lambert, ${ }^{84}$ the type of which is Scutella perrini Weaver. The open petals, large spine bases, and inflated test are apparently the distinguishing characters of Merriamaster. The specimens from the Pecten and Acila zones appear to be closely related to $D$. coalingaensis and may be abnormal individuals of that species. Inasmuch, however, as sand dollars with the characters of Merriamaster have been found at localities from central California to Cedros Island, Lower California, it is convenient to recognize them as distinct, whatever their genetic relations to species of Dendraster may be. Merriamaster is, therefore, treated as a subgenus of Dendraster.

The common sand dollar in the Pecten and Trachycardium zones, D. (M.) perrini (Weaver) (pl. 46, figs. $1,2,4,7,10,12$ ), is a small inflated form with inflated margins and large spine bases. A form with larger spine bases on the petals, $D$. (M.) arnoldi Twitchell, also occurs in the Pecten and Trachycardium zones (pl. 46, figs. 3, 5, 6, 8, 11). D. (M.) arnoldi is found in the overlying Acila zone (pl. 39, fig. 5; pl. 41, fig. 3), but some specimens are not quite so inflated as the typical form (pl. 46, fig. 9). Some specimens from the Acila zone that have poorly defined Merriamaster characters are practically indistinguishable from $D$. coalingaensis. The sand dollars from the Acila zone classified as $D$. (M.) cf. D. (M.) arnoldi might be considered a variety of $D$. coalingaensis, whereas those from the Pecten and Trachycardium zones classified as $D$. (M.) arnoldi might be considered a variety of $D$. (M.) perrini.

The two small imperfect specimens from the Coalinga district described by Twitchell as Sismondia? arnoldi and Sismondia? coalingaensis are young specimens of Merriamaster or Dendraster; and, therefore, according to the classification here adopted are homonyms of $D$. (M.) arnoldi and $D$. coalingaensis respectively. $D$. (M.) arnoldi Twitchell is given arbitrary priority over Sismondia? arnoldi Twitchell, and D. coalingaensis Twitchell is likewise given arbitrary priority over

52 Clark, W. B., and Twitchell, M. W., The Mesozoic and Cenozoic Echinodermata of the United States: U. S. Geol. Survey Mon. 54, p. 196, 1915.

${ }^{83}$ After this account was written Dendraster (Calaster) oregonensis gibbosus was renamed Anorthoscutum oregonense quaylei (Grant, U. S., IV, and Hertlein, L. G., The West American Cenozoic Echinoidea: California Univ. at Los Angeles Pub. Math. Phys. Sci., vol. 2, p. 93, 1938).

84 Lambert, J., Rev. crit. paléozool., 15th year, p. 64, 1911. 
Sismondia? coalingaensis Twitchell. Orchoporus koehleri Lambert and Thiéry, ${ }^{85}$ the type of Orchoporus Lambert and Thiéry, ${ }^{86}$ was based on the same specimen as Sismondia? arnoldi (Arnold's figured Astrodapsis sp. undet). ${ }^{87}$ This specimen, apparently a young specimen of $D$. (M.) perrini, is labeled U. S. G. S. locality 4708 , a locality in North Dome that probably represents the Acila zone. $D$. (M:) perrini was not found in the Acila zone during the field work for the present report. Inasmuch as the collection from locality 4708 has no additional sand dollars agreeing in preservation and morphology with the type specimen and inasmuch as three specimens from locality 4715 (Pecten zone at Las Morones in South Dome) are very similar in preservation and morphology to the type specimen, the locality 4708 may be an error. The type of Sismondia? coalingaensis is from a locality in the Kreyenhagen Hills not mentioned in Bulletin 398 (U. S. G. S. locality 4779, "little sea urchin bed near top of Etchegoin half a mile east of A. Kreyenhagen's house on Jacalitos Creek"). It is probably a young specimen of the small variety of $D$. coalingaensis that occurs near the top of the San Joaquin formation in the Kettleman Hills.

Relations of Kettleman Hills sand dollars.-The sand dollars of the $D$. gibbsii and $D$. coalingaensis groups may be classified according to the degree of eccentricity of the apical system. As expressed by the ratio $\frac{a}{p}$, in which $a$ is the distance from the anterior margin of the test to the center of the apical system and $p$ is the distance from the posterior margin of the test to the center of the apical system, the degree of eccentricity is as follows:

Degree of eccentricity of sand dollars of $D$. gibbsii and D. coalingaensis groups

D. coalingaensis . .

D. gibbsii . . . $\frac{a}{p}$ is greater than 2

D. gibbsii humilis........................ $\frac{a}{p}$ is greater than 3

This artificial classification corresponds roughly to the stratigraphic position of the forms in the North Dome section. It is, however, of but local significance as $D$. jacalitosensis $\mathrm{Kew}$, which has an apical system similar to that of $D$. coalingaensis, was described from the Jacalitos formation, underlying the Etchegoin formation, in association with $D$. gibbsii humilis. The characters of $D$. jacalitosensis and of specimens from the Jacalitos formation identified as $D$. gibbsii are not well known. In the degree of eccentricity of the apical

${ }^{85}$ Lambert, J., and Thiêry, P., Essai de nomenclature raisonnée des échinides, pt. 4, p. 293, Chaumont, 1914.

80 Idem.

${ }^{87}$ Arnold, Ralph, op. cit. (Bull. 396), pI. 28, figs. 5, $5 \mathrm{a}$. system the living $D$. excentricus is more like $D$. coalingaensis than like $D$. gibbsii, but some living specimens have an $\frac{a}{p}$ ratio greater than 2 .

The periproct of $D$. gibbsii is located at a distance from the margin of the test about equal to the diameter of the periproct and, in general, is a little closer to the margin than on $D$. excentricus. D. coalingaensis, however, cannot be separated from $D$. excentricus on this character, because there are too many exceptions, particularly in $D$. coalingaensis macer and in the living species. The position of the peristome as expressed by the ratio $\frac{a}{p}$, in which $a$ is the distance from the anterior margin of the test to the posterior edge of the peristome, and $p$ is the distance from the posterior margin of the test to the posterior edge of the peristome, is as follows:

Position of peristome on sand dollars of D. gibbsii and D. coalingaensis groups and in the living $D$. excentricus

D. excentricus (75 Recent specimens)

D. coalingaensis (30 specimens from Pecten and Acila zones)

D. coalingaensis gibbosus (50 specimens from Pecten zone) $--\frac{a}{p}=1.5$

D. coalingaensis macer (50 specimens from upper Pseudo-

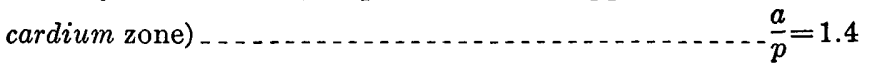

D. gibbsii (250 specimens from Siphonalia zone and Patino-

pecten zone(?))

D. gibbsii humilis (40 specimens from Patinopecten zone) $--\frac{a}{p}=1.7$

The peristome, in general, is less eccentric at successively higher horizons, but the decrease in eccentricity is interrupted in the stratigraphic sequence by $D$. coalingaensis macer. D. jacalitosensis may also have a less eccentric peristome than $D$. gibbsii. The ratio expressing the eccentricity is not alone as useful as might appear from the figures, for, although the average ratio for the 75 specimens of $D$. excentricus measured is 1.3 , the range is 1.2 to 1.5 , thus including the average ratio for $D$. coalingaensis.

On the actinal floor of about 50 specimens of $D$. gibbsii examined the interambulacral ridges connecting the auricles and the pillars are wide and high and are separated by a channel. Thin-test forms of $D$. excentricus usually lack these ridges or show only a trace of them. On 10 specimens of thick-test forms of $D$. excentricus examined the ridges are distinct, but the interambulacral areas between the ridges are also built up, so that there is no deep channel as on $D$. gibbsii. $D$. coalingaensis usually lacks these ridges, thus resembling the thin-test form of $D$. excentricus, but one specimen, probably $D$. coalingaensis gibbosus, from U. S. G. S. locality 4712 (Pecten zone in Kreyenhagen 


\section{PLATE 39}

[Figures natural size unless otherwise designated]

Figures 1, 6. Discinisca sp. Locality 18.5. Cascajo conglomerate member of San Joaquin formation.

1. Length (incomplete) $14.7 \mathrm{~mm}$., height $4.5 \mathrm{~mm}$. U. S. Nat. Mus. 495851.

6. Length $16.8 \mathrm{~mm}$., height $5.9 \mathrm{~mm}$. U. S. Nat. Mus. 495850.

2. Cryptomya cf. C. quadrata Arnold. Crushed double-valve specimen. Length $37 \mathrm{~mm}$., height $26 \mathrm{~mm}$. Locality 68 , Acila zone, San Joaquin formation. U. S. Nat. Mus. 495852.

3. Macoma affinis plena Stewart, n. var. Type. Length $36.2 \mathrm{~mm}$., thickness $6.5 \mathrm{~mm}$. Locality 238a, Littorina zone, Etchegoin formation. U. S. Nat. Mus. 495853.

4. "Nassa" cf. "N." waldorfensis Arnold. Height (incomplete) $16.4 \mathrm{~mm}$., width $8.4 \mathrm{~mm}$. About 100 yards north of locality 63, Acila zone, San Joaquin formation. Collected by Richard Bramkamp. U. S. Nat. Mus. 495854.

5. Dendraster (Merriamaster) arnoldi Twitchell. Length $24 \mathrm{~mm}$., width $24.2 \mathrm{~mm}$., height $4.6 \mathrm{~mm}$. Locality 60 , sand a few feet below Acila zone, San Joaquin formation. U. S. Nat. Mus. 495855.

7. Dendraster cf. D. coalingaensis Twitchell. Length $48.3 \mathrm{~mm}$., width $50 \mathrm{~mm}$., height $9.5 \mathrm{~mm}$. Locality 76, Pecten zone, San Joaquin formation. U. S. Nat. Mus. 495856.

8. Pseudocardium densatum (Conrad) of Arnold. Length $50.8 \mathrm{~mm}$., height $45 \mathrm{~mm}$., thickness $20.5 \mathrm{~mm}$. Locality $266 \mathrm{a}$, Siphonalia zone, Etchegoin formation. U. S. Nat. Mus. 495857.

9. Dendraster coalingaensis macer Stewart, n. var. Length $54 \mathrm{~mm}$., width $58 \mathrm{~mm}$., height 8 to $9 \mathrm{~mm}$. About 400 feet south of locality 238, upper Pseudocardium zone, Etchegoin formation. U. S. Nat. Mus. 495858. 

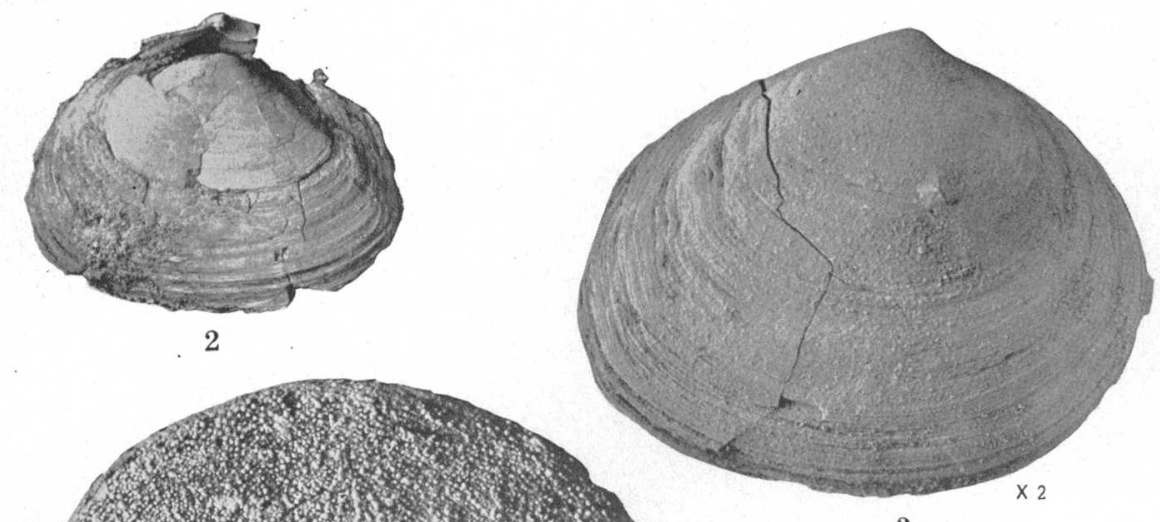

3
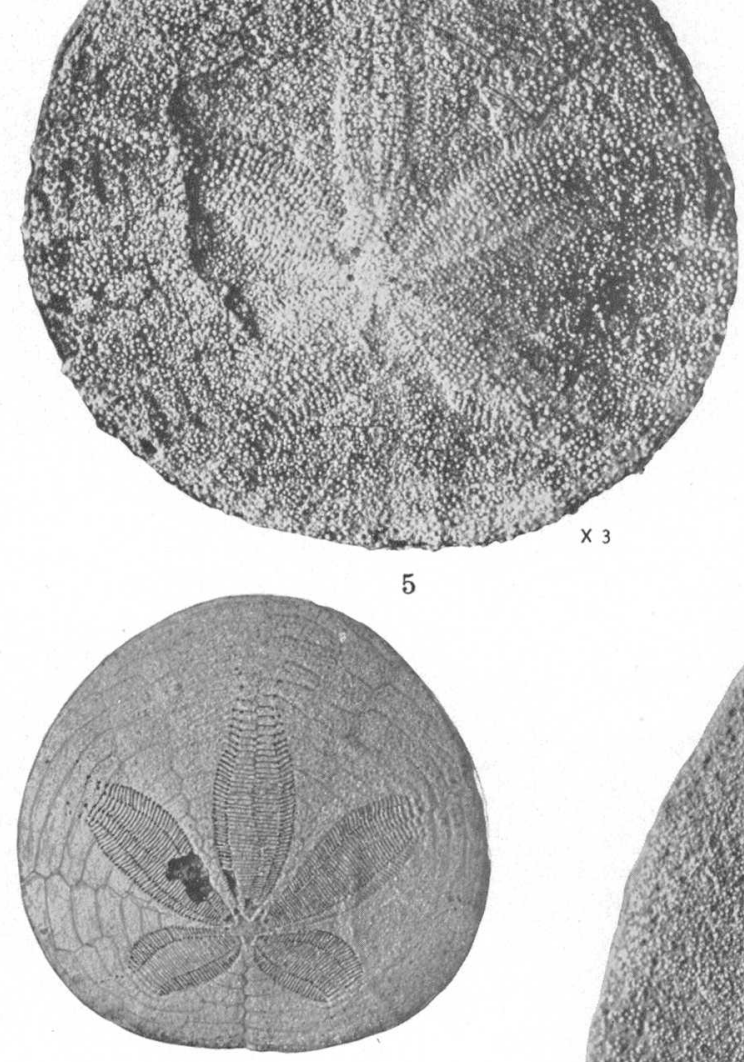

7

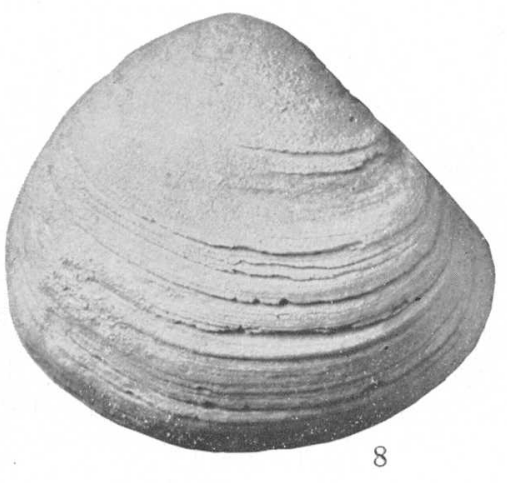

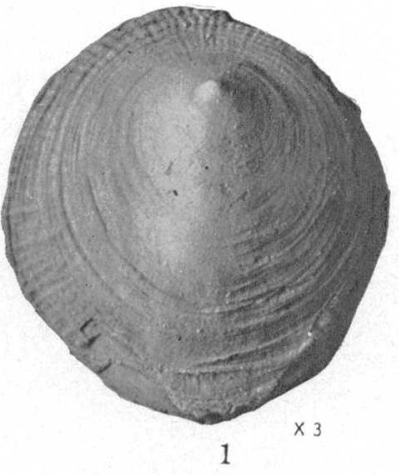
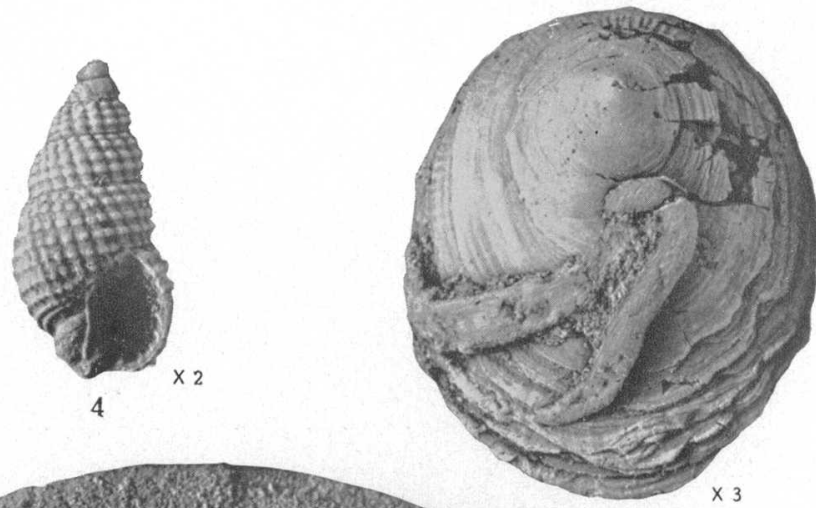

6

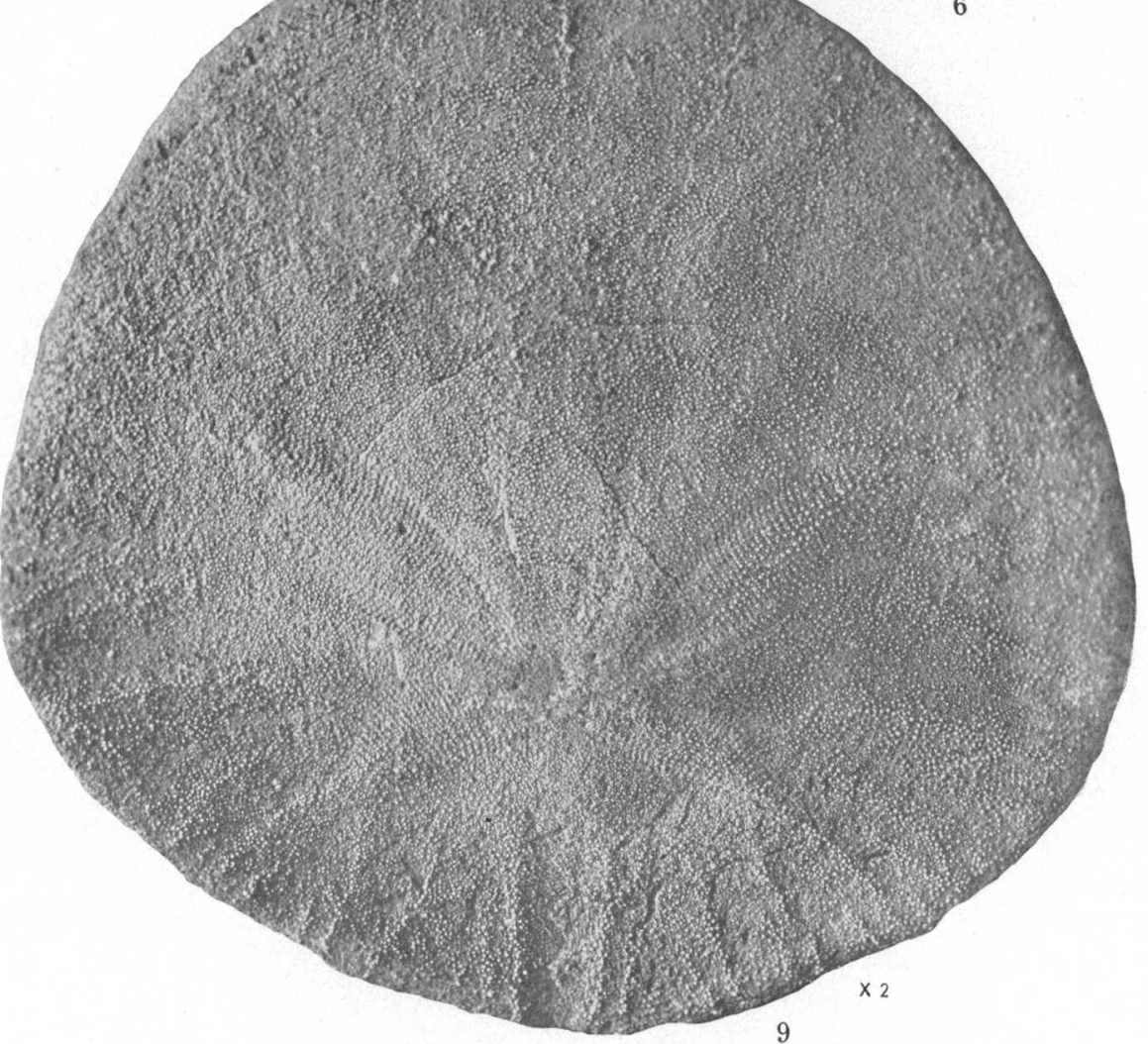

SAND DOLLARS AND OTHER FOSSILS FROM SAN JOAQUIN AND ETCHEGOIN FORMATIONS OF NORTH DOME. 


\section{PLATE 40}

[Figures natural size unless otherwise designated]

Figdre 1. Dendraster coalingaensis macer Stewart, n. var. Length $47 \mathrm{~mm}$., width $47.8 \mathrm{~mm}$., height $7 \mathrm{~mm}$. Locality 242 , upper Pseudocardium zone. U. S. Nat. Mus. 495859.

2. Dendraster gibbsii (Rémond). Length $62.1 \mathrm{~mm}$., width $68 \mathrm{~mm}$., height (slightly crushed) $10 \mathrm{~mm}$. Locality 288 , Siphonalia zone (?). U. S. Nat. Mus. 495860.

3, 4. Dendraster gibbsii (Rémond). Length $45.6 \mathrm{~mm}$., width $48.3 \mathrm{~mm}$., height $11 \mathrm{~mm}$. Locality 343, Patinopecten zone. U. S. Nat. Mus. 495861.

5. Dendraster coalingaensis macer Stewart, n. var. Length $56.4 \mathrm{~mm}$., width $61 \mathrm{~mm}$., height $7.5 \mathrm{~mm}$. Locality 249 , upper Pseudocardium zone. U. S. Nat. Mus. 495862a. 


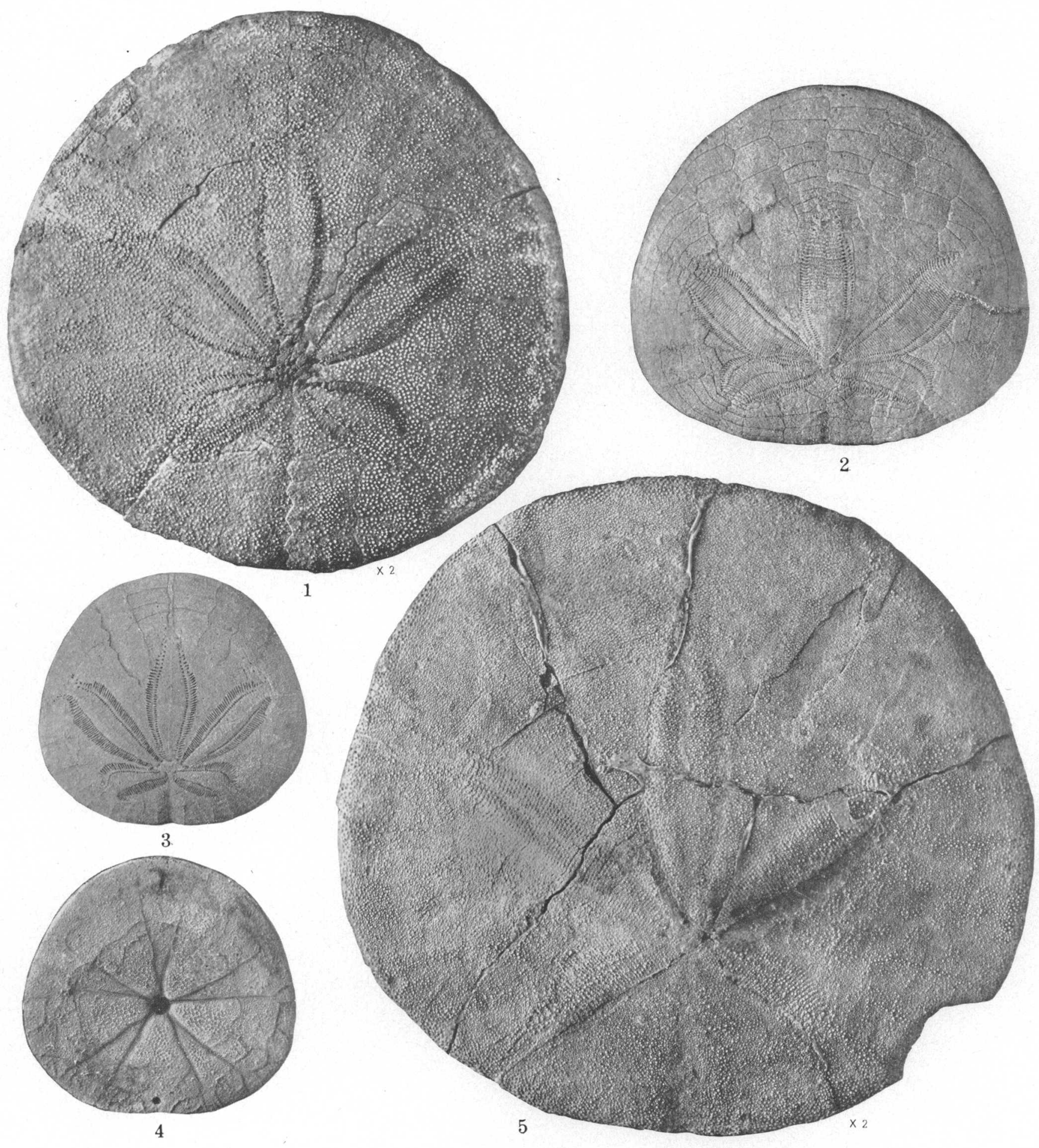

SAND DOLLARS FROM ETCHEGOIN FORMATION OF NORTH DOME. 


\section{PLATE 41}

Figures 1, 2. Dendraster coalingaensis macer Stewart, n. var. Type. Length $50 \mathrm{~mm}$., width 50.9 mm., height $8 \mathrm{~mm}$. Locality 242, upper Pseudocardium zone, Etchegoin formation. U. S. Nat. Mus. 495862.

3. Dendraster (Merriamaster) arnoldi Twitchell. Length $37.3 \mathrm{~mm}$., width $34.3 \mathrm{~mm}$., height (crushed) $7.2 \mathrm{~mm}$. Locality 60, sand a few feet below Acila zone, San Joaquin formation. U. S. Nat. Mus. 495863.

4. Dendraster coalingaensis macer Stewart, n. var. Length $36 \mathrm{~mm}$., width $34.6 \mathrm{~mm}$., height $5.4 \mathrm{~mm}$. Locality 241 , upper Pseudocardium zone, Etchegoin formation. U. S. Nat. Mus. 495864. 

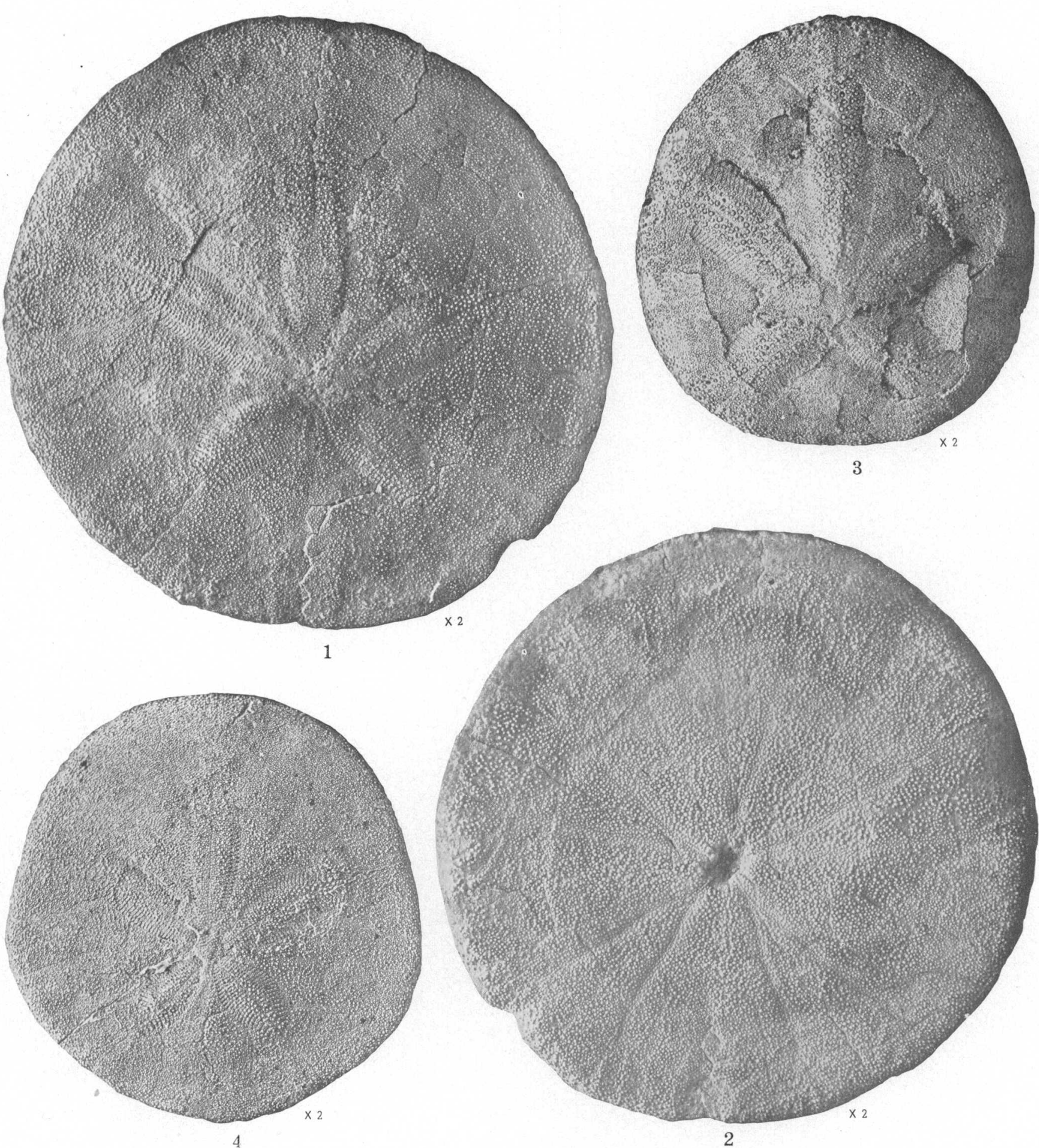

SAND DOLLARS FROM ETCHEGOIN AND SAN JOAQUIN FORMATIONS OF NORTH DOME. 


\section{PLATE 42}

Figures 1-5. Dendraster gibbsii (Rémond).

1. Length $37.5 \mathrm{~mm}$., width $34.8 \mathrm{~mm}$., height $8.7 \mathrm{~mm}$. Locality 343 , Patinopeclen zone. U. S. Nat. Mus. 495865 .

2. Length (almost complete) $38.3 \mathrm{~mm}$., width $43.8 \mathrm{~mm}$, height $9.6 \mathrm{~mm}$. Locality 343 , Patinopecten zone. U. S. Nat. Mus. 495866.

3, 4. Length $19.8 \mathrm{~mm}$., width $20.2 \mathrm{~mm}$., height $4.1 \mathrm{~mm}$. Locality 343, Patinopecten zone. U. S. Nat. Mus. 495867.

5. Length $59.5 \mathrm{~mm}$., width $57.9 \mathrm{~mm}$, height (incomplete) $15 \mathrm{~mm}$. Locality $332 \mathrm{~b}$, Patinopecten zone. U. S. Nat. Mus. 495868. 

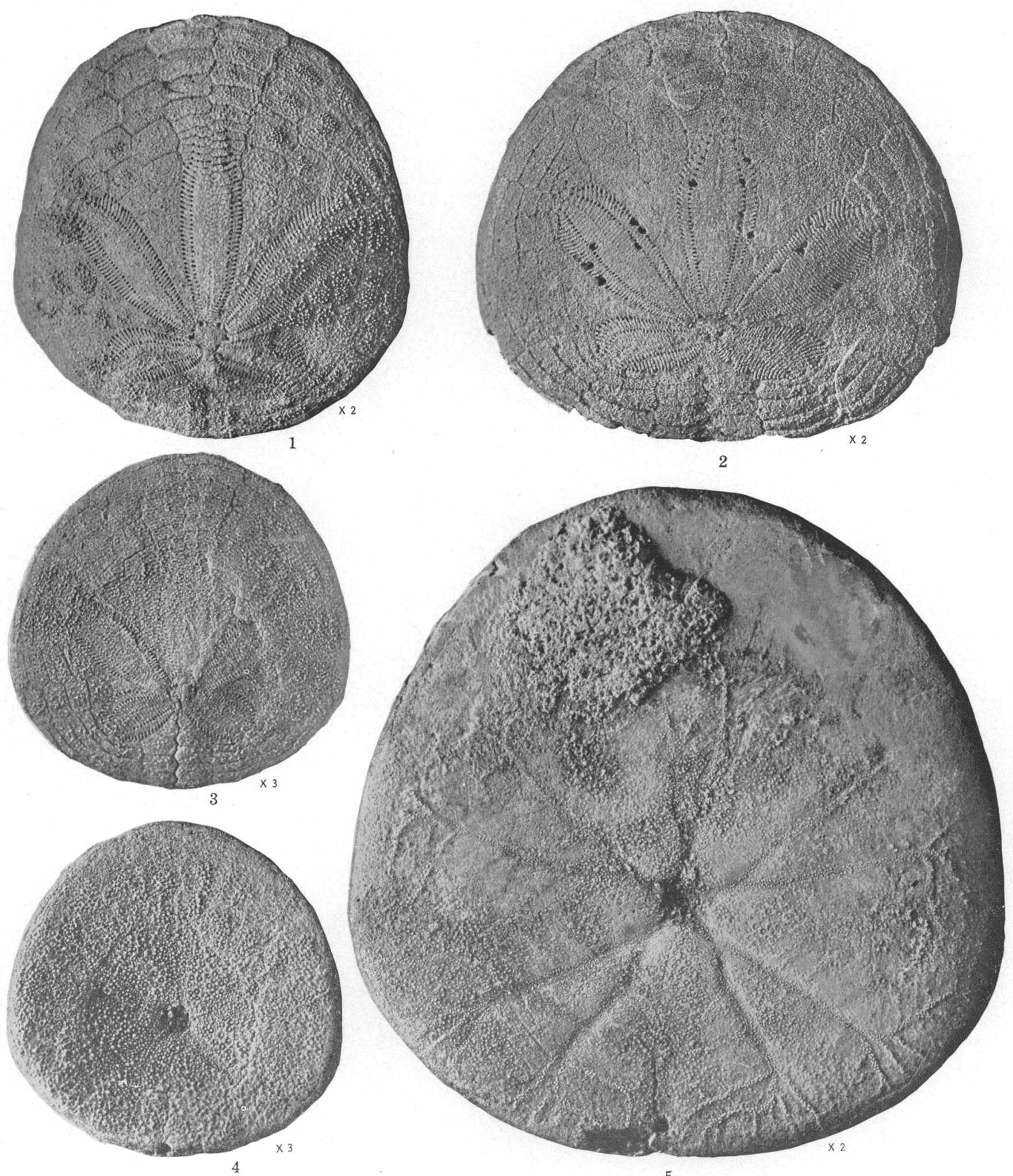

5

SAND DOLLARS FROM ETCHEGOIN FORMATION OF NORTH DOME. 


\section{PLATE 43}

Figure 1. Dendraster gibbsii (Rémond). Length $20 \mathrm{~mm}$., width $19 \mathrm{~mm}$., height $4.6 \mathrm{~mm}$. Locality 340 , Patinopecten zone. U. S. Nat. Mus. 495869. Young specimen found with very eccentric variety of D. gibbsii.

2. Dendraster gibbsii (Rémond). Length $56 \mathrm{~mm}$., width $60 \mathrm{~mm}$., height $12 \mathrm{~mm}$. Locality $332 \mathrm{~b}$, Patinopecten zone. U. S. Nat. Mus. 495870.

3. Dendraster gibbsii humulis Kew. Lcngth 32.7 mm., width $28.2 \mathrm{~mm}$., height $7 \mathrm{~mm}$. Locality 307, Patinopecten zone. U. S. Nat. Mus. 495871.

4, 5. Dendraster gibbsii (Rémond). Length $60.7 \mathrm{~mm}$., width $59.8 \mathrm{~mm}$., height $11.5 \mathrm{~mm}$. Locality uncertain, Siphonalia zone (?). U. S. Nat. Mus. 495872. 

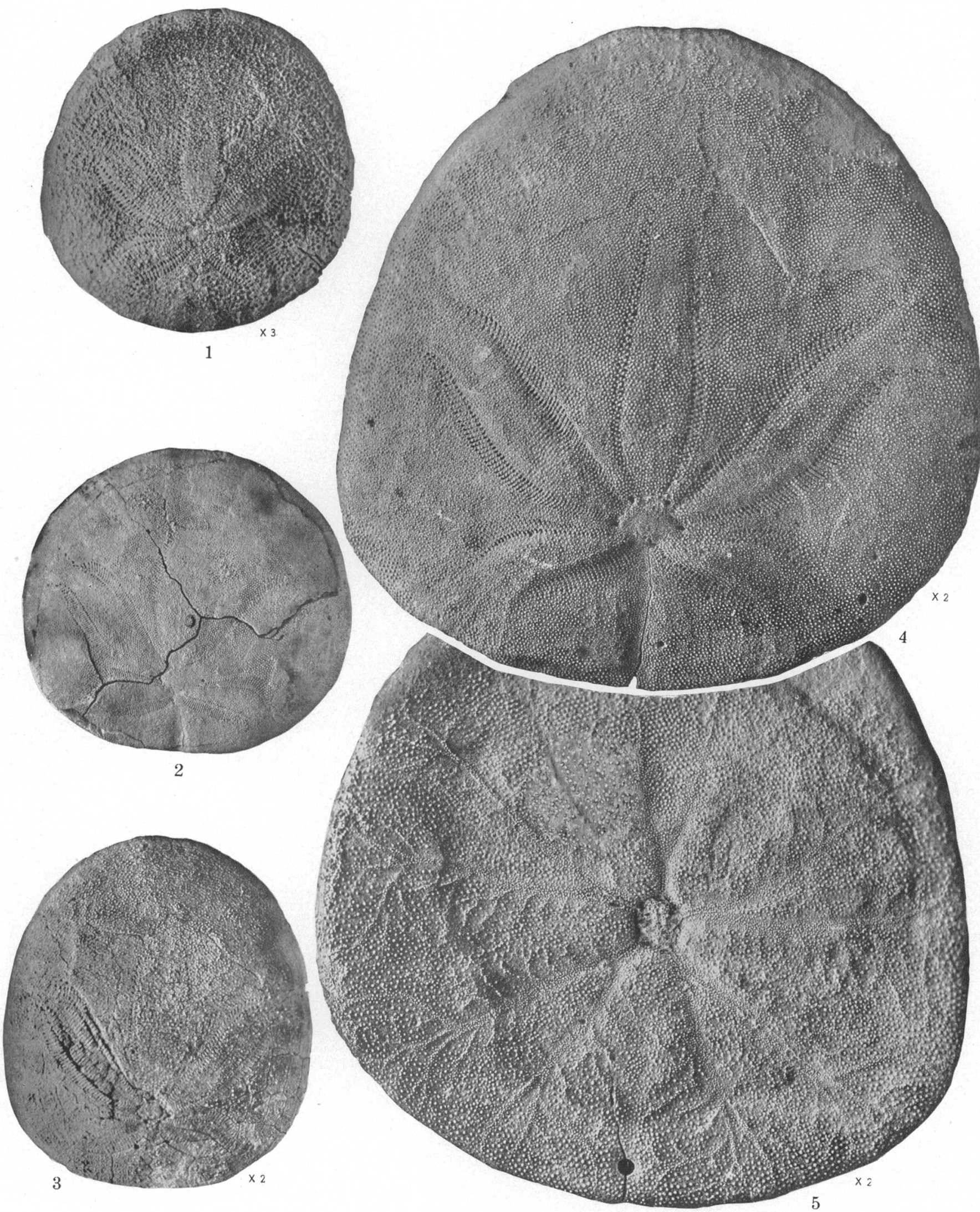


\section{PLATE 44}

Figures 1, 2. Dendraster gibbsii (Rémond) var. Length $34.8 \mathrm{~mm}$., width $36.3 \mathrm{~mm}$, height $7.6 \mathrm{~mm}$. Locality uncertain, Siphonalia zone (?). U. S. Nat. Mus. 495873.

3. Dendraster coalingaensis Twitchell, n. var.? Length $46.5 \mathrm{~mm}$., width $49.4 \mathrm{~mm}$., height $8 \mathrm{~mm}$. Locality 190 , near base of San Joaquin formation. U. S. Nat. Mus. 495874.

4. Dendraster gibbsii mirus Stewart, n. var. Length $25.1 \mathrm{~mm}$., width $21.8 \mathrm{~mm}$., height (fractured specimen) $5 \mathrm{~mm}$. Locality 275a, Siphonalia zone. U. S. Nat. .Mus. 495875.

5. Dendraster gibbsii mirus Stewart, n. var. Type. Length $26.8 \mathrm{~mm}$., width $27.7 \mathrm{~mm}$., height $5.5 \mathrm{~mm}$. Locality $275 \mathrm{a}$, Siphonalia zone. U. S. Nat. Mus. 495876.

6. Dendraster gibbsii (Rémond). Length $62 \mathrm{~mm}$., width $62.7 \mathrm{~mm}$., height $16 \mathrm{~mm}$. Locality 332b, Patinopecten zone. U. S. Nat. Mus. 485877. 


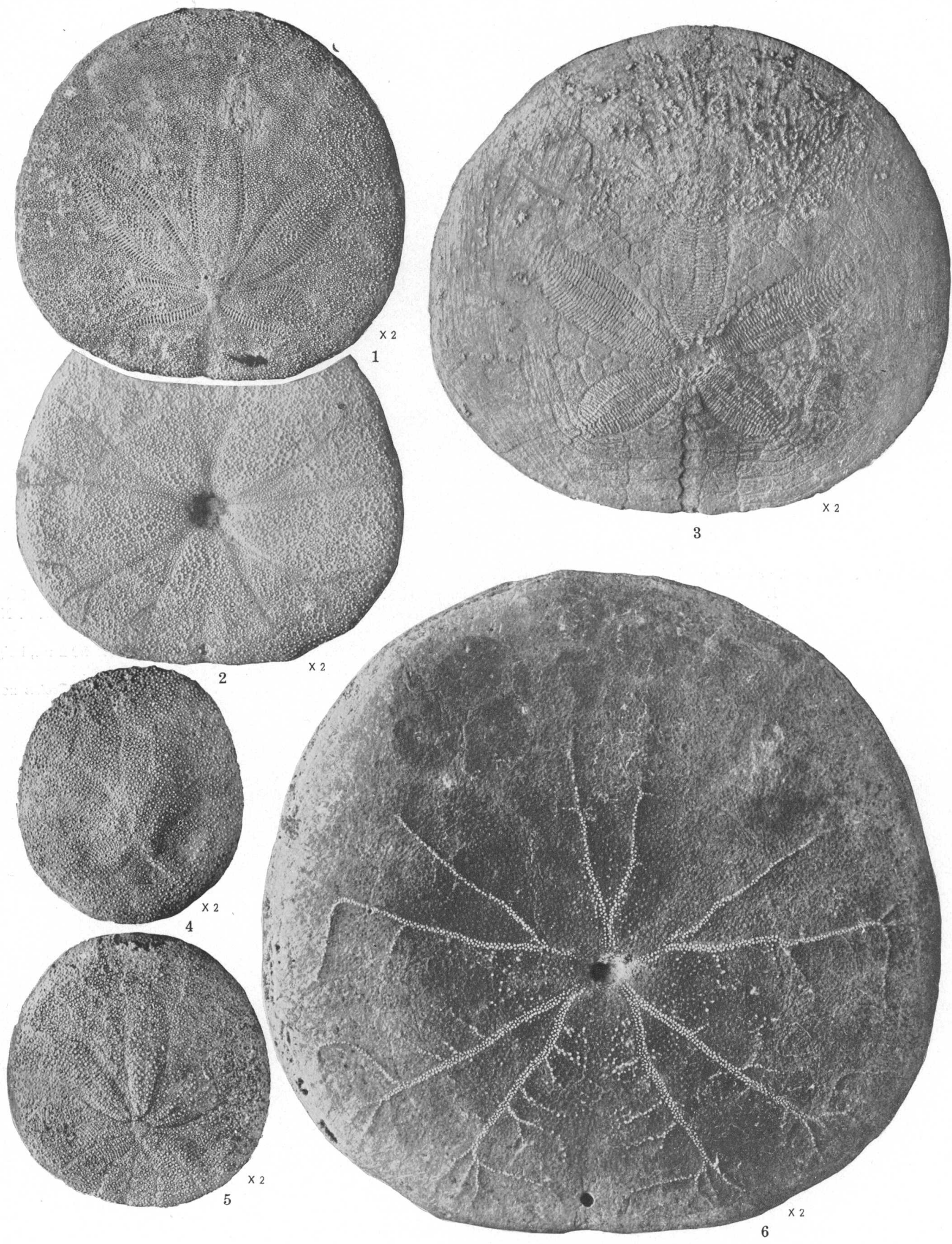

SAND DOLLARS FROM ETCHEGOIN FORMATION OF NORTH DOME. 
PLATE 45

Figures 1-6. Dendraster coalingaensis Twitchell.

1. Length $45.6 \mathrm{~mm}$., width $47.4 \mathrm{~mm}$., height $9.5 \mathrm{~mm}$. Locality 76, Pecten zone. U. S. Nat. Mus. 495878 .

2. Typical form. Length $36.1 \mathrm{~mm}$., width $37.5 \mathrm{~mm}$., height $7.8 \mathrm{~mm}$. Locality 81 , Pecten zone. U. S. Nat. Mus. 495879.

3, 4. Variety with slightly raised petals and deep ambulacral furrows. Length $30.3 \mathrm{~mm}$., width $29 \mathrm{~mm}$., height $7.4 \mathrm{~mm}$. Locality 60, Acila zone; just above layer with Acila. U. S. Nat. Mus. 495880.

5, 6. Variety gibbosus Kew. Length $46.2 \mathrm{~mm}$., width $51.8 \mathrm{~mm}$., height $9.5 \mathrm{~mm}$. Locality 81 , Pecten zone. U. S. Nat. Mus. 495881. 


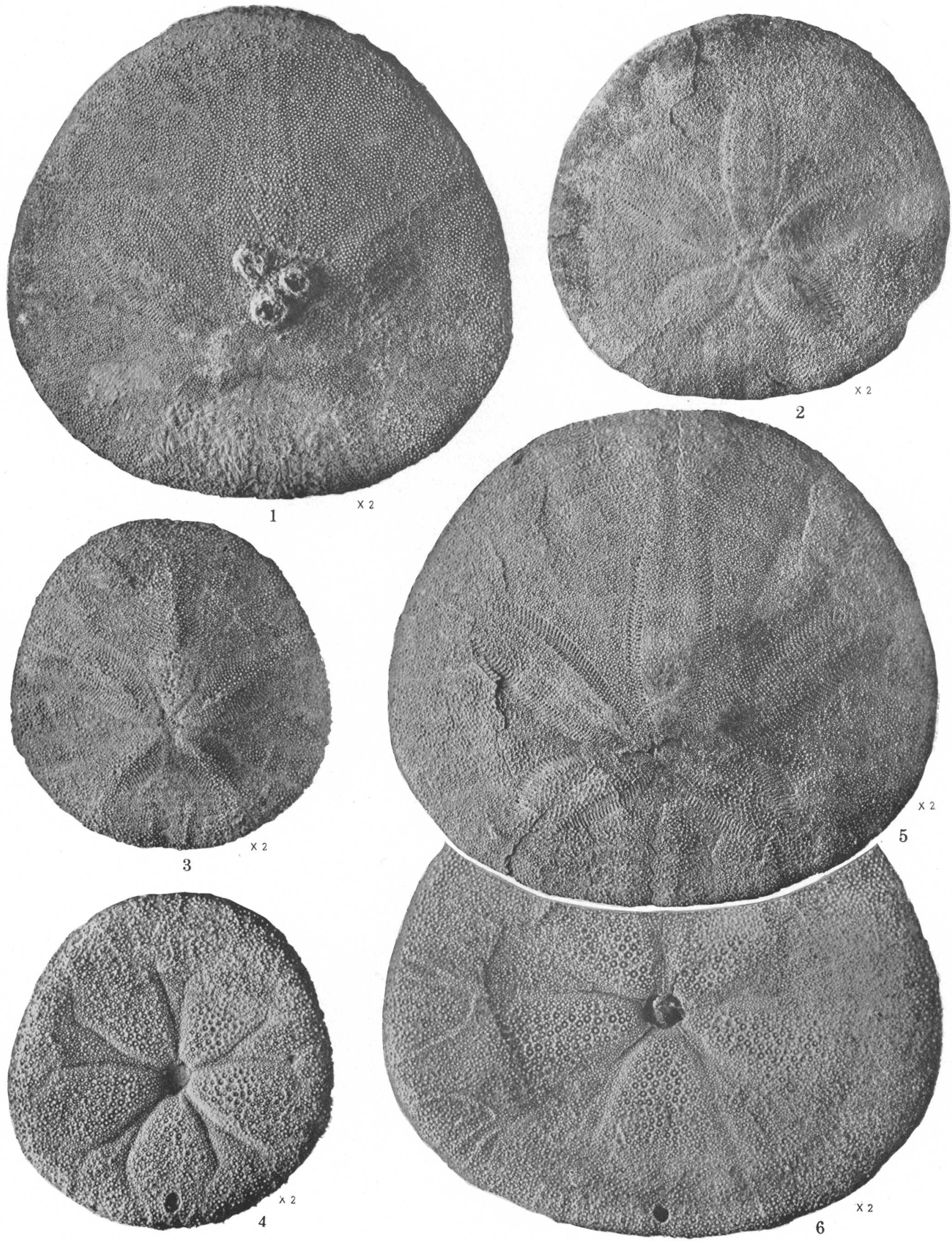

SAND DOLLARS FROM UPPER PART OF SAN JOAQUIN FORMATION OF NORTH DOME. 


\section{PLATE 46}

[Figures natural size unless otherwise designated]

Figure 1. Dendraster (Merriamaster) perrini (Weaver). Pentagonal form. Length $27.1 \mathrm{~mm}$. width $25.5 \mathrm{~mm} .$, height $6.2 \mathrm{~mm}$. Locality 81, Pecten zone. U. S. Nat. Mus. 495882.

2. Dendraster (Merriamaster) perrini (Weaver). Length $26 \mathrm{~mm}$., width $25.5 \mathrm{~mm}$., height $7.3 \mathrm{~mm}$. Locality 81 , Pecten zone. U. S. Nat. Mus. 495883.

3. Dendraster (Merriamaster) arnoldi Twitchell. Outline incomplete. Length $21.5 \mathrm{~mm}$., width $21.4 \mathrm{~mm}$., height $5.1 \mathrm{~mm}$. Locality 121, Trachycardium zone. U. S. Nat. Mus. 495884.

4. Dendraster (Merriamaster) perrini (Weaver). Length $21.4 \mathrm{~mm}$., width $21.6 \mathrm{~mm}$., height $4.6 \mathrm{~mm}$. Locality 121 . Trachycardium zone. U. S. Nat. Mus. 495885.

5. Dendraster (Merriamaster) arnoldi Twitchell. Length $28.6 \mathrm{~mm}$., width (almost complete) $28.1 \mathrm{~mm}$., height (crushed) $5.7 \mathrm{~mm}$. Locality 121, Trachycardium zone. U. S. Nat. Mus. 495886.

6. Dendraster (Merriamaster) arnoldi Twitchell. Length $22.4 \mathrm{~mm}$., width $22.6 \mathrm{~mm}$., height $4 \mathrm{~mm}$. Locality 94 , Pecten zone. U. S. Nat. Mus. 495887.

7. Dendraster (Merriamaster) perrini (Weaver). Length $27.8 \mathrm{~mm}$., width $26.7 \mathrm{~mm}$., height $7.4 \mathrm{~mm}$. Locality 81 , Pecten zone. U. S. Nat. Mus. 495888.

8: Dendraster (Merriamaster) arnoldi Twitchell. Length $17.6 \mathrm{~mm}$., width $17 \mathrm{~mm}$., height $3.7 \mathrm{~mm}$. Locality 121, Trachycardium zone. U. S. Nat. Mus. 495889.

9. Dendraster (Merriamaster) cf. D. (M.) arnoldi Twitchell. Length $29.3 \mathrm{~mm}$., width $27.4 \mathrm{~mm}$., height $5.3 \mathrm{~mm}$. Locality 60, sand a few feet below Acila zone. U. S. Nat. Mus. 495890.

10. Dendraster (Merriamaster) perrini (Weaver). Length $31 \mathrm{~mm}$., width $26.8 \mathrm{~mm}$., height (crushed) $5 \mathrm{~mm}$. Locality 121 , Trachycardium zone. U. S. Nat. Mus. 495891.

11. Dendraster (Merriamaster) arnoldi Twitchell. Young specimen. Length $22.5 \mathrm{~mm}$., width $22 \mathrm{~mm}$., height (crushed) 4 mm. Locality 121, Trachycardium zone. U. S. Nat. Mus. 495892 .

12. Dendraster (Merriamaster) perrini (Weaver). Length $32 \mathrm{~mm}$., width $30.5 \mathrm{~mm}$., height $7.6 \mathrm{~mm}$. Locality 81 , Pecten zone. U. S. Nat. Mus. 495893.

13. Dendraster (Merriamaster) cf. D. (M.) arnoldi Twitchell. Length $31.2 \mathrm{~mm}$., width $29.3 \mathrm{~mm}$., height $6.4 \mathrm{~mm}$. Locality 121, Trachycardium zone. U. S. Nat. Mus. 495894. 

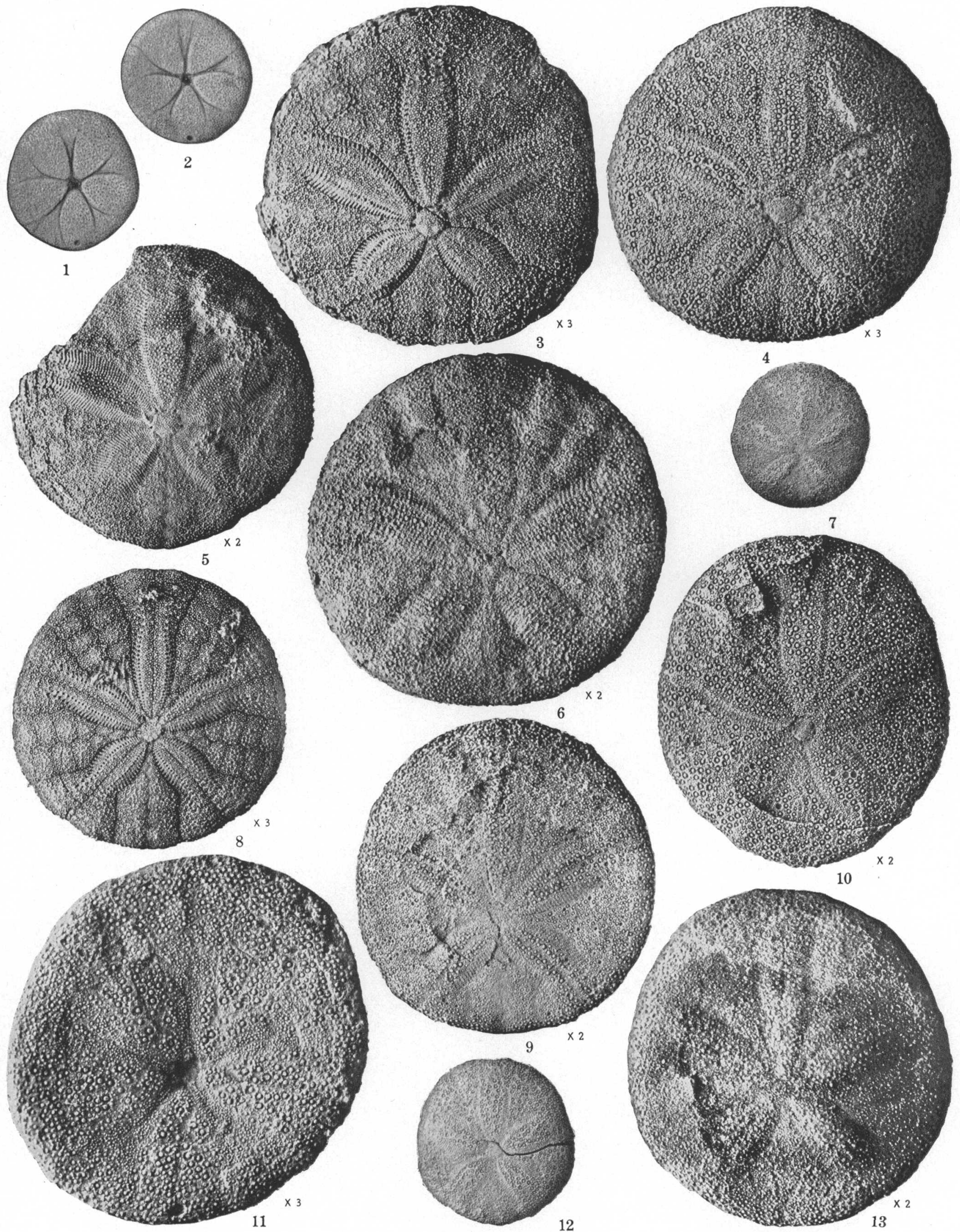

SAND DOLLARS FROM UPPER PART OF SAN JOAQUIN FORMATION OF NORTH DOME. 
Hills), has ridges and channels resembling those of $D$. gibbsii. The thin $D$. coalingaensis macer has an actinal floor resembling that of $D$. excentricus, though not identical.

The sand dollars of the $D$. gibbsii and $D$. coalingaensis groups have slightly differert secondary ambulacral branches from those of $D$. exentricus. Although these minor branches are variable in number and pattern, two main branches can be recognized on the outer (interambulacral) sides of the dichotomus ambulacral furrows. On $D$. excentricus the minor branch closer to the peristome is larger, whereas on $D$. gibbsii and $D$. coalingaensis the minor branch farther from the peristome is larger. The furrows of $D$. excentricus are in general larger and deeper, and therefore more prominent. Some specimens of $D$. excentricus, particularly one from Puget Sound, have minor branches resembling in pattern those of $D$. gibbsii, but the furrows are deeper, as in other specimens of $D$. excentricus.

The minor branches of $D$. coalingaensis are near the periphery of the test, so that for the greater part of their length the furrows lack branches. In this feature the sand dollars from the Neverita zone, considered a small variety of $D$. gibbsii, are more like $D$. coalingaensis than like large forms of $D$. gibbsii. Perhaps, however, this feature is to be correlated with the small size of the specimens in the Neverita zone, for small specimens of $D$. gibbsii from the Etchegoin formation also appear to lack the minor branches near the peristome.

Despite the exceptions, the pattern of the ambulacral furrows is the most satisfactory basis that has been found for separating $D$. gibbsii, D. coalingaensis, and $D$. excentricus, indicating that the two fossil species are distinct and extinct species. Unfortunately the minor branches are not preserved on many specimens that would ordinarily be regarded as well-preserved specimens.

The form of the small flat-petaled sand dollars in the San Joaquin formation characterized by a supramarginal periproct (pl. 10, fig. 11) might be classified with Anorthoscutum Lambert and Thiéry, ${ }^{88}$ which also has a supramarginal periproct and the type of which is Scutella interlineata Stimpson. The ambulacral furrows are not well developed on this form, but the short posterior petals indicate a Dendraster, and this form is considered a small variety of $D$. coalingaensis. The classification of this form seems to be important, for if it is related to Anorthoscutum it is a northern element in the San Joaquin fauna. Anorthoscutum is probably to be regarded as a subgenus of Phelsumia Pomel, a gonus now represented on the Pacific const north of Puget Sound by P. parma (Lamarck), better known as Echinarachinus parma. The ambulacral furrows of Anorthoscutum are not well known, but they may be more of less intermediate between the straight furrows of Phelsumia, trifurcate near the margin of the test,

${ }^{69}$ Lnmbort, J., and Thiory, P., op. cit., pt. 4, p. 319. and the dichotomously branched furrows of Dendraster. Calaster Kew, proposed as a subgenus of Dendraster, is a synonym of Anorthoscutum.

The genus Astrodapsis Conrad, which occurs in strata on the Pacific coast now assigned to the upper Miocene and lower Pliocene, has the characters that distinguish Merriamaster from Dendraster proper. Astrodapsis, however, has straight ambulacral furrows, short ambulacral plates, and generally has raised petals. Superficially, at least, Merriamaster may be thought of as an Astrodapsis-like Dendraster.

The classification of the Kettleman Hills sand dollars here adopted has been influenced by an examination of the collections of the Recent species Dendraster excentricus and Phelsumia parma in the National Museum. If it could be shown that at least two living species are included under $D$. excentricus, or that northern and southern subspecies are recognizable, some of the apparent variation of the Dendraster living on the Pacific coast might disappear. According to the collection of Phelsumia parma, however, sand dollars from one dredging may be very much alike and slightly different from those from another locality. The same impression is gained from a study of the collections from the Kettleman Hills. The collections of living forms indicate that the minor variations, which might be quite useful to geologists in correlating local outcrops, would be of little significance in correlating with other regions. For this reason and also on account of their similar morphology, the locally recognized forms in the Kettleman Hills are treated as varieties rather than as species or subspecies.

\section{MOLLUSKS}

In the following discussion of the stratigraphically important mollusks references are omitted for systematic names cited by Grant and Gale ${ }^{89}$ in their elaborate catalogue of the Pliocene and Pleistocene marine mollusks of California. This catalogue is indispensable and should be available to anyone who might need the references.

\section{GASTROPODS}

Trochidae.-The genus Calliostoma is represented in the Patinopecten and Siphonalia zones of the Etchegoin formation, in the Pecten and Acila zones of the San Joaquin formation, and by an unidentified fragment in the Cascajo conglomerate member of the San Joaquin. C. coalingense Arnold (pl. 11, figs. 2, 3; pl. 15, figs. 15, 16) may be recognized by its blunt rounded spire and beaded collar. It resembles $C$. supragranosum Carpenter, a smaller and more turreted species living in southern California. In size $C$. coalingense is more like another possible relative, a Japanese species in the collections of the National Museum labeled C. mul-

${ }^{69}$ Grant, U. S., IV, and Gale, H. R., op. cit. (San Diego Soc. Nat. History Mem., vol. 1). 
tiliratum Sowerby, ${ }^{90}$ which, however, also has a more turreted spire. A variety named $C$. coalingense var. privum Stewart, n. var. (pl. 32, fig. 5), which has a lower spire than $C$. coalingense, occurs in the Etchegoin formation. A single specimen of $C$. coalingense from the Pliocene of the Santa Maria district (U. S. G. S. locality 4474) is peculiar in having the spirals outside the columellar area on the base so poorly developed as to be scarcely distinguishable. C. kerri Arnold (pl. 15, fig. 21) has a straight-sided acute spire and beaded spirals. It is very similar to C. "annulatum (Martyn)" and $C$. variegatum Carpenter, both of which range from Alaska to southern California. A single specimen of C. kerri is sufficiently well preserved to show, however, that the spirals on the early whorls are not beaded as they are on its living relatives. $C$. cf. $C$. gemmulatum Carpenter (pl. 15, figs. 22, 23) has a turreted spire and two main spirals. The few incomplete specimens available have a slightly more prominent beaded collar than $C$. gemmulatum, a species living in southern California. (R.S.)

The genus Turcica was found only in the Pecten and Acila zones. The fossils are named Turcica caffea Gabb var. brevis Stewart, n. var. (pl. 11, figs. 1-6). They differ from the Recent California T. caffea in the tighter coiling of the later whorls and in the narrower interval between the main spiral band and the next band toward the base. Only one large specimen (length, 30 millimeters) of $T$. caffea is avilable. This living California species is very closely related to $T$. imperialis A. Adams ${ }^{91}$ from Japan; in fact, the distinguishing characters of these two species are not known. The fossils from the Kettleman Hills differ also from $T$. imperialis, 25 specimens of which were examined, in the tighter coiling of the later whorls. T. caffea brevis occurs with a typical Pecten zone fauna at the northwest end of Jacalitos Dome, in the foothills west of the Kettleman Hills (U. S. G. S. localities 4758 and 12323). On the basis of the narrow interval it is also present in the Santa Maria district ${ }^{92}$ in strata that are possibly of the same age as the upper part of the San Joaquin; and at Pacific Beach, San Diego, presumably in the San Diego formation. (R.S.)

Turbinidae.-The only representative of the family Turbinidae is a large Pachypoma, from the Siphonalia zone of the Etchegoin formation, comparable to $P$. precursor (Dall) of the Empire formation of Oregon. On $P$. precursor the interval between the basal carina and the next spiral toward the suture is wider than in the living California species P. "inaequalis (Martyn)." The presence of two rows of nodes between the basal carina and the diagonal ribs on some Recent specimens

\footnotetext{
oc Pilsbry, H. A., Manual of conchology, vol. 11, p. 342, pl. 15, figs. 45, 46, 1889.

il Pilsbry, H. A., Idem, p. 414, pl. 63, figs. 30, 31.

${ }^{22}$ Arnold, Ralph, and Anderson, Robert, Geology and oil resources of the Santa Maria oil district, Santa Barbara County, Calif.: U. S. Geol. Survey Bull. 322, p. 60, pl. 21, figs. 4, 5 (Thalotia caffea), 1907.
}

suggests that the living species has one more spiral band than $P$. precursor. (R.S.)

Viviparidae?-The discovery of molds of the viviparid(?) operculum Scalez petrolia Hanna and Gaylord, in association with fresh-water fossils and leaves on the east side of South Dome at a horizon between the Pecten zone and the probable equivalent of the Neverita zone, is of special interest, as they are the only specimens so far discovered at an outcrop locality. Scalez petrolia has been discussed by Woodring, Roundy, and Farnsworth. ${ }^{93}$ The horizon at which the Kettleman Hills fossils were found corresponds approximately to the upper Scalez zone in the southern San Joaquin Valley subsurface section..$^{94}$ Viviparus sp.? has been recorded from the upper Scalez zone ${ }^{95}$ and immediately overlying strata, and it has been suggested that similar shells in the lower Scalez zone represent Vipiparus. ${ }^{96}$ These shells in both zones, however, are probably to be assigned to a relatively large Fluminicola, possibly $F$. kettlemanensis Pilsbry. In the subsurface section Scalez is more abundant in the lower Scalez zone than in the upper Scalez zone. No specimens of Scalez have been found in the Kettleman Hills in strata that correspond roughly to the lower Scalez zone according to the suggested correlations shown in figure 13-strata between the Littorina zone and the top of the Etchegoin formation. (W.P.W.)

Littorinidae.-Littorina mariana Arnold occurs in the Tulare formation (pl. 4, figs. 4-6), in the upper Mya zone (pl. 8, figs. 1-6) and Pecten zone of the San Joaquin formation, and in the Littorina zone (pl. 29, figs. 8, 9) and upper Pseudocardium zone of the Etchegoin. . The type of $L$. mariana and of the variety alta Arnold was collected from the upper Mya zone of the Kettleman Hills. Large suites of specimens from a single locality show gradations between the two forms. Arnold considered $L$. mariana to be closely allied to $L$. grandis Middendorff, a northern living species. $L$. mariana differs from Alaskan and Japanese specimens of $L$. grandis, however, in having a smaller aperture, and the early whorls are not carinate as on the living species. The fossils are probably related to $L$. scutulata Gould, a Recent species ranging from Alaska to Lower California, but have a thicker shell and coarser spirals. They also appear to be closely related to $L$. remondii Gabb, an upper Miocene species that is smaller and has flatter whorls and a carinate to sub. rounded periphery. L. pittsburgensis Clark, ${ }^{97}$ based on a rounded smooth (worn?) specimen from the type region of $L$. remondii, closely resembles small worn

${ }^{93}$ Woodring, W. P., Roundy, P. V., and Farnsworth, H. R., Geology and oil resources of the Elk Hills, Calif., including Naval Petroleum Reserve No. 1: U. S. Geol. Survey Bull. 835, pp. 33-36, pl. 10, 1932.

of Barbat, W. F., and Galloway, John, San Joaquin clay, Calif.: Am. Assnc: Petroleum Geologists Bull., vol. 18, p. 486, fig. 1, 1934.

os Idem.

oo Woodring, W. P., Roundy, P. V., and Farnsworth, H. R., op. cit., pp. 34-35.

'7 Clark, B. L., Fauna of the San Pablo group of middle California: California Univ., Dept. Geol., Bull., vol. 8, p. 484, pl. 65, fig. 22, 1915. 
specimens of $L$. mariana. Should $L$. remondii be found to include round-shouldered forms, $L$. mariana may be considered a variety or a synonym of that species. (W. P.W., R.S.)

Amnicolidae.-Amnicolids are particularly abundant in the lower part of the Tulare formation. They also occur in fresh-water strata in the San Joaquin formation, in the upper part of the Littorina zone of the Etchegoin formation, and in Etchegoin strata overlying the Littorina zone.

Fluminicola kettlemanensis Pilsbry, ${ }^{98}$ a relatively large species, occurs in the Pecten zone, and similar forms occur in the San Joaquin formation below the Pecten zone and also in the upper Pseudocardium zone. The common Fluminicola from the Tulare formation is identified as $F$. cf. $F$. spiralis Pilsbry (pl. 4, figs. 7-11). This form appears to lack the microscopic spiral striae of $F$. spiralis, the type of which is from a well in the San Joaquin Valley. A carinate species from the Tulare formation, $F$. cf. $F$. yatesiana (Cooper) (pl. 4, fig. 12), resembles the larger $F$. yatesiana, described from a locality in Santa Clara County. (W. P.W.)

The genus Pyrgulopsis is represented in the Tulare formation by a small species, $P$. vincta Pilsbry (pl. 4, figs. 13-16), the body whorl of which is strongly carinate or rounded. (W.P.W.)

Three species of the extinct genus Calipyrgula are present in the Tulare formation. C. carinifera Pilsbry (pl. 4, figs. 17, 18) has a carinate or weakly carinate shoulder; C. ellipsostoma Pilsbry (pl. 4, fig. 19) has less convex and less turreted whorls and a rounded or faintly carinate shoulder; and C. stewartiana Pilsbry (pl. 4, figs. 20,21$)$ is a small species. (W.P.W.)

Littoridina woodringi Pilsbry (pl. 4, fig. 22) is a Tulare species belonging to a genus now living in South America and Central America and as far north along the Atlantic const as Delaware but not on the Pacific coast of the United States. (W.P.W.)

Amnicola is the most abundant genus in the Tulare formation. The Tulare species is identified as $A$. longinqua Gould (pl. 4, figs. 23-27), which is living in southern California. The form that is most similar to specimens from the type region of $A$. longinqua in the Colorado Desert is abundant at localities 20 and 21, but even in these lots only a few shells have the completely detached peristome (pl. 4, fig. 23) characteristic of most adults from the type region. Many lots include specimens, or consist principally of specimens, that are more slender and have less inflated whorls (pl. 4, figs. 26, 27). The shells at locality 17 are stouter than elsewhere. An unidentified Amnicola occurs near the top of the Etchegoin. The small shells from the upper part of the Littorina zone identified as Amnicola? are poorly preserved, generally due to a calcareous crust. It is

${ }^{08}$ Pilsbry, F. A., Mollusks of the fresh-water Pliocene beds of the Kettleman Hills and noighboring oil flelds, Calif.: Acad. Nat. Sci. Philadelphia Proc., vol. 86, p. 549, pl. 19, flgs, 1-3, 1935. The Tulare amnlcollds also are described in this publication. reasonably certain, however, that they represent the fresh-water genera Amnicola or Hydrobia and not the brackish-water genus Syncera, also known as Assiminea. (W.P.W.)

In the collections from the Tulare formation Hydrobia is less ábundant than Amnicola. Hydrobia may, however, be more abundant than the collections indicate, for at many localities where collections were not made small smooth amnicolids were assumed to represent Amnicola. Hydrobia andersoni (Arnold) (pl. 4, figs. 28-34) is recognized by its acute many-whorled turreted spire. As shown by the illustrations, the outline is variable. An exceptionally short, stout form, apparently not represented in the collections of the Geological Survey, has been named $H$. andersoni sterea Pilsbry. The type of H. andersoni and three other specimens from the type locality (U. S. 'G. S. locality 4732) are shown on plate 4, figures $28-31$. The type is exceptionally large. A. birkhauseri Pilsbry, a small slender form, appears to be rare. $(W . P . W$.

The extinct genus Brannerillus is represented in the Tulare formation by two species. B. physispira Hannibal (pl. 4, figs. 35-38), the type of the genus, is carinate, and $B$. involutus Pilsbry (pl. 4, figs. 39-50; pl. 5, figs. $1-3$ ) is rounded. At locality 21 , where about 1,500 specimens were collected, $B$. involutus is very variable. Most of the shells from this locality have the sunken perforate apex characteristic of the genus, but some show gradations to a form with a convex imperforate apex (pl. 4, figs. 40,42, 44, 46, 48). Specimens that have a convex imperforate apex may be confused with stout specimens of Amnicola longinqua, with which they are found, but the wider umbilicus and many-whorled minute protoconch of Brannerillus, which may be somewhat awry, generally serve to distinguish them. On several specimens of $B$. involutus from locality 21 the apex extends down to the level of the upper edge of the aperture, completely filling the umbilicus. These shells represent a transition to apparently sinistral, actually ultradextal, shells (pl. 5, fig. 1), on one of which the aperture emerges in a plane at right angles to the normal position (pl. 5, figs. 2, 3). The figures of the apparently sinistral shells should be inverted to be oriented like the other figures of this species. (W.P.W.)

Pleuroceridae.-Goniobasis kettlemanensis Arnold occurs in the Pecten zone (pl. 15, figs. 5, 6, 14) of the San Joaquin formation and in strata between the Pecten and Neverita zones. The Tulare form $G$. kettlemanensis woodringi Pilsbry (pl. 4, figs. 51, 52) is larger and has subdued axial ribs or wrinkles, but lacks the strongly frilled spirals of $G$. occata (Hinds) that lives in the Sacramento River. The smooth Tulare species G. arnoldiana Pilsbry (pl. 4, figs. 53, 54) is stouter than the Recent $G$. nigrina Lea, and the outer lip is more sinuous. (W.P.W.)

Turritellidae.-Turritella is represented by two specimens from the Siphonalia zone of the Etchegoin for- 
mation. Though they are poorly preserved, they are determined as T. vanvlecki Arnold (pl. 31, fig. 2) with reasonable certainty. T. vanvlecki was described from the Glycymeris zone of the Etchegoin on Anticline Ridge, northwest of North Dome. According to Nomland, ${ }^{99}$ it occurs in the lowest invertebrate fossil zone in the Pliocene section on Anticline Ridge; where it is associated with a fauna corresponding to the Etchegoin fauna of North Dome with the exception of Lyropecten "terminus (Arnold)," " recorded by Nomland at his locality 2096. Outside the Coalinga district $T$. vanvlecki has been found 3 miles north of Bradley, ${ }^{2}$ in the Salinas Valley, and in the Santa Clara Valley ${ }^{3}$ in Ventura County. T. cf. T. vanvlecki has been reported with a fauna of probable Miocene age from the subsurface section of the Fruitvale oil field ${ }^{4}$ near Bakersfield. (R.S.).

Calyptraeidae.-Two forms of Calyptraea, one smooth and the other ribbed, are recorded from the Etchegoin and San Joaquin formations. The smooth form is listed as $C$. cf. $C$. inornata (Gabb) (pl. 11, fig. 7 ; pl. 15, fig. $10 ;$ pl. 20, fig. 6), the ribbed form as C. cf. C. filosa (Gabb) (pl. 8, fig. 7). It is possible that only one species is represented and that the smooth specimens are exfoliated or are a smooth variety of the ribbed form. The smooth shells, however, resemble a Recent West Coast species recorded as $C$. mamillaris Broderip or C. fastigiata Gould but are generally higher and more slender, whereas no species similar to the ribbed form is living on the Pacific coast. A ribbed Calyptraea in the Pliocene of coastal southern California resembles the Recent $C$. radians (Lamarck). Smooth shells from the Kettleman Hills on which the apex is preserved have a large apex. The apex is not preserved on the ribbed fossils. $C$. inornata was described from the Pliocene Purisima formation at Halfmoon Bay; its characters are not well known. The type of $C$. filosa is from the upper Miocene of Contra Costa County. (W. P.W.).

Crepidulidae.-Two forms of Crepidula, one large and the other small, are present in the Etchegoin and San Joaquin formations, and an undetermined Ianacus? was found in the Siphonalia zone. The large Crepidula is identified as $C$. princeps Conrad, which was described from late Pliocene or early Pleistocene strata at Santa Barbara. It is most abundant in the Etchegoin formation, particularly in South Dome, but occurs at several

\footnotetext{
${ }^{99}$ Nomland, J. O., The Etchegoin Pliocene of middle California: California Univ., Dept. Geology, Bull., vol. 10, p. 228 (locality 2096), p. 229 (locality 2377), table opp. p. 230 . pl. 12, fig. $5,1917$.

1 It appears to be doubtful whether the Coalinga district Lyropecten recorded as $L$. terminus is that form. (See Woodring, W. P., Lower Pliocene mollusks and echinoids trom the Los Angeles Basin, Calif,, and their inferred environment: U. S. Geol. Survey Prof. Paper 190, p. 34, 1938.)

${ }^{2}$ Arnold, Ralph, op. cit. (Bull. 396), p. 85, 1909 [1910].

8 Grant, U. S., IV, and Gale, H. R., op. cit. (San Diego Soc. Nat. History Mem., vol. 1), pp. 34, 773, pl. 24, flg. 22, 1931.

- Gale, H. R., in Preston, H. M., Report on Fruitvale oil field: California Oil Fields (California Dept. Nat. Res. Div. Oil and Gas), vol. 16, no. 4, p. 16, 1931.
}

horizons in the San Joaquin. The small forms, identified as C. cf. C. onyx Sowerby (pl. 31, fig. 6), may possibly represent young shells of the large form. $C$. onyx is a Recent California species. (W. P.W., R.S.). Naticidae.-The relative abundance of the naticid genera Neverita and Lunatia is reversed in the Etchegoin and San Joaquin formations. Lunatia is relatively abundant in the Etchegoin and rare in the San Joaquin, whereas Neverita is perhaps the most abundant gastropod in the San Joaquin but was not found in the Etchegoin.

Neverita reclusiana (Deshayes), a Recent California species, is the most abundant gastropod in the Neverita (pl. 20, figs. 1-5), Pecten, and Trachycardium (pl. 15, figs. 11, 19, 20) zones; and poorly preserved and doubtfully identified specimens occur in the Cascajo conglomerate member and Acila zone of the San Joaquin formation. The shells are generally exfoliated (pl. 20, fig. 1) but are locally well preserved. With the exception of rare specimens they are small or of medium size. The outline is variable, ranging from subcylindrical to conical. Subcylindrical specimens (pl. 15, fig. 19; pl. 20, fig. 4) are not represented in collections of Recent. shells at the National Museum or the Academy of Natural Sciences of Philadelphia. The Recent shell with a subcylindrical outline figured by Grant and Gale. is evidently the Pleistocene and Recent form designated imperforata. ${ }^{5}$ The Kettleman Hills fossils that are subcylindrical resemble in outline a Miocene form described by Gabb as Neverita callosa. N. reclusiana is the type of the subgenus Glossaulax Pilsbry, which is characterized by the groove on the umbilical callus. and is represented throughout the Tertiary on the Pacific coast. (W. P.W., R. S.).

The specimens identified as Lunatia cf. L. lewisii (Gould) (pl. 15, fig. 8) 'are generally poorly preserved. L. lewisii is a Recent species that has a more northern range than Neverita reclusiana.

"Nassidae".-Four species of "Nassa" are recognized in the Kettleman Hills fauna: a large and a small species in the Etchegoin and a large and a small species in the upper part of the San Joaquin. They are assigned to "Nassa" because their more exact generic relationships have not been worked out.

The large Etchegoin species, "Nassa" moraniana Martin (pl. 34, figs. 5, 6), occurs in the Siphonalia zone, and probably in the Macoma and Patinopecten zones. It has lirations on the columella and inner lip, thus resembling the Recent California species " $N$." fossata Gould. Apertures are accessible on only three Kettleman Hills specimens from two localities, but the lirations are well shown on many specimens from the Santa Maria district, one of which was figured by Arnold and Anderson as "Nassa" californiana (Con-

'Grant, U. S., IV, and Gale, H. R., op. cit. (San Diego Soc. Nat. History Mem., vol. 1), fig. 14, p. 803 . 
rad). ${ }^{6}$ The large species from the Pecten zone and probably from the Acila zone of the San Joaquin is "Nassa" coalingensis Arnold (pl. 15, fig. 3). It has a smooth inner lip and high spire and is typically more slender than "N." moraniana. "N." coalingensis is probably closely related to a living California species called " $N$." californiana (Conrad). The living species has more axial ribs on the body whorl and large specimens have lirations on the posterior part of the outer lip, which were not observed on the fossils. The distinction between " $N$." moraniana and " $N$." coalingensis may prove useful in separating Etchegoin and San Joaquin faunas in the Coalinga district. Inasmuch, however, as " $N$." moraniana occurs in the Santa Maria district with a fauna of possible San Joaquin nge, it is not likely that the two species will prove useful in distinguishing equivalents of the Etchegoin and San Jonquin in other areas. (R.S.)

The small "Nassa" from the Etchegoin is named "Nassa" miser (Dall) iniqua Stewart, n. var. (pl. 34, fig. 8). It differs from the living " $N$." miser" from the Pacific const of Central America and Mexico in being more slender; some fossil specimens have pseudovarices on the body whorl. "N." miser iniqua has seven spirals on the body whorl, only the posterior three of which are completely exposed on the whorls of the spire; young specimens of " $N$." moraniana of the same size have 11 spirals on the body whorl. Arnold ${ }^{8}$ - figured " $N . "$ miser iniqua from the Etchegoin of the Jacnlitos Fills as " $N . "$ californiana (Conrad). " $N . "$ cf. $N$. valdorfensis Arnold (pl. 39, fig. 4) is the small spocies that is found in the upper part of the San Joaquin formation. It differs from " $N$." miser iniqua in having nine spirals on the body whorl and four exposed on the whorls of the spire. These four spirals indicate a close relationship to the living California " $N$." mendica Gould. "N." waldorfensis was described from the Santa Maria district in association with a fauna resembling that of the upper part of the San Joaquin. About 100 specimens from the Santa Maria district are nvailablo. They are very similar to "N." mendica. Most of them can, however, be distinguished from the living species by their prominent posterior spiral, but this character is not well defined on the type specimen. " $N . "$ waldorfensis also lacks the secondary spiral" above the suture that is present on some specimens of " $N$." mendica. (R.S.)

Neptuneidae.-The genus Siphonalia is now living in Japanese waters but has not been found living in the eastern Proific. Perhaps its nearest relatives in the eastern Pacific are Solenosteira and Kelletia. Siphonalia is represented in the Siphonalia, Macoma, and

\footnotetext{
6 Arnold, Ralph, and Andorson, Robert, Geology and oil resources of the Santa Maria oll district, Santa Barbara County, Calif,: U. S. Geol. Survey Bull. 322, p. 59 , pl. 24, fig. 4, 1807 .

7 Dall, W. H., The Mollusca and the Brachiopoda (Albatross Repts.): Harvard Coll. Mus. Comp. Zoology Bull., vol. 43, p. 307, pl. 4, fig. 1, 1908.

8 Arnold, Ralph, op. cit. (Bull. 390), pl. 27, fig. 8, 1909 [1910].
}

Patinopecten zones of the Etchegoin and in the Acila and Pecten zones of the San Joaquin. The Etchegoin Siphonalia is a large species sculptured with strong nodes, S. kettlemanensis (Arnold) (pl. 31, figs. 1, 7). A form of this species that has practically no nodes occurs in the Pecten zone. Arnold's specimens of $S$. kettlemanensis from the Jacalitos formation are at least related to that species, though they are too poorly preserved to be unquestionably identified. An apparently closely related upper Miocene species has been named Chrysodomus pabloensis Clark. ${ }^{8 a}$ As suggested by Grant and Gale, ${ }^{\theta}$ the inadequately known $S$. diegoensis (Dall) from the Pliocene San Diego formation may prove to be conspecific with S. kettlemanensis; in that event $S$. diegoensis will be the valid name for the Kettleman Hills species. The Siphonalia from the Acila zone is a smaller, more slender, and weakly sculptured species identified as $S$. cf. $S$. humerosa (Gabb) (pl. 11, fig. 9). S. humerosa was originally described from strata generally assigned to the lower Pliocene, at Elsmere Canyon in Ventura County. It resembles the living Japanese $S$. trochulus (Reeve) ${ }^{10}$ in that it lacks axial ribs or nodes on the body whorl. "Chrysodomus" portolaensis Arnold, from the Etchegoin of the White Creek syncline northwest of Coalinga is probably related to $S$. humerosa. Poorly preserved specimens from the oldest exposed Etchegoin strata in South Dome are similar to "Chrysodomus" portolaensis. (R. S.)

Muricidae.-With the exception of unidentified poorly preserved specimens, muricid gastropods were found only in the Pecten zone of the San Joaquin formation. The most abundant species is identified as Jaton cf. J. festivus (Hinds) (pl. 15, figs. 2, 9). The form shown on plate 15 , figure 9 , is a variety on which the varices are not curved, but some specimens have the typical curved varices. This variety with straight varices is possibly more abundant in the Pecten zone than among living members of $J$. festivus. Although numerous specimens of the fossils are available, none show the development of the ornamentation. Jaton is better known in California as Purpura, a name used by Martyn. Martyn's "Universal Conchologist" as a source for valid systematic names is, however, very doubtful. ${ }^{11}$ Two groups of Jaton, probably of at least subgeneric rank, are now living on the California coast. $J$. festivus (Hinds) and $J$. carpenteri (Dall) represent one group; "Purpura foliata Martyn" and "Purpura" nuttalli (Conrad), characterized by a "tooth" on the outer lip, represent the other group, the range of which extends farther north. Just which, if either, of these

\footnotetext{
8a Clark, B. L., Fauna of the San Pablo group of middle California: California Univ., Dept. Geology, Bull., vol. 8, p. 496, pl. 67, fig. 8, 1915.

- Grant, U. S., IV, and Gale, H. R., op. cit. (San Diego Soc. Nat. History Mem.. vol, 1), p. 643.

10 Reeve, L. A., Conchologia Iconica, Buccinum, pl. 2, fig. 7, 1845

11 Winckworth, R., Notes on nomenclature: Malacol. Soc. London Proc., vol. 18, pp. 228-229, 1929. Stewart, R. B., Gabb's California Cretaceous and Tertiary type laraellibranchs: Acad. Nat. Sci. Philadelphia Spec. Pub. 3, p. 30, 1930.
} 
two groups is typical Jaton is not known, but presumably typical Jaton lacks the "tooth." (R.S.)

The Pecten zone Tritonalia cf. T. lurida Middendorff (pl. 15, fig. 12) may be specifically distinct from the living California T. lurida, because the spirals on the body whorl are more distinctly differentiated as primary and secondary spirals than on Recent specimens. (R.S.)

Thaididae.-Nucella etchegoinensis (Arnold) is abundant in the Cascajo conglomerate member of the San Joaquin (pl. 24, figs. 16-18) and occurs at other horizons in the San Joaquin and Etchegoin formations. A large variety sculptured with relatively strong spirals is present in the Macoma and Patinopecten zones of the Etchegoin (pl. 36, figs. 1, 7). N. etchegoinensis is closely related to the Recent Pacific coast species called $N$. lamellosa (Gmelin) and perhaps should be cited as a variety or subspecies of the living species. The fossils lack the axial lamellae characteristic of the living species in the northern part of its range. The axial lamellae, however, vary in strength, and they are absent or faintly developed on a form named $N$. lamellosa var. franciscana (Dall), ranging from San Francisco Bay ${ }^{12}$ to Puget Sound. This Recent form has not been studied, but perhaps it is the same as the Cascajo form. (W.P.W.)

The genus Forreria occurs in and below the Siphonalia zone and at the base of the exposed section in South Dome of the Etchegoin formation and in the Pecten zone of the San Joaquin.

Forreria coalingensis (Arnold), characterized by strong widely spaced spirals, was found only in the type region near the south end of South Dome. This species also occurs near the base of the Etchegoin in the Kreyenhagen Hills ${ }^{13}$ and in the Jacalitos formation. ${ }^{14}$ It is also associated with Jacalitos species in a collection from U. S. G. S. locality 11132, about a mile south of Curry Mountain. Its distribution in the foothills west of the Kettleman Hills suggests that the oldest Etchegoin strata exposed in South Dome are close to the base of the formation. (W.P.W.)

The typical form of Forreria magister (Nomland) (pl. 36, figs. 11, 12) occurs in the Etchegoin of North Dome. Some specimens have a spine or varix on the lower (anterior) angulation of the later part of the body whorl. No specimens from the Pecten zone show this character. It is convenient, therefore, to distinguish the Pecten zone variety with the name $F$. magister var. munda Stewart, n. var. (pl. 15, figs. 17, 18). The form from Anticline Ridge, apparently from the lower part of the Etchegoin, named $F$. belcheri var. avita (Nomland), was described as having a more evident develop-

12 Packard, E. L., Molluscan fauna from San Francisco Bay: California Univ., Pub. in Zoology, vol. 14, p. 337, pl. 40, figs. 5a, 5b, 1918.

${ }^{13}$ Arnold, Ralph, and Anderson, Robert, op. cit. (Bull. 398), p. 133 (locality 4749).

14 Nomland, J. O., Fauna from the lower Pliocene at Jacalitos Creek and Waltham Canyon, Calif.: California Univ., Dept. Geology, Bull., vol. 9, p. 203, 1916. The Etchegoin Pliocene of middle California: Idem vol. 10, pp. 213, 221, 1917. ment of nodes on the lower part of the body whorl than $F$. magister. This form, therefore, is probably more closely related to the typical $F$. magister than is the variety munda. $F$. magister seems distinct from $F$. belcheri (Hinds), which ranges from San Pedro southward to Lower California and is the only living species along the Pacific coast. The bases of the varixlike spines of large fossil specimens are smaller than those of the living species, and it seems doubtful whether the whorls of the spire had the varixlike spines that are well developed on the living species. (R.S.)

Cancellariidae.-Three large Cancellarias are recognized in the Pecten zone of the San Joaquin formation: a form that lacks nodes, Cancellaria rapa Nomland (pl. 15, figs. 1, 7), and two noded forms, C. altaspira Gabb and $C$. cf. C. tritonidea Gabb. The occurrence of C. rapa in the Pecten zone is of interest, because the stratigraphic position of this species in the Coalinga district was not heretofore known. C. rapa has been identified in the Santa Maria district, ${ }^{15}$ and $C$. elodiae Carson, from the same locality, is probably $C$. rapa. C. hamlini Carson, from Elsmere Canyon in Ventura County, is also probably closely related to C. rapa. The noded form identified as $C$. altaspira Gabb does not have such a high spire as typical C. altaspira, which is from Elsmere Canyon, and may represent the variety perrin Carson, described from the Santa Maria district. It seems likely, however, that $C$. rapa itself is a variety of C. altaspira that lacks nodes. C. altaspira and its allies can be separated from the Pleistocene $C$. tritonidea Gabb, as figured from San Pedro by Arnold, ${ }^{16}$ by the absence of a shoulder on the early whorls. Not enough specimens of $C$. tritonidea are available to determine whether this criterion is of specific value. The distinction may, however, be useful and may have a stratigraphic significance. C. altaspira is presumably older than $C$. tritonidea, but their ranges possibly overlap. A small imperfect specimen from the Pecten zone is identified as $C$. cf. $C$. tritonidea on the basis of the shoulder. The nearest living relative of this group of large Cancellarias seems to be $C$. spengleriana Deshayes from Japan. None of these species represents Cancellaria in the restricted sense. Superficially they are similar to Progabbia and Euclia, but a closer relation with Merica and Crawfordiana may be evident when the development of their ornamentation is known. $(R . S$.

A worn specimen referable to Progabbia (pl. 15, fig. 4) was found in the Pecten zone, and this genus also occurs in the Siphonalia zone.

Columbellidae.-A stout Mitrella from the Neverita zone is identified as $M$. gausapata (Gould) (pl. 20, fig. 7), a Recent species living on the California coast. A more slender form from the Acila zone, $M$. cf. $M$. gausapata (pl. 11, fig. 5), may be referable to $M$. richthofeni Gabb,

\footnotetext{
is Carson, C. M., New moliuscan species from the California Pliocene: Southern California Acad. Sci. Bull., vol. 25, p. 51, 1926.

${ }^{16}$ Arnold, Ralph, op. cit. (Bull. 396), pl. 26, fig. 10.
} 
a Pliocene species from Sonoma County, the characters of which are not well known. Unidentified remains of Mitrella were found in the Etchegoin of North and Middle Domes. (W. P.W.)

Planorbidae.-Menetus vanvlecki (Arnold) (pl. 5, figs. $10-15)$ is the most abundant of the Tulare planorbids. This species is the type of the extinct subgenus Planorbifex Pilsbry, characterized by a rounded periphery combined with a wealjy or strongly carinate shoulder and base, producing a Valvata-like outline. Carinifex sanctaeclarae marshalli Arnold (pl. 5, figs. 4-6) also is abundant. This form is smaller and less carinate than typical C. sanctaeclarae Hannibal, which is based on fossils from Santa Clara County. It is also smaller than the Recent $C$. newberryi (Lea) and lacks the peripheral carina of the living species. The absence in the Tulare formation of large planorbids of the genus Helisoma is noteworthy. The small form described as Helisoma? kettlemanensis Pilsbry was not recognized in the collections of the Geological Survey. (W.P.W.)

\section{PELECYPODS}

Nuculidae.-The genus Acila, represented by the living $A$. castrensis (Hinds) (pl. 11, figs. 11-17), is a notable member of the Acila zone fauna. Except rare specimens from a horizon above the Acila zone and unidentified molds from the lower part of the Etchegoin of Middle Dome, the genus was not found at other horizons. A. castrensis is reported from Bering Sea to San Diego. A great deal of information on this species has been recently collected. ${ }^{17} \quad(R . S$.

Arcidae.-An incomplete paired specimen from the Siphonalia zone of the Etchegoin formation, Arca cf. A. sisquocensis Reinhart, is the first representative of the Arca noae group discovered in the Coalinga district. It is much larger than $A$. sisquocensis, ${ }^{18}$ the type of which is from the Pliocene of the Santa Maria district. The Etchegoin Arca is probably more closely related to a Japanese species in the collections of the National Museum labeled $A$. krausii Philippi ${ }^{19}$ (123666) than to the living Pacific coast species from Lower California, as the cardinal area has many more ligamental grooves than the living American species. The cardinal area of $A$. terminumbonis Grant and Gale, from the Pliocene of Elsmere Canyon, also has numerous ligamental grooves. When more representatives of the California Miocene ${ }^{20}$ and Pliocene Arcas are known they may prove to represent a distinct group. ( $R$. S.)

The genus Anadara is one of the most abundant fossils in the Etchegoin and San Joaquin formations.

\footnotetext{
17 Schenck, H. O., Nuculid bivalves of the genus Acila: Geol. Soc. America Spec. Pub. 4, pp. 96-99, 135, pl. 10, 1936.

is Roinhart, P. W., Three new species of the pelecypod family Arcidae from the Plioceno of California: Jour. Paleontology, vol. 11, p. 182, pl. 28, figs. 1-3, 1937.

10 Phllippi, R. A., Abblldungen und Beschrelbungen neuer oder wenig gekannter Conchylien, vol. 3, p. 88, Arca, pl. 5, figs. 8-10, Cassel, Fischer, 1851.

${ }^{20}$ Lool, Wayne, and Corey, W. H., The Vaqueros formation, lower Miocene of California, I, Palcontology: California Univ., Dept. Geol. Scl., Bull., vol. 22, p. 141, 1932. Woodring, W. P., A Miocene Haliotis from southern California: Jour. Paleontology, vol. 5, p. 35,1831 .
}

All the forms appear to represent one species, which is traditionally identified as $A$. trilineata (Conrad). That identification is accepted and the species is cited as Anadara trilineata (Conrad) of Arnold, for the usage in the present report is based on Arnold's identification of specimens from the Coalinga district. Anadara trilineata was described by Conrad as having been collected by Newberry at Santa Barbara. According to Newberry's itinerary, however, he was nowhere near Santa Barbara, and no Anadara has been found at Santa Barbara. The type specimen appears to be lost and the characters of $A$. trilineata will remain uncertain until it is found at Santa Barbara or until some other type locality is arbitrarily selected. It is possible that Conrad mixed collections from Newberry and Blake received at about the same time and that the original material of $A$. trilineata came from the Kettleman Hills or nearby. Under the locality designation "Tulare Valley?" Conrad described as Arca microdonta a fossil received from Blake, who cited the locality as "the hills of the Coast Mountains near the Tulares." The Kettleman Hills fit this description, for Blake approached the foothills from the east. The type of Arca microdonta, a well-preserved right valve of an Anadara, is in the National Museum. Not only is it unlike any form of Anadara known from "the hills of the Coast Mountains near the Tulares," but it is unlike any fossil or living species so far discovered in California; it may have been collected by Blake in Panama during his trip to California. ${ }^{21}$ This is a matter of speculation now not subject to verification, but it may be worth consideration should a decision be reached to fix arbitrarily a type locality for $A$. trilineata. (W. P.W.)

The typical form of Anadara trilineata, as here accepted, occurs at intervals throughout the San Joaquin formation (pl. 11, figs. 10, 19-24; pl. 20, fig. 17), and small specimens also occur near the top of the Etchegoin, at least in the Pseudocardium-Anadara zone of Middle and South Domes. It is particularly abundant in the Acila zone. It is markedly inequilateral and has an asymmetrical base. A small elongate flat variety that has a more symmetrical base occurs in the Neverita zone (pl. 20, figs. 15, 16) and Pecten zone (pl. 14, fig. 7). A short inflated variety (pl. 29, figs. 2, 6), many specimens of which are thick-shelled, is characteristic of the upper Pseudocardium zone. Aside from this upper Pseudocardium zone variety and the small specimens near the top of the Etchegoin; the Anadaras from the Etchegoin have the beaks roughly halfway between the ends of the cardinal area (pl. 31 , fig. 9)-that is, the Anadaras are almost equilateral. This more equilateral variety resembles Conrad's figure of $A$. canalis, but inasmuch as the figure is the only

21 For a fuller discussion of this matter with literature citations see Woodring, $W$. P., Lower Pliocene mollusks and echinoids from the Los Angeles Basin, Calif., and their inferred environment: U. S. Geol. Survey Prof. Paper 190, p. 31, 1938. 
GEOLOGY OF THE KETTLEMAN HILLS OIL FIELD, CALIFORNIA

basis for identification, it is cited as $A$. trilineata variety cf. canalis. $A$. canalis, as well as $A$. trilineata, was claimed to have been collected by Newberry at Santa Barbara. A. trilineata variety cf. canalis also occurs in the Cascajo conglomerate member and at a higher horizon in the lower part of the San Joaquin between the Cascajo and the Neverita zone (pl. 24, fig. 7). Though the ranges of the strongly inequilateral and more equilateral forms overlap, the forms may prove to have stratigraphic significance, at least in the Coalinga district. (W.P.W., R.S.)

Anadara trilineata and its allies appear to be extinct, and a close living relative has not been recognized. Anadara amicula (Yokoyama), ${ }^{22}$ from the Neogene of Japan, is probably a closely related species, but the group is apparently absent from the living fauna of Japan. A. trilineata variety cf. canalis (Conrad) resembles $A$. tatunokutiensis (Nomuri and Hatai), ${ }^{23}$ which is also from the Neogene of Japan. (R.S.)

Glycymeridae.-Glycymeris was found only in the Etchegoin formation of North Dome. The species represented is identified as G. grewingki Dall (pl. 29, figs. 10,$11 ; \mathrm{pl} .33$, figs. 7,8 ), the type of which is from the Empire formation of Oregon. The North Dome species is probably conspecific with $G$. coalingensis Arnold, from the Etchegoin at Alcalde Canyon in the Coalinga district, the differences between $G$. coalingensis and $G$. grewingki cited by Arnold being due to differences in the state of preservation of the type specimens. The North Dome species can be separated from the living $G$. subobsoleta (Carpenter) by its greater height. The fossils, therefore, resemble the original figure of G. septentrionalis (Middendorff), but only a few beachworn specimens of $G$. septentrionalis are available for comparison. Unfortunately it is not possible to determine whether the fossils are more closely related to the northern $G$. septentrionalis and $G$. subobsoleta or to the southern G. migueliana Dall and G. corteziana Dall. The greater height of the North Dome fossils is most evident on large specimens and suggests $G$. profunda (Dall), ${ }^{24}$ a San Diego fossil, but North Dome specimens are not so much inflated as the few specimens of $G$. profunda available. If the greater inflation of $G$. profunda is not constant, the North Dome species may be conspecific with $G$. profunda. The name grewingki would, however, still be useful for the flat forms, at least as a variety, assuming that they are distinct from G. septentrionalis. Arnold's $G$. septentrionalis from the Etchegoin of the Coalinga district apparently represents young shells of his G. coalingensis. (R.S.)

22 Yokoyama, M., Tertiary Mollusca from Shinano and Echigo: Tokyo Imp. Univ., Fac. Sci., Jour., sec. 2, vol. 1, p. 19, pl. 7, figs. 2-4 (Arca), 1925. Nomura, S., and Hatai, K., On some species of the genus Arca from the Neogene of northeast Honsyâ, Japan: Japanese Jour. Geology and Geography, Trans. and Abstracts, vol. 13, pp. 63-69, pls. $12,13,1936$.

23 Idem.

24 Dall, W. H., Fossil mollusks from later Tertiaries of California: U. S. Nat. Mus. Proc., vol. 1, p. 13, 1879 (Axinea). Elycymeris profunda is one of the few names for California Pliocene or Pleistocene mollusks omitted from Grant and Gale's catalog.
Mytilidae.-Mytilus coalingensis Arnold occurs in the Etchegoin and San Joaquin formations and is particularly abundant in the Siphonalia zone (pl. 32, figs. 3,4$)$. Shorter and more curved forms from the lower part of the Patinopecten zone resemble $M$. kewi Nomland, described from a Coalinga district locality that probably represents the Jacalitos formation. These forms from the Patinopecten zone appear to be variations of the typical $M$. coalingensis. Specimens of $M$. coalingensis are as large as the living $M$. californianus Conrad but may be distinguished from the living species by the thicker hinge plate and by the absence of radiating ridges. The nearest living relative of $M$. coalingensis seems to be the large Japanese species $M$. crassitesta Lischke, ${ }^{25}$ which, however, does not have so thick a hinge plate and the teeth of large specimens of which are more distinctly formed. Specific criteria distinguishing $M$. coalingensis from the many California Miocene forms that have been named have not yet been worked out. (R.S.)

A small Mytilus from the upper Mya zone, and doubtfully from a horizon between the upper $M y a$ and Acila zones, is identified as $M$. cf. $M$. edulis Linné (pl. 8, fig. 8). It represents the same species as the living species on the California coast called $M$. edulis. It is not certain, however, that the living California species is the European M. edulis. This small Mytilus has a thinner hinge plate than young specimens of M. coalingensis. (W.P.W.)

Volsella cf. V. modiolus (Linné) (pl. 37, figs. 1, 2), a relatively short, broad species, occurs near the base of the exposed Etchegoin in South Dome but was not found at other horizons; in fact, the genus was not observed in the Etchegoin of North Dome. The fossils, all of which are paired, appear to be identical with small specimens of the Recent California species called $M$. modiolus, but the California species may not be the same as the European $M$. modiolus. Two species of Volsella, both comparable to living California species, occur in the Pecten zone: a narrow species, $V$. cf. V. recta (Conrad) (pl. 13, fig. 15), and a broad species, $V$. cf. $V$. capax (Conrad) (pl. 16, fig. 3). $V$. cf. V. recta is a common fossil in the Neverita zone (pl. 20, figs. 13, 14). $V$. directa (Dall), from the Empire formation of Oregon, is probably the same form, but the relations of the Pliocene and Recent forms have not been determined. (W. P. W., R. S.)

Pectinidae.-The genus Pecten, represented by $P$. coalingaensis Arnold (pl. 13, figs. 1, 2, 17, 18; pl. 16, fig. 4), is characteristic of the Pecten zone and was found in place only in that zone. A specimen collected at an Acila zone locality may have been derived from older alluvium. On 150 valves of this species the number of ribs ranges from 15 to 23 , but three-fourths of the inflated valves have 19 to 21 ribs, and three-

${ }^{25}$ Lischke, C. E., Japanische Meers-Conchylien, vol. 1, p. 151, pl. 11, flgs. 1,2, 1869. 
fourths of the flatter valves have 18 to 20 ribs. The nearest living relative of $P$. coalingaensis is $P$. cataractes Dall, from the Gulf of California. The living apecies may be distinguished from $P$. coalingaensis by the presence of secondary radials in the interspaces on the flatter valve. All of 150 valves of $P$. coalingaensis lack secondary radials except 5 , which have a radial in one or two interspaces, but only 1 of 29 left valves of $P$ : cataractes lack the radials, and that valve is small (height, 22 millimeters). P. coalingaensis and its allies may be distinguished from $P$. bellus Conrad, a fossil species from Santa Barbara, and its allies, by the greater number of ribs, the greater inflation of the inflated valve, and the shorter internal channelscorresponding to the external ribs-on the flatter valve. The cross section of the ribs of the inflated valve also differ in the two groups: $P$. bellus has squaretopped ribs, whereas $P$. coalingaensis has roundtopped ribs. $P$. coalingaensis was treated as a variety of $P$. bellus by Grant and Gale, but a close relationship seems very doubtful. The two groups are evidently distinct in the living Japanese fauna, $P$. bellus being represented by $P$. laqueatus Lischke ${ }^{26}$ and $P$. coalingaensis being represented by $P$. puncticulatus Dunker, ${ }^{27}$ which does not have secondary radials on the flat valve. The two specimens of $P$. puncticulatus available differ from $P$. coalingaensis in having fewer large ribs on the flatter valve and small ribs at the dorsal margins of the disc. The inflated right valve of the Japanese species has slightly flatter ribs. $P$. vogdesi, from the Pleistocene at San Pedro, may be a connecting form between $P$. coalingaensis and the living $P$. cataractes. The two specimens of $P$. vogdesi examined lack the secondary radials on the flatter valve, thus resembling $P$. coalingaensis. According to Grant and Gale, ${ }^{28}$ however, $P$. vogdesi and $P$. cataractes cannot be consistently distinguished from each other by this character. Pecten auburyi Arnold, from the Pliocene of the Puente Hills, near Los Angeles, and $P$. lecontei Arnold, from the Pliocene of Cedros Island, Lower California, apparently lack secondary ribs on the flat valve and according to figures are probably very closely relnted to $P$. coalingaensis. Two other forms described from Pliocene strata on the Lower California mainland are also probably related to $P$. coalingaensis: $P$. heimi Hertlein, which evidently lacks secondary ribs on the flat valve; and $P$. hartmanni Hertlein, the flat valve of which has not been described. (R.S.).

Aequipecten was found only in the San Joaquin formation. Aequipecten circularis impostor (Hanna) is locally abundant in the Pecten zone (pl. 13, figs. 3, 4, $6-9)$, and fragmentary remains of a similar form occur

${ }^{20}$ Lischke, C. E., op. cit., vol. 2, p. 157, pl. 12, figs. 1-2, 1871. Reeve, L. A., Conchologla Iconlca, Pecten, pl, 30, fig. 135 (?), 1853.

97 Pilsbry, H. A., Now and hitherto unfigured Japanese mollusks: Acad. Nat. Sci. Philadelphla Proc., vol. 43, p. 473, pl. 19, figs. 1-3, 1882.

${ }^{29}$ Grant, U. S., IV, and Gale, H. R., op. cit. (San Diego Soc. Nat. History, Mem., vol, 1, p. 220 .

$152180-40-7$ in the Cascajo conglomerate member. The Pecten zone variety differs from the living California $A$. circularis Sowerby and its allies in having a smaller thinner shell and smaller ears. These fossils were identified by Arnold as $A$. deserti Conrad, the type of which is from the Colorado Desert. They are probably very closely related to that species, which, however, appears to have not quite so many ribs, and at least some specimens have ribs on the lateral areas. On the Pecten zone fossils the lateral areas are smooth. $A$. circularis eldridgei (Arnold) (pl. 24, figs. 10-13), found only in the Cascajo conglomerate of South Dome, is smaller than $A$. circularis impostor and has a thicker shell. The Cascajo specimens are smaller and less inflated than specimens from the type locality near McKittrick, where they occur in strata suggested in the present report as representing the equivalent of the Cascajo. This small pecten was heretofore recorded only at the type locality. (W. P.W., R.S.)

Chlamys etchegoini (Anderson) is present in the Siphonalia zone (pl. 32, fig. 1) of the Etchegoin, and one small specimen (pl. 13, fig. 5) was found in the Pecten zone of the San Joaquin. This species is, however, abundant in the Pecten zone in the foothills farther west. $C$. etchegoini is closely related to the living Japanese $C$. swiftii (Bernardi). The Kettleman Hills specimens are very similar to $C$. swiftii, but they differ from 20 valves of that species available for comparison in having the ears more distinctly separated from the discs by angles that form furrows on the exterior of the valve. The difference is most marked on large specimens, particularly on left valves. It is not known whether all the American fossil forms can be separated from $C$. swiftii by this character. It is not well marked on the type of C. parmeleei (Dall), from the Pliocene at San Diego, possibly because it is a small specimen, but it seems likely that all the American forms will prove to be more closely related to $C$. parmeleei than to $C$. swiftii. $C$. parmeleei has prominent concentric swellings and is probably the same species as C. wattsi (Arnold), from the Coalinga district. Although the form with prominent concentric swellings may be a variation of $C$. etchegoini, it has not yet been found with that species in the Kettleman Hills. In the Kreyenhagen Hills this form occurs in the Jacalitos formation ${ }^{29}$ as well as in the Pecten zone. Another Chlamys, C. cf. C. islandicus (Müller), is represented by fragments in the Acila zone. It is the last of the Pectinidae in the Kettleman Hills. (R. S.)

The genus Patinopecten is abundant in the Etchegoin formation, particularly in the Patinopecten zone, and is rare in the San Joaquin. The Etchegoin species is identified as Patinopecten lohri (Hertlein) (pl. 35, figs. 2-5). Many of the North Dome specimens have the

3 Nomland, J. O., Fauna from the lower Pliocene at Jacalitos Creek and Waltham Canyon, Fresno County, Calif.: California Univ., Dept. Geology Bull., vol. 8, pp. 203, 204, 1936. 
primary ribs on the right valve divided at an earlier growth stage than that shown in the figure of the type of $P$. lohri. No specimens from the type localitySanta Maria district-are available, and it cannot be determined whether or not the type is an abnormal specimen. Two forms of $P$. lohri may, however, eventually be recognized on the basis of the difference in growth stage marked by the division of the primary ribs. A Patinopecten fragment from the Pecten zone is identified as $P$. cf. P. healeyi (Arnold). Although some specimens of $P$. healeyi, originally described from the Pliocene at San Diego, have small secondary ribs in a few of the interspaces of right valves, none of the some 50 specimens available from various localities have so large or so many secondary ribs as are present on right valves of some 30 specimens of $P$. lohri. The specimen from Elsmere Canyon, in Ventura County, figured by Grant and Gale ${ }^{30}$ as $P$. lohri, evidently lacks the prominent secondary radials on the right valve and would be identified as $P$. healeyi on the basis of the criteria suggested. (R.S.)

Fragments of Lyropecten cf. L. estrellanus (Conrad), all probably representing one valve, were found on the outcrop of the Siphonalia zone. As the locality is near a former habitation, this material may have been transported by man. Lyropecten, however, has been collected from the oldest fossiliferous zone in the Etchegoin of Anticline Ridge, ${ }^{31}$ northwest of the Kettleman Hills. (R.S.)

Ostreidae.-In the Kettleman Hills Ostrea atwoodii Gabb (pl. 29, figs. 1, 13), the type of which was collected in the Coast Ranges west of Coalinga, is characteristic of the Etchegoin. It is abundant in the upper Pseudocardium zone but was not found at higher horizons. The numerous fine radial ribs on the lower valve and the smooth flat upper valve distinguish this species from other forms in the Kettleman Hills. O. vespertina Conrad (pl. 14, fig. 9), characterized by a strongly plicate lower valve and an upper valve that is generally as strongly plicate as the lower valve, occurs in the Pecten zone. Arnold considered the Kettleman Hills specimens identical with $O$. vespertina from the Colorado Desert, and no characters have been found to distinguish them. ${ }^{32}$ The oýster in the upper Mya zone (pl. 8, figs. 10-14) was described by Arnold as 0 . vespertina sequiens. It also occurs in strata between the upper Mya and Acila zones (pl. 10, figs. 1-5). The upper valve of this form is not strongly plicate and is generally undulate or smooth. Small specimens, identified as $O$. cf. $O$. vespertina, are probably dwarfs of this form. These small specimens and also some larger undulate specimens of the variety sequens are indistinguishable from the living California O. lurida Carpenter. A small

\footnotetext{
so Grant, U. S., IV, and Gale, H. R., op. cit. (San Diego Soc. Nat. History Mem., vol. 1), p. 197, pl. 6, figs. 1a, 1b.

31 Nomland, J. O., op. cit. (California Univ., Dept. Geology, Bull., vol. 10), p. 228 (locality 2096), table opposite p. 230 .

32 Woodring, W. P., op. cit. (Prof. Paper 190), pp. 42-47, 1938.
}

unidentified oyster, represented generally by fragments, occurs in the Cascajo conglomerate and Acila zone. (W.P.W.)

Unionidae.-The two species of fresh-water mussels in the Tulare formation are related to Recent California species. Anodonta kettlemanensis Arnold (pl. 6, figs. $1-3$ ) is generally more strongly inflated than $A$. muttalliana Lea, and the beak sculpture is finer and spread over a larger area. Some of the fossils are elongate and strongly inflated (pl. 6, fig. 3). Gonidea coalingensis Arnold (pl. 6, figs. 4-9) is more elongate than G. angulata Lea and has a heavier hinge. The beak sculpture of the fossils also is somewhat finer and covers a larger area. The most common form among the fossils is moderately inflated and has a low beak (pl. 6, figs. 5-8). Other specimens are more strongly inflated and have a high beak (pl. 6, fig. 9). Shells that are exceptionally inflated (pl. 6, fig. 4) were collected from a horizon below the upper Amnicola zone. Unidentified forms of Anodonta and Gonidea also occur in the San Joaquin formation, and Anodonta was found in Etchegoin strata above the Littorina zone. The locality where Nomland collected the Anodonta that he described as $A$. nitida ${ }^{33}$ represents a horizon in the Etchegoin above the Littorina zone, not below the upper Pseudocardium zone as Nomland thought. (W:P.W.)

Tellinidae--Specimens of the Miocene Tellina oldroydi Wiedey, ${ }^{34}$ which is evidently not a typical Tellina, have not been examined. The Pecten zone (pl. 14, fig. 8) and Siphonalia zone (pl. 33, fig. 5) specimens identified as Tellina? cf. T.? oldroydi are probably closely related to that species. The Kettleman Hills form is probably related to $T$. lutea Gray, living on the Alaskan coast, but is more nearly equilateral. It is also probably closely related to $T$. venulosa Schrenck, ${ }^{35}$ a living Japanese species that has the outline of the fossils but has concentric ribs. T. lutea lacks concentric ribs, and they are probably absent on T.? cf. T.? oldroydi. The Kettleman Hills fossils are slightly more inflated than either of the living species: $T$. cf. T. bodegensis Hinds (pl. 33, fig. 2), from the Siphonalia zone, resembles the living California $T$. bodegensis. (R.S.)

A paired specimen from the Patinopecten zone is identified as Macoma of: $M$. indentata Carpenter (pl. 35, fig. 1). $M$. indentata is a living species said to range from Puget Sound to Lower California. A poorly preserved specimen also from the Patinopecten zone resembles $M$ : vanvlecki Arnold, which was described from the Jacalitos formation and may be an inflated form of $M$. indentata. (R.S.)

Macoma affinis Nomland ranges through the Etchegoin and Sañ Joaquin formations and is particularly

${ }^{33}$ Nomland, J. O., op. cit. (California Univ., Dept. Geol., Bull., vol. 10), pp. 215-216, 231, pl. 9, fig. 2.

34 Wiedey, L. W., Notes on the Vaqueros and Temblor formations of the California Miocene with descriptions of new species: San Diego "Soc. Nat. History Trans., vol. 5, no. 10, p. 148, pl. 19, fig. 3, 1928.

${ }^{85}$ Schrenck, L. v., Reisen und Forschungen im Amur-Lañde, vol, 2, p. 556, pl. 22, figs. $2-5,1867$. 
abundant in the Macoma zone of the Etchegoin (pl. 34, figs. 1-4) and in the upper Mya zone of the San Joaquin (pl. 9, figs. 1-3). This species was described from the upper Mya zone at the top of the San Joaquin in the foothills west of the Kettleman Hills. It is similar to the Recent species $M$. inquinata (Deshayes) that ranges from Monterey, Calif., to Alaska and Japan. On the Kettleman Hills fossils that show the pallial sinus the sinus is not so close to the anterior adductor scar as on the living species. The outline of the pallial sinus is variable on about 50 Recent specimens, but in general it is closer to the left anterior adductor scar than to the right; that is, the sinus of the left valve is deeper than the sinus of the right valve, though the difference is not so marked as on M: nasuta (Conrad): ${ }^{36}$ The deeper sinus of the left valve of M. nasuta and the posterior twist of the shell is associated with the animal's habit of lying in the mud on the left side. It is not known whether $M$. indentata also lies on its left side. A left and right valve of $M$. affinis of about the same size do not show a deeper left pallial sinus. Specimens of $M$. affinis were found in the Macoma zone normal to the bedding, and their symmetrical pallial sinuses may be associated with this position. The dorsal apex of the pallial sinus of $M$. affinis is angulated (pl. 9, fig. 3 ; pl. 34, fig. 2) or rounded (pl. 34, fig. 1). Recent specimens of $M$. inquinata show the same variation, but the apex is. wider than in the fossils. On some specimens from the upper Mya zone a line similar to the sinus, but fainter, extends from the dorsal apex of the sinus toward the umbo (pl. 9, fig. 3). M. affinis much resembles an unidentified living Japanese species, represented by one specimen in the National Museum (341099). It has a symmetrical pallial sinus, but the sinus is not so deep as on $M$. affinis, and the outline of the valves is more rounded. (W.P.W., $R S$.)

The small Macoma of the Littorina zone is named M. affinis plena Stewart, n. var. (pl. 29, fig. 12; pl. 39, fig. 3). This form is about half as long as $M$. affinis; it also is more circular, and some specimens are more inflated. The pallial sinus is not well known. This small Macoma also occurs in the upper oolite (pl. 24, fig. 3) between the Neverita zone and Cascajo conglomerate. A similar form was found in the Pecten zone and between the Pecten and Neverita zones (pl. 15, fig. 13). The Pecten zone specimens are not so rounded as specimens from the Littorina zone. Their sinuses resemble the sinus. of $M$. affinis. ( $R . S$.)

Two other species of Macoma are comparable to living California species. M. cf. M. nasuta (Conrad), the interior of which is not known, occurs in the lower part of the Etchegoin of South Dome, in the Neverita zone (pl. 20, fig. 12), and in the Pecten zone (pl. 14, fig. 5). M. cf. M. secta (Conrad) (pl. 16, fig. 1) is represented by two worn left valves from the Pecten zone.

\footnotetext{
80 Woymouth, F. W., The edible clams, mussels, and scallops of California: California Fish and Came Comm. Fish Bull. 4, pp. 13, 43, fig. 12, 1920.
}

The genus Apolymetis was found only in the Siphonalia zone. The fossils are listed as $A$. cf. A. dombei (Hanley) (pl. 32, fig. 2). They are larger than the few available specimens of $A$. dombei $i^{37}$ and have a more prominent posterior sulcus. In view of the range of $A$. dombei-Panama to Peru-it is doubtful whether these fossils from the San Joaquin Valley are related to it. They are, however, more produced anteriorly than the living California $A$. biangulata (Carpenter). (R.S.)

Mactridae-Mactra? coalingensis Arnold, described from the Etchegoin of Alcalde Canyon in the Coalinga district, was found in the Siphonalia zone (pl. 33, fig. 1), and similar forms occur in the Patinopecten and Pecten zones. This species is probably a Spisula, but the hinge is not known. (R.S.)

Pseudocardium densatum is the most common mactrid. In North Dome it is abundant in and below the upper Pseudocardium zone. A few specimens of the genus were found, however, in Etchegoin strata between the upper Pseudocardium and Littorina zones and in strata that may be the equivalent of the Littorina zone. In Middle and South Domes $P$. densatum is abundant in the Pseudocardium-Anadara zone, which is considered the essential equivalent of the Littorina zone, and also occurs in the Cascajo conglomerate at the base of the San Joaquin formation. The Cascajo specimens may have been transported as fossils. Worn specimens, doubtfully identified as Pseudocardium, found in conglomerate between the Pecten and Acila zones on the west flank of Middle Dome, were doubtless transported as fossils.

Pseudocardium densatum, like Anadara trilineata, and Anadara canalis, were said to have been collected by Newberry: at. Sainta Barbara, but, like the other two forms; has not been found at or near Santa Barbara. But for Newberry's definite statément to the :contrary, ${ }^{38}$ it would be reasonable to assume that the fossil Conrad described as Mulinia densata came from the San Pablo group, expesed on San Pablo Bay, where Newberry collected. Should a type locality be arbitrarily chosen it may ibe desirable to: ignore Newberry's statement. If, however; the Kettleman Hills are arbitrarily chosen as the type locality: of Anadara timlineatauit may be advantageous to select the same locality densata, for specimens similar in outline to Conrad's figure occur there as well as in. the San Pablo group. Arnold's identification of Coalinga specimens and Conrad's figure are accepted for the nomenclature used in the present report; and the species is cited as Pseudocardium densatum (Conrad) of Arnold. (W. P.W. R.S.) $\because \quad: \quad:$ :

Specimens that are: anteriorly produced, silike Conrad's figure, were found in the. Siphonalia (pl:! 39; fig. 8)

37 Hanley, Sylvanus, in Sowerby, G. B: Thesaurus conchyliorum, Tellina, p: 323 pl. 62, fig. 182, 1847. $\because:$. : it

.88. Newberry; JiS., Repot upon the geology of the route [Williamson's survey in: California and Oregon]: U. S., Pacific 'R: R. Expl., vol: 6, pt. 2, p. 14, 1856. 
and upper Pseudocardium zones-in the upper Pseudocardium zone not at the localities included in the list of fossils-in the Pseudocardium-bearing conglomerate (pl. 37, fig. 9) and underlying strata in Middle Dome, and in the Pseudocardium-bearing sandstone of South Dome (pl. 37, fig. 3). This form is, however, relatively rare. The most common form in the Etchegoin of North Dome (pl. 29, fig. 16; pl. 30) and in the Etchegoin of Middle Dome below the PseudocardiumAnadara zone (pl. 37, figs. $7,8,10$ ) is a large more equilateral variety. This variety is similar in outline to Pseudocardium gabbii Rémond, from the San Pablo group. Inasmuch as the relations of the fossils from the two regions have not been determined, the Kettleman Hills form is identified as $P$. densatum variety c. gabbii. A shorter and generally smaller variety (pl. 37, figs. 4-6) is abundant in the Pseudocardium-bearing sandstone of South Dome. The form in the Pseudocardium-Anadara zone (pl. 24, figs. 19, 20 ) is a small variety. A similar form (pl. 24, fig. 14), accompanied by an exceptionally elongate form (pl. 24, fig. 15), occurs in the Cascajo conglomerate of South Dome. The different forms of this species are probably the result of different environmental conditions. Nevertheless, the predominance of the variety similar to $P$. gabbii in the lower part of the section and the decrease in size shown by specimens in the Pseudocardium-Anadara zone, Cascajo conglomerate, and Etchegoin strata between the upper Pseudocardium and Littorina zones may be useful in determining stratigraphy at least in the Coalinga district. (W.P.W., R. S.)

Pseudocardium appears to be extinct in the eastern Pacific but is known in northern Japan, where it is represented by "Mactra" sachalinensis Schrenck. ${ }^{39}$ "This species has the long laterals, inflated valves, and shallow sinus of Pseudocardium. The dorsal margins of about 50 available specimens of $P$. sachalinensis are more inflated than those on some 100 specimens from North Dome, and it is possible that this character may serve to distinguish the American and Asiatic forms. In the Asiatic specimens the dorsal side of the left posterior lateral is pitted or striated, or both, and on some specimens the left anterior lateral is similarly ornamented. A few of the best-preserved specimens from the upper Pseudocardium zone show similar ornamentation. Some specimens of Pseudocardium, both living and fossil, have a small ridge dividing the two parts of the ligament, so that Pseudocardium might be cited as a connecting form between Mactra and Spisula. Some specimens of typical Spisula, however, have at least a suggestion of this ridge, and Pseudocardium is probably more closely related to Spisula than to Mactra. In Mulinia, to which $P$.

${ }^{30}$ Schrenck, L. v., Reisen und Forschungen im Amur-Lande, vol. 2, p. 575, pl. 23 , figs. 3-7, 1867. An earlier name for this species, cited but not accepted by Lamy (Jour. Conchyliologie, vol. 36, p. 314, 1917), is Mactra sibyllae Valenciennes (Acad. Sici. Paris Comptes rendus, vol. 46 , p. 760,1858 ). densatum was long assigned, the ligament is covered by the shell. "Mactra" orthomorpha, described by Grant and Gale from a well in the San Joaquin Valley and compared with $P$. sachalinensis, is probably a form of $P$. densatum. The name may prove useful for small specimens such as occur at the upper limit of the range of the genus in the Kettleman Hills. (R.S.)

Veneridae.-The Saxidomus found in the Siphonalia (pl. 33, fig. 6), Pecten (pl. 16, fig. 8), and upper Mya (pl. 8, fig. 15) zones has a wider and longer anterior end than the living California $S$. nuttalli Conrad and is named S. nuttalli latus Stewart, n. var. Poorly preserved remains from other horizons in the Etchegoin and San Joaquin formations may represent the same form. Some specimens from the upper Mya zone have smaller adductor scars and a shallower pallial sinus than the Recent form, but the figured specimen from that horizon has a deep pallial sinus. (R.S.)

Venerupis laciniata hannibali (Howe) occurs in the Etchegoin formation of North Dome (pl. 29, fig. 5). This variety is shorter than Recent specimens from San Diego and San Pedro in the collections of the $\mathrm{Na}$ tional Museum labeled ' $V$. staminea laciniata (Carpenter). These Recent specimens have a more produced posterior ventral margin than $V$. staminea (Conrad) and its allies, and connected forms have not been observed in the collections of the National Museum. $V$. hannibali was described from Lawson's Wildcat series (Pliocene) of the Eel River Basin in northern California and is also known from the Empire formation of Oregon. It is apparently a little shorter than the Recent specimens identified as $V$. laciniata. Two specimens comparable to the living California V. tenerrima (Carpenter). were found in the Macoma zone. A small circular venerid in the Pecten zone of South Dome appears to be a dwarfed Venerupis. It has a shallow pallial sinus like that of the Recent $V$. grata (Say), which is reported from Lower California to Chile. The fossil form is more nearly circular than the living $V$. grata and has a thick deposit of callus on the inner side of the valves. It is named V. grata tarda Stewart, n. var. (pl. 13, figs. 10-13). The specimen from the Pecten zone at Los Morones figured by Arnold ${ }^{40}$ as Paphia staleyi (Gabb)? represents this form. (R. S.)

A small venerid identified as Transennella cf. $T$. tantilla (Gould) is recognized in the upper Pseudocardium, Pecten, and upper Mya zones. It is probably the Recent species and is the same as T. californica Arnold, which was based on one specimen from the Pecten zone. (R.S.).

A small trigonal concentrically sculptured venerid from the Cascajo conglomerate member of the San Joaquin and the upper oolite between the Cascajo and the Neverita zone is probably a new species of Psephidia (pl. 24, figs. 4-6). It is smaller and more trigonal than the Recent $P$. lordi (Baird) and $P$. ovalis Dall, which

${ }^{10}$ Arnold, Ralph, op. cit. (Bull. 396), pl. 26. fig. 8. 
also lack sculpture. In outline and sculpture the fossil species resembles the Recent $P$. cymata Dall, which, however, has a short anterior lateral tooth that is absent on the fossils. According to Dall's classification, Transennella and Psephidia are placed in different subfamilies, Transennella being characterized by an anterior lateral and Psephidia by the absence of an anterior lateral. Nevertheless, $P$. cymata, which was assigned to Psephidia by Dall, has a short anterior lateral lying close to the anterior cardinal. The West coast species assigned to these two genera are apparently closely allied and are perhaps referable to one genus. It is doubtful whether any of them represents Transennella. Typical Transennella from the Atlantic coast has a deeper pallial sinus, and the right anterior cardinal lies athwart the lateral lamellae instead of almost in line with them as in $T$. tantilla. Moreover, typical Transennella is not known to be viviparous, ${ }^{41}$ whereas T. tantilla, ${ }^{42} P$. lordi ${ }^{43}$ and $P$. ovalis ${ }^{44}$ are viviparous. (W.P.W.)

Cardiidae.-Specimens of Cerastoderma from the Etchegoin and San Joaquin formations identified as Cerastoderma cf. C. meekianum (Gabb) (pl. 24, figs. 8, 9 ; pl. 29, fig. 14) are poorly preserved. The largest specimens were found in strata between the Cascajo conglomerate member and the Neverita zone of the San Joaquin, the largest being almost twice as large as the specimen shown on plate 24 , figures 8 and 9 . Specimens from this horizon have about 30 ribs as compared with 22 to 24 on $C$. meekianum from the Pliocene of northern California. A small Cerastoderma occurs in the Littorina zone (pl. 29, fig. 3) and in the PseudocardiumAnadara zone. (W.P.W., R.S.)

Trachycardium cf. T. quadragenarium (Conrad) is characteristic of the Pecten (pl. 16, fig. 2) and Trachycardium zones. The ornamentation on the fossils is not sufficiently well preserved to permit a satisfactory comparison with the Recent form. One specimen from locality 71 has spines on both sides of the anterior median ribs, whereas on available specimens of the living form analogous ribs have spines only on their posterior side. It is not likely that the ornamentation of the fossil is due to weathering, but this specimen may be exceptional. Another Trachycardium-apparently a new species-not referable to the subgenus Dallocardia was found in the Patinopecten and Siphonalia zones. $(R: S$.

Myacidae.-Mya is one of the most abundant fossils in the San Jonquin formation and in the upper part of the Etchegoin, but it is very rare below the upper Pseudocardium zone. Some Mya layers contain few if any other fossils. The species is identified as Mya cf.

\footnotetext{
11 D.Jll, W. H., Contributions to the Tertiary fauna of Florida: Wagner Free Inst. Sci. 'Trans., vol. 3, pt. 6, p. 1240, 1903.

4 Idem.

is Dall, W. H., Synopsis of the family Veneridae and of the North American Recent specles: U. S. Nat. Mus. Proc., vol. 20, p. 401, 1902.

"Idom, p. 408.
}

M. dickersoni Clark. The largest specimens are from the upper Mya (pl. 9, figs. 4-9) and Neverita zones. At any horizon the outline of the shell is generally variable. An exceptionally equilateral specimen (pl. 24, fig. 2) was collected from the upper oolite between the Cascajo conglomerate and Neverita zone, and an exceptionally elongate specimen (pl. 24, fig. 21) came from the Pseudocardium-Anadara zone of Middle Dome. The Kettleman Hills Mya was identified by Arnold as the living Alaskan and Japanese M. japonica Jay. A close relationship with the living species is very doubtful. The fossils that show the pallial sinus and chondrophore have a narrower pallial sinus than the living species and a more prominent deposit of callus on the middle of the chondrophore than that on Recent specimens. The fossils are probably closely related to $M y a$ dickersoni Clark, from a horizon near the top of the San Pablo group. ${ }^{45}$ Inasmuch as the sinus of $M$. dickersoni has not been described and it is not known whether this species has callus on the middle of the chondrophore, the Kettleman Hills species is identified as Mya cf. $M$. dickersoni. $M$. dickersoni has been recorded from the upper Miocene Santa Margarita sandstone north of Coalinga. ${ }^{46}$ (W. P.W., R.S.)

A new species of Platyodon, $P$. colobus Woodring (pl. 21 , figs. 1, 2), is represented by four specimens found in their burrows at the base of the Neverita zone. It is related to the Miocene $P$. piedraensis Wiedey ${ }^{47}$ but has radial sculpture and a shorter, narrower siphonal gape. The elongate Recent species $P$. cancellatus (Conrad), the only living species, has been recorded from strata as old as the upper Miocene. (W.P.W.)

The genus Corbula is represented by only the worn specimens from the Pecten zone. They are comparable to C. gibbiformis Grant and Gale, described from San Joaquin Valley subsurface specimens and recorded by Grant and Gale from the Pecten zone of the Kettleman Hills. The subsurface bed may be the equivalent of the Pecten zone. C. gibbiformis may be related to $a$ species living on the Pacific coast of Central America, C. speciosa Reeve. ${ }^{48} \quad$ (R.S.)

Solenidae.-The Solen from the San Joaquin (pl. 8, fig. 9 ; pl. 24, fig. 1) and Etchegoin formations has a straighter dorsal margin than the Recent California $S$. sicarius Gould and is identified as $S$. perrini Clark, described from the San Pablo group. (W.P.W., R.S.)

An undetermined species of the genus Siliqua occurs in the Etchegoin of North Dome in and below the Siphonalia zone and in the lowest Etchegoin strata exposed in South Dome. It is most abundant in the Siphonalia zone (pl. 33, fig. 3). This genus is character-

is Clark, B. L., Fauna of the San Pablo group of middle California: California Univ., Dept. Geology, Bul., vol. 8, pp. 401, 478, 509 (locality 1617, sbout 150 feet below the Pinole tuff), pl. 63, figs. 3, 4, 1915 .

${ }^{16}$ Nomland, J. O., Fauna of the Santa Margarita beds in the north Coalinga region of California: California Univ., Dept. Geology, Bull., vol. 10, p. 300, 1917.

17 Wiedey, L. W., New Miocene mollusks from California: Jour. Paleontology, vol. 3, p. 289, pl. 33, fig. 2, 1929.

18 Reeve, L. A.. Conchologia Iconica, Corbula, pl. 1, fig. 6, 1843. 
ized by an internal ridge extending downward from the beak at about a right angle to the dorsal margin of the shell. Impressions of this ridge are present on internal molds, so that Siliqua may be readily identified on the basis of such material. Many of the fossils are preserved with the valves wide open but attached by the ligament. (R.S.)

Pholadidae.-The larger borer from the Macoma zone identified as Zirfaea gabbi (Tryon) var. differs from 20 available Recent specimens of $Z$. gabbi in having more widely spaced concentric lamellae on the anterior umbonal part of the shell beyond the overlapping dorsal margin. Remains from other horizons probably represent the same form. It may prove to be distinct, but its relation to the Miocene $Z$. dentata Gabb is not known. (R.S.)

\section{BARNACLES}

Large barnacles are abundant in the lower part of the Etchegoin of North Dome and were also found in the lower part of the formation in South Dome. In and below the Patinopecten zone and in strata assigned to the Macoma zone they form reeflike clusters in which the barnacles stand upright in living position (pl. 27, A).

These barnacles are identified as Balanus (Tamiosoma) cf. $B$. (T.) gregarius (Conrad). In large specimens the greatly elongated basis is partly filled with blistery horizontal or oblique septa, as in Tamiosoma, the type of which is T. gregaria. Opercular valveseight scuta and one broken tergum - were found at the locality shown on plate $27, A$. They may be present at many other localities, for 77 scuta and 1 tergum were later collected at locality $342 \mathrm{a}$ near the base of the Macoma zone (?). According to these opercular valves, the large Etchegoin barnacle is a Balanus of the group of $B$. concavus Bronn, which was based on fossils from the Italian Pliocene. In terms of the criteria used by Pilsbry, ${ }^{49}$ the Etchegoin barnacle might be classified as a subspecies of $B$. concavus. The scutum (pl. 36 , figs. $2,3,8,9$ ) is similar to that of $B$. concavus proteus Conrad ${ }^{50}$ and $B$. concavus chesapeakensis Pilsbry, ${ }^{51}$ Miocene Atlantic coast forms, but the adductor ridge is shorter and the strongly developed ridge bordering the depressor pit is closer to the adductor ridge. The spur on the tergum (pl. 36, figs. 4,5 ) is closer to the basi-scutal angle than on these Atlantic coast forms, and the spur furrow is more completely closed by infolding of the sides. The strong radial sculpture on the figured scutum is probably due to corrosion, as it is not so strong on the more complete but smaller scutum from locality 342a. The characters that differentiate the Etchegoin opercular valves from those of the Atlantic coast fossils also differentiate

10 Pilsbry, H. A., The sessile barnacles (Cirripedia) contained in the collections of the U. S. National Museum, including a monograph of the American species: U. S. Nat. Mus. Bull. 93, pp. 100-108, 1907.

so Idem. p. 103, pl. 22, figs. 3-3c.

51 Idem, pp. 103-104, pl. 22, figs. 1-1c. the Kettleman Hills fossils from the form living on the Pacific coast, $B$. concavus pacifus Pilsbry. ${ }^{52} \mathrm{It}$, therefore, is improbable that the Kettleman Hills barnacle is directly related to this living form. Opercular valves-seven scuta and four corroded terga-of a Tamiosoma similar to Balanus (Tamiosoma) gregarius also are available in a collection from a locality representing a late Miocene or early Pliocene horizon on the east border of Salinas Valley (U: S. G. S. locality 3586, Wildhorse Canyon near Mr. Copley's house, NW11/4 sec. 14, T. 20 S., R. 9 E.; King City quadrangle.) ${ }^{53}$ The opercular valves from this locality, particularly the scuta, are exceptionally thick regardless of size. The scuta are not so strongly sculptured as scuta from the Kettleman Hills; the ridge bordering the depressor pit is wider and cruder; and the articular ridge is longer. The spur on the tergum is wider and apparently closer to the basi-scutal angle. Some of these differences may be due to the thickness of the valves from the Salinas Valley, but according to this material the Kettleman Hills barnacle is distinguishable from the Salinas Valley barnacle. It is not known whether the Salinas Valley barnacle represents Balanus (Tamiosoma) gregarius proper. The data on the original locality of that species, ${ }^{54}$ Monterey County, are indefinite, the type material appears to be lost, and opercular valves were not found with the type material. The barnacle from the Salinas Valley is associated with Astrodapsis salinasensis, which is considered characteristic of a horizon between the upper Miocene Santa Margarita sandstone and the lower Pliocene Jacalitos formation. ${ }^{55} \quad B$. gregarius has been considered a Santa Margarita form, but the horizon from which the type material was collected appears to be indeterminable. Barnacles similar to $B$. gregarius are now known to occur in the Santa Margarita sandstone, in the Astrodapsis salinasensis zone, and in the Jacalitos and Etchegoin formations, the Etchegoin form being the last known survivor. Opercular valves of the Santa Margarita and Jacalitos forms have not yet been recorded.

The opercular valves from the Kettleman Hills and Salinas Valley confirm Pilsbry's conclusion that Tamiosoma gregaria is a Balanus. ${ }^{56}$ Nevertheless, the partial filling of the elongate basis with a mass of vesicular calcareous septa is a well-defined character, and it is convenient to emphasize this character in the California

32 Idem. pp. 104-108, pl. 23.

53 This material was collected by Homer Hamlin. According to the field labels, the collection, which includes exceptionally well preserved barnacles, has the same field number and was collected at the same time as the material that for some reason was given a different locality number, 4555 . The barnacles that have the locality number 4555 formed the basis for Dall's discussion of Tamiosoma (Dall, W. H., On the true nature of Tamiosoma: Science, new ser., vol. 15, po. 366, pp. $5-7,1902)$ and later were forwarded to Pilsbry. It seems strange that Dall's attention was not called to the opercular valves.

s4 Conrad, T. A., Descriptions of three new genera; twenty-three new species middle Tertiary fossils from California, and one from Texas: Acad. Nat. Sci. Philadelphia Proc., 1856, p. 315, 1857; Description of the Tertiary fossils collected on the survey: U. S., Pacifle R. R. Expl., vol. 6, pt. 2, pp. 72-73, pl. 4, fig. 18, 1856.

ss Richards, G. L., Jr., Revision of some California.species of Astrodapsis: San Diego Soc. Nat. History Trans., vol. 8, no. 9, pp. 59-66, pl. 7, 1935.

sf Pilsbry, H. A., op. cit., pp. 125-126. 
fossils by retaining the name Tamiosoma for a minor subdivision of Balanus. This nomenclatorial emphasis appears to be justified, even though the same character was independently acquired by a living Chilean barnacle, Balanus levis coquimbensis Sowerby, ${ }^{57}$ which belongs to a group of Balanus characterized by one to three longitudinal furrows on the exterior of the scutum.

Fragmentary barnacle remains from the Siphonalia zone of the Etchegoin may represent Tamiosoma, but none that were collected show the elongate basis of Tamiosoma. These fossils and others from horizons in the upper part of the Etchegoin and in the San Joaquin are listed as Balanus sp.

The very small barnacle Balanus hesperius Pilsbry var. from the upper Mya zone of the San Joaquin formation is represented by isolated compartments and at locality 35 by six scuta and two terga. Similar compartments occur in the Cascajo conglomerate member. The compartments resemble those of the living Alaskan B. hesperius, ${ }^{58}$ but the scutum is not so strongly sculptured; the ridges on the callus above the adductor ridge are not so well defined; and the spur on the tergum is shorter.

\section{FISH}

The curious fish bones called "bulbous fish growths" by Arnold and Anderson, ${ }^{59}$ and colloquially called "fish flippers" by field geologists, are abundant in the fresh-water strata at the base of the Tulare formation. They are also fairly abundant in the Pecten zone, Neverita zone, and Cascajo conglomerate member of the San Joaquin but are rare in the Etchegoin formation. The specimens from the San Joaquin formation are polished, as though they were transported before burial, whereas those from the Tulare formation and the few specimens from the Siphonalia and Patinopecten zones of the Etchegoin are not polished. Locally in the Tulare formation these dense bones are accompanied by spines and plates and rarely by vertebrae. A collection of these fossils from the Tulare formation at locality 23 was forwarded to Dr. W. K. Gregory, of the American Museum of Natural History, who kindly prepared the following comments:

The "bulbous fish growths" and related objects have proved to be very difficult to identify. Fairly extensive examination of the literature, as recorded on unpublished cards in our department bibliography, shows that similar swellings occur in several families of marine or estuarine teleosts, notably the sciaenids or weak fishes, the gadids or cods, the angel fishes (Epihippidae), and in Caranx caringopsis; the same thing occurs in certain freshwater siluroids (catfishes). Usually the swellings are limited to median bones, but in a cod skeleton which we have just prepared many of the paired bones are more or less affected. The largest curved bones ${ }^{60}$ are undoubtedly opercular bones, which, if allowance is made for inflation, are close to those of Recent hakes

\footnotetext{
or Pilsbry, H. A., op. cit., pp. 122-123, pl. 28, fig. 4.

s9 Idem, pp. 193-196, pl. 49, figs. 1-1d, 7-8.

o0 Arnold, Ralph, and Anderson, Robert, op. cit. (Bull. 398), pp. 138, 143-144, pl. 47, figs. $6,6 \mathrm{a}, 6 \mathrm{~b}, 8$.

oo Arnold, Ralph, and Anderson, Robert, op. cit. (Bull. 398), pl. 47, figs. 6, 6a, 6b.
}

(Merlucius) of the cod family. The small asymmetrical bones with a median crease are swollen haemal spines that may pertain to the same species. We have failed to identify the other bones even after many attempts. Many somewhat similar bulbous fish growths have been figured from the Crag of Belgium by van Beneden ${ }^{81}$ and from the Vienna Basin by Steindachner, ${ }^{62}$ but of the numerous figures and plates compared not one agrees satisfactorily with any of the Tulare fossils.

The large curved plate with the sculptured pitted surface in many respects is close to the dermal angular plate of a large Lepidosteus spatula but does not correspond closely enough to warrant specific identification. It differs in many details from plates of sturgeon and in other ways from those of catfishes.

The bone that looks something like an elongated oval leaf has been compared with many kinds of fish bones but without success. The same is true of the fine-sculptured small bone with a triangular cross section. We have failed to match this sculpture in our collection of fish skeletons. Dr. R. W. Miner will not admit the sculpture to be the work of any encrusting invertebrate.

The abundance of these bones in the Tulare formation suggests that they represent fresh-water or brackishwater fish. In the San Joaquin and Etchegoin formations they are generally associated with marine fossils, but the same strata also contain remains of land animals. Though the Etchegoin specimens are not polished, they may also represent the remains of freshwater or brackish-water fish. Similar fish remains have not been recorded elsewhere in California.

\section{LAND MAMMALS}

Land mammals, which were examined by Dr. C. L. Gazin, of the National Museum, were found at various horizons in the Etchegoin and San Joaquin formations. The remains are generally fragmentary, usually consisting of isolated bones and teeth. A mastodon skull was discovered, but not collected, in the Siphonalia zone of the Etchegoin at locality 299a, and Matthew ${ }^{63}$ described a mastodon skull found during excavation in strata a few feet below the Pecten zone of the San Joaquin formation.

A greater variety of remains of land mammals was found in the Pecten zone than in other strata, and teeth of the extinct beaver Castor californicus ${ }^{64}$ were not discovered in other strata. .Horse teeth, identified as Plesippus, are relatively abundant in the Pecten zone. A mastodon femur, tibia, and fibula were found at locality 81a a few feet below the base of the Pecten zone, but they were doubtless washed out of the Pecten zone. These remains are of particular interest, as corals, oysters, bryozoa, and a barnacle were attached to them, showing that they were immersed in sea water before burial. Both the femur and tibia

6! van Beneden, P. J., Sur un poisson fossile nouveau des environs de Bruxelles et sur certain corps énigmatiques du crag d'Anvers: Acad. royale sci. Belgique, 50th year, ser. 3, vo!, 1, pp. 116-126, 1 pl., 5 figs., 1881.

62 Steindachner, Franz, Beiträge zur Kenntniss der fossilen Fisch-Fquna Österreichs: K. Akad. Wiss., Math.-naturwiss. Kl. Sitzungsber:, vol. 37, pp. 673-703, 7 pls., 1859. o3 Matthew, W. D., A Pliocene mastodon skull from California, Pliomastodon vexillarius, n. sp.: California Univ., Dept. Geol. Sri., Bull., vol. 19, pp. 335-348, pls. 41-44, 2 figs.; 1930 .

of Stirton, R. A., A review of the Tertiary beavers: Idem, vol. 23, p. 445, figs. $132-140,1935$. 
were fractured, but the fractures fit together fairly well. Ordinarily such fractures are due to breaking after fossilization. Corals are attached to the fractured surface of the tibia, however, showing that the fractured surface was exposed as the bone lay on the sea floor. Possibly these bones are the remains of a mastodon whose left hind leg was broken shortly before death or after death in transit. The fractured bones may have been held together by tendons and muscles until they were deposited on the floor of the sea, where they were not buried until the marine animals had become attached to them.

Mastodon remains, mostly tusk fragments but also molar fragments, are more abundant in the upper part of the Siphonalia zone of the Etchegoin and near the base of an overlying blue conglomerate than at other horizons. Horse teeth identified as Pliohippus occur in the Patinopecten zone of the Etchegoin and probably in the Siphonalia zone.

Two horse teeth from the Etchegoin formation were recently examined by Professor Chester Stock, of the California Institute of Technology. One tooth is from the Siphonalia zone 20 feet northwest of locality 296 ; the other tooth was collected from the Patinopecten zone at locality 319. Professor Stock prepared the following comments on these fossils.

The two horse teeth are referable presumably to the same genus and species. These specimens belong to a small type of Pliohippus and show greatest resemblance to teeth of Calippus martini Hesse (type specimen, University of California 32814) from Beaver County, Okla. Resemblance is also shown to teeth of a species of Pliohippus from Gidley's Clarendon beds of Texas. The teeth from the Kettleman Hills are slightly larger than comparable teeth in the type of $C$. martini, but the occlusal pattern in both shows several points of similarity. Also in both the crowns are distinctly curved. In view of this similarity the teeth from the Kettleman Hills suggest an age comparable to that assigned to the Texas and Oklahoma occurrences, that is, later lower Pliocene.

It is interesting to note that two teeth in the collections of the University of California (29767), collected from the Etchegoin in 1913, represent apparently the Kettleman Hills form. So far as I am aware, no other Pliohippus from the California Tertiary has the characters of these specimens.

\section{MARINE MAMMALS}

Fragmentary remains of marine mammals were discovered in the Etchegoin and San Joaquin formations. According to identifications by Dr. Remington Kellogg, of the National Museum, sea lion (?), eared seals, whales, and porpoises are represented in this material.

Dr. Kellogg's comments on eared seal limb bones from the sandstone between the PseudocardiumAnadara zone and the Pseudocardium-bearing conglomerate in the upper part of the Etchegoin of Middle Dome at locality 350 are as follows:

(a) Left radius broken in three pieces, including complete proximal and distal ends; (b) inner half of proximal end of right radius and a section of distal end of shaft of a right radius; (c) a short section of proximal end of right humerus; (d) external condyle from distal end of right femur, wholly unlike any known extinct and living otarid and may possibly have belonged to some other type of mammal.

The following remarks on eared seal remains from the Neverita zone of the San Joaquin formation at locality 166 were prepared by Dr. Kellogg:

Distal end of right humerus, comprising trochlea and internal condyle. This humerus is larger than that of the oldest male of the Recent Eumetopias jubata in the National Museum and is likewise larger than that of the Pliocene Pliopedia pacifica. The distal trochlea is, however, considerably narrower than in these two forms, and the internal condyle is produced farther distally, the distal margin being almost on a level with the trochlea.

The distal end of a metapodial of an eared seal was collected from the Cascajo congomerate member of the San Joaquin at locality 199.

Dr. Kellogg prepared the following statement concerning the porpoise remains:

A right periotic from strata between the Neverita zone and the upper oolite in the lower part of the San Joaquin formation (locality 169) belongs to an extinct porpoise. In general this periotic shows a type of specialization that finds its nearest counterpart in the Recent Inia geoffrensis, which inhabits the Amazon River. A left humerus of a small porpoise from the Neverita zone (locality 167) is even smaller than that of the smallest Recent porpoise, the South American Stenodelphis blainvillei.

A fragment of a right periotic from the Cascajo conglomerate (locality 199) represents, according to Dr. Kellogg, a porpoise that is not related to the form from locality 169 . Porpoise vertebrae were found in the Macoma and Patinopecten zones of the Etchegoin.

Two periotics from the Macoma and Neverita zones were identified by Dr. Kellogg as representing whalebone whales. Four whole whale vertebrae, apparently articulated, were found in the Pecten zone at locality 87.

\section{DIATOMS}

Diatoms were found in the three formations exposed in the Kettleman Hills. They are probably present in strata other than those in which they were found. Light-colored clay and silt appear to constitute the most promising type of lithology for diatoms in this region. A search of the Jacalitos formation in the foothills west of the Kettleman Hills and a more exhaustive examination of the Etchegoin and San Joaquin formations in the foothills and in the Kettleman Hills may result in a more complete sequence of Pliocene marine diatom floras in the Coalinga district. Such a sequence might be useful in stratigraphic determinations in subsurface explorations.

Lists of diatoms from the Kettleman. Hills, prepared by K. E. Lohman, of the Geological Survey, and brief remarks on the floras may be found under the heading "Stratigraphy of exposed formations." Some of the characteristic species are shown on plates $7,22,23$, and 38. A consolidated list and a discussion of the floras has been recently published..$^{65}$

${ }^{65}$ Lohman, K. E., Pliocene diatoms from the Kettleman Hills, Calif.: U. S. Geol. Survey Prof. Paper 189, pp. 81-102, pls. 20-23, 1938. 


\section{CALCAREOUS ALGAE}

A sample of the algal layer in the lower Amnicola zone of the Tulare formation at La Salida on the east side of Middle Dome was forwarded to the late Dr. M. A. Howe, of the New York Botanical Garden. He wrote that the alga seems to be allied to Lithomyxa calcigena, ${ }^{60}$ a Recent form from Furnace Creek, near Harpers Ferry, W. Va.

\section{LAND PLANTS}

Land plants were found at several horizons in the San Jonquin and Etchegoin formations. A more thorough search would doubtless increase the number of species. According to identifications by $\mathrm{R}$. W. Brown, of the Geological Survey, the species collected in the Kettleman Hills are recorded from Pliocene formations elsewhere in California. ${ }^{67}$

\section{ENVIRONMENT SUGGESTED BY FOSSILS}

In attempts to reconstruct environmental conditions suggested by fossils paleontologists consider generally only a few of the complex and interrelated factors that determine the composition of living communities of animals and plants. Only a few members of fossil communities generally leave a record, if any record is available. Other essential data are unavailable. Moreover, such attempts at reconstruction are necessarily based on information gathered for the most similar living communities.. . So far as the Pacific coast is concerned, detailed and prolonged studies of particular localities-such as MacGinitie's recent work on the ecologic aspects of Elkhorn Slough, ${ }^{68}$ a marine estuary on the coast of Monterey Bay-are urgently needed.

The presence or absence of marine fossils in strata of apparently indistinguishable lithologic composition and depositional features is itself a problem that is immediately apparent to a geologist working in the Kettleman Hills. In that area marine fossils are most abundant in sand, gravel, and silty sand. Some beds of such composition contain numerous fossils, and others are barren or almost barren. Paleontologists assume generally that the presence of marine fossils in marine strata is the normal condition and attempt to explain their absence in strata thought to be marine by invoking special or exceptional conditions. Perhaps, however, the opposite view is to be emphasized-that the hard parts of animals living on the sea floor or in sediments forming the floor are subject to destruction during life by sting rays and other predators, and after death under conditions of nondeposition or slow deposition may be destroyed by erosion and solution without leaving a trace; and that the burial of shells and other hard parts before destruction indicates un-

of Howe, M. A, The geologic importance of the lime-secreting algae: U. S. Geol. Survey Prot. Paper 170, pp. 63-64, pls. 19-23, 1932.

of Dorf, Erling, Pliocene floras of California: Carnegie Inst. Washington Pub. 412, pp. 1-108, 13 pls., l fig., 1930.

os MacGinitie, O, E., Ecological aspects of a Californis marine estuary: Am. MidIsnd Naturalist, vol. 16, no. 5, pp. 629-765, 21 figs., 1935. usual events or even exceptional events of a minor catastrophic character. In the Kettleman Hills the Mya in living position with siphon end upward, and other burrowers and borers found in a similar position, were doubtless overwhelmed by shifting sand or by otherwise exceptionally rapid deposition of sediments. The animals in some of the Mya layers and the marine animals in the lower part of the Littorina zone may have been killed by relatively abrupt freshening of the water. The conditions determining the presence of fossils in other fossiliferous beds are not known.

The marine formations exposed in the Kettleman Hills were deposited in an inland sea of relatively great extent, as shown on Reed's Pliocene paleogeographic map. ${ }^{69}$. Marine Pliocene formations containing the same fossils are found from the south end of the San Joaquin Valley northward to localities a few miles north of Anticline Ridge, in the Coalinga district. The sea did not reach the present foothills of the southern Sierra Nevada, where a nonmarine Pliocene formation is exposed, but in the Bakersfield region a subsurface marine Pliocene tongue almost reaches the present foothills. The ancestral Coast Ranges and the ancestral Sierra Nevada supplied detritus to the inland sea. According to information now available, the inland San Joaquin Valley sea was joined to the open ocean by a strait extending from the Coalinga district northwestward across the present trend of the Coast Ranges to the mouth of the present Salinas Valley. Marine Pliocene formations are found in the Coast Ranges along the trend of this inferred strait. At times the sea may have been connected with the ocean by an arm extending southwestward from the present Salinas Valley to the present site of Santa Barbara. ${ }^{70}$ The thick.Pliocene section in the Kettleman Hills and adjoining foothills and the absence in these areas of the pre-Tulare unconformity characteristic of the foothills farther north and south indicate that the Kettleman Hills and adjoining foothills lay along, or close to, the trough of the sea and its connecting strait. During late Etchegoin time and during San Joaquin time the sediments were at times deposited in brackish or fresh water. Deposition of the entire Tulare formation, with the apparent exception of brackish-water deposition of brief duration, was in fresh water. The change from saline to brackish and fresh water during late Etchegoin and San Joaquin times was probably due to shallowing of the water through deposition at a rate exceeding the rate of the sinking of the basin. Offshore bars gradually enclosed estuaries that locally were at times filled with fresh water. The final freshening of the water was probably due to blocking of the connection with the ocean by deposition or by deformation in the adjoining Coast Ranges.

${ }^{\circ}$ Reed, R.D., Geology of California, fig. 51 (p. 252), Tulsa, Am. Assoc. Petroleum Geologists, 1933.

io Idem. 
In view of the deposition of the Kettleman Hills formations in an inland sea, it is natural to attempt a reconstruction of environmental conditions by comparison with the largest sea extending inland from the present California coast-San Francisco Bay and its continuation, San Pablo Bay, and Suisun Bay. The mollusks of San Francisco Bay and San Pablo Bay and certain of their ecologic aspects have been described by Packard. $^{71}$ Suisun Bay, the least saline part of the San Francisco Bay system, where conditions might be similar to those during the deposition of brackish-water Etchegoin and San Joaquin strata, has apparently not been studied.

\section{ETCHEGOIN AND SAN JOAQUIN FORMATIONS}

In the marine faunas of the Etchegoin and San Joaquin formations the species of pelecypods outnumber the species of gastropods, the average ratio being about $2: 1$. The Acila zone, in which the same number of both groups are represented, is a notable exception. The living fauna between Alaska and San Diego has about three times as many shell-bearing gastropods as pelecypods, ${ }^{72}$ and in general Tertiary faunas have more gastropod than pelecypod species. Doubtless many factors affect this ratio, but the shallow waters of estuaries and bays have generally more species of pelecypods than of gastropods. In San Francisco Bay, where the salinity is lower than in the ocean, the ratio of gastropods to pelecypods is about 1:1.3; in Elkhorn Slough, which has practically the same salinity as the ocean, the ratio of shell-bearing gastropods to pelecypods is about 1:2.6.

The recurrence of certain marine species and genera in Etchegoin and San Joaquin strata and their absence in intervening strata that contain marine fossils suggest that their recurrence is controlled by a recurrence of a combination of environmental conditions and that their apparent local extinction is due to a change in environment. . Different conditions at different times are also indicated by a comparison of the marine faunas. The marine fauna of the Littorina zone may be considered as an impoverished upper Pseudocardium zone fauna; the Acila zone fauna as an impoverished Pecten zone fauna with the notable addition of Acila; and the upper Mya zone fauna as an impoverished Neverita zone fauna with a preponderance of species, the modern analogs of which thrive in brackish water.

The recurrence of certain forms is shown by the presence in and below the Siphonalia zone of the Etchegoin and in the Pecten zone or Acila zone of the San Joaquin, or :generally in both, of the genera $\mathrm{Cal}$ liostoma, "Nassa," Siphonalia, Forreria, Progabbia, Chlamys, and Compsomyax. These genera are absent

1 Packard, E. L., Molluscan fauna from San Francisco Bay: California Univ., Pub. Zoology, vol. 14, pp. 199-452, pls. 14-60, 1918.

${ }^{72}$ Dall, W. H., Summary of the marine shell-bearing mollusks of the northwest coast of America, from San Diego, Calif., to the Polar Sea $*^{*} *$ : U. S. Nat. Mus. Bull. 112, p. 4, 1921. in intervening marine zones, with the exception of a fragment of Calliostoma in the Cascajo conglomerate, and were not found in marine strata above the Acila zone. "Nassa" is the only one of these genera that was found in both San Francisco Bay and Elkhorn Slough, and a few specimens of Chlamys were found among rocks in Elkhorn Slough. Siphonalia, however, is no longer living on the Pacific coast; San Francisco Bay is north of the recorded northern limit of Progabbia; and both localities are north of the recorded northern limit of Forreria. These genera that occur in the lower part of the Etchegoin and recur in the Pecten and Acila zones may indicate a more open sea and probably deeper water during the deposition of the Patinopecten, Macoma,-Siphonalia, Pecten, and Acila zones than during the deposition of the other zones. Acila in particular suggests water of moderate depth. This genus was not found in San Francisco Bay but was dredged outside the bay at depths of 39 to 68 fathoms. ${ }^{73}$ The Acila zone fauna probably lived in deeper water than any other fauna in the Etchegoin and San Joaquin formations.

The Pecten zone was recognized over a larger area than the Acila zone and represents less uniform conditions. The relative abundance of Pecten and Aequipecten in the Pecten zone in the south half of the Kettleman Hills is reversed in the north half. The abundance of Aequipecten in the south half may indicate shallower and calmer water in that region. The local lagoonal facies, indicated by $M y a$, and the fresh-water facies in the south half also suggest shallow water, possibly controlled by a peninsula extending eastward from the ancestral Coast Ranges.

Mya occurs at many horizons in the upper part of the Etchegoin formation above the upper Pseudocardium zone and in the San Joaquin formation, generally in beds that contain no other fossils or few other species. The genus is rare below the upper Pseudocardium zone. In Elkhorn Slough Mya thrives best where it receives fresh water seepage. ${ }^{74}$ It is one of the prevalent genera in San Pablo Bay, ${ }^{75}$ the upper part of San Francisco Bay, where the mean annual salinity in round numbers is 15 to 25 parts per thousand, ${ }^{76}$ as compared with 34 parts per thousand in the ocean outside the Golden Gate. ${ }^{77}$. Live specimens were dredged in Carquinez Strait, ${ }^{78}$ where the discharge of the Sacramento and the San Joaquin Rivers reduces the salinity to 15 or 16 parts per thousand, as well as in the more saline waters of San Pablo Bay and San Francisco Bay proper. Along the Oregon coast Mya lives generally in mud

73 Packard, E. I., op. cit., p. 247

7 MacGinitie, G. E., op. cit., p. 730.

is Packard, E. L., op. cit., p. 221.

70 Sumner, F. B., and others, A report upon the physical conditions in San Fran. cisco Bay, based upon the operations of the United States Fisheries Steamer Albatross during the years 1912 and 1913: California Univ., Pub. Zoology, vol. 14, pl.4, 1914. " Packard, E. L., op. cit., p. 214.

${ }^{78}$ J.dem, pl. 52. 
flats at river mouths. ${ }^{79}$ The Mya layers in the San Joaquin and Etchegoin formations appear to represent brackish water. Mya, Ostrea, Macoma, and Littorina, all of which thrive in brackish water, are the most abundant genera in the upper Mya zone, the last of the marine zones. Though Calyptraea and Transennella, which occur in the upper Mya zone, were not found in San Francisco Bay, the upper Mya zone represents probably less saline water than any of the other named zones. These two genera, as well as the upper Mya zone genus Nucella, were not found in Elkhorn Slough, where the salinity is about the same as in the ocean. At least locally the top of the upper Mya zone contains only small oysters, probably dwarfs of the larger oyster in the lower part of the zone, and toward the south end of South Dome these small oysters are the only fossils discovered in the zone. They may indicate adverse conditions, possibly reduced salinity marking a transition stage to the freshering of the water at the beginning of the inmediately succeeding Tulare time.

Arnold ${ }^{80}$ suggested that the abundance of Arca [Anadara] in the lower part of the Etchegoin indicates an environment somewhat warmer than that now prevailing at the latitude of Coalinga $\left(36^{\circ} \mathrm{N}\right.$.). He also pointed out that a cold-water mud flat species Mya japonica is abundant in overlying strata, now assigned to the upper part of the Etchegoin; that still younger strata (the Pecten zone) contain a fauna having many characteristics in common with the fauna of the Gulf of California; and that the upper Mya zone contains species supposed to have been best suited to cold-water and possibly estuarine conditions. As explained under the heading "Age and correlation of exposed formations," these suggestions have been expanded and converted in to climatic and age assignments.

The Anadara species is extinct, and a closely related living species has not yet been recognized. Moreover, Anadara is more abundant in the San Joaquin than in the Etchegoin. Forreria, Apolymetis, the new variety of "Nassa" miser, and Trachycardium might be cited as suggesting warmer water for the lower part of the Etchegoin than now present north of Point Conception. The indicated difference is not great, however, possibly not so great as the probable errors involved in the assumption that the present range of identical or closely related species can be used as a close guide in reconstructions. ${ }^{81}$ The difference might be due to a change in the outline of the coast causing a local change in the temperature of the water.

Arnold's identifications of the species "supposed to have been best suited to cold-water and possibly estuarine conditions" are open to question. As explained

\footnotetext{
70 Maccinitio, O. E., op. cit., p. 730.

80 Arnold, Ralph, op. cit. (Bull. 396), p. 43, 1909 [1910]. Arnold, Ralph, and Anderson, Robert, op. cit. (Bull. 398), pp. 137-138, 1910.

81 For a discussion of this assumption see Woodring, W. P., op. cit. (Prof. Paper 190), p. 12, 1938.
}

under the heading "Paleontology of exposed formations," his Mya japonica is considered more closely allied to the upper Miocene Mya dickersoni than to the living Alaskan species; his Macoma inquinata is considered an extinct species, $M$. affinis, probably closely related to $M$. inquinata, which is recorded from Japan and Bering Strait southward to Monterey Bay; and Lettorina mariana is apparently not closely allied to the Alaskan $L$. grandis, but is probably closely related to the upper Miocene $L$. remondii and to the living $L$. scutulata, which has a reported range from Alaska to Lower California. These forms probably indicate estuarine conditions rather than "cold-water and possibly estuarine conditions."

As was recognized by Arnold, some species in the Pecten zone fauna resemble forms now living in the Gulf of California. A striking example is Pecten coalingaensis, which is not only related to a species now living in the Gulf of California but is also related to a species now living in Japan. The differences between the Pecten zone fauna and the fauna now living in the Gulf of California, however, outweigh the resemblances, which are apparently due to survival in the gulf of relatives of Pecten coalingaensis and of Ostrea vespertina. Nevertheless, Calliostoma cf. C. gemmulatum, Jaton, Forreria, and Corbula are southern forms, or are related to southern forms, and give a southern cast to the Pecten zone fauna. These forms, or their living relatives, are not now found north of Point Conception. The abundance of Trachycardium and the poor development of Cerastoderma in the Pecten zone also suggests warm water. Trachycardium is at present a southern genus and Cerastoderma a northern genus, but their ranges overlap between Santa Barbara and San Diego. Though other conditions might be considered, it is reasonable to assume that the water of the Pecten zone was warmer than the present coastal water north of Point Conception but not necessarily warmer than that at Santa Barbara. The Neverita zone fauna suggests the living fauna north of Point Conception. Aside from its smaller size and the absence of the forms of warm-water aspect, the Neverita zone fauna closely resembles the fauna of the Pecten zone. Mitrella, Adula, and Platyodon are the only Neverita zone molluscan genera not found in the Pecten zone, and they have no particular temperature significance. Neverita, the most abundant gastropod in both zones, was not found in either San Francisco Bay or Elkhorn Slough. The more northern Lunatia, which is rare in the Neverita and Pecten zones, occurs. in both San Francisco Bay and Elkhorn Slough. Possibly Neverita is not able to survive winter temperatures in relatively small estuaries and bays but could survive in the large San Joaquin Valley inland sea, where the winter temperature of the water was presumably not as low as in the smaller bays. The fauna of San Francisco Bay was found to have a more northern aspect than the fauna outside the bay, pre- 
sumably owing to lower winter temperatures in the bay. ${ }^{82}$

Even if the suggestion that the Pecten zone fauna indicates warmer water than the other San Joaquin faunas were accepted, it does not necessarily follow that the warm water indicates a general climatic change. During the deposition of the Pecten zone the San Joaquin Valley sea may have joined the ocean near the present site of Santa Barbara, whereas during the deposition of the Neverita and other San Joaquin zones it may have joined the ocean near the present Monterey Bay. This paleogeographic suggestion is not supported by known occurrences of a fauna similar to the Pecten zone fauna; in fact, marine Pliocene strata are not preserved in most of the area between the Salinas Valley and Santa Barbara. Outside of the San Joaquin Valley and its borders the Pecten zone fauna has been recognized only in Priest Valley in the Coast Ranges between the Coalinga district and the Salinas Valley. Pecten coalingaensis has been recorded from a locality east of Monterey Bay, near Hollister, ${ }^{83}$ but it is not known whether a fauna similar to the Pecten zone fauna occurs in this region.

Many of the marine fossils of the Etchegoin and San Joaquin formations, including forms that have no close living relatives along the Pacific coast of North America, are closely related to species now living in Japanese waters. The species that have no living relatives along the American coast represent presumably forms that formerly had a more extensive distribution but have become extinct in American waters. The possible environmental significance of their survival in Japanese waters is not known. A comparison of the later Tertiary faunas of Japan with those of the Pacific coast of North America and more data on the later Tertiary faunas of Alaska may yield some information concerning the geologic history of these forms.

\section{TULARE FORMATION}

The thin-bedded sediments in the lower part of the Tulare formation suggest lake deposits, and this suggestion is supported by the fauna. According to Pilsbry, ${ }^{84}$ it is inferred that the Tulare fresh-water mollusks lived in a large relatively shallow lake that had copious aquatic vegetation and well-aerated water. Some of the fossils may have been carried into the lake by streams, but none of the species is considered distinctly fluviatile by Pilsbry. Land shells, which might be expected if streams contributed a considerable part of the shells, have not been found. The diatoms in the white clay at the base of the formation indicate fresh water and brackish water of varying salinity from place to place. The Littorina in the tuff immediately over-

Packard, E. L., op. cit., p. 233.

${ }^{83}$ Kerr, P. F., and Schenck, H. G., Active thrust faults in San Benito County, Calif.: Geol. Soc. America Bull., vol. 36, p. 475, 1925.

it Pilsbry, H. A., Mollusks of the fresh-water Pliocene beds of the Kettleman Hills and neighboring oil fields, Calif.: Acad. Nat. Sci. Philadelphis Proc., vol. 86, pp. $542-544,1835$. lying the white clay also indicates brackish water. A brackish-water diatom flora was found near the top of the lower Amnicola zone on the east side of Middle Dome. Brackish-water mollusks are not known in the lower Amnicola zone, but mollusks were not found with the diatoms. The presence in the Tulare formation of the four genera Fluminicola, Goniobasis, Carinifex, and Parapholyx not now found south of the latitude of San Francisco Bay may indicate a cooler climate than at present, ${ }^{85}$ but Fluminicola and Goniobasis occur in fresh-water strata in the Pecten zone, the marine fossils of which have a relatively warm-water facies.

The sandstones and conglomerates making up most of the Tulare formation appear to represent stream deposits spread out on a plain extending eastward from the ancestral Coast Ranges. Some of these strata contain oysters and Littorina. If these shells were transported into the Tulare sediments as fossils, they were presumably derived from the present Kreyenhagen Hills. In that event other fossils, particularly the thick-shelled durable Pseudocardium, the most abundant detrital fossil in the alluvium of the Kettleman Hills, might be expected, unless only a narrow outcrop near the top of the San Joaquin formation was supplying detritus. Both oysters and Littorina thrive in brackish water, and their presence in the upper part of the Tulare may indicate temporary connections. with the ocean, as Arnold concluded. ${ }^{86}$. If they represent a recurrence of brackish water, some indication of-brackish=water or marine fossils may be expected in strata of the same age farther west.

\section{AGE AND CORRELATION OF EXPOSED FORMATIONS}

\section{AGE}

\section{ETCHEGOIN AND SAN JOAQUIN FORMATIONS}

Arnold ${ }^{87}$ assigned to the upper Miocene the formations in the Coalinga district now considered of Pliocene age. With notable exceptions the marine fossils of these formations closely resemble species from strata in the San Francisco Bay region assigned to the San Pablo formation at the time when Arnold prepared the reports on the Coalinga district. Arnold considered the San Pablo formation, now designated the San Pablo group, of upper Miocene age, and it is still so considered. The most apparent differences between the fauna of the two regions are shown by the echinoids. The San Pablo group, the youngest formation of which is now known as the Neroly formation, contains the echinoid genera Astrodapsis and "Scutella," 88 whereas

\footnotetext{
s3 Idem, pp. 542-543.

${ }^{86}$ Arnold, Ralph, op. cit. (Bull. 396), p. 48, 1909 [1910]. Arnold, Ralph, and Anderson, Robert, op. cit. (Bull. 398), p. 151, 1910.

${ }_{87}$ Arnold, Ralph, op. cit. (Bull. 396), pp. 28, 44, 1909 [1910]. Arnold, Ralph, and Anderson, Robert, op. cit. (Bull. 398), pp. 112, 138-139, 1910.

${ }_{88}$ The California Miocene echinoids assigned to Scutella are probably closely related to the living Pacific coast genus Phelsumia. The generic name Twitchcllia has been proposed by Lambert and Thiéry for a small Miocene species similar to the species in the San Pablo. (See p. 131.) The relations of these small forms to Phelsumia are still undetermined. (R. S.)
} 
the Jacalitos formation-the oldest formation in the Conlinga district assigned to the Pliocene-contains Astrodapsis and Dendraster; the Etchegoin contains Dendraster; and the San Joaquin contains Dendraster and Merriamaster. In addition to the occurrence of Astrodapsis, a close relation in age or facies, or both, between the Jacalitos and San Pablo is shown by the presence in these two stratigraphic units of the molluscan genern Trophosycon, Lyropecten, Dosinia, and Chione. These genera have not been recognized in the Etchegoin and San Joaquin of the Kettleman Hills with the possible exception of Lyropecten in the Etchegoin. Lyropecten, however, is recorded from strata on Anticline Ridge assigned by Nomland ${ }^{89}$ to the lowest fossiliferous zone in Arnold's Etchegoin of that area.

The Jacalitos and Etchegoin, the latter including the equivalent of the San Joaquin, were assigned to the Pliocene as a result of the discovery of vertebrate remains at scattered localities a fow miles north of Anticline Ridge ${ }^{00}$ and as a result of further study of the San Pablo invertebrates. ${ }^{11}$ Neohipparion was found in strata correlated with the Jacalitos formation; Pliohippus at the base of the Etchegoin; and an advanced Pliohippus or Equus, now assigned to Plesippus, higher in the section in strata generally considered of late San Joaquin age but more probably representing a lower horizon.

The assignment of the Jacalitos, Etchegoin, and San Joaquin formations to the Pliocene is now generally accepted. The marine faunas of these formations have a Pliocene aspect in terms of the succession of Tertiary faunas on the Pacific coast. The vertebrate evidence now known is not opposed to this assignment. In the Kettleman Hills horse teeth identified as Calippus were found in the Patinopecten and Siphonalia zones of the Etchegoin; Pliohippus in the Patinopecten zone and probably in the Siphonalia zone; Pliohippus or Plesippus in strata immediately underlying the Neverita zone of the San Joaquin; Plesippus in the Pecten zone of the San Joaquin; and a hoof of a small horse representing possibly Nannippus or Calippus, was collected from the Macoma zone of the Etchegoin. The other vertebrate remains also are not opposed to a Pliocene assignment. A more noncommittal term, such as "late Neogene" might be preferable, but it is doubtful whether much is to be gained by discarding the terms "Miocene" and "Pliocene" after almost a century of usage in the Const Ranges.

A transitional Pliocene-Pleistocene age has recently been assigned to the Pecten zone of the San Joaquin formation and a Pleistocene age to the overlying part

\footnotetext{
${ }^{s 0}$ Nomland, J. O., The Etchegoin Pliocene of middle California: California Univ., Dopt. Geology, Bull., vol. 10, pp. 228, table opposite p. 230 (locality 2096), 1917.

90 Merriam, J. C., 'Tertiary vertebrate faunas of the north Coalinga region of Californla: Am. Philos. Soc. Trans., new ser., vol. 22, pp. 191-234, 49 figs., 1915. Relationship of Equus to Pliohippus suggested by characters of a new species from the Pliocene of Californla: California Univ., Dept. Geol., Bull., vol. 9, pp. 525-534, 18 Ags., 10.16.

"Clark, B. L., 'The muna of the San Pablo group of middle California: Idem, vol. 8, pp. 434-436. 1915.
}

of the San Joaquin. ${ }^{92}$ This assignment was based on an interpretation of the climatic aspects of the late Etchegoin and San Joaquin faunas.

Arnold's suggestion that the Pliocene faunas of the Coalinga district include cool-water species was emphasized by Gale. ${ }^{93}$ Arnold's cool-water species in the Mya "japonica" zone (the upper Mya zone at the top of the San Joaquin) were considered by Gale as evidence of the approaching cold of the Pleistocene glacial epoch and, therefore, as evidence for assigning this zone to the upper Pliocene-a quite reasonable age assignment on ordinary faunal grounds. Arnold's lower Mya zone (probably the Littorina zone of the Etchegoin), however, which presumably would have the same climatic and age implication as his upper Mya zone, was not considered.

This climatic interpretation was carried to a logical conclusion by Barbat and Galloway. The Mya-bearing strata assigned to the Littorina zone of the Etchegoin in the present report were interpreted as indicating a "fairly abrupt chilling of the basin" ${ }^{94}$ and the PliocenePleistocene boundary was, accordingly, lowered to place these strata in the upper Pliocene and the overlying San Joaquin in the Pleistocene.$^{95}$ According to the discussion under the heading "Environment suggested by fossils," it is doubtful whether Arnold's coolwater species are reliable indicators of cool water. Furthermore, if they indicate cool water, the suggestion that they also indicate the oncoming of Pleistocene glaciation is based on the assumption that Pleistocene glaciation is the result of a gradual decrease in the temperature of the earth's atmosphere and hydrosphere. The assignment of the San Joaquin formation to the Pleistocene is not in agreement with the faunal evidence. The few vertebrate remains represent forms generally considered of upper Pliocene age. Many of the marine fossils are similar to species in coastal California formations that are assigned to the Pliocene and underlie strata containing a marine fauna of more modern aspect considered of Pleistocene age.

\section{TULARE FORMATION}

The age of the Tulare formation is not satisfactorily known. It is generally considered Pleistocene on stratigraphic grounds. Arnold and Anderson ${ }^{96}$ assigned the Tulare to the Pliocene and Pleistocene. This age designation was influenced by the assignment of the underlying marine formations to the Miocene and by the occurrence in the upper part of the Tulare of an oyster identified as the living Ostrea lurida. The same

\footnotetext{
92 Barbat, W. F., and Galloway, John, San Joaquin clay, California: Am. Assoc Petroleum Geologists Buil., vol. 18, pp.495-496, p. 498 (table), 1934. In the table the " $\mathrm{C}$ " zone of the San Joaquin-that is the Pecten zone-is assigned to the Pleistocene.

${ }^{93}$ Grant, U. S., IV, and Gale, H. R., op. cit. (San Diego Soc. Nat. History Mem., vol. 1), p. 53,1931 .

"Barbat, W. F., and Galloway, John, op. cit., p. 490.

PS Idem, p. 498 (table).

${ }^{\circ 6}$ Arnold, Ralph, and Anderson, Robert, op. cit. (Bull. 398), pp. 140, 154, 1910.
} 
form of oyster is present in the upper part of the San Joaquin formation, and the Tulare specimens may have been transported as fossils. At all events, they are apparently of no importance so far as age determination is concerned.

The lower part of the Tulare contains the largest fossil fauna of fresh-water mollusks known on the Pacific coast. Of the 31 forms recognized only 4 (Valvata humeralis, Amnicola longinqua, Menetus centervillensis, and Physa humerosa) are identified as living forms. In addition, Valvata virens platyceps is closely allied to the living $V$. virens; Parapholyx cf. $P$. effusa closely resembles the Recent $P$. effusa; and some of the indefinitely.identified species may represent living forms. Nevertheless, this fauna is not a modern fauna. It includes, besides many extinct species, two extinct genera (Calipyrgula and Brannerillus), an extinct subgenus (Planorbifex), and a genus (Littoridina) no longer found in the western United States. Though the age relations of the Tulare fauna are uncertain without more data on the succession of Tertiary and Pleistocene fresh-water faunas on the Pacific coast, an assignment to the upper Pliocene is consistent with the character of the fauna. Special conditions might be invoked to account for the relatively rapid extinction of a Pleistocene fresh-water fauna of ancient aspect, as has been implied, ${ }^{97}$ but the special conditions should be supported by evidence other than the extinction.

Unfortunately no mammalian remains were found in the Tulare formation of the Kettleman Hills. A horse tooth, identified as Plesippus?, was found in the bottom of an arroyo in an area underlain by the Tulare, but it may have been derived from older strata. Fragmentary camelid and rodent remains collected in the Elk Hills, ${ }^{98}$ near the south end of the San Joaquin Valley, are the only land mammals so far recorded from strata of undisputed Tulare age. Two carnivores; representing forms generally considered of upper Pliocene age, were found many years ago near McKittrick in strata of uncertain stratigraphic position. ${ }^{99}$ The vertebrate-bearing beds at this locality have been assigned to the Tulare formation, ${ }^{1}$ but the stratigraphic position still appears to be doubtful. ${ }^{2}$ The stratigraphic and age assignments at this locality, however, have no direct bearing on the age of the Tulare in the Kettleman Hills, for the base of the Tulare in the basinward

\footnotetext{
97 Barbat, W. F., and Galloway, John, op. cit., pp. 492, 497.

${ }^{88}$ Woodring, W. P., Roundy, P. V., and Farnsworth, H. R., Geology and oil resources of the Elk Hills, Calif., including Naval Petroleum Reserve No. 1: U. S. Geol. Survey Bull. 835, p. 26, 1932.

${ }^{90}$ Merriam,.J. C., The Pliocene and Quaternary Canidae of the Great Valley of California: California Univ., Dept. Geol., Bull., vol. 3, pp. 278-283, 1903. A new sabre-tooth cat from California: Idem, vol. 4, pp. 171-175, 1905. Relationships of Pliocene mammalian faunas from the Pacific coast and Great Basin provinces of North America: Idem, vol. 10 , p. 425,1917

1 Matthew, W. D., and Stirton, R. A., Osteology and affinities of Borophagus: Idem, vol. 19, pp. 179-180, 1930. Russell, R. D., and Vander Hoof, V. L., A vertebrate fauna from a new Pliocene formation in northern California: Idem, vol. 20, p. 20,1931 .

I Barbat, W. F., and Galloway, John, op. cit., p. 496.
}

Kettleman Hills may be at a lower horizon than at McKittrick, which lies near the edge of the basin.

Because of the uncertainty concerning the age of the upper part of the Tulare, the formation is considered of upper Pliocene and Pleistocene(?) age.

\section{CORRELATION}

In the Coalinga district Pliocene formations containing distinct faunal zones are exposed in direct superposition. The succession and composition of these faunal zones is now fairly well known, though more information is needed for many parts of the district. A comparison of the Coalinga Pliocene faunas with those in Pliocene formations deposited in relatively small embayments extending inland from the present coast, and an attempt to correlate the formations, is difficult owing to the different facies at different localities. Moreover, it is difficult to determine the faunal sequence in coastal California owing to the lack of stratigraphic control at many localities. In the following paragraphs the faunas are briefly compared and correlations are suggested on the basis of the mollusks and echinoids-the most abundant fossils in the Coalinga district. The California and Oregon localities mentioned are shown in figure 12.

Inasmuch as three marine formations are represented in the San Joaquin Valley Pliocene, it is convenient to designate the Jacalitos formation lower Pliocene, the Etchegoin formation middle Pliocene, and the San Joaquin formation upper Pliocene. These age terms have, however, only a rolative meaning.

\section{SAN JOAQUIN VALLEY}

The Jacalitos fauna was described by Arnold in his reports on the Coalinga district and by Nomland. ${ }^{3}$ At a later date Nomland 4 abandoned the name "Jacalitos formation" and assigned the entire marine Pliocene section embracing several faunal zones to the Etchegoin. Nomland's Chione elsmerensis zone included most of the Jacalitos. He correlated his overlying Turritella nova zone with Arnold's Glycymeris zone, defined as representing the basal part of the Etchegoin on Anticline Ridge. The presence of Trophosycon in the Turritella nova zone suggests, however, a closer relationship with the Jacalitos.

The Jacalitos formation contains Astrodapsis, Trophosycon, Lyropecten, Dosinia, and Chione. These genera suggest a warm-water facies. 'Though they may represent a particular facies, their presence in Pliocene strata in the San Joaquin Valley is presumptive evidence for an assignment to the Jacalitos. Outside the foothills west of the Kettleman Hills, marine Jacalitos

3 Nomland, J. O., Fauna from the lower Pliocene at Jacalitos Creek and Waltham Canyon, Fresno County, Calif.: California Univ., Dept. Geology, Bull., vol. 9. pp. 199-214, pls. 9-11, 1916.

4 Nomland, J. O., The Etchegoin Pliocene of middle California: Idem, vol. 10. pp. 144-197, 216, 1917 


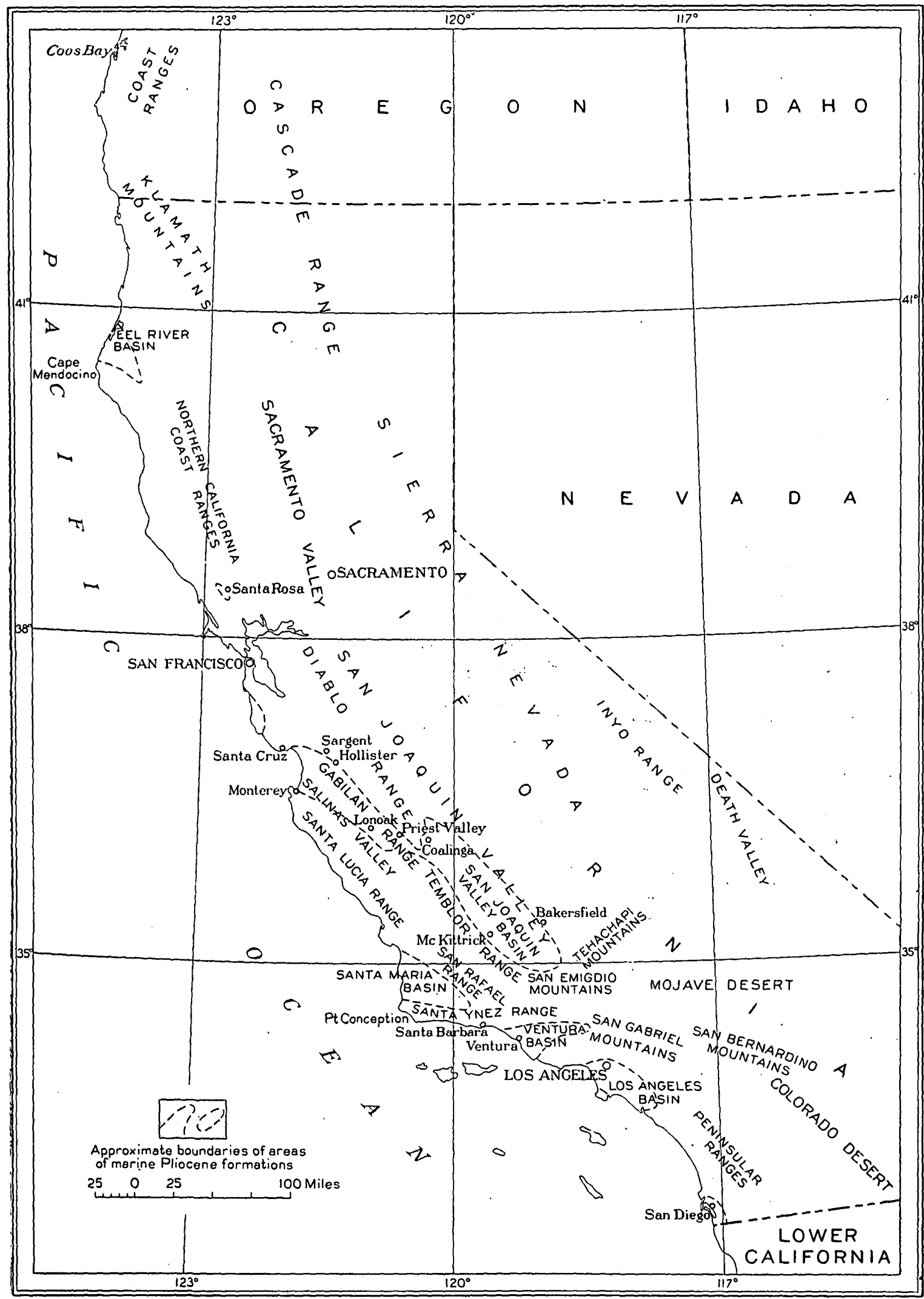

Fioure 12,-Sketch map of California and southern Oregon showing principal areas of marine Pliocene formations.

invertebrates have been recognized in surface outcrops only in the foothills of the San Emigdio Mountains, at the south end of the San Joaquin Valley, where Astrodapsis arnoldi crassus and Lyropecten "terminus"? are recorded. ${ }^{5}$ A collection from this region in the National Museum (U. S. G. S. locality 12887, north side

B Clark, B. L., in Hoots, H. W., Geology and oil resources along the southern border of San Joaquin Valley, Calif.: U. S. Geol. Survey Bull. 812, p. 278, 1930. 
of Los Lobos Creek), consisting of fragments of a. Terebratalia-like brachiopod and poorly preserved large echinoids with strongly raised petals, apparently Astrodapsis, suggests the Jacalitos formation, if the strata at this locality are Pliocene.

The Pseudocardium-bearing strata that unconformably overlie Miocene shale at the south end of the San Joaquin Valley ${ }^{6}$ appear to represent the only recorded outcrop occurrence of Etchegoin fossils outside the Coalinga district. Collections from these strata (U. S. G. S. localities 12879, Muddy Creek; and 12881, first arroyo east of Muddy Creek) contain "Nassa" moraniana, Siphonalia, Anadara trilineata variety cf. canalis, Macoma?, Pseudocardium densatum, and Schizothaerus. These fossils indicate that in the foothills of the San Fmigdio Mountains an undetermined part of the Etchegoin, possibly corresponding to the Siphonalia zone or of older age, overlaps onto the Miocene.

Fossiliferous strata of the San Joaquin formation, which like the Jacalitos and Etchegoin is generally overlapped by the Tulare, likewise appear to be recorded at only one locality outside the Coalinga district. The gravel and sand near McKittrick containing Aequipecten circularis eldridgei ${ }^{7}$ and a small oyster appear to be the equivalent of the Cascajo conglomerate at the base of the San Joaquin. These fossiliferous strata, like the Etchegoin in the San Emigdio foothills, unconformably overlie Miocene shale.

On Anticline Ridge, northwest of the Kettleman Hills, marine Jacalitos strata are absent. The nonmarine formation containing Neohipparion in this area has been correlated with the Jacalitos. ${ }^{8}$ Although this correlation is quite reasonable on stratigraphic grounds, the relations between the nonmarine formation and the marine Jacalitos is still undetermined. Arnold's Glycymeris zone, assigned by him to the base of the Etchegoin, embrace the oldest marine Pliocene strata on Anticline Ridge. Farther north the marine zones of the Etchegoin and San Joaquin gradually disappear. According to Nomland's faunal list, ${ }^{9}$ the Glycymeris zone corresponds to the Siphonalia zone of the Kettleman Hills or older strata. The Mya "japonica" zone of this region is evidently not the upper Mya zone at the top of the San Joaquin formation, as is implied in Nomland's table. ${ }^{10}$ His faunal list, ${ }^{11}$ aside from Glycymeris, represents forms that occur in the Littorina zone of the Etchegoin as well as in the upper Mya zone and intervening strata. That this Mya "japonica". zone is close to the horizon of the Littorina zone is indicated by the

\footnotetext{
6 Pack, R. W., The Sunset-Midway oil field, Calif., pt. 1, Geology and oil resources: U. S. Geol. Survey Prof. Paper 116, p. 45, pl. 11, 1920. Hoots, H. W., op. cit. (Bull. 812), pp. 276-279, pl. 35, $A$, 1930.

7 Arnold, Ralph, and Johnson, H. R., Preliminary report on the McKittrick-Sunset oil region, Kern and San Luis Obispo Counties, Calif.: U. S. Geol. Survey Bull. 406, p. 80, 1910. Pack, R. W., op. cit. (Prof. Paper 116), p. 46.

Arnold, Ralph, and Anderson, Robert, op. cit. (Bull. 398), pp. 107-108: Nomland, J. O.. op. cit. (California Unjv., Dept. Geol., Bull., vol. 9), pp. 79, 83, 1916.

Idem, pp. 81-82.

10 Idem, p. 85 .

11 Idem, p. 83
}

occurrence of Glycymeris, which in the Kettleman Hills was not found above the upper Pseudocardium zone and in the foothills farther west is not known above the Pecten zone, and by the occurrence of Pseudocardium and Tamiosoma in immediately underlying strata. ${ }^{2}$ Nomland's identification of the Pecten zone in this section was based on the occurrence of "Pecten nutteri," 13 a form of Chlamys etchegoini that has concentric swellings. Though this form was not found in the Etchegoin of the Kettleman Hills and is not recorded from the Etchegoin of the foothills to the west, it is recorded from the Jacalitos formation. Because of the occurrence of vertebrate remains at localities north of Anticline Ridge the relations between the section there and the marine section farther south are of considerable importance and need further investigation.

Suggested correlations between the Etchegoin and San Joaquin section in the Kettleman Hills and the subsurface section in the San Joaquin Valley, embodying correlations already discussed under the heading "Stratigraphy of exposed formations," are shown in figure 13. The tentative identification of the Jacalitos in a subsurface marine tongue in the Fruitvale oil field ${ }^{14}$ near Bakersfield is doubtful. According to the list of mollusks, the marine tongue is probably younger, possibly Etchegoin.

\section{CoAst Ranges between CoAlinga District AND SALINAS VALLEY}

Marine Pliocene formations are exposed in the Coast Ranges between the Coalinga district and the Salinas Valley, ${ }^{15}$ but details of the stratigraphy and paleontology are not available. This is an important region, for it is the first link between the Coalinga district and coastal California. A progressive seaward change in facies might be apparent from a study of the Pliocene faunas of this region. The Pecten coalingaensis zone fauna, which has been recognized in Priest Valley, ${ }^{16}$ may serve as a useful guide in correlations. The Etchegoin sand dollar Dendraster gibbsii is, however, recorded from the Pecten coalingaensis zone of this region. ${ }^{17}$ The lignitic shale, including beds of lowgrade coal, that immediately underlies the Pecten coalingaensis zone in Priest Valley. ${ }^{18}$ indicates freshwater or lagoonal deposition during early San Joaquin time. Nomland's list of fossils, ${ }^{19}$ including Dendraster gibbsii and Pseudocardium ["Mulinia"], from localities about 14 miles southeast of Priest Valley suggests the

\footnotetext{
12 Idem

${ }^{13}$ Idem, p. 82

1" Gale, H. R., in Preston, H. M., Report on Fruitvale oil field: California Oil Fields (California Dept. Nat. Res. Div, Oil and Gas), vol. 16, no. 4, p. 16, 1931

15 Pack, R. W., and English, W. A., Geology and oil prospects in Waltham, Priest, Bitterwater, and Peachtree Valleys, Calif.: U. S. Geol. Survey Bull. 581, pp. 132-135, 1914.

16 Idem, pp. 135,158

17 Kew, W. S. W.. Cretaceous and Cenozoic Echinoidea of the Pacific coast of North America: California Univ., Dept. Geology, Bull., vol. 12, p. 126, 1920. Univ. California locality 3004 is in Priest Valley.

18 Pack, R. W., and English, W. A., op. cit., pp. 134, 158.

10 Nomland, J. O., The Etchegoin Pliocene of middle California: California Univ., Dept. Geology, Bull., vol. 10, p. 215, 1917.
} 


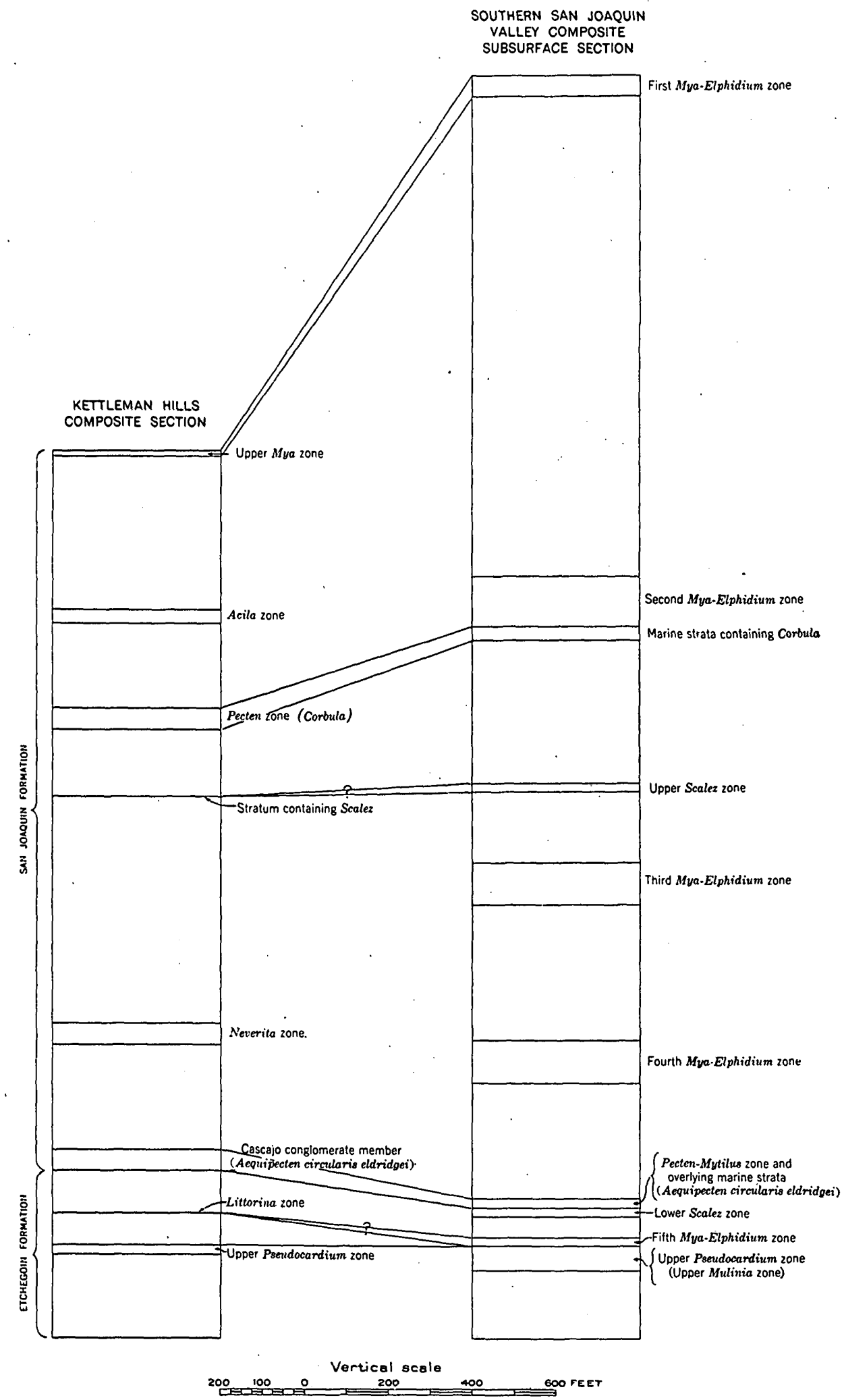

Ficure 13.-Suggested correlation of upper part of Etchegoin formation and San Joaquin formation in Kettleman Hills with subsurface section in southern San Jonquin Valloy. San Jorquin Valley subsurface section after Barbat and Galloway (Am. Assoc. Petroleum Geologists Bull., vol. 18, pp. 486-488, fig. 1, 1934).

Etchegoin, but Lyropecten ["Pecten" estrellanus catalinae] presumably indicates older strata than those exposed in the Kettleman Hills, possibly corresponding to the Glycymeris zone of Anticline Ridge. Pliocene formations, identified as the Jacalitos and Etchegoin, ${ }^{20}$. also are exposed in the hills bordering the east side of

20 English, W. A., Geology and oil prospects of the Salinas Valley-Parkfield area, Calif.: U. S. Geol. Survey Bull. 691, p. 231, 1918. 
southern Salinas Valley, but no lists of fossils are available.

The few Pliocene fossils, including Ostrea atwoodii and Lyropecten ["Pecten" estrellanus var.] listed by Nomland ${ }^{21}$ from a locality near Lonoak again suggest the Etchegoin, possibly the Glycymeris zone. This region is the type locality of Ostrea atwoodii, which in the Kettleman Hills was not found above the upper Pseudocardium zone of the Etchegoin.

The U. S. National Museum has recently received a collection of Pliocene fossils, strongly suggestive of the lower part of the Etchegoin, from localities on the east side of the San Benito River, southeast of San Benito, The fossils include Dendraster gibbsii, Siphonalia kettlemanensis, "Chrysodomus" portolaensis, Forreria magister, Glycymeris grewingki, Ostrea atwoodii, and Pseudocardium densatum.

\section{SALINAS VALXEY}

Most of the Salinas Valley is underlain by the nonmarine Paso Robles formation. On the grounds of stratigraphic position and origin the Paso Robles is generally correlated with the nonmarine Tulare formation, though in the Salinas Valley proper the Paso Robles overlies Miocene strata. According to Robert Anderson, ${ }^{22}$ the lower part of the Paso Robles is marine and is the equivalent of part of the marine Pliocene section in the Coalinga district. The fossils, however, have not been described or listed.

\section{SARGENT DISTRICT}

Two marine faunas have been listed from the Sargent oil field, ${ }^{23}$ in the Coast Ranges east of the mouth of Salinas Valley, the lower one designated Etchegoin and the upper one Merced (p. 109). The lower fauna includes the Jacalitos and Recent genus Chione, and the upper fauna includes the Jacalitos and Recent genus Dosinia. As neither fauna includes Astrodapsis, Trophosycon, and Lyropecten - extinct Jacalitos generathey are considered later than the Jacalitos. In this region and doubtless elsewhere in coastal California Chione and Dosinia evidently do not have the stratigraphic significance that they have in the Coalinga district. The lower faunal list includes Dendraster gibbsii ["Echinarachnius"], Siphonalia kettlemanensis ["Thais"], "Chrysodomus" portolaensis, Glycymeris, Chlamys etchegoini ["Pecten"], Patinopecten lohri ["Pecten oweni"], Ostrea atwoodii, and Macoma indentata. The upper faunal list includes Acila castrensis and Cancellaria tritonidea. These fossils suggest that the lower fauna is Etchegoin and the upper fauna is San Joaquin. Other forms listed from the upper fauna- "Nassa" moraniana, "Arca" canalis, Venerupis tenerrima ["Paphia"], and Pandorahowever, do not confirm this correlation, for these forms occur in the Etchegoin of the Coalinga district and are

\footnotetext{
21 Nomland, J. O., op. cit. (California Univ., Dept. Geol., Bull., vol. 10), p. 215. 22 Arnold, Ralph, and Anderson, Robert, op. cit. (Bull. 398), p. 142

${ }^{23}$ Martin, Bruce, The Pliocene of middle and northern California: California
} Univ., Dept. Geology, Bull., vol. 9, pp. 233, 245, 1916. unknown in the San Joaquin. Dendraster (Merriamaster) arnoldi, a sand dollar characteristic of the upper part of the San Joaquin formation, is recorded from the "upper Etchegoin formation" near the Sargent oil field. ${ }^{24}$ Kew used the designation "upper Etchegoin formation" for the San Joaquin formation, but it is not known with which of Martin's faunas this sand dollar is associated. Dendraster ashleyi, possibly Martin's Echinarachnius gibbsii, is also recorded from Sargent. ${ }^{25}$ An earlier record of Pseudocardium ["Mulinia"] in the Sargent oil field ${ }^{26}$ was not mentioned by Martin. Possibly this genus is rare or absent at Sargent owing to a more open sea than in the San Joaquin Valley. At all events it is not recorded at any other locality in coastal California but is known in coastal Oregon-a distribution suggesting that Pseudocardrum is essentially a northern genus. This suggestion is supported by the occurrence of the genus, called Mulinia by Dall and Mertie, in late Tertiary strata in Alaska. ${ }^{27}$ The presence of two Pliocene faunas in the Sargent district invites not only a more detailed study of the stratigraphy and paleontology but also a more detailed comparison with the Pliocene faunas of the Coalinga district. Such work may make more profitable a comparison between the Coalinga Pliocene faunas and Pliocene faunas from localities north of Sargent.

Marine Pliocene fossils are recorded fron a locality near Hollister, southeast of Sargent. ${ }^{28}$ The few species listed suggest the Etchegoin rather than the San Joaquin, with the exception of Pecten coalingaensis and Patinopecten healeyi ["Pecten healyi"]. Confirmation of the occurrence of Pecten coalingaensis in this region and data on the associated fauna are desirable.

\section{SANTA CRUZ QUADRANGLE AND SAN FRANCISCO} PENINSULA

Martin's list ${ }^{29}$ is the most recent faunal list for the Purisima formation of the Santa Cruz quadrangle. According to this list the Purisima might represent either the Etchegoin or San Joaquin; in fact, it suggests botb. Dendraster gibbsii ["Echinarachnius"], "Nassa" moraniana, "Chrysodomus" portolaensis, "Arca" canalis, Patinopecten lohri ["Pecten oweni"], Lucinoma ["Phacoides"], Venerupis tenerrima ["Paphia"], and Pandora ["Clidiophora"] suggest the Etchegoin, whereas Dendraster (Merriamaster) perrini ["Scutella"], Acila castrensis, "Arca" trilineata, and Patinopecten healeyi ["Pecten"] suggest the San Joaquin. A more northern aspect than shown by the faunas of the Coalinga district is indicated by Neptunea ["Chrysodomus"], Fusitriton ["Argobuccinum"], Miopleiona, and Thracia. Perhaps,

${ }^{24}$ Kew, W. S. W., op. cit. (California Univ., Dept. Geol., Bull., vol. 12), p. 115, pl. 28, figs. 2a, 2c, 1920 .

${ }^{25}$ Idem, p. 116.

${ }^{26}$ Jones, W. F., The geology of the Sargent oil feld: Idem, vol. 6, p. 68, 1911.

${ }^{27}$ Dall, W. H., in Mertie, J. B., Jr., Notes on the geography and geology of Lituya Bay, Alaska: U.S. Geol. Survey Bull. 836, p. 130, 1931. Woodring, W. P., in Capps, S. R., Kodiak and vicinity, Alaska: U. S. Geol. Survey Bull. 868, p. 118, 1937.

${ }_{28}^{2} \mathrm{Kerr}$, P. F., and Schenck, H. G., Active thrust faults in San Benito County, Calif:: Geol. Soc. America Bull., vol. 36, p. $475,1925$.

${ }_{20}$ Martin, op. cit. (California Univ., Dept. Geol., Bull., vol. 9), p. 243. 
however, these forms indicate deeper water. The southern genus Dosinia also is recorded. The northern sand dollar Anorthoscutum, which is Kew's Calaster and is probably a subgenus of the Recent Phelsumia, is represented by $A$. interlineatum ["Scutella"]. According to $\mathrm{Kew},{ }^{30}$ Anorthoscutum oregonensis ["Dendraster (Calaster)"] occurs in the Purisima formation in association with Dendraster gibbsii humilis and Dendraster (Merriamaster) perrini.

Martin's faunal lists ${ }^{31}$ also are the latest for the fauna of the Merced formation of the San Francisco Peninsula and adjoining parts of the Santa Cruz quadrangle. Martin considered the Merced younger than the Purisima. The Merced formation is generally divided into two parts. The only sand dollars in the lower part of the Merced represent the northern Anorthoscutum ["Scutella"], and an undetermined form is the only representative of the Pectinidae. The mollusks listed from the lower part of the Merced are not strongly suggestive of the San Jonquin formation as opposed to the Etchegoin formation. Perhaps Dendraster gibbsii and Merriamaster, both of which are recorded from the Purisima, became extinct before the deposition of the Merced, and perhaps the lower part of the Merced is younger than the San Joaquin. Inasmuch, however, as neither Dendraster nor Merriamaster are recorded at localities farther north, with the exception of an Alaskan record of D. gibbsii ["Echinarachnius'], ${ }^{32}$ perhaps the absence of these sand dollars in the Merced is due to a faunal barrier that did not exclude the northern Anorthoscutum, and perhaps the lower part of the Merced is the equivalent of some part of the San Joaquin. The upper part of the Merced, which contains the living Dendraster excentricus and living species of mollusks, has long been considered of probable Pleistocene age.

\section{SANTA ROSA DISTRICT}

Pliocene marine strata at localities near Santa Rosa, in Sonoma County, have been correlated with the Merced. They interfinger with the volcanics of the Sonoma andesite. Dickerson's indirect correlation of the marine strata with the Jacalitos formation ${ }^{33}$ is not justified, as Neohipparion, on which the correlation was based, occurs in the Petaluma formation, which unconformably underlies the Sonoma. ${ }^{34}$ Dickerson's lists of marine fossils ${ }^{35}$ include "Chrysodomus" impe-

\footnotetext{
${ }^{30}$ Kew, W. S. W., op. cit. (California Univ., Dept. Geology, Bull., vol. 12), p. 134. s1 Martin, Bruce, op. cit. (California Univ., Dept. Ceology, Bull., vol. 9), pp. 229-232.

82 Dall, W. H., in Mertie, J. B., Jr., op. cit. (Bull. 836), p. 130. The single specimen from locallty 7932 , orroneously cited as 17932 , is not Dendraster gibbsii. The oral surface is inaccessible, but the relatively long posterior petals indicate that this sand dollar is related to Phelsumia; the periproct is not supramarginal. Five poorly preserved specimens from locality 4414, recorded as Echinarachnius sp. (idem, p. 129, locallty " 013 "), represent apparently the same form. The eccentricity of the apical system and the rolative length of the posterior petals are variable.

Bs Dickerson, R. E., 'Tertlary and Quaternary history of the Petaluma, Point Reyes, and Santo Rosa quadrangles: California Acad. Sci. Proc., 4th ser., vol. 11, p. 559, 1922.

3 Morso, R. R., and Balley, T. L., Ceological observations in the Petaluma district, Calif.: Geol. Soc. America Bull., vol. 46, pp. 1447-1449, 1935.

as Dickerson, R. E., op. cit., pp. 544-545, 550 .
}

rialis, which occurs in the Jacalitos formation but is not certainly known in younger formations in the Coalinga district. A more profitable comparison of the Pliocene fauna from this region with the Coalinga faunas may be possible when the relations between the Merced of the San Francisco Peninsula and the Coalinga formations are more satisfactorily known.

\section{EEL RIVER BASIN}

Martin divided Lawson's Wildcat series of the Eel River Basin, in Humboldt County, into two parts and listed fossils from each part. ${ }^{36}$ No sand dollars are included in the list for the lower part. Neptunea ["Chrysodomus"], Liomesus, Fusitriton ["Argobuccinum"], and Thyasira suggest a cool-water (deepwater(?)) facies for the lower part. The deep-water genus Solemya was also recognized in the lower part. The northern sand dollar Anorthoscutum ["Scutella"] is the only echinoid listed from the upper part. In this respect the upper part of Lawson's Wildcat resembles the lower part of the Merced. A cool-water (deep-water(?)) facies for the upper part of the Eel River Basin Pliocene is suggested by the occurrence of Neptunea ["Chrysodomus"], Fusitriton ["Argobuccinum"], Admete, Bela, Taranis, and Thracia; but Chione also is recorded. Though Chione is now a warm-water genus, species assigned to Chione are found in late Tertiary faunas from Central America to Alaska. The absence of Anadara in the Eel River Basin is probably due to some unknown environmental condition, as it is present farther north in Oregon. The upper part of Lawson's Wildcat may be the equivalent of the lower part of the Merced.

\section{COOS BAY, OREG.}

The late Tertiary fauna in the Empire formation of the Coos Bay district has been described by Dall ${ }^{37}$ and Howe ${ }^{38}$ The Empire formation was assigned to the Miocene by Dall and to the Pliocene by Howe. Anorthoscutum ["Dendraster" or "Scutella"] is the only echinoid recorded from the Empire, as well as from the lower part of the Merced and the upper part of Lawson's Wildcat. "Chrysodomus" imperialis, Glycymeris grewingki, Lucinoma ["Phacoides"], Macoma indentata, Pseudocardium ["Mulinia"], and Venerupis laciniata hannibali ["Paphia"] suggest the Jacalitos or Etchegoin faunas. "Chrysodomus" imperialis is the only one of these forms that is not certainly found above the Jacalitos in the Coalinga district, according to Nomland. ${ }^{39}$ The Empire formation was assigned to the

${ }^{36}$ Martin, Bruce, op. cit. (California Univ., Dept. Geology, Bull., vol. 9), pp. 238-239.

${ }^{37}$ Dall, W. H., The Miocene of Astoria and Coos Bay, Oreg.: U. S. Geol. Survey Prof. Paper 59, 1909.

38 Howe, H. V., Faunal and stratigraphic relationships of the Empire formation, Coos Bay, Oreg.: California Univ., Dept. Geol. Sci., Bull., vol. 14, pp. 85-114, pls. $7-12,1922$.

89 Nomland, J. O., op. cit. (California Univ., Dept. Geology, Bull., vol. 10), p. 220. This species is recorded by Arnold and Anderson (Bull. 398, p. 132) from an Etchegoin locality in the Kreyenhagen Hills (locality 4750). The only specimen in the collection from this locality is an apical fragment too poorly preserved for certain identifcation. 
Pliocene by Howe principally on account of the presence of Anorthoscutum ["Calaster"], which was considered a subgenus of Dendraster. If Anorthoscutum is more closely related to Phelsumia than to Dendraster, however, it is not necessarily indicative of the Pliocene. Though the sand dollars and Pectinidae characteristic of the upper Miocene San Pablo group of California have not been found as far north as Oregon, the Empire fauna is more probably Pliocene than Miocene. If it is Pliocene, it is probably more nearly the equivalent of the Etchegoin than of the Jacalitos or San Joaquin.

\section{SANTA MARIA BASIN}

Numerous well-preserved Pliocene fossils are found in the Santa Maria Basin. This area is important as offering the most promising possibility for a comparison and correlation of the Pliocene faunas of the Coalinga district with those of localities farther south in coastal California, but details of the stratigraphy and paleontology have not been published. L. M. Clark ${ }^{40}$ correlated the lower part of Porter's Foxen formation, as interpreted by himself, with the Jacalitos and the middle and upper parts with Arnold's Etchegoin, which included the San Joaquin formation. Clark's record of Astrodapsis and Lyropecten estrellanus terminus ["Pecten"] from the lower part of Porter's Foxen formation strongly suggests the Jacalitos. Clark's faunal subdivisions have not been recognized in Arnold and Anderson's list of fossils from this area." "Nassa" moraniana ["Nassa californiana"] (U. S. G. S. locality 4477) occurs in the Etchegoin formation, and a form similar to "Nassa" waldorfensis (localities 4473 and 4474) occurs in the upper part of the San Joaquin. Turcica caffea brevis ["Thalotia" caffea], another fossil from the upper part of the San Joaquin, is in the collection from locality 4475. This form and "Nassa" waldorfensis suggest the upper part of the San Joaquin, but in the Santa Maria Basin "Nassa" waldorfensis is recorded in association with "Nassa" moraniana. The occurrence of Patinopecten lohri ["Pecten oweni"] suggests the Etchegoin. The sand dollar Dendraster ashleyi ["Echinarachnius"] is recorded in association with "Nassa" moraniana, but a sand dollar that appears to be D. ashleyi ["Echinarachnius excentricus var."] ${ }^{42}$ and a Calliostoma, probably related to the Etchegoin form C. coalingense privum are, however, in the collection from locality 4474 in association with species of San Joaquin aspect. Unfortunately the details of the ambulacral furrows on the sand dollars available from the Santa Maria Basin are not sufficiently well preserved to permit comparison with the extinct Coalinga forms and the living species. According to Kew's illustration of

\footnotetext{
40 Clark, L. M., in Reed, R. D., Geology of California, pp. 231, 232, Tulsa, Am. Assoc. Petroleum Geologists, 1933.

1 Arnold, Ralph, and Anderson, Robert, Geology and oil resources of the Santa Maria oil district, Santa Barbara County, Calir.: U. S. Geol. Survey Bull. 322, pp. 58-60, 1907.

12 Idem, pl. 24, fig. 8.
}

D. ashleyi ${ }^{43}$ the branches of the ambulacral furrows are more like those of $D$. gibbsii than like those of the living $D$. excentricus. D. ashleyi is probably a flat thin form of $D$. gibbsii. D. ashleyi ynezensis ${ }^{44}$ should be compared with $D$. coalingaensis.

\section{SANTA BARBARA}

The name "Santa Barbara formation" is adopted for the marine formation exposed in the southwestern part of Santa Barbara. This formation was assigned to the Fernando formation by Arnold. ${ }^{45}$ The name "Santa Barbara" was first used in a zonal sense by Smith. ${ }^{46}$ The Santa Barbara formation is considered of Pleistocene age and is correlated with the San Pedro sand, including a marl member and a silt member, of the San Pedro district in the Los Angeles Basin. ${ }^{47}$

The Santa Barbara formation contains a well-preserved fauna listed and partly illustrated by Arnold. ${ }^{48}$ No faunal basis for comparison with the Pliocene formations in the Coalinga district is apparent. The fauna is essentially modern. Assignment to the upper Pliocene, aside from a climatic interpretation by Gale, ${ }^{49}$ is based on the occurrence in the lower part of the formation of extinct species generally considered characteristic of the Pliocene-particularly Crepidula princeps and Pecten bellus. Anadara and Lyropecten are not known to occur in the Santa Barbara formation. The upper part of the formation represents probably water too deep for these genera, but the lower part appears to have been deposited in shallow water. The Santa Barbara formation may have been deposited after the extinction of Anadara and Lyropecten along this part of the California coast. No discontinuity is apparent in this formation, which is strongly transgressive and rests unconformably on strata as old as the Sespe formation, locally of upper Eocene to lower Miocene age. Inasmuch as the Pliocene-Pleistocene boundary cannot be rigidly drawn in marine strata on faunal grounds, a combination of faunal and diastrophic criteria is preferable so long as the faunal evidence is not strongly opposed to the diastrophic evidence. In view of the essentially modern character of the fauna in the Santa Barbara formation, the entire formation is considered of Pleistocene age, and the extinct species are considered Pleistocene survivals. Other extinct species are present in the upper part of the formation at Santa

\footnotetext{
${ }^{43}$ Kew, W.S. W., op. cit. (California Univ., Dept. Geology, Bull , vol. 12.) pl. 27 flg ic. 4 Idem, p. 116, pl. 36 , figs. $2 \mathrm{a}, 2 \mathrm{~b}$.

is Arnold, Ralph, Geology and oil resources of the Summerland district, Santa Barbara County, Calif.: U. S. Geol. Survey Bull. 321, pp. 31-32, 1907.

46 Smith, J. P., Geologic range of Miocene invertebrate fossils of California: California Acad. Sci. Proc., 4th ser., vol. 3, p. 169, 1912; Climatic relations of the Tertiary and Quaternary faunas of the California region: Jdem, vol. 9, pp. 150-151, 1919.

${ }^{7}$ Arnold assigned the Santa Barbara formation to the Pliocene and Pleistocene in The paleontology and stratigraphy of the marine Pliocene and Pleistocene of San Pedro, Calif.: California Acad. Sci. Mem., vol. 3, pp. 50-53, 1903; op. cit. (Bull. 321), p. 31 [assignment qualifled]. J. P. Smith assigned it to the upper Pliocene (op. cit., vol. 9). Bailey assigned the lower part to the upper Pliocene and the upper part tentatively to the lower Pleistocene in Lateral change of fauna in the lower Pleistocene: Geol. Soc. America Bull., vol. 46, p. 494, 1935.

18 Arnold, Ralph, op. cit. (Bull. 321), p. 32, pls. 11-16.

19 Grant, U. S., IV, and Gale, H. R., op. cit. (San Diego Soc. Nat. Bistory Mem., vol. 1), pp. 35-36
} 
Barbara and at localities elsewhere in formations assigned to the Pleistocene.

The same faunal succession is found at Rincon Point, about 12 miles southeast of Santa Barbara, where the Santa Barbara formation lies unconformably on vertical beds of Miocene shale. A coarse-grained sand at the base contains Crepidula princeps and Pecten bellus. Overlying calcareous sand and marl contain a fauna that in the San Pedro district is assigned to the Pleistocene.

VENTURA BASIN

In a 20,000-foot Pliocene and Pleistocene section exposed in the Ventura Basin no evidence for major discontinuities is apparent. In the western part of the basin the lower part of the Pliocene is assigned to the Repetto formation and the upper part to the Pico formation, the subdivision being based on differentiation of the foraminiferal faunas. The Pliocene in the eastern part of the basin is assigned to the Pico formation, the type region of which is in this area. The eastern part of the basin has been mapped by Kew, ${ }^{50}$ whose report includes a list of Pliocene fossils. The stratigraphy and paleontology, particularly of the eastern part of the basin, have been discussed by Gale. ${ }^{51}$

The strata at Elsmere Canyon in the eastern part of the basin resting directly on the granitic rocks of the San Gabriel Range contain Astrodapsis, Trophosycon, Dosinia, and Chione. The fauna at this locality is strongly suggestive of the Jacalitos formation; and a correlation with the Jacalitos is generally accepted. Kew, ${ }^{52}$ however, called attention to the presence in this fauna of the living species of sand dollar Dendraster excentricus. Whether this record indicates an exceptionally long range for this species or a misidentification is not known. The possibility that it indicates an age as young as Pleistocene, in conformity with other records of $D$. excentricus, is too remote for serious consideration.

Faunas from localities in the eastern part of the basin west and northwest of Elsmere Canyon are similar in most respects to the fauna at Elsmere Canyon, but Astrodapsis and Trophosycon have not been found. Despite the absence of these genera English ${ }^{53}$ considered the faunas at the different localities of the same age. Gale, however, considered the faunas at localities other than Elsmere Canyon of middle Pliocene age and designated the beds the San Diego zone on account of the resemblance of the fauna to that of the San Diego formation. (See p. 112.) Gale correlated his San Diego zone with the Pecten coalingaensis zone. Lyropecten, Dosinia, and Chione, recorded by Gale in his

\footnotetext{
${ }^{30} \mathrm{Kow}$, W. S. W., Coology and oil resources of a part of Los Angeles and Ventura Counties, Calif.: U. S. Geol. Survey Bull. 753, pp. 69-75, 77-79, pl. 1, 1924.

s1 Grant, U. S., IV, and Gale, F. R., op. cit. (San Diego Soc. Nat. History Mem.

vol. 1). pp. 26-30, 46-49. Faunal lists for the localities discussed may be assembled from the records in the systematic part of the memoir.

9 Kow, W. S. W., op. cit. (Bull. 753), p. 78.

os English, W, A., The Fernando group near Newhall, Calif.: California Univ., Dept. Geol. Scl., Bull., vol. 8, p. 211, 1914.
}

San Diego zone, suggest the Jacalitos formation in terms of the faunal succession in the Coalinga district, though these genera are quite certainly younger than Jacalitos in coastal California, the last two surviving until the present time; Turritella vanvlecki suggests the Etchegoin; and Siphonalia humerosa ["Cantharus"], which also is present at Elsmere Canyon, a variety of Anadara trilineata ["Arca"], Pecten coalingaensis, Chlamys of the $C$. etchegoini group ["Pecten (Pallium) swiftii var."], Aequipecten of the $A$. deserti group, Ostrea vespertina, and Patinopecten healeyi suggest the upper part of the San Joaquin formation. In the correlation of his San Diego zone with the Pecten coalingaensis zone Gale emphasized the occurrence in the Ventura Basin of Pecten coalingaensis, a form of Chlamys etchegoini with concentric swellings, Aequipecten of the $A$. deserti group, and Ostrea vespertina. The identification of Pecten coalingaensis should be confirmed by an examination of the inner side of the flat valves. According to the figure, ${ }^{54}$ the form identified as $P$. coalingaensis might rather be associated with $P$. hemphilli. The Chlamys figured as Pecten (Pallium) swiftii form parmeleei ${ }^{55}$ resembles specimens of Chlamys etchegoini from the Siphonalia zone of the Etchegoin, whereas the form with concentric swellings figured as Pecten (Pallium) swiftii form wattsi ${ }^{56}$ resembles specimens in the Pecten coalingaensis zone of the foothills west of the Kettleman Hills. Though this form was not found in the Etchegoin of the Kettleman Hills, it is present in the Jacalitos. ${ }^{57}$ The significance of the identification of Aequipecten circularis impostor is doubtful, as unequivocal criteria permitting the recognition of this form have not yet been worked out. Ostrea vespertina is unknown in the Jacalitos and Etchegoin but is recorded from the upper Miocene Santa Margarita sandstone north of Anticline Ridge, ${ }^{58}$ and its value as a guide fossil is doubtful. The correlation of Gale's San Diego zone in the Ventura Basin with the Pecten zone cannot be regarded as established. These strata may be of Jacalitos, Etchegoin, or San Joaquin age. They are probably the equivalent of the Etchegoin, if the strata at Elsmere Canyon are the equivalent of the Jacalitos. They doubtless represent a facies similar to that of the San Joaquin.

Mollusks appear to be rare in the thick Pliocene section in the western part of the Ventura Basin, and the stratigraphic position of Gale's San Diego zone in this thick section is not known. Waterfall ${ }^{69}$ listed a small

\footnotetext{
st Grant, U. S., IV and Gale, H. R., op. cit. (San Diego Soc. Nat. History Mem., vol. 1.), p. 227 , pl. 2 , flg. 2.

ss Idem, pl. 10, fig. 2.

s6 Idem, pl. 10, fig. 3 .

${ }^{77}$ Nomland, J. O., op. cit. (California Univ., Dept. Geology, Bull., vol. 9), pp. 203 204. The absence of a record of this form in the equivalent of the Jacalitos in Nom land's flnal consolidated list (idem, vol. 10, p. 219) is evidently an error that might have misled Gale.

ss Nomland, J. O., Fauna of the Santa Margarita beds in the north Coalinga region of California: California Univ., Dept. Geology, Bull., vol. 10, p. 300, 1917.

so Waterfall, L. N., A contribution to the paleontology of the Fernando group Ventura County, Calif.: Idem, vol. 18, pp. 82-83, table opposite p. 78, 1929.
} 
fauna from the lower part of the. Pico formation of this region. The list includes Siphonalia humerosa ["Cantharus"], suggestive of the San Joaquin but also found at Elsmere Canyon, and Glycymeris grewingki, an Etchegoin species. A fauna from the upper part of the Pico formation in the western part of the Ventura Basin also was recorded by Waterfall. ${ }^{60}$ This fauna resembles the fauna of the Santa Barbara formation and like it includes northern species, indicating cool water and probably water of moderate depth. The strata in the Ventura Basin containing this fauna were designated the Santa Barbara zone by Gale. Bailey ${ }^{61}$ found that the mudstones containing this fauna interfinger with normally overlying marine sand and gravel containing a modern fauna considered Pleistocene by all geologists familiar with this region. The Pleistocene marine sand and gravel constitute the marine Saugus of Kew and Waterfall, the San Pedro of Bailey, and the Las Posas formation of Pressler. An assignment to the Pleistocene of the strata containing the fauna similar to that at Santa Barbara is preferable to an assignment to the upper Pliocene. A satisfactory Pliocene-Pleistocene lithologic boundary in the western part of the Ventura Basin has not yet been recorded.

On the south slope of the Santa Susana Mountains, forming the southern boundary of the Ventura Basin, Pliocene fossils occur in sandstone, formerly assigned to the Saugus formation by Kew, ${ }^{62}$ that rests unconformably on strata as old as Upper Cretaceous. The fauna includes Merriamaster [Dendraster pacificus, $D$. cedrosensis], Dendraster, Lyropecten ["Pecten" cerrosensis], and a Chlamys with concentric swellings recorded as $C$. swiftii parmeleei. These forms, aside from Lyropecten, suggest the Pecten zone of the San Joaquin formation more strongly than any fauna in the Ventura Basin owing to the occurrence of Merriamaster.

\section{LOS ANGELES BASIN}

The Pliocene of the Los Angeles Basin is divided into a lower part, the Repetto formation, and an upper part, the Pico formation. The subdivision, as in the western part of the Ventura Basin, is based on the differentiation of the foraminiferal faunas. The type locality of the Repetto formation is in this area.

The Repetto formation contains mollusks and echinoids of deep-water facies and mollusks of shallowwater and also of intermediate-depth facies. ${ }^{63}$ The fossils of shallow-water facies include Lyropecten cerrosensis, Ostrea vespertina, Trachycardium cf. T. quadragenarium, and Corbula gibbiformis. These forms suggest Gale's San Diego zone and also, aside from Lyropecten, the Pecten zone of the San Joaquin forma-

\footnotetext{
00 Waterfall, L. N., op. cit., pp. 77-83, table opposite p. 78 .

${ }^{61}$ Bailey, T. L., Lateral change of fauna in the lower Pleistocene: Geol. Soc. America Bull., vol. 46, pp. 489-502, pl. 44, fig. 1, 1935.

$.82 \mathrm{Kew}$, W. S. W., op. cit. (Bull. 753), pp. 84-85, 88 (localities $8139,8144,8145,8151$, $8153,8154,8157,8159)$. Woodring, W. P., Pliocene deposits north of Simi Valley, Calif.: California Acad. Sci. Proc., 4th ser., vol. 19, pp. 57-64, 1930.

os Woodring, W. P., op. cit. (Prof. Paper 190), pp. 13-15, 1938.
}

tion. That the resemblance to the Pecten zone is a facies resemblance rather than an age resemblance is suggested by the stratigraphic position of these fossils. in the Los Angeles Basin section.

In sandstone resting unconformably on Miocene shale near Santa Monica, near the northwest border of the Los Angeles Basin, is a small Pliocene fauna characterized by the abundance of Pectinidae and brachiopods. ${ }^{64}$ The stratigraphic position of this fauna in the Los Angeles Basin section is not recorded, but it presumably represents a sandy facies of a part of the Pico formation. Aside from its smaller size and the absence of Merriamaster, this fauna is closely similar to that occurring on the south slope of the Santa Susana Mountains, mentioned under the heading "Ventura Basin" above, and ever since it was discovered has been considered of San Diego age.

A large fauna from the upper Pico formation as exposed in the city of Los Angeles has been listed by Moody ${ }^{65}$ and Grant. ${ }^{66}$ It is not comparable with any fauna in the Coalinga district. Siphonalia gilberti, described from this locality, is considered a variety or subspecies of $S$. fortis, which occurs in the Santa Barbara formation and in Pleistocene strata at San Pedro. The absence of sand dollars, Anadara, Lyropecten, and Ostrea in this fauna from Los Angeles and the presence of the living northern Patinopecten caurinus, Propeamussium, and other forms suggests water of moderate depth. Anadara and Lyropecten may have become locally extinct by the time this fauna lived, but their absence is more probably due to deposit on at depths too great for those genera. The fauna is not modern enough to be of Pleistocene age. A similar fauna, but one including Lyropecten cerrosensis, is recorded from a locality representing the Pico formation near Santa Monica. ${ }^{67}$

Pliocene fossils from the Puente Hills, on the northeast border of the Los Angeles Basin, have been listed by Arnold. ${ }^{68}$ They represent probably one or more horizons in the Pico formation. These fossils are of particular interest as they include Pecten auburyi, which may be very closely related to $P$. coalingaensis or may be identical with that species.

\section{SAN DIEGO}

The fauna of the San Diego formation, which plays an important role in discussions of California Pliocene fossils, is in need of revision. Arnold's list, ${ }^{69}$ represent-

\footnotetext{
64 For the most recent list see Woodring, W. P., in Hoots, H. W., Geology of the eastern part of the Santa Monica Mountains, Los Angeles County, Calif.: U. S. Geol. Survey Prof. Paper 165, p. 119, 1931.

os Moody, C. L., Fauna of the Fernando of Los Angeles: California Univ., Dept. Geology, Bull., vol. 10, pp. 39-62, pls. 1-2, 1916.

BB Soper, E. K., and Grant, U. S., IV, Geology and paleontology of a portion of Los Angeles, Calif.: Geol. Soc. America Bull., vol. 43, pp. 1058-1067, 1932 [1933].

67 Woodring, W. P., in Hoots, H. W., op. cit. (Prof. Paper 165), p. 116.

${ }_{68}$ Eldridge, G. H., and Arnold, Ralph, The Santa Clara Valley, Puente Hills, and Los Angeles oil districts, southern California: U. S. Geol. Survey Bull. 309, p. 10;, 1907.

${ }^{68}$ Arnold, Ralph, The Tertiary and Quaternary pectens of California: U. S. Geoi. Survey Prof. Paper 47, p. 28, 1907.
} 
Suggested correlation of marine Pliocene and lower Pleistocene formations in California, Oregon, and Lover Californic

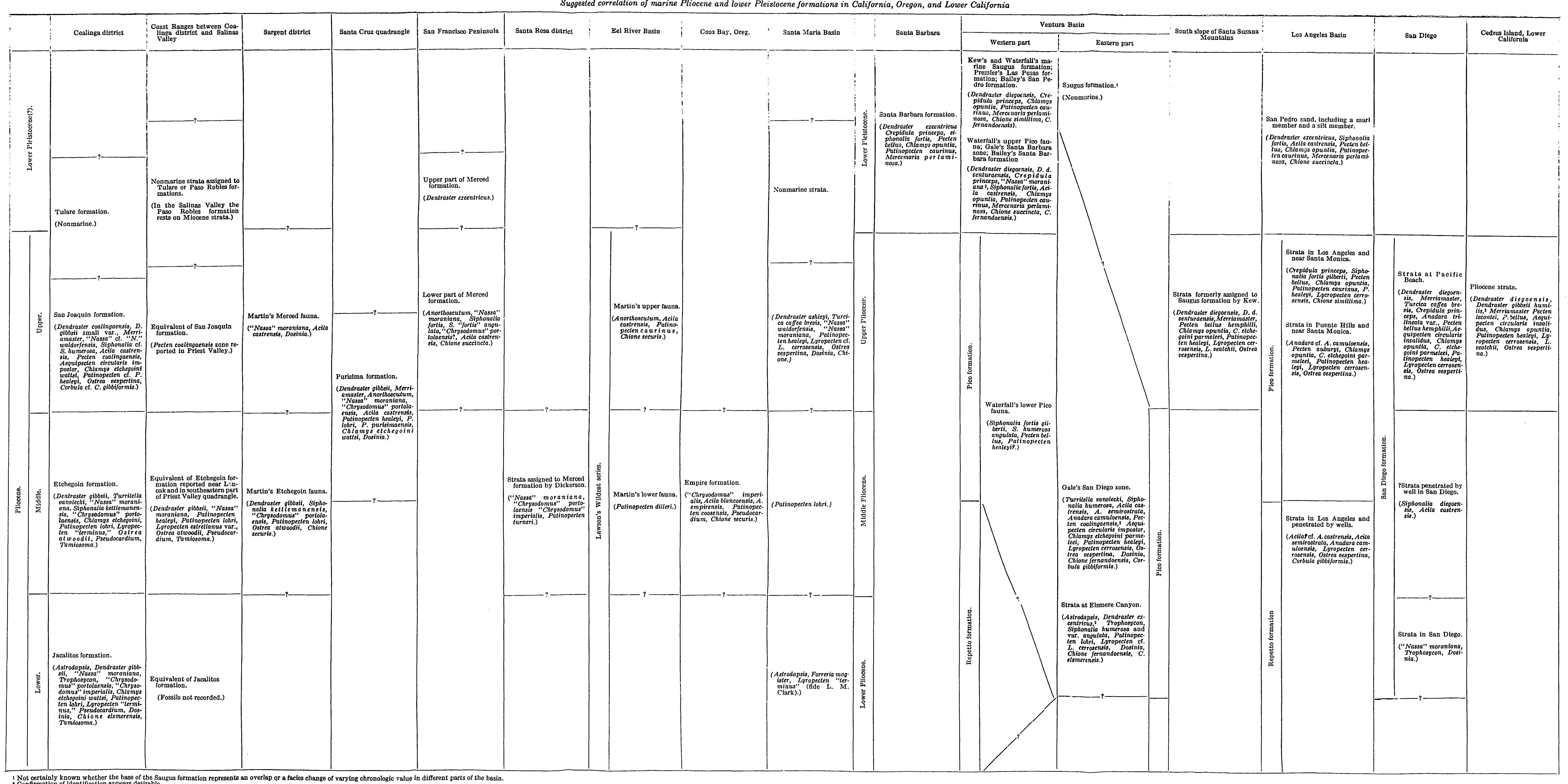


ing only fossils from Pacific Beach, is the latest list available, but many records for Pacific Beach and other localities are included in the systematic part of Grant and Gale's catalog.

If all the late Tertiary strata at and near San Diego are to be included in the San Diego formation, three faunal zones are probably represented. The lower zone containing Trophosycon, a large form of "Nassa" moraniana, and Dosinia is present in the city of San Diego. This zone is suggestive of the Jacalitos formation. A middle zone may be present in strata penetrated by a well in San Diego. Siphonalia diegoensis, which was collected from the well, may be the same form as $S$. kettlemanensis from the Etchegoin formation. The upper zone, which is exposed in the sea cliff at Pacific Beach, contains Dendraster diegoensis, Dendraster (Merriamaster) pacificus, a variety of Anadara trilineata, an Aequipecten of the A. circularis group, a form of Chlamys etchegoini with concentric swellings, Lyropecten cerrosensis, and Ostrea vespertina, all of which, with the exception of Lyropecten, are suggestive of the Pecten zone of the San Jorquin formation. Turcica caffea brevis, another fossil from the upper part of the San Jonquin, is in a collection from Pacific Beach. Dendraster (Merriamaster) pacificus, which resembles $D$. (M.) arnoldi, is particularly suggestive of the upper part of the San Joaquin. According to Kew's figure of the type of Dendraster diegoensis, ${ }^{70}$ the ambulacral furrows are more or less intermediate between those of the Coalinga Dendrasters and the living $D$. excentricus. The pattern of the minor branches is like that of $D$. gibbsii, but the degree of eccentricity is more like that of $D$. coalingaensis.

\section{CEDROS ISLAND, LOWER CALIFORNIA}

A fauna from Cedros Island, about 300 miles south of San Diego, has been described by Jordan and Hertlein ${ }^{71}$ and correlated with that of the San Diego formation nt Pacific Beach. The fossils include Dendraster gibbsii humilis, D. diegoensis, Merriamaster [Dendraster pacificus, D. cedrosensis, Astrodapsis kewi, $A$. israelskyi], and Pecten lecontei, which may be identical with $P$. caolingaensis. Aside from Dendraster gibbsii humilis, these forms are suggestive of the Pecten zone of the San Jonquin formation. Cedros Island is the type locality of Lyropecten cerrosensis, which occurs at many localities in coastal southern California in strata that have been correlated with the part of the San Diego formation exposed at Pacific Beach.

\section{SUMMARY}

The correlations suggested in the preceding discussion are summarized in the table opposite page 112. Many of these suggested correlations are unsatisfactory, as they are based on echinoids and on selected

${ }^{10}$ Kow, W. S. W., op. cit. (Calịfornia Univ., Dept. Geology, Bull., vol. 12), pl. 30, Ag. 2 b.

i Jordan, E. K., and Hertlein, L. G., Contribution to the geology and paleontology of the Tertiary of Cedros Island and adjacent parts of Lower California: California Acad. Sci. Proc., 4th ser., vol. 15, pp. 409-464, 27-34, 1926. genera and species of mollusks and for the most part on second-hand information in the form of faunal lists. Evidence from other groups of fossils should be in agreement if the correlations are substantiated. Foraminifera have proved particularly useful in correlations covering areas where depositional conditions were essentially uniform, as in the Los Angeles Basin and the western part of the Ventura Basin. They have even been used for refined correlations of minor faunal units between regions as far distant as the Los Angeles Bassin and the Eel River Basin in northern California, ${ }^{72}$ regions in which the depositional environment was presumably similar. Foraminifera should be particularly useful in correlation of formations, such as the Repetto and much of the Pico, in which other fossils are rare or absent; in fact, the stratigraphic subdivisions in the Pliocene of the Los Angeles Basin and the western part of the Ventura Basin are based solely on them. In the Pliocene formations of the Coalinga district Foramanifera are relatively rare.

Difficulties in the proposed faunal correlations resulting from changes in facies are hard to overcome at present. It is expected, however, that more satisfactory correlations between the Coalinga district and coastal California may be made when the Pliocene formations and fossils of the area northwest of the Coalinga district and those of the Santa Maria Basin are better known.

The genetic relations of the sand dollars assigned to Merriamaster are uncertain; they may possibly be variations of the species of Dendraster with which they are associated. Nevertheless, the occurrence of Merriamaster appears to be the most useful ground now available for the correlation of the San Joaquin formation with coastal formations. The correlation of Merriamaster-bearing strata at localities in southern coastal California is supported by other faunal evidence and by diastrophic evidence. For example, wherever Merriamaster occurs in southern coastal California and Lower California it is associated with Lyropecten cerrosensis. In southern coastal California Merriamasterbearing strata are strongly transgressive and rest unconformably on formations ranging in age from Miocene to Upper Cretaceous. In the absence of faunal evidence to the contrary, an assumption that this transgression is essentially synchronous at different localities may be justified, but more data on the stratigraphic position of Merriamaster and the associated fauna with reference to the sequence of Pliocene faunas in coastal California are needed.

The assignment of the part of the San Diego formation exposed at Pacific Beach to the upper Pliocene is a corollary of its proposed correlation with the upper part of the San Joaquin. The assignment of strata at Elsmere Canyon and in San Diego to the lower Pliocene

12 Reed, R. D., Southern California as a structural type: Am. Assoc. Petroleum Gcologists Bull., vol. 21, pp. 552-553, fig. 2, 1937 
is based principally on the occurrence of the extinct Trophosycon. Trophosycon may, of course, have survived later in the Ventura Basin than in the San Joaquin Valley and may have survived still later at San Diego. At Elsmere Canyon, however, it is accompanied by the extinct echinoid Astrodapsis, and at San Diego it is associated with a large form of "Nassa" moraniana also found in the lower part of the Etchegoin and in the Jacalitos. The assignment of the Santa Barbara formation and strata in the Ventura Basin containing a similar fauna to the Pleistocene results from combining faunal and diastrophic criteria in an attempt to determine the Pliocene-Pleistocene boundary in the marine formations. The transgression of the Santa Barbara formation at Santa Barbara and nearby localities is comparable with the early Pleistocene transgression in the San Pedro region, and with few exceptions the faunas in the two regions are similar. The faunal criteria minimize the survival of species formerly considered characteristic of the Plioceneparticularly Crepidula princeps and Pecten bellus-and emphasize the local extinction of Anadara and Lyropecten.

\section{STRATIGRAPHY AND PALEONTOLOGY OF FORMA- TIONS PENETRATED BY WELLS AND EXPOSED NEARBY}

The formations penetrated by wells in the Kettleman Hills range in age from Pliocene to Eocene. Those penetrated depend, of course, on the location. Wells at the north end of North Dome start at or near the top of the exposed Tulare formation and pass through the entire section so far described. The exposed formations are, however, not included under the present heading with the exception of the Etchegoin formation, only a small part of which is exposed in North and Middle Domes. In South Dome a greater thickness of Etchegoin, but apparently not the entire formation, is exposed. The subsurface formations crop out at nearby localities along the foot of the Coast Ranges, and brief descriptions of outcrop sections are included in the following discussion.

The subsurface formations are shown in the generalized stratigraphic section on plate 51 . Their thickness and character are summarized in the following table:

Subsurface section in Kettleman Hills

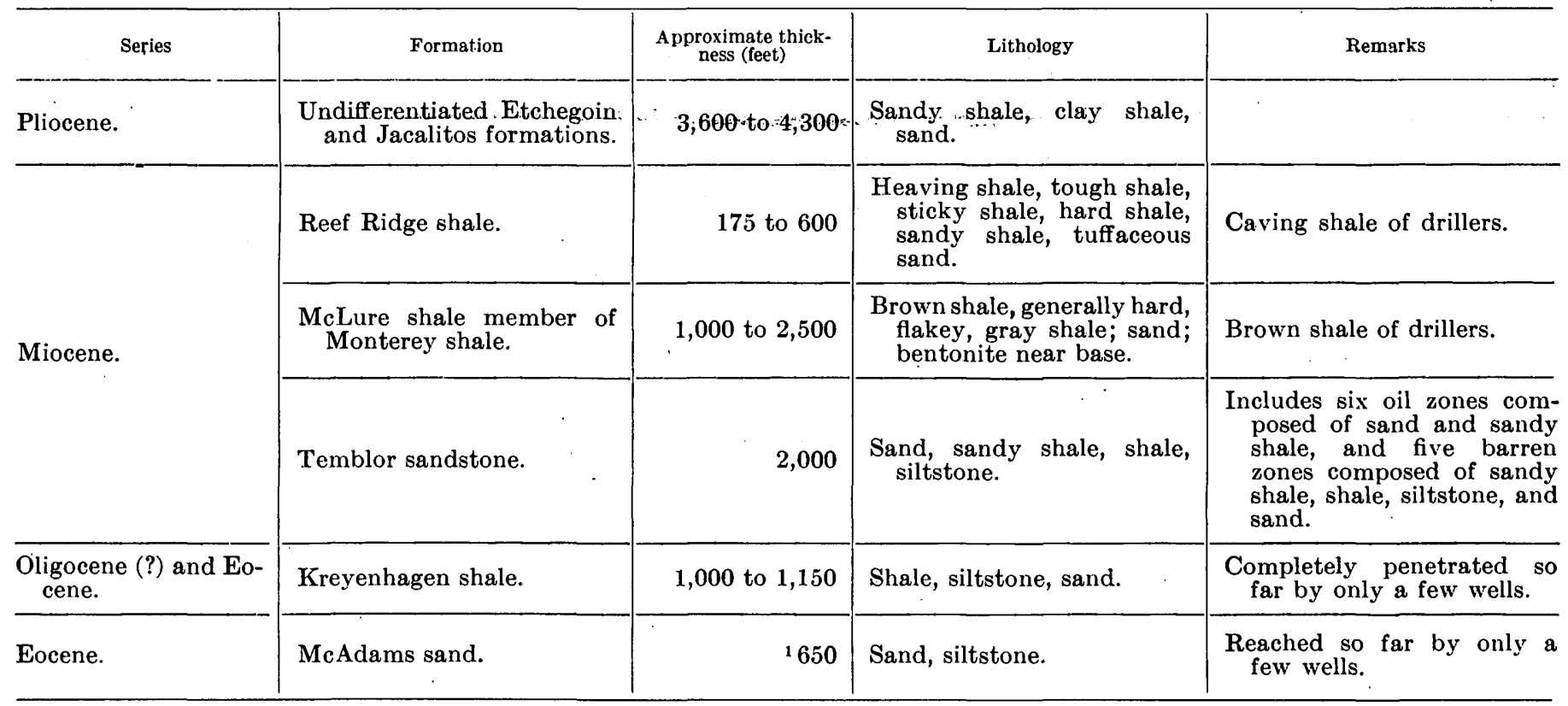

Base not reached at time report was completed (October 1, 1937).

The term "sand" is used throughout the description of the subsurface section for sandy strata regardless of the degree of consolidation.

\section{PLIOCENE SERIES}

\section{UNDIFFERENTIATED ETCHEGOIN AND JACALITOS} FORMATIONS

The Pliocene subsurface section is treated as representing undifferentiated Etchegoin and Jacalitos formations. There is no economic incentive to distinguish these two formations-if, indeed, their differentiation is practicable in subsurface work.

The Jacalitos formation, which, as shown in the table on page 27, is included in the Etchegoin by some geologists, was named by Arnold and Anderson. ${ }^{73}$ The type region is in the Jacalitos Hills and Kreyenhagen Hills adjoining Jacalitos Creek in the foothills west of the Kettleman Hills. On the advance edition

${ }^{73}$ Arnold, Ralph, and Anderson, Robert, Preliminary report on the Coalinga oil district: U. S. Geol. Survey Bull. 357, p. 40, 1908. Arnold, Ralph, and Anderson, Robert, op. cit. (Bull. 398), p. 96. 
of the Kettleman Hills geologic map, issued in 1934, the designation "Jacalitos sandstone" was used to contrast this part of the section with underlying units, but the lithology appears to be too diverse for the term "sandstone."

STRATIGRAPHY, LITHOLOGY, AND FOSSILS

OUTCROP SECTIONS OF JACALITOS FORMATION

Kreyenhagen Hills and Jacalitos Hills.-In the Kreyenhagen Hills and Jacalitos Hills the Jacalitos formation, as described by Arnold and Anderson, consists of sandstone, conglomerate, silty shale, and tuff and hos a thickness of 3,000 to 3,300 feet, ${ }^{74}$ excluding the silty shale and silty sandstone now referred to the underlying Reef Ridge shale. Marine fossils occur at various horizons; some beds in the lower part of the formation contain silicified wood, carbonaceous material, and leaf imprints. According to Nomland, ${ }^{75}$ a scour discontinuity is apparent at the base of the formation near the west end of Reef Ridge. Throughout much of the Kreyenhagen and Jacalitos Hills the base of the overlying Etchegoin formation was drawn by Arnold and Anderson at the base of the zone of blue sandstone, but southeast of Canons Creek the zone of blue sandstone was said to extend progressively farther down into the Jacalitos, reaching a horizon more than 1,000 feet below the top of the Jacalitos southeast of Big Tar Canyon. ${ }^{78}$ A collection of fossils from the upper part of the Jacalitos at Arnold and Anderson's locality 4642, 2 miles southeast of Big Tar Canyon, appears to support this claim, as it includes Lyropecten and Chione. In view, however, of the statement that near Zapata Creek the zone of blue sandstone in the Etchegoin has a thickness of more than 2,500 feet, whereas southeast of Big Tar Canyon the thickness is less than 800 feet, ${ }^{77}$ the possibility that this apparent downward extension of blue sandstone into the Jacalitos represents an overlap of Etchegoin may need investigation.

Northwest of Jacalitos Creek the Jacalitos overlaps onto Cretaceous rocks. ${ }^{78}$ This overlap was recognized by Arnold and Ariderson, but on the geologic map accompanying Bulletin 398 the overlapping strata are shown as Vaqueros (Temblor of present terminology) with the explanation in the legend that in the Alcalde Hills the Vaqueros possibly includes some Jacalitos.

Sandstones in the lower part of the Jacalitos along Canoas Canyon and Big Tar Canyon were reported by Bramlette ${ }^{79}$ to contain an abundance of fresh zoned

14 Arnold, Ralph, and Anderson, Robert, op. cit. (Bull. 398), pp. 98-104.

is Nomland, J. O., 'Tho Etchegoin Pliocene of middle California: California Univ,, Dopt. Geol. Bull., vol. 10, pp. 201-202, 1917.

70 Arnold, Ralph, and Anderson, Robert, op. cit. (Bull, 398), pp. 103-104.

" Idom, p. 118.

78 Idem, p. 108. Pack, R. W., and English, W. A., Ceology and oil prospects in Waltham, Priest, Bitterwater, and Peachtree Valleys, Calif.: U. S. Geol. Survey Bull. 581, pl. 5, 1014. Fenry, Gerard, McLure shale of the Coalinga region, Fresno and Kings Countios, Calif.: Am. Assoc. Petroleum Geologists Bull., vol. 14, p. 408, 1930

19 Bramlette, M. N., Heavy mineral studies on correlation of sands at Kettleman Hills, Calif.: Am. Assoc. Petroleum Geologists Bull., vol. 18, p. 1570, 1934. andesine, more or less altered volcanic glass, and ferromagnesian minerals. Hornblende is the most abundant ferromagnesian mineral in the lower part of the section, but at higher horizons augite is progressively more abundant. A large part of these sandstones consists of pyroclastic material, with which ordinary clastic debris is mixed. Most of the original glass has been altered to minute zeolitic crystals that appear to be clinoptilolite.

Anticline Ridge.-On the north slope of Anticline Ridge conglomerate, sandstone, and reddish and greenish clay, constituting a thickness of about 1,600 feet, underlie the Etchegoin formation and rest on upper Miocene sandstone-the Santa Margarita sandstone. $^{80}$ The absence of marine fossils, the abundance of petrified wood, the presence of leaf imprints and remains of land mammals, and the character of the rocks indicate that these strata are nonmarine. The reddish clay has a considerable amount of iron oxide and farther north, on the Domengine ranch, has been mined to make up heavy drilling mud for operations in the Kettleman Hills. On the south slope of Anticline Ridge the nonmarine formation overlaps the Santa Margarita sandstone and rests on the Temblor sandstone (Vaqueros of Arnold and Anderson). Two miles farther southwest the nonmarine formation in turn overlaps the Temblor sandstone and rests on Kreyenhagen shale. ${ }^{81}$ The nonmarine formation was referred to the Jacalitos by Arnold and Anderson. ${ }^{82}$ Though it may be the essential equivalent of the marine Jacalitos, the relations of the marine formation in the one area to the nonmarine formation in the other area are not known.

SUBSURFACE SECTION

The subsurface undifferentiated Etchegoin and Jacalitos formations in the Kettleman Hills are similar lithologically to the outcrop section in the Kreyenhagen and Jacalitas Hills. Blue sands are conspicuous in unweathered well samples apparently representing the Etchegoin formation. Tar sands have been encountered in the lower part of the section.

Goudkoff ${ }^{83}$ differentiated the Jacalitos and Etchegoin formations in the Kettleman Hills subsurface section on faunal and lithologic grounds and recognized nine zones in these formations. Sufficient samples are not now available to attempt recognition of more than generalized subdivisions.

The thickness of subsurface undifferentiated Etchegoin and Jacalitos formations is shown in the second table following. The total approximate thickness of the two formations in outcrop and subsurface sections is shown below.

\footnotetext{
${ }^{80}$ Arnold, Ralph, and Anderson, Robert, op. cit. (Bull. 398), pp. 107-108.

81 The representation of this overlap precisely along an east-west land section line on plate 1 of Bulletin 398 is probably $a$ drafting error, as it does not agree with the preliminary geologic map (Bull. 357, pl. 1).

82 Arnold, Ralph, and Anderson, Robert, idem.

83 Goudkoff, P. P., Subsurface stratigraphy of Kettleman Hills oil field, Calif.
} Am. Assoc. Petroleum Geologists Bull., vol. 18, pp. 438-443, 1934. 
Approximate thickness, in feet, of undifferentiated Etchegoin and Jacalitos formations in outcrop and subsurface sections Feet

Outcrop section in Kreyenhagen Hills _. . . . - 6, 000 Outcrop section on Anticline Ridge ............... 3, 300 Outcrop and subsurface sections in Kettleman Hills: North end of North Dome (Lillis-Welch No. 1, sec.

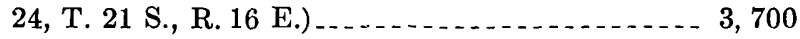
Central part of North Dome . . . . . . . . . . . 4, 400

Central part of Middle Dome... . . . . . . . . . 5, 100 South Dome (Ohio Smith No. 1, sec. 35, T. 24 S.,

R. 19 E.) _... 5, 300

The undifferentiated Etchegoin and Jacalitos consist chiefly of sandy shale, clay shale, and sand. The following table, compiled from well logs, shows the percentage of these constituents in nine wells spaced at average intervals of 2.4 miles from the north end of North Dome to South Dome.

The southward increase in thickness appears to be due mainly to a general southward increase in the percentage of sand. The records of the Huffman and Burbank wells, however, show marked exceptions to this general trend. Possibly the exceptions are partly due to logging of the same type of lithology as sand or as sandy shale in different wells. The sands presumably contain much tuffaceous material, as in the outcrop sections, and such material might be recorded as sand or sandy shale depending on individual preference.

Principal lithologic constituents in subsurface undifferentiated Etchegoin and Jacalitos formations in Kettleman Hills

\begin{tabular}{|c|c|c|c|c|}
\hline Well & Sand & Sandy shale & Clay shale & $\begin{array}{l}\text { Thickness of } \\
\text { formations }\end{array}$ \\
\hline 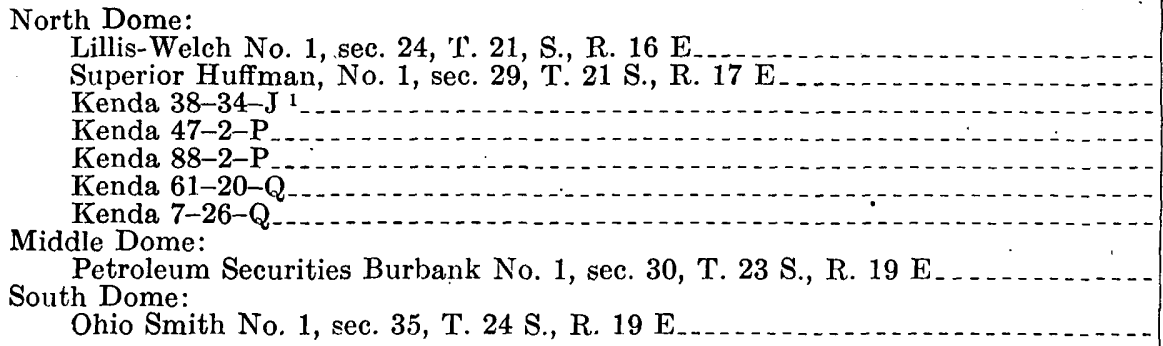 & $\begin{array}{r}\text { Percent } \\
20 \\
6 \\
34 \\
20 \\
21 \\
27 \\
51 \\
6 \\
49\end{array}$ & $\begin{array}{r}\text { Percent } \\
26 \\
77 \\
43 \\
53 \\
63 \\
59 \\
23 \\
. \quad 60 \\
60 \\
18\end{array}$ & $\begin{array}{r}\text { Percent } \\
54 \\
17 \\
23 \\
27 \\
16 \\
14 \\
26 \\
\\
34 \\
\\
33\end{array}$ & $\begin{array}{l}\text { Feet } \\
3,670 \\
4,480 \\
4,500 \\
4,445 \\
4,500 \\
4,500 \\
4,275 \\
4,350 \\
3,780\end{array}$ \\
\hline Average & 26 & 47 & 27 & 4,280 \\
\hline
\end{tabular}

1 The term "Kenda" is an acrostic abbreviation for Kettleman North Dome Association. . This association and the Standard Oil Co. of California have adopted for their wells a system of notation in which the first number represents the location of the well in a section, the second number represents the section, and the letter represents the township. For outline maps showing the system of well location and township designations see plate 51.

According to well logs, the undifferentiated Etchegoin is made up of thick sand zones separated by relatively thin shale zones. The lower, or Jacalitos, part of the section is marked by a slight increase in the percentage of shale. The following generalized subdivisions may be recognized in descending order: (1) Pseudocardium zone, (2) upper sand zone,. (3) lower sand and shale zone.

Pseudocardium zone.-Fragments of Pseudocardium ["Mulinia"] shells recognized in ditch samples indicate a zone near the top of the subsurface section that may be designated the Pseudocardium zone. This zone doubtless includes a greater thickness than the upper Pseudocardium zone (upper Mulinia zone) of the outcrop section in North Dome. Wells in the central part of North Dome start at a horizon below the subsurface Pseudocardium zone. Goudkoff ${ }^{84}$ recorded an Anadara ["Arca"]-Mya-Pseudocardium ["Mulinia"] association, strongly suggestive of the outcrop Pseudocardium-Anadara zone, from Chanslor-Canfield-Midway McGlashan No. 1 well, sec. 17 , T. 24 S., R. 19 E., at a depth between 720 and 970 feet. If these fossils represent the Pseudocardium-Anadara zone that was used in Middle Dome as the datum for the structure

84 Goudkoff, P. P., op. cit. (Am. Assoc. Petroleum Geologists Bull., vol. 18), pp. $439,442$. contours shown on plate 51 the contours are in error at this locality by a margin of 150 to 400 feet.

Upper sand zone.-A thick zone consisting of about 2,500 feet of sand interbedded with minor beds of sandy shale and light-colored clay immediately underlies the Pseudocardium zone. Wells in the central part of North and Middle Domes and in the southern part of South Dome start in this zone. The sand is recorded generally as fine-grained gray sand, but some of it is logged as green or bluish-green sand, and the recorded texture ranges from fine-grained to fairly coarse grained.

Lower sand and shale zone.-The lower half of the undifferentiated Etchegoin and Jacalitos consists in descending order of (1) 200 to 400 feet of greenish clay shale, (2) about 500 feet of fine-grained gray sand, (3) 200 to 400 feet of dark-gray clay and sandy clay, (4) about 1,000 feet of fine-grained gray and greenishgray sand, and (5) 200 to 400 feet of dark bluish-gray claystone and siltstone. Sand dollars and mollusks occur in some beds of sand, and Foraminifera and diatoms in some beds of shale and clay. Carbonized plant fragments are common in both sand and shale. Goudkoff ${ }^{85}$ recorded Foraminifera and the characteristic Jacalitos mollusks Lyropecten "terminus" ["Pecter

os Idem, $\mathrm{p} 412$ 
estrellanus terminus"] and Dosinia jacalitosana from this part of the section.

\section{AGE AND CORRELATION OF JACALITOS FORMATION}

The age and correlation of outcrop sections of the Jacalitos formation are discussed under the heading "Age and correlation of exposed formation." Approximately the lower two-thirds of the subsurface undifferentiated Etchegoin and Jacalitos in North and Middle Domes and most of the section in South Dome correspond presumably to the Jacalitos of the Kreyenhagen and Jacalitos Hills. Goudkoff ${ }^{86}$ correlated diatomite at the top of the section exposed on Chico Martinez Creek, in the Coast Range foothills 40 miles southerst of the Kettleman Hills, and diatomaceous silt and siltstone in the subsurface section in the nearby Lost Hills, North Belridge, and Belridge fields (fig. 15) with the Jacalitos of the Coalinga district. Diatoms are the most abundant fossils in the strata involved in the proposed correlation, and so far as known the diatom floras have not been compared with the sequence of floras in the Coalinga district.

\section{MIOCENE SERIES}

\section{CLASBIFICATION AND NOMENCLATURE}

The present confusion in the classification and nomenclature of Miocene strata in the Coalinga and nearby districts illustrates the difficulties encountered in attempting to establish a satisfactory classification and stratigraphic terminology for formations that change rapidly in thickness, lithology, and fossil content and that show virtually complete sections at one locality and discontinuities and overlaps at adjoining localities. This confusion has become so acute that, instead of affording a ready means for transferring concepts, the stratigraphic names are so heavily loaded with qualifications that they really lose the primary usefulness of names. Consideration of the history of the classification and terminology of Miocene formations in the Coast Ranges and of the principles involved is beyond the scope of this report. Nevertheless, certain aspects of these matters need consideration in justification of the system adopted.

The principle that lithologic constitution is the controlling basis for the subdivisions designated formations was long ago adopted by the Geological Survey, ${ }^{87}$ and this principle has recently been restated and recommended by several organizations. ${ }^{88}$ The advantages of this basis in the economic application of geology and in the requirements of the layman

\footnotetext{
26 Cloudkoff, P. P., op. cit., pp. 443-447,

87 Powell, J. W.. Conference on map publication: U. S. Geol. Survey 10th Ann. Rept., pt. 1, p. 6.1, 1890 . Walcott, C. D., Nomenclature and classification for the geologlc atlas of the United States: U. S. Geol. Survey 24th Ann. Report., pp. 21-27. 1803.

89 Ashley, G. H., and others, Classification and nomenclature of rock units: Geol. Soc. America Bull., vol. 44, p. 431, article 5 (b), 1933; Am. Assoc. Petroleum Ceolo. gists Bull., vol. 17, p. 850, 1933.
}

as. shown by Powell ${ }^{89}$ are evident. Moreover, this basis has an underlying genetic significance; a change, for example, from sandstone to shale denotes an environmental change controlled by events that are generally significant in the geologic history of a region. If lithologic constitution is accepted as the basis for subdivision, it follows that a formation need not be of the same age in different localities; in fact, the age may differ markedly from place to place, ${ }^{90}$ for the environmental conditions that control the genetic unity of a formation may extend over larger or smaller areas from time to time.

Stratigraphic subdivisions based on criteria of chronologic value are essential in any geologic investigation-particularly so perhaps in the Coast Ranges, where striking facies changes occur within short distances-for the geologic history of a region cannot be deciphered without the correlations that are based. on them. Paleontologic subdivisions, called zones, ${ }^{91}$ generally constitute the most readily available basis for attempting to establish chronologic relations over extensive areas. Among some paleontologists the simple term "zone" has fallen into disrepute on account of its lack of precision, but it is still a useful term and its indefiniteness is an advantage, as it does not imply precise knowledge as to the absolute range of species and faunas. ${ }^{92}$

Yet it is essential to keep in mind that formations consisting of a lithologic unit, or of subordinate units, that have a genetic unity are not to be confused with faunal zones. The two systems of subdivisions are more or less incompatible and should be treated as wholly independent, a matter that was emphasized many years ago by H. S. Williams. ${ }^{93}$ Chronologic subdivisions based on fossils or other criteria of chronologic value may be independently superimposed on lithologic subdivisions.

The classification and terminology of Coast Range Miocene strata have suffered from the misconception that the formations, originally based on lithologic subdivisions, represent essential time units each characterized by a distinct fauna-a misconception against which Louderback protested. ${ }^{94}$ Detailed mapping and work in micropaleontology confirm Louderback's contention that similar lithologic units in different regions overlap chronologically, and that contemporaneous sandstone and shale faunas are quite different, as might be expected. The recent development of micropaleontology, particularly the study of Foraminifera, on which the

\footnotetext{
89 Powell, J. W., Methods of geologic cartography in use by the United States Geological Survey: 3d Internat. Geol. Cong. Compte rendu, p. 232, 1888.

${ }^{80}$ Ashley, G. H., and others, op. cit. (Geol. Soc. America Bull., vol. 44), p. 432. article 6.

91 Idem, p. 430, article 2 (d); p. 440, article 16 (d).

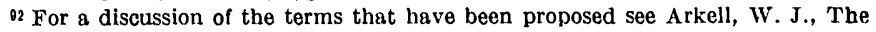
Jurassic system in Great Britain, pp. 14-37, Oxford, 1933.

93 Williams, H. S., Dual nomenclature in geological classification: Jour. Geology, vol. 2, pp. 145-160, 1894 .

${ }^{4}$ Louderback, G. D., The Monterey series in California: California Univ., Dept. Geology, Bull., vol. 7, pp. 177-241, 1913
} 
greatest amount of work has been done so far, is of special significance, for at many places a large part of these Miocene beds consist of fine-grained rocks in which other fossils are rare or absent. In the light of new data on chronology, some geologists claim that the formations should be defined in terms of the time interval represented in the type region, or in more complete sections should the section in the type region be found to be incomplete, as is often the case in the Coast Ranges. But this method attempts to combine two essentially incompatible systems of subdivision and results in a nomenclature that needs extensive qualifications and is subject to violent changes. And the defining of formations in terms of faunal zones leads to the position of recognizing a formation on a lithologic basis in the type region but perhaps in no other region. It would, of course, be advantageous to have maps on which both lithologic and chronologic subdivisions, based on faunal zones, are shown, but inasmuch as lithologic units are the units dealt with in most engineering and industrial applications of geology and inasmuch as even reconnaissance lithologic maps are available for only a small part of the Coast Ranges, the time when lithologic-chronologic maps may be made appears to be rather distant.

Recognizing the difficulty of expressing the strictly chronologic aspects of geologic events in terms of lithologic units that have a changing chronologic value, R. M. Kleinpell ${ }^{95}$ has proposed a chronologic subdivision of the Coast Range Miocene based principally on zoning by means of. Foraminifera. It is expected that this proposed chronologic subdivision will provide an impetus in clarifying the Miocene history of the Coast Ranges and in stimulating attempts to refine the chronology. In view of the desirability of distinguish. ing more sharply between lithologic and chronologic subdivisions and in view of current American practice of giving geographic names to lithologic subdivisions, there appears to be some doubt as to the advisability of applying geographic names in adjective form to the larger chronologic subdivisions designated stages by Kleinpell, for faunal designations seem particularly appropriate for faunal units. The need for distinguishing by formal terms faunal units of different rank is hardly urgent in view of the elastic concept involved in the term "zone." "That there is danger of confusing lithologic and faunal systems of subdivisions is apparent from the tentative proposal to introduce the name "Reliz formation," ${ }^{96}$ which is likely to be confused with Kleinpell's Relizian stage. Kleinpell's designations have, however, the advantage of avoidance of awkward terms such as "lower upper Miocene."

\footnotetext{
95 Kleinpell, R. M. Difficulty of using cartographic terminology: Am. Assoc. Petroleum Geologists Bull., vol. 18, pp. 374-379, 1934: Proposed biostratigraphic classification of California Miocene [abstract]: Geol. Soc. America Proc., 1934, pp. 390-391: Miocene stratigraphy of California, pp. 87-135, Tulsa, Am. Assoc. Petroleum Geologists, 1938.

os Goudkoff, P. P., op. cit. (Am. Assoc. Petroleum Geclogists Bu.l, vol. 18), p. 451 (footnote).
}

The subsurface Miocene section in the Kettleman Hills consists of the following three main lithologic units in descending order: (1) soft silty shale, (2) hard porcelaneous mudstone, (3) sandstone with minor shale units. The names that are used for these major units, the corresponding units recognized by drillers and oil operators, and the names used in Bulletin 398 for the outcrop section on Reef Ridge are shown in the following table.

Miocene formations in Kettleman Hills subsurface section

\begin{tabular}{c|l|l}
\hline Name used in this report & $\begin{array}{l}\text { Corresponding major } \\
\text { unit recognized by } \\
\text { drillers and oil oper- } \\
\text { ators }\end{array}$ & $\begin{array}{l}\text { Name used in Bulletin 398 } \\
\text { for outcrop section on } \\
\text { Reef Ridge }\end{array}$ \\
\hline Reef Ridge shale. & Caving shale. & $\begin{array}{l}\text { Transition zone in- } \\
\text { cluded in Jacalitos } \\
\text { formation or Santa } \\
\text { Margarita (?) for- } \\
\text { mation. }\end{array}$ \\
\hline $\begin{array}{c}\text { McLure member of } \\
\text { Monterey shale. }\end{array}$ & Brown shale. & $\begin{array}{l}\text { Santa Margarita (?) } \\
\text { formation. }\end{array}$ \\
\hline Temblor sandstone. & Temblor sand. & Vaqueros sandstone. \\
\hline
\end{tabular}

This classification is the same as the classification proposed by Gester and Galloway, ${ }^{97}$ and aside from a minor difference in formal nomenclature, the terminology also is the same. The correspondence of the formally named units to the informal units of drillers and oil operators is an indication that this classification is based on lithologic features. Details of the lithology, stratigraphy, paleontology, and mineralogy are lacking, or are not available, in many parts of the section, not only in the Kettleman Hills but also in nearby outcrop sections. It is by no means certain that the classification here adopted adequately reflects the principal events in the Miocene history of the region. Many discontinuities may be hidden within the principal lithologic units; indeed, according to Goudkoff, ${ }^{98}$ such discontinuities are recognizable, and the discontinuities and faunal zones are adequate grounds for a different classification.

Plate 47 shows the relations of the Kettleman Hills Miocene section to nearby outcrop sections, based on fossil and heavy-mineral data; and figure 14 is a generalized representation of the inferred chronologic relations. Regardless of the interpretation of the chronologic relations of the Miocene formations in the areas covered, the sections on plate 47 show several features: (1) The regional southward thickening from Anticline Ridge to Chico Martinez Creek, where the Miocene section is almost seven times as thick as on Anticline Ridge, 65 miles distant; (2) the southward decrease in the proportion of coarse detrital constituents, and conversely the southward increase in the proportion of

\footnotetext{
${ }^{07}$ Gester, G. C., and Galloway, John, Geology of Kettleman Hills oil field, Calif.: Am. Assoc. Petroleum Geologists Bull, vol. 17, pp. 1174-1182, 1933.

${ }_{98}$ Goudkoff, P. P., op. cit. (Am. Assoc. Petroleum Geologists Bull., vol. 18), pp.
} 438-469. 
NW.

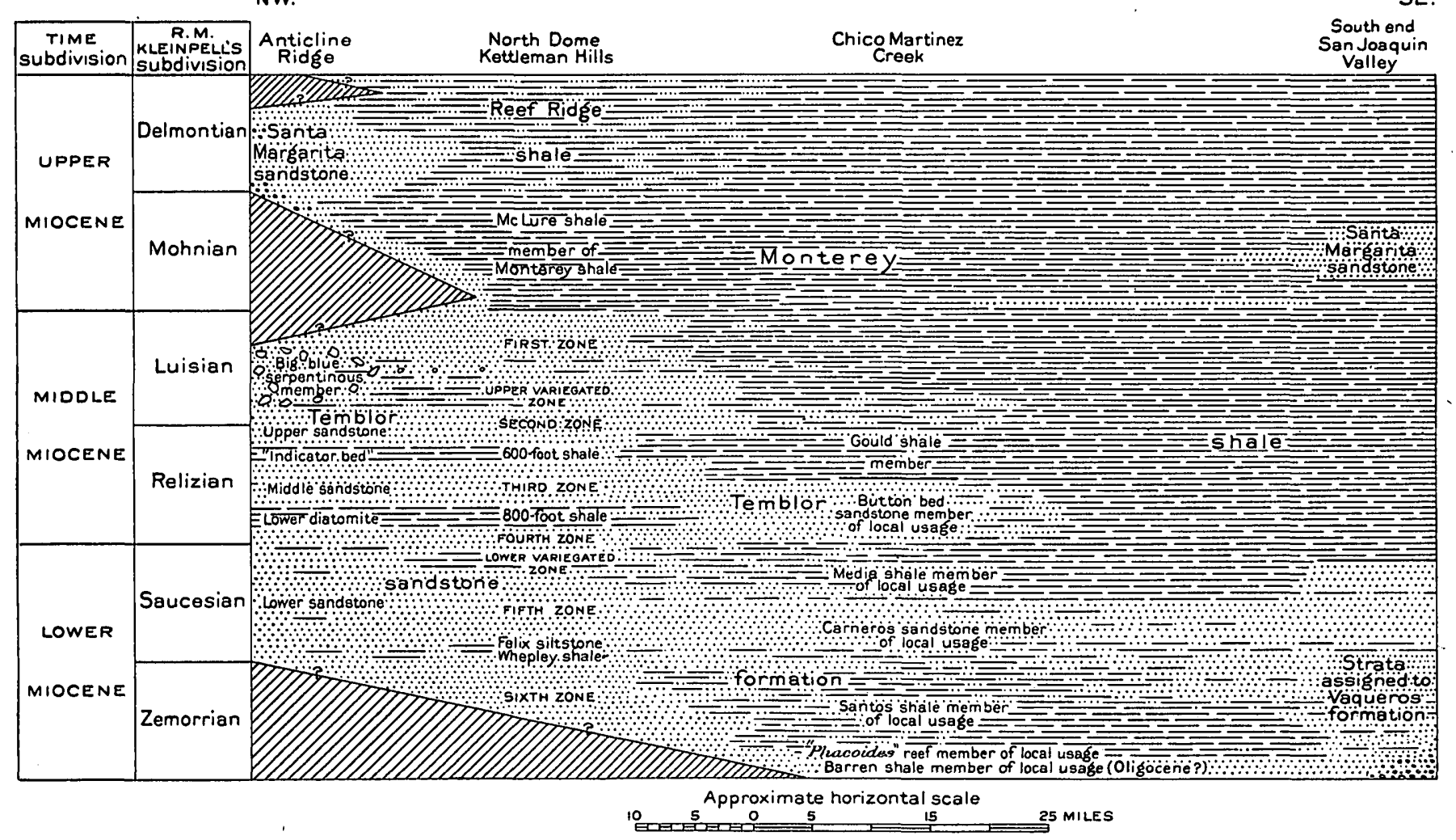

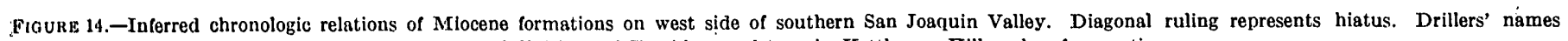
used for subdivisions of Temblor sandstone in Kettleman Hills subsurface section.

siliceous shale of Monterey type; (3) the eastward thickening from Reef Ridge to the Kettleman Hills.

\section{REEF RIDGE SHALE}

Underlying the Jacalitos formation is a relatively thin lithologic unit consisting chiefly of soft silty shale with subordinate beds of silty sandstone. This unit is the caving shale of drillers and has recently been named the Reef Ridge shale. ${ }^{99}$ The type region is along the foot of Reef Ridge. Arnold and Anderson considered the Reef Ridge shale as a transition zone between the :Santa Margarita (?) formation (McLure shale member of Monterey shale) and the Jacalitos formation. Along the greater part of Reef Ridge they mapped the transition zone with the Jacalitos, ${ }^{1}$ but near the southeast end of Reef Ridge ${ }^{2}$ most of the transition zoneperhaps all-and in McLure Valley ${ }^{3}$ the entire transition zone was mapped as part of the Santa Margarita (?) formation.

\section{STRATIORAPHY, IITHOLOGY, AND FOSSILS}

OUTCROP SECTION ALONG REEF RIDGE

Along the foot of Reef Ridge are sharp-crested spurs, which are formed by hard beds in the McLure shale member of the Monterey shale. A narrow depression

\footnotetext{
of Gester, G. C., and Galloway, John, op. cit. (Am. Assoc. Petroleum Geologists Bull., vol. 17), pp. 1174-1176, 1933. Barbat, W. F., and Johnson, F. L., Stratigraphy and Foraminifern of the Reef Ridge shale, upper Miocene, Calif.: Jour. Paleontology vol, 8, pp. 3-17, pl. 1, 1934 .

1 Arnold, Ralph, and Anderson, Kobert, op. cit. (Bull. 398), pp. 92, 93, 98, 99, 100 :101, 103, fig. 4.

Idem, p. 82 (uppermost member of sertion).

2 Idem, p. 104.
}

between these spurs and low rounded hills formed by sandstone in the lower part of the Jacalitos formation is occupied by the Reef Ridge shale (pl. 48). Exposures of the shale and interbedded sandstone are found along stream banks, as along Zapata Canyon and Jasper Canyon, but for the most part these rocks are poorly exposed. They form a narrow belt of characteristic clayey soil that is deeply cracked during the long dry season, indicating, as Bramlette suggests, that they contain much bentonitic material. Foraminifera from a locality in this region are considered in the discussion of fossils from wells in the Kettleman Hills.

As recorded by Barbat and Johnson, the thickness of the Reef Ridge shale along the foot of Reef Ridge ranges from 182 to 855 feet. The range in thickness was doubtfully attributed to erosion before the deposition of the Jacalitos formation, but it was recognized that the apparent variation may be due to inadequate exposures and to uncertainty as to the limits of the formation. Arnold and Anderson recorded a thickness of 400 to 600 feet for the transition zone corresponding to the Reef Ridge shale. ${ }^{4}$ In a section measured by M. N. Bramlette, K. E. Lohman, and R. M. Kleinpell along a ravine about 200 yards north of Big Tar Canyon the thickness of the Reef Ridge shale appears to be about 280 feet, but the base and top are indefinite.

Details of the stratigraphy of the Reef Ridge shale and of its relations to the Jacalitos formation and the

\footnotetext{
- Arnold, Ralph, and Anderson, Robert, op. cit. (Bull. 398), pp. 92 (uppermost
} member of section), 99, 101. 102 (lowest member of section). 
McLure shale are not available and are apparently not well known. ${ }^{5}$ Near Jasper Canyon the Jacalitos was described as resting on an irregular surface of shale now referred to the Reef Ridge, ${ }^{6}$ a relation that may be the result of submarine scouring. In Zapata Canyon a basal sandstone of the Reef Ridge shale is described as indicating discontinuity, and north of the west end of Reef Ridge the Reef Ridge shale is said to overlap onto Cretaceous rocks, ${ }^{7}$ as does the Jacalitos formation. It seems probable that the Reef Ridge shale represents a transition from the siliceous shale of the McLure to the sandstone of the Jacalitos formation.

\section{SUBSURFACE SECTION}

The strata immediately underlying the Jacalitos formation in the Kettleman Hills subsurface section are similiar lithologically and faunally to the Reef Ridge shale and are assigned to that formation. With few exceptions the top of the Reef Ridge shale is recorded

\footnotetext{
- For a recent discussion of these features published after the present report was prepared see Seigfus, S. S., Stratigraphic features of Reef Ridge shale in southern California: Am. Assoc. Petroleum Geologists Bull., vol. 23, pp. 24-44, 5 flgs., 1939. 6 Nomland, J. O., The Etchegoin Pliocene of middle California: California Univ., Dept. Geology, Bull, vol. 10, pp. 201-202, 1917.

7 Barbat, W. F., and Johnson, F. L., op. cit., p. 6.
}

from ditch samples and is placed at a horizon where shale predominates over sand. Inasmuch as the lower part of the Jacalitos consists of alternating beds of sand and shale and inasmuch as the Reef Ridge shale contains some sand, the top of the formation is generally uncertain. The base of the formation is perhaps more satisfactorily determined by the occurrence of hard shale in the underlying McLure shale, but soft shale in the upper part of the McLure may be included in the Reef Ridge shale. Strata assigned to the Reef Ridge shale range in thickness from about 175 feet to about 750 feet in North Dome. In Middle Dome the thickness is about 725 feet and in South Dome about 675 feet. The average thickness in the entire area is about 500 feet. Owing to the presence of tough, sticky blue shale, which tends to slough off from the walls of wells, the Reef Ridge shale is generally called by drillers the caving shale or heaving shale.

As recorded in logs and as represented by cores that were examined, the subsurface Reef Ridge shale consists of various types of shale, sandy shale, and sand. The percentage of principal lithologic constituents in nine wells is shown in the following table, compiled from logs.

\section{Principal lithologic constituents in subsurface Reef Ridge shale in Kettleman Hills}

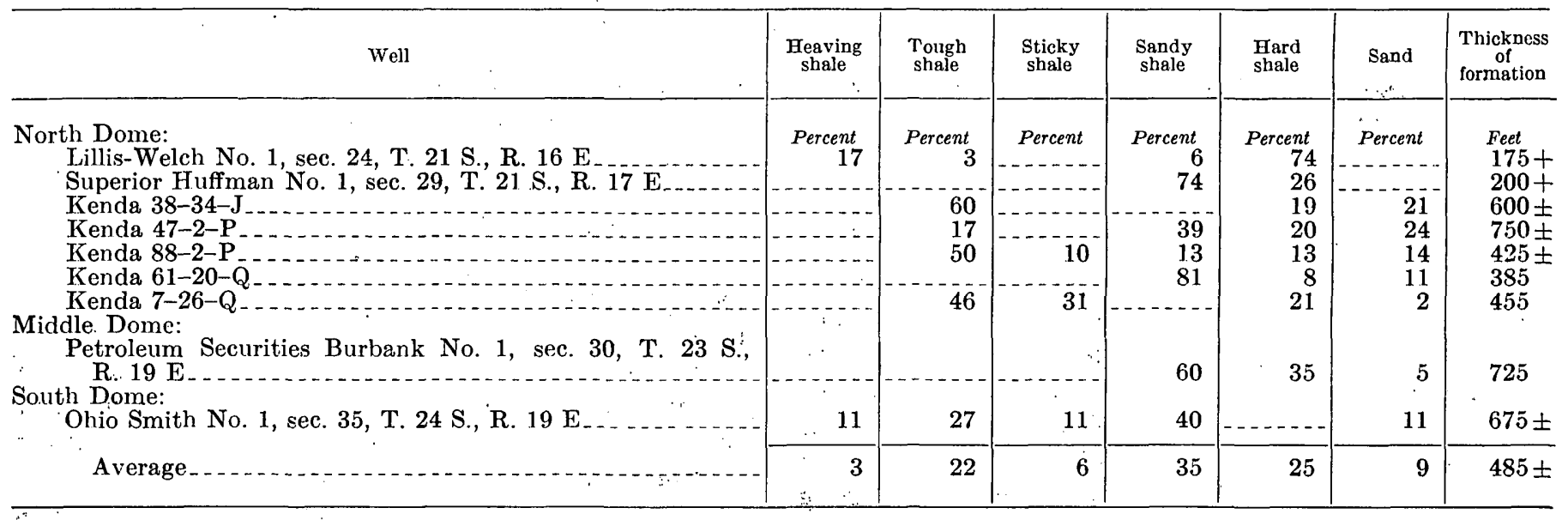

The upper part of the Reef Ridge shale in the northwestern part of North Dome consists of sandy shale, generally grayish rather than bluish. Sands of varying thickness are recorded in wells southeast of Kenda well 38-34-J but appear to be absent farther northwest.

Goudkoff ${ }^{8}$ reported that the upper part of the Reef Ridge shale--his I zone, tentatively assigned to the Jacalitos, and the upper part of his $\mathrm{J}$ zone, assigned to the McLure-is missing in wells on the crest of North Dome. The discontinuity advocated by Goudkoff is not recognizable on the basis of available data.

According to Bramlette, ${ }^{9}$ sands in the lower part of the subsurface Reef Ridge shale have a distinct miner, Goudkoff, P, P., op. cit. (Am. Assoc. Petroleum Geologists Bull., vol. 18), pp. 442-443, 451-452.

Bramlette, M. N., op. cit. (Am. Assoc. Petroleum Geologists Bull., vol. 18), p 1570. alogical composition. They contain a bentonitic matrix or groundmass that shows characteristic swelling in water. The sand grains include very abundant andesine phenocrysts, much biotite, spherules of barite, and rhombs of secondary dolomite. At higher horizons in the Reef Ridge shale the pyroclastic material has a hornblende andesite composition, grading upward into the andesitic sands of the Jacalitos formation.

Foraminifera from the Reef Ridge shale of wells in the Kettleman Hills and in the North Belridge field have been described by Barbat and Johnson, ${ }^{10}$ who also listed a few mollusks recovered from cores. ${ }^{11}$ Foraminifera from the lower part of the Reef Ridge shale of the Kettleman Hills were also recorded by Goudkoff, ${ }^{12}$

\footnotetext{
${ }^{10}$ Barbat, W. F., and Johnsön, F. L.," op: cit.

11 Idem, p. 8.

12 Goudkoff, P. P., op. cit. (Am. Assoc. Petroleum Geologists Bull., vol. 18), p. 452.
} 
who placed this part of the caving shale in the McLure shale. R. M. Kleinpell has identified the following Foraminifera in core material from the Kettleman Hills and in an outcrop sample from the foot of Reef Ridge. Some of the characteristic species are shown on plate 49 .

\section{Foraminifera from Reef Ridge shale of wells in Kettleman Hills and of outcrop at foot of Reef Ridge}

[Identifications by R. M. Kleinpell. R, rare; F, few; C, common; A, abundant]

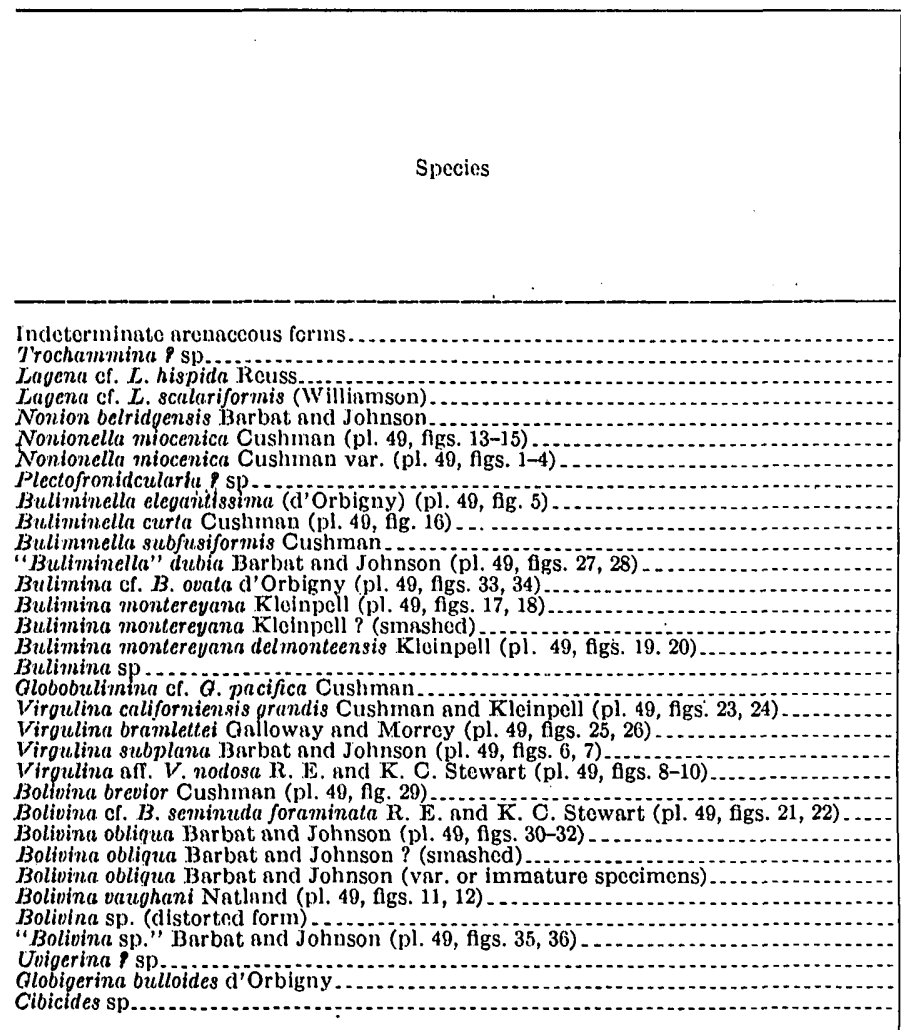

Reef Ridge. first prominent ravine northwest of Big Tar Canyon, 140 feet. below owermost sandstone of Jacalitos formation. R. M. Kleinpell, collector.

2. Konda well 27-34-J, depth 5,198 feet.

3. Sume well, depth 5,204 feet.

4. Standard woil $8-1-P^{3}$, depth 4,875 to 4,891 feet.

5. Sithe well, depth 4,881 fent.

6. Petroloum Securities Robinson well No. 1, sec. 14, T. 22 S., R. 17 E., depth 8,296 to 8,300 feot.

7. Bolsa Chica Ferguson well No. 1, sec. 24, T'. 22 S., R. 17 E., depth 6,929 to 6,939 , 8 .

Stume well, depth 7,038 to 7,015 feet.

Kleinpell's comments on these Foraminifera are as follows:

The fauna of the Reef Ridge shale is a well-defined local unit, characterized by the abundance of Nonionella miocenica (pl. 49, figs. 13-15), Bulimina montereyana (pl. 49, figs. 17, 18), Bulimina montereyana delmonteentsis (pl. 49, figs. 19, 20), Virgulina californiensis grandis (pl. 49, figs. 23, 24), and the presence of Bolivina obliqua (pl. 49, figs. 30-32). The strata containing this fauna may be referred to the Bolivina obliqua zone, ${ }^{13}$ but the upper limit of the zone in this region is uncertain. A similar fauna. has been recorded from a well in Salinas Valley, where it occurs immediately above a fauna representing the "middle Nonicn fauna" of the Monterey shale in the type region.14 The species of the family Buliminidae, and particularly the presence of Bolivina obliqua, suggest correlation of the Reef Ridge shale faun ${ }^{\prime}$ with the fauna of Hoots' lithologic unit $18^{15}$ in the upper part of the Modelo formation of the Santa Monica Mountains. Buliminella.curta (pl. 49, fig. 16), Buliminella dubia (pl. 49, figs.

13 Klólnpoll, R. M., Mioceno stratigraphy of California, pp. 134-135, Tulsa, Am. Assoc. Potroleum Qeologists, 1938.

"I ldem, fig. 14 (pocket).

15 Hroots, H. W., Geology of the eastern part of the Santa Monica Mountains, Los Angeles County, Calif.: U. S. Gool. Survay Prof. Paper.165, pp. 103, 112-114, 1931.

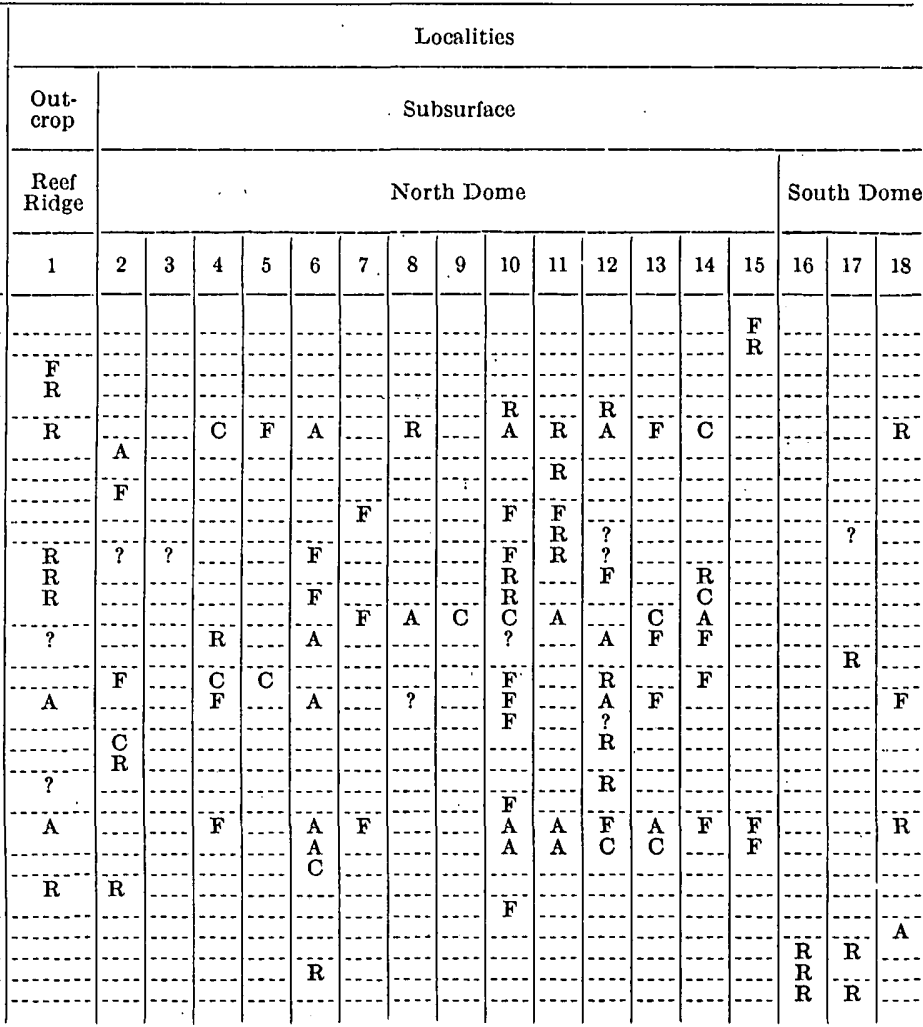

9. Same well, depth 7,107 to 7,119 feet.

10. Same well, depth 7,385 to 7,394 feet.

12. Standard well $87-27-\Omega$, depth' 5,100 to 5,107 feet.

13. Same well, depth 5,107 to 5,126 feet.

14. Same well, depth 5,126 to 5,144 feet.

15. Same well, depth 5,187 feet.

16. Chanslor-Canficld-Midway Sahlen well No.1, sec. 28, T. 24 S., R. 19 E.. depth 5,511 feet.

17. Same well, depth 5,623 feet.

18. Same well, depth 5,775 feet.

27, 28), Bulimina montereyana, Virgulina californiensis grandis, and Bolivina brevior (pl. 49, fig. 29) indicate a Miocene age rather than Pliocene, but it would not be surprising to find that some of these species occur higher than is now apparent. Buliminella curta is recorded from strata in the Los Angeles Basin referred to the lower Pliocene, ${ }^{10}$ but these strata may be slightly older than the lower Pliocene of other localities in the Los Angeles and Ventura Basins.

The collections from Kenda well 27-34-J and from the Sahlen well at depths of 5,511 and 5,623 feet represent a dwarf fauna. These collections differ from others assigned to the Reef Ridge shale in the absence of Bolivina obliqua and in the presence of Virgulina aff. $V$. nodosa and Cibicides sp. They may be of lower Pliocene age, but this appears improbable.

\section{AGE AND CORRELATION}

The Reef Ridge shale is considered of upper Miocene age. According to Kleinpell, its Foraminifera have Miocene affinities. He considers that the formation

10 Stewart, R. E., and Stewart, K. C., "Lower Pliocene" in eastern end of Puente Hills, San Bernardino County, Calif.: Am. Assoc. Petroleum Geologists Buli., vol. 14, no. 11, pp. 1445-1450, 1930. 
corresponds closely to his Delmontian stage ${ }^{17}$ and that the formation is probably the equivalent of the upper diatomite member in the type region of the Monterey shale (Galliher's lithologic member 1$)^{18}$. On faunal and lithologic grounds the Reef Ridge-Jacalitos boundary is a convenient Miocene-Pliocene boundary.

Barbat and Johnson ${ }^{19}$ recorded Reef Ridge Foraminifera from the upper part of the subsurface Miocene section in the Belridge field (Ohio Bear State No. 23), 45 miles southeast of the Kettleman Hills, and suggested that these strata are to be correlated with the unnamed diatomaceous shale member at the top of the Miocene section along the nearby mountain front on Chico Martinez Creek. (See section, p. 125.)

On general lithologic grounds assignment of the entire shale unit between the Jacalitos formation and the Temblor sandstone to one formation rather than assignment of formation rank to the Reef Ridge shale may be justified. In outcrop sections, however, the Reef Ridge shale does not include shale of Monterey type, whereas the underlying McLure shale does.

\section{MCLURE SHALE MEMBER OF MONTEREY SHALE}

The most characteristic and widespread Miocene formation in the Coast Ranges consists of a considerable thickness, generally several thousand feet, of rocks characterized by the preponderance of various kinds of hard siliceous shale and soft shale containing microscopic siliceous fossils. These strata include varying proportions of ordinary sedimentary rocks and of the unusual siliceous rocks, but the siliceous rocks, diverse as they are, give the formation a characteristic unity. The pioneer workers in the Coast Ranges realized this unity, ${ }^{20}$ and so has every geologist since, but the unity has become lost in the involved stratigraphic nomenclature that has come into usage.

Monterey shale, or Monterey formation, is the earliest name for Coast Range Miocene rocks characterized by this lithology. The name "Monterey formation" was first used by Blake in $1855 .{ }^{21}$ It is quite improbable, as Louderback ${ }^{22}$ maintained, that Blake intended to introduce a formal stratigraphic name; he did not use the name in two accounts of the geology at Monterey. ${ }^{23}$ Nevertheless his description is quite ade-

\footnotetext{
17 Klenpell, R. M., op. cit., p. 165.

18 Galliher, E. W., Geology and physical properties of building stone from Carmel Valley, Calif.: Mining in California (Division of Mines), vol. 28, no. 1, p. 24, fig. 3, 1932.

io Barbat. W. F., and Johnson, F. L., op. cit., pp. 8-9.

20 Trask, J. B., Report on the geology of the Coast mountains [Calif.], pp. 28-29 [Sacramento], 1855. Blake, W. P., Geological report: U. S., Pacific R. R. Expl., vol. 5, pt. 2, p. 189, 1857. Whitney, J. D., Geological survey of California, Geology, vol. 1, Report of progress and synopsis of the field work from 1860 to 1864, pp. 74, 153-154, 1865.

al Blake, W. P., Notice of remarkable strata containing the remains of Infusoria and Polythalmia in the Tertiary formation of Monterey, Calif.: Acad. Nat. Sci. Philadelphia Proc., vol. 7, p. 331, 1855.

${ }^{22}$ Louderback, G. D., The Monterey series in California: California Univ., Dept. Creology, Bull., vol. 7, pp. 193-195, 1913.

${ }^{23}$ Blake, W. P.. Observations on the physical geography and geology of the coast of California from Bodega Bay to San Diego: U. S. Coast Survey Rept. Superintendent 1855, app. 65, pp. 390-392, 1856; Geological report: U. S., Pacific R. R. Expl., vol. 5, pp. 180-182, 1857.
}

quate. The type region of the Monterey shale is in the vicinity of Monterey, where it has a thickness of about 3,000 feet and rests on granitic rocks. ${ }^{24}$ The basal part, which ranges in thickness from a few inches to 200 feet, consists of sandstone and calcareous shale.

Until 1913 Monterey was used as the name for a unit of formation rank in publications of the Geological Survey dealing with the Coast Ranges, but in that year Monterey was raised to group rank to include the Vaqueros sandstone, which underlies the shale in some districts. Inasmuch as the use of the same name for a group and for a formation within the group is ambiguous and confusing, this action seemed to demand the introduction of a new name- †Salinas shale ${ }^{25}$-for the shale formerly called Monterey in an area adjoining the type region of the Monterey. ${ }^{26}$ A further complication was introduced by the proposal of another name- $†$ Maricopa shale-for the shale along the south and west sides of the San Joaquin Valley also formerly referred, wholly or in part, to the Monterey shale. When the name Maricopa was introduced ${ }^{27}$ it apparently was intended simply as a replacement of the former name Monterey shale, a replacement made necessary by the raising of Monterey to group rank, but later it was retained on the grounds that whatever its lithologic character it embraces the chronologic equivalent not only of part of the original Monterey shale but also of the overlying Santa Margarita formation, ${ }^{28}$ grounds that are not now considered sufficient for a new name.

The raising of Monterey to group rank was based on the view, then entirely reasonable, that the Vaqueros sandstone and Monterey shale together constitute a stratigraphic unit of varying lithologic facies separated from the overlying Santa Margarita sandstone by a widespread unconformity, or from the overlying San Pablo formation by an unconformity, or marked faunal change. ${ }^{29}$ The occurrence of a widespread unconformity between Monterey and Santa Margarita is no longer accepted $^{30}$ It also is now recognized that the Santa Margarita consists of sandstone that in different regions is at dif-

24 Galliher, E. W., Geology and physical properties of building stone from Carmel Valley, Calif.: Mining in California (Division of Mines), vol. 28, no. 1, pp. 14-41, 25 figs., map, 1932. The basal part of the section, referred by Galliher to the Temblot (?), is here included in the Monterey shale.

${ }^{25}$ A dagger ( $\dagger$ ) preceding a geologic name indicates that the name has been abandoned or rejected for use in classification in publications of the U.S. Geological Survey.

${ }^{26}$ English, W: A., Geology and oil prospects of the Salinas Valley-Parkfleld area, Calif.: U. S. Geol. Survey Bull. 691, pp. 227-229, 1918.

${ }^{27}$ English, W. A., Geology and oil prospects of Cuyama Valley, Calif.: U. S. Geol. Survey Bull. 621, pp. 198-200, 1916.

${ }^{28}$ F.nglish, W. A., Geology and oil prospects of the Salinas Valley-Parkfeld area, Calif.: U. S. Geol. Survey Bull. 691, p. 228, 1918. Pack, R. W., The Sunset-Midway oil field, Calif., pt. 1, Geology and oil resources: U. S. Geol. Survey Prof. Paper 116, pp. 27-28, 1920.

${ }^{29}$ Louderback, G. D., The Monterey series in California: California Univ., Dept. Geology, Bull., vol. 7, pp. 177-241, 1913. Lawson, A. C., U. S. Geol. Survey Geol. Atlas, San Francisco folio (no. 193), pp. 9-11, 1914.

${ }^{30}$ Reed, R. D., The post-Monterey disturbance in the Salinas Valley, Calif.: Jour. Geology, vol. 33, pp. 588-607, 3 figs., 1925; Geology of California; pp. 206-207. Tulsa, Am. Assoc. Petroleum Geologists, 1933. 


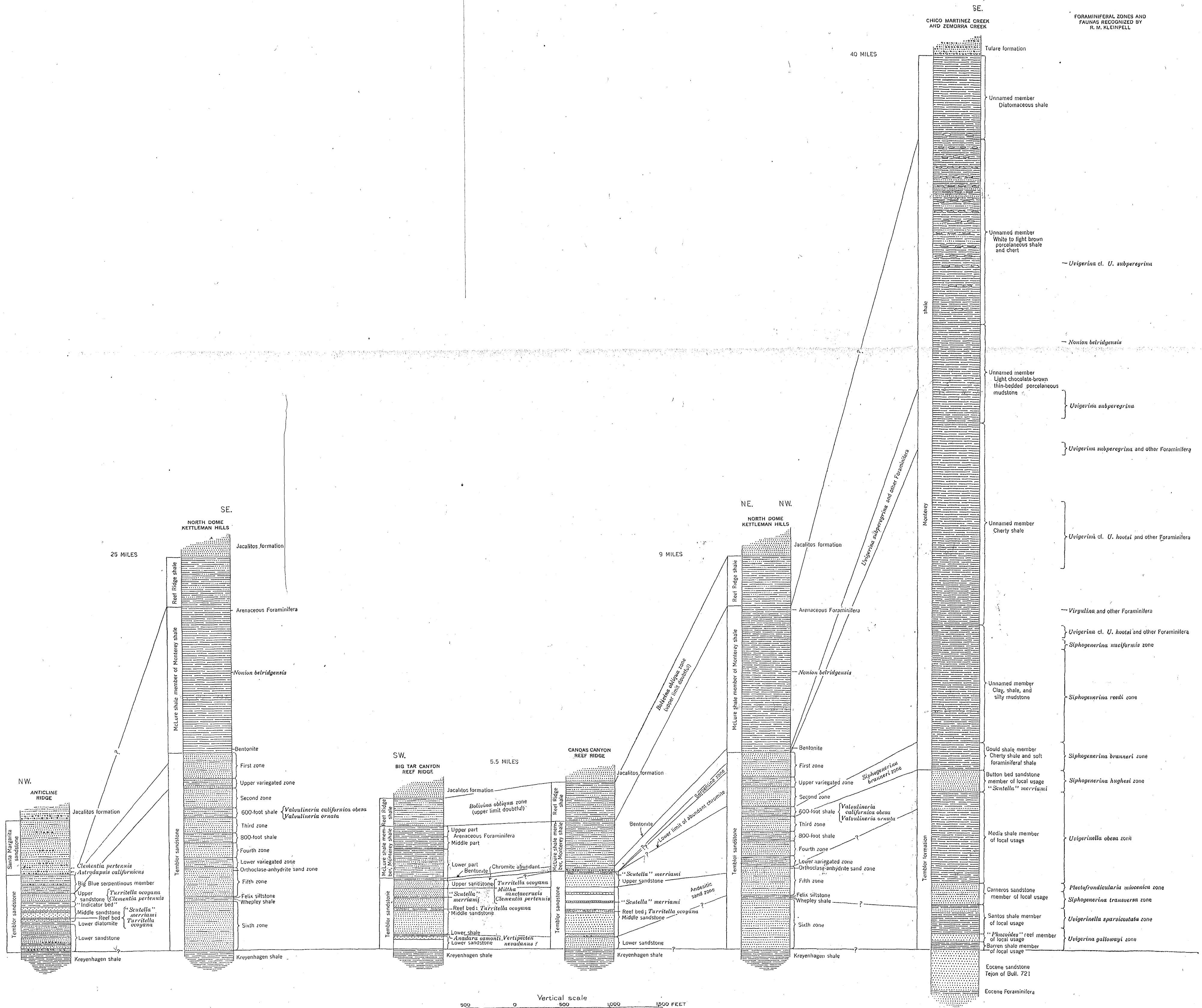

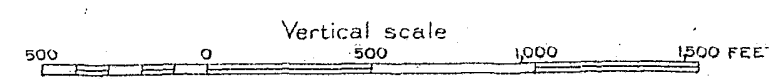
MIOCENE FORMATIONS OF NORTH DOME SUBSURFACE SECTION AND NEARBX OUTCROP SECTTONS
CHRONOLOGIC RELATIONS AS INFERRED FROM FAUNAL AND MINERALOGICAL DATA.

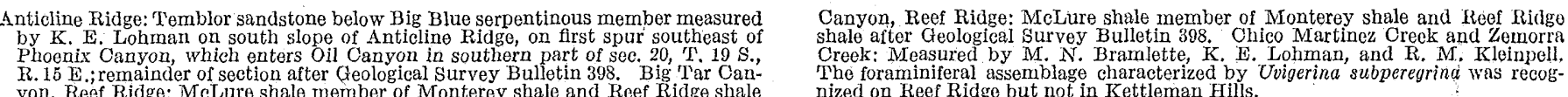




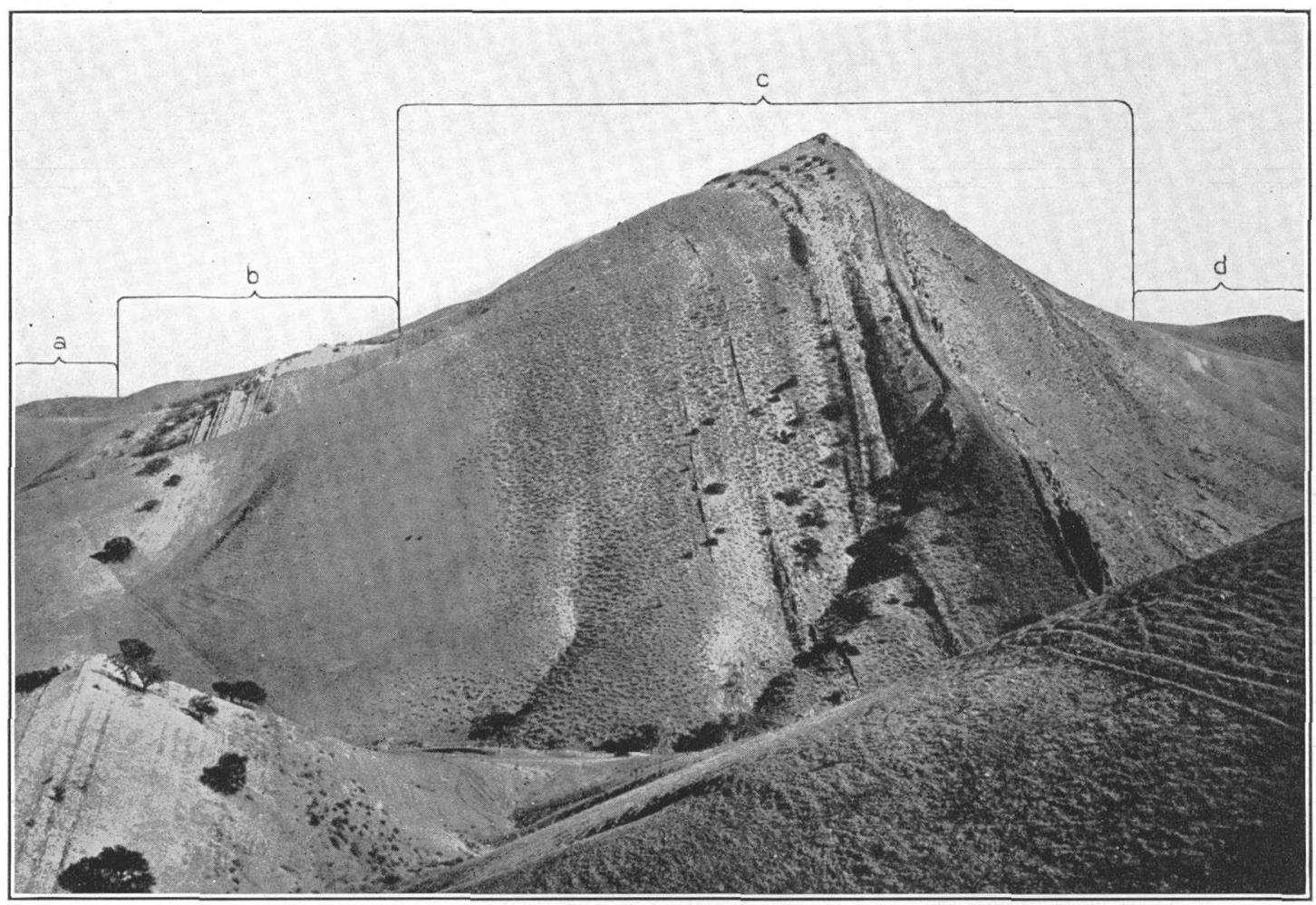

A. VIEW LOOKING SOUTHEASTWARD ACROSS TAR CANYON.

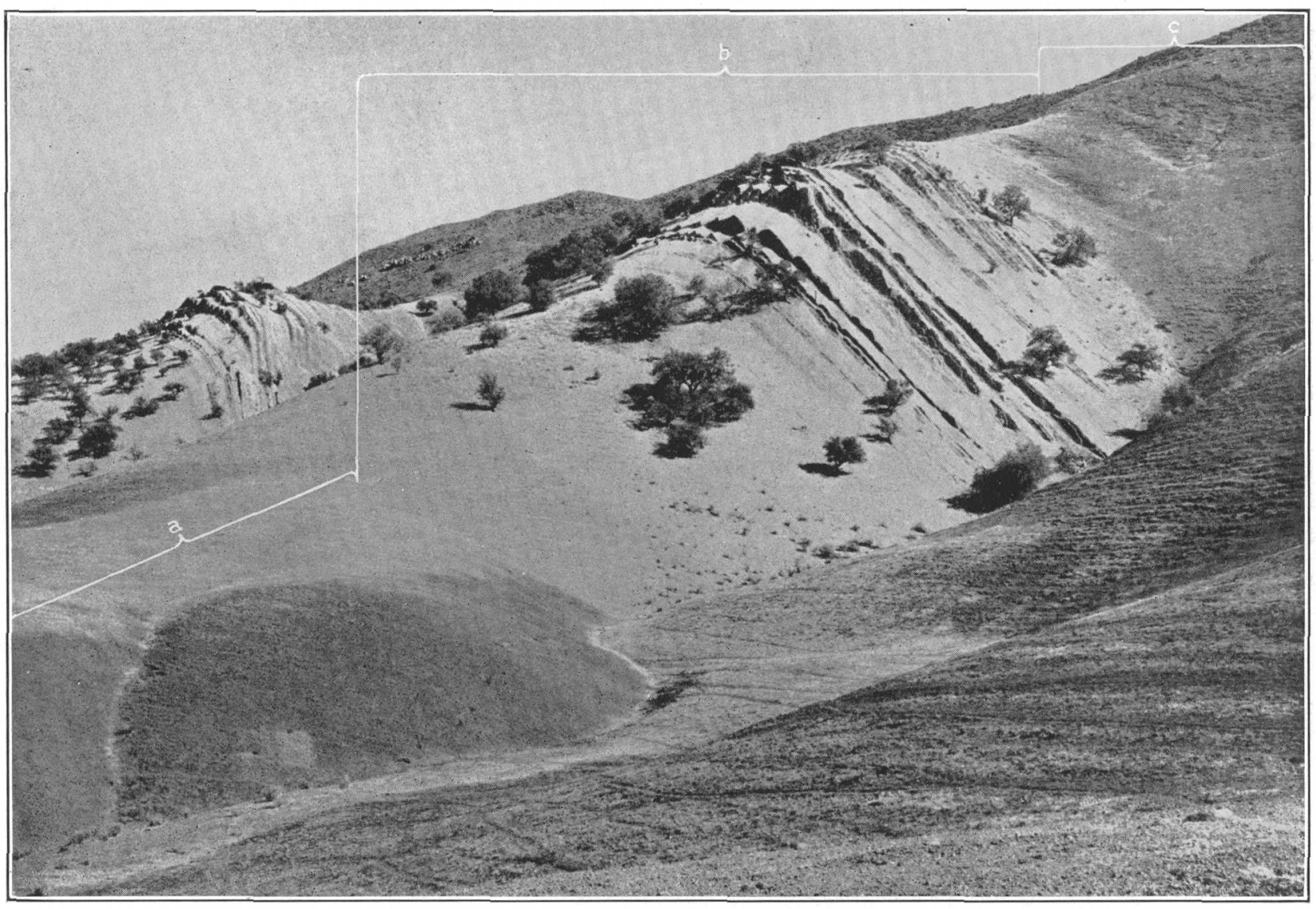

B. VIEW LOOKING SOUTHEASTWARD FROM FIRST SPUR SOUTHEAST OF TAR CANYON.

MIOCENE FORMATIONS ON REEF RIDGE, 8 MILES SOUTHWEST OF KETTLEMAN HILLS.

a. Reef Ridge shale.

b. McLure shale member of Monterey shale.

c. Temblor sandstone.

Kreyenhagen shale (Eocene).
Photographs by K. E. Lohman. 


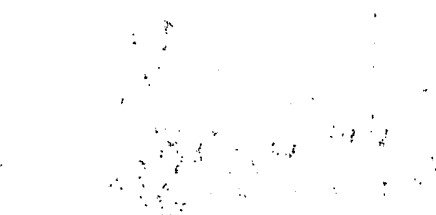

PLATE 49

Figures 1-4. Nonionella miocenica Cushman var. Kenda well No. 27, sec. 34, T. 21 S., R. 17 E., depth 5,198 feet. U. S. Nat. Mus. 373089.

5. Buliminella elegantissima (d'Orbigny). Same locality as preceding. U. S. Nat. Mus. 373088.

6, 7. Virgulina subplana Barbat and Johnson. Same Jocality as preceding. U. S. Nat. Mus. 373091.

8-10. Virgulina aff. V. nodosa R. E. and K. C. Stewart." Same locality as preceding. U. S. Nat.' Mus. 373092.

11, 12. Bolivina vaughani Natland. Same locality as preceding. U. S. Nat. Mus. 373090.

13-15. Nonionella miocenica Cushman. Petroleum Securities Co. well No. 1, sec. 14, T. 22 S., R. 17 E., depth 8,296-8,300 feet. U. S. Nat. Muś. 373086.

16. Buliminella curta Cushman." Bolsa Chica Oil Co. well No. 1, sec. 24, T. 22 S., R. 17 E., depth 6,929-6,939 feet. U. S. Nat. Mus. 373084.

17, 18. Bulimina montereỹana Kleinpell. Standard Oil Co. well No. 87, sec. 27, T. 22 S., R. 18 E., depth 5,126-5,144 feet. U. S. Nat. Mus. 483781 .

19, 20. Bulimina montereyana delmonteensis Kleinpell. Petroleum Securities Co. well No. 1, sec. 14, T, 22 S., R. 17 E., depth 8,296-8,300 feet. U. S. Nat. Mus. 373082.

21, 22. Bolivina cf. B. seminuda foraminata R. E. and K. C. Stewart. Bolsa Chica Oil Co. well No. 1, sec. 24, T. 22 S., R. 17E., depth 7,385-7,394 feet. U. S. Nat. Mus. 373105 .

23, 24. Virgulina californiensis grandis Cushman and Kleinpell. Standard Oil Co. well No. 87, sec. 27, T. 22 S., R. 18 E., depth 5,100-5,107 feet. U. S. Nat. Mus. 373079.

25, 26. Virgulina bramlettei Galloway and Morey. Bolsa Chica Oil Co. well No. 1, sec. 24, T. 22 S., R. 17 E., depth 7,3857,394 feet. U. S. Nat. Mus. 373081 .

27, 28. "Buliminella" dubia Barbat and Johnson. Same locality as preceding. U. S. Nat. Mus. 373085.

29. Bolivina brevior Cushman. Standard Oil Co. well No. 87, sec. 27, T. 22 S., R. 18 E., depth 5,100-5,107 feet. U. S. Nat. Mus. 373103.

30-32. Bolivina obliqua Barbat and Johnson. Petroleum Securities Co. well No. 1, sec. 14, T. 22 S., R. 17 E., depth 8,2968,300 feet. U.'S. Nat. Mus. 373087.

33, 34. Bulimina cf. B. ovata d'Orbigny. Standard Oil Co. well No. 87, sec. 27, T. 22 S., R. 18 E., depth 5,100-5,107 feet. U. S. Nat. Mus. 373083 .

35, 36. "Bolivina sp." Barbat and Johnson. Chancellor-Canfield-Midway Oil Co. Sahlen well No. 1, sec. 28, T. 24 S., R. 19 E. depth 5,775 feet. U. S. Nat. Mus. 373106 . 


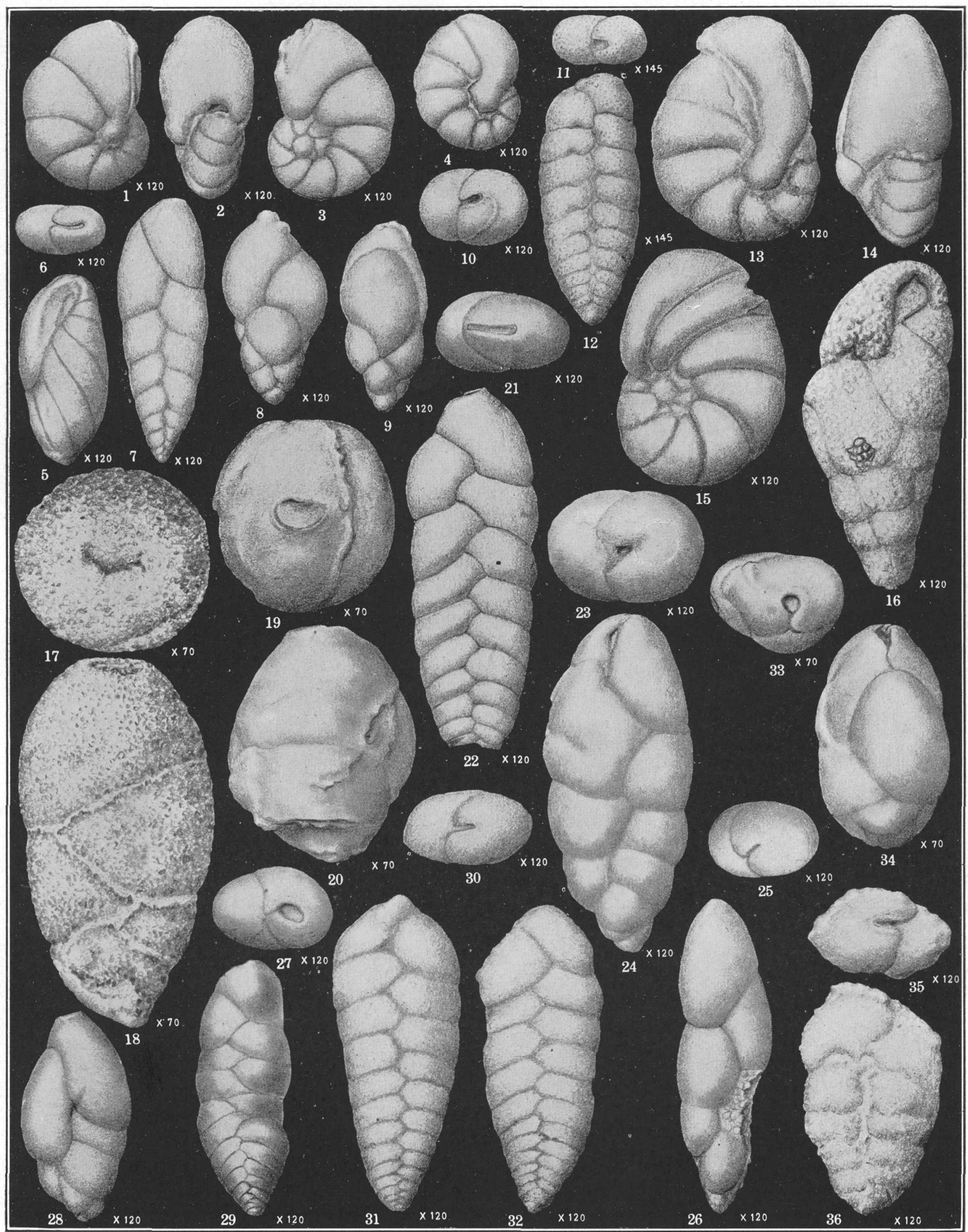

FORAMINIFERA FROM REEF RIDGE SHALE OF WELLS IN KETTLEMAN HILLS AND OF OUTCROP ALONG FOOT OF REEF RIDGE. 


\section{PLATE 50}

Figdres 1, 2. Robulus aff. $R$. nikobarensis (Schwager). McLure shale, Reef Ridge, $3 / 8$ mile north of Sulphur Spring Gap. U. S. Nat. Mus. 373093.

3, 4, 7. Cancris brongniartii d'Orbigny. McLure shale, same locality as preceding. U. S. Nat. Mus. 373094.

5,6. Uvigerina subperegrina Cushman and Kleinpell. McLure shale, same locality as preceding. U. S. Nat. Mus 373098.

8-10. Cibicides cf. C. illingi (Nuttall). McLure shale, same locality as preceding. U. S. Nat. Mus. 373095.

11, 12. Bolivina cuneiformis Kleinpell. McLure shale, same locality as preceding. U. S. Nat. Mus. 373096.

13, 14. Nonion costiferum (Cushman). Base of Gould shale, Zemorra Creek: U. S. Nat. Mus. 373102.

15-17. Valvulineria californıca obesa Cushman. Gould shale, same locality as preceding. U. S. Nat. Mus. 373099.

18, 19. Buliminella subfusiformis Cushman. Gould shale, same locality as preceding. U. S. Nat. Mus. 373097.

20, 21. Bolivina imbricata Cushman. Gould shale, same locality as preceding. U. S. Nat. Mus. 373101.

22-24. Valvulineria ornata Cushman. Gould shale, same locality as preceding. U. S. Nat. Mus. 373100. 


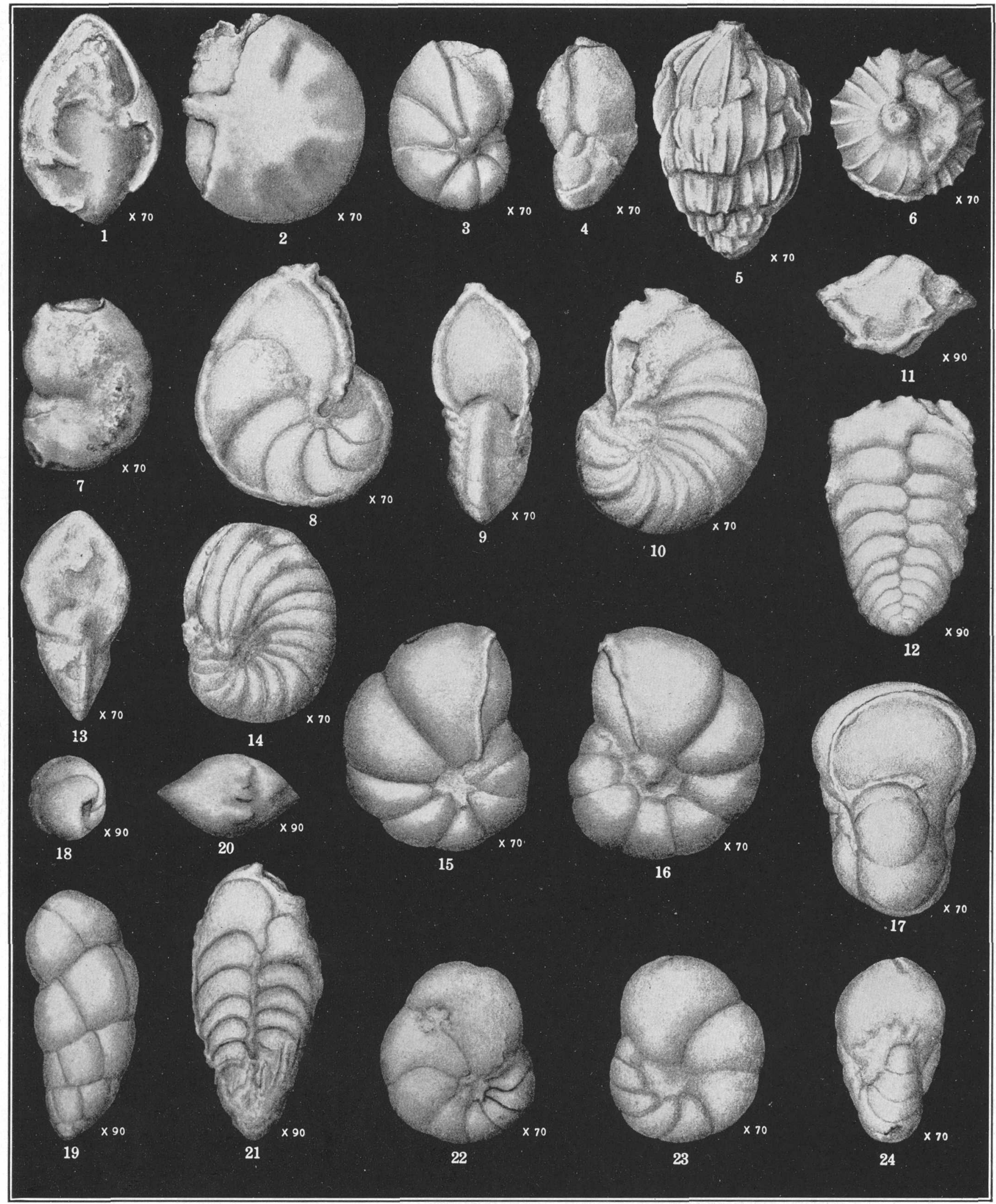

FORAMINIFERA FROM BASAL PART OF MCLURE SHALE MEMBER OF MONTEREY SHALE ON REEF RIDGE AND FROM GOULD SHALE MEMBER OF MONTEREY SHALE ON ZEMORRA CREEK. 
ferent horizons in the upper part of the Monterey shale, and that the San Pablo consists principally of sandstone that is of the same age as the upper part of Monterey shale elsewhere..$^{32}$ These views are generally accepted by geologists working in the Coast Ranges. Therefore, the grounds for using Monterey as a group name including the Vaqueros are no longer tenable, and if Monterey is extended to embrace the entire Coast Range section referred to the Miocene, as it logically should be if the name is applied to Coast Range Miocene strata below a widespread unconformity, it loses its utility. ${ }^{33}$ Many California geologists have continued to use Monterey as a formation name, but tho usage is not uniform. Some geologists use it for a type of shale, which is the usage here recommended; others give it a chronologic implication either in terms of the section in the type region or of more complete sections.

From this brief history of the name "Monterey" as affecting the Conlinga and nearby regions it is apparent that it has been used: (1) as a formation name for a particular type of lithology without any definite chronologic implication other than Miocene; (2) as a formation name based on a chronologic implication of varying value; and (3) as a group name. It is proposed to abandon Monterey as a group name including the Vaqueros sandstone and to treat Monterey shale as a formation name for Miocene strata in the Coast Ranges characterized by hard siliceous shale and soft shale containing microscopic siliceous fossils, regardless of varying chronologic relations of these strata within the Miocene, in accordance with the principle that a formation need not be of the same age from place to place. In areas where units of formation rank are recognized within the Monterey, group usage is still retained. This proposal results in the abandonment of Salinas shale and Maricopa shale as synonyms of Monterey shale. Geologists who favor giving formations a sharply defined and invariable chronologic value may urge that all three names are useful, as they have different age connotations, but unless the names are used in a very narrow sense only for the time equivalent represented in the type region, they need qualifications as to locality and faunal zones as much as the general name "Monterey"; and, furthermore, if the names are used in this narrow sense, a great many more names are needed.

The proposed usage of Monterey shale has the merits of calling attention to a widespread distinctive type of lithology and of simplifying the nomenclature, but its practical application at places may be difficult on

31 Barbat, W. F., and Weymouth, A. A., Stratigraphy of the Borophagus littoralis locality, Callf.: California Univ., Dept. Geol. Sci., Bull., vol. 21, pp. 30-31, 1931. Reod., R. D., op. cit. (Geology of California), p. 190. Richards, G. L., Jr., Revision of somo California species of Astrodapsis: San Diego Soc. Nat. History Trans., vol. 8 , no. 0, p. 03,1935

38 Kleinpell, R. M., Mioceno Foraminifera from Contra Costa County, Calif. [abstract]: Geol. Soc. America Proc., 1033, p. 390, 1934; Miocene stratigraphy of Californin, pp. 106-107, Tulsa, Am. Assoc. Petroleum Geologists, 1938.

ss Reed. R. D., op. cit. (Creology of California), p. 163 $152100-40-9$ account of the varying proportions of ordinary kinds of rock interbedded with shale of Monterey type. In areas where rocks other than siliceous shale form a considerable part of the section, Monterey formation rather than Monterey shale is preferable. As mapping progresses member names may be proposed for lithologic units within the Monterey; or formations may be recognized, as has been done in the San Francisco Bay region..$^{34}$ In areas where sandstone or ordinary shale greatly predominate over siliceous shale a different nomenclature may be advantageous. It is not the purpose of this account to attempt to consider Miocene stratigraphic nomenclature in different parts of the Coast Ranges, for in many areas much work remains to be done; the purpose is to attempt to clarify the basis for the nomenclature adopted for the Coalinga and nearby districts.

The usage of Monterey shale here advocated was adopted by the Geological Survey in 1935 for the Miocene strata of the Palos Verdes Hills ${ }^{35}$ (San Pedro Hills), which adjoin the Los Angeles Basin; but; as stated in the account dealing with the Palos Verdes Hills, this action was based on the arguments now presented.

The unit here designated the McLure shale member of the Monterey shale is the only Miocene shale of Monterey type in the Reef Ridge and Kettleman Hills sections. According to the principles followed in this report, it would be proper to call it simply Monterey shale, as was done 30 years ago. The name McLure, however, has come into such wide usage that it appears undesirable to urge its abandonment. The McLure is considered a member of the Monterey on the grounds that it represents a particular type of Monterey lithology-porcelaneous mudstone. This type of lithology is present but is apparently not recognizable as a mappable unit in the thick section of Monterey shale on Chico Martinez Creek, which includes the chronologic equivalent of the McLure. (See p. 125.)

\section{STRATIGRAPHY, IITHOLOGY, AND FOSSIIS}

OUTCROP SECTIONS

Reef Ridge.-The McLure shale is the Miocene shale of Monterey type cropping out along Reef Ridge. In this region it was called the Monterey shale by F. M. Anderson, ${ }^{36}$ the Santa Margarita (?) formation by Arnold and Anderson, ${ }^{37}$ and the McLure shale by Henny. ${ }^{38}$ The type region is on the south side of

34 Lawson, A. C., U. S. Geol. Survey Geol. Atlas, San Francisco folio (no. 193). pp. 9-11, 1914.

ss Woodring, W. P., Bramlette, M. N., and Kleinpell, R. M., Miocene stratigraphy and paleontology of Palos Verdes Hills, Calif.: Am. Assoc. Petroleum Geologists Bull., vol. 20, pp. 125-149, 3 figs., 1936.

36 Anderson, F. M., A stratigraphic study in the Mount Diablo Range of California: California Acad. Sci. Proc., 3d ser., vol. 2, p. 171, pl. 34, section 1, 1905.

${ }^{37}$ Arnold, Ralph, and Anderson, Robert, op. cit. (Bull. 398), pp. 90-94.

38 Henny, Gerard, McLure shale of the Coalinga region, Fresno and Kings Counties, Callf.: Am. Assoc. Petroleum Geologists Bull., vol. 14, pp. 403-410, 3 figs. 1930 
McLure Valley, south of the southeast end of Reef Ridge. Along the part of Reef Ridge opposite the Kettleman Hills and in the Pyramid Hills the thickness of the McLure increases southward from 200 feet to 1,200 feet. $^{39}$ Henny ${ }^{40}$ cited 800 feet as the average thickness in this area. It consists principally of chocolate-brown porcelaneous mudstone that breaks with a conchoidal fracture and may be divided into three main parts, the middle part containing the hardest beds. The hard middle part forms the crest of spurs, on which the hardest beds crop out in little ridges (pl. 48). At the base of the formation are sandy beds containing glauconite grains and phosphatic pellets. The following section, which was kindly supplied by M. N. Bramlette, was measured by M. N. Bramlette, K. E. Lohman, and R. M. Kleinpell in a ravine about 200 yards northwest of Big Tar Canyon.

Section of McLure shale member of Monterey shale on north slope of Reef Ridge about 200 yards northwest of Big Tar Canyon

Reef Ridge shale:

$$
\text { [Measured by M. N. Bramlette] }
$$

Poorly exposed soft silty shale; weathered surface suggests bentonitic soil; increasingly sandy toward top, apparently grading upward into sandstone of Jacalitos formation.

McLure shale member of Monterey shale:

Upper part:

Soft chocolate-brown mudstone containing Cyclammina and other arenaceous Foraminifera and a few calcareous concretions......

Middle part:

Reef-forming hard brown porcelaneous mudstone containing Cyclammina, Gaudryina? and other undeterminable arenaceous Formaminifera (identifications by R. M. Kleinpell); calcareous concretions absent. The hardest beds have a thickness of 1 to 2 feet and alternate

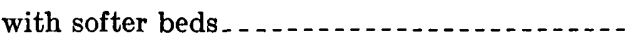

Chocolate-brown porcelaneous mudstone, harder than underlying beds; progressively more porcelaneous and harder upward; contains a few arenaceous Foraminifera.........

Lower part:

Chocolate-brown porcelaneous mudstone; diatom impressions more numerous than in underlying mudstone; zones of calcareous concretions at intervals of 5 to 10 feet

Chocolate-brown porcelaneous mudstone containing a few arenaceous Foraminifera and a few impressions of diatoms; zones of diatombearing 1- to 2-foot ovoid calcareous concretions at intervals of about 20 feet. .........

Green sand with abundant glauconite grains and phosphatic pellets, and numerous sponge

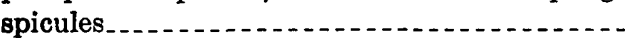

"Arnold, Ralph, and Anderson, Robert, op. cit. (Bull. 398), p. 23.

10 Henny, Gerard, op. cit., p. 404. 100
Section of McLure shale member of Monterey shale on north slope of Reef Ridge about 200 yards northwest of Big TarCanyon-Con.

McLure shale member of Monterey shale-Continued.

Lower part-Continued.

Soft clayey sand with glauconite grains and sponge spicules, and a few ovoid calcareous

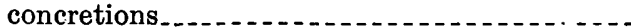

Hard clayey fine-grained sandstone with glauconite grains and a few phosphatic pellets....

Soft clayey fine-grained sand and sandy clay, poorly exposed....... Greenish-gray bentonite, poorly exposed......

Soft clayey siltstone or silty clay, poorly exposed.

Thickness of McLure shale.

Feet

Temblor sandstone:

Reef-forming sandstone with a 1-foot oyster-bearing conglomerate at top. Columns belonging to a cheek tooth crown of the marine mammal Desmostylus, probably representing $D$. hesperus (identification by Remington Kellogg), were found in sandstone immediately underlying the conglomerate.

The 2-foot bed of bentonite 15 feet above the base of the McLure is a noteworthy feature of this section. A bed of bentonite in the same part of the section has been recognized in Canoas Canyon 5 $1 \frac{1}{2}$ miles northwest. of Big Tar Canyon. Foraminifera from a horizon near the base of the McLure on Reef Ridge are considered. in the discussion of fossils from Kettleman Hills wells.

Along Reef Ridge the McLure rests with apparent conformity on the Temblor sandstone. At the south. end of Reef Ridge, however, the McLure extends across the edges of the Temblor and underlying Tertiary formations and, along the borders of McLure Valley, overlaps onto Cretaceous rocks. ${ }^{41}$

Chico Martinez Creek.-Shale of Monterey type increases in thickness southward in the Temblor Range to the region near Chico Martinez Creek, 40 miles. southeast of the Kettleman Hills, where the greatest. thickness is exposed. At this locality the Monterey shale overlies the Temblor formation. The shale was: called the Monterey shale by F. M. Anderson, ${ }^{42}$ the Monterey shale and Santa Margarita (?) formation by Arnold and Johnson, ${ }^{43}$ and the Maricopa shale by English. ${ }^{44}$ The following section, measured on Chico Martinez Creek by M. N. Bramlette, K. E. Lohman, and R. M. Kleinpell, and made available by M. N. Bramlette, shows a thickness of 7,235 feet. The top of the section is marked by an unconformable overlap.

\footnotetext{
4 Arnold, RaIph, and Anderson, Robert, op. cit. (Bull. 398), p. 91

12 Anderson, F. M., op. cit., p. 169.

3 Arnold, Ralph, and Johnson, H. R., Preliminary report on the McKittrickSunset oil region, Kern and San Luis Obisno Counties, Calif.: U. S. Geol. SurveyBull. 406, pp. 58-59, 65-66, 1910.

4 English, W. A., Geology and petroleum resources of northwestern Kern County Calif.: U. S. Geol. Survey Bull. 721, pp. 13-25, 1921.
} 
Section of Monterey shale on Chico Martinez Creek in Temblor Range, 40 miles southeast of Kettleman Hills

\section{[Measured by M. N. Bramlette]}

Tulare formation:

Conglomerate and sandstone resting with angular discordance on the Monterey shale.

Monterey shale:

Unnamed member:

11. White to dove-colored diatomaceous shale..

10. Diatomaceous shale with thin chert beds and zones of calcareous concretions.........

Unnamed member (?):

9. White to light-brown porcelaneous shale with abundant diatom impressions; thin chert beds numerous; zones of calcareous concretions at intervals of 10 to 20 feet. Thin beds of fine-grained sandstone, some of which are impregnated with tar, in about the middle part of this unit. . . . . . 1, 885

Unnamed member (?):

8. Light chocolate-brown, thin-bedded porcelaneous mudstone with diatom impressions becoming less distinct downward; zones of calcareous concretions at intervals of 10 to 20 feet.............. 1, 015

Unnamed member (?):

7. White-weathering, dove-colored cherty shale with vague diatom impressions; zones of calcareous concretions at intervals of 10 to 20 feet..................

6. Brown-weathering, buff to dove-colored cherty shale with vague diatom impressions; few zones of calcareous concretions. -

5. Thinly laminated shale, less siliceous than overlying shale; no diatom impressions; zones of calcareous concretions at intervals of 10 to 20 feet.....................

4. Alternating zones of hard and soft slightly calcareous, cherty shale; numerous zones of calcareous concretions. .................

Unnamed member:

3. Soft foraminiferal clayey shale with phosphatic nodules and stringers; zones of calcareous concretions at intervals of 10 to 20

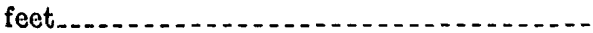

2. Silty mudstone; zones of calcareous concretions at intervals of 10 to 20 feet......... Gould shale member:

1. Hard cherty shale interbedded with soft foraminiferal shale; few zones of calcareous concretions. .........

Thickness of Monterey shale

$\longrightarrow$

Temblor formation (Button bed sandstone member of local usage).

This section and the foraminiferal zones recognized by R. M. Kleinpell are shown on plate 47 . The subdivision of this thick section of Monterey shale into members is tentative. The light chocolate-brown porcelaneous mudstone, which has a thickness of 1,015 feet and constitutes the third member from the top, is lithologically comparable to the McLure shale of McLure Valley and Reef Ridge but is more thinly bedded. The lowest member has been formally named the Gould shale by Barbat; ${ }^{45}$ who referred it to the Temblor formation. On a lithologic basis it is part of the Monterey shale-a classification that agrees with the classification first proposed for this region. ${ }^{46}$

Anticline Ridge.-The McLure shale and the Reef Ridge shale are missing on Anticline Ridge and on the west side of San Joaquin Valley north of Anticline Ridge. Their absence constitutes one of the contrasts in the geology of different parts of the Coalinga district. On Anticline Ridge and father north sandstone and conglomerate that have a maximum thickness of 600 to 850 feet $^{47}$ are in the corresponding part of the section. These strata represent part of the Coalinga beds of F. M. Anderson ${ }^{48}$ and the Santa Margarita (?) formation of Arnold and Anderson ${ }^{49}$ and of Anderson and Pack. ${ }^{50}$ If a local name is desired for the sandstone and conglomerate, the term "Coalinga" is available with suitable restriction imposed on F. M. Anderson's restriction. ${ }^{51}$ Santa Margarita formation, or preferably Santa Margarita sandstone, bowever, may be an appropriate name for this formation, as for sandstone in the upper part of the Miocene section in other districts in the Coast Ranges.

The Ladd well of the Petroleum Securities Co. in the Guijarral Hills, between Anticline Ridge and the Kettleman Hills, encountered a thickness of 895 feet of brown shale. The correlation of this brown shale with the McLure is supported by the occurrence of a bed of bentonite 38 feet above the base of the shale. According to this correlation, Miocene shale of Monterey type is represented in a subsurface section 10 miles southeast of the outcrop of coarse detrital Miocene strata on Anticline Ridge.

\section{SUBSURFACE BECTION}

In the Kettleman Hills subsurface section the Reef Ridge shale is underlain by hard shale that is similar litbologically to the McLure shale and is, therefore, assigned to the McLure. The hard shale is designated the brown shale by drillers-a somewhat misleading designation, as much of the shale is gray, though it has a brownish color when wet. During the drilling of a few early wells a larger proportion of the McLure shale was cored than of any unit so far considered. One to

19 Barbat, W. F., Age of producing borizon at Kettleman Hills, Calif.: Am. Assoc. Petroleum Geologists Bull., vol. 16, pp. 611-612, 1932.

${ }^{6}$ Anderson, F. M., op. cit., pp. 169-170.

17 Arnold, Ralph, and Anderson, Robert, op. cit. (Bull. 398), p. 90. Anderson Robert, and Pack, R. W., Geology and oil resources of the west border of the San Joaquin Valley north of Coalinga, Calif.: U. S. Geol. Survey Bull. 603, p. 23, 1915.

4 Anderson, F. M., A stratigraphic study in the Mount Diablo Range of California: California Acad. Sci. Proc., 3d ser., vol. 2, pp. 174-178, 1805.

to Arnold, Ralph, and Anderson, Robert, op. cit. (Bull. 398), pp. 82-90.

${ }^{60}$ Anderson, Robert, and Pack, R. W., op. cit., pp. 91-93.

s1 Anderson, F. M., A further stratigraphic study in the Mount Diablo Range of California: California Acad. Sci. Proc., 4th ser., vol. 3, pp. 17-23, 1908. 
three thin beds of bentonite occur near the base of the McLure, 100 feet or less above the top of the oil-bearing Temblor sandstone in North Dome. The bentonite is readily recognized in core or ditch samples and is an important horizon marker. Until recently, when electrical logging ${ }^{52}$ came into general use, cores were generally taken near the base of the McLure to locate the bentonite. In wells in which the First zone of the Temblor was open to production a water string was set about 25 feet below the bentonite. A strong flow of salt water is encountered about 300 feet below the top of the McLure.

The top of the brown shale is logged where hard shale that markedly slows down the rate of drilling is encountered. ${ }^{53}$ Structure contours drawn on the top of the brown shale in North Dome show an anticline surface resembling in general that shown by contours drawn on the top of the underlying Temblor sandstone but showing minor irregularities that appear to be arranged in channel-like patterns suggestive of an eroded surface. Whether this apparently irregular surface represents a discontinuity between the Reef Ridge shale and McLure shale, as has been advocated, ${ }^{54}$ appears to be doubtful. It is likely that the top of the

32 The term "electrical log" is used for logs showing the results of surveys made by the Schlumberger method. For descriptions of this method see Schlumberger, Conrad, Schlumberger, Marcel, and Leonardon, E. G., Electrical coring, a method of determining bottom-hole data by electrical measurements: Am. Inst. Min. Met. Eng. Trans., vol. 110, Geophysical prospecting, pp. 237-272, 22 figs., 1934; A new contribution to subsurface studies by means of electrical measurements in drill holes: Idem, pp. 273-288, 9 figs.

${ }_{53}$ Schenck, H. G., Miocene brown shale of the Kettleman Hills wells, Calif. [abstract]: Geol. Soc. America Bull., vol. 42, p. 300, 1931.

s Gester, G. C., and Galloway, John, Geology of Kettleman Hills oil field, Calif: Am. Assoc. Petroleum Geologists Bull., vol. 17, p. 1177, 1933. brown shale represents different horizons in a continuous section, for if the upper part of the subsurface McLure includes soft shale, as in the outcrop section on Reef Ridge, the soft shale is doubtless included in the overlying Reef Ridge shale. Goudkoff's interpretation ${ }^{55}$ of the subsurface stratigraphy is different from the interpretation adopted in the present report, as he divided the McLure shale of the present report into two main parts separated by a discontinuity.

As shown in the table below, the thickness of the McLure shale, as logged, ranges from 930 to 1,500 feet in North Dome, the average being about 1,300 feet. In Middle Dome the thickness is about 2,100 feet, and in South Dome about 2,500 feet. The thickness is greater than in the outcrop section on Reef Ridge, and in the three anticlines of the Kettleman Hills it is progressively greater southward, as in the outcrop sections southward from Reef Ridge.

The subsurface McLure appears to include two main parts. The upper part consists chiefly of massive hard brown or gray shale interbedded with streaks of darker brown shale, some of which contains pyritized diatoms. The lower part is made up mainly of grayish-brown shale and zones of brittle and flaky brown to brownishblack shale. The lithologic constituents in nine wells, disregarding a few minor constituents, are shown in the following table. This table was compiled from logs, but some of the logs are based on a considerable percentage of cores.

os Goudkoff, P. P., op. cit. (Am. Assoc. Petroleum Geologists Bull., vol. 18), pp. 451-454, 457-458.

Principal lithologic constituents in subsurface McLure shale member of Monterey shale in Kettleman Hills

\begin{tabular}{|c|c|c|c|c|c|c|c|}
\hline Well & $\begin{array}{l}\text { Brown } \\
\text { shale }\end{array}$ & $\begin{array}{l}\text { Hard } \\
\text { shale }\end{array}$ & $\begin{array}{l}\text { Clay } \\
\text { shaie }\end{array}$ & $\begin{array}{l}\text { Black } \\
\text { shale }\end{array}$ & $\begin{array}{l}\text { Sandy } \\
\text { shale }\end{array}$ & Sand & $\begin{array}{l}\text { Thick: } \\
\text { ness of } \\
\text { forma- } \\
\text { tion }\end{array}$ \\
\hline 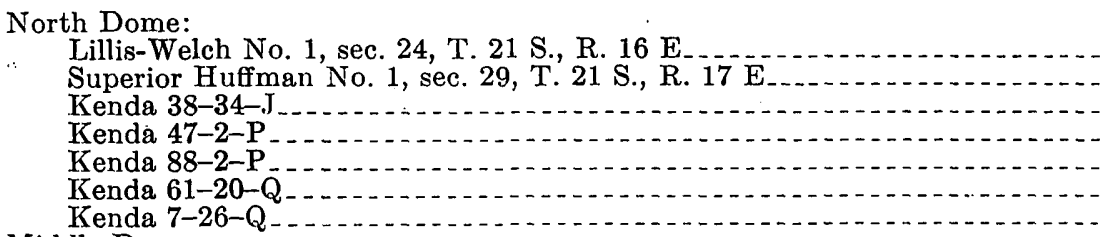 & $\begin{array}{c}\text { Percent } \\
10 \\
35 \\
5 \\
29 \\
10 \\
10 \\
53\end{array}$ & $\begin{array}{c}\text { Percent } \\
75 \\
36 \\
38 \\
67 \\
52 \\
83 \\
47 \\
47\end{array}$ & $\begin{array}{r}\text { Percent } \\
6 \\
25 \\
18 \\
-19 \\
-\end{array}$ & $\begin{array}{l}\text { Percent } \\
\\
\\
\\
\\
\end{array}$ & $\begin{array}{r}\text { Percent } \\
8 \\
4 \\
25 \\
4 \\
17 \\
2 \\
-\end{array}$ & \begin{tabular}{r} 
Percent \\
1 \\
-14 \\
14 \\
\hdashline 2 \\
5
\end{tabular} & $\begin{array}{c}\text { Feet } \\
1,340 \\
1,215 \\
1,250 \\
930 \\
1,300 \\
1,400 \\
1,500\end{array}$ \\
\hline $\begin{array}{l}\text { Middle Dome: } \\
\text { Petroleum Securities Burbank No. 1, sec. } 30 \text {, T. } 23 \text { S., R. } 19 \text { E... } \\
\text { South Dome: } \\
\text { Ohio Smith No. 1, sec. } 35 \text {, T. } 24 \text {, S., R. } 19 \text { E. }\end{array}$ & $\begin{array}{r}25 \\
4 \\
\end{array}$ & $\begin{array}{l}40 \\
47\end{array}$ & $\begin{array}{r}4 \\
31 \\
\end{array}$ & 16 & $\begin{array}{r}6 \\
10 \\
\end{array}$ & 9 & $\begin{array}{l}2,125 \\
2,500 \\
\end{array}$ \\
\hline Average & 19 & 53 & 13 & 2 & 8 & 5 & 1,500 \\
\hline
\end{tabular}

A few thin hard beds, logged as limestone or shell, correspond probably to the calcareous concretions in the outcrop sections: If the base of the McLure is marked by conglomerate or sandstone, these strata are probably assigned to the underlying Temblor. An 8- to 10-inch bed of hard coarse-grained sandstone containing limestone pebbles as much as half an inch in diameter is recorded in Kenda well 8-8-Q at a horizon 4 feet above the top of the Temblor.
Small dark-colored phosphatic pellets, composed of impure collophane, are found at several horizons in the lower 600 to 750 feet of the McLure. These pellets have been described by Galliher ${ }^{56}$ as fecal pellets of unknown origin. They are locally given the acrostic name "sporbo" (smooth, polished, round,

s6 Galliher. E. W., Collophane from Mlocene brown shale of California: Am. Assoc. Petroleum Geologists Bull., vol. 15, pp. 25i-269, 1931: Organic structure in sediments: Jour. Sedimentary Petrology, vol. 2, pp. 46-47, 2 figs., 1932. 
black objects). Similar pellets are found in the lower part of the McLure in the outcrop section on Reef Ridge.

One to three thin beds of bentonite ranging in thickness from a few inches to 2 feet are present in most North Dome wells at a horizon 30 to almost 100 feet above the base of the McLure. Bentonite was found 286 feet above the base of the McLure in Petroleum Securities Burbank well No. 1 in Middle Dome and 340 feet above the base in Continental Gatchell well No. 28-7 in South Dome. The beds of bentonite are particularly useful horizon markers, as they are readily identified and are found at fairly uniform intervals above the productive sands. The bentonite recovered from cores is white when dry and somewhat waxy. In water it swells slightly, sloughs in characteristic flakes, and changes in color to light gray or dark gray, or may show a slight greenish to bluish tint. Glass shards in varying proportions indicate that this material is altered volcanic ash. Core samples examined by P. G. Nutting, of the Geological Survey, have a high silica content, indicating that they are only partly altered. Samples collected from the lower part of the McLure exposed on Reef Ridge and from shallow wells near the outcrop show a more complete alteration to bentonite. Moreover, the degree of alteration varies indirectly with distance from the outcrop and depth from the surface. This relation is so constant that the bentonite in the Kettleman Hills and on Reef Ridge is likely to represent products of the same ash fall. At least one bed of bentonite 1 to 2 feet thick may extend over the entire area of North and Middle Domes. The bentonite has been cored or logged in nearly all North Dome wells drilled since it was discovered in August 1929. ${ }^{57}$ It was not, however, recorded in 13 early wells drilled close to the crest of the anticline but has subsequently been found in nearby wells, including wells located in structurally higher positions. Practically all wells that encounter the top of the Temblor sand below the $-5,500$-foot structure contour drawn on the top of the Temblor show at least one bed of bentonite and some show two. Three beds of bentonite are reported only in wells in which the top of the Temblor is encountered at the $-6,000$-foot structure contour or lower. These relations suggest that North Dome may have been the site of a submarine ridge during the early part of McLure time and that deposition of sediments was more rapid on the slopes of the ridge than on the crest. Should future drilling show that bentonite is missing along much of the crest, this suggestion will be supported by that evidence. In Middle Dome bentonite has been found in three of the five wells drilled to December 1936.

The thickness of strata between the bentonite and the top of the Temblor increases southeastward from 40

"Dodd, H. V., Recent developments in the Kettleman Hills fleld: California Oil Fiolds (Callornia, Div. Oll and Gas), vol. 17, no. 1, p. 12, 1931 [1932]. feet in the Guijarral Hills (between North Dome and Anticline Ridge) to 275 feet in Middle Dome, a rate of 10 feet to the mile. Farther west the thickening of this stratigraphic interval in the same direction from Canoas Creek to the Devils Den district is at a rate of 12 feet to the mile.

Fish scales are abundant in the subsurface McLure shale as well as at the outcrop. Pyritized diatoms, which may be accompanied by pyritized sponge spicules, occur at various horizons. Poorly preserved arenaceous Foraminifera are found in the upper part of the shale. Despite their poor preservation, these Foraminifera played an important role in the drilling of the discovery well. D. D. Hughes recognized their similarity to arenaceous forms in the upper part of the McLure exposed on Reef Ridge. The occurrence of these fossils and the similar lithology furnished grounds for correlation with the outcrop section and led to deeper drilling in the expectation of finding oil in sand that was expected to underlie the McLure.

A few Foraminifera from the middle part of the McLure of Kenda well 81-34-Q were identified by R. M. Kleinpell, whose list of species and comments are as follows:

Foraminifera from middle part of McLure shale member of Monterey shale of Kettleman North Dome Association well No. 81, sec. 34, T. 22 S., R. 18 E., depth 5,805-5,818 feet

[Identiflcations by R. M. Kleinpell]

Nonion belridgensis Barbat and Johnson, abundant. Nonionella miocenica Cushman, abundant. Bulimina cf. B. ovata d'Orbigny, abundant. Virgulina sp. (poorly preserved specimens), few.

The occurrence of Nonion belridgensis in the well material and as molds or impressions in the part of the Monterey shale on Chico Martinez Creek lying between strata containing Uvigerina cf. U. subperegrina and strata containing Uvigerina subperegrina suggests an approximate correlation. (See pl. 47.) The core specimens show'a slight tendency toward the development of limbate sutures that is not apparent on the' molds from Chico Martinez Creek. The range of Nonion belridgensis and the other species in the preceding list is so great, however, that the correlation is doubtful.

No fossils are available from the base of the McLure shale of Kettleman Hills wells, and fossils are rare at this horizon at the outcrop along Reef Ridge. R. M. Kleinpell identified the following Foraminifera in samples collected near Sulphur Spring Gap, about 3 miles southeast of Big Tar Canyon. The characteristic species of this fauna, which is of considerable stratigraphic importance, are shown on plate 50.

The following remarks on these fossils were prepared by Kleinpell, who assigns the fossiliferous basal part of the McLure to his Bulimina uvigerinaformis zone. ${ }^{68}$

This small fauna is characterized by Robulus aff. $R$. nikobarensis (pl. 50, figs. 1, 2), Bolivina cuneiformis (pl. 50, figs. 11, 12), Uvigerina subperegrina (pl. 50, figs. 5, 6), which is the most abundant and most characteristic species, Cancris brongni-

${ }^{38}$ Kleinpell, R. M., Miocene stratigraphy of California, p. 129, Tulsa, Am. Assoc. Petroleum Geologists, 1938. 
artii (pl. 50, figs. $3,4,7$ ), and Cibicides cf. C. illingi (pl. 50, figs. 8-10). In the Monterey shale on Chico Martinez Creek molds and impressions of Uvigerina subperegrina are numerous in the lower part of the light chocolate-brown porcelaneous mudstone, constituting lithologic unit 8 of the section on page 125 , and in the upper part of the underlying white-weathering dove-colored cherty shale of lithologic unit 7. This part of the Monterey on Chico Martinez Creek is considered the chronologic equivalent of the strata containing the fauna in the basal part of the McLure on Reef Ridge. In the section on Chico Martinez Creek Uvigerina subperegrina appears to be associated with molds of Uvigerina carmeloensis, which is a characteristic species in Galliher's "lower Nonion fauna" in the type Monterey section. ${ }^{58}$

The small fauna from the basal part of the McLure shale may be more satisfactorily compared with the fauna from a horizon 250 feet above the base of the Modelo formation in Topanga Canyon in the Santa Monica Mountains. Uvigerina subperegrina and Robulus aff. $R$. nikobarensis characterize both assemblages; Uvigerina hootsi, a characteristic species in the Modelo, is doubtfully represented in the McLure; and Bolivina cuneiformis and Cibicides of. C. illingi, two other forms from the basal McLure, are also present in the basal Modelo of the Santa Monica Mountains and occur at the same or closely related horizons elsewhere in southern California.

Bolivina cuneiformis, which occurs at the base of the McLure, was recognized in a sample from Ohio Smith well No. 1, in South Dome, at a depth of 5,120-5,125 feet, or 1,750 feet above the base of the McLure. Its stratigraphic significance in the well material is uncertain.

Foraminfera from basal part of McLure shale member of Monterey shale at outcrop on Reef Ridge near Sulphur Spring Gap

[Identiflcations by R. M. Kleinpell. R, rare; F, few: O, common; A, abundant]

\begin{tabular}{|c|c|c|c|}
\hline \multirow{2}{*}{ Species } & \multicolumn{3}{|c|}{ Localities } \\
\hline & 1 & 2 & 3 \\
\hline $\begin{array}{l}\text { Reophax? sp. } \\
\text { Textularia cf. T. subplana Reuss } \\
\text { Robulus aff. } R \text {. nikobarensis Schwager (pl. } \\
\text { 50, figs. 1, 2) } \\
\text { Bolivina cuneiformis Kleinpell (pl. 50, figs. } \\
\text { 11, 12) } \\
\text { Uvigerina hootsi Rankin? } \\
\text { Uvigerina subperegrina Cushman and } \\
\text { KRleinpell (pl. 50, figs 5, 6) } \\
\text { Discorbis sp sp. } \\
\text { Cancris brongniartii d'Orbigny (pl. 50, } \\
\text { figs. 3, 4, 7) } \\
\text { Cassidulina pulchella d'Orbigny } \\
\text { Globigerina bulloides d'Orbigny } \\
\text { Planulina sp } \\
\text { Cibicides cf. C. illingi (Nuttall) (pl. 50, } \\
\text { figs. 8-10) }\end{array}$ & $\begin{array}{l}\mathrm{C} \\
\mathrm{C} \\
\mathrm{C} \\
\mathrm{A}\end{array}$ & $\mathrm{R}$ & $\begin{array}{l}\mathrm{F} \\
\mathrm{A}\end{array}$ \\
\hline
\end{tabular}

1. Three-eights of a mile north of Sulphur Spring Gap, on Reef Ridge between Big Tar Canyon and Little Tar Canyon, about 12 feet above base of basal conglomerate of McLure shale. M. N. Bramlette, R. M. Kleinpell, and K. E. Lohman, collectors.

2. Same locality, shale bed 3 feet higher stratigraphically. M. N. Bramlette, R. M. Kloinpell, and $\mathbf{K}$. E. Lohman, collectors.

3. A quarter of a mile north of Sulphur Spring Gap, about 12 feet above base of basal conglomerate of McLure shale. R. D. Reed and C. Cassel, collectors.

\section{AGE AND CORRELATION}

Though the brown shale of the North Dome subsurface section is three times as thick as the McLure shale of the Big Tar Canyon outcrop section, it appears to be the essential chronological equivalent of the McLure exposed at Big Tar Canyon and nearby. In both sec-

so Galliher, E. W., Stratigraphic position of the Monterey formation: Micropaleontology Bull., vol. 2, no. 4, pp. 71-74, 1931. tions bentonite occurs near the base and arenaceous Foraminifera in the upper part. In both sections the McLure is overlain by the Reef Ridge shale that contains Foraminifera of the Bolivina obliqua zone. Moreover, the basal sandy strata containing phosphatic pellets in the outcrop section are in about the same stratigraphic position as the shale containing similar pellets in the subsurface section. The glauconite accompanying the pellets at the outcrop has not been recognized, however, in the subsurface section. The increased thickness in North Dome, as compared with the outcrop section on Reef Ridge, and the southward increase in thickness from North Dome to Middle Dome and South Dome are attributed to basinward thickening. The thick section of Monterey in the Temblor Range on and near Chico Martinez Creek represents not only a continuation and maximum development of the southward thickening but also a southward gradation of the upper part of the Temblor sandstone of the Coalinga district into shale:

According to Kleinpell's age determination of the Foraminifera in the basal part of the McLure shale and in the Reef Ridge shale, the McLure shale of the Coalinga district is in the lower part of the upper Miocene of current Coast Range chronology and corresponds approximately to his Mohnian stage. ${ }^{80}$ In terms of the succession of foraminiferal zones the McLure is the chronologic equivalent of about the middle part of the Monterey shale of the type region.

When Arnold and Anderson referred the shale of Monterey type cropping out on Reef Ridge to the Santa Margarita (?) formation, the Santa Margarita was regarded as occupying a definite place in the Miocene time scale above the Monterey. Northwest of Reef Ridge the shale of Monterey type overlies sandstone containing fossils that are considered of Santa Margarita age. ${ }^{61}$ Henny later claimed that the shale unconformably overlies sandstone containing Santa Margarita fossils. ${ }^{62}$ There still appears to be some doubt concerning these fossils, which may have come from the basal sandy part of the McLure shale. One of them was cited as an Astrodapsis with "prominent raised petals." If the age assignment of the McLure as based on Foraminifera is accepted, the occurrence of an Astrodapsis of this character either in sandstone unconformably underlying the McLure or in the basal part of the McLure itself is apparently not in agreement with Kew's evolutionary scheme for Astrodapsis, ${ }^{63}$ in which the large species with strongly raised petals are later than small species with flat or weakly raised petals. According to this scheme, the earliest and most primitive described species of Astrodapsis is $A$.

60 Kleinpell, R. M., op. cit., p. 165.

os Arnold, Ralph, and Anderson, Robert, op. cit. (Bull. 398), pp. 89, 95

62 Henny, Gerard, McLure shale of the Coalinga region, Fresmo and Kings Counties, Calif.: Am. Assoc. Petroleum Geologists Bull., vol. 14, p. 406, 1930.

o3 Kew, W. S. W., Cretaceous and Cenozoic Echinoides of the Pacific coast of North America: California Univ., Dept. Geology, Bull., vol. 12, pp. 41-45, 1920. 
brewerianus from the Briones sandstone, which according to Kleinpell ${ }^{64}$ is a little younger than the base of the McLure. Astrodapses from the base of the Modelo formation in the Santa Monica Mountains are considered more primitive than $A$. brewerianus in terms of Kew's scheme, ${ }^{65}$ a conclusion that is in apparent agreement with the age assignment of the foraminiferal zones in the Modelo formation of the Santa Monica Mountains, the base of which constitutes the base of Kleinpell's Mohnian stage and represents the base of the upper Miocene of the Coast Ranges, as now generally accepted.

The chronologic relations of the McLure shale to the Santa Margarita sandstone exposed on Anticline Ridge are uncertain. The occurrence of large Astrodapses with strongly raised petals in the Santa Margarita sandstone suggests a horizon high in the upper Miocene, but the Astrodapsis of Santa Margarita aspect at the base of the McLure northwest of Reef Ridge, or in sandstone underlying the McLure, throws doubt on this assignment. That there may be discontinuities at both the bottom and the top of the Santa Margarita sandstone of Anticline Ridge is indicated by the occurrence at these horizons of nonmarine strata-the Big Blue member of the Temblor below it and the nonmarine formation referred to the Jacalitos by Arnold and Anderson above it. The Santa Margarita sandstone of this region may be the chronologic equivalent of the Reef Ridge shale. (See fig. 14.)

\section{TEMBLOR SANDSTONE}

The age and nomenclature of the oil-bearing sands underlying the McLure shale in the Kettleman Hills have been treated in different ways by different geologists. They have been referred to the 'Temblor, partly to the Vaqueros and Temblor, and partly to the Vaqueros, Temblor, and Monterey. The diverse and confusing stratigraphic nomenclature is due principally to attempts to assign essentially invariable age designations to the formations, Vaqueros, Temblor, and Monterey. The oil-bearing sands and interbedded relatively thin shales constitute a major lithologic unit between the McLure shale and Kreyenhagen shale, and this unity is recognized in the proposal to apply one formation name to them-Temblor sandstone.

Formation names were first given to the Miocene strata in this part of the Coast Ranges by F. M. Anderson in 1905. On the northeast slope of the Temblor Range 40 miles southeast of the Kettleman Hills the Miocene section consists of the great thickness of shale, mostly of Monterey type, already described, below which lie alternating units of sandstone and shale. It is natural to divide this section at the top of

\footnotetext{
of Kloinpell, R. M., Miocene stratlgraphy of Callfornia, fig. 14 (in pocket), Tulsa, Am. Assoc. Petroloum Ceologists, 1938.

os Woodring, W. P., in Hoots, H. W., Geology of the eastern part of the Sante Monica Mountnins, Los Angeles County, Calif.: U. S. Geol. Survey Prof. Paper 165,
} pp. 110-111, 1931. the uppermost sandstone, as was done by F. M. Anderson, who appropriately designated the overlying shale Monterey and proposed the new name "Temblor" for the alternating sandstone and shale. ${ }^{66}$ The sandstone on Reef Ridge underlying the Monterey shale (McLure shale member of Monterey shale, according to the terminology adopted in the present report) and forming the crest of the ridge also was assigned to the Temblor. ${ }^{67}$ Due to a misidentification of older siliceous shale (Kreyenhagen shale) as Monterey, sandstone in the same part of the section on Anticline Ridge, including the "reef bed," was not recognized as Temblor and was grouped with overlying strata to constitute the Coalinga beds, ${ }^{68}$ an interpretation that was corrected in a later account. ${ }^{69}$ Arnold and Anderson regarded the sandstone at these localities as of the same age as the previously described Vaqueros sandstone of the outer Coast Ranges. Consequently, they used the name Vaqueros sandstone and considered Temblor a synonym of Vaqueros. ${ }^{70}$

Discussion concerning the stratigraphic and chronologic relations of the Vaqueros and Temblor have been summarized by several writers. ${ }^{71}$ It is generally recognized that the current usage of these two formation names is unsatisfactory. The term "Vaqueros sandstone" is currently used for sandstone throughout the Coast Ranges containing the Turritella inezana fauna; and the term "Temblor sandstone," or "Temblor formation," for sandstone containing the Turritella ocoyana fauna; ${ }^{72}$ that is, they are generally used for faunal zones. $^{73}$ A typical Vaqueros fauna is readily distinguished from a typical Temblor fauna. At many localities only the one or the other is represented. Where they are found in the same section, the Vaqueros fauna underlies the Temblor fauna, as was suggested many years ago ${ }^{74}$ but in many regions a transition zone containing fossils of intermediate aspect is recognized. ${ }^{75}$ The ranges of the index species after which the Turritella inezana zone and the Turritella ocoyana zone were named, and of other species, are now known to overlap.

The usage of formation names for faunal zones is improper. Such usage for the terms "Vaqueros" and

\footnotetext{
${ }^{60}$ Anderson, F. M., A stratigraphic study in the Mount Diablo Range of California: California Acad. Sci. Proc., 3d ser., vol. 2, pp. 169-170, 1905.

${ }^{67}$ Idem, p. 171, pl. 34, section 1.

${ }^{83}$ Idem, pp. 172-173, 174-176, pl. 34, section 3.

${ }^{60}$ Anderson, F. M., A further stratigraphic study in the Mount Diablo Range of California: California Acad. Sci. Proc., 4th ser., vol. 3, pp. 16, 19-20, 1908.

70 Arnold, Ralph, and Anderson, Robert, op. cit. (Bull. 398), p. 87.

"1 Louderback, G. D., The Monterey series in California: California Univ., Dept. Geology, Bull., vol. 7, pp. 177-241, 1913. Wiedey, L. W., Notes on the Vaqueros and Temblor formations of the California Miocene with descriptions of new species: San Diego Soc. Nat. History Trans., vol. 5, no. 10, pp. 98-107, 1928. Loel, Wayne, and Corey, W. H., The Vaqueros formation, lower Miocene of California, pt. 1 Paleontology: California Univ., Dept. Geol. Scl., Bull., vol. 22, pp. 45-50, 1932 Kleinpell, R. M., Miocene stratigraphy of California, pp. 161-163, Tulsa, Am. Assoc. Petroleum Geologists, 1938.

7 Wilmarth, M. G., Names and definitions of the geologic units of California: U. S. Geol. Survey Bull. 826, pp. 88-89, 94, 1931.

${ }^{73}$ Louderback, G. D., op. cit., pp. 230-231.

" Merriam, J. C., A note on the fauna of the lower Miocene in California: California Univ., Dept. Geology, Bull., vol. 3, p. 380, 1904.

7s Lool, Wayne, and Corey, W. H., op. cit., pp. 125-127.
} 
"Temblor" is of long standing, however, and in a general way has proved useful. An attempt to put into general effect logical usage is likely to be more confusing than helpful. Nevertheless for the purpose of the present report these terms are not used for faunal zones.

\section{STRATIGRAPHY, IITHOLOGY, AND FOSSILS}

\section{OUTCROP SECTYONS}

Zemorra Creek.-The type region of the Temblor formation is in the Temblor Range near Carneros Creek. ${ }^{76}$ The following section shows the principal subordinate units on Zemorra Creek, the south fork of Chico Martinez Creek, which is $2 \frac{1}{2}$ miles southeast of Carneros Creek. This section, measured by M. N. Bramlette, K. E. Lohman, and R. M. Kleinpell, is a continuation of the Chico Martinez Creek section on page 125.

Section of Temblor formation in type region on Zemorra Creek in Temblor Range, 40 miles southeast of Kettleman Hills

[Measured by M. N. Bramlette]

Gould shale member of Monterey shale.

Temblor formation:

Button bed sandstone member of local usage:

Moderately coarse grained sandstone with some glauconite and phosphate pellets; uppermost 10 feet harder and more calcareous, and containing abundant "buttons" ("Scutella" merriami); cross-bedding 25 feet below top......

Sandstone, softer and finer grained than overlying sandstone; some glauconite.............

Media shale member of local usage:

Dark silty shale, in part foraminifera]; few zones of calcareous concretions. A hard sandstone about 5 feet thick is 160 feet below the top; and the top of a 50-foot zone of cherty shale is 40 feet lower

Carneros sandstone member of local usage:

Coarse-to-medium grained sandstone with many zones of hard limy concretions; a thin foraminiferal shale 80 feet below the top.........

Santos shale member of local usage:

Dark silty shale, some beds containing Foraminifera. A hard reef-forming calcareous sandstone is 60 feet below the top; 120 feet below the top the shale is phosphatic and includes some thin beds of soft glauconitic sandstone; a bed at the base a foot thick contains phos-

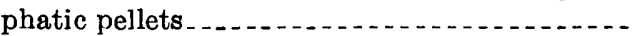

"Phacoides" reef member of local usage:

Medium-grained glauconitic sandstone with hard fossiliferous reef at base............

Barren shale member of local usage:

Hard purplish-brown highly fractured sandy to silty shale; few Foraminifera ..............

Thickness of Temblor formation _.... 1,830 Massive, "cavernous," poorly sorted sandstone (Tejon formation of Bulletins 406 and 721).

${ }^{70}$ For geologic maps of this region see Arnold, Ralph, and Johnson, H. R., Preliminary report on the McKittrick-Sunset oil region, Kern and San Luis Obispo Counties, Calif.: U. S. Geol. Survey Bull. 406, pl. 1, 1910; English, W. A., Geology and petroleum resources of northwestern Kern County, Calif.: U. S. Geol. Survey Bull. 721, pl. 1, 1921.
According to a section measured by K. E. Lohman, the Temblor formation on Carneros Creek has a thickness of 1,500 feet and consists of the same main units as on Zemorra Creek. With the exception of the Santos shale member of local usage, the main units are considerably thinner on Carneros Creek than on $\mathrm{Ze}$ morra Creek. Also on Carneros Creek a hard fossiliferous reef lies at the top of the "Phacoides" reef member of local usage instead of at the base.

The names for the members cited in the preceding section have come into general use among geologists working in this region. ${ }^{77}$ They are not considered in the present report, for some still have informal status; and so far only one of the formally named members, the Carneros sandstone member, has been defined. ${ }^{78}$

The foraminiferal zones recognized by Kleinpell in the Temblor formation of the type region have recently been described. ${ }^{79}$ Their stratigraphic positions are shown on plate 47. A published account of the mollusks in the "Phacoides" reef member of local usage is not available, other than F. M. Anderson's list ${ }^{80}$ which is assumed to include fossils from this horizon. The informal name for the member is derived from the abundance of "Phacoides" acutilineatus [Lucinoma acutilineata]. There also is no published list for the mollusks in the Carneros sandstone member of local usage. The button bed sandstone member of local usage at the top of the Temblor formation is characterized by the abundance of little sand dollars ("buttons"). These sand dollars were described by Anderson as Astrodapsis merriami ${ }^{81}$ and are generally known as Scutella merriami. ${ }^{82}$ Stefanini ${ }^{83}$ and Lambert and Thiery $^{84}$ have pointed out that at least some of the Pacific coast Miocene sand dollars assigned to Scutella are allied to the genus Phelsumia, formerly known as Echinarachnius, which is now represented on the Pacific coast as far south as Puget Sound by $P$. parma (Lamarck) ${ }^{85}$ In Phelsumia the ambulacral furrows tri-

"1 Gester, G. C., and Galloway, John, op. cit. (Am. Assoc. Petroleum Geologists Bull., vol. 17), fig. 3 (p. 1169).

78 Cushman, J. A., and Barbat, W. F., Notes on some arenaceous Foraminifora from the Temblor formation of California: Cushman Lab. Foram. Research Contr. vol. 8, p. 31, 1932. Packard, E. L., and Kellogg, Remington, A new cetothere from the Miocene Astoria formation of Newport, Oregon: Caruegie Inst. Washington Pub. 447, p. 17, 1934.

72 Kleinpell, R. M., Miocene stratigraphy of California, pp. 103-117, Tulsa, Am. Assoc. Petroleum Geologists, 1938. Kleinpell gives lists of species on pp. 40-45, 54-55.

80 Anderson, F. M., op. cit., p. 170. A few species are mentioned in Kleinpell, R. M., op. cit., p. 39 .

${ }^{81}$ Anderson, F. M., op. cit., pp. 193-194, pl. 14, figs. 33, 34. Recorded from Tar Springs [Big Tar Canyon], Kreyenhagen's [Canoas Canyon], and Temblor. According to Kew (op. cit., p. 73), the cotypes are from the east side of the Temblor Range [presumably near Carneros Creek].

82 Arnold, Ralph, and Anderson, Robert, op. cit. (Bull. 398), pl. 28, fig. 4 (incor rectly oriented; posterior end is on right side). Kew, W. S. W., Cretaceous and Cenozoic Echinoidea of the Pacific coast of North America: California Univ. Dept. Geology, Bull., vol. 12, pp. 72-73, pl. 12, figs. 3a-f, 1920.

83 Stefanini, G., Sugli echini terziari dell'America del Nord: Soc. geol.italiana Bol., vol. 30 , p. 703, 1912; Relations between American and European Tertiary echinoid faunas: Geol. Soc. America Bull., vol. 35, p. 845, 1924.

Bt Lambert, J., and Thiéry, P., Essais de nomenclature raisonnée des échinides, pt $8-9$, p. $583,1925$.

8s Lambert, J., and Thiéry, P. (op. cit., pt. 4, p. 316, 1914) proposed the generic name Phelsumaster for this species on the grounds that Phelsumia was invalidated by an earlier name Phelsuma. 
furcate near the margin of the test. The ambulacral furrows are not clearly discernible on specimens of "Scutella" merriami and allied species that are available. The generic name Twitchellia has been proposed for "Scutella" merriami. ${ }^{86}$ This species is here assigned to "Scutella," as its generic relations are still uncertain. ${ }^{87}$ A group of "Scutellas" consisting of species much larger than "S." merriami occurs in the California Miocene but has not been discovered along the west side of the San Joaquin Valley.

According to the foraminiferal zones represented, the greater part of the Temblor in the type region represents the lower Miocene of the Coast Range section as generally accepted, ond the barren shale member of local usage is probably of Oligocene age. In view of the age relations some geologists assign the lower part of the section to the Vaqueros. This assignment has received further support by the recent announcement that Lyropecten magnolia and Ostrea vaquerosensis have been found in a sandstone in the upper part of the Santos shale of local usage. ${ }^{88}$ Lyropecten magnolia has long been considered one of the most characteristic of typical Vaqueros fossils. Its discovery in the Santos shale of local usage indicates how little reliance can be placed on the absence of typical Vaqueros species, which are not known in the "Phacoides" reef of local usage or in the Carneros sandstone of local usage, though according to the horizon and facies they might be expected in these strata. Vaqueros fossils were recorded from the northenst slope of the Temblor Range by Arnold and Anderson, ${ }^{89}$ who cited Turritella inezana, "Pecten" magnolia, and "Pecten" bowersi from a locality in sec. 36, T. 26 S., R. 17 E., south of Antelope Valley. It is assumed that this citation refers to the collection that has the locality number 4941 (three-quarters of a mile north of Miller Brothers' house, along their grade road; 6 miles east of Annette, Kern County). This collection includes three specimens of Turritella inezana that are most similar to $T$. inezana in the restricted sense, as interpreted by Loel and Corey. ${ }^{90}$ The only pectens

\footnotetext{
so Lambert, J., Rov. Crit. Paleozoologle, 20th year, p. 171, 1915. Twitchellia was proposed for Twitchellia merriami (Anderson) as figured by Twitchell under the name Scutellap merriami (Anderson) (U. S. Geol. Survey Mon. 54, pl. 85, figs. 7a-c, 1915; specimon from locality 4772. Scutella merriami bed in Canoas Canyon). Lambert considered the other specimon flgured by Twitchell (figs. $8 \mathrm{a}-\mathrm{b}$; specimen from locality 4775, Garza Creok gorgo in Reef Ridge, hard sandstone "button bed") as a different speofos, for which he proposed the name Twitchellia packi. These two specimens are poorly preserved and appear to be immature; the petals on the flgures are greatly retouched. They are regarded as representing the same species-"Astrodapsis" merriami Anderson. Lator Lambert and Thiery claimed that Tuitchellia packi is the type of Twitchellia; that the specimen represented by Twitchell's fig. 7 should he referred to Orchoporus merriami (Twitchell); and that the "true" Scutella merriami is an Astrodapsis (Lambort and Thlory, op. cit., pt. 8-9, p. 577, 1925).

${ }^{87}$ Astrodapsis merriami has recently been assigned to Echinarachnius (Grant, U. S., IV, and Hertlein, L. G., Tho West American Cenozoic Echinoidea: California Univ. at Los Angeles Pub. Math. Phys. Sci., vol. 2, p. 60, 1938), and the specimen from Canoas Canyon figured by $T$ witchcll as Scutella? merriami has been named Orchoporus lamberti (Idem, p. 52). Orchoporus was based on an immature Merriamaster (see p. 82 of present report).

s9 Clark, L. M., and Clark, Alex, The Vaqueros in the Temblor Range [abstract]: Am. Assoc. Petroleum Geologists Bull., vol. 19, p. 137, 1935.

80 Arnold, Ralph, and Anderson, Robert, op. cit. (Bull. 398), p. 87.

00 Loel, Waync, and Coroy, W. H., The Vaqueros formation, lower Miocene of Callfornia, pt. 1, Palcontology: California Univ., Dept. Geol. Sci., Bull., vol 22, pp. 254-255. 1932.
}

$152.190-40-10$ now in the collection are Lyropecten miguelensis and Vertipecten nevadanus (cited as "Pecten" bowersi). The stratigraphic position of the strata containing these fossils is not known. The claim that the lower part of the Temblor is of the age of Vaqueros elsewhere has ample paleontologic support. Instead of dividing this section into Vaqueros and Temblor parts it appears to be more satisfactory to refer the alternating sandstone and shale to one formation; to separate and name as many members as is compatible with the degree of refinement in mapping; and to express the chronologic relations of the formation and its members in terms of faunal zones.

Reef Ridge.-The sandstone that forms the crest of the greater part of Reef Ridge (pl. 48), west of the Kettleman Hills, is referred to the Temblor sandstone. This sandstone was not adequately examined during the field work for the present report, but it appears to be divisible into several parts.

The following section was measured along Big Tar Canyon:

Section of Temblor sandstone in Big Tar Canyon, Reef Ridge

Temblor sandstone (top not exposed):

Upper sandstone:

14. Soft dirty sandstone, iron-stained at base, lighter in color toward top; few beds of harder and cleaner sandstone 1 to 2 feet thick; some layers oil-stained. Upper part contains Turritella ocoyana, Miltha sanctaecrucis, Clementia pertenuis and other fossils (see p. 142) ...........................

Middle sandstone:

13. Limy sandstone and medium-grained sandstone. Basal layer, $1 \frac{1}{2}$ feet thick, forms uppermost virtually continuous reef (the uppermost reef extending for a short distance on the east side of the canyon, as shown on plate $48, A$, is in the overlying sandstone); contains Oliva, Aequipecten andersoni, Dosinia, and barnacles........

12. Dirty sandstone, poorly exposed . . . . ....

11. Coarse-grained, limy, reef-forming sandstone containing "buttons" ("Scutella" merriami) and Aequipecten andersoni........

10. Clean medium-grained sandstone and thinner layers of poorly exposed dirty sand-

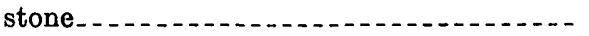

9. Main reef forming crest of Reef Ridge:

h. Limy sandstone containing many specimens of Turritella ocoyana.........

g. Medium-grained sandstone..........

f. Sandy limestone, molds of shells; forms crest of reef . . . . . .

e. Medium-grained sandstone

d. Sandy limestone, indeterminable fossils .

c. Medium-grained sandstone..........

b. Sandy limestone, molds of shells . . . . . -

a. Coarse-grained limy sandstone, molds of shell

8. Dirty sandstone resembling unit $6 \ldots \ldots . . . .$.

7. Cleaner and harder sandstone, with ferruginous concretionary nodules and layers.
Feet 
Section of Temblor sandstone in Big Tar Canyon, Reef RidgeContinued

Temblor sandstone (top not exposed)-Continued. Middle sandstone-Continued.

6. Dirty sandstone weathering into small bJocks or spheroidal masses................

5. Medium-grained sandstone; some layers oilstained. Upper part forms low reef on southwest slope of Reef Ridge...........

4. Dirty iron-stained sandstone and cleaner oilstained sandstone; layers half a foot to several feet thick.....................

Lower shale:

3. Light chocolate-brown shale containing coarse sand grains...................

Lower sandstone:

2. Iron-stained soft dirty sandstone........

1. Sandstone:

e. Medium-grained sandstone weathering into spheroidal masses. . .........

d. Dirty thin-bedded sandstone..........

c. Iron-stained concretionary sandstone containing Anadara osmonti and Vertipecten $\mathrm{cf}$. $V$. nevadanus...........

b. Sandstone similar to unit a, with lenses of pebbly sandstone, in which small black chert pebbles are most conspicuous; contains Vertipecten cf. $V$. nevadanus.-

a. Medium-grained, poorly cemented sandstone with small pebbles, grades up-

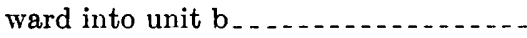

Thickness of measured section _ 596

Base of formation not exposed.

The base and top of the formation are not exposed in the region where this section was measured. The highest exposures appear to be close to the top of the formation, but a considerable thickness may be missing at the base. It is estimated that the total thickness is about 700 feet. The base of the sandstone is well exposed in a canyon on the southwest slope of Reef Ridge about a mile southeast of Big Tar Canyon, where the sandstone rests on Kreyenhagen shale. At the base is a conglomerate, 2 or 3 inches thick, that is heavily impregnated with gypsum and contains small rounded pebbles of black chert and flat pebbles of Kreyenhagen shale. The strata overlying the basal conglomerate consist of dirty gray sandstone and harder cleaner buff sandstone.

Bramlette ${ }^{91}$ reported that the lower sandstone of the preceding section has a mineral composition of rather nondescript character. The middle sandstone constitutes a sharply differentiated andesite sand zone characterized by the abundance of andesine and andesitic rock grains of finer texture, varying amounts of more or less altered shards of volcanic glass, and considerable green and basaltic (brown) hornblende, augite, and actinolite. The upper sandstone has a rather nondescript mineral assemblage but contains abundant chromite, and the uppermost sample contains a small

${ }^{91}$ Bramlette, M. N., op. cit. (Am. Assoc. Petroleum Geologists Bull., vol. 18), table 4 (p. 1564), p. 1567, fig. opposite p. 1567. amount of serpentine and uvarovite. ${ }^{92}$ Fossils from the upper sandstone are discussed under the heading "Age and correlation."

A section measured in Canoas Canyon $5 \frac{1}{2}$ miles northwest of Big Tar Canyon is as follows:

Section of Temblor sandstone in Canoas Canyon, Reef Ridge

McLure shale member of Monterey shale.

Temblor sandstone:

Upper sandstone:

Soft grayish sandstone with lenses of cross-bedded sandy limestone. Sandstone contains abundant "buttons" ("Scutella" merriami) ........

Sandy limestone containing abundant "buttons" ("Scutella" merriami) and some Aequipecten

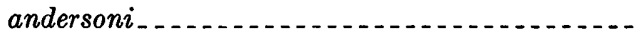

Soft buff-gray sandstone, some harder layers; oil seeps . . . . . . . . . . . . . . . . . . . . . . 136

Middle sandstone:

Medium-grained buff-gray sandstone; poorly preserved fossils

Unexposed (on east side of canyon a bed of sandstone, 2 to 3 feet thick, lying 3 feet below base of overlying sandstone contains abundant Aequipecten andersoni) ....................

Medium-grained buff-gray sandstone. An 8inch bed containing poorly preserved fossils is present 5 feet above base and another fossiliferous bed a foot thick occurs at top........

Unexposed...............................

Thin-bedded dirty sandstone, containing "buttons" ("Scutella" merriami), Aequipecten andersoni, and Neverita?, capped by a 5 -inch layer of harder, cleaner sandstone............

Massive cavernous buff-gray sandstone with harder concretionary layers and partings of dirty sandstone. A few layers 1 to 2 inches thick contain small pebbles. Much of the sandstone is oil-stained. . . . . . . . . . . . .

Sandstone

Thin-bedded dirty sandstone............... Main reef forming crest of Reef Ridge:

Sandy limestone. Some layers contain specimens of Turritella ocoyana and consist of almost pure limestone, others are more sandy, and some contain small chert pebbles. Fossils throughout entire thickness, mostly molds. Forms crest of reef -

Medium-grained sandstone...............

Sandy limestone; poorly preserved fossils. -

Medium-grained sandstone...............

Coarse-grained pebbly sandstone, grading upward into limy sandstone; pebbles mostly chert and quartz . . ............

Soft medium-grained massive sandstone; few hard concretionary layers and thin-bedded layers of dirtier sandstone . . . . . . . . . ....

Coarse-grained pebbly sandstone forming low reef on southwest slope of Reef Ridge........

Iron-stained and oil-stained dirty sandstone....

Thickness of measured section.......... 683

Lowest part of formation, presumably including equivalent of lower sandstone in Big Tar Canyon, not exposed.

12 Idem, table 4 (p. 1564), p. 1572, fig. opposite p. 1567. 
The lowermost part of the formation is not exposed along Canoas Canyon. Exposures on a spur on the southwest slope of Reef Ridge about half a mile northwest of the canyon indicate that a thickness of about 125 feet, mainly soft gray dirty sandstone, underlies the lowest exposures in the canyon, making a total thickness of about 800 feet. This sandstone corresponds presumably to the lower sandstone in Big Tar Canyon. $A$ bed of conglomerate, consisting of chert pebbles and some serpentine pebbles overlies the upper sandstone. The conglomerate has a thickness of an inch to a foot and fills channels in the sandstone. The conglomerate is overlain by 60 feet of glauconitic clayey sand, 10 feet above the base of which is a bed of bentonite. The clayey sand represents the basal part of the McLure shale member of the Monterey, and the conglomerate is also assigned to the McLure.

According to Bramlette, ${ }^{93}$ a sample from tbe lowest part of the formation exposed on a spur northwest of Canoas Canyon is similar in mineral composition to the lower sandstone of the Big Tar Canyon section. The middle sandstone represents the well-defined andesitic sand zone. The upper sandstone, however, has a smaller proportion of chromite than the upper sandstone in Big Tar Canyon.

Fossils from various localities on Reef Ridge were listed and described by F. M. Anderson ${ }^{94}$ and Arnold. ${ }^{95}$ The specimen of "Scutella?" merriami figured by Twitchell, ${ }^{06}$ on which the genus Twitchellia was based (see p. 131), is from locality 4772 , wbich apparently represents the sandstone at the top of the Temblor in Canoas Canyon. ${ }^{97}$

Anticline Ridge.-The following section of the Temblor sandstone on the south slope of Anticline Ridge, northwest of the Kettleman Hills, near Phoenix Canyon, .wbich enters Oil Canyon in the southern part of sec. 20, T. 19 S., R. 15 E., was measured by K. E. Lohman.

Section of Temblor sandstone on first ridge southeast of Phoenix Canyon on south slope of Anticline Ridge

[Measured by K. E. Lohman]

Nonmarine formation assigned to Jacalitos by. Arnold and Anderson.

Temblor sandstone:

Big Blue serpentinous member: Greenish silt and sandstone with lenses of pebbles, including serpentine; thickness approximate . . . . . . . . . . . . . . .

Upper sandstone: Gray poorly bedded fine-grained to moderately coarse grained generally soft sandstone; a few harder beds form small ledges; upper part fossiliferous; lowermost part iron-stained and fossiliferous

88 Bramletto, M. N., op. clt. (Am. Assoc. Petroleum Geologists Bull., Vol. 18), tnble 4 (p. 1504), pp. 1567, 1572, Ag. opposite p. 1567.

it Andorson, F. M., op. cit., pp. 171-172, 205.

of Arnold, Raiph, op. cit. (Bull. 396), pp. 16-20, 54-63, pls. 5-9, 1909 [1910]. Arnold, Ralph, and Anderson, Robert, op. cit. (Bull. 398), pp. 84-88, pls. 27-31, 1910.

of Clark, W. B., and Twitchell, M. W., The Mesozolc and Cenozoic Echinodermata of the United Statos: U. S. Geol. Survey Mon. 54, pp. 185-186, pl. 85, figs. $7 \mathrm{a}-\mathrm{c}, 1815$,

${ }^{\circ 7}$ Arnold, Ralph, and Anderson, Robert, op. cit. (Bull. 398), pp. 84, 86. According to the soction on p. 84, locality 4772 represents the base of the uppermost 180 feet of Vaqueros sandstone in Canoas Canyon, but the type of preservation suggests that the fossils were collected at the top of the sandstone.
Section of Temblor sandstone on first ridge southeast of Phoenix Canyon on south slope of Anticline Ridge-Continued

Temblor sandstone-Continued.

Feet

"Indicator bed": Pale chocolate brown to white .laminated punky diatomite. Northeastward along strike changes to hard porcelaneous and cherty

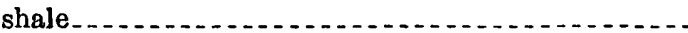

Middle sandstone:

Soft, poorly exposed medium-grained to coarsegrained sandstone; near top grades into finergrained sandstone and siltstone............

Discontinuous light buff to gray reef-forming moderately coarse grained calcareous sandstone

Soft poorly exposed medium to coarse-grained

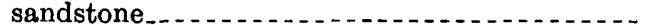

Hard light buff to gray medium- to coarsegrained fossiliferous, calcareous sandstone; forms main reef

Soft medium- to coarse-grained sandstone; lower part poorly exposed.

Lower diatomite: Massive conchoidally fracturing white clayey (?) diatomite. . . . . . . . . . . .

Lower sandstone:

Chocolate-brown to buff, white weathering sandy siltstone containing poorly sorted angular sand grains and a few diatoms; lower 40 feet poorly exposed.......................

Massive coarse-grained chocolate-brown oilstained sandstone, grading near top into sandy shale and sandy siltstone. . . . . . . . . . .

Chocolate-brown to buff white weathering hackly fracturing siltstone containing diatoms.

Massive chocolate-brown to buff oil-stained sandstone; upper part forms ledge, lower part softer; few pebbles at base..............

Chocolate-brown fractured mudstone with silty

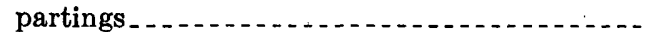

Reddish-brown moderately coarse grained poorly cemented sandstone; grains subrounded and poorly sorted; coarser towards base........

Conglomerate consisting of well-rounded pebbles having an average length of about $1 \frac{1}{2}$ inches but ranging in length from 1 to 4 inches. Granite, quartzite, and a basic rock are the most abundant constituents. .............. .

Thickness of Temblor sandstone

646 Kreyenhagen shale.

Bramlette ${ }^{98}$ reported that the Temblor of this area shows a marked difference in mineral content from that of Reef Ridge. Sandstones underlying the Big Blue serpentinous member contain abundant hypersthene, which is very rare or absent in sandstones on Reef Ridge, and also some andalusite and kyanite, which are not present in the strata on Reef Ridge. The Big Blue serpentinous member forms the most distinct mineral zone in the Temblor of the Coalinga district.

Fossils from the Temblor sandstone on Anticline Ridge were listed and described by F. M. Anderson ${ }^{99}$

\footnotetext{
98 Bramlette, M. N., op. cit. (Am. Assoc. Petroleum Geologists Bull., vol. 18), p. 1573.

10 Anderson, F. M., op. cit., pp. 176 (first two lists and probably also the third),
} 177, 196, 197, 200, 203. 
and Arnold. ${ }^{1}$ Fossils from the upper sandstone are discussed under the heading "Age and correlation."

SUBSURFACE SECTION

The subsurface Kettleman Hills section assigned to the Temblor sandstone is about 2,000 feet thick. It is more than twice as thick as the Temblor sandstone on Reef Ridge and on Anticline Ridge but is not much thicker than the Temblor formation in the type region farther south. As in the outcrop section in the type region, the formation in the subsurface section consists of alternating units made up chiefly of sand and shale, but the proportion of sand is greater in the subsurface section. With regard to the proportion of sand and shale the subsurface section is intermediate between the Reef Ridge and type region outcrop sections. Mineral zones represented in the Temblor on Reef Ridge are recognized in the subsurface section, and a distinctive mineral zone in the upper part of the subsurface section is clearly the equivalent of at least part of the Big Blue serpentinous member on Anticline Ridge. Though the subsurface Temblor is in general comparable to the Temblor in the type region, it is inferred that the upper part of the subsurface Temblor is younger, for a shale in the upper part of the subsurface section contains a foraminiferal fauna similar to that in the Gould shale member of the Monterey shale overlying the Temblor

1 Arnold, Ralph, op. cit. (Bull. 396), pp. 16-20, 54-63, pls. 5-9, 1909 [1910]. Arnold, Ralph, and Anderson, Robert, op. cit. (Bull. 398), pp. 84-88, pls. 27-31, 1910. in the type region. (See fig. 14 and discussion under heading "Age and correlation," p. 141.)

Lillis-Welch well No. 1, sec. 24 , T. 21 S., R. 17 E., at the north end of North Dome, penetrated the entire Temblor sandstone. The thickness of the formation in this well is about 1,900 feet, or about 1,500 feet if the lowermost 365 feet of sandy strata are assigned to the "Leda" zone of the Kreyenhagen shale. In Standard well $46-13-\mathrm{H}$ the Temblor is reported to be 1,670 feet thick. In another deep well, Kenda well 4-18-J, at the north end of North Dome, the Temblor is reported to be 1,700 feet thick. In Kenda well 38-34-J, which also penetrated the entire formation, the thickness is about 2,200 or 2,000 feet, depending on the assignment of the lowermost 200 feet of hard siltstone, silty shale, and sand. Continental Gatchell well No. 28-7, sec. 7, T. 25 S., R. 20 E., drilled in South Dome during 1935, is reported to have penetrated a thickness of 1,833 feet of strata referred to the Temblor, disregarding dip and possible deviation of the well from vertical.

Much of the subsurface Temblor is, of course, more completely represented by core material than overlying subsurface formations. Since electrical logging has come into general usage, however, much less coring is done than formerly. Inasmuch as only six wells have so far reached the Temblor sandstone in Middle Dome and only three in South Dome, the formation is not so well known in those areas as in North Dome.

The percentage of the principal lithologic constituents in the subsurface Temblor is as follows:

Principal lithologic constituents in subsurface Temblor sandstone in Kettleman Hills

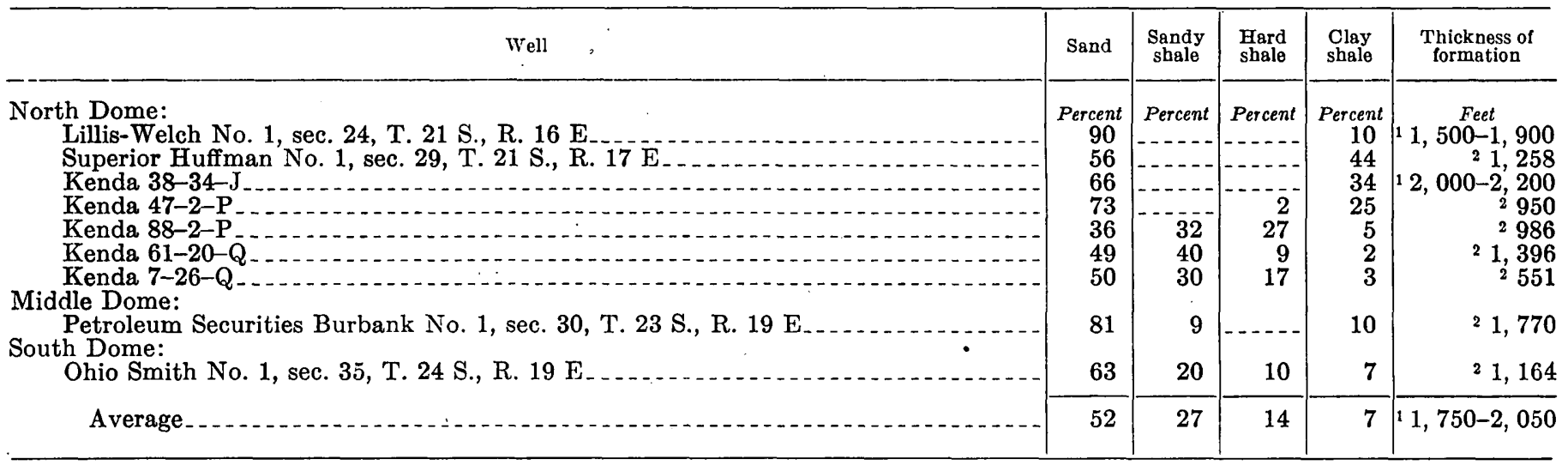

1 Thickness depends on interpretation of contact between Temblor and Kreyenhagen.

2 Base not reached.

The subdivisions adopted for the Temblor of North Dome are essentially the same as the subdivisions used by Dodd ${ }^{2}$ and by Gester and Galloway. ${ }^{3}$ Six zones of oil-bearing sand and sandy shale and five barren zones, consisting chiefly of shale or siltstone and sandy shale,

\footnotetext{
2 Dodd, H. V., Recent developments in the Kettleman Hills field: Californis Oil Fields (California, Div. Oil and Gas), vol. 17, no. 1, pp. 5-44, 13 pls., 1931 [1932]. Dodd, H. V., and Kaplow, E. J., Kettleman North Dome and Kettleman Middle Dome flelds, progress in development: Idem, vol. 18, no. 4, pp. 5-20, 3 pls., 1933 [1934].

a Gester, G. C., and Galloway, John, op. cit. (Am. Assoc. Petroleum Geologists Bull.; vol. 17), pp. 1180-1182.
}

are now recognized. The lowest barren zone is divided into two parts. The zones of oil-bearing strata are numbered in consecutive order downward in the section, and drillers' terms are used for the barren zones. Drillers' names have also been used for some of the oil zones. Owing to lateral changes in lithology and to incomplete data some of the subordinate units are not clearly recognizable throughout North Dome. These units and their principal features are as follows: 
Subsurface Temblor sandstone of North Dome

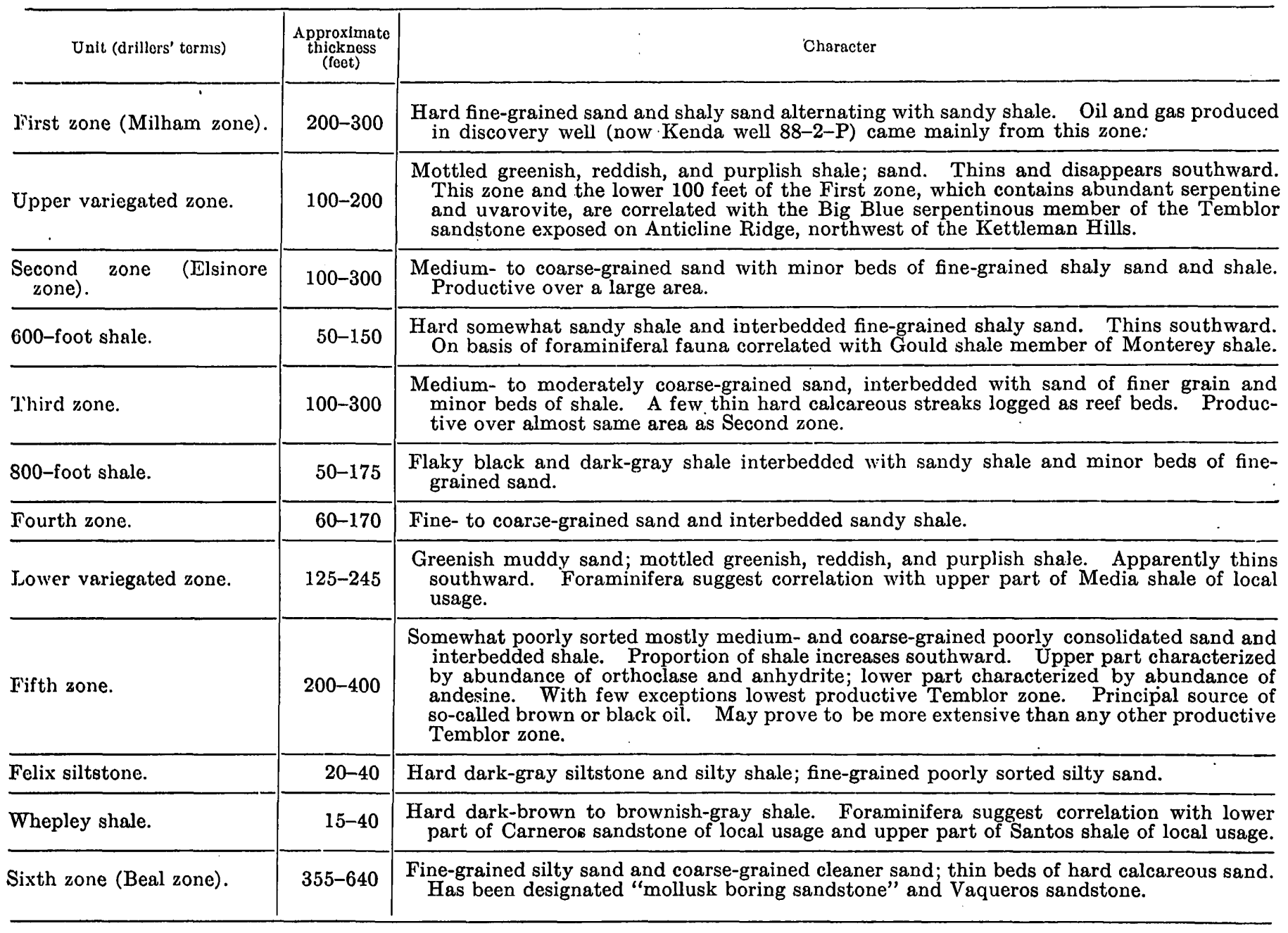

First zone (Milham zone).-The First zone, which is the first productive zone, is designated by drillers the Milham zone or Elliott zone. These terms are derived from the discovery well of the Milham Exploration Co., on the Elliott lease in sec. 2, T. 22 S., R. 17 E., now Kenda well $88-2-\mathrm{P}$. The oil and gas produced by this well came mainly from this zone.

The thickness of the First zone ranges from about 200 feet at the north end of North Dome to a maximum of about 300 feet on the crest of the central part of the anticline. According to Goudkoff's identification ${ }^{4}$ of the underlying upper variegated zone in Petroleum Securities Burbank well No. 1, in Middle Dome, a thickness of a little more than 100 feet of hard fine- to medium-grained sand may be assigned to the First zone in Middle Dome. In South Dome an undetermined thickness of sand and sandy shale, including the sand 150 feet below the top of the Temblor that yielded the strong flow of salt water encountered in Obio Smith well No. 1, may be tentatively regarded as representing the First zone.

In North Dome the First zone consists of hard fine-

- Goudkofr, P P., op. cit. (Am. Assoc. Petroleum Geologists Bull., vol. 18), p̀. 456. grained gray sand and shaly sand alternating with darkbrown sandy shale. In wells that were cored or electrically logged seven to eight sands and at least seven shales are present in this zone. In the north half of the anticline about 80 percent of the First zone consists of sand and in the south half about 50 percent.

Bramlette ${ }^{5}$ reported that about the upper 100 feet of the First zone in North Dome has a rather uniform mineral assemblage of nondescript character. The underlying 150 feet extending down almost to the base of the First zone constitute the serpentine zone--the most distinctive mineral zone in the subsurface section. ${ }^{6}$ It is characterized by the abundance of serpentine and the green garnet, uvarovite, and by the common occurrence of glaucophane. These minerals were clearly derived from the area of Franciscan (Jurassic?) rocks on Joaquin Ridge, northwest of Anticline Ridge. On the basis of this sharply differentiated and readily recognized mineral zone, the lower part of the First zone is correlated with at least part of the Big Blue serpentinous member of the Temblor sandstone exposed

\footnotetext{
- Bramlette, M. N., op. cit. (Am. Assoc. Petroleum Geologists Bull., vol. 18), p. 1569. - Idem, pp. 1568-1569.
} 
on Anticline Ridge and farther north. ${ }^{7}$ The Big Blue has the same suite of minerals and occurs in about the same part of the section.

Mollusks are reported from the First zone in the logs of many wells. According to these records, fragments of oysters and of a small pecten, some of which are identified as Aequipecten andersoni ["Pecten"], appear to be most abundant.

Upper variegated zone.-The upper variegated zone, which includes variegated shale, has a thickness of 100 to 200 feet in North Dome. Toward the south it thins and disappears. Inasmuch as the marked change in color from the grayish and brownish rocks of the First zone to greenish, reddish, and purplish rocks is readily recognized, the upper variegated zone is a useful key zone. During the early development of the oil field cores were taken to locate the zone, which serves as a guide for landing casing to shut off the First zone.

The upper variegated zone thins rapidly southward and in the southern half of North Dome shows only traces. Goudkoff, ${ }^{8}$ however, identified the zone in Petroleum Securities Burbank well No. 1, in Middle Dome. The zone has not been found in South Dome.

Mottled greenish, reddish, and purplish shale are the most conspicuous constituents of the upper variegated zone, particularly in the upper 20 to 25 feet. The underlying 75 to 175 feet consists chiefly of gray sand with thin beds of shale. Some of the sand and shale in the lower part of the zone are also variegated. A brittle crumbly greenish-purple shale, logged in a few wells, may be considered the base of the zone. Rounded pebbles of green, red, and black chert are common in the sands. Stringers of small pyrite crystals are recorded in sands and sandy shales.

Goudkoff ${ }^{9}$ pointed out that the thickness of strata between the bentonite near the base of the McLure and the top of the upper variegated zone increases from 268 feet at the north end of North Dome to 328 feet in the central part of the anticline and that the thickness increases at a more uniform rate than the thickness of strata between the bentonite and the top of the Temblor sandstone.

The upper variegated zone is doubtless the equivalent of part of the Big Blue serpentinous member, or more probably is the equivalent of nonmarine strata immediately underlying the Big Blue and generally considered part of that member.

Second zone (Elsinore zone).-Underlying the upper variegated zone is the Second zone. It is also designated by drillers the Elsinore zone, a name derived from North American Elsinore well No. 1, sec. 36, T. 21. S., R. $17 \mathrm{E}$. This zone is the source of the oil produced

\footnotetext{
'Arnold, Ralph, and Anderson, Robert. op. cit. (Bull. 398), pp. 89-90. Anderson, Robert, and Pack, R. W., Geology and oil resources of the west border of the San Joaquin Valley north of Coslinga, Calif.: U. S. Geol. Survey Bull. 603, pp. 83-84, 1915. 8 Goudkoff, P. P., op. cit. (Am. Assoc. Petroleum Geologists Bull., vol. 18), p. 456. Idem, pp. $455-456$.
}

from that well. As pointed out by Gester and Galloway, ${ }^{10}$ the Second zone was at one time thought to extend over a larger area than any other productive zone in North Dome. The thickness of the Second zone in North Dome ranges from 100 to 300 feet, depending on the shale that is selected as representing the top of the underlying 600-foot shale. A zone about 150 feet thick overlying shale correlated with the 600 -foot shale may be regarded as the equivalent of the Second zone in Middle Dome. About 80 feet of medium- to finegrained sand, with a few thin beds of hard shell and shale and a 2-foot reef bed, were recorded in the 110foot interval above shale correlated with the 600-foot shale in Continental Gatchell well No. 28-7, in South Dome.

The Second zone in North Dome consists of mediumto coarse-grained sand interbedded with fine-grained shaly sand and a few thin beds of shale. The porosity of some of the sands is as high as 16 to 20 percent. Some marginal wells in which less than 100 feet of this zone is open to production are highly productive. Strata in Middle Dome that may correspond to the Second zone consist of fine-grained sand, shaly sand, and a few beds of brittle black shale.

In mineral content the Second zone, as well as the First zone, differs from that of underlying zones in the abundance of chromite, which is less common lower in the section. ${ }^{11}$

According to well records, oysters and pectens, some of the latter of which are identified as Aequipecten andersoni ["Pecten"], are the most abundant fossils in the Second zone, as in the First zone. Goudkoff ${ }^{12}$ grouped the First and Second zones under the designation "Pecten andersoni sand." He recorded Turritella ocoyana from his Pecten andersoni sand and listed Foraminifera from shale near the base. Chlamys branneri ["Pecten"] and Chione temblorensis are recorded in the Gatchell well in South Dome from strata corresponding to the Second zone.

600-foot shale.-The barren zone underlying the Second zone has been named the 600 -foot shale, as it occurs about 600 feet below the top of the Temblor in the northern part of North Dome. It is an important zone in establishing correlations within the Kettleman Hills and with the outcrop section fartber south in the type region of the Temblor. The 600-foot shale is identified in the three anticlines in the Kettleman Hills and has been recognized in wells near the foot of Reef Ridge ${ }^{13}$ but apparently not in the Reef Ridge outcrop section.

The 600 -foot shale has a minimum thickness of about 50 feet in the northern part of North Dome, a maximum

\footnotetext{
10 Gester, G. C., and Galloway, John, op. cit. (Am. Assoc. Petroleum Geologists Bull., vol. 17), p. 1181.

11 Bramlette, M. N., op. cit. (Am. Assoc. Petroleum Geologists Bull., vol. 18), p. 1568.

12 Goudkoff, P. P., op. cit. (Am. Assoc. Petroleum Geologists Bull., vol. 18), pp. $455-456$.

${ }^{13}$ Siegfus, Stanley, personal communication.
} 
of about 150 feet in the central part, and thins farther south. It consists chiefly of hard dark-brown somewhat sandy shale interbedded with fine-grained shaly sand. The beds of shale are generally not more than 15 feet thick. In many of the early wells the 600 -foot shale was left open, but in later wells that produce from underlying zones it is generally cased off.

Goudkoff ${ }^{14}$ reported that the thickness of strata between the bentonite near the base of the McLure shale and the top of the 600 -foot shale ranges within limits of 584 and 650 feet from the north end of North Dome to South Dome, whereas the thickness of strata between the top of the Temblor sandstone (his Pecten andersoni sand) and the top of the 600 -foot shale is quite irregular, indicating that sand near the top of the Temblor grades laterally into shale. The thickness of strata belween the bentonite and the 600-foot shale and other units in the Temblor in seven wells between the north end of North Dome and South Dome is shown in the following table.

Thickness, in feet, of strata between bentonite near base of McLure shale member of Monterey shale and 600-foot shale and other units in Temblor sandstone in Kettleman Hills

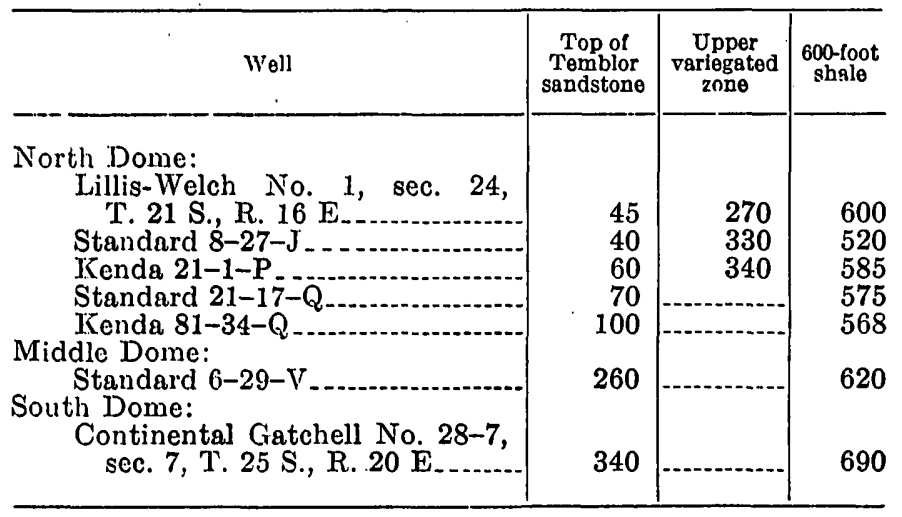

The preceding table indicates that, in general, the section thickens southward, and that the top of the Temblor sandstone is a less reliable stratigraphic guide than the upper variegated zone or the 600-foot shale. Nevertheless, the top of the sandstone is important economically, and it is not known whether the variation in thickness between the bentonite and the top of the sandstone is due to lateral gradation of sand into shale, which is a reasonable inference, to the grouping of sand of varying thickness at the base of the McLure with the Temblor, or to erosional discontinuity between these formations.

Poorly preserved Foraminifera from the 600-foot shale of Kenda well 27-34-J, and of Standard well 87-27-Q, were submitted to R. M. Kleinpell. Samples from Superior Huffman well No. 1 and Petroleum Securities well No. 1 were made available to $\mathrm{Mr}$. Kleinpell through the kindness of Mr. D. D. Hughes. The Fornminifera from the 600 -foot shale and from the

1 Goudkon, P. P., op. cit. (Am. Assoc. Petroleum Geologists Bull., vol. 18), p. 457.
Gould shale member of the Monterey shale, with which Kleinpell correlates the 600-foot shale, are listed in the. table on page 138. Some of the characteristic species of the Gould shale are shown on plate 50. Mr. Kleinpell has prepared the following remarks on these fossils:

The fauna of the Gould shale, representing the Siphogenerina branneri zone, is characteristic and widespread. It is marked by the earliest appearance of several species, including typical Bolivina imbricata (pl. 50, figs. 20, 21), Valvulineria californica obesa (pl. 50, figs. 15-17), and Pullenia miocenica, and by the extensive development of other species, including Nonion costiferum in the restricted sense (pl. 50, figs. 13, 14), Buliminella subfusiformis (pl. 50, figs. 18, 19), Siphogenerina branneri, Valvulineria miocenica depressa, Valvulineria ornata (pl. 50, figs. 22-24), and Baggina robusta. The abundance of Nonion costiferum, Bolivina imbricata, Valvulineria californica obesa, and Valvulineria ornata, and the doubtful occurrence of Baggina robusta, afford grounds for correlating the 600 -foot shale with the Gould shale.

Foraminifera from the 600 -foot shale of Kettleman Hills wells were listed by Goudkoff, ${ }^{15}$ who correlated the 600 -foot shale with the Gould shale. Other geologists have correlated the basal part of the McLure shale or the upper part of the Temblor sandstone (upper part of First zone) with the Gould shale. ${ }^{16}$

Third zone.-The Third zone is recognized in the developed parts of North Dome as well as in Middle and South Domes. In North Dome it is productive over almost the same area as the Second zone, but in Middle and South Domes it has not yet been found to be productive. The thickness of the Third zone in North Dome is 100 to 300 feet and averages about 180 feet.

Medium- to moderately coarse-grained sand is the principal constituent of the Third zone. Sand of finer grain, shale, generally recorded as sandy shale, and a few thin hard calcareous streaks, logged as reef beds are also present. According to tests by P. G. Nutting, the porosity of the sand ranges from about 12 to 20 percent and the permeability from 5 to 12.5 cubic centimeters per minute.

Bramlette ${ }^{17}$ reported that chromite is less abundant in sands assigned to the Third zone than in sands in the Second and First zones. Largely on the basis of this distinction the 600 -foot shale was tentatively located in Petroleum Securities Burbank well No. 1, in Middle Dome, before it was known that the shale contains Foraminifera characteristic of the 600 -foot shale.

Fossils recorded from the Third zone, principally fragments of oysters and pectens, are apparently similar to those in the overlying productive zones.

800 -foot shale.-The third barren zone is encountered about 800 feet below the top of the Temblor in wells

is Goudkoff, P. P., op. cit. (Am. Assoc. Petroleum Geologists Bull., vol. 18), pp. 456-457.

10 Cunningham, G. M., and Barbat, W. F., Age of producing horizon at Kettleman Bills, Calif.: Am. Assoc. Petroleum Geologists Bull., vol. 16, pp. 417-421, 1932. Barbat, W. F., Age of producing horizon at Kettleman Hills, Calif.: Am. Assoc. Petroleum Geologists Bull., vol. 16, pp. 611-612, 1932. Gester, G. O., and Galloway, John, op. cit. (Am. Assoc. Petroleum Geologists Bull., vol. 17), pp. 1179-1181, fig. 3.

${ }_{17}$ Bramlette, M. N., op. cit. (Am. Assoc. Petroleum Geologists Bull., vol. 18), p. 
Foraminifera from Gould shale member of Monterey shale at outcrop on Zemorra Creek and from 600-foot shale of wells in Kettleman

[Identifications by R. M. Kleinpell. R, rare; F, few; C, common; A, abundant]

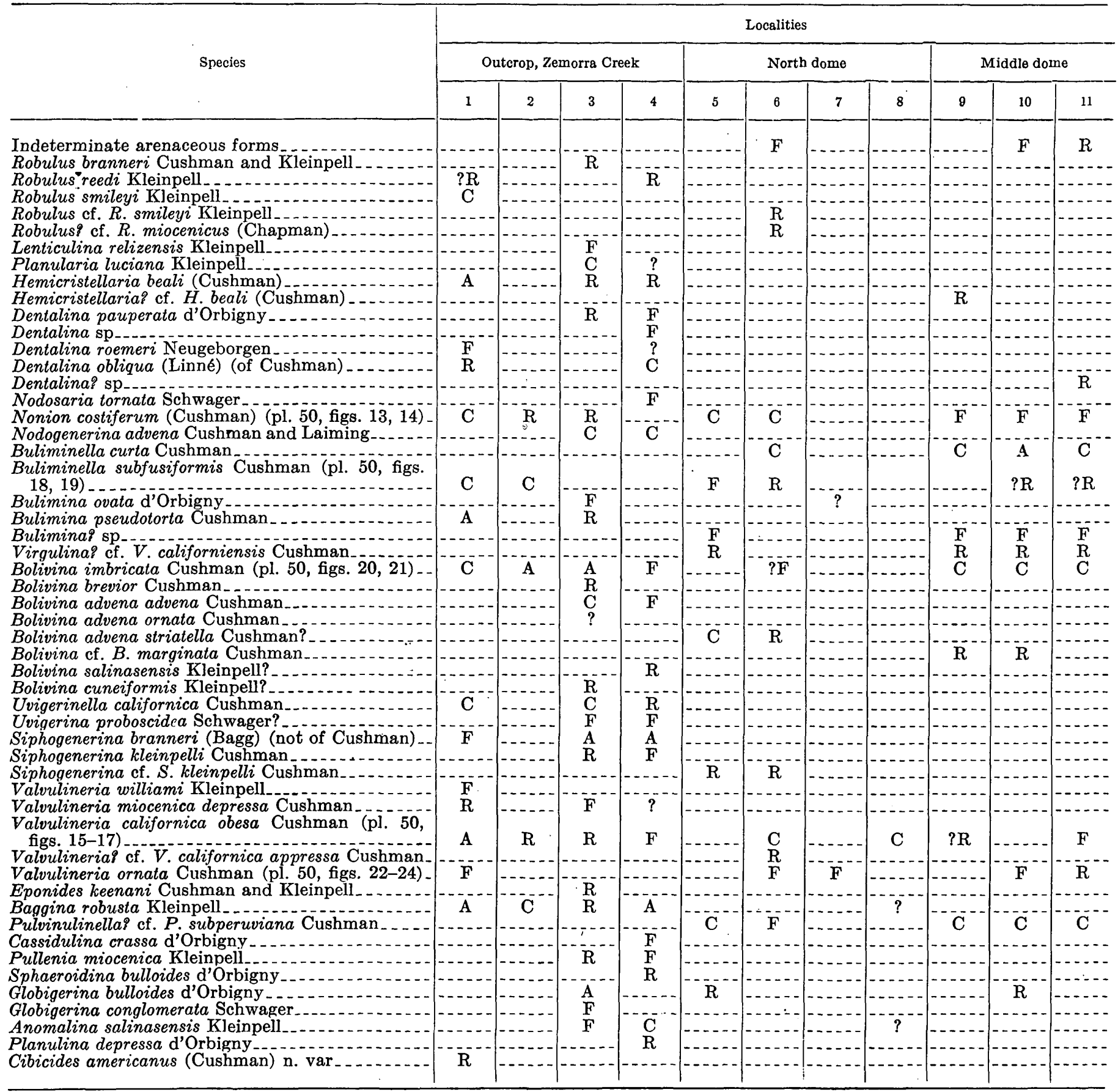

1. Zemorra Creek, 2 feet above base of Gould shale.

2. Same locality, 75 feet above base of Gould shale.

3. Same locality, 215 feet above base of Gould shale.

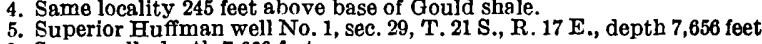

6. Same well, depth 7,666 feet.

along or close to the crest of northern North Dome, and is, consequently, known as the 800 -foot shale. Its thickness in North Dome appears to range from 50 to 175 feet. It has not been completely cored in any well and has been partly cored in only a few wells. The results of electrical logging show, however, that it extends throughout the developed area. This barren zone is
7. Kenda well 27-34-J, depth 7,361 to 7,372 feet.

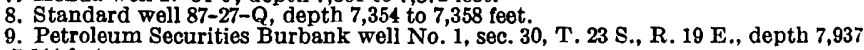
to 7,944 feet.

10. Same well, depth 7,959 feet.

11. Same well, depth 7,970 feet.

now generally cased off in wells on the flanks or plunging ends of North Dome.

Black flaky shale and dark-gray shale, interbedded with sandy shale and thin beds of fine-grained sand, are the principal constituents of the 800-foot shale in North Dome. Some of the sands contain "Scutella," Turritella, and pectens. In Middle Dome only thin beds of shale 
are reported at the approximate stratigraphic position of the 800-foot shale. In South Dome about 130 feet of shale encountered in Continental Gatchell well No. 28-7 appears to be the equivalent of the 800 -foot shale. These strata consist of hard massive black shale to fissile grayish-brown shale with several beds, each about a foot thick, made up almost entirely of phosphatic pellets.

Fourth zone.-Underlying the 800 -foot shale is the Fourth zone, the thickness of which in North Dome is about 60 to 170 feet, and the average is about 120 feet. About 300 feet of sand, in Middle and South Domes, which has not yet been found to be productive, may tentatively be regarded as the equivalent of this zone.

In North Dome the Fourth zone consists of fine- to medium-grained sand interbedded with sandy shale. In the northeastern part of the anticline electrical logs indicate an average thickness of about 20 feet of very porous rock, presumably coarse-grained sand. The thickness of rock of this type rather than the thickness of the zone itself is an important factor in the productiveness of the zone. A thickness of almost 60 feet of rock of this type is indicated in and near the King lease in sec. 29, T. 21 S., R. 17 E., about 80 feet in part of the Felix area in sec. 35, T. 21 S., R. 17 E., and adjoining. sections, and considerably less on the crest of the northern part and in the southern part of North Dome.

Samples from sands assigned to the Fourth zone were examined by Bramlette. ${ }^{18}$ They appear to show no distinctive minerals except possibly a relative abundance of feldspars.

According to logs, a small pecten, generally identified as Aequipecten andersoni ["Pecten"], is the most abundant fossil in the Fourth zone. Several occurrences of "Scutella" are recorded. Goudkoff ${ }^{18}$ recorded "Scutella" only from the Third and Fourth zones and grouped these strata under the term "button bed sandstone."

Lower variegated zone.-The fourth barren zone is designated the lower variegated zone because in part of North Dome the zone, generally the lower part, includes variegated shale. The lower variegated zone is apparently persistent as a generally unproductive zone throughout the Kettleman Hills, though it is not reported in the logs of many wells, even in wells that are only about 900 feet distant from wells in which it was identified either in cores or in ditch samples. Fragments of reddish, greenish, and purplish shales are conspicuous in ditch samples at localities where this zone includes variegated shale, and its stratigraphic position has been determined by such cuttings more frequently than by coring. The lower variegated zone has been reported in wells here and there in the northern

\footnotetext{
18 Bramlette, M. N., op. cit. (Am. Assoc. Petroleum Geologists Bull., vol. 18), tablo 2 (p. 1502); depth 6875 to 7073 feet, inclusive.

10 Goudkoff, P. P., op. cit. (Am. Assoc. Petroleum Geologists Bull., vol. 18), pp. 458-459, 0g. 7.
}

three-fourths of North Dome and is traceable by means of electrical logs. It is apparently recognizable as a zone including shale in Middle and South Domes. By means of an epidote-augite-hornblende assemblage and a Nonion-Nonionella foraminiferal fauna Goudkoff ${ }^{20}$ has traced the lower variegated zone from North Dome to South Dome and farther south.

In North Dome the thickness of the lower variegated zone appears to range from 125 to 245 feet. Toward the south it thins and loses the variegated shale. In wells in which the zone has been most completely cored it consists mainly of muddy greenish sand with streaks of variegated shale. Beds of shale more than a foot thick are rare. Sands containing black, red, and green chert pebbles and shale pebbles are as characteristic of the zone as variegated shale. Goudkoff ${ }^{21}$ identified the lower variegated zone in Petroleum Securities Burbank well No. 1, in Middle Dome, on the basis of the mineral content and foraminiferal fauna. Variegated shale, however, is not recorded in this well, and sandy shale and sand containing small pebbles at a horizon 250 feet lower is suggestive of the zone. About 120 feet of black, brown, or gray sandy shale encountered in Ohio Smith well No. 1, in South Dome, may be the equivalent of the lower variegated zone. A 155-foot shale zone, logged under the name "Media shale" in the Continental Gatchell well No. 28-7, in South Dome, may also be the equivalent of the lower variegated zone. The shale zone in the Gatchell well consists of hard shale. Cores representing hard darkbrown shale and hard dark-gray silty carbonaceous shale were recovered. According to these tentative identifications, the lower variegated zone loses the variegated shale and chert pebbles southward, and the proportion of shale increases in the same direction.

A few species of Foraminifera, among which Nonion incisum, Nonionella, and Virgulina are most abundant, are recorded from the upper part of the lower variegated zone by Goudkoff. ${ }^{22} \mathrm{He}$ has recognized a similar assemblage in the type region of the Temblor formation immediately underlying the button bed sandstone of local usage - that is, in the upper part of the Media shale of local usage-and in a shale streak about 400 feet below the top of the Temblor sandstone at Big Tar Canyon. ${ }^{23}$

Fifth zone.-The Fifth zone is with few exceptions the lowest productive zone penetrated by wells in North Dome. It is the principal source of the so-called brown or black oil. It is not only productive in a large area in North Dome, where it may prove to be more extensive than any other productive zone, but is also tentatively recognized in Middle and South Domes. The Fifth zone is 200 to 400 feet thick in North Dome.

\footnotetext{
${ }_{20}$ Goudkoff, P. P., op. cit. (Am. Assoc. Petroleum Geologists Bull., vol. 18), p. 459 , figs. 4,5 .

21 Idem, p. 459.

2a Idem.

${ }^{23}$ Idem, p. 464.
} 
According to data now available, its average thickness is about 300 feet.

According to logs and cores, the Fifth zone in North Dome consists chiefly of somewhat poorly sorted and poorly consolidated greenish sand. The sand shows a considerable variation in grain size, but medium- and coarse-grained sand is more abundant than fine-grained sand, except near the top and bottom of the zone where the grains are so small that some of the rock would be properly classified as siltstone. Clay shale of variable thickness is interbedded with the sand and may be correlated by means of electrical logs in at least the northern two-thirds of North Dome. It may eventually be possible and even desirable to subdivide this zone into smaller units separated by the more persistent shales. This possibility is indicated by casing perforation records of wells recently completed in this zone. The relative proportion of sand and shale appears to vary irregularly from well to well, but in general the percentage of shale increases southward from about 10 percent in northern North Dome to 25 percent in southern North Dome. In Middle and South Domes, however, the proportion of sand is as high as in northern North Dome.

At the top of the Fifth zone and apparently extending upward into the lower variegated zone, is a thin distinctive mineral zone that is designated the orthoclase-anhydrite zone by Bramlette. ${ }^{24}$ As its name implies, this mineral zone is characterized by the abundance of orthoclase, much of which is fresh, and anhydrite. The zone may represent alkalic pyroclastic debris, but no bentonitic material was recognized. Most of the Fifth zone represents Bramlette's andesitic sand zone ${ }^{25}$ which is characterized in the well material by the abundance of green hornblende and basaltic hornblende.

A few fossils, including Aequipecten andersoni ["Pecten"] and oysters, are recorded from sands in the Fifth zone.

Felix siltstone.-The fifth or lowermost barren zone, which has a thickness of 35 to 80 feet, is divided into two parts. The upper part is designated by drillers the Felix siltstone, as it was first recognized in wells drilled on the Felix lease of the Petroleum Securities Co.in sec. 35, T. 21 S., R. 17 E., and adjoining areas.

The Felix siltstone has been identified in a little more than the northern half of North Dome, but has not been recognized in Middle Dome or South Dome. It has a thickness of 20 to 40 feet and consists of hard gray siltstone, silty sand, and silty shale. In some wells sand containing phosphatic pellets was encountered. Near the north end of North Dome a few poorly preserved fossils, including Macoma and Mactra, are recorded.

\footnotetext{
24 Bramlette, M. N., op. cit. (Am. Assoc. Petroleum Geologists Bull., vol. 18), p. 1568.

${ }^{2 s}$ Idem, pp. 1567-1568.
}

Whepley shale.-The lower part of the fifth barren zone is designated by drillers the Whepley shale. It was first penetrated by a well on the Whepley lease of the Associated Oil Co. in sec. 35, T. 21 S., R. 17 E. When first encountered it was called the "Leda" zone, as it was thought to represent the "Leda" zone of the underlying Kreyenhagen shale, but it is now assigned to the Temblor. In North Dome the Whepley shale is recognized in about the same area as the Felix siltstone, except near the north end of the anticline. It has also been identified near the south end of North Dome and may be presented in Petroleum Securities Burbank well No. 1, in Middle Dome, about 925 feet below the 600 -foot shale. The probable equivalent of the Whepley in this well includes hard, sandy, black and gray shale. A shale about 50 feet thick encountered in Continental Gatchell well No. 28-7, in South Dome, was logged under the name "Santos shale." It may be the equivalent of the Whepley. The absence of the Whepley shale near the north end of North Dome is attributed by some geologists to an erosional discontinuity.

In North Dome the Whepley shale ranges from 15 to 40 feet in thickness and averages probably 30 feet. It consists of brittle, hard, dark-brown or brownishgray shale of rather uniform character wherever recognized. Small pyritized pectens are abundant in some wells, and other mollusks and Foraminifera are present. The following mollusks are represented in core material from two wells.

Mollusks from Whepley shale

[Identifications by W. P. Woodring]

\begin{tabular}{c|c|c}
\hline Species & 1 & 2 \\
\hline $\begin{array}{l}\text { Nuculana sp... } \\
\text { Hyalopecten cf. } H . \text { peckhami (Gabb) }\end{array}$ & $\mathrm{X}$ & $\mathrm{X}$ \\
Cyclocardia? of. C. montereyana (Arnold) & & $\mathrm{X}$ \\
\hline
\end{tabular}

1. Petroleum Securities Felix well No. 3, sec. 35, T. 21 S., R. 17 E., depth 8,495 to 8,516 feet.

2. Kenda well 61-2-P, depth 8,312 to 8,328 feet.

The Whepley shale was first designated the "Leda" zone from the occurrence of Nuculana ["Leda"] and other fossils similar to those in the "Leda" zone of the Kreyenhagen shale. The Nuculana in the Whepley shale resembles the species from the Monterey shale of the Santa Cruz Mountains recorded under the name Yoldia impressa (Conrad) ${ }^{26}$ but is smaller and more inequilateral. The posterior dorsal margin is less excavated than in the Nuculana from the "Leda" zone of the Kreyenhagen shale. The little pecten is represented by many impressions and molds of crushed speci-

26 Arnold, Ralph, Descriptions of new Cretaceous and Tertiary fossils from the Santa Cruz Mountains, Calif.: U. S. Nat. Mus. Proc., vol. 34, p. 351, pl. 35, fig. 3, 1908. Branner, J. C., Newsom, J. F., and Arnold, Ralph, U. S. Geol. Survey Geol. Atlas, Santa Cruz folio (no. 163), pl. 2, fig. 49, 1909. Nucula impressa Conrad (U. S. Expl. Exped., Geology, p. 726, pl, 18, figs. 7 a-e, 1849) [not Nucula impressa Sowerby 1825], from the Miocene of Astoria, Oreg., has been named Yoldla (Portlandia) astoriana by J. Henderson (Nautilus, vol. 33, p. 122, 1920). It is considered a relatively elongate Saccella. 
mens, which retain some shell material replaced by pyrite that shows the microscopic camptonectes sculpture. These specimens resemble Hyalopecten peckhami (Gabb), the type material of which is from the Monterey shale of the Ventura Basin. ${ }^{27}$ Similar pectens are found in the Kreyenhagen shale. The small Cyclocardia? is similar to "Venericardia" montereyana Arnold ${ }^{28}$ from the Monterey shale of the Santa Cruz Mountrins but lacks nodes on the ribs. In addition to these mollusks, Odostomia, "Nassa", Acila, "Phacoides", Macrocallista, and fish scales are recorded from the Whepley shale in well logs.

According to Goudkoff, ${ }^{2 \theta}$ Foraminifera from the Whepley shale indicate that it is the equivalent of strata in the lower part of the Temblor formation in the type region. R. M. Kleinpell considers the Whepley shale fauna to represent approximately his Siphogenerina transversa zone, which embraces strata in the Carneros sandstone of local usage and the Santos shale of local usage. (Sec pl. 47.)

Sixth zone (Beal zone).-The Sixth zone is the lowest productive zone in the Temblor and also the lowest subdivision. This zone is designated by drillers the Beal zone, a name derived from the lease in sec. 34, T. 21 S., R. 17 E., where it was first encountered. It has been designated Vaqueros (? ${ }^{30}$ and has been described under the name "mollusk boring sand." ${ }^{31}$ It is doubtful whether the irregular borings that characterize much of the sand in this zone were made by mollusks.

So far the Sixth zone has been completely penetrated by only a fow wells. In North Dome the thickness of the zone increases from 355 feet at the north end of the anticline to 640 feet in sec. 34, T. 21 S., R. $17 \mathrm{E}$. It consists of fine-grained somewhat silty sand, fine- to coarse-grained cleaner sand, silty shale, and a few thin beds of hard calcareous sand. The electrical $\log$ of Kenda well 38-34-J indicates a more or less regular alternation of porous and less porous strata, corresponding approximately to the distribution of barren and oil-bearing core samples.

The lowest 300 feet of strata penetrated by Petroleum Securities Burbank well No. 1, in Middle Dome, may represent the Sixth zone. These strata consist of sandy shale and fine-grained sand grading downward in to medium- and coarse-grained sand. A considerable thickness of sand underlying the probable equivalent of the Whepley shale in Continental Gatchell well No.

\footnotetext{
27 For a discussion of this group of pectens, see Woodring, W. P., Lower Pliocene mollusks and echinoids from the Los Angeles Basin, Calif., and their inferred environ. ment: U. S. Ceol. Survey Prof. Paper 190, pp. 35-41, 1938.

Arnold, Ralph, op. cit., pp. 380-381, pl. 35, flg. 4. Branner, J. C., Newsom, J. F., ond Arnold, Ralph, op. cit., pl. 2, Ag. 48.

so Goudkoff, P. P., op. cit. (Am. Assoc. Petroleum Geologists Bull., vol. 18), pp. $450-460$.

so Idom, p. 460, Ag. 4.

si Dodd, H. V., and Kaplow, E. J., Kettleman North Dome and Kettleman Middle Dome felds, progress In development: California On Fields (California, Dept. Nat. Res. Div. Oil and (Geol.), vol. 18, no. 4, p. 12, 1933 [1934].
}

28-7, in South Dome; may be the equivalent of the Sixth zone.

Samples from the Sixth zone show a mineral content corresponding to that of the lower sandstone in the Temblor at Big Tar Canyon. ${ }^{32}$

\section{AQE AND CORRELATION}

The Kettleman Hills Temblor section is not closely similar to the outcrop sections on Carneros Creek, Reef Ridge, and Anticline Ridge, and yet it combines features of the outcrop sections in these three regions. The foraminiferal faunas from the 600 -foot shale, lower variegated zone, and Whepley shale are rather meager, but they offer a basis for comparison with the section in the type region of the Temblor formation. An andesitic sand zone and a zone characterized by abundant chromite are recognized in the subsurface section and on Reef Ridge. The serpentine zone of the subsurface section affords a datum plane for comparison with the section on Anticline Ridge. Correlations based on these and other data are shown on plate 47 and figure 14.

The lower part of the Temblor in the Kettleman Hills appears to be of the same age as the lower part of the Temblor in the type region and, therefore, is to be correlated with part of the Vaqueros sandstone of many regions; in fact, the Sixth zone has been provisionally referred to the Vaqueros. ${ }^{33}$ An undetermined additional part of the Kettleman Hills section, probably up to or including the Fifth zone, may also be the equivalent of Vaqueros elsewhere. The 600 -foot shale is considered the chronologic equivalent of the Gould shale member of the Monterey. From this correlation and the correlation of the McLure shale it follows that the Kettleman Hills section from the base of the 600-foot shale upward to the top of the Temblor sandstone is of the same age as most of the lower half of the Monterey shale in the type region of the Temblor. Geologists who define Monterey in terms of the age of Monterey shale in the Chico Martinez Creek section assign this part of the Kettleman Hills section to the Monterey. ${ }^{34}$ If, however, Monterey is used for the time interval represented in the type region in Monterey Peninsula, as indicated by foraminiferal zones, the base of the Monterey in the Kettleman Hills section is to be shifted to an undetermined higher horizon, probably near the base of the upper variegated zone.

The lower sandstone in the sections examined on Reef Ridge appears to be the equivalent of an undetermined division of the lower part of the Temblor of the Kettleman Hills and of the type region and doubtless is Vaqueros according to the terminology of some

32 Bramlette, M. N., op. cit. (Am. Assoc. Petroleum Geologists Bull., vol. 18), p. 1567, table 1 (p. 1562), depth, 7,876 to 7,916 feet, inclusive.

${ }^{33}$ Goudkoff, P. P., op. cit. (Am. Assoc. Petroleum Geologists Bull., vol. 18), p. 460. 31 Goudkoff, P. P., Age of producing horizon at Kettleman Hills, Calif.: Am. Assoc. Petroleum Ceologists Bull., vol. 15, pp. 839-842, 1931; Subsurface stratigraphy of Kettleman Hills oil fleld, Calif.: Idem, vol. 18, pp. 454-458, 1934. 
geologists. The middle sandstone exposed on Reef Ridge constitutes the andesitic sand zone, which includes most of the Fifth zone. ${ }^{35}$ The upper sandstone exposed in Canoas Canyon may represent the Fourth and Third zones. In the abundance of chromite the upper sandstone exposed in Big Tar Canyon is similar to sands in the Second and First zones overlying the 600 -foot shale. ${ }^{36}$ Bramlette, therefore, suggested that the part of the subsurface section above the 600-foot shale is not represented in Canoas Canyon, whereas the part between the 600 -foot shale and the base of the serpentine zone, near the base of the First zone, is represented in Big Tar Canyon-features pointing to discontinuities at different horizons in the Temblor exposed on Reef Ridge, probably due to nondeposition.

The meager paleontologic evidence is not opposed to Bramlette's suggestion. In Big Tar Canyon "Scutella" occurs in the middle sandstone and in Canoas Canyon it occurs in both the middle and the upper sandstones. In the subsurface section "Scutella" is recorded from the Third and Fourth zones, but if the andesitic sand zone is at the same horizon as on Reef Ridge, "Scutella" may be expected to occur also in the Fifth zone. In the type region of the Temblor, "Scutella" occurs in the button bed sandstone of local usage. Though "Scutella"-bearing sandstones at other localities may not be the chronologic equivalent of the button bed sandstone, the mineral zones suggest that these little sand dollars are not found either in the subsurface section or on Reef Ridge in the part of the section that some geologists refer to the Monterey. The following fossils were collected from the upper part of the upper sandstone on" the slope on the east side of Big Tar Canyon:

Fossils from upper division of upper sandstone of Temblor sandstone on east side of Big Tar Canyon (U. S. G. S. locality 19198)

[Identiflcations by W. P. Woodring.]

Gastropods: Turritella ocoyana Conrad. Neverita sp.

Forreria sp.

2 undetermined species.

Pelecypods:

Anadara sp.

Aequipecten andersoni (Arnold)?

Ostrea cf. O. titan Conrad.

Miltha sanctaecrucis (Ar-

nold).

Pelecypods-Continued.

Lucinoma cf. L. acutilineata (Conrad).

Macoma pierci Arnold.

Apolymetis n. sp.?

Dosinia cf. D. mathewsonii Gabb.

Clementia pertenuis (Gabb).

Trachycardium cf. T. vaquerosensis (Arnold).

This faunal zone is not represented in the "Scutella"bearing upper sandstone exposed in Canoas Canyon. Miltha sanctaecrucis (Bull. 398, pl. 28, fig. 6) and Clementia pertenuis (Bull. 398, pl. 30, fig. 3) are not recorded from the middle and lower sandstones exposed on Reef Ridge. Inasmuch as these two species occur in the

\footnotetext{
ss Bramlette, M. N., op. cit. (Am. Assoc. Petroleum Creologists Bull., vol. 18), pp. 1567-1568.

30 Idem, p. 1572.
}

Vaqueros sandstone, ${ }^{37}$ they cannot be accepted as dependable chronologic guides for a particular part of the Temblor in the Coalinga district unless long-continued collecting and independent evidence indicates that the unknown environmental control that determined their presence or absence in this region has a chronologic significance. The type of Miltha sanctaecrucis is from "Scutella"-bearing Temblor sandstone in the Devils Den district, south of the Kettleman Hills (locality 4861 , reef bed in sec. 23 , T. 25 S., R. 18 E., a quarter of a mile southeast of Barton's cabin) ${ }^{38}$ It should be pointed out that the type of "Scutella" andersoni Twitchell ${ }^{39}$ is from this locality. As compared with 50 other specimens from this locality, mostly poorly preserved, the type of "S." andersoni is exceptionally domed; and the periproct is slightly supramarginal, whereas it is marginal on some specimens. These sand dollars have petals resembling those of "Scutella" merriami from the button bed sandstone of local usage in the type region of the Temblor, the largest specimens of which have notches in the posterior ambulacral areas, as in "S." andersoni. Large suites of specimens from different localities are needed to determine the relations of these forms. "Scutella" andersoni is recorded from the Vaqueros. ${ }^{40}$ It is not known whether the "Scutella"-bearing sandstone in the Devils Den district is older or younger than the Gould shale member of the Monterey. West of the Devils Den district ${ }^{41}$ and also at the northwest end of Reef Ridge ${ }^{42}$ Temblor sandstone overlaps onto Cretaceous rocks.

The serpentine zone of the Kettleman Hills section represents at least part of the Big Blue serpentinous member of the Temblor on the Coalinga anticline; ${ }^{43}$ perhaps the upper variegated zone, which underlies the serpentine zone, also is to be correlated with the Big Blue or with nonmarine strata immediately underlying the Big Blue. The southward thinning and disappearance of the serpentine zone and upper variegated zone conform to their inferred derivation from a source to the northwest. The lower variegated zone, which includes strata similar to those in the upper variegated zone, also loses these characteristic strata southward. Nonmarine strata corresponding to the lower variegated zone have not been recognized on Anticline Ridge.

\footnotetext{
${ }^{37}$ Loel, Wayne, and Corey, W. H., The Vaqueros formation, lower Miocene of California, pt. 1, Paleontology: California Univ., Dept. Geol. Sci., Bull., vol. 22, pp. 211, 218, 1932.

38 Arnold, Ralph, op. cit. (Bull. 396), pp. 58-59, 1909 [1910].

${ }^{30}$ Clark, W. B., and Twitchell, M. W., The Mesozoic and Cenozoic Echinodermata of the United States: U. S. Geol. Survey Mon. 54, pp. 183-184, pl. 85, figs. 3a-d, 1915. $60 \mathrm{Kew}$, W. S. W., Cretaceous and Cenozoic Echinoides of the Paciflc coast of North America: California Univ., Dept. Geology, Bull., vol. 12, pp. 62-64, 1920 (the figured specimen from the Tejon Hills on the east side of northern San Joaquin Valley appears to represent "Scutella" tejonensis Kew). Loel, Wayne, and Corey, W. H., op. cit., p. 177.

"Arnold, Ralph, and Johnson, H. R., Preliminary report on the McKittrickSunset oil region, Kern and San Luis Obispo Counties, Calif.: U. S. Geol. Survey Bull. 406, p. 45, 1910. English, W. A., Geology and petroleum resources of north. western Kern County, Calif.: U. S. Geol. Survey Bull. 721, pl. 1, 1921. Reed, R. D., Geology of California, pp. 176-177, Tulsa, Am. Assoc. Petroleum Geologists, 1933.

12 Arnold, Ralph, and Anderson, Robert, op. cit. (Bull. 398), pp. 67, 80.

4 Bramlette, M. N., op. cit. (Am. Assoc. Petroleum Geologists Bull., vol. 18).

pp. 1568-1569, 1573.
} 
Perhaps, however, some of the sandstone included in the lower sandstone of that area is the equivalent of the lower variegated zone.

The serpentine zone is thin or absent at the two localities examined on Reef Ridge. As the serpentine zone is several hundred feet above the 600 -foot shale, the Big Blue is considered younger than any sandstone in the type region of the Temblor; that is, it is Monterey in the nomenclature of some geologists. ${ }^{44}$

" Soo discussion by Roed. R. J.. op. cit., pp. 217-220; Kleinpell, R. M., Miocene stratigraphy of Callfornin, pp. 70-71, Tulsa, Am. Assoc. Petroleum Geologists, 1938.
It has long been recognized that the Big Blue has the stratigraphic position of Monterey shale and that it may be the chronological equivalent of part of the Monterey. ${ }^{45}$ The upper sandstone exposed on Anticline Ridge between the Big Blue and the "indicator bed" may also be younger than strata at the top of the type Temblor. The following fossils occur in the upper sandstone:

15 Anderson, F. M., A further stratigraphic study in the Mount Diablo Range of California: California Acad. Sci. Proc., 4th ser., vol. 3, p. 21, 1908. Arnold, Ralph, and Anderson, Robert, op. cit. (Bull. 398), pp. 76, 88, 1910.

Fossils from upper sandstone of Temblor sandstone exposed on Anticline Ridge and farther north

[Identifications by W. P. Woodringi

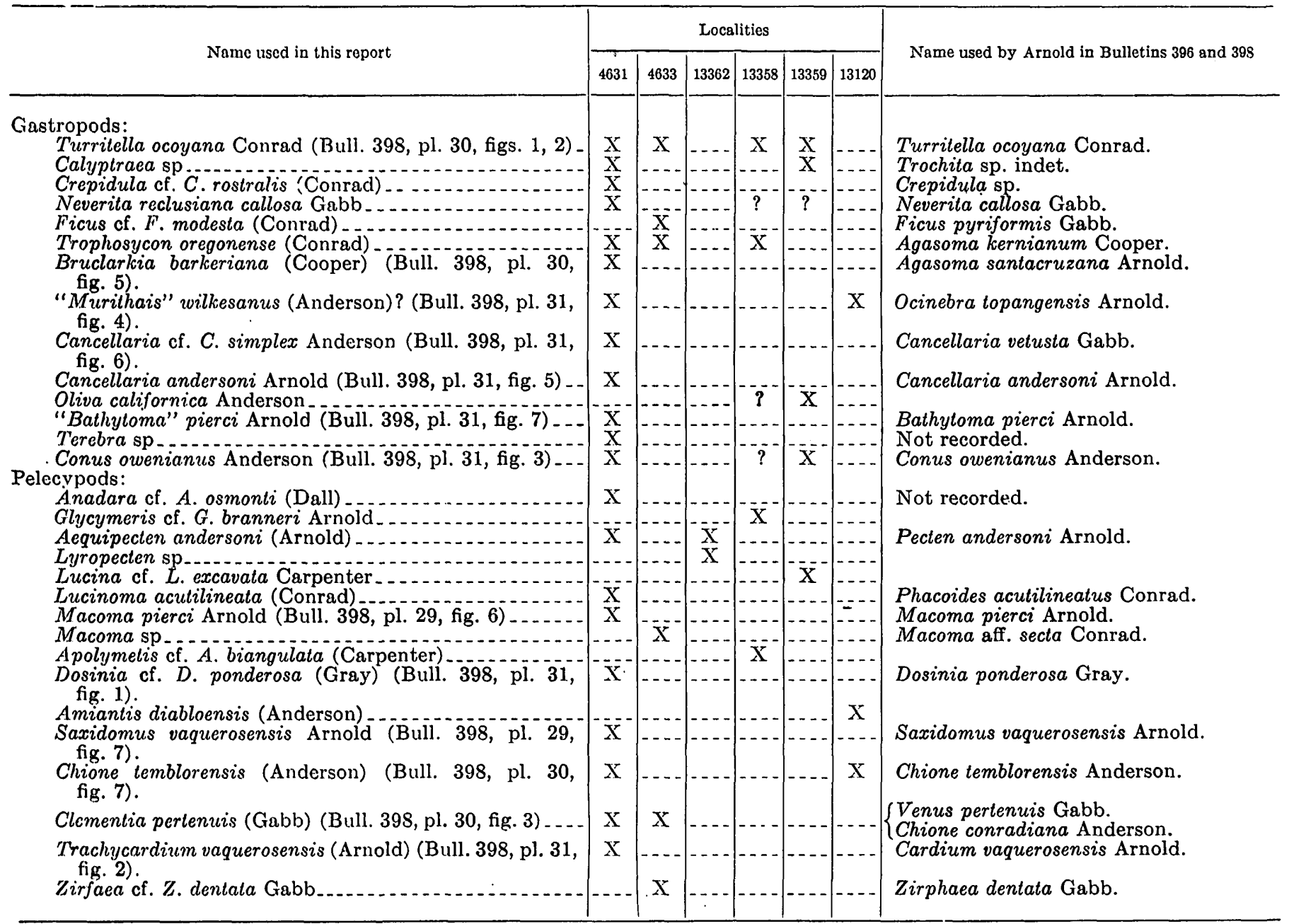

4031. T'urritella hed on enst flank of high hill northeast of Oil City, in SE 34 NE 34 sec. 10, T. 19 S., R. 15 E.; collected by Ralph Arnold and J. H. Pierce, 1907. 4033. Turritella bed about 11 miles NNE. of Coalinga.just below Big Blue on ridge in sec. 10. T. : $\theta$ S., R. $15 \mathrm{E}$.; collecter by Ralph Arnold, 1907.

13302. West side of first long canyon east of Oil Canyon, 1,800 feet west of the southeast corner of sec. 20 . T. 19 S., R. 15 E., 4 feet above top of "indicator bed"; collected by K. E. Lohman, 1834 .

Many of the species in the preceding list are not recorded from the "Scutella"-bearing parts of the Temblor in the Coalinga district. It was apporently this feature that led Arnold to consider that the fossils from the upper part of the Temblor on Anticline Ridge represent a "unique" fauna. ${ }^{46}$ Additional collecting
13358. First ridge east of Oil Canyon, 2,400 feet N. $81^{\circ} \mathrm{W}$. from the southeast corner of sec. 20, T. 19 S., R. 15 E., 84 feet above top of "indicator bed"; collected by K. E.

L.ohman, 1934 . 13359 . Same locality as preceding, but float within 5 feet of outcrop and apparently from same bed; collected by K. E. Lohman, 1934 .

13120 . Second spur southeast of mouth of Phoenix Canyon, float about 20 feet above "indicator bed"; collected by W. P. Woodring, 1933.

and more work on the fossils are needed to determine the chronological significance of this faunal zone. It would ordinarily be considered indicative of "Temblor age," as it includes Turritella ocoyana, which is the most abundant species, Bruclarkia barkeriana, Aequipecten andersoni, Chione temblorensis, and other species that have been regarded as characteristic Temblor 
fossils. Some of the species that, so far as the Coalinga district is concerned, have been found only in the part of the Temblor overlying the "Scutella"-bearing sandstone are known from the Vaqueros sandstone. It is inferred that their absence in the "Scutella"-bearing sandstone is due to unknown environmental conditions and that they may appear at any horizon in the Temblor provided the environment was suitable. Miltha sanctaecrucis has been found in the upper sandstone exposed in Big Tar Canyon but not in the upper sandstone on Anticline Ridge. Clementia pertenuis, which occurs in the upper sandstone in both areas, is more abundant in the Santa Margarita sandstone overlying the Big Blue. ${ }^{47}$ A list of fossils from a horizon said to be in the Santa Margarita sandstone north of Coalinga ${ }^{48}$ includes many species that occur in the upper sandstone of the Temblor on Anticline Ridge. "Scutella" has not been found in the upper sandstone exposed on Anticline Ridge and in Big Tar Canyon, but the significance of its. apparent local extinction is uncertain. Though it has not been found in the Santa Margarita sandstone of the Coalinga district, "Scutella" gabbi (Rémond), ${ }^{49}$ which apparently is related to the small "Scutella" of the Coalinga district, occurs in the upper Miocene San Pablo group.

According to the correlations that now appear to be reasonable, the Big Blue is of late middle Miocene age, according to current Coast Range chronology. Moreover, it appears probable that the upper sandstone on Anticline Ridge and in Big Tar Canyon is probably assignable to the middle part of the middle Miocene, that is, it is probably the age equivalent of the Gould shale member of the Monterey shale or a little younger.

The age of the sandstone underlying the Big Blue in terms of the marine section is of particular interest, as on the Domengine ranch 6 miles north of Anticline Ridge the land mammals of the Merychippus zone occur a few feet below the base of the Big Blue. ${ }^{50}$ This fauna is assigned to a stratigraphic position between the Mascall of Oregon and the Barstow of California, that is, it is considered of late middle Miocene age. ${ }^{51}$

The chronologic relations of the remainder of the section on Anticline Ridge are uncertain. The diatombearing "indicator bed" has the same relative stratigraphic position as the 600 -foot shale and Gould shale. The middle sandstone, which includes the main reef bed containing "Scutella", would be expected to correspond

\footnotetext{
4 Arnold, Ralph, and Anderson, Robert, op. cit. (Bull. 398), Idem, p. 94 (cited as Chione conradiana). Woodring, W. P., American Tertiary mollusks of the genus Clementia: U. S. Geol. Survey Prof. Paper 147, pp. 40-42, 1926.

${ }^{18}$ Anderson, F. M., A further stratigraphic study in the Mount Diablo Range of California: Callfornia Acad. Sci. Proc., 4th ser., vol. 3, p. 23, 1908.

$10 \mathrm{Kew}$, W. S. W., Cretaceous and Cenozoic Echinoidea of the Pacific coast of North America: California Univ., Dept. Geology, Bull., vol. 12, pp. 69-71, pl. 12, figs. $4 \mathrm{a}, \mathrm{b}$; pl. 13, flgs. 1, 2a, b, 3, 1920 .

so Merriam, J. O., Tertiary vertebrate faunas of the north Coalinga region of Calffornia: Am. Philos. Soc. Trans., new ser., vol. 22, pp. 194-196, 1915. . Bode, F.. D. The fauna of the Merychippus zone, north Coalinga district, Calif.: Carnegie Inst. Washington Pub. 453, pp. 65-96, 2 pls., 10 figs. 1935.

is Bode, F. D., idem, pp. 84-86.
}

to the andesitic sand zone of the Kettleman Hills and Reef Ridge or to overlying sandstone, but it is characterized by an abundance of hypersthene, which is rare in the other two areas, and by the presence of andalusite and kyanite, which were not found in the other areas. ${ }^{52}$ A comparison of the diatoms in the "indicator bed" and lower diatomite with those in the shales of the Temblor formation and the lower part of the Monterey on Carneros Creek and Chico Martinez Creek may afford data for a determination of the chronologic relations of this part of the Temblor. This matter is now being investigated by K. E. Lohman.

\section{OLIGOCENE (?) AND EOCENE SERIES}

\section{KREYENHAGEN SHALE}

The major shale unit underlying the Temblor sandstone in the Kettleman Hills subsurface section is assigned to the Kreyenhagen shale. A discussion of the Kreyenhagen shale is likely to be confusing to readers unfamiliar with the geology of the Coalinga and nearby districts, for the term "Kreyenhagen" has been used with different meanings, and the name for a faunal zone in the Kreyenhagen has also been used with different meanings. The term "Kreyenhagen shale" is used in the present report for the entire shale unit and interbedded sandstone, regardless of whether the strata in this unit are of Oligocene and Eocene age or only of Eocene age.

The name "Kreyenhagen shales" was introduced by F. M. Anderson at the time when the other formations in this region were named. ${ }^{53}$ The principal features of the Kreyenhagen and the long-continued controversy concerning the usage of the name have been reviewed by Jenkins. ${ }^{54}$ Much of the controversy is traceable to the citation of two localities in the original descriptionone on Anticline Ridge and the other at the Kreyenhagen wells on Reef Ridge (Canoas Canyon). The formation exposed on Anticline Ridge assigned to the Kreyenhagen by F. M. Anderson is not similar lithologically to the formation exposed in Canoas Canyon, and it is now generally agreed that the formation exposed on Anticline Ridge is considerably older. In his first account of the geology of this region F. M. Anderson referred the shale exposed on Anticline Ridge, now generally considered the equivalent of the Kreyenhagen in Canoas Canyon, to the Monterey. This error is readily understandable, for the shale identified by F. M. Anderson as Monterey is remarkably similar lithologically to the Monterey. It might have been avoided, however, for on Anticline Ridge the Temblor sandstone containing characteristic fossils overlies the

\footnotetext{
B3 Bramlette, M. N., op. cit. (Am. Assoc. Petroleum Geologists Bull., vol. 18),

s8 Anderson, F. M., A stratigraphic study in the Mount Diablo Range of California: California Acad. Sci. Proc., 3d ser., vol. 2, p. 163, 1905.

os Jenkins, O. P., Stratigraphic significance of the Kreyenhagen shale of California: Mining in California, vol. 27, no. 2, pp. 141-186, 11 figs., 1931.
} p. 1573. 
shale identified by F. M. Anderson as Monterey, whereas on Reef Ridge the Temblor sandstone underlies the Monterey. In view of the name itself and of long-established usage, Canoas Canyon and adjoining parts of Reef Ridge are considered the type region of the Kreyenhagen shale. F. M. Anderson still objects to the generally accepted usage of the name "Kreyenhagen shale" for the formation exposed on Anticline Ridge. ${ }^{55}$ Part of the controversy also is attributable to failure to recognize that at different localities the Kreyenhagen includes strata of different age.

The Kreyenhagen shale is a shale of Monterey type. It consists chiefly of porcelaneous mudstone and diatomaceous shale, and parts of the formation show abundant siliceous micro-organisms-diatoms, radiolaria, and silicoflagellates. This remarkable duplication of lithologic, floral, and faunal facies is one of the striking fentures in the geology of this region. It is quite

os Anderson, F. M., Kroyonhagen shales and the Lillis shale [abstract]: Geol. Soc. Amorica Bull, vol. 42, pp. 302-303, 1931. natural that early workers ${ }^{6 \theta}$ identified this siliceous shale on Anticline Ridge as Monterey, for at that locality the younger siliceous shale exposed on Reef Ridge (McLure shale member of Monterey shale), only 20 miles distant, is absent. Moreover, on Reef Ridge where both siliceous shale formations are present, the Kreyenhagen is generally poorly exposed, whereas the McLure stands out in bold relief.

\section{STRATIGRAPHY, LITHOLOGY, AND FOSSILS} OUTCROP SECTIONS

Region north of Anticline Ridge.-The shale of Monterey type north of Anticline Ridge (the Kreyenhagen shale of the present report) underlies Miocene sandstone (Temblor sandstone) and overlies Eocene sandstone (Domengine sandstone). It has been treated in different ways, as shown in the following table.

se Watts, W. L., The gas and petroleum yielding formations of the central valley of California: California State Min. Bur. Bull. 3, pp. 61-63, 65, 1894. Eldridge, G. H. The petroleum flelds of California: U. S. Geol. Survey Bull. 213, p. 307, 1903. Anderson, F. M., op. cit., pp. 172-173, 174-176, pl. 34, sec. 3 .

Classification and nomenclature of shale of Monterey type (Kreyenhagen shale) north of Anticline Ridge

\begin{tabular}{|c|c|c|c|c|c|c|c|c|c|c|c|c|c|}
\hline \multicolumn{2}{|c|}{ F. M. Anderson, } & \multicolumn{2}{|c|}{$\begin{array}{c}\text { Anderson and Pack, } \\
1915^{8}\end{array}$} & \multicolumn{3}{|c|}{ Condit, 1903 s } & \multicolumn{2}{|r|}{ Jenkins, 1931 । } & \multicolumn{2}{|c|}{$\begin{array}{l}\text { F. M. Anderson, } \\
1931 \text { s }\end{array}$} & \multicolumn{3}{|c|}{ Atwill, $1835^{\circ}$} \\
\hline \multirow{4}{*}{ 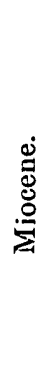 } & \multirow{3}{*}{ Monterey } & \multirow{4}{*}{ 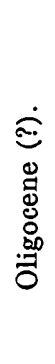 } & \multirow{4}{*}{$\begin{array}{c}\text { Kreyenhagen } \\
\text { shale } \\
\text { (sandstone } \\
\text { considered } \\
\text { down-faulted } \\
\text { Vaqueros). }\end{array}$} & \multirow{4}{*}{ 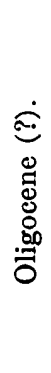 } & \multirow{4}{*}{ 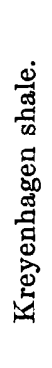 } & A horizon. & \multirow{3}{*}{ 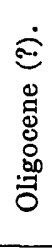 } & Leda zone. & \multirow{4}{*}{ 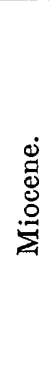 } & \multirow{4}{*}{$\begin{array}{l}\text { Lillis } \\
\text { shale. }\end{array}$} & \multirow{3}{*}{$\begin{array}{l}\dot{0} \\
\stackrel{\Xi}{0} \\
\stackrel{0}{0} \\
.00\end{array}$} & \multirow{3}{*}{ 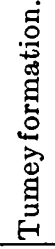 } & \multirow{3}{*}{$\begin{array}{r}\text { Tumey } \\
\text { shale. } \\
\text { Tumey } \\
\text { sandstone. }\end{array}$} \\
\hline & & & & & & B horizon. & & Intermediate & & & & & \\
\hline & & & & & & C horizon. & & and shale. & & & & & \\
\hline & shales. & & & & & D horizon. & 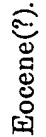 & $\begin{array}{l}\text { Kreyenhagen } \\
\text { shale } \\
\text { proper. }\end{array}$ & & & 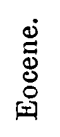 & & $\begin{array}{l}\text { reyenhagen } \\
\text { shale. }\end{array}$ \\
\hline
\end{tabular}

1 Anderson, F. M., A stratigraphic study in the Mount Diablo Range of California: Callfornia Acad. Sci. Proc., 3d ser., vol. 2, pp. 172-173, 1905.

2 Anderson, Robert, and Pack, R. W., Geology and oll resources of the west border of tho San Jonquin Valloy north of Coallnga, Calif.: U. S. Geol. Survey Bull. 603, pp. 74-78, 1915.

Age of the Kreyenhagen shale in the Cantus Creek-Panocho Croek district, Calif.: Jour. Palcontology, vol. 4, pp. 259-262, 1930.

The "Leda" zone at the top of the Kreyenhagen consists of white diatomaceous silty shale. Calcareous concretions in this zone contain a few mollusks, first recorded by F. M. Anderson, ${ }^{57}$ on the basis of which this zone has been correlated with the Weaver's Lincoln formation of Washington, which is considered of Oliogocene age. ${ }^{58}$ The "Leda" zone has a maximum thickness of about 150 feet and is known to occur only in the region extending across Arroyo Ciervo ${ }^{59}$ and 13 miles farther southeast on the Domengine ranch. ${ }^{60}$ The contact between the "Leda" zone and the underlying shale is described as representing a discontinuity. ${ }^{61}$

\footnotetext{
s Andierson, F. M., op. cit., p. 173, 1805. Anderson, F. M., A further stratigraphic study in the Mount Dlablo Range of California: California Acad. Scl. Proc., 4th ser., vol. 3, p. 16, 1808

o8 Clark, B. L., The San Loronzo serios of middle Callfornla: Callfornia Univ., Dept. Geology, Bull., vol. 11, p. 63-64, 99, 1918.

so Atwlll, E. R., op. cit., p. 1100.

00 Jonkins. O. P., op. cit., p. 145.

o1 Idom.
}

4 Jenkins, O. P., op. cit.

Anderson, F. M., Kreyenhagen shales and the Lillis shale [abstract]: Geol. Soc. America Bull. vol. 42, pp. 302-303, 1931.

Geologists Bull., vol, 19, pp. 1192-1204, 3 Ags., 1935.

The part of the Kreyenhagen constituting Atwill's Tumey shale (Condit's B horizon) has a thickness of about 700 feet ${ }^{62}$ and is made up principally of light chocolate-brown diatomaceous shale, which on weathered surfaces has generally a whitish or purplishbrown stain. This shale has been designated as part of the Uvigerina cocoaensis zone, which is reported to contain Foraminifera similar to those in Schenck's Bassendorf shale and Schenck's Keasey shale, both of which are Oregon formations tentatively assigned to the lower Oligocene. ${ }^{63}$ According to Atwill, a Uvigerina in this shale is more similar to $U$. glabrans than to $U$. cocoaensis, ${ }^{64}$ so that the usage of the term "Uvigerina cocoaensis zone" is likely to be confusing. Diatoms

or Atwill, E. R., op. cit., fig. 3 (p. 1197).

${ }_{63}$ Goudkoff, P. P., in Condit, D. D., op. cit., p. 260 . Goudkoff, P. P., op. clt. (Am. Assoc. Petroleum Geologists Bull., vol. 18), p. 470.

of Atwill, E. R., op. cit., pp. 1199, 1203-1204. 
described from this region are presumably from this division. ${ }^{65}$

Atwill's Tumey sandstone (Anderson and Pack's downfaulted Vaqueros; Condit's C horizon) is in the form of a lens that has a maximum thickness of about 800 feet. The sandstone rests with an irregular surface on the underlying shale, pebbles of which are represented in the basal conglomerate, indicating discontinuity. Fossils from the sandstone are considered of Oligocene age. ${ }^{66}$

The underlying shale (Condit's D horizon; restricted Kreyenhagen of Jenkins and Atwill) has a thickness of 1,400 to 2,500 feet ${ }^{67}$ and consists of light chocolatebrown porcelaneous mudstone with light-colored porcelaneous and diatomaceous shale toward the top. It rests with apparent gradational contact on Eocene sandstone (Domengine sandstone). The upper part of the shale contains Foraminifera, Church's Markley fauna, which he considered of upper Eocene age. ${ }^{68}$ Hughes and Laiming ${ }^{69}$ recorded Foraminifera of their upper Spiroplectammina fauna from the base of this shale and pointed out its similarity to their lower Spiroplectammina fauna found in Eocene shale underlying the Domengine sandstone. Apparently the same fauna is recorded by Atwill..$^{70}$

Anticline Ridge.-On Anticline Ridge the Kreyenhagen shale, corresponding to the upper member of the Tejon formation of Arnold and Anderson, ${ }^{71}$ bas a thickness of about 1,000 feet. It consists of light chocolate-brown porcelaneous mudstone, porcelaneous shale, cherty shale, and toward the top diatomaceous shale. It appears to correspond essentially to the restricted Kreyenhagen of Atwill and Jenkins farther north. Diatoms and silicoflagellates bave been described from the upper diatomaceous shale. ${ }^{72}$ Foraminifera from the lower part represent Church's Markley fauna. ${ }^{73}$ The "Leda" zone and Atwill's Tumey shale are not known to occur on Anticline Ridge.

Reef Ridge.-The Kreyenhagen shale of the type region on Reef Ridge (upper part of Tejon formation of Arnold and Anderson ${ }^{74}$ ) has been described by Von Estorff. ${ }^{75}$ It has a maximum thickness of about 1,000 feet and disappears west of Sulphur Spring Canvon owing to overlap by Temblor sandstone. The Kreyen-

\footnotetext{
as Hanna, G. D., The lowest known Tertiary diatoms in California: Jour. Paleon. tology, vol. 1, pn. 103-127, pls. 17-21, 1927. (See data on p. 107 under locality 995.)

${ }_{66}$ Atwill, E. R., op. cit., pp. 1200-1201.

B7 Idem, fig. 3 (p. 1197).

${ }^{68}$ Church, C. C., Foraminifera of the Kreyenhagen shale: Mining in California, vol. 27, no. 2, pp. 202-213, 3 pls., 1931.

${ }^{69}$ Hughes, D. D., and Laiming, Boris, Notes on the distribution of the Kreyenhagen foraminiferal fauna along the western border of the San Joaquin Valley. Unpublished report presented before Pacific Section, Soc. Econ. Paleontologists and Mineralogists, April 6, 1933.

io Atwill, E. R., op. cit., p. 1202.

7 Arnold, Ralph, and Anderson, Robert, op. cit. (Bull. 398), pp. 65-66.

72 Hanna, G. D., op. cit. (See data on D. 107 under locality 894.) Hanna, G. D., Diatoms and silicoflagellates of the Kreyenhagen shale: Mining in California, vol. 27, no. 2, pp. 187-201, 3 pls., 1931.

73 Church, C. C., op. cit., pp. 203-204.

11 Arnold, Ralph, and Anderson, Robert, op. cit. (Bull. 398), pp. 69-70, 1910.

75 Von Estorff, F. E., Kreyenhagen shale of type locality, Fresno County, Calif.: Am. Assoc. Petroleum Geologists Bull., vol. 14, pp. 1321-1326, 5 figs., 1930.
}

hagen in this region consists chiefly of light chocolatebrown porcelaneous mudstone that rests with gradational contact on Eocene sandstone (Avenal sandstone). The sandstone, sandy shale, and clay at the base of the formation, representing the transition zone of Arnold and Anderson and of Von Estorff, is excluded by Jenkins ${ }^{76}$ from his Kreyenhagen shale proper. According to Von Estorff, ${ }^{77}$ sandstone in Arnold and Anderson's transition zone is characterized by about equal amounts of quartz and relatively fresh feldspar, whereas in a sandstone higher in the section quartz greatly predominates. Antigorite in the upper sandstone was attributed by Von Estorff to a Franciscan source. Propeamussium interradiatus (Gabb) ${ }^{78}$ is found in the upper part of Arnold and Anderson's transition zone and in the lower part of the porcelaneous mudstone overlying their transition zone. ${ }^{79}$ The Foraminifera of the Kreyenhagen in this region are assigned by Hughes and Laiming ${ }^{80}$ to their upper Spiroplectammina fauna and to their lower Spiroplectammina fauna, both of which are of Eocene age. Their upper Spiroplectammina fauna occurs in the uppermost part of the Kreyenhagen, and their lower Spiroplectammina fauna occurs in the lower part of the formation within and below the stratigraphic range of Propeamussium interradiatus. The Kreyenhagen exposed on Reef Ridge contains Radiolaria, but no preserved diatoms have been recognized. The "Leda" zone, Atwill's Tumey shale, and apparently also strata containing Church's Markley fauna are missing.

Devils Den.-Strata that crop out on the south slope of Wagonwheel Mountain, 10 miles southwest of South Dome, have been assigned to the Kreyenhagen. They consist of an upper shale, a middle sandstone, and a lower shale. The upper shale contains Foraminifera referred to the Uvigerina cocoaensis zone, ${ }^{81}$ but according to Atwill, ${ }^{82}$ the Uvigerina in this part of the section is Uvigerina cf. U. glabrans. The middle sandstone contains a few fossils of probable Oligocene age. ${ }^{83}$ This sandstone is part of Johnson's Wagonwheel formation. ${ }^{84}$ Oil-bearing sands in nearby oil fields correlated with this sandstone have received the designation "Wagonwheel zone." The uppermost part of the lower shale contains Foraminifera of the restricted Uvigerina cocoaensis zone of Atwill, ${ }^{85}$ and the remainder represents

io Jenkins, O. P., op. cit., pp. 156, 181.

77 Von Estorff, F. E., op. cit., pp. 1327-1330.

$78 \mathrm{Gabb}, \mathrm{W}$. M., Cretaceous and Tertiary fossils: California Geol, Survey, Paleontology, vol. 2, pp. 199-200, pl. 33, figs. 98, 98a, 1869. Arnold, Ralph, and Anderson, Robert, op. cit. (Bull. 398), pl. 25, flgs. 7, 11, 1910. Stewart, R. B., Gabb's Cretaceous and Tertiary type lamellibranchs: Acad. Nat. Sci. Philadelphia Spec. Pub. 3, pp. 123-124, pl. 8, fg. 10, 1930.

70 Von Estorff, F. E., op. cit., fig. 3, (p. 1326).

30 Hughes, D. D., and Laiming, Boris, op. cit.

81 Goudkoff, P. P., op. cit. (Am. Assoc. Petroleum Geologists Bull., vol. 18), p. 469. Hughes, D. D., and Laiming, Boris, op. cit.

32 Atwill, E. R., op. cit., p. 1203.

${ }^{83}$ Arnold, Ralph, and Johnson, H. R., Preliminary report on the McKittrickSunset oil region, Kern and San Luis Obispo Counties, Calif.: U. S. Geol. Survey Bull. 406, p. $41,1910$.

84 Johnson, H. R., Geology of the McKittrick-Sunset district, Calif. labstract Science, new ser., vol. 30 , pp. 63-64, 1909.

ss Atwill, E. R., op. cit., p. 1204. Hughes, D. D., and Laiming, Boris, op. cit. 
Atwill's restricted Kreyenhagen. Propeamussium interradiatus is recorded from the lower part of the lower shale. . $^{80}$

Hughes and Laiming ${ }^{87}$ found Foraminifera of their lower Spiroplectammina fauna in massive sandstone underlying strata assigned to the Kreyenhagen in the Devil's Den district and also in massive sandstone exposed on Carneros and Chico Martinez Creeks. This massive sandstone is the Tejon formation of Bulletins 406 and 721.88 According to Hughes and Laiming, on Chico Martinez Creek Propeamussium interradiatus is associnted with the Foraminifera.

\section{SUBSURFACE SECTION}

At the present time it is uncertain whether the Kreyenhrgen shale of the Kettleman Hills subsurface section resembles the section exposed north of Anticline Ridge or the section exposed on Reef Ridge; that is, it is uncertain whether the subsurface Kreyenhagen is of Oligocene and Eocene age or is entirely of Eocene age. Inasmuch as a fairly complete section may be expected in the Kettleman Hills, it may be expected that the subsurface Kreyenhagen includes strata of Oligocene and Eocene age.

So far only a fow wells located at or near the north end of North Dome have penetrated the entire Kreyenhagen shale. Strata penetrated in Continental Gatchell well No. 28-7, in South Dome, were doubtfully assigned to the Wagonwheel zone of drillers, but the Kreyenhagen shale is apparently absent in this well.

In Lillis-Welch well No. 1, sec. 24, T. 21 S., R. 16 E., the thicknoss of the Kreyenhagen shale is about 1,300 feet, or about 1,000 foet depending on the assignment of sandy strata to the Temblor or Kreyenhagen. In Kenda well 4-18-J the thickriess is about 1,150 feet. Kend $\Omega$ well $67-20-J$ penetrated a thickness of 1,023 feet of Kreyęnhagen.

The subsurface Kreyenhagen consists of hard brown or brownish-gray shale and siltstone interbedded with

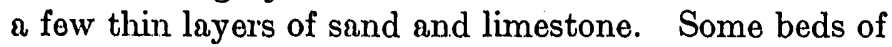
sand and siltstone contain glauconite and others contain phosphatic pellets. Bentonite reported in ditch samples from the Lillis-Welch well at a horizon 600 feet above the base of the Kreyenhagen may prove to be a useful key bed in future deep drilling.

According to Goudkoff; ${ }^{89}$ the upper part of the Kreyenhagen penetrated by the Lillis-Welch well represents the "Leda" zone and the Uvigerina cocoaensis zone. Inasmuch, however, as paleontologic evidence for the recognition of the "Leda" zone is not recorded and inasmuch as the foraminiferal zones that may be designated Atwill's Uvigerina cf. U. glabrans zone and

\footnotetext{
80 Jenklns, O.P. on, clt., D. 155.

st Hughes, D. D., and Laiming, Boris, op. cit.

Bs Arnold, Ralph, and Johnson, H. R., op. cit. (U. S. Geol. Survey Bull. 406), pp. 38-39, 1010. English, W. A., Geology and petroleum resources of northwestern Kern County, Callf.: U. S. Geol. Survey Bull. 721, pp. 10-12, 1921.

Bo Goudkofl, P. P., op. cit. (Am. Assoc. Petroleum Geologists Bull., vol. 18), p. 472, fig. 7 (p. 448).
}

his restricted Uvigerina cocoaensis zone may not have been differentiated, the presence of Oligocene strata in the Kettleman Hills section may be considered uncertain on the basis of available information. Uvigerina cocoaensis and other Foraminifera are recorded in the logs of Kenda wells 4-18-J and 67-20-J.

According to the log of Continental Gatchell well No. 28-7, in South Dome, a thickness of 390 feet of strata below a layer of bentonite was doubtfully assigned to the Wagonwheel zone. These strata consist chiefly of fine- to coarse-grained sand, some of which contains pebbles, interbedded with siltstone and silty to sandy shale. No formation lithologically comparable with the Kreyenhagen was penetrated in this well.

AGE AND CORRELATION

The Kreyenhagen north of Anticline Ridge includes a lower division of Eocene age and an upper division of Oligocene age. On Reef Ridge and apparently also on Anticline Ridge only the Eocene division is represented. The Eocene affinities of Kreyenhagen Foraminifera from Reef Ridge have been mentioned by Cushman and Siegfus. ${ }^{90}$ The Eocene division of the Kreyenhagen may include the equivalent of the Tejon formation, which in the type region at the south end of the San Jorquin Valley consists of sandstone, siltstone, and bentonite. ${ }^{91}$ The mollusks of the Tejon formation ${ }^{92}$ have been compared with those of the middle Eocene Claiborne group of the Gulf coast. Strata younger than the Tejon formation may also be included in the Eocene division of the Kreyenhagen.

If the lower part of the Temblor sandstone exposed on Reef Ridge is of lower Miocene age, as indicated by the meager fauna now known, and if the underlying Kreyenhagen shale is Eocene, Oligocene strata are missing and the Kreyenhagen-Temblor contact represents a discontinuity of sufficient magnitude to be designated a disconformity.

A discussion of the age and correlation of the Kreyenhagen shale in the subsurface Kettleman Hills section must await publication of descriptions of Foraminifera in different zones of the Kreyenhagen at outcrop localities and a comparison of the species from the Kettleman Hills with those from outcrop sections. As the age of the upper part of the Kreyenhagen in the Kettleman Hills appears to be uncertain, it is assigned to the Oligocene (?) and Eocene.

\section{EOCENE SERIES \\ MCADAMS SAND}

Several deep wells in North Dome have encountered a productive sandstone below the Kreyenhagen shale. This sandstone is designated by drillers the McAdams

${ }^{00}$ Cushman, J. A., and Siegfus, S. S., New species of Foraminifera from the Kreyenhagen shale of Fresno County, Calif.: Cushman Lab. Foram. Research Contr., rol. 11, p. $91,1935$.

o1 Hoots, H. W., Geology and oil resources along the southern border of San Joaquin valley, Calif.: U. S. Geol. Survey Bull. 812, pp. 250-253, 1930.

02 Stewart, R. B., Gabb's Cretaceous and Tertiary type lamellibranchs: Acad. Nat. Sci. Philadelphia Spec. Pub. 3, p. 19, 1930 
sand. It was first penetrated in North Kettleman Oil \& Gas Co.'s Lillis-Welch well No. 1, sec. 24, T. 21 S., R. $16 \mathrm{E}$., also known as the McAdams well. On the advance edition of the geologic map of the Kettleman Hills issued by the Geological Survey the sandstone was designated the Avenal (?) sandstone. The term McAdams sand has, however, come into general usage, and a local subsurface designation is preferable to a doubtful outcrop designation.

\section{STRATIGRAPHY, IITHOLOGY, AND FOSSILS}

\section{OUTCROP SECTION}

On Reef Ridge an Eocene sandstone conformably underlies the Kreyenhagen shale and rests unconformably on Upper Cretaceous shale and sandstone. This Eocene sandstone was named the Avenal sandstone from exposures at the Avenal wells in Big Tar Canyon. ${ }^{93}$ The Avenal sandstone was designated the lower part of the Tejon formation by Arnold and Anderson ${ }^{94}$ and the Domengine sandstone by Vokes. ${ }^{95}$ It has recently been studied by Ralph Stewart, whose report is now in preparation. ${ }^{96}$

According to descriptions by F. M. Anderson, Arnold and Anderson, and Vokes the Avenal sandstone is about 500 feet thick. At the base is a local conglomerate ranging in thickness from a few feet to 100 feet or more. Reed ${ }^{97}$ reported that the Avenal sandstone is characterized by abundance of feldspar and scarcity of ferromagnesian, minerals. Lists of fossils from the Avenal sandstone have been published at different times, ${ }^{98}$ and some of the species were figured by Arnold and Vokes.

\section{SUBSURFACE SECTION}

Lillis-Welch well No. 1, at the extreme north end of North Dome, penetrated a thickness of 29 feet of sand underlying the Kreyenhagen shale. A 1-foot core recovered from the sand was recorded as poorly sorted coarse-grained light-gray sand stained light brown with oil. Two other wells at the north end of North Dome, Kenda 4-18-J and Kenda 67-20-J, are producing from the McAdams sand. Kenda 4-18-J has penetrated a thickness of 1,061 feet assigned to the McAdams sand and Kenda 67-20-J a thickness of 510 feet. The strata consist chiefly of hard gray sand with some siltstone and claystone. Discocyclina clarki

\footnotetext{
03 Anderson, F. M., A stratigraphic study in the Mount Diablo Range of California: California Acad. Sci. Proc., 3d ser., vol. 2, p. 164, 1905.

04 Arnold, Ralph, and Anderson, Robert, op. cit. (Bull. 398), pp. 67-70.

to Vokes, H. E., Molluscan faunas of the Domengine and Arroyo Hondo formations of the California Eocene: New York Acad. Sci. Annals, vol. 38, pp. 20-21, 1939.

oo Stewart, Ralph, Geology of Reef Ridge, Calif.: U. S. Geol. Survey Prof. Paper (in preparation).

${ }^{97}$ Reed, R. D., Role of heavy minerals in the Coalinga Tertiary: Econ. Geology, vol. 19, pp. 731, 733, 738, 1924; Geology of California, p. 127, Tulsa, Am. Assoc. Potroleum Geologists, 1933.

is Anderson, F. M., op. cit., p. 164. Arnold, Ralph, op. cit. (Bull. 396), pp. 12-16, 49-54, pls. 2-4, 1909 [1910]. Arnold, Ralph, and Anderson, Robert, op. cit. (Bull. 398), pp. 70-74, pls. 24-26, 1910. Von Estorff, F. E., Kreyenhagen shale at type locality, Fresno County, Calif.: Am. Assoc. Petroleum Geologists Bull., vol. 14, p. 1327,1930 . Vokes, H. E., op. cit., pp. 24-26, 40-184, pls. 1-22.
}

and other Eocene Foraminifera are recorded in the $\log$ of Kenda 4-18-J.

\section{AGE AND CORRELATION}

In the region north of Anticline Ridge an Eocene sandstone underlies the Kreyenhagen shale, but unlike the Avenal sandstone it rests on Eocene shale. This Eocene sandstone was named the Domengine sandstone ("Domijean sands") ${ }^{9 \theta}$ and was designated the Tejon formation by Anderson and Pack. ${ }^{1}$ The Avenal sandstone has been assigned to the Domengine. ${ }^{2}$ Both the Avenal sandstone and the Domengine sandstone contain mollusks of middle Eocene age, but a local name is preferable for the sandstone exposed on Reef Ridge. The McAdams sand includes doubtless the equivalent of the Avenal sandstone and perhaps a greater time interval than the Avenal. The absence of lower Eocene and Paleocene formations in the outcrop section on Reef Ridge shows that the Upper CretaceousAvenal contact represents a disconformity.

\section{STRUCTURE}

\section{GENERAL RELATIONS}

The Kettleman Hills lie along the trend of the Coalinga anticline. As shown in figure 15, the Coalinga anticline begins in the Diablo Range with an eastward trend. Farther east it bends southeastward parallel to the trend of the range and of the other major structural features of the region, of which the San Andreas fault zone is the most prominent.

Structurally the Kettleman Hills consist of three anticlines: North Dome, Middle Dome, and South Dome. The anticlines trend northwestward, are slightly asymmetrical, with the steeper $\operatorname{limb}$ to the southwest, and are en echelon to each other, each fold being offset westward with reference to the one to the north. North and Middle Domes are doubly plunging anticlines, and the plunging northwest end of North Dome is offset westward in relation to the southeastward-plunging end of the Coalinga anticline. Only the northwest end of South Dome anticline is exposed, the southeastern part being covered by alluvium of the San Joaquin Valley. About 10 miles southeast of South Dome, the southeastward-trending doubly plunging anticline of Lost Hills rises out of the alluvium. The relations between the anticlines of Lost Hills and South Dome are obscured by the intervening cover of alluvium, but there is said to be subsurface evidence that South Dome and Lost Hills form a continuous anticline in Miocene formations, but that a saddle may lie between them in the Pliocene formations. $^{3}$ In the Lost Hills, strata probably representing

\footnotetext{
${ }^{99}$ Anderson, F. M., op. cit., p. 167.

1 Anderson, Robert, and Pack, R. W., Geology and oil resources of the west border of the San Joaquin Valley north of Coalinga, Calif.: U. S. Geol. Survey Bull. 603, pp. $69-70,1915$.

2 Von Estorff, F. E., op. cit., p. 1325. Vokes, H. E., op. cit., pp. 20-21.

Cunningham, G. M., and Kleinpell, W. D., Importance of unconformities to oil production in the San Joaquin Valley, Calif: Problems of Petroleum Geology, p. 796, Tuls?, Am. Assoc. Petroleum Geologists, 1934.
} 


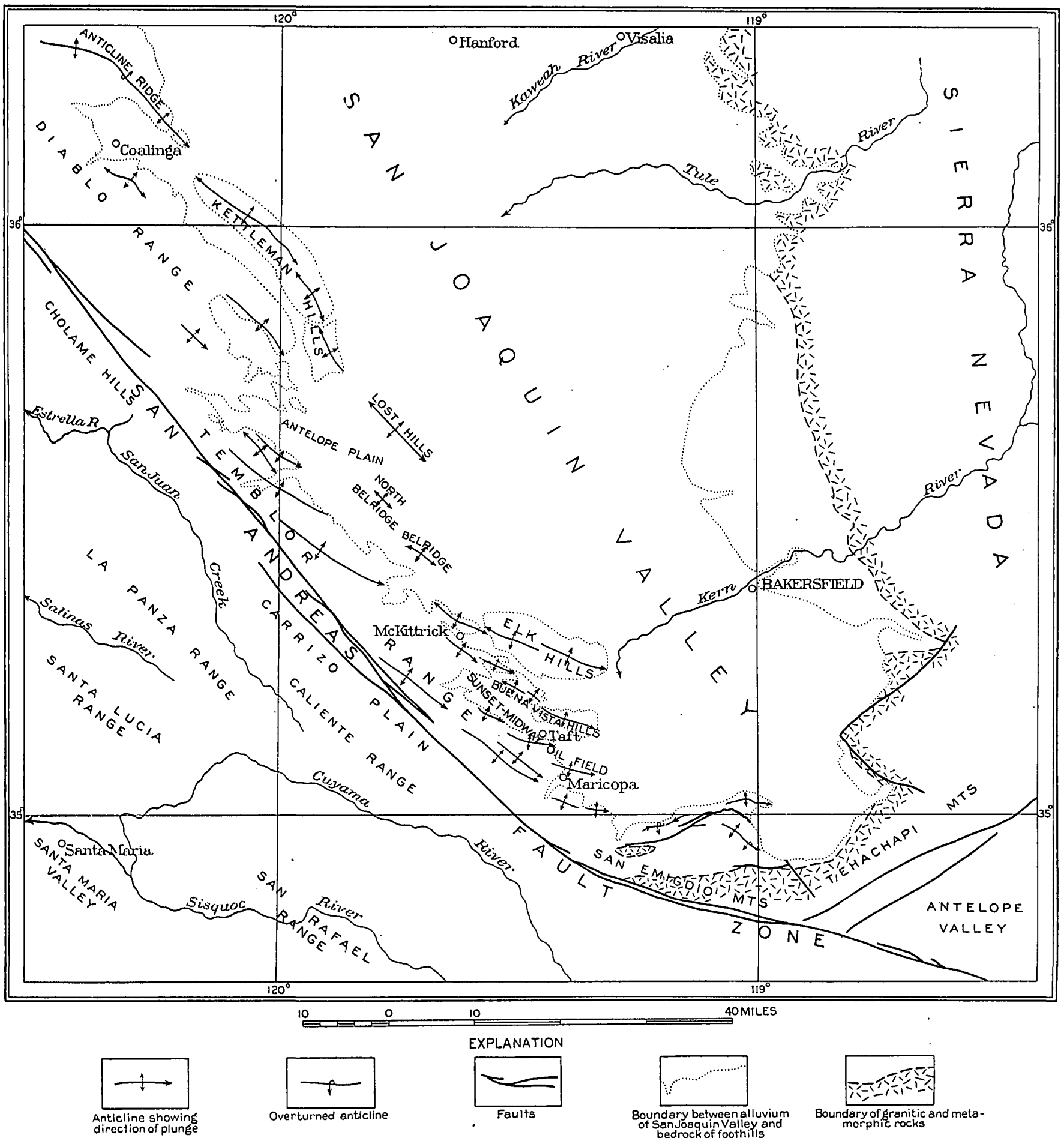

FuURe 15.-Sketch map showing location of anticlines in Kettleman Hills with relation to other anticlines along west border of southern San Joaquin Valley. (Complled from published and unpublished reports of Geological Survey. Geographic base and San Andreas fault zone adapted from Fault map of California, Issued by Seismological Society of America, 1922.)

the Tulare formation are only slightly folded and rest unconformably on more steeply folded strata assigned to the Etchegoin formation, ${ }^{4}$ and several thousand feet of Pliocene beds represented in the Kettleman Hills are missing beneath the unconformity. In the Kettleman Hills the unconformity is absent and the Tulare formation is as steeply folded as the underlying strata.
Folding, therefore, took place in the Lost Hills before the deformation of the Kettleman Hills.

The attitude of the formations exposed in the Kettleman Hills is shown by means of structure contours on plate 51 ; and the structure sections on the same plate show some features of the subsurface structure. The structure contour map is essentially the same as the advance edition issued in 1934 by the Geological Survey. 
The Littorina zone of the Etchegoin formation is the datum plane for the contours in North Dome. The contours of Middle Dome and South Dome are drawn on the Pseudocardium-Anadara zone of the Etchegoin formation, which is regarded as the essential equivalent of the Littorina zone. The contours and faults are based on mapping of varying degrees of certainty represented by appropriate symbols on the areal geologic map (pl. 3), but for the sake of legibility solid lines are used to represent the contours and also the projections of the faults at the horizon of the contoured bed. The area along the faults represented by stippling indicates the part of the fault plane between the displaced edges of the contoured bed. It is shown only where the displacement is great enough or where the dip of the fault plane is low enough to be shown on a map of this scale. Computations of stratigraphic thickness were made on an assumption of no appreciable thickening or thinning of individual beds as a result of folding, which appears to agree with subsurface data more closely than an assumption of appreciable change in thickness of beds as a result of folding.

\section{NORTH DOME}

General description.-North Dome is the northernmost of the three northwestward-trending anticlines of Kettleman Hills. It is about 18 miles long and 5 miles wide. In the central part the axis is essentially horizontal for about 8 miles. At the southeast end it plunges at an angle of about $6^{\circ}$ toward the saddle that separates North and Middle Domes, and the structural rise from the saddle to the crest of the anticline is about 1,600 feet. At the northwest end the axis plunges about $7^{\circ}$, and the structural rise from the northwesternmost exposed strata involved in the folding is about 3,100 feet. The anticline is slightly asymmetrical, the average dip on the southwest flank being about $5^{\circ}$ higher than on the northeast flank. The maximum observed dip on the southwest flank is $43^{\circ}$ and on the northeast flank is $40^{\circ}$. The central part of the anticline is broken by numerous normal faults with displacements ranging from a few feet to about 300 feet. The faults belong to two sets: (1), strike faults on both sides of the anticline that trend northwestward about parallel to the crest; (2), diagonal faults that trend slightly east of north at an angle of about $60^{\circ}$ to the axis of the anticline and to the general strike of the strata. (See pl. 52.) The general faulting of the crest was mentioned by $\mathrm{McCollough}^{5}$ and described by Gester and Galloway. ${ }^{6}$

Strike faults.-More than half of the faults in North Dome are strike faults that trend about parallel to the axis of the anticline. The strike faults, which are

S McCollough, E. H., Kettleman Hills oil field, Calif.: Am. Assoc. Petroleum Geologists Bull., vol. 13, p. 1481, 1929.

${ }^{\circ}$ Gester, G. C., and Galloway, John, Geology of Kettleman Hills oil field, Calif. Idem., vol. 17, pp. 1187-1189, 1933. about equally numerous along each side of the axis, have displacements ranging from a few feet to about 300 feet. Most of the strike faults dip toward the axis at angles that average about $60^{\circ}$. A few on each side of the anticline, however, dip away from the axis of the anticline at angles that average slightly more than $60^{\circ}$. Comparatively few striae were observed on the fault planes, but the observed striae almost invariably lie parallel to the dips of the fault planes. At most places the axis of the anticline lies in the block between the southwesternmost of the southwestwarddipping faults and the northeasternmost of the northeastward-dipping faults. At $\Omega$ few localities, however, the axis lies between the southwesternmost two of the southwestward-dipping faults or the northeasternmost two of the northeastward-dipping faults. The axis of the middle part of the anticline, therefore, lies in the structurally lowest part of a-complex fault trough that extends along the crest of the fold. The structurally lowest part of the trough and the axis of the anticline are not, however, equally distant from each side of the trough at all places. In the middle part of the anticline the structurally lowest part lies near the north side of the trough, and toward each end it lies near the south side.

A minor graben about 30 feet wide, too small and too poorly exposed to be shown on the map, is on the west side of the trough near the center of North Dome (east side of La Cima, sec. 20, T. 22 S., R. 18 E.). Similar minor grabens are probably present southeastward along the La Cima-Cerro Alto ridge. The few faults that strike westward may be associated with the strike faults because some of the strike faults on the south flank appear to change near their ends to a more westerly strike.

Diagonal faults. - Normal faults of the second set nave displacements of less than 100 feet. They trend slightly east of north and cross the axis of the anticline and the general strike of the strata at angles of about $60^{\circ}$. These faults may be referred to as diagonal faults. Diagonal faults, which are present along the axis of the entire anticline except the extreme ends, are most numerous in zones surrounding the area near each end where pronounced plunge of the axis begins. Most of the diagonal faults on and near the plunging ends of the anticline dip in the general direction of the plunge at an average angle of about $60^{\circ}$, but a few of the faults dip in the opposite direction. In the central part of the anticline, where the axis is essentially horizontal, eastward-dipping and westwarddipping diagonal faults are about equally numerous, but in the western part the greater number dip eastward and in the eastern part the greater number dip westward. The trend and angle of inclination of striae on the planes of many diagonal faults were measured, and with only a few exceptions they were found to be oblique to the strike and dip of the fault 
planes and to lie at angles of about $60^{\circ}$ to the strike. (See pl. 52.) The trend of the striae down the plane of the diagonal faults on the northeast flank is south of the direction of dip of the fault planes, and on the southwest flank the trend of the striae down the planes of the diagonal faults is north of the direction of dip of the faults. Thus the striae are inclined toward the axis of the anticline.

Joints.-Abundant closely spaced tight joints lie almost parallel to the planes of the diagonal faults in n zone nbout 5 feet wide on each side of the faults (pl. $53, C)$. Beyond this zone and also near the strike faults are numerous more widely spaced open joints, some of which strike and dip parallel to the plane of the closest fault; some strike parallel to the closest fault but dip in the opposite direction; and many other joints both strike and dip at various angles to the plane of the closest fault and are not obviously related geometrically to any of the more pronounced structural reatures.

\section{MIDDLE DOME}

Because of unsatisfactory exposures over a large part of Middle Dome, its structure is not as well known as the structure of North Dome. Outcrops of the Pseudocardium-Anadara zone, on which the structure contours are drawn, and of the underlying Pseudocardium-bearing conglomerates are for the most part well defined, but the observed relations in some of the areas where these strata are exposed may be interpreted in different ways. Normal contacts and faults may have been confused in mapping the boundary between the lower and upper parts of the Etchegoin formation at the north and south ends of the anticline. The structure of the area underlain by the lower part of the Etchegoin is a matter of inference.

Middle Dome is about $7 \frac{1}{2}$ miles long and about 5 miles wide. As the structure has been interpreted, Middle Dome has a closure of 800 feet and is 400 feet lower structurally than the highest part of North Dome. The saddle between Middle and South Domes is 150 feet lower structurally than the downthrown side of the fault through the saddle between North and Middle Domes. The virtual symmetry shown on plate 51 may be incorrect. No dips are recorded in the Tulare formation along the central part of the east limb, whereas dips of $35^{\circ}$ and $40^{\circ}$ are recorded on the west limb. It appears probable that the west limb is a little steeper than the east one but that the asymmetry is less than in North Dome. Middle Dome consists of three parts, the main central part and a faulted minor dome at each plunging end. At both ends of the anticline the 1,000-foot structure contour crosses the axis almost a mile beyond the place where it approaches the axis in the central part. In the faulted saddles between the central part and the minor domes the axis of the anticline bends sharply. On the concave side of the bend faults are more numerous than in other parts of the anticline.

The faults recognized in Middle Dome are normal faults. They have a maximum displacement generally of about 150 feet. Most of the faults trend almost at right angles to the strike of the strata (radial faults) or are diagonal to the strike (diagonal faults); a few are parallel to the regional strike (strike faults).

Aside from some diagonal faults at the ends of the anticline that pass into strike faults, the only strike faults recognized are near the base of down-dropped wedges pointing toward the concave side of sharp bends in the anticlinal axis between the central part of the anticline and the minor domes. In both areas of such wedges the outcrops of the Pseudocardium-Anadara zone and the Pseudocardium-bearing conglomerate are interpreted as indicating strike faults dipping toward the axis of the anticline. These faults are nearly parallel to the regional strike but are diagonal to the strike in the faulted areas. Exposures of the strike faults were not seen in either area, and the displacement of radial and diagonal faults by strike faults is based on the assumption that the strike faults are later than the other faults. Toward the ends of the anticline the strike faults are limited by diagonal faults; in the opposite direction they appear to die out. The structure of the central part of the anticline appears to be simple, but the contours in the area underlain by the lower part of the Etchegoin formation are uncontrolled, and the location of the axis itself is uncertain. It is reasonably certain, however, that there are no faults in this area with displacements great enough to drop strata in the upper part of the Etchegoin.

The pattern of approximately radial faults is partly determined by the assumed extension of faults exposed for short distances and therefore may not be genuine. As these faults are drawn, most of them have a more northward trend than a strictly radial trend. The diagonal faults also have a general north-northeastward trend; a few trend northwestward or westward. The greatest displacement is along diagonal faults with a north-northeastward trend. Toward the ends of the anticline diagonal faults apparently cross the axis. On the east limb most of the faults in the central part of the anticline and in the area adjoining the minor dome at the north end dip westward; on the west limb most of the faults as far south as the minor dome at the south end dip eastward.

For the most part, fault planes in Middle Dome are inaccessible without extensive excavations. They are assumed to have a dip of $60^{\circ}$, the average of many measurements in North Dome. Closely spaced tight joints give a clue to faults in sandstone, and the jointed sandstone generally projects above the unjointed sandstone as a narrow rib. According to observations in North Dome, tight joints are practically parallel to the fault plane. The trend of such joints at many places in 
Middle Dome was assumed to represent the trend of faults.

The two areas of pronounced faulting constitute the most striking feature of Middle Dome structure as it is now understood. Both areas form wedges that taper toward the axis and lie on the concave side of bends in the axis between the central part of the anticline and the minor dome at each end. The change of strike in these areas is well shown by the strike of the PseudocardiumAnadara zone and of the Pseudocardium-bearing conglomerate. The location and relations of the areas of pronounced faulting indicate that they are related to the doming of the ends of the anticline. Though there is little indication of asymmetric doming at the surface, the pronounced faulting may perhaps be due to asymmetric doming at greater depth.

\section{SOUTH DOME}

The part of South Dome that is exposed has a length of about $5 \frac{1}{2}$ miles and a maximum width of about 4 miles. The structure appears to be simple. Only minor diagonal or approximately radial faults were recognized in the area underlain by the San Joaquin formation and the upper part of the Etchegoin formation, where the structure is adequately controlled, and also in the area underlain by the lower part of the Etchegoin, where the structure is uncertain. The trend of the axis is reasonably certain as far south as the southeastern part of sec. 34, T. 24 S., R. 19 E. Beyond this the trend is not known except by inference from a few strike and dip observations. There may be undetected complications on the exposed part of the east limb, where the structure contours are drawn on an assumption of simple structure. At all events, in the area underlain by the lower part of the Etchegoin formation there are no faults that have a displacement great enough to drop strata in the upper part of the Etchegoin formation or in the San Joaquin formation.

Though details of the structure are uncertain, South Dome is evidently part of an anticline that is considerably wider and structurally higher than North and Middle Domes. The area underlain by the Etchegoin formation, measured across the axis from the place where the San Joaquin-Etchegoin boundary is overlapped by alluvium on the east limb, is about half again as wide as the widest part of North Dome or Middle Dome; and, according to the trend of the boundary, the South Dome anticline is even wider south of the overlap. The axis of South Dome apparently rises rapidly southward. That it is still rising virtually as far south as the hills extend is supported by the occurrence of a faunal zone that appears to represent a lower horizon than the lowest exposed part of the Etchegoin in North Dome. The highest structure contour shown in South Dome is 800 feet higher than the highest one in North Dome and 1,200 feet higher than the highest one in Middle Dome. Arnold and
Anderson recognized the absence of closure at the south end of the hills.?

Location of axis of Kettleman Plains syncline west of South Dome.-The location of the axis of the Kettleman Plain syncline west of southern South Dome is uncertain. As tentatively located on plate 51 , the axis extends obliquely across the southwest end of the Kettleman Hills. This location is essentially the same as that shown by English on the geologic map accompanying Bulletin $721 .^{8}$ The boundary between the alluvium and the Tulare formation cropping out in the hill $\varepsilon$ is represented to be farther east on his map than on plate 51. The boundary, however, is indefinite in this region, where low hills imperceptibly merge into the plain. The axis of the syncline as shown on plate 51 is based on airplane photographs on which patterns are interpreted as indicative of outcrops with northeasterly dips. The inferred outcrop patterns could not be confirmed on the ground. In view of the close relation between structure and outline of the hills in areas where the hills rise more abruptly above the alluvium, the tentative location of the axis of the syncline needs confirmation.

\section{ORIGIN OF STRUCTURE}

GeNERAL AND REgIONAL FeATURES

The deformation of the Kettleman Hills is attributed to compression in a north-south direction applied to a northwestward-trending zone of weak strata in which echelon anticlines were being formed. The upward squeezing of incompetent material lifted and folded the strata; the faulting is attributed to shearing that accompanied differential vertical stresses in competent strata overlying the rising incompetent material. The strike faults of the axial fault trough of North Dome were evidently formed after the strata had been lifted above the levels of direct influence of the north-south compression. Inasmuch as nearly all the strike faults dip toward rather than away from the axis of the anticline it is inferred that the compression on the flanks sufficed to localize the movement on these inward-dipping faults, which may be regarded as shear planes. The diagonal faults appear to have been formed before the strata had been raised entirely above the levels of the effect of the north-south compression. The oblique striae of the diagonal faults (pl. 52) appear to have been formed in a stage intermediate between the formation of the diagonal and strike faults. Greater pressure on the flanks of Middle Dome than on North Dome may account for the absence of an axial fault trough there and for the general strike of the faults almost at right angles to the axis. On South Dome the dimensions of the incompetent material may have been such as to balance the horizontal and vertical stresses in

\footnotetext{
' Arnold, Ralph, and Anderson, Robert, op. cit. (Bull. 398), pp. 124, 165.

8 English, W. A., Geology and petroleum resources of northwestern Kern County, Calif: U. S. Geol. Survey Bull. 721, pl. 1, 1921.
} 
the overlying competent rocks during the uplifting of the strata; under these conditions no axial fault trough would be formed.

The exposed strata of the Kettleman Hills may represent an early stage in a structural sequence in which thrust faulting was not reached, because the mass of the incompetent material was thick enough to lift the competent material above the direct action of the horizontal compression prior to any faulting of the competent material.

The structural features of the Kettleman Hills appear to be related in origin to nearby structural features, notably the Coalinga anticline, to the northwest, and the San Andreas fault, to the west. As mapped by Arnold and Anderson ${ }^{9}$ the Coalinga anticline swings westward at its north end. Apparently the greatest uplift has taken place where the axis is east-west, perhaps because of a fundamental north-south horizontal compression or shortening. The San Andreas fault ${ }^{10}$ appears to be a great flaw along which considerable horizontal displacement has occurred. It may thus be a shear plane due to failure under fundamental northsouth compression. The suggestion of north-south compression in this nearby structure is so strong that it seems reasonable to attribute the fundamental cause of the Kettleman Hills uplift to the same forces.

The zone of weak strata in the Kettleman Hills is oblique to the assumed north-south compression. In order to account for the echelon arrangement, not only of the Kettleman Hills but of the structural features of the region in general, Arnold and Anderson ${ }^{11}$ suggested two main sets of compressional forces-an earlier, acting along a roughly $\mathrm{N} .50^{\circ} \mathrm{E}$. trend and a later, along a N. $20^{\circ}-30^{\circ}$ trend. Such a second set of stresses might produce broad saddles in the main folds formed by the earlier northeastward-trending compression, but it is not evident how the axes of the main folds would thereby be offset. Under a north-south shortening, echelon anticlines could form with their individual axes lying more or less parallel but with more westerly trends than the trend of the zone of weakness. This weak zone would be oblique to either an east-west or a northsouth compression. If the compression had been eastwest the anticlines would be expected to be offset to the left instead of to the right. Offsetting to the left by a regional north-south compression would require rotation of stresses reaching almost $90^{\circ}$. But before rotation to this degree would be attained, the stresses

\footnotetext{
- Arnold, Ralph, and Anderson, Robert, op. cit. (Bull. 398), pl. 1

10 Gllbert, G. K., The San Franclsco earthquake and fire: U. S. Geol. Survey Bull. 324 , p. 5, pl. 1, 1907. Lawson, A. C., and others, The Californla earthquake of April 18, 1906: Oarnegle Inst. Washlngton Pub. 87, vol. 1, p. 148, 1908. Reid, H. F., The elastio rebound theory of earthquakes: California Univ., Dept. Geology, Bull., vol. 6, pp. 417-42s, 1911. Willis, Balley, Folding or shearing, which?: Am. Assoc. Petroloum Ceologists Bull., vol. 11, pp. 34, 35, 39, 1927. Noble, L. F., The San Andreas rift In the desert region of southeastern Callfornia: Carnegle Inst. Washington Year Book 31, pp. 355-305, 1932 . Bucher, W. H., The deformation of the earth's crust, pp. 311-318, Princeton University Press, 1933. Reed, R. D., Santa Margarita conglomerate of the Temblor Range [abstract]: Geol. Soc. America Proc., 1933, pp. 309810, 1933.

" Arnold, Ralph, and Anderson, Robert, op. cit. (Bull. 398,) p. 160.
}

operating with gradually changing directions would first produce folds offset to the right.

One long anticline or a series of parallel anticlines in the pre-existing zone of weakness in the Kettleman Hills: could be produced under horizontal compression acting uniformly from all directions. The effects of such compression would be the same as those of northeastsouthwest compression, but under either condition the echelon arrangement of the three anticlines in the Kettleman Hills would be fortuitous.

The weak zone in the Kettleman Hills is presumably either a thick prism of sedimentary rocks trending northwestward or a flaw like the San Andreas fault buried. beneath sedimentary strata; or it may consist of both such a prism and a flaw. The sinking of the San Joaquin Valley may somehow be connected with this zone of weakness. Seismographic observations made on the San Joaquin Valley side of the Kettleman Hills have been interpreted as indicating a major syncline trending northwestward. ${ }^{12}$ The Kettleman Hills have recently been called "a youthful appendage to an ancient perhaps Mesozoic fold," the Joaquin-Coalinga Anticline Ridge. ${ }^{13}$ In a recent discussion by Clark ${ }^{14}$ the distribution of strata of the Coalinga region is in part attributed to faulting, and rather large-scale folding is attributed to drag along fault planes.

\section{TIME OF DEFORMATION}

The Tulare formation, which is assigned to the upperPliocene and Pleistocene (?), is involved in the folding of the Kettleman Hills, the main part of which preceded the deposition of the older alluvium in the hills. The amount of erosion that has occurred in the hills seems sufficient to place the beginning of the folding somewhere in the Pleistocene epoch, and it may have been contemporaneous with deformations in other areas of Californir in which lower Pleistocene strata were involved. Such deformations are usually considered mid-Pleistocene; they have recently been named Pasadenan. ${ }^{15}$ There is perhaps some value in grouping deformations of this type together under periods of deformation, and the term may be quite useful, particularly in southern California. Unfortunately the term was expanded to include any Pleistocene folding.

It seems possible that the general stress that deformed the Kettleman Hills existed before the folding of the hills, and it may have been locally relieved by the downward bulging that formed the trough in which the sediments were deposited and by upward relief farther

19 Vaughan, F. E., in Lawson, A. C., Slerra Nevada in the light of isostasy: Geol. Boc. America Bull., vol. 47, p. 1699, 1936.

18 Reed, R. D., and Hollister, J. S., Structural evolution of southern California: Am. Assoc. Petroleum Geologists Bull., vol. 20, p. 1613, 1936.

14 Clark, B. L., Tectonics of the Mount Diablo and Coalinga areas, middle Cosst. Ranges of California: Geol. Soc. Amerlca Bull., vol. 46, pp. 1030-1034, 1040-1074, bl. 89, 1935.

is Stille, Hans, The present tectonlc state of the earth: Am. Assoc. Petroleum .Cleologists Bull., vol. 20, pp. 867, 869, 1936. A translation by Hans Ashauer of part ofthe following: Stille, Hans, Der derzeltige tektonische Erdzustand: Preuss. Akad. Wiss., Phys.-Math. Kl., Sitzungsber., pp. 179-219, 3 figs., 1935. [Kettleman Bills: mentioned on p. 207.] 
west during late Pliocene time as suggested by the presence of conglomerates in the San Joaquin formation. When the sinking ceased and the direction of relief became upward, the sediments deposited in the trough formed an incompetent mass lying oblique to the assumed north-south compression. The deformation forming the hills would result from a local change in direction of relief. Some areas in California may have been sinking and receiving sediments while others were being folded, though all these areas were under northsouth compression. The recent displacements along the San Andreas fault suggest that the nortb-south compression is still active. The regional forces that folded the Kettleman Hills may now be maintaining the strata in their present attitudes and may cause additional folding.

\section{PHYSIOGRAPHY}

\section{GENERAL FEATURES}

The Kettleman Hills are an elongate group of hills about 30 miles long and 5 miles wide that rise fairly abruptly several hundred feet above the plains on the west side of the San Joaquin Valley. They are separated from the Diablo Range by Kottleman Plain, an almost flat plain 3 to 5 miles wide. The bills attain a maximum altitude of 1,366 feet above sea level near the north end, and they decrease in height more or less gradually toward the south until they merge almost imperceptibly into the plain of the San Joaquin Valley. As pointed out by Arnold and Anderson ${ }^{16}$ and by Reed, ${ }^{17}$ the Kettleman Hills represent land forms carved from a deformed surface of low relief developed across folded beds of the Tulare (upper Pliocene and Pleistocene (?)) and older formations. The deformation of this surface is here interpreted as renewed arching along the axis of the Kettleman Hills anticline without further movement on the faults. This old surface has been modified and largely destroyed by erosion. The Kettleman Hills contain two concentric rows of hills, which are locally cuestas. The crests of these hills in some localities may represent parts of the old surface as modified by subsequent erosion.

The amount of relief and ruggedness in general decrease from north to south. Most of the streams are consequent and flow down the slopes roughly at right angles to the trend of the hills, but many of the tributaries are more or less parallel to the strike of the strata, and their courses are determined mainly by the resistance of the rocks to erosion. One stream, however, flows entirely across the hills at Avenal Gap, between Middle and South Domes, and has evidently maintained itself during the later uplift of the hills.

\footnotetext{
16 Arnold, Ralph, and Anderson, Robert, op. cit. (Bull. 398), pp. 37, 45

17 Reed, R. D., Geology of California, p. 262, Tulsa, Am. Assoc. Petroleum Geolo-
} gists, 1933.

\section{OLD SURFACES OF LOW RELIEF}

A nearly flat surface covers an area a mile long and a quarter of a mile wide at El Prado, near the north end of Kettleman Hills, in sec. 32, T. 21 S., R. 17 E. As shown on plates $53, A$, and 54 , this surface is remarkably smooth and truncates strata in the upper part of the San Joaquin formation. It ranges in altitude from 1,100 to 1,225 feet and drops about 100 feet to the mile northwestward. The underlying strata dip about 400 feet to the mile in the same direction. This erosion surface has such low relief and covers such a large area that it evidently was formerly much more extensive than now and presumably covered the entire Kettleman Hills, but it has not been traced with certainty beyond its present limits. A surface truncating the lower part of the San Joaquin formation on La Palomera (pl. 53, $B$ ), in sec. 16, T. $22 \mathrm{~S}$., R. $18 \mathrm{E}$., may be a remnant of the surface at El Prado, but it seems to lie below the probable projection of that surface. Dissected surfaces on Las Alturas, in Middle Dome, and on Las Colinas, in South Dome, correspond probably to one or the other of the North Dome surfaces.

In the central part of North Dome in the vicinity of La Cima, in sec. 20 , T. 22 S., R. 18 E., some of the hilltops that consist of resistant sandstone rise above benches that seem to fall in the projection of the old erosion surface at El Prado. They perhaps represent hills that stood above the old surface. La Cima itself is the highest point in the Kettleman Hills, and its prominence is due to resistant strata that have been exposed over a relatively wide area owing to repetition by faulting.

The erosion surface at El Prado bevels the San Joaquin formation; and the probable projection of this surface truncates the younger Tulare formation, which conformably overlies the San Joaquin. The strata on the flanks of the hills have been tilted as much as $43^{\circ}$, and about 5,000 feet of Tulare, San Joaquin, and Etchegoin beds has been eroded from the central part of the anticline. As the Tulare is assigned to the upper Pliocene and Pleistocene (?), the folding and truncating of the sediments presumably took place mainly in the Pleistocene.

A determination of the degree of arching of the erosion surfaces in the Kettleman Hills depends upon an exact correlation of the present remnants of these surfaces. These correlations have not been attempted because the surfaces appear to have been too greatly modified and destroyed to justify such correlation. The general altitude of the hills becomes less toward the south. The old surfaces probably also sloped in that direction. The alluvium at the edge of the hills also is lower at the south end of the hills than at the north end, but the difference is not so great as that of the general altitude nor presumably so great as that of the old surfaces. The hills, therefore, have been tilted 


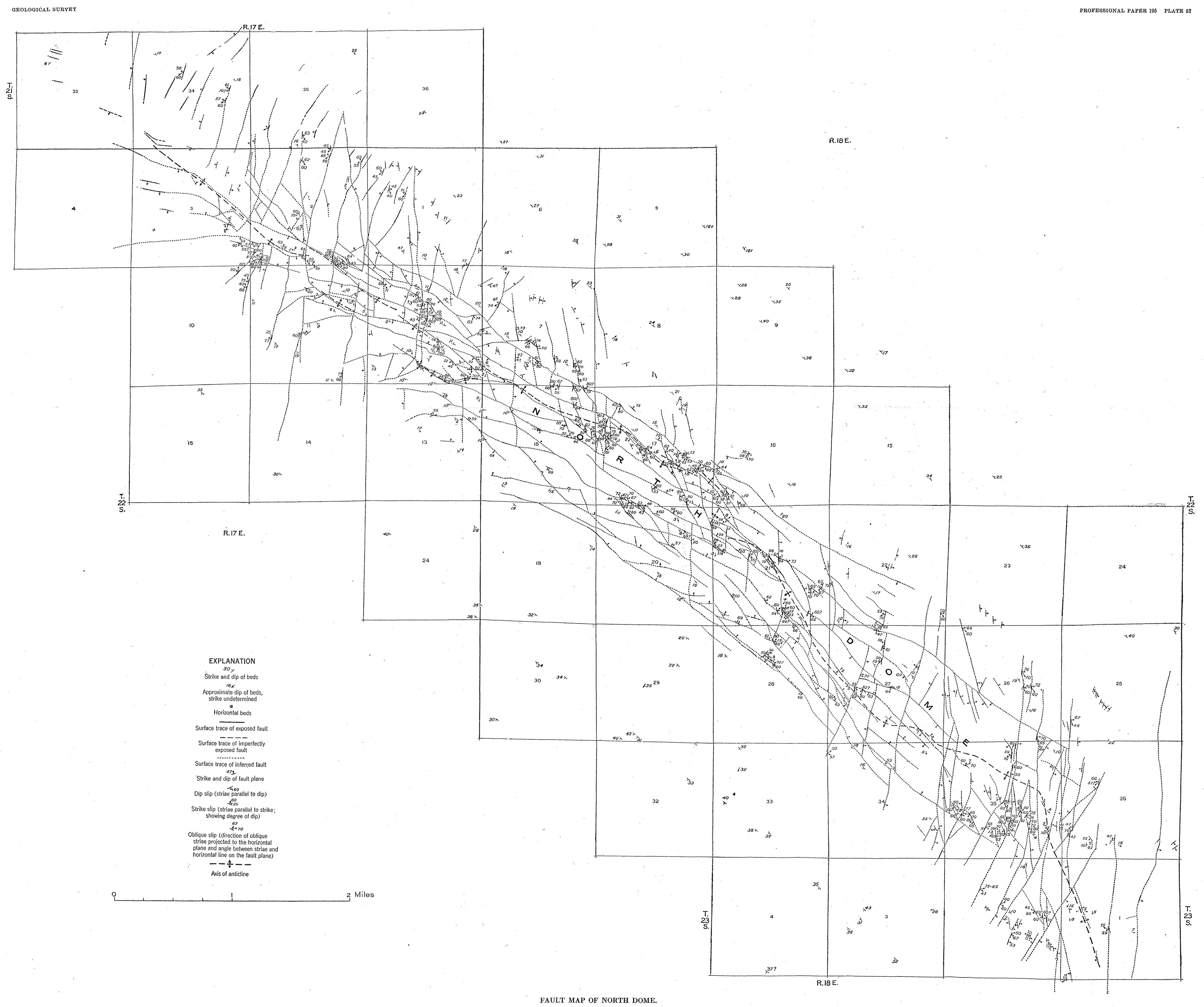




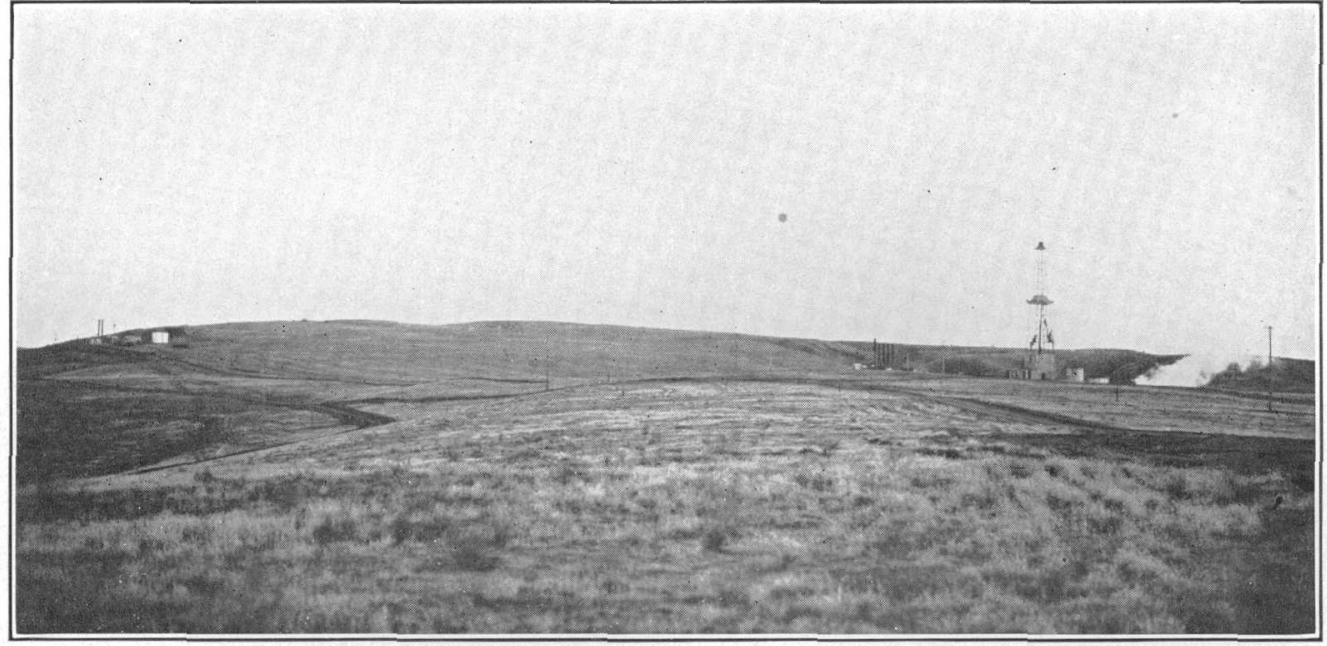

A. EROSION SURFACE VIEWED FROM THE NORTHWEST AT EL PRADO, SEC. 32, T. 21 S., R. 17 E. THE SURFACE TRUNCATES TILTED STRATA IN THE UPPER PART OF THE SAN JOAQUIN FORMATION.

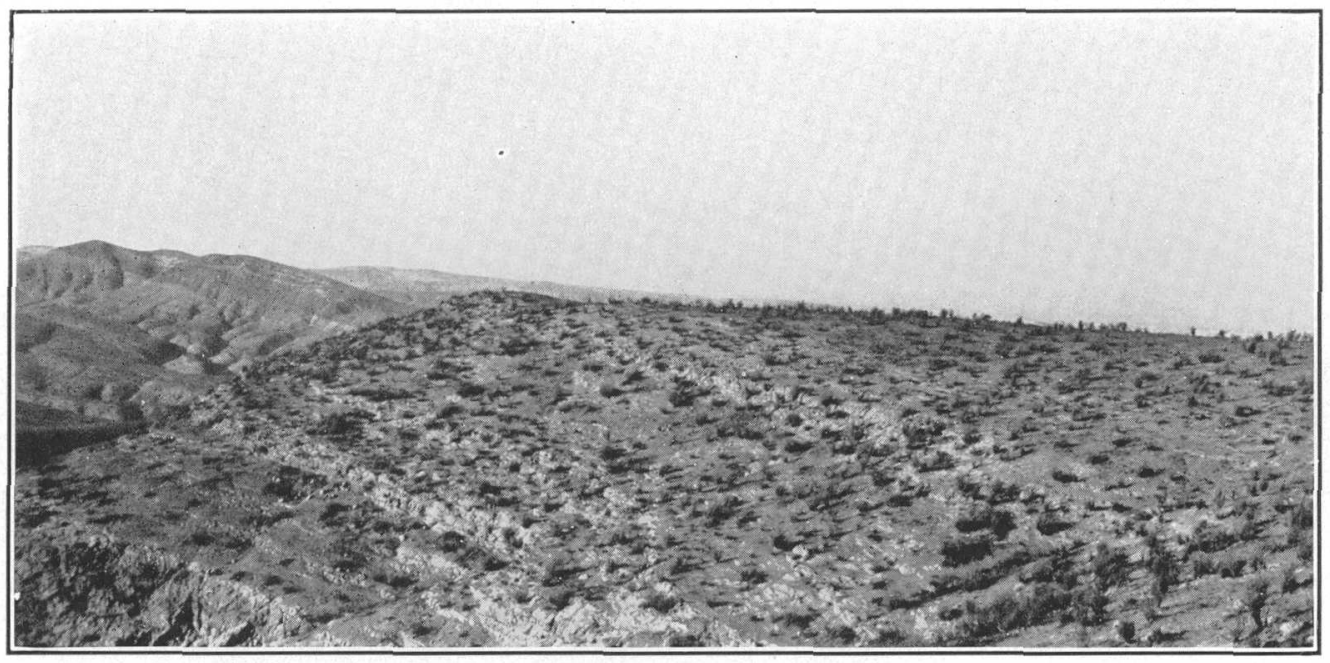

B. EROSION SURFACE VIEWED FROM THE SOUTHEAST AT LA PALOMERA, SEC. J6, T. 22 S., R. 18 E. THE SURFACE TRUNCATES TILTED STRATA IN THE LOWER PART OF THE SAN JOAQUIN FORMATION.

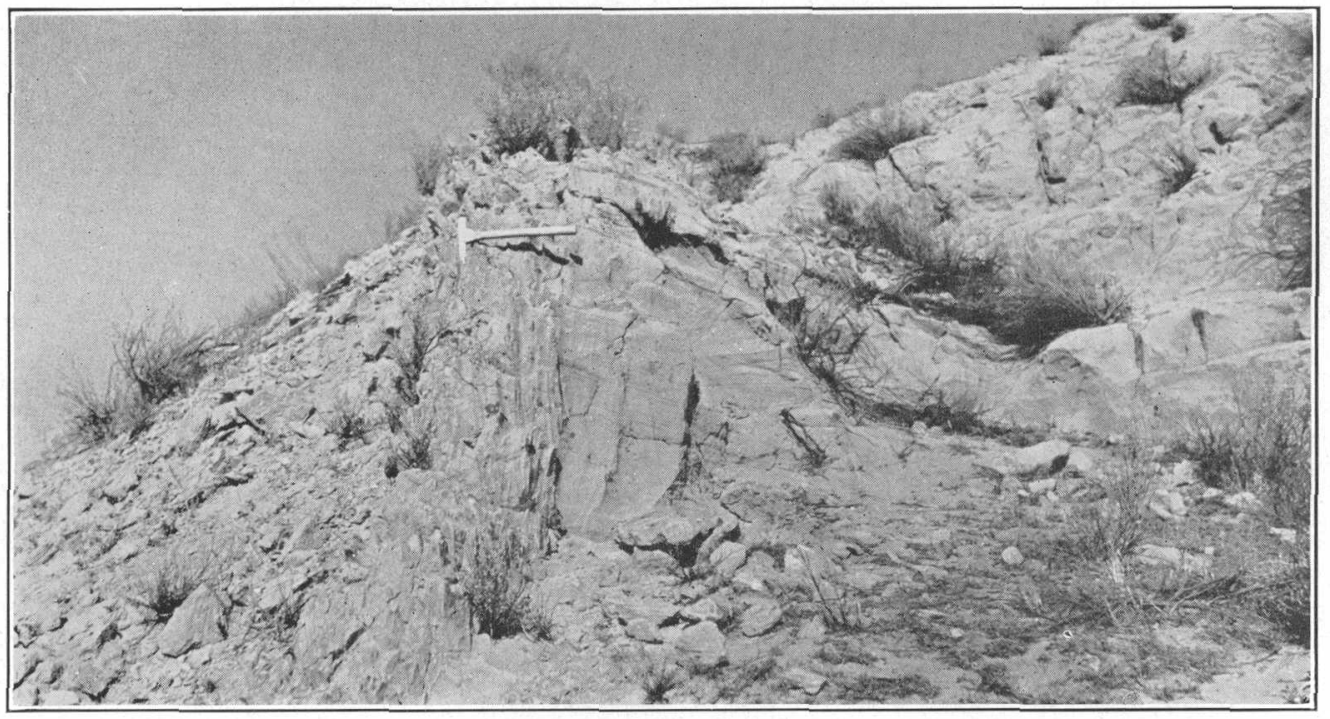

C. JOINTS PRACTICALLY PARALLEL TO FAULT PLANE (TO LEFT OF HAMMER) IN CROSS-BEDDED BLUE SANDSTONE ON NORTHWEST RIDGE OF EL TOLETE, SEC. 7, T. 22 S., R. 18 E. 


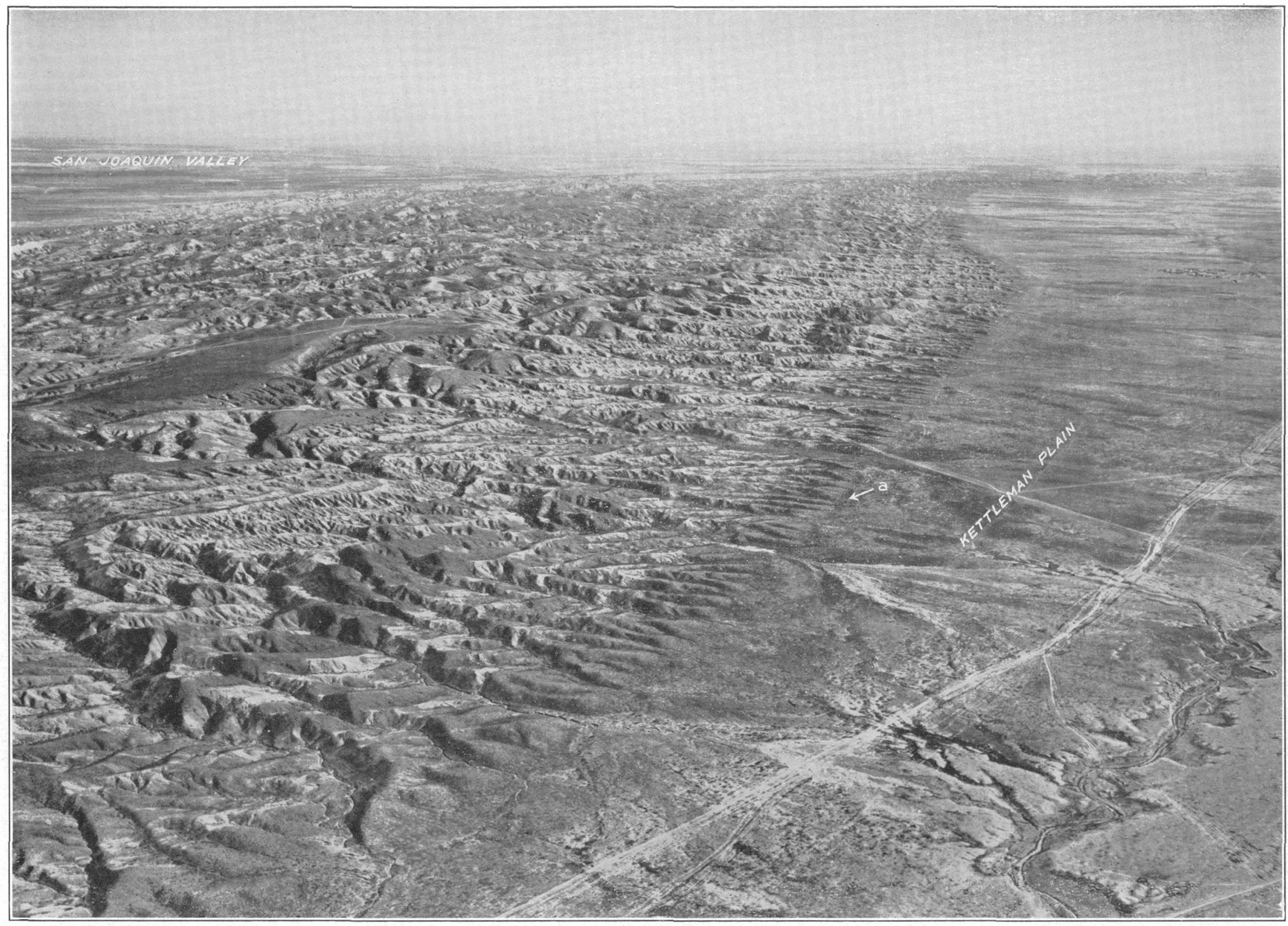

WEST FLANK OF NORTH DOME. Airplane view looking southeastward. El Prado in left center. Asymmetric tributaries and flat floors of arroyos, in which present streams lie in shallow trenches, shown in left foreground. Note straight trend of contact
(a) between tilted strata of Tulare formation and flat-lying alluvium at edge of hills. Photograph by Fairchild Aerial Surveys. 


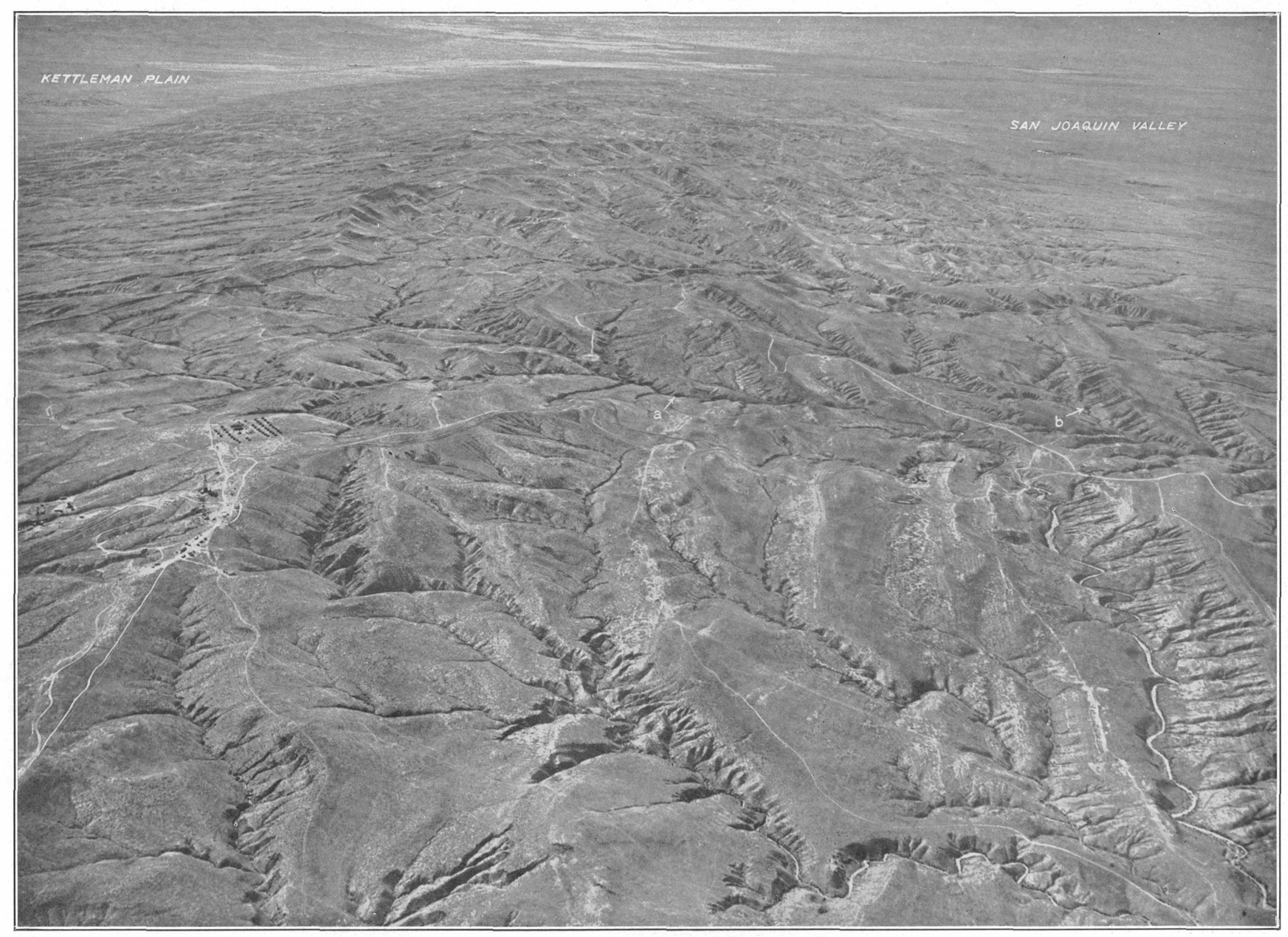

EAST FLANK OF NORTH DOME.
Airplane view looking northwestward showing rounded hilltops and steep gullied slopes adjoining streams. Gullies are more numerous on southward-facing slopes than on northward-facing slopes. Upper course of north
fork of Arrovo Robador (a) is evidently a former tributary of Arroyo Degollado (b). Photograph by Spence Air Photos. ounded hilltops and steep gullied slopes adjoining streams. Gullies are more numerous on southward-facing slopes than on
fork of Arroyo Robador (a) is evidently a former tributary of Arroyo Degollado (b). Photograph by Spence Air Photos. 


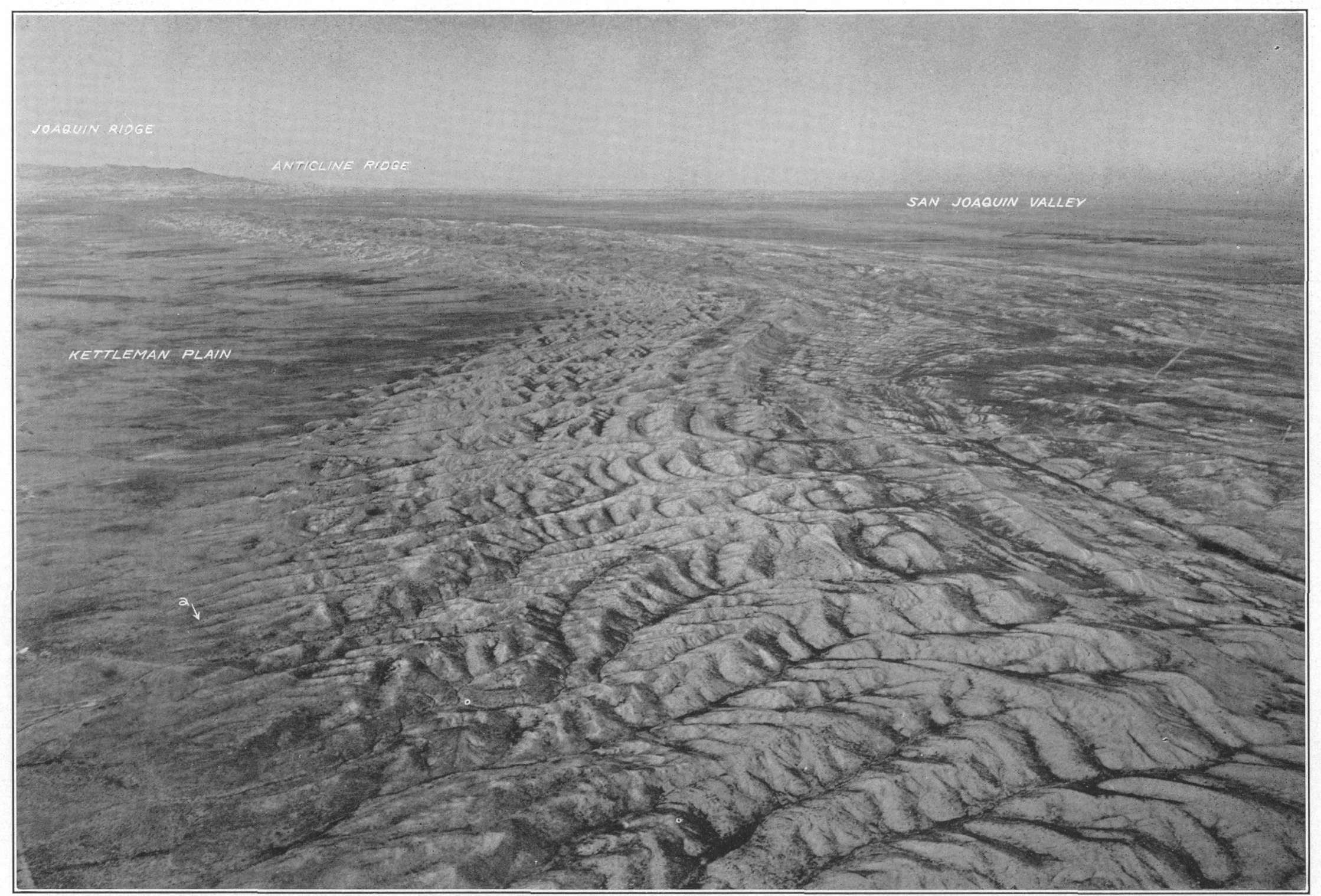

WEST FLANK OF NORTHERN MIDDLE DOME.

Airplane view looking northward. Las Alturas in center. Note irregular and indefinite contact (a) between tilted strata of Tulare formation and flat-lying alluvium at edge of hills. Photograph by Fairchild Aerial Surveys. 


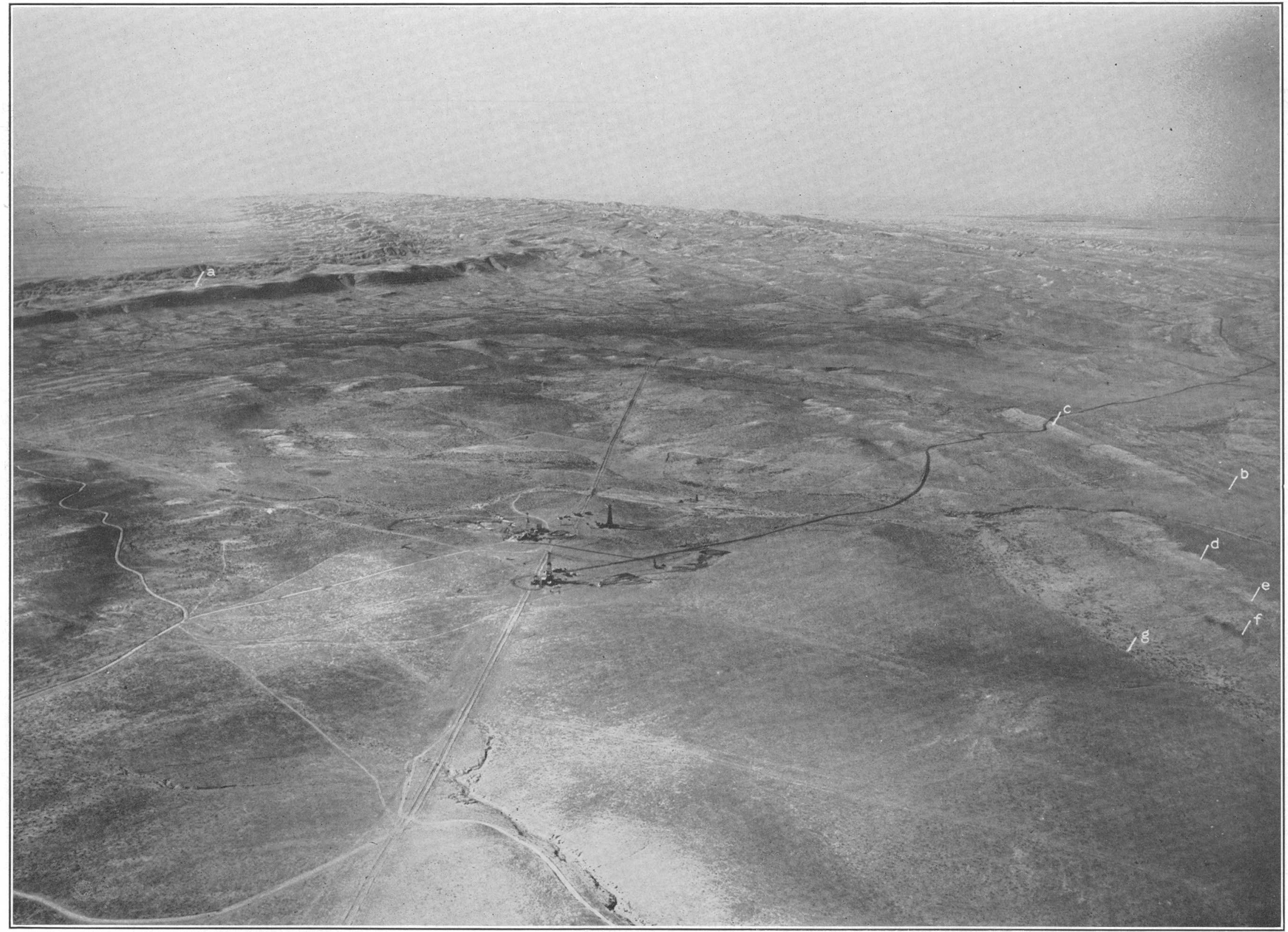

\section{NORTHERN MIDDLE DOME.}

Airplane view looking northwestward along crest. Shows southward decrease in altitude and ruggedness from North Dome (in background) and straight east front of Las Alturas (a). Photograph by Spence Air Photos. a. Las Alturas.
c. Third $M$ zone of San Joa Jaquin formation.
c. San Joaquin formation.

c. Third Mya layer of San Joaquin formation.
d. Cascajo conglomerate member at base of San Joaquin formation.

e. Cascajo conglomerate member at base of San Joaquin formation
e. Pseudium-Anadara zone of Etchegoin formation.
Pseudocardium-bearing conglomerate of Etchegoin formation.

f. Pseudocardium-bearing conglomerate of Etchegoin formation.
g. Contact between lower and upper parts of Etchegoin formation. 
southward relative to the alluvium, unless the alluvium has accumulated faster at the south end than at the north since the uplift of the hills. The alluvium has probably been deformed also, for the position of the divide in the Kettleman. Plain appears to be due to uplift.

\section{MINOR EROSIONAL FEATURES}

The lowest dissected erosion surface recognized is the most conspicuous because of the older alluvium associated with it. La Vega, in sec. 36, T. 21 S., R. 17 E., shows this surface very well. The older alluvium is located mainly on the east side of North and Middle Domes in areas underlain by the San Joaquin formation, though a few scattered patches are found higher in the hills on the Etchegoin formation.

Several areas of cobbles and boulders lie 125 to 150 feet above the floor of Avenal Gap. These gravels, which are described under the heading "Older alluvium," probably came from Reef Ridge. At least some lie at lower elevations than the probable southward projection of the erosion surface at El Prado. These gravels were presumably deposited by the predecesior of the stream flowing through Avenal Gap and may have been contemporaneous with the deposition of older alluvium on La Vega and elsewhere.

\section{PRESENT LAND FORMS}

The topography of North Dome is more rugged than that of Middle and South Domes (pls. 54-57). The entire area of the Kettleman Hills is characterized by rounded hilltops, but in most of North Dome and on the west side of Middle Dome the lower parts of the sides of the stream valleys are relatively steep (pl. 55), and locally the land is gullied, as in badland topography. The streams are all ephemeral and form alluvial fans whore they empty onto the adjoining plains. The headwaters of the streams in North Dome have relatively narrow valleys and steep sides, and they are actively degrading their courses; but the lower parts of some streams have moderately wide and flat bottoms and are depositing alluvium in their channels. In most of Middle Dome and in South Dome the valley slopes are less steep and the stream bottoms are wider than in North Dome.

The profiles of many of the valleys are asymmetrical. The north or northwest sides of such valleys (pl. 54), particularly Arroyo Recto, in sec. 30, T. 21 S., R. 17
E., are commonly less steep than the south or southeast sides. The northwest sides are more exposed to the sun and thus support less vegetation and have less soil. They accordingly are more subject to erosion and hence wear away faster than the southeast sides, and thus develop gentler slopes.

Several streams seem to have captured other streams during the development of the hills. The most noteworthy is Arroyo Robador (the robber stream), which in the northwest corner of sec. 22, T. 22 S., R. $18 \mathrm{E}$., has captured a part of Arroyo Degollado (pl. 55). The older alluvium exposed in the lower part of the course of Arroyo Degollado contains sand dollars that are not found in strata now cropping out in the present course of that stream. Such strata, however, are exposed in the headwaters of Arroyo Robador. The inference therefore follows that the original course fo Arroyo Degollado has been diverted by headward erosion of Arroyo Robador, and this inference is further borne out by the departure of Arroyo Robador from the usual stream pattern of the east flank of North Dome.

Patches of dune sand are found in a few places in the Kettleman Hills, notably at Los Medanos, in sec. 30, T. 22 S., R. 19 E.; the south side of Mesa Roida, in sec. 28 , T. 22 S., R. 18 E.; along Arroyo del Paso in sec. 7, T. 23 S., R. 19 E.; and near La Llanura, in sec. 18, T. 23 S., R. 19 E. The two small areas of depression contours on El Prado, in sec. 32, T. 21 S., R. 17 E., and at La Marmita, in sec. 15, T. 22 S., R. 18 E., may perhaps have been formed by the wind.

In the San Joaquin Valley east of the north end of North Dome are long northwestward trending ridges of sandy material. They are asymmetric, the northeast slope being the steeper. These ridges have attracted the attention of some geologists, for they ar especially conspicuous on airplane photographs, and they have been cited in nontechnical publications as evidence of recent faulting. It is suggested that they may be old dunes.

\section{FOSSIL LOCALITIES}

In the following list the fossil localities are described, and the locality numbers used in this report (see pl. 3) are correlated with the permanent Geological Survey locality numbers and the field numbers. The figures following the land-net data represent distances from the section lines to the fossil locality. 
Fossil localities

\begin{tabular}{|c|c|c|c|}
\hline $\begin{array}{l}\text { This } \\
\text { report } \\
\text { No. }\end{array}$ & $\begin{array}{l}\text { Permanent } \\
\text { Geological } \\
\text { Survey No. }\end{array}$ & Field No. & Locality data \\
\hline & & & TULARE FORMATION \\
\hline 1 & 1839 & & $\begin{array}{l}\text { North Dome, sec. } 20, \text { T. } 21 \text { S., R. } 17 \text { E.; } 980 \text { feet north, } 730 \text { feet west; on road west of Arroyo Vadoso. } \\
\text { White clay at base of formation. }\end{array}$ \\
\hline 2 & 12544 & $3 \mathrm{M}$ & $\begin{array}{l}\text { North Dome, sec. } 28, \text { T. } 21 \text { S., R. } 17 \text { E.; } 930 \text { feet south, } 770 \text { feet west; between Arroyo Vadoso and Ar- } \\
\text { royo Largo. Lower Amnicola zone. }\end{array}$ \\
\hline 3 & 12542 & $1 \mathrm{M}$ & $\begin{array}{l}\text { North Dome, sec. } 28, \text { T. } 21 \text { S., R. } 17 \text { E.; } 1,190 \text { feet south, } 600 \text { feet west; between Arroyo Vadoso and } \\
\text { Arroyo Largo. Below lower Amnicola zone. }\end{array}$ \\
\hline 4 & 13253 & $21 \mathrm{~W}$ & $\begin{array}{l}\text { North Dome, sec. 27, T. } 21 \text { S., R. } 17 \text { E.; } 2,000 \text { feet north, } 650 \text { feet west; north end of La Ceja. Below } \\
\text { lower Amnicola zone. }\end{array}$ \\
\hline 5 & $\left\{\begin{array}{r}1838 \\
11678\end{array}\right.$ & & $\begin{array}{l}\text { North Dome, sec. } 35 \text {, T. } 21 \text { S., R. } 17 \text { E.; on north section line; } 2,340 \text { feet east; prospect pit, La Ceja. } \\
\text { White clay at base of formation. }\end{array}$ \\
\hline 6 & 12478 & $3 \mathrm{~W}$ & $\begin{array}{l}\text { North Dome, sec. } 35 \text {, T. } 21 \text { S., R. } 17 \text { E.; } 370 \text { feet south, } 2,080 \text { feet west; La Ceja. Lower Amnicola } \\
\text { zone, unit 4a of section (p. 17). }\end{array}$ \\
\hline 7 & 12479 & $5 \mathrm{~W}$ & North Dome, same locality. Lower Amnicola zone, units $7 \mathrm{~d}$ and $7 \mathrm{e}$ of section (p. 17). \\
\hline 8 & 12677 & $7 \mathrm{~T}$ & $\begin{array}{l}\text { North Dome, sec. 14, I } 22 \text { S., R. } 18 \text { E.; } 430 \text { feet north, 1,200 feet east; Arroyo Degollado. Lower } \\
\text { Amnicola zone. }\end{array}$ \\
\hline 9 & & ...... & North Do...e, sec 14, T. 22 S., R. 18 E.; 2,050 feet north, 1,800 feet west; float in Arroyo Degollado. \\
\hline 10 & 12705 & $64 \mathrm{~T}$ & $\begin{array}{l}\text { North Dome, sec. } 23 \text {, T. } 22 \text { S., R. } 18 \text { E.; } 2,360 \text { feet north, } 850 \text { feet west; ridge north of Arroyo Robador. } \\
\text { Lower Amnicola zone. }\end{array}$ \\
\hline 11 & ${ }^{1} 1053$ & $156 \mathrm{~W}$ & $\begin{array}{l}\text { North Dome, sec. } 25 \text {, T. } 22 \text { S., R. } 18 \text { E.; } 1,040 \text { feet south, } 2,670 \text { feet east; south fork of Arroyo Robador } \\
\text { White clay at base of formation. }\end{array}$ \\
\hline 12 & 12702 & $40 \mathrm{~T}$ & $\begin{array}{l}\text { North Dome, sec. 8, 'T. } 23 \text { S., R. } 19 \text { E.; } 170 \text { feet south, on west section line; Los Viejos. Upper Amnicola } \\
\text { zone. }\end{array}$ \\
\hline 13 & 12703 & $59 \mathrm{~T}$ & $\begin{array}{l}\text { North Dome, sec. 8, T. } 23 \text { S., R. } 19 \text { E.; } 1,160 \text { feet south, 2,000 feet west; Los Viejos. Above upper } \\
\text { Amnicola zone. }\end{array}$ \\
\hline 14 & 13254 & $117 \mathrm{~W}$ & $\begin{array}{l}\text { Middle Dome, sec. 17, T. } 23 \text { S., R. } 19 \text { E.; 1,690 feet south, 1,870 feet east; La Salida. Lower Amnicola } \\
\text { zone, unit 1a of section (p. 19). }\end{array}$ \\
\hline 15 & 13252 & $119 \mathrm{~W}$ & Middle Dome, same locality. Lower Amnicola zone, unit 2c of section (p. 19). \\
\hline 16 & 11061 & $122 \mathrm{~W}$ & Middle Dome, same locality. Lower Amnicola zone, unit 6b of section (p. 19). \\
\hline 17 & 12683 & $26 \mathrm{M}$ & $\begin{array}{l}\text { Middle Dome, sec. } 17, \text { T. } 23 \text { S., R. } 19 \text { E.; } 1,980 \text { feet south, 1,960 feet east; La Salida. Lower Amnicola } \\
\text { zone. }\end{array}$ \\
\hline 18 & 12681 & $21 \mathrm{M}$ & $\begin{array}{l}\text { Middle Dome, sec. 20, T. } 23 \text { S., R. } 19 \text { E.; } 350 \text { feet south, 1,910 feet west; El Portillo. Lower Amnicola } \\
\text { zone. }\end{array}$ \\
\hline 19 & 12843 & $163 \mathrm{~W}$ & $\begin{array}{l}\text { Middle Dome, sec. } 28 \text {, T. } 23 \text { S., R. } 19 \text { E.; } 1,700 \text { feet north, } 410 \text { feet west; south of La Porteria. Upper } \\
\text { Amnicola zone. }\end{array}$ \\
\hline 20 & 12546 & $5 \mathrm{M}$ & $\begin{array}{l}\text { North Dome; sec. } 30, \text { T. } 21 \text { S., R. } 17 \text { E.; } 860 \text { feet south, 1,960 feet west; east of La Luneta. Lower } \\
\text { Amnicola zone. }\end{array}$ \\
\hline 21 & 12548 & $7 \mathrm{M}$ & $\begin{array}{l}\text { North Dome, sec. } 30, \text { T. } 21 \text { S., R. } 17 \text { E.; } 240 \text { feet north, } 2,210 \text { feet west; between Arroyo Recto and } \\
\text { Arroyo Corto. Lower Amnicola zone. }\end{array}$ \\
\hline 22 & 12554 & $13 \mathrm{M}$ & $\begin{array}{l}\text { North Dome, sec. } 32 \text {, T. } 21 \text { S., R. } 17 \text { E.; 1,100 feet north, 1,350 feet east; west of El Prado. Luwer } \\
\text { Amnicola zone. }\end{array}$ \\
\hline 23 & 12555 & $15 \mathrm{M}$ & $\begin{array}{l}\text { North Dome, sec. } 5 \text {, T. } 22 \text { S., R. } 17 \text { E.; } 620 \text { feet south, } 2,270 \text { feet west; branch of La Cañada Simada. } \\
\text { Lower Amnicola zone. }\end{array}$ \\
\hline 24 & 12552 & $12 \mathrm{M}$ & $\begin{array}{l}\text { North Dome, sec. } 9 \text {, T. } 22 \text { S., R. } 17 \text { E.; } 2,640 \text { feet south, on west section line; east of Arroyo Curvo. } \\
\text { Lower Amnicola zone. }\end{array}$ \\
\hline 25 & 12556 & $16 \mathrm{M}$ & $\begin{array}{l}\text { North Dome, sec. } 14 \text {, T. } 22 \text { S., R. } 17 \text { E.; } 100 \text { feet north, } 2,350 \text { feet west; west of Arroyo Chico. Lower } \\
\text { Amnicola zone. }\end{array}$ \\
\hline 26 & 12689 & $36 \mathrm{M}$ & $\begin{array}{l}\text { North Dome, sec. } 33, \text { T. } 22 \text { S., R. } 18 \text { E.; } 1,600 \text { feet north, } 2,280 \text { feet east; between Arroyo Delgado and } \\
\text { Arroyo Raso. Below lower Amnicola zone. }\end{array}$ \\
\hline 27 & 12674 & $21 \mathrm{~T}$ & $\begin{array}{l}\text { North Dome, sec. } 33 \text {, T. } 22 \text { S., R. } 18 \text { E.; } 1,270 \text { feet north, } 2,460 \text { feet east; between Arroyo Delgado } \\
\text { and Arroyo Raso. Below lower Amnicola zone. }\end{array}$ \\
\hline 28 & 12704 & $60 \mathrm{~T}$ & $\begin{array}{l}\text { North Dome, sec. } 3 \text {, T. } 23 \text { S., R. } 18 \text { E.; } 2,400 \text { feet north, } 1,250 \text { feet east; between Arroyo Raso and } \\
\text { Arroyo Escaso. Upper Amnicola zone. }\end{array}$ \\
\hline & & & $\begin{array}{l}\text { SAN JOAQUIN FORMATION } \\
\text { Upper Mya zone }\end{array}$ \\
\hline 29 & & $2 \mathrm{~W}$ & North Dome, sec. 35, T. 21 S., R. 17 E.; 320 feet \\
\hline 30 & & $36 \mathrm{~T}$ & \\
\hline 31 & 12480 & $6 \mathrm{~W}$ & North Dome, sec. 35, T. 21 S., R. 17 E.; 630 feet south, 1,630 feet west; La Ceja. \\
\hline 32 & 12325 & $3 \mathrm{~S}$ & North Dome, sec. 35, T. 21 S., R. 17 E.; 1,370 feet south, 380 feet west; Arroyo Bifido. \\
\hline 33 & 12326 & $4 \mathrm{~S}$ & North Dome, sec. 36, T. 21 S., R. 17 E.; 1,840 feet south, 150 feet east; south end of La Ce \\
\hline
\end{tabular}


Fossil localities-Continued

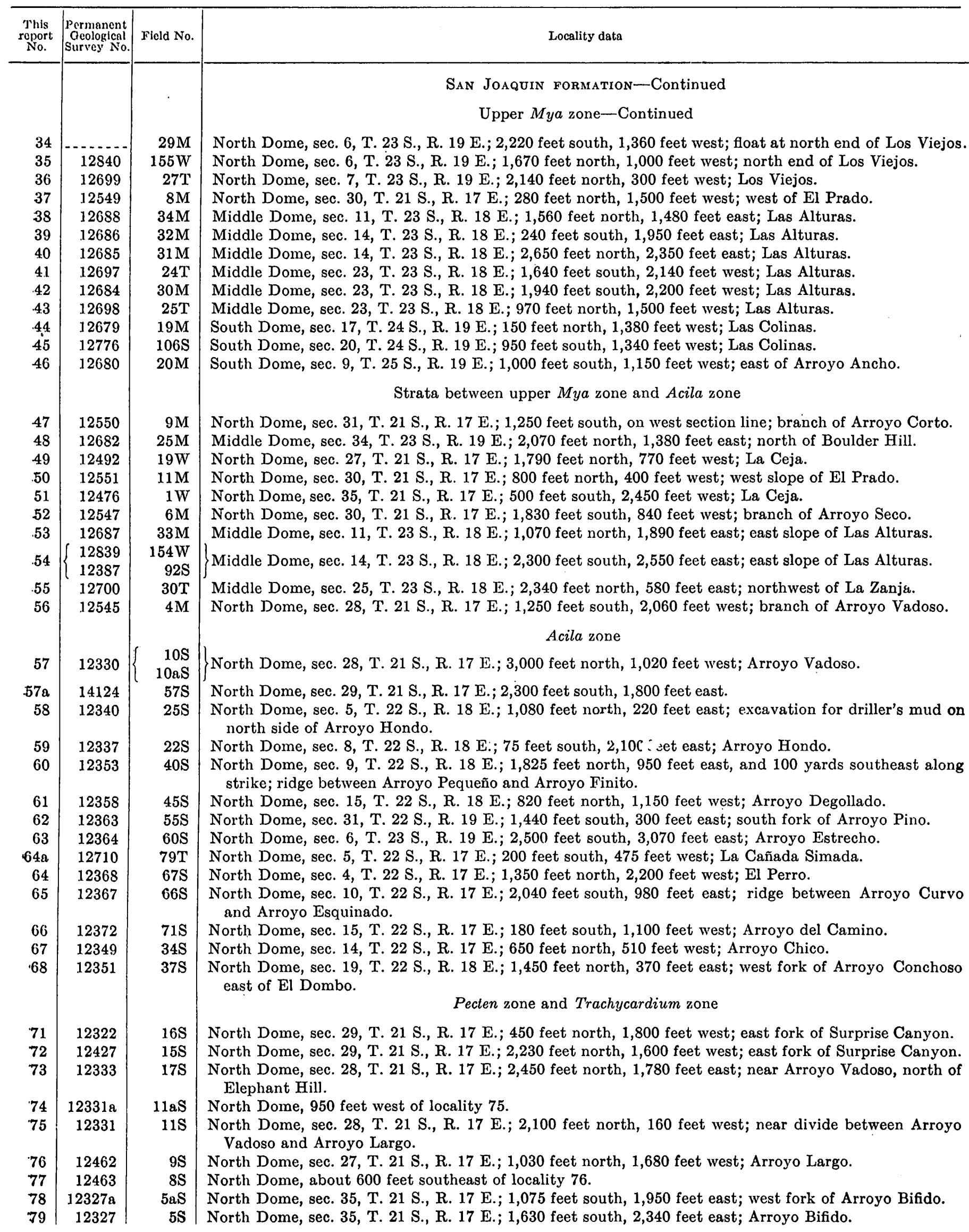


Fossil localities-Continued

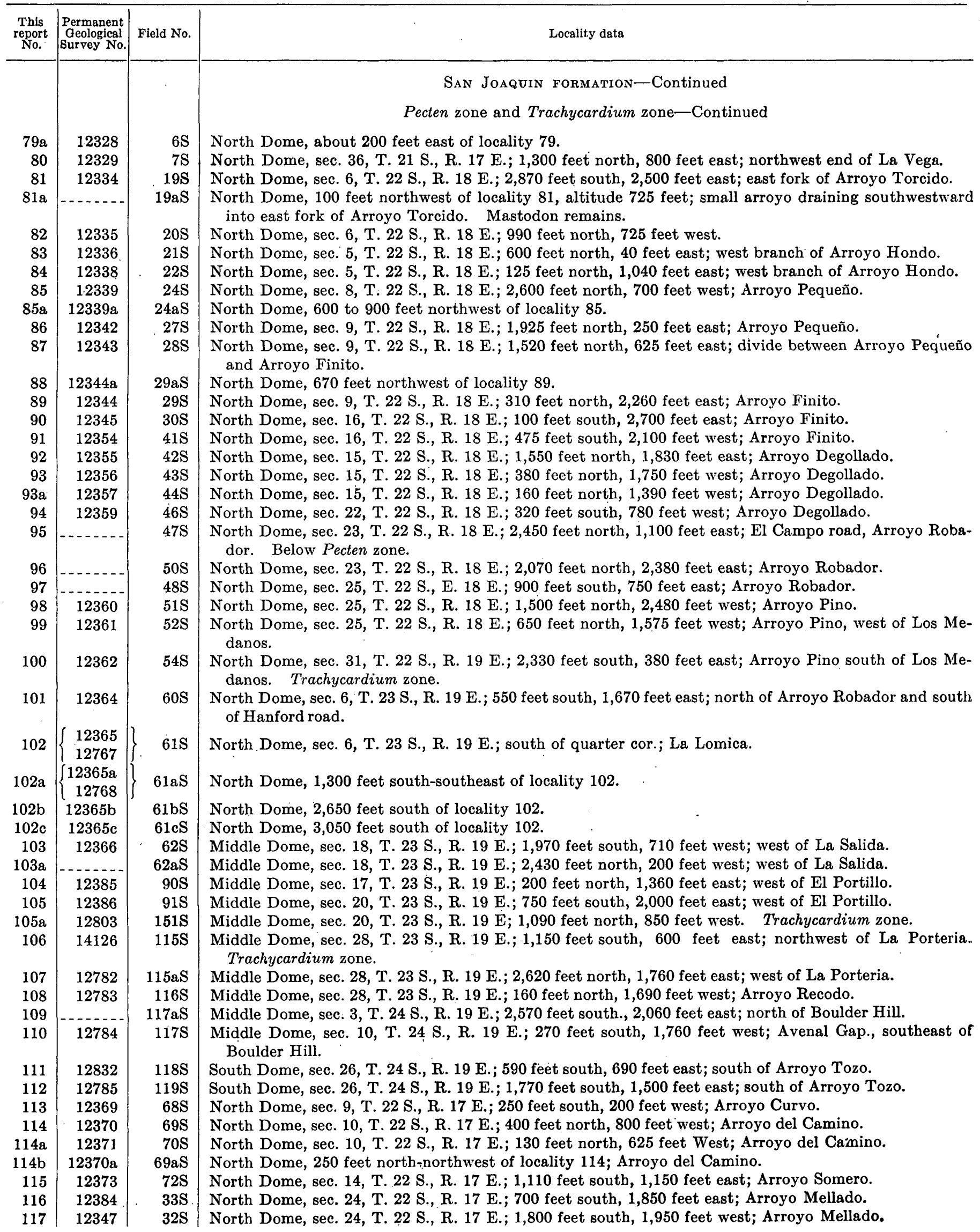


Fossil localities-Continued

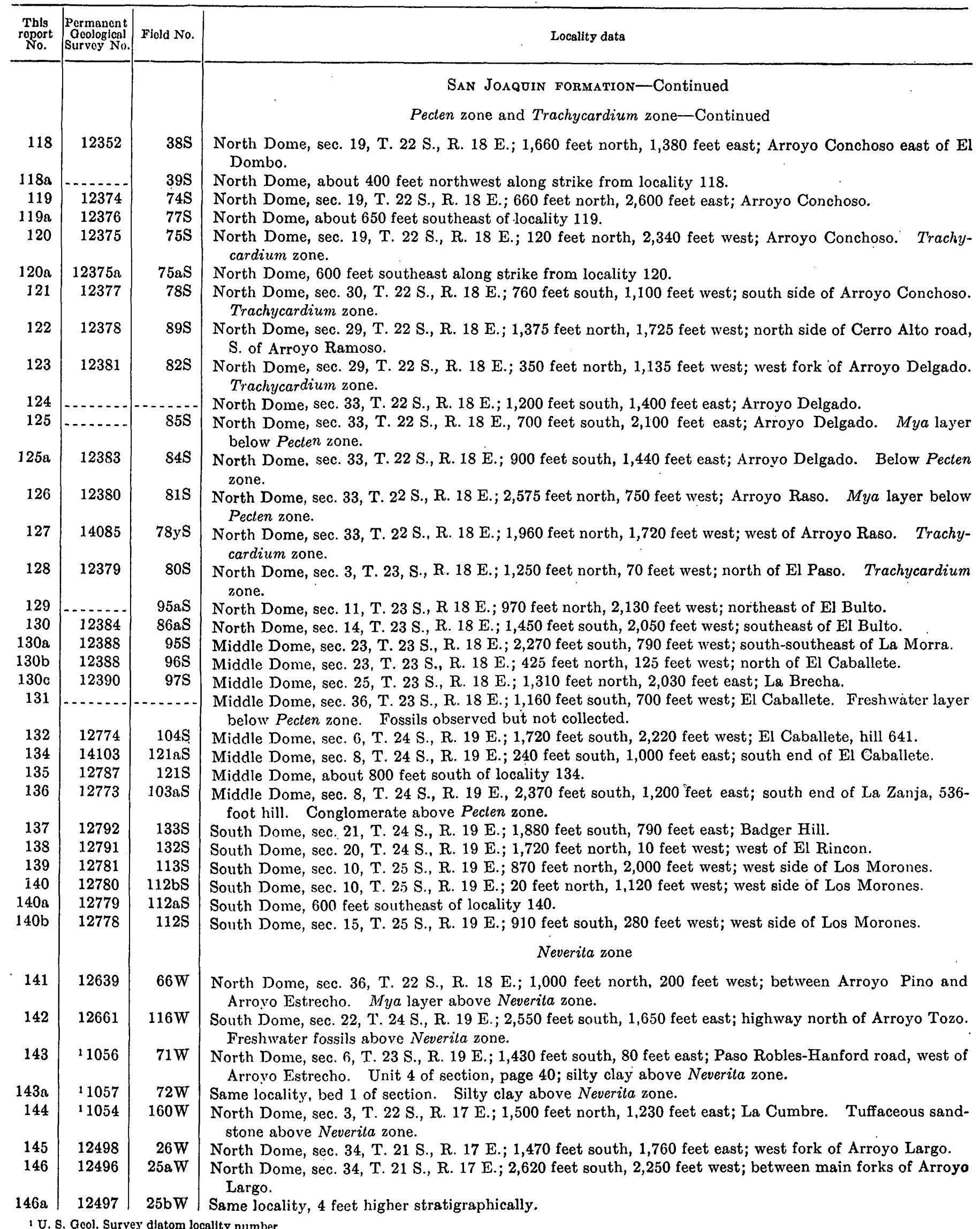


Fossil localities-Continued

\begin{tabular}{|c|c|c|c|}
\hline $\begin{array}{l}\text { This } \\
\text { report } \\
\text { No. }\end{array}$ & $\begin{array}{c}\text { Permanent } \\
\text { Ceological } \\
\text { Survey No. }\end{array}$ & Field No. & Locality data \\
\hline & & & $\begin{array}{l}\text { San Joaquin Formation-Continued } \\
\text { Neverita zone-Continued }\end{array}$ \\
\hline 147 & 12495 & $24 \mathrm{~W}$ & North Dome, sec. 35, T. 21 S., R. 17 E.; 2,530 feet north, 300 feet east; east of Arroyo Large. \\
\hline 148 & 12493 & $22 \mathrm{aW}$ & North Dome, sec. 35, T. 21 S., R. 17 E.; 1,620 feet north, 2,600 feet west; Arroyo Bifido. \\
\hline 150 & 12512 & $43 \mathrm{~W}$ & North Dome, sec. 1, T. 22 S., R. 17 E.; 860 feet south, 1,570 feet east; Arroyo Torcido. \\
\hline 151 & 12511 & $42 \mathrm{~W}$ & North Dome, sec. 1, T. 22 S., R. 17 E.; 1,270 feet south, 2,480 feet west; Arroyo Torcido. \\
\hline 152 & 12510 & $41 \mathrm{~W}$ & North Dome, sec. 6, T. 22 S., R. 18 E., 270 feet north, 2,500 feet east; ridge of Arroyo Murado. \\
\hline 153 & 12509 & $40 \mathrm{~W}$ & North Dome, sec. 7, T. 22 S., R. 18 E.; 170 feet south, 1,470 feet west; east fork of Arroyo Torcido. \\
\hline 154 & 12508 & $39 \mathrm{~W}$ & North Dome, sec. 7, T. 22 S., R. 18 E.; 250 feet south, 1,340 feet west; east fork of Arroyo Torcido. \\
\hline 155 & 12513 & $44 \mathrm{~W}$ & $\begin{array}{l}\text { North Dome, sec. } 7 \text {, T. } 22 \text { S., R. } 18 \text { E.; } 750 \text { feet south, } 950 \text { feet west; between east fork of Arroyo Tor- } \\
\text { cido and west fork of Arroyo Hondo. }\end{array}$ \\
\hline 159 & 12636 & $59 \mathrm{~W}$ & North Dome, sec. 16, T. 22 S., R. 18 E.; 1,030 feet south, 1,100 feet east; branch of Arroyo Doblegado. \\
\hline 160 & 12637 & $60 \mathrm{~W}$ & North Dome, sec. 16, T. 22 S., R. 18 E.; 1,270 feet south, 1,580 feet east; branch of Arroyo Doblegado \\
\hline 161 & 12635 & $58 \mathrm{~W}$ & North Dome, sec. 16, T. 22 S., R. 18 E.; 2,250 feet north, 1,120 feet west; south of Arroyo Doblegado. \\
\hline 162 & 12638 & $62 \mathrm{~W}$ & North Dome, sec. 22, T. 22 S., R. 18 E.; 1,600 feet south, 2,170 feet west; branch of Arroyo Robador. \\
\hline 163 & 12499 & $27 \mathrm{~W}$ & North Dome, sec. 33, T. 21 S., R. 17 E.; 670 feet north, 270 feet west; butte east of Lower Road. \\
\hline $163 a$ & 12500 & $27 \mathrm{aW}$ & Same locality, from overlying sand. \\
\hline 164 & 12520 & $51 \mathrm{~W}$ & North Dome, sec. 24, T. 22 S., R. 17 E.; 50 feet south, 1,200 feet west; branch of Arroyo Mellado. \\
\hline $164 \mathrm{a}$ & 12521 & $51 \mathrm{aW}$ & Same locality, 15 feet lower stratigraphically. \\
\hline 165 & 12519 & $50 \mathrm{~W}$ & North Dome, sec. 24, T. 22 S., R. 17 E.; 100 feet south, 1,350 feet west; branch of Arroyo Mellado. \\
\hline 166 & $--\ldots . .$. & $162 \mathrm{~W}$ & $\begin{array}{l}\text { North Dome, sec. 2, T. } 23 \text { S., R. } 18 \text { E.; } 1,660 \text { feet south, } 750 \text { feet east; between Paso Robles-Hanford road: } \\
\text { and Arroyo del Paso. }\end{array}$ \\
\hline 167 & & $152 \mathrm{~W}$ & Middle Dome, sec. 28, T. 23 S., R. 19 E.; 500 feet north, 1,630 feet east; north of Arroyo Recodo. \\
\hline 168 & 11051 & $146 \mathrm{~W}$ & Middle Dome, sec. 33, T. 23, S., R. 19 E.; 1,680 feet south, 2,130 feet west; south of Arroyo Recodo. \\
\hline 175 & 12841 & $157 \mathrm{~W}$ & $\begin{array}{l}\text { North Dome, sec. } 22 \text {, T. } 22 \text { S., R. } 18 \text { E.; } 2,530 \text { feet south, } 1,430 \text { feet west; between forks of Arroyo Robador } \\
\text { north of El Campo. Upper oolite. }\end{array}$ \\
\hline 176 & 13259 & $131 \mathrm{~W}$ & $\begin{array}{l}\text { Middle Dome, sec. } 33 \text {, T. } 23 \text { S., R. } 19 \text { E.; } 2,400 \text { feet north, } 1,700 \text { feet west; south of Arroyo Recodo. } \\
\text { Upper oolite. }\end{array}$ \\
\hline 177 & 12842 & $161 \mathrm{~W}$ & $\begin{array}{l}\text { North Dome, sec. } 7, \text { T. } 22 \text { S., R. } 18 \mathrm{E} . ; 1,520 \text { feet south, } 200 \text { feet west; north fork of Arroyo Hondo. Cerasto- } \\
\text { derma-bearing sandstone. }\end{array}$ \\
\hline \multirow[t]{2}{*}{178} & 12706 & $70 \mathrm{~T}$ & $\begin{array}{l}\text { North Dome, sec. } 16 \text {, T. } 22 \text { S., R. } 18 \text { E.; } 2,730 \text { feet north, } 1,750 \text { feet west; branch of Arroyo Doblegado. } \\
\text { Cerastoderma-bearing sandstone. }\end{array}$ \\
\hline & & & Cascajo conglomerate member and immediately overlying and underlying strata \\
\hline 183 & 14087 & $590 \mathrm{~S}$ & North Dome, sec. 34, T. 22 S., R. 18 E.; 280 feet south, 20 feet east; south slope of Cerro Ultimo. \\
\hline 184 & & $591 \mathrm{~S}$ & $\begin{array}{l}\text { North Dome, sec. } 28, \text { T. } 22 \text { S., R. } 18 \text { E.; } 1,540 \text { feet north; } 2,200 \text { feet west; Arroyo Delgado, northwest of } \\
\text { Cerro Ultimo. Just below blue conglomerate assigned to Cascajo. }\end{array}$ \\
\hline 185 & 14088 & $818 \mathrm{~S}$ & $\begin{array}{l}\text { North Dome, sec. } 28 \text {, T. } 22 \text { S., R. } 18 \text { E.; } 2,080 \text { feet south, 1,260 feet east; Arroyo Delgado on south side } \\
\text { of Cerro Alto. }\end{array}$ \\
\hline 186 & $6-1$ & 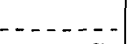 & North Dome, sec. 20, T. 22 S., R. 18 E.; 760 feet north, 60 feet west; El Lobo. \\
\hline 189 & 14089 & $575 \mathrm{~S}$ & $\begin{array}{l}\text { North Dome, sec. } 19, \text { T. } 22 \text { S., R. } 18 \text { F.; } 100 \text { feet south, } 1,880 \text { feet east; near head of west fork of Arroyo } \\
\text { Conchoso. A foot above first Mya layer. }\end{array}$ \\
\hline $189 a$ & ${ }^{\circ} 14090$ & $576 \mathrm{~S}$ & $\begin{array}{l}\text { North Dome, sec. } 18 \text {, T. } 22 \text { S., R. } 18 \text { E.; } 1,440 \text { feet north, } 270 \text { feet east; ridge southeast of Los Jinetes. } \\
\text { Between Cascajo conglomerate and first } M y a \text { layer. }\end{array}$ \\
\hline
\end{tabular}


Fossil localities-Continued

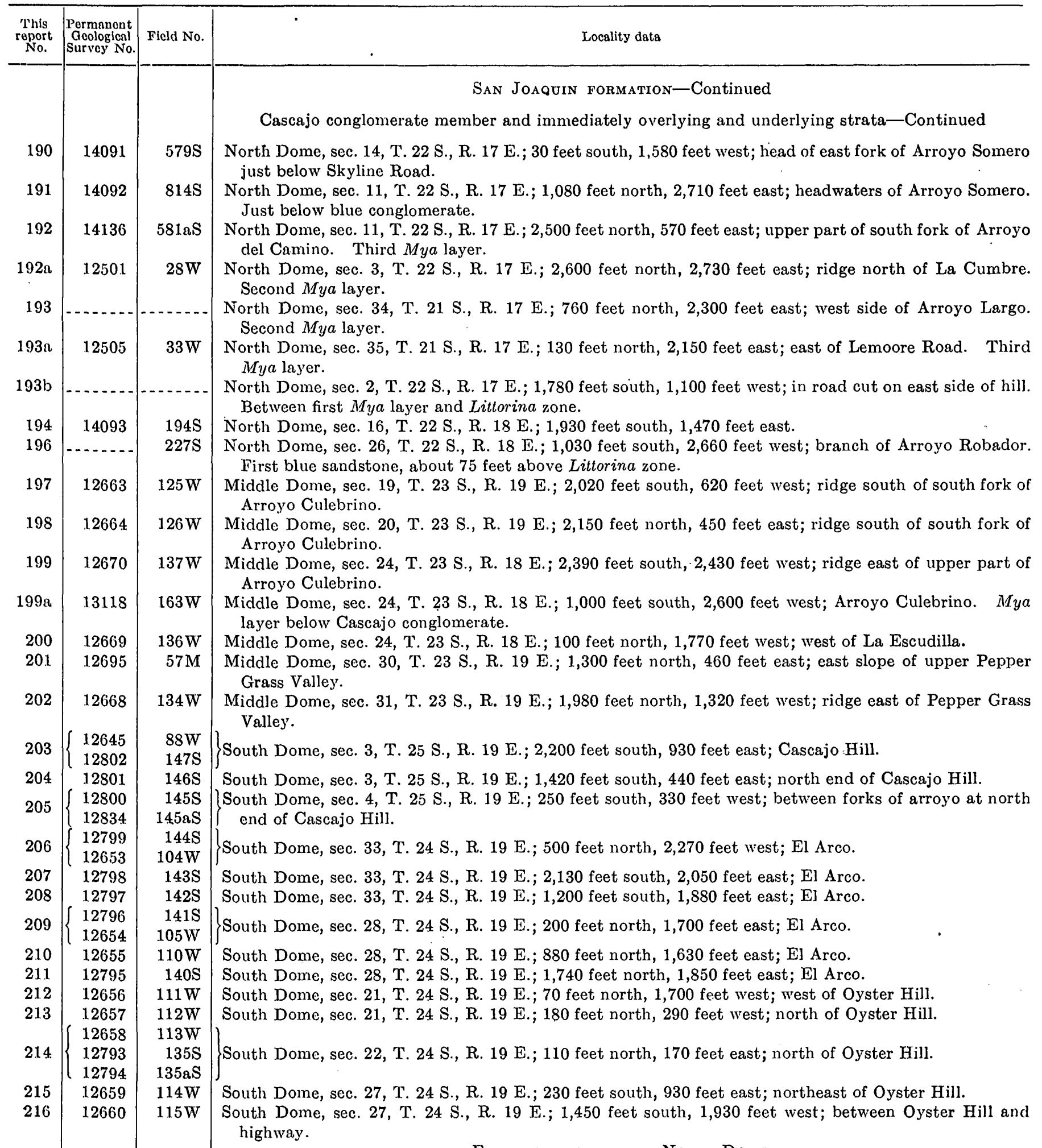

Etchegoin formation, North Dome

Littorina zone

$200 \mathrm{~S}$ $53 \mathrm{~W}$ $203 \mathrm{aS}$ $205 \mathrm{~S}$
Sec. 19, T. 22 S., R. 18 E.; 1,250 feet south, 320 feet west; El Piso on west wide of La Cima. Sec. 18, T. 22 S., R. 17 E.; 600 feet north, 940 feet east; branch of Arroyo Conchoso.

Sec. 13, T. 22 S., R. 17 E.; 2,050 feet north, 1,200 feet west; Arroyo Mellado, south of Los Jinetes. Sec. 13, T. 22 S., R. 17 E.; 2,200 feet south, 2,400 feet east; west fork of Arroyo Mellado, west of Los Jinetes. 
Fossil localities-Continued

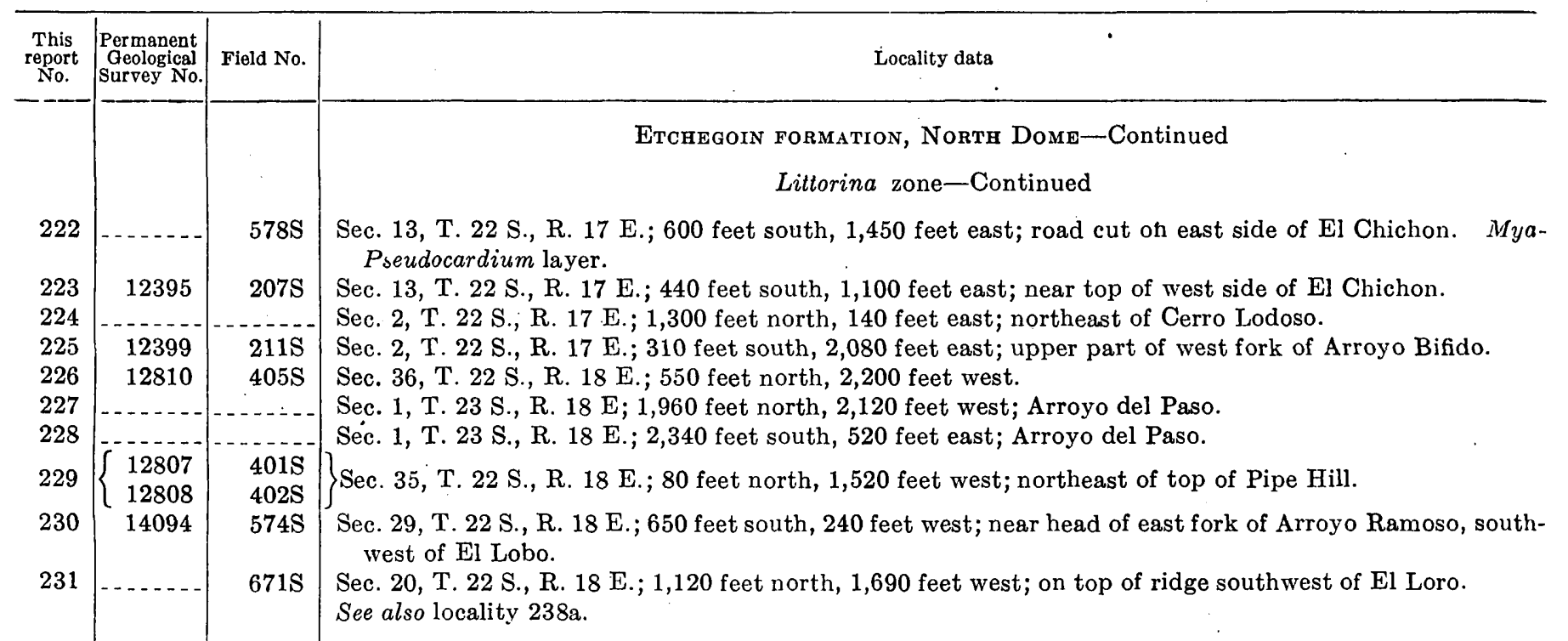

Upper Pseudocardium zone (upper Mulinia zone)

\begin{tabular}{|c|c|c|}
\hline 237 & 14095 & $669 \mathrm{~S}$ \\
\hline 238 & 14096 & $671 \mathrm{eS}$ \\
\hline $238 a$ & $14096 a$ & 671eaS \\
\hline $238 \mathrm{~b}$ & $14096 b$ & 671es \\
\hline 239 & 14097 & $370 \mathrm{~S}$ \\
\hline $239 a$ & 12524 & $54 \mathrm{~W}$ \\
\hline $239 b$ & 12414 & $250 \mathrm{~S}$ \\
\hline 240 & 12522 & $52 \mathrm{~W}$ \\
\hline 241 & 14098 & $551 \mathrm{aS}$ \\
\hline 242 & 14099 & -- \\
\hline 243 & 12517 & $48 \mathrm{~W}$ \\
\hline $243 a$ & 12518 & $49 W$ \\
\hline 244 & 14127 & $521 \mathrm{~S}$ \\
\hline 245 & 14102 & $522 \mathrm{~S}$ \\
\hline 247 & 12398 & $210 \mathrm{~S}$ \\
\hline 248 & 12504 & $32 \mathrm{~W}$ \\
\hline 249 & 14100 & $561 S$ \\
\hline 250 & 12400 & 214S \\
\hline 251 & 12401 & $215 \mathrm{~S}$ \\
\hline 252 & 12405 & $222 \mathrm{~S}$ \\
\hline $252 \mathrm{a}$ & 12460 & $223 \mathrm{~S}$ \\
\hline 253 & 12406 & $224 \mathrm{~S}$ \\
\hline 255 & 14101 & $560 \mathrm{~S}$ \\
\hline 256 & 12804 & $\begin{array}{l}268 \mathrm{bS} \\
216 \mathrm{bS}\end{array}$ \\
\hline 257 & & 219S \\
\hline $257 a$ & & \\
\hline 258 & 12404 & $220 \mathrm{~S}$ \\
\hline 259 & & \\
\hline 260 & & $220 a$ \\
\hline 261 & 12820 & 456S \\
\hline 262 & & $266 \mathrm{~S}$ \\
\hline $262 a$ & & \\
\hline
\end{tabular}

Sec. 20, T. 22 S., R. 18 E.; 1,260 feet north, 1,240 feet west; south side of E1 Loro.

Sec. 20, T. 22 S., R. 18 E.; 2,390 feet north, 2,680 feet east; east side of El Leon.

60 feet stratigraphically above locality 238 . Littorina zone.

120 feet stratigraphically below locality 238. Siphonalia zone; fine-grained gray sand 6 feet thick.

Sec. 18, T. 22 S., R. 18 E.; 1,250 feet north, 600 feet east; upper part of west fork of Arroyo Conchoso. Sec. 18, T. 22 S., R. 18 E.; 100 feet west of locality 239.

Sec. 19, T. 22 S., R. 18 E.; 480 feet south, 330 feet west; west slope of ridge north of La Cima.

Sec. 13, T. 22 S., R. 17 E.; 830 feet south, 2,060 feet east; south side of Skyline Road.

Sec. 11, T. 22 S., R. 17 E.; 1,560 feet north, 2,050 feet west; headwaters of south fork of Arroyo Torcido.

Sec. 11, T. 22 S., R. 17 E.; 840 feet south, 2,450 feet east; between forks of Arroyo Torcido.

Sec. 2, T. 22 S., R. 17 E.; 1,160 feet north, 400 feet east; northeast of Cerro Lodoso.

430 feet south, 100 feet west of locality 243 .

Sec. 3, T. 22 S., R. 17 E.; 1,910 feet south, 860 feet west; upper part of Arroyo Largo.

Sec. 3, T. 22 S., R. 17 E.; 1,560 feet south, 630 feet west; upper part of Arroyo Largo.

Sec. 3, T. 22 S., R. 17 E.; 530 feet south, 1,560 feet west; Arroyo Largo, northeast of La Cumbre.

Sec. 2, T. 22 S., R. 17 E.; 1,400 feet south, 940 feet east; Arroyo Largo.

Sec. 2, T. 22 S., R. 17 E.; 1,880 feet south, 2,260 feet east; west of Double Hill.

Sec. 2, T. 22 S., R. 17 E.; 2,060 feet south, 1,050 feet west; north branch of Arroyo Torcido, east of Double Hill. The main fossiliferous ledge contains chiefly single valves of Pseudocardium and worn valves of Cerastoderma. These species are also present in underlying sand, which contains double-valved specimens of Lucinoma.

Sec. 1, T. 22 S., R. 17 E.; 2,200 feet north, 2,340 feet west; north of El Taco.

Sec. 8, T. 22 S., R. 18 E.; 2,100 feet north, 600 feet east; Arroyo Hondo east of La Cuesta.

Sec. 8, T. 22 S., R. 18 E.; 830 feet north, 1,740 feet east; ridge on southeast side of El Perno.

Sec. 16, T. 22 S., R. 18 E.; 2,240 feet south, 870 feet east; north branch of Arroyo Doblegado, southeast of El Rascador. About 60 feet below Littorina zone.

\section{Siphonalia zone}

Sec. 2. T. 22 S., R. 17 E.; 2,420 feet south, 1,710 feet east; southwest of Double Hill. About 15 feet below blue conglomerate.

Sec. 2, T. 22 S., R. 17 E.; 2,200 feet north, 2,320 feet east; south of Double Hill.

Sec. 2, T. 22 S., R. 17 E.; 2,120 feet north, 2,170 feet east; second ridge southwest of Double Hill. About 60 feet below Mytilus layer.

Sec. 2, T. 22 S., R. 17 E.; 1,620 feet north, 1,030 feet east; Arroyo Torcido east of Cerro Lodoso.

Sec. 2, T. 22 S., R. 17 E.; 1,370 feet north, 1,770 feet east; Arroyo Torcido, second ridge southwest of Double Hill.

Sec. 2, T. 22 S., R. 17 E.; 660 feet north, 1,970 feet east; east of Cerro Lodoso.

Sec. 2, T. 22 S., R. 17 E.; 2,440 feet north, 1,300 feet east; Arroyo Torcido basin, northeast of Cerro Lodoso.

Sec. 1, T. 22 S., R. 17 E.; 780 feet north, 1,830 feet east; first ridge west of El Taco. Macoma zone (?). Sec. 1, T. 22 S., R. 17 E.; 970 feet north, 2,560 feet west; north slope of El Taco.

700 feet southeast of locality 262, southeast side of EI Taco. About 100 feet below blue conglomerate. 
Fossil localities-Continued

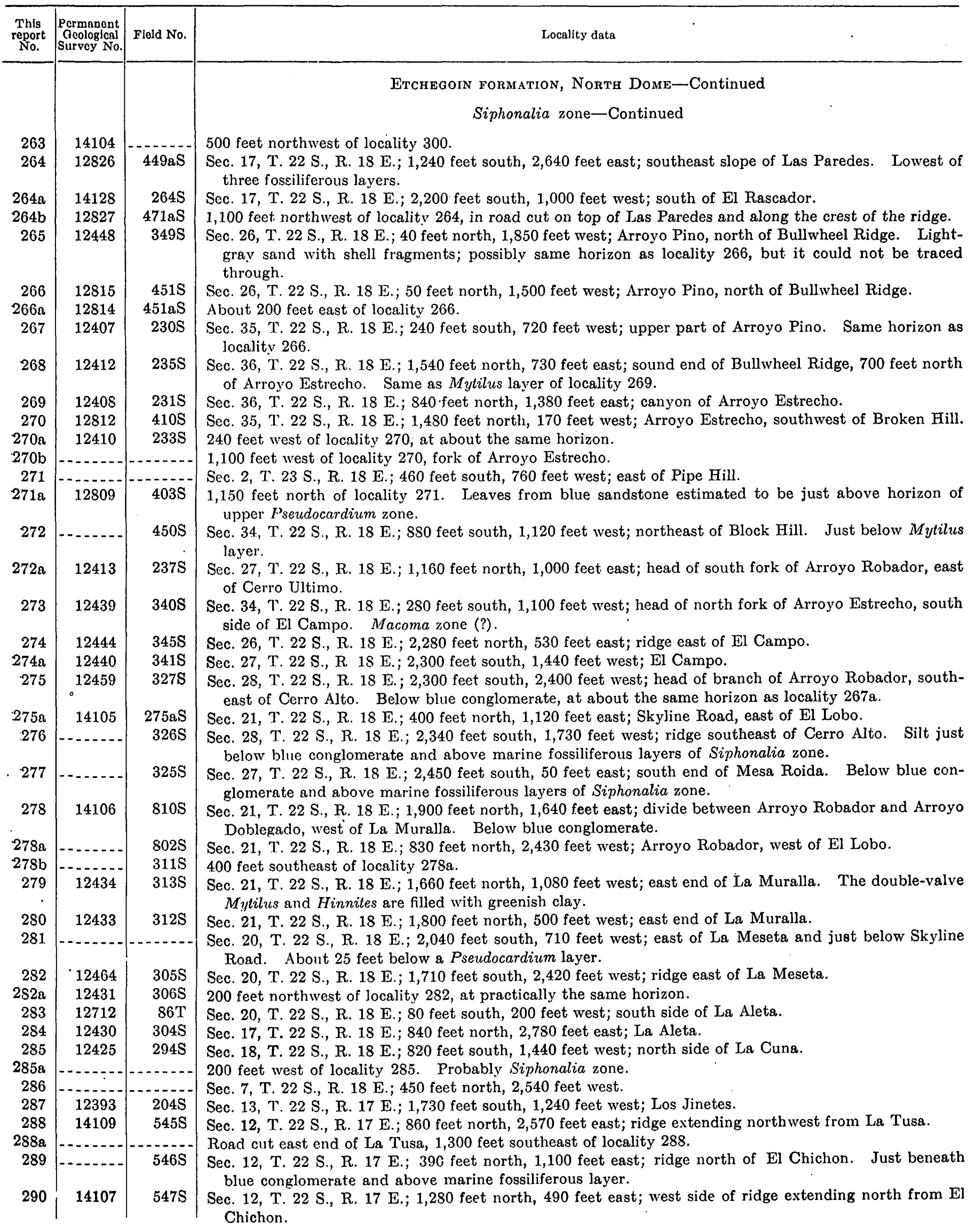


Fossil localities-Continued

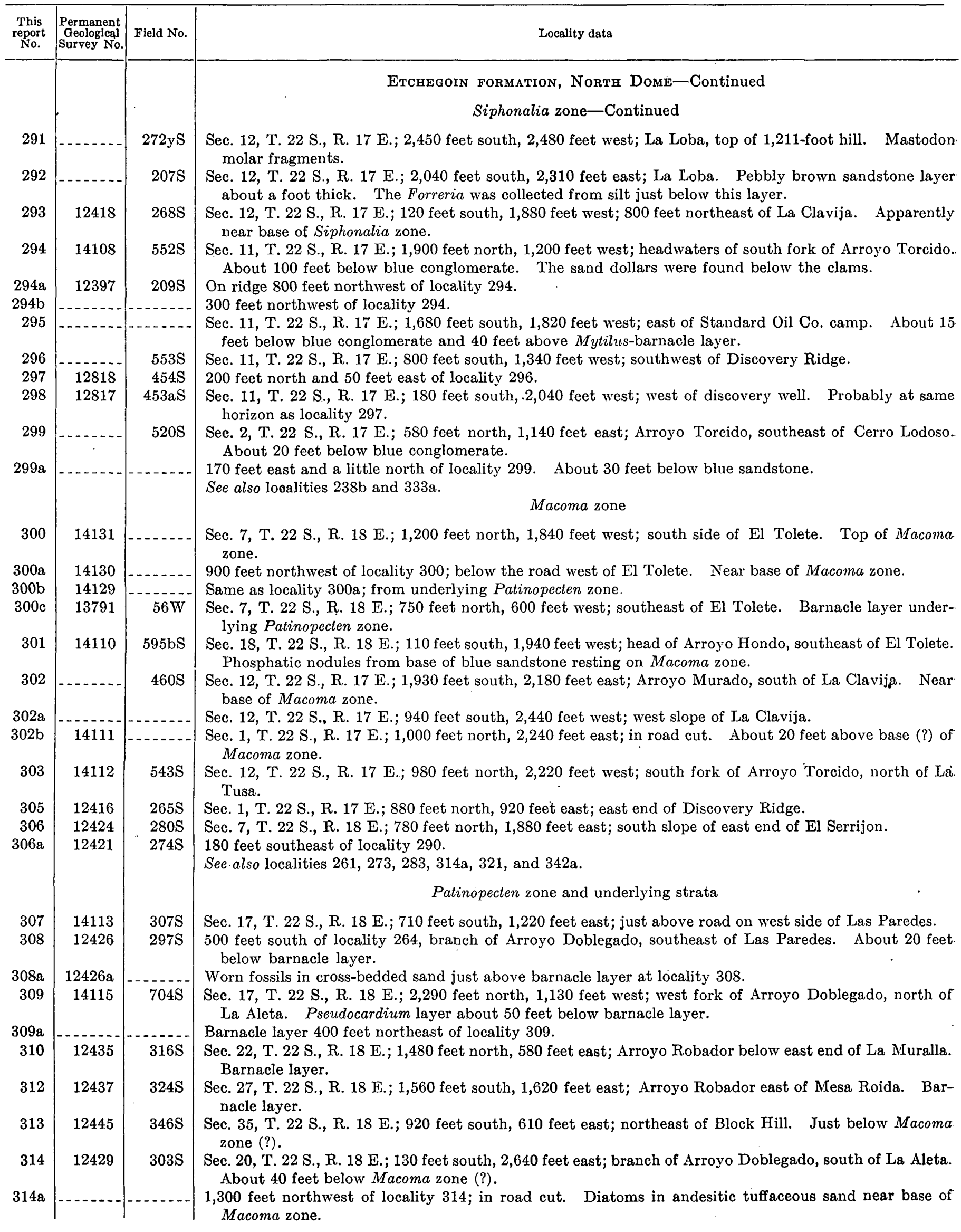


Fossil localities-Continued

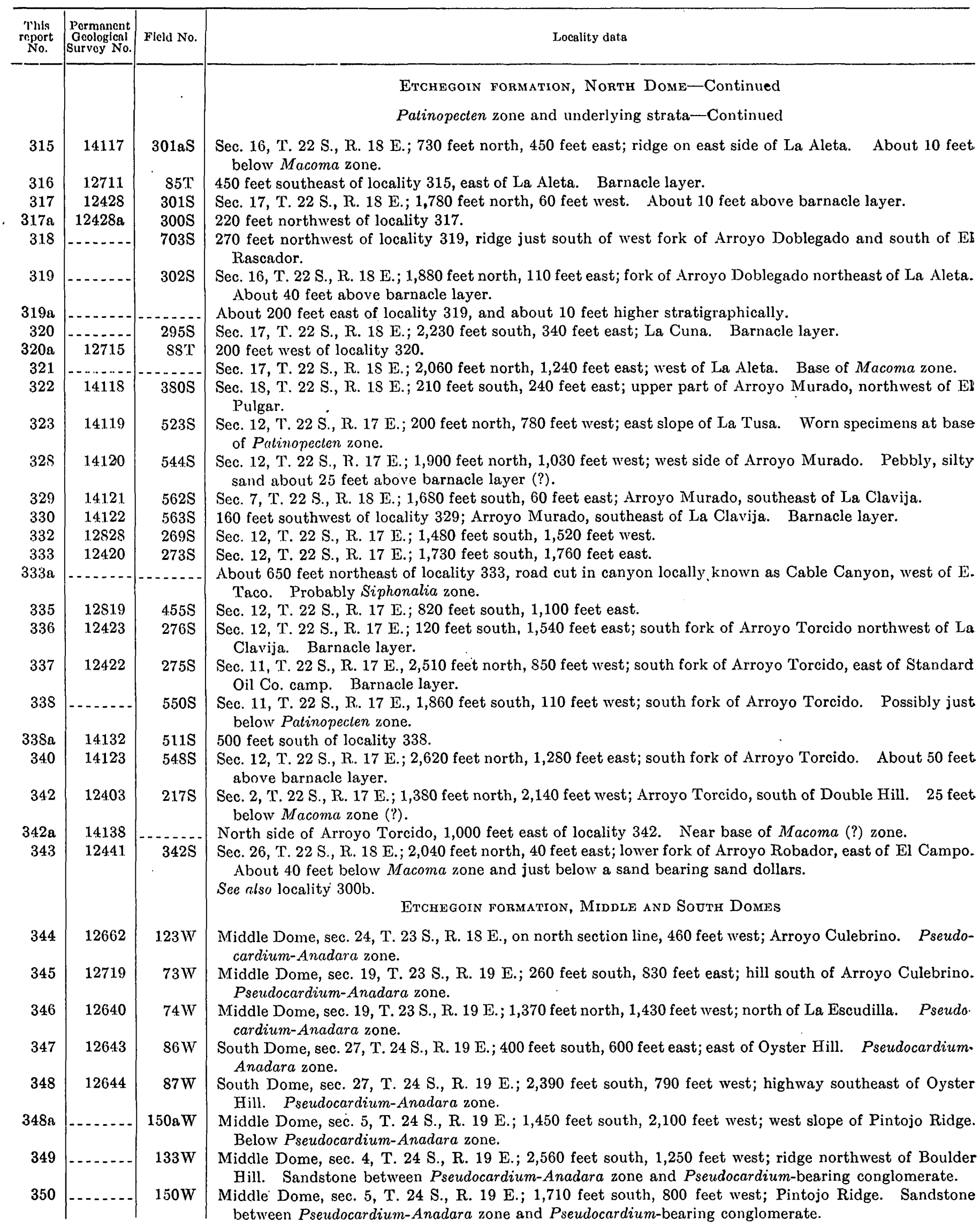


Fossil localities-Continued

\begin{tabular}{|c|c|c|c|}
\hline $\begin{array}{l}\text { This } \\
\text { report } \\
\text { No. }\end{array}$ & $\begin{array}{c}\text { Permanent } \\
\text { Geological } \\
\text { Survey No. }\end{array}$ & Field No. & Locality data \\
\hline & & & Etchegoin formation, Middle and South Domes-Continued \\
\hline 351 & 12665 & $128 \mathrm{~W}$ & $\begin{array}{l}\text { Middle Dome, sec. 29, T. } 23 \text { S., R. } 19 \text { E.; 2,650 feet north, 1,510 feet west; Parejo Hill. Pseudocardium- } \\
\text { bearing conglomerate. }\end{array}$ \\
\hline 352 & 12666 & $129 \mathrm{~W}$ & $\begin{array}{l}\text { Middle Dome, sec. 33, T. } 23 \text { S., R. } 19 \text { E.; } 2,070 \text { feet south, 1,450 feet east; south of Arroyo Recodo. } \\
\text { Pseudocardium-bearing conglomerate. }\end{array}$ \\
\hline 353 & 12667 & $130 \mathrm{~W}$ & $\begin{array}{l}\text { Middle Dome, sec. } 33 \text {, T. } 23 \text { S., R. } 19 \text { E.; } 1,850 \text { feet north, 2,070 feet east; south of Arroyo Recodo. } \\
\text { Pseudocardium-bearing conglomerate. }\end{array}$ \\
\hline 354 & 12671 & $139 \mathrm{~W}$ & $\begin{array}{l}\text { Middle Dome, sec. } 32 \text {, T. } 23 \text { S., R. } 19 \text { E.; } 1,750 \text { feet north, } 350 \text { feet east. Pseudocardium-bearing con- } \\
\text { glomerate. }\end{array}$ \\
\hline 355 & 12837 & $148 \mathrm{~W}$ & $\begin{array}{l}\text { Middle Dome, sec. } 32 \text {, T. } 23 \text { S., R. } 19 \text { E.; } 950 \text { feet north, 2,570 feet west. Pseudocardium-bearing } \\
\text { conglomerate. }\end{array}$ \\
\hline 356 & 12838 & $149 \mathrm{~W}$ & $\begin{array}{l}\text { Middle Dome, sec. } 32 \text {, T. } 23 \text { S., R. } 19 \text { E.; } 400 \text { feet north, 2,250 feet west. Pseudocardium-bearing } \\
\text { conglomerate. }\end{array}$ \\
\hline 357 & 12672 & $140 \mathrm{~W}$ & $\begin{array}{l}\text { Middle Dome, sec: } 19, \text { T. } 23 \text { S., R. } 19 \text { E.; } 1,720 \text { feet south, } 630 \text { feet east; hill south of Arroyo Culebrino. } \\
\text { Below Pseudocardium-bearing conglomerate. }\end{array}$ \\
\hline 358 & 12673 & $141 \mathrm{~W}$ & $\begin{array}{l}\text { Middle Dome, sec. } 32 \text {, T. } 23 \text { S., R. } 19 \text { E.; 1,530 feet north, 1,740 feet west. Below Pseudocardium- } \\
\text { bearing conglomerate. }\end{array}$ \\
\hline 359 & 12642 & $77 \mathrm{~W}$ & $\begin{array}{l}\text { South Dome, sec. } 28 \text {, T. } 24 \text { S., R. } 19 \text { E.; } 350 \text { feet south, 1,100 feet west; road west of Oyster Hill. Pseudo- } \\
\text { cardium-bearing sandstone. }\end{array}$ \\
\hline 360 & 12641 & $75 \mathrm{~W}$ & $\begin{array}{l}\text { South Dome, sec. } 28 \text {, T. } 24 \text { S., R. } 19 \text { E.; } 430 \text { feet south, } 210 \text { feet west; Oyster Hill. Pseudocardium- } \\
\text { bearing sandstone. }\end{array}$ \\
\hline 361 & 11058 & $79 \mathrm{~W}$ & $\begin{array}{l}\text { South Dome, sec. } 11 \text {, T. } 25 \text { S., R. } 19 \text { E.; } 2,330 \text { feet north, } 460 \text { feet east; hill east of Los Morones. Below } \\
\text { horizon of Pseudocardium-bearing sandstone. }\end{array}$ \\
\hline 362 & 12716 & $1 \mathrm{G}$ & $\begin{array}{l}\text { Middle Dome, sec. 32, T. } 23 \text { S., R. } 19 \text { E.; } 370 \text { feet south, 1,220 feet west; north of Arroyo Recodo. } \\
\text { Lower part of Etchegoin. }\end{array}$ \\
\hline 363 & 12647 & $93 \mathrm{~W}$ & $\begin{array}{l}\text { South Dome, sec. 34, T. } 24 \text { S., R. } 19 \text { E.; } 450 \text { feet south, 2,440 feet west; Las Lomas. Lower part of } \\
\text { Etchegoin. }\end{array}$ \\
\hline 364 & 060 & $94 \mathrm{~W}$ & South Dome, sec. 34, T. 24 S., R. 19 E.; 1,700 feet north, on east section line. Lower part of Etchegoin. \\
\hline 365 & 646 & $92 \mathrm{~W}$ & South Dome, sec. 34 , T. 24 S., R. 19 E.; 220 feet north, 1,630 feet west. Lower part of Etchegoin. \\
\hline $\mathbf{3 6 6}$ & 12650 & 98W & $\begin{array}{l}\text { South Dome, sec. 11, T. } 25 \text { S., R. } 19 \text { E.; } 300 \text { feet south, 1,070 feet west; ridge south of El Vejon. Lower } \\
\text { part of Etchegoin. }\end{array}$ \\
\hline 367 & 12651 & $99 \mathrm{~W}$ & $\begin{array}{l}\text { South Dome, sec. 11, T. } 25 \text { S., R. } 19 \text { E.; } 500 \text { feet south, } 950 \text { feet west; ridge south of El Vejon. Lower } \\
\text { part of Etchegoin. }\end{array}$ \\
\hline 368 & 12652 & $100 \mathrm{~W}$ & $\begin{array}{l}\text { South Dome, sec. 2, T. } 25 \text { S., R. } 19 \text { E.; } 690 \text { feet north, 1,670 feet west; ridge south of El Vejon. Lower } \\
\text { part of Etchegoin. }\end{array}$ \\
\hline 369 & 12649 & $97 \mathrm{~W}$ & $\begin{array}{l}\text { South Dome, sec. 11, T. } 25 \text { S., R. } 19 \text { E.; } 170 \text { feet south, } 850 \text { feet west; ridge south of El Vejon. Lower } \\
\text { part of Etchegoin. }\end{array}$ \\
\hline 370 & 12648 & $96 \mathrm{~W}$ & $\begin{array}{l}\text { South Dome, sec. 1, T. } 25 \text { S., R. } 19 \text { E.; } 320 \text { feet north, } 550 \text { feet east; east slope of ridge south of El } \\
\text { Vejon. Lower part of Etchegoin. } \\
\text { See also locality 199a. }\end{array}$ \\
\hline
\end{tabular}

I U. S. Geol. Survey diatom locality number. 


\section{INDEX}

A cila zono, conditions during deposition of correlation of.

fossill localitios in. fossils in and near............................................. $33-34,78$ (insert) soctions of . .

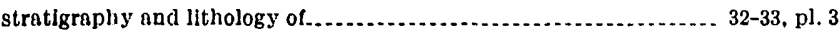
thickness of thicknoss of strata between Pecten zone and .......................... 28, 34 Acknow ledgment for aid ..................................................... 5 Algae, occurrence of ............................................. 78 (insert), 99

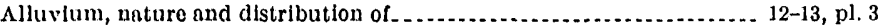

A mnicola zono, conditions during deposition of .......................... 102

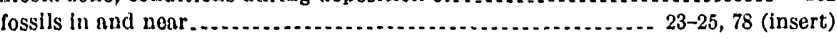

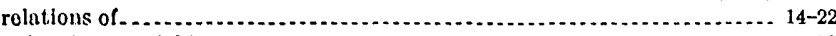

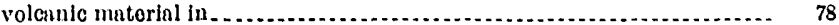
A mnicolidac, mombers of ...................................................... 85, pls. 4,5

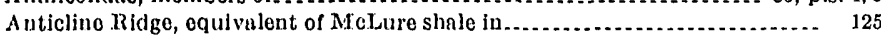
fossils from.

Jncalitos formation in.-................ 115

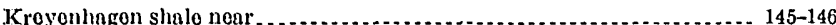

Tomblor sundstone on.................................................... 133

A rcidue, mombers of. .............................. $89-90$, pls. $11,14,20,24,29,31$

Arroyo Bifldo, section of upper Mya zone near . . ........................... 29

Arroyo Conchoso, Tulnre formation on . ..................................... 20 upper Mya zone on.

A rroyo Delgado, Tulare formation on

Arroyo Doblegado, Siphonalia zone near.

Arroyo Dstrecho, San Jonquin formation near

A rroyo Hondo, San Jokquin formation near

A rroyo Largo, Sun Joaquin formation on.

A rroyo Robador, upper Mya zone on.

A venal-Lemoore rond, San Jonquin formation on

A venal sandstone, equivalent of.

\section{$\mathbf{B}$}

$30,31,33,38$ (insert),

Burnucles, occurrence of

54,66 (insert), 68, 70, 77, 78 (insert), 96-97, pls. 27, 36

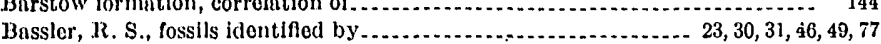

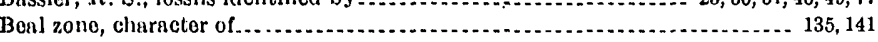

Bentonite, occurrence of..................................... 13, 14, 120, 124-128, 147

Bibliogrnphy.

$6-9$

Blg bluo momber, rolations of............................. 129, 135-136, 142, 143, 144

Big Tar Canyon, fossils from.

Tomblor formation in...................................................... 131-132

Bird, fossil, occurrence of

Bleaching clay, occurrence of .................................. 13,14,120,124-128, 147

Brachiopods, occurrence of................... 38 (insert), 54.78 (insert), pls. 16. 39

Bramlette, M. N., mineral determination by ........................... 42

sections measured by $124,125,130$

Briones sandstone, relations of ......................................... 128-129

Brown, $R$. W., fossils identifled by ........................... 40, 58, 61,66 (insert)

Brown shnlo. See McLuro shale; Monterey shale.

Bryozon, occurrence of ......................... 30,31, 38 (insert), 46, 77, $78^{\circ}$ (insert)

Calliostoma conlingonse privum.

84, pl. 32

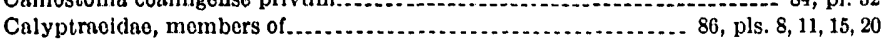

Cancellarlidae, members of ....................

Canons Cnnyon, Temblor formation in ................................... 132-133

Canons Creck, Casçjo conglomerate member along.......................... 53

Cardildno, members of............................................. 95, pls. 16, 24, 29

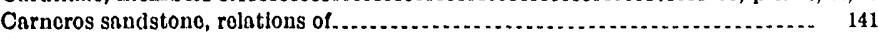

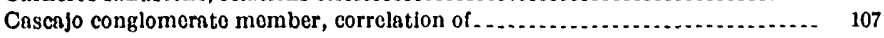

distribution of

fossil localitles in and near.................................................. 160-161 fossils in and near.......................... relations and thickness of .......................................... 27-28

strata between Noverita zone and

48

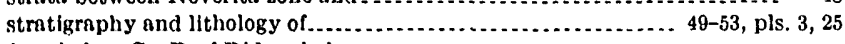

Caving shale. See Reel Ridge shale.

Cedros Island, Lower California, faunal correlation of .............. 112 (insert), 113

Chlco Martinez Creek, Monterey shale on............................... 124-125
Chione elsmerensis zone correlation

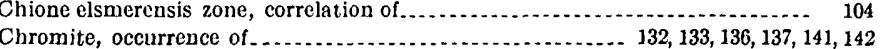
Climate of the area

Coalinga beds, equivalent of

Coalinga district, Pliocene formations in correlation of formations in . . . .

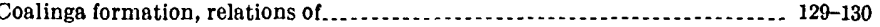

Coast Ranges, Cascajo conglomerate member in. correlation of formations in .............................. 106-108, 112 (insert)

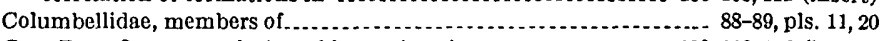
Coos Bay, Oreg., correlation of formations in .................. 109-110, 112 (insert) Corals, occurrence of .............................. 38 (insert), 54, 78 (insert), pl, 16 Correlation of formations, summary ol ....................... 112 (insert), 113-114 Crepidulidae, members of ........... 31

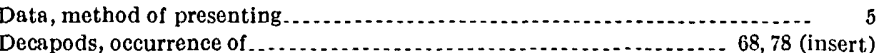
Decapods, occurrence of $\ldots \ldots \ldots \ldots$
Delmontian stage, equivalent of . $\ldots \ldots \ldots \ldots \ldots \ldots$ Dendraster coalingaensis group, fossils in ................. 81, pls. 10, 39-41,44, 45 Dendraster coalingaensis macer ....................................... 81 , pls. 41 Dendraster gibbsii group, fossils in . ......................

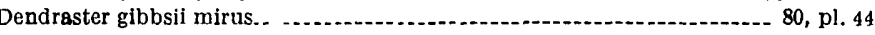
Devils Den, Kreyenhagen shale of . Diatoms, occurrence of . ..................... 24-25, 41, 47, 67, 75, 78, 98, pls. 7, 22-23, 38

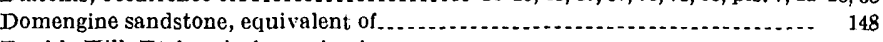

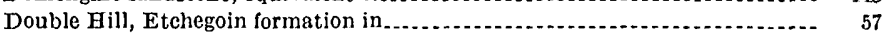

Echinoids, occurrence of ......................................... 31, 33, 38 (insert), $46,49,54,63,66$ (insert), 68, 70, 78 (insert), 79-83, pls. 10, 20, 21, 39-46 Eel River Basin, correlation of formations in $\ldots 109,112$ insert) 800-foot shale, character of - 135, 137 -139 El Bulto, San Joaquin formation near............. El Leon, Siphonalia zone in ............................................ $65-66$, pl. 28 strata between Littorina zone and upper. Pseudocardium zone in ........ 61 strata between upper Pseudocardium zone and Siphonaiia zone in ....... 64 upper Pseudocardium zone in .......................... 26 El Tolete, Macoma zone in............................................. 28 Patinopecten zone in Elliott zone, character of . . . Elsinore zone, character of Empire formation, age and correlation of . Environment suggested by tossils...... 99-102 Eocene series, formations of ...................................... 114, 144-148, pl 51 Eolian deposits, nature and distribution of ..................... 12-13 Etchegoin formation, age of boundary of $-4-5,12,26-27$ character of............................ 11, 55-56, 69-77, 114-117, pls. 17, 25-28 conditions during deposition of .................................. 99, 100-102

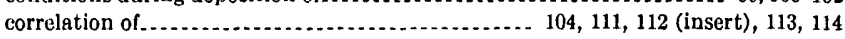

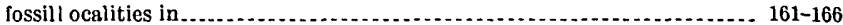
fossils from _. $60,63,66$ (insert), 67, 68, 70, 72, 74, 75, 77, 78, 78 (insert), 116-117 sections of.................. $57,58,59,61,62,64,65,66,67,68,71,73$, pls. 25-28 stratigraphic units in

volcanic matcrial in Felix siltstone, character of . . ......................................... 135, 140

Fernando formation, correlation of .................................... 110

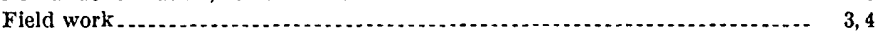

Fif th zone, character of ...................... 135, 139-140 correlation of

First zone. character of ..................... 135-136

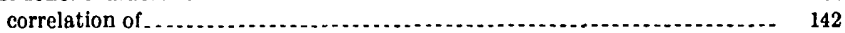

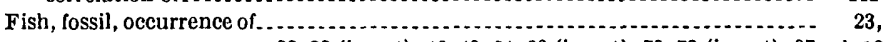

33,38 (insert), 46, 49, 54, 66 (insert), 70, 78 (insert), 97, pl. 13 Foraminifera, occurrence of ........... 78 (insert), 121, 127, 128, 138, pls. 49-50 Forreria magister munda........................ 88, pl. 15

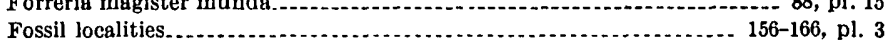
Fossils, new species and varieties........... See also names of groups. 
Fourth zone, character of

Page

Foxen formation, correlation of

Fuller's earth, possible occurrence of See also Bentonite.

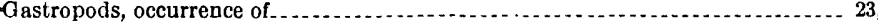
$30,33,38$ (insert), 40, 46, 49, 54, 60, 63, 66 (insert), 68, 70, 74, 77, 78 (insert), 79, 83-89, 142, 143, pls. 4, 5, 8, 11, 15, 20, 24, 29, 31-32, 34, 36, 39 Gazin, C. L., mammal identified by ............... 30,38 (insert), 49, 54, 68, 70, 74 Geography of the area........................ 9-11, 149, pls. 1-3, 54-57 Geologic maps of the area

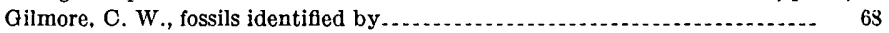
Glycymeridae, members of .............................. 90,33 Glycymeris zone, correlation of $\quad 104-106,107,108$

Gould shale member, correlation and age of

$125,137,141,144$ fossils from

Gregory, W. K., quoted

Hoffmeister, J. E., fossils identified by

I

I

$\mathbf{J}$

Jacalitos Dome, Cascajo conglomerate member in

Jacalitos formation, age and correlation of $-104-111,112$ (insert) $113,114,117$

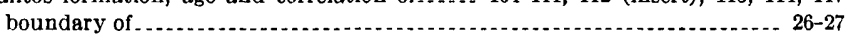
character and fossils of

Jacalitos Hills, Jacalitos formation in . . .

Joints, character of . .............................................. 151, 152, pl. 53

\section{$\mathrm{K}$}

Kollogg, Remington, fossils identified by quoted.

Kleinpell, R. M., fossils identifled by..

$46,49,54,68,70,74$ quoted

Kreyenhagen Hills, Cascajo conglomerate member in Jacalitos formstion in

Krevenhagen shale, age and correlation of character, thickness, and fossils of ............................. 48 equivalents of relations of

L

La Aleta, Siphonalia zone in..

La Clavija, Macoma zone near

Las Alturas, San Joaquin formation in

Las Posas formation, correlation of

Leda mone, character and rolations of

ittorina zone, age of

conditions during deposition of...

correlation of.

rossil localities in.

fossils in and near.

sections in and near

strata between Pseudocardium zone and

strata overlying, stratigraphy and lithology of .

stratigraphy and lithology of

Littorinidae. members of

Location of Kettleman Hills.

Lohman, K. E., fossils identifled by section measured by

Los Angeles Basin, correlation of formations in . . . . . .

Los Jinetes, Siphonalia zone on .

M

McAdams sand, age and correlation of character, thickness, and fossils of equivalents of .

McLure shale member, age and correlation of equivalents of section of. stratigraphy, lithology, and fossils of

Macoma affinis plens...

. 93, pls. 24, 29, 39 fossils in..

sections of

stratigraphy and lithology of volcanic materinl in

Mactridae, members of.

Maricopa shale, crjuivalent of
Merced formation, correlation of

Merriamaster group, fossils in... Middle Dome, Acila and related zones in .............. Cascajo conglomerate member and related strata in ........ 48, 52-53, pl. 3 fossil localities in $156-161,165-166$ fossils from........ 23-25, 31, 38 (insert), 40, 46, 47, 49, 72, 74, 75, 78 (insert) Jacalitos formation in .............................. 116-117

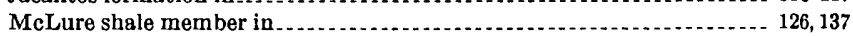

Neverita and related zones in .

Pecten and related zones in ......................... 34-37, 39, pls. 3,12

Pseudocardium-A nadara and related zones in .......... 3

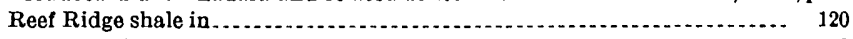

structure of ............

Temblor sandstone in . . .

topography of ........

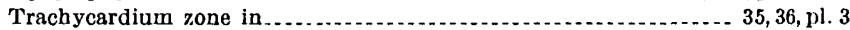

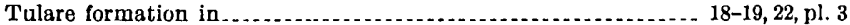

upper Mya and related zones in . .

volcanic material in

Milham zone, character of .....

Miocene series, classification and nomenclature of $117-119$ formations of ......................

Modelo formation, relations of

Mohnian stage, equivalent of $\ldots$

Monterey shale, age and correlation of .............................. 128-129, 144 confusion of, with Kreyenhagen shale definition of . . . .

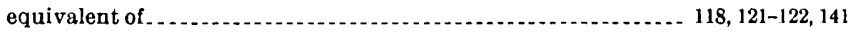

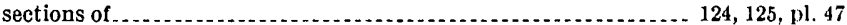
stratigraphy, lithology, and fossils of ............. 11, 114, 122-128, 138, 140, pl. 47 Mulinia zone. See Pseudocardium zone.

Muricidae, members of . .......................................... 87-88, pl. 15

Mya-Elphidium zones, correlation of ................. 107

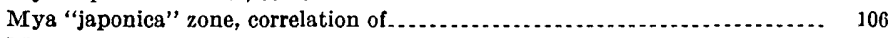

Mya zone, upper, age of

conditions during deposition of ............ 100-101

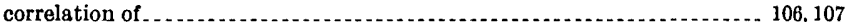

fossils between Acila zone and.................... 31-32, 78 (insert)

fossil localities between Acila zone and

fossil localities in ............... 156-157

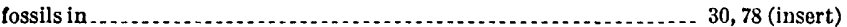

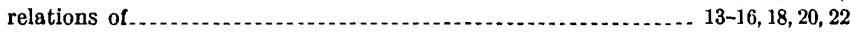

sections of . . .

stratigraphy and lithology of $\ldots \ldots \ldots \ldots \ldots . . .28-30$

stratigraphy and lithology of strata between Acila zone and .............. 30-31

thickness of strata between Acila zone and........................ 28, 30-31

Myacidae, members of ................ 95, 9, 21, 24

Mytilidae, members of ................................... 90. pls. 8, 13, 16, 20, 32, 37

$\mathbf{N}$

"Nassa" miser iniqua.

$87, \mathrm{pl} .34$

Nassidae," members of

Naticidae, members of -.

Neptuneidae, members of

Neroly formation, age of

Neverita zone, age of

conditions during deposition of . . . .

correlation of . . . . .

fossil localities in and near.

fossils in and near.................................... 40-41, 45-49, 78 (insert)

sand and sandstone from ........................................... 18

section of -

strata between Cascajo conglomerate member and ........................ 48

stratigraphy and lithology of ................................. 42-45, pls. 18, 19

stratigraphy and lithology of strata between Cascajo conglomerate member and.

thickness of ......................

thickness of strata between Cascajo conglomerate member and............ 28

volcanic material below

Nomlaki tuff, volcanic material in .

North Dome, Acila and related zones in

Cascajo congolmerate member and related zones in ............ 47-48,50-52, pl. 3

Etchegoin formation in .

fossil localities in ............................. 156-165 fossils from ..... 23-25, 31, 38 (insert), 40-41, 46, 49, 60, 63, 67, 68, 70, 78 (insert), 121 Jacalitos formation in ................................................ 116-117 Kreyenhagen shale in 34

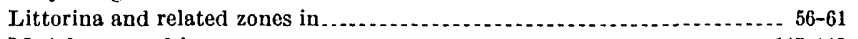

McAdams sand in

McLure shale member in .......................................... 126-129

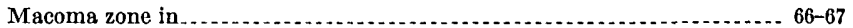

Neverita and related zones in

Patinopecten and related zones in ...

Pecten and related zones in ..................................... 34-37, 39-40 
Page

North Dome, Pseudocardium and related zones in

$61-64,116$

120

Siphonalia and related zones in....................................... $64-66$ structure of ..................................................... 150-151

Tomblor sandstone in.......................................... 134-144 thickness of strata between M.cLure shale and Temblor sandstone in ...... 137 topography of ..................................................... 9,155

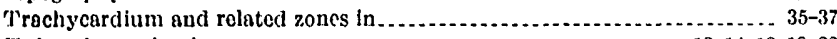
Tularo formation in......................................... 13, 14-18, 19-22 upper $\mathrm{M} y \mathrm{n}$ and related zones in................................... 30-31 voleanic material in ........................................................... $78-79$ Nuculidae, members of .................................................. 89, pl. 11

\section{0}

Oll-boaring sands, age and nomenclature of . Orinda formation, volcnulc material in

Ostracodes, occurrence of

Ostreidne, members of $114,144-147$, pl. 51 23,38 (insert), 49, 78 (insert)

O toliths. See Fish. 92 , pls. $8,10,14,29$

Pasadenan period of deformation, folding during Paso Robles-Finnford rond, San Jonquin formation on..................... 40 Tulare formation near.

Patinopecten zono, age of fossll locnlitics in and near fossils in.

sections of

strata undorlying, nature of stratigraphy and lithology of $164-165$ cten cosingnensis rone, corrclation 70,78 (insert) 68 , pls. 3,28 69, pl. 27 tion of $\ldots-107,111,112$ (insert)

-Mylitus zone, correlation of

Pecten zone, age of. conditions during deposition of correlation of.............................................. 106, 107, 111, 112,113 distribution of fossil localities in and near .......... fossils in and near................. sections of...

stratigraphy and lithology of ................................. 34-38, pls. 12, 18 stratigraphy and lithology of strata between Neverita zone and......... 39-40 thickness of.

thickness of stratn betwcon Acila zone and

thickness of strata between Neverita zone and volcantc material in.

Pectinidac, mombers of (insert), 40, 46, 49, 54,60,63,66 (insert), 68, 70,74, 77, 78 (insert), 79, 89-96, 140, 142, 143, pls. 5, 6, 8-11 $13-16,20,21,24,29-37,39$

Potalumn formation, relations of

Pholadidac, members of.

Physiogrnphy, fentures of $154-155$, pls. $1,2,53-57$

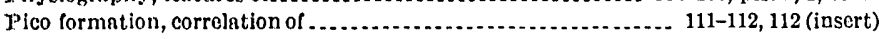

Pinole tuff, volcanic material in.

Planorbidac, mombers of

Plants, (ossil, occurrence of

Platyodon colobus ................................................. 95, pl. 21

Plelstoceno (?) and Pliocene deposits, features of .................... 13-26, pl. 3

Pleistocene deposits, character and distribution of ................ 12-13, pls. 3, 51

Pleuroceridae, members of

Pliocene series, classifleation and nomenclature of $\ldots \ldots \ldots \ldots . . . . . .13-27$ formations of.

Prlest Valley, correlntion of formations in ...................... 112 (insert)

Pscudocardium-Anndarn zone, fossils in and near $\ldots .72,74,75,78$ (insert) section of strata underlying.

sections of strnta overlying.

stratigraphy and lithology of

stratigrnphy and lithology of strata overlying ........... stratigraphy and lithology of strata underlying ............................. 73-74

Psoudocardium-bearing conglomerate, lithology of.

Pseudocardlum-benring sandstone, lithology of.

Psoudocardium zone, character and relations of

Pseudocardium zone, uppor, correlation of

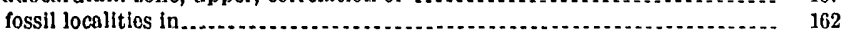

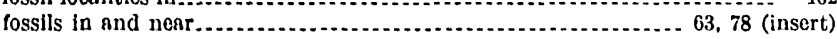

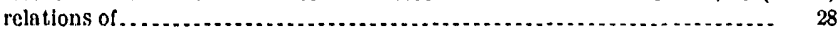

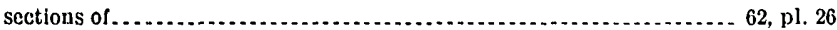

strata between Siphonalia zone and stratigraphy and lithology of volcanic material above.

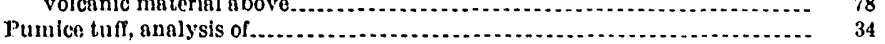

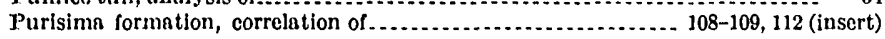

$\mathbf{R}$

Rathbun, M. J., fossils iden
Recent deposits, features of

$12-13,01,38$

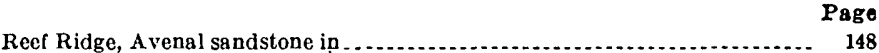

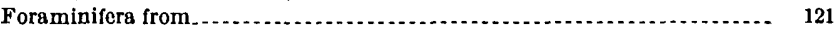

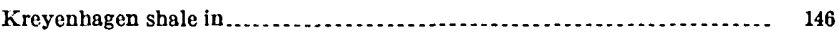

McLure shale member in ............................................. 123-124

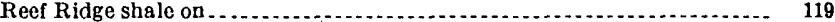

sections of Temblor formation in

Reef Ridge shale, age and correlation of ......... 121-122 equivalents of ............................................... 118, 129

stratigraphy, lithology, and fossils of ............. 11,114, 119-121, pls. 47-48 Repetto formation, correlation of .......................... 111, 112, 112 (insert)

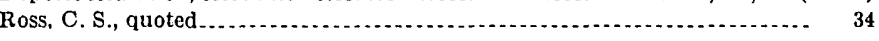

Salinas shalc, equivalent of $\quad$ S Salinas Valley, Correlation of formations in ............................. 108, 112 (insert) San Andreas fault, deformation related to ............................... 153, 154 San Diego, correlation of formations near . ................... 112-113, 112 (insert) San Diego formation, correlation of .......................... 112-113, 112 (insert) San Diego zone, correlation of . . . . . San Francisco Peninsula, correlation of formations in ........... 108-109, 112 (insert)

San Joaquin formation, age of . ....................................... 102-103 analysis of pumice tuff from . . . . . . . . . . . . 34

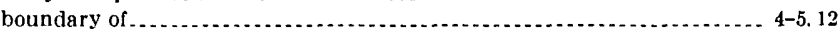
character of .................... 11, 27-28, pls. 12, 17-19, 25 conditions during deposition of . ................................ 99, 100-102 correlation of $. . . .79,106-108,109,111,112,112$ (insert), 113

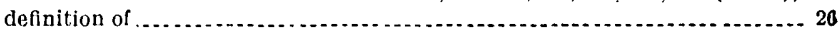
deformetion affecing . . . fossil localities in . . . . . . . . . . . fossils in sections of...................... 29, 31, 32-33,35,40,43,44,48,50,52, pls.3, 12, 17, 25 strata in ...................... $37-54$, pls. $3,17,25$ volcanic material in . . . . . .

San Joaquin Valley, Cascajo conglomerate member in

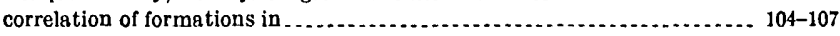

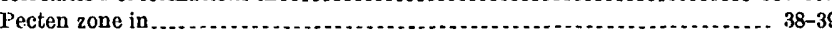

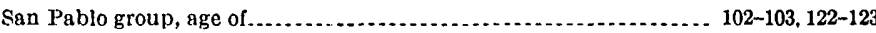
San Pedro sand, correlation of $\ldots \ldots, 110,112,112$ (insert)

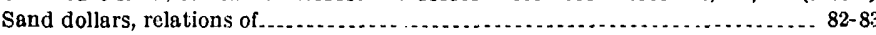
Santa Barbara, correlation of formations exposed near. Santa Barbara zone, correlation of ............................. 112, 112 (insert) Santa Barbara formation, correlation of $110-111,112,112$ (insert), 114 Santa Cruz quadrangle, correlation of formations in ............. 108-109, 112 (insert) Santa Margarita formation, relations of .............. 122-123, 125, 128, 129, 144, pl. 47 Santa Maria Basin, correlation of formations in ..................... 110,112 (insert) Santa Rosa district, correlation of formations in . . . ................ 109, 112 (insert) Santa Susana Mountains, correlation of formations in . . . . .............. 112 (insert)

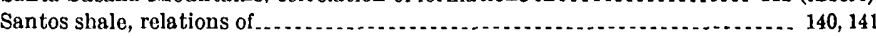
Sargent district, correlation of formations in . . ..................... 108, 112 (insert) Saugus formation, correlation of . . Saxidomus nuttalli latus.......................................... 94, pls. 8, 16, 33

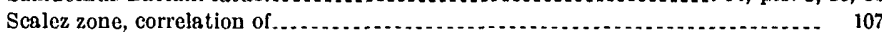
Scope and plan of report........... 3-4, 5

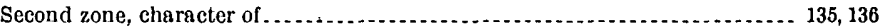

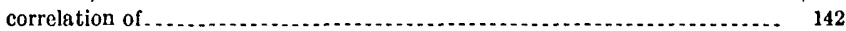

Sespe formation, relations of

Siphonalia zone, age of $\ldots{ }^{2}$ conditions during deposition of ...................................... 100

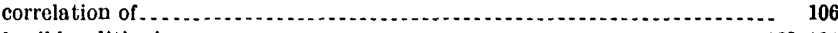

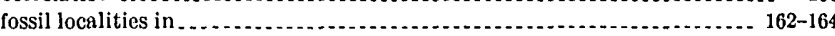
fossils in . . . . sections of ................................................... $65-66$, pls. 28

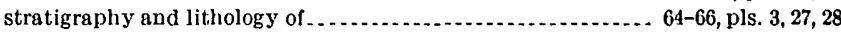
volcanic material in.......................................................... 78 600 -foot shale, character of . correlation of . . . . .

Foraminifera from

Sixth zone, character of

Solenidae, members of

Sonoma andesite, correlation of ....................................... 109

volcanic material in . . . . .

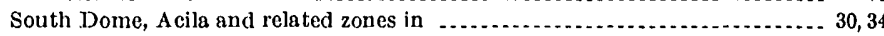
Cascajo conglomerate member in . . . fossil locelities in

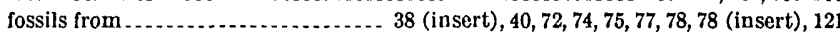

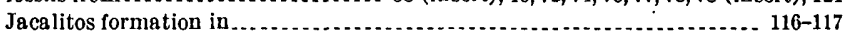
McLure shale member and related zones in ......................... 126-129, 137 Neverita and related zones in ....................................... 39, 458

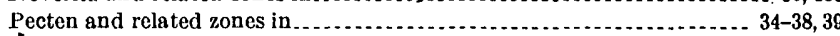
Pseudocardium-Anadara and related zones in ................. $69,71,72-73,74-75$ Pscudocardium zone in .............................................. 116 Reef Ridge shale in . . . .

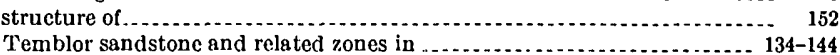
Temblor sandstone and related zones in $\ldots \ldots \ldots \ldots \ldots \ldots$
topography of $\ldots \ldots \ldots \ldots \ldots \ldots \ldots \ldots$

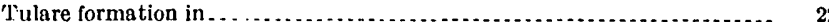


South Dome, upper Mya and related zones in . ........................ Page volcanic material in. 78-79 Stewart, Ralph, fossils identifled by .............................. 33, 38 (insert), $40,46,49,54,60,63,66$ (insert), 68,70

Stock, Chester, quoted Stratigraphy of the area $11-78,114-148$, pls. $3,17,25-28,47-48.51$ Structure. 148-154, pls. 51-53

\section{$\mathrm{T}$}

Taylor, G. F., sections measured by $16,18,20,21-22,29$ Tehama formation, relations of Tejon formation, equivalent of $146,147,148$ Tellinidae, members of ..................... 92-93, pls. 9, 14, 16, 20, 24, 29, 33-35, 39 Temblor sandstone, age and correlation of ............. 118, 129-130, 141-144, pl. 47

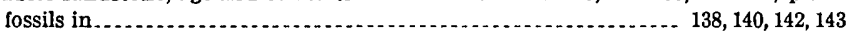
sections of . . . . . . . . . . . stratigraphy and lithology of ....................... 11, 114, 129-141, pls. 47, 48 Thaididae, members of ............................................ 88 pls. $15,24,36$ Third zone, character of . . ................... 135, 137 Topography of the area................................... 154-155, pls. 1-3, 53-57

Trachycardium zone, fossil localities in and near ......................... 157-159 fossils in and near..................... 38 (insert) relations of. stratigraphy and lithology of ................................ $34-38$, pl. 12 Trochidae, members of ....................................... 83-84, pls.11, 15, 32

Tulare formation, age of conditions during deposition of . . correlation of deformation of fossil localities in

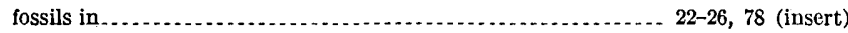
sections of .............................. 15-22

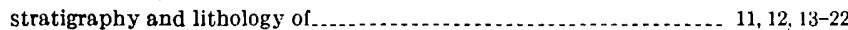

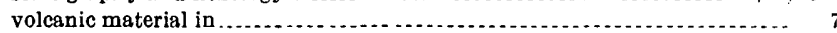
Tumey formation, equivalent of ........................... 145-146

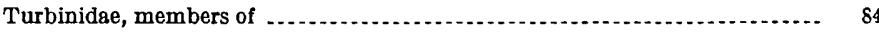
Turcica caffea brevis..................................................... 84, pl. 11 Turritella nova zone, correlation of . . . .

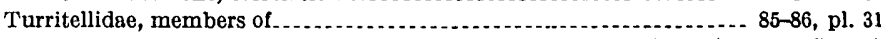
Turtles, occurrence of............................ 38 (insert), 68, 78 (insert)

Tuscan tuff, volcanic material in.

\section{U}

92, pl. 6

Unionidae, members of

\section{$\mathrm{V}$}

Vaqueros sands

135,141 relations of $122,129-130,141-142$

Variegated zone, lower, character of upper, character of

Vegetation of the area . . . .

Veneridae, members of................................. 94-95, pls. 8, 13, 16, 24, 29, 33

Venerupis grata tarda ........................................................ 13

Ventura Basin, correlation of formations in .................. 111-112, 112 (insert)

Viviparidae, members of

Volcanic material, source of .............

Wagonwheel formation, equivalent of $W$

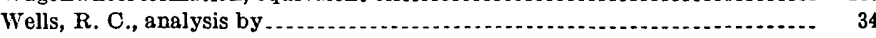

Wetmore, Alexander, fossil identified by

Whepley shale, character of $135,140-14$

Wildcat series, correlation of ................................ 109, 112 (insert)

Woodring, W. P., fossils identifed by ......... 23, 40, 49, 54, 72, 74, 77, 140, 142, 143

Worm tubes, occurrence of ................................. 38 (insert), 78 (insert)

$Z$ section of Temblor formation on . . . . 
The use of the subjoined mailing labei to return this report will be official business, and no postage stamps will be required

UNITED STATES DEPARTMENT OF THE INTERIOR

GEOLOGICAL SURVEY

OFFICIAL BUSINESS

This label can be used only for returning Thicial publications. The address be changed.
PENALTY FOR PRIVATE USE TO AVOID PAYMENT OF POSTAGE, $\$ 300$

\section{GEOLOGICAL SURVEY,}

